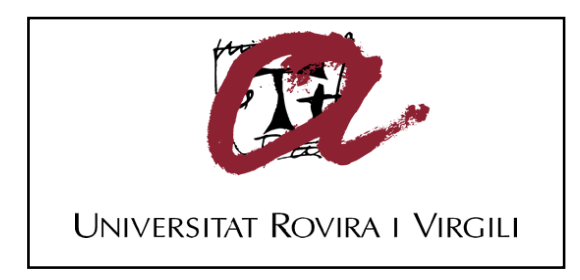

\title{
La pena de privación del derecho a conducir vehículos a motor y ciclomotores en el sistema penal español
}

\author{
David Lanaspa Mainz
}

ADVERTIMENT. L'accés als continguts d'aquesta tesi doctoral i la seva utilització ha de respectar els drets de la persona autora. Pot ser utilitzada per a consulta o estudi personal, així com en activitats o materials d'investigació i docència en els termes establerts a l'art. 32 del Text Refós de la Llei de Propietat Intel-lectual (RDL 1/1996). Per altres utilitzacions es requereix l'autorització prèvia i expressa de la persona autora. En qualsevol cas, en la utilització dels seus continguts caldrà indicar de forma clara el nom i cognoms de la persona autora i el títol de la tesi doctoral. No s'autoritza la seva reproducció o altres formes d'explotació efectuades amb finalitats de lucre ni la seva comunicació pública des d'un lloc aliè al servei TDX. Tampoc s'autoritza la presentació del seu contingut en una finestra o marc aliè a TDX (framing). Aquesta reserva de drets afecta tant als continguts de la tesi com als seus resums i índexs.

ADVERTENCIA. El acceso a los contenidos de esta tesis doctoral y su utilización debe respetar los derechos de la persona autora. Puede ser utilizada para consulta o estudio personal, así como en actividades o materiales de investigación y docencia en los términos establecidos en el art. 32 del Texto Refundido de la Ley de Propiedad Intelectual (RDL 1/1996). Para otros usos se requiere la autorización previa y expresa de la persona autora. En cualquier caso, en la utilización de sus contenidos se deberá indicar de forma clara el nombre y apellidos de la persona autora y el título de la tesis doctoral. No se autoriza su reproducción u otras formas de explotación efectuadas con fines lucrativos ni su comunicación pública desde un sitio ajeno al servicio TDR. Tampoco se autoriza la presentación de su contenido en una ventana o marco ajeno a TDR (framing). Esta reserva de derechos afecta tanto al contenido de la tesis como a sus resúmenes e índices.

WARNING. Access to the contents of this doctoral thesis and its use must respect the rights of the author. It can be used for reference or private study, as well as research and learning activities or materials in the terms established by the 32nd article of the Spanish Consolidated Copyright Act (RDL 1/1996). Express and previous authorization of the author is required for any other uses. In any case, when using its content, full name of the author and title of the thesis must be clearly indicated. Reproduction or other forms of for profit use or public communication from outside TDX service is not allowed. Presentation of its content in a window or frame external to TDX (framing) is not authorized either. These rights affect both the content of the thesis and its abstracts and indexes. 


\section{UNIVERSITAT ROVIRA i VIRGILI}

LA PENA DE PRIVACIÓN DEL DERECHO A CONDUCIR VEHÍCULOS A MOTOR Y CICLOMOTORES EN EL SISTEMA PENAL ESPAÑOL

David Lanaspa Mainz 
La Pena de privación del derecho a conducir vehículos a motor y ciclomotores en el sistema penal español David Lanaspa Mainz 列 
La Pena de privación del derecho a conducir vehículos a motor y ciclomotores en el sistema penal español David Lanaspa Mainz 列 
David Lanaspa Mainz

\section{LA PENA DE PRIVACIÓN DEL DERECHO A CONDUCIR VEHÍCULOS A MOTOR Y CICLOMOTORES EN EL SISTEMA PENAL ESPAÑOL}

\section{TESIS DOCTORAL}

Dirigida por la Dra. Núria Torres Rosell

Departamento de Derecho Público



Tarragona

2020 
La Pena de privación del derecho a conducir vehículos a motor y ciclomotores en el sistema penal español David Lanaspa Mainz 列 


\section{UN UNVESTITT}

FAIG CONSTAR que aquest treball, titulat "La pena de privación del derecho a conducir vehículos a motor y ciclomotores en el sistema penal español", que presenta David Lanaspa Mainz per a l'obtenció del títol de Doctor, ha estat realitzat sota la meva direcció al Departament de Dret Públic d'aquesta Universitat.

HAGO CONSTAR que el presente trabajo, titulado "La pena de privación del derecho a conducir vehículos a motor y ciclomotores en el sistema penal español", que presenta David Lanaspa Mainz para la obtención del título de Doctor, ha sido realizado bajo mi dirección en el Departamento de Derecho Público de esta Universidad.

I STATE that the present study, entitled "The penalty of deprivation of the right to drive motor vehicles and mopeds in the Spanish penal system", presented by David Lanaspa Mainz for the award of the degree of Doctor, has been carried out under my supervision at the Department Public Law of this University.

Tarragona, 10 de desembre de 2020 / Tarragona, 10 de diciembre de 2020 / Tarragona, december 10, 2020.

$\mathrm{El} / \mathrm{s}$ director/s de la tesi doctoral

$\mathrm{El} /$ los director/es de la tesis doctoral

Doctoral Thesis Supervisor/s

[signatura] / [firma] / [signature]

Núria Signat

Torres digitalment per

Núria Torres

Rosell - DNI Rosell - DNI

Dra. Núria Torres Rosell

43722834H 43722834H (SIG)

(SIG) Data: 2020.12.13 
La Pena de privación del derecho a conducir vehículos a motor y ciclomotores en el sistema penal español David Lanaspa Mainz 列 
La Pena de privación del derecho a conducir vehículos a motor y ciclomotores en el sistema penal español David Lanaspa Mainz

A mis padres.

A Begoña, por tu apoyo incondicional. 
La Pena de privación del derecho a conducir vehículos a motor y ciclomotores en el sistema penal español David Lanaspa Mainz 列 


\section{AGRADECIMIENTOS}

Llego al final del viaje iniciado hace unos años y es el momento de recordar a quienes han colaborado en la resolución de todas las incertidumbres que surgían en la investigación.

En primer lugar, como no podía ser de otro modo, mostrar mi gratitud eterna a la doctora Núria Torres, directora de esta tesis, por su permanente ilustración, criterio jurídico y análisis crítico. $Y$, sobre todo, por sus constantes palabras de ánimo y su infinita paciencia en las tutorías y correcciones realizadas.

También quiero destacar el apoyo de mis compañer@s del área de Derecho Penal de la Universitat Rovira i Virgili.

Gracias a los responsables del CRAI del Campus Catalunya y a Agnés Figuera, bibliotecaria del Ilustre Colegio de la Abogacía de Tarragona, por resolver siempre las consultas y peticiones bibliográficas.

En la esfera judicial tarraconense subrayar la atención recibida ante mis solicitudes de información por los Letrados de la Administración de Justicia Sergio Macián de Greef, Rafael Angulo Vivaracho y Francisco Javier Sánchez Benito, así como por los Magistrados Jesús María del Cacho Rivera e Ignacio Echeverría Albacar.

Igualmente agradecer el trato dispensado por parte del equipo del Fiscal de Sala Coordinador de Seguridad Vial en Madrid, al responder siempre a los correos electrónicos y llamadas con las cuestiones que les planteaba. En el ámbito de la Fiscalía Provincial de Tarragona dar las gracias a Anna Fonts i Torres, Fiscal Delegada de Seguridad Vial en Tarragona, y a Carlos Domínguez López. Asimismo, mencionar a Quim Soldevila Romero, que fue Fiscal Delegado de Seguridad Vial en Girona, y que es uno de los mayores expertos en delincuencia vial que he conocido.

Por último, quiero recordar a $\mathrm{M}^{\mathrm{a}}$ del Carmen Padial Sayas, quien fue Jefa Provincial de Tráfico de Tarragona, y que amablemente atendió mis consultas relativas a la incidencia de la pena de privación del derecho a conducir en el ámbito administrativo.

Gracias a tod@s. 
La Pena de privación del derecho a conducir vehículos a motor y ciclomotores en el sistema penal español David Lanaspa Mainz 列 


\section{RESUMEN}

La investigación tiene como objetivo el análisis de la pena de privación del derecho a conducir vehículos a motor y ciclomotores en el sistema penal español. Se trata de una pena privativa de derechos que ha adquirido una importancia cuantitativa relevante en estas últimas décadas y que puede desarrollar una función importante en la sanción de delitos en los que se emplean vehículos a motor. En concreto, la investigación se endereza a, en primer lugar, realizar un análisis integral de la situación actual de la pena de privación del derecho a conducir en el sistema penal español; en segundo lugar, analizar su aplicación en la práctica de los Juzgados y Tribunales, y finalmente detectar los déficits que presenta para así, realizar propuestas para una mejor regulación, aplicación y ejecución de la misma.

Para analizar estas cuestiones, el trabajo se estructura en seis capítulos. El primero de ellos examina la naturaleza jurídica de la privación del derecho a conducir, haciendo referencia al ámbito penal y administrativo. El segundo capítulo aborda los fines que persigue la pena objeto de estudio desde la óptica de la prevención, el retribucionismo y las teorías que mantienen la existencia de fines mixtos. El tercero, precisa el contenido de la pena de privación del derecho a conducir, tanto desde la perspectiva de lo que ha de entenderse como vehículo a motor o ciclomotor en la esfera penal, como desde el análisis de los delitos que conllevan la imposición de esta pena, haciendo énfasis en la consecuencia prevista en el art. 47.3 del CP. Las condiciones de ejecución de la pena de privación del derecho a conducir se exponen en el cuarto capítulo, detallando tanto los trámites que se llevan a cabo, las consecuencias administrativas derivadas de la condena a esta pena y asimismo se estudia la opción de cumplir de forma fraccionada la misma. El quinto capítulo analiza la concurrencia de la pena objeto de investigación con otras sanciones penales, bien sean penas o medidas de seguridad, así como con la consecuencia accesoria del decomiso del vehículo a motor o ciclomotor. Finalmente, el sexto capítulo plantea una serie de propuestas de lege ferenda relacionadas con la extensión de la pena de privación del derecho a conducir a delitos que no la prevén y, también, la opción de regular la misma como pena accesoria. En el ámbito de la ejecución se desarrollan propuestas con el objetivo tanto de flexibilizar como de mejorar su cumplimiento. 
La metodología utilizada para la elaboración de la tesis ha sido la propia de las ciencias sociales. Se ha analizado tanto la doctrina relacionada con el sistema de penas, las penas privativas de derechos en particular, así como la relacionada con los delitos contra la seguridad vial y la vida e integridad física y psíquica. Igualmente, se ha realizado un exhaustivo análisis jurisprudencial de los supuestos en los que se ha impuesto la privación del derecho a conducir, bien como pena, medida de seguridad o medida cautelar, mayoritariamente de las Audiencias Provinciales y de forma minoritaria del Tribunal Supremo y Tribunal Constitucional.

En cuanto a las principales conclusiones alcanzadas se destaca que: I) la pena de privación del derecho a conducir tiene un elevado grado de aplicación en nuestros Juzgados y Tribunales; II) existen aspectos de su regulación que deberían ser reformados, tanto a nivel procesal como sustantivo y III) es una pena que tiene una aplicación práctica en constante evolución, motivada por las reformas penales implementadas en los últimos años. 


\section{ÍNDICE DE CONTENIDOS}

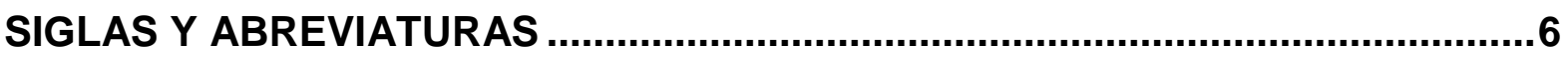

INTRODUCCIÓN .......................................................................................

CAPÍTULO 1. NATURALEZA JURÍDICA DE LA PRIVACIÓN DEL DERECHO A

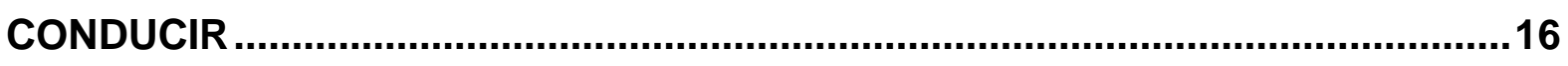

1.1. Antecedentes de la privación del derecho a conducir en la legislación penal

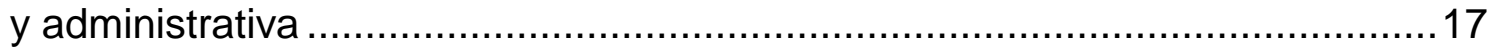

1.2. La privación del derecho a conducir como sanción penal .........................21

1.2.1 La privación del derecho a conducir como pena privativa de derechos y pena principal................................................................................ 23

1.2.2. La privación del derecho a conducir como medida de seguridad............26

1.3. La privación del derecho a conducir como medida cautelar penal.............35

1.3.1. Marco procesal y criterios jurisprudenciales....................................41

1.3.2. Hacia una mayor aplicación de la medida cautelar .............................45

1.4. La medida de privación del derecho a conducir en el Derecho Penal Juvenil

1.5. La privación del derecho a conducir en el ámbito del Derecho

Administrativo 60

1.5.1. La regulación administrativa de la privación del derecho a conducir ......60

1.5.2. La entrada en vigor del "carnet por puntos" y su influencia en la pena de privación del derecho a conducir.

1.6. Toma de posición respecto la naturaleza jurídica de la privación del derecho a conducir

CAPÍtUlo 2. FINES DE LA PENA DE PRIVACIÓN DEL DERECHO A CONDUCIR.

2.1. La realización de fines retributivos en la pena de privación del derecho a conducir

2.2. La realización de fines preventivos en la pena de privación del derecho a conducir

2.2.1. La prevención general en la pena de privación del derecho a conducir..79

a) La prevención general negativa 
b) La prevención general positiva.

2.2.2. La prevención especial en la pena de privación del derecho a conducir 87

a) La prevención especial negativa. 89

b) La prevención especial positiva 92

2.3. La realización de fines mixtos en la pena de privación del derecho a conducir 96

2.4. Toma de posición sobre los fines de la pena de privación del derecho a conducir 100

\section{CAPÍTULO 3. CONTENIDO Y ÁMBITO DE APLICACIÓN DE LA PENA DE PRIVACIÓN DEL DERECHO A CONDUCIR

3.1. Contenido de la pena de privación del derecho a conducir vehículos a motor y ciclomotores 105

3.1.1. Concepto de vehículo a motor y ciclomotor

3.1.2. Alcance de la privación del derecho a conducir vehículos a motor y ciclomotores

3.2. Ámbito de aplicación de la pena de privación del derecho a conducir vehículos a motor y ciclomotores

3.2.1. Delitos que conllevan la pena de privación del derecho a conducir vehículos a motor y ciclomotores. 128

a) Delitos contra la vida e integridad física y psíquica 129

b) Delitos contra la seguridad vial 135

3.2.2. La despenalización de las faltas por imprudencia e incidencia en la pena de privación del derecho a conducir vehículos a motor y ciclomotores.

3.3. La pérdida de vigencia del permiso o licencia (art.47.3 CP) y su relación con la pena de privación del derecho a conducir vehículos a motor y ciclomotores

3.3.1. Discusión sobre la naturaleza penal o administrativa de la pérdida de vigencia del permiso o licencia 160

3.3.2. Cómputo del plazo de los dos años 164

3.3.3. Efectos de la pérdida de vigencia del permiso o licencia 167

3.3.4. Toma de posición 171 


\section{CAPÍTULO 4. CONDICIONES DE EJECUCIÓN DE LA PENA DE PRIVACIÓN DEL} DERECHO A CONDUCIR

4.1. La ejecución ordinaria de la pena de privación del derecho a conducir vehículos a motor y ciclomotores.

4.1.1. Trámites requeridos para la ejecución de la pena.............................181

a) Entrega del permiso o licencia .................................................. 181

b) Advertencia de abstenerse de conducir ......................................... 184

c) Práctica de liquidación y comunicación a la Dirección General de Tráfico 187

d) Control por parte de la Jefatura Central de Tráfico

4.1.2. Efectos administrativos vinculados a la ejecución. La obligatoriedad de realizar el curso de sensibilización y reeducación vial 193

4.1.3. Supuesto de concurrencia de la privación del derecho a conducir con la previsión del art.47.3 CP

4.1.4. La suspensión de la ejecución de la pena de privación del derecho a conducir vehículos a motor y ciclomotores por interposición de recurso de amparo y petición de indulto

a) Supuestos de suspensión por interposición de recurso de amparo ..........205

b) Supuestos de suspensión por petición de indulto .................................209

4.2. Singularidades en la ejecución ordinaria........................................216

4.2.1. El cumplimiento fraccionado de la pena de privación del derecho a conducir vehículos a motor y ciclomotores



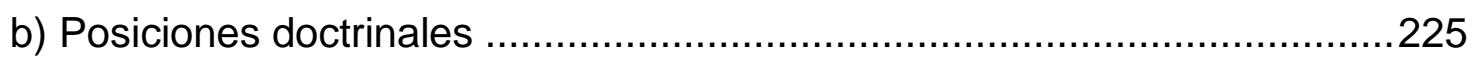

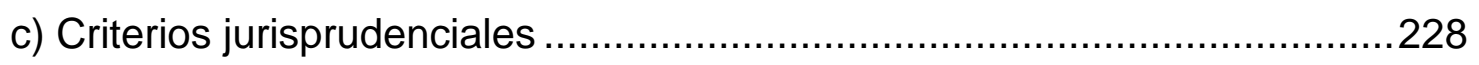

d) Modalidades de cumplimiento fraccionado .....................................235

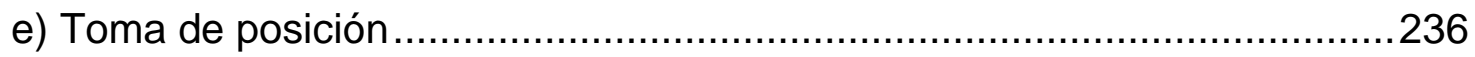

4.2.2. El cumplimiento transnacional de la pena de privación del derecho a conducir vehículos a motor y ciclomotores ..........................................240

4.3. Control de la ejecución y quebrantamiento de la pena ..........................253

\section{CAPÍTULO 5. APLICACIÓN ACUMULATIVA DE LA PENA DE PRIVACIÓN DEL DERECHO A CONDUCIR CON OTRAS SANCIONES PENALES

5.1. Aplicación acumulativa de la pena de privación del derecho a conducir con otras penas 
5.1.1. Concurrencia con la pena de prisión

a) Marco normativo y ámbito de aplicación. ................................................263

b) Cuestiones de ejecución ...................................................................270

5.1.2. Concurrencia con la pena de multa................................................279

5.1.3. Concurrencia con la pena de trabajos en beneficio de la comunidad ...284

a) Marco normativo y ámbito de aplicación ...............................................284

b) Cuestiones de ejecución ..................................................................290

5.1.4. Concurrencia de la pena de privación del derecho a conducir con la pena de inhabilitación para el ejercicio de profesión y oficio.

5.2. Concurrencia de la pena de privación del derecho a conducir y medidas de

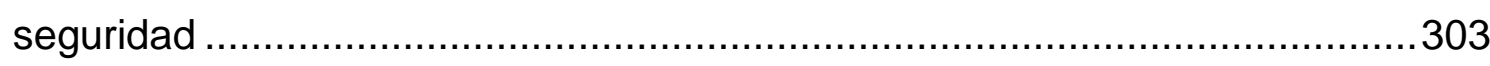

5.2.1. Concurrencia con medidas de seguridad privativas de libertad ............304

5.2.2. Las medidas de seguridad no privativas de libertad ............................306

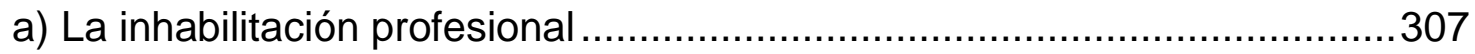

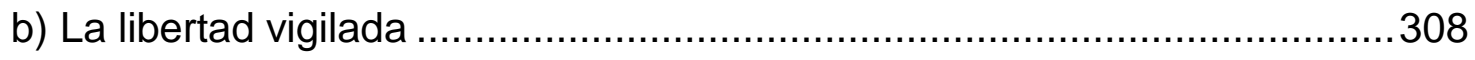

c) La medida consistente en la privación del derecho a conducir vehículos a

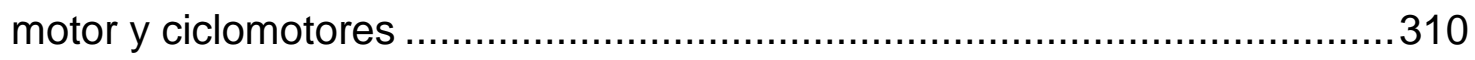

5.3. La pena de privación del derecho a conducir y el decomiso .....................311

5.3.1. Marco normativo y ámbito de aplicación ..............................................311

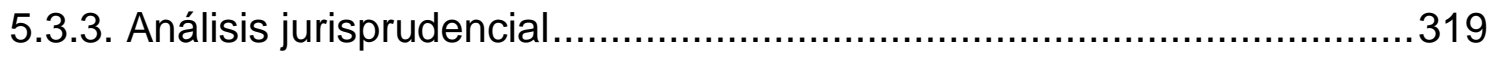

\section{CAPÍtULO 6. PROPUESTAS DE LEGE FERENDA RELATIVAS A LA APLICACIÓN Y LA EJECUCIÓN DE LA PENA DE PRIVACIÓN DEL DERECHO A CONDUCIR

6.1. Extensión de la aplicación de la pena de privación del derecho a conducir a

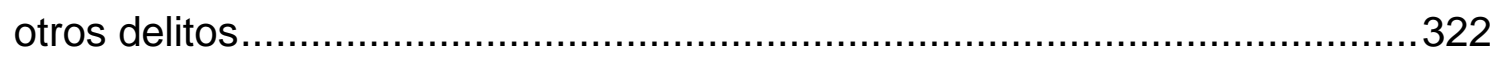

6.1.1. Delitos relacionados con la vida e integridad física y psíquica...............324

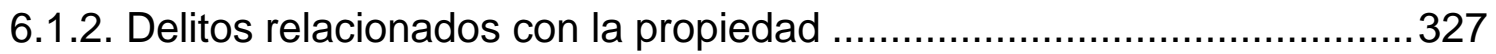

6.1.3. Delitos formales relacionados con la seguridad vial.............................328

6.1.4. Otros delitos relacionados con la seguridad vial ..................................333

6.2. Aplicación de la pena de privación del derecho a conducir a posibles nuevos tipos penales en el ámbito de la seguridad vial .................................337

6.3. Regulación de la pena de privación del derecho a conducir como pena accesoria. 
6.4. Extensión de la atenuación prevista en el art.385 ter CP a la pena de privación del derecho a conducir

6.5. Inmovilización temporal del vehículo a motor o ciclomotor por tiempo igual

a la pena de privación del derecho a conducir.

6.6. Sustitución y suspensión en la ejecución de la pena de privación del derecho a conducir 362

6.6.1. Sustitución de la pena de privación del derecho a conducir 363

6.6.2. Suspensión de la pena de privación del derecho a conducir 365

7. CONCLUSIONES 371 BIBLIOGRAFÍA 386 
SIGLAS Y ABREVIATURAS

AA.VV

AAP

AP

Art.

ATC

ATS

CE

Coord.

CGPJ

$\mathrm{CP}$

BCPP

DA

DGT

Dir.

Ed.

FGE

INE

LECrim

LO

LORPM

LOTC

LTSV

Núm.

op.cit.

pp.

$\mathrm{RD}$

RDL

RGCon

RECPC

SAP

STC

StGB

STS
Autores Varios

Auto de la Audiencia Provincial

Audiencia Provincial

Artículo

Auto del Tribunal Constitucional

Auto del Tribunal Supremo

Constitución Española

Coordinador

Consejo General del Poder Judicial

Código Penal

Borrador Código Procesal Penal de 2013

Disposición Adicional

Dirección General de Tráfico

Director

Editorial

Fiscalía General del Estado

Instituto Nacional de Estadística

Ley de Enjuiciamiento Criminal

Ley Orgánica

Ley Orgánica de responsabilidad penal del menor

Ley Orgánica del Tribunal Constitucional

Ley de Tráfico y Seguridad Vial

Número

Obra citada

Páginas

Real Decreto

Real Decreto Legislativo

Reglamento General de Conductores

Revista Electrónica de Ciencia Penal y Criminología

Sentencia de la Audiencia Provincial

Sentencia Tribunal Constitucional

Strafgesetzbuch

Sentencia Tribunal Supremo 
STSJ

TBC

TC

TS

Vid.

VMP
Sentencia Tribunal Superior de Justicia Trabajos en beneficio de la comunidad Tribunal Constitucional Tribunal Supremo vide (véase)

Vehículo de movilidad personal

\title{
BASES DE DATOS JURISPRUDENCIALES
}

\author{
ARP (Aranzadi penal) \\ EDJ (El Derecho) \\ JUR (Aranzadi Westlaw) \\ TOL (Tirantonline)
}




\section{INTRODUCCIÓN}

La sociedad occidental en los últimos 70 años ha evolucionado hacia la prosecución de mayores cuotas y objetivos de bienestar de sus miembros. Esta transformación a partir de la segunda mitad del S.XX, asociada a un mayor progreso económico y tecnológico, tuvo como finalidad que la ciudadanía lograra disponer de mayores comodidades, que se incrementara el uso de los bienes de consumo y en términos globales, pudiera mejorar su calidad de vida. Un factor relevante que coadyuvó al desarrollo económico, social y laboral de parte de la población mundial desde el siglo pasado fue la progresiva generalización del uso de los vehículos a motor y ciclomotores entre los sectores sociales conocidos como clase media. La adquisición de un vehículo, además de contribuir al progreso global de sus propietarios, era una evidencia de la prosperidad económica y del éxito social de los mismos, siendo valorado en ocasiones como un logro equiparable a un trofeo.

Como todo avance tecnológico, la universalización del uso de los vehículos a motor y ciclomotores entre la población originó riesgos hasta entonces inexistentes, problemáticas a las que había que dar respuesta y disfunciones motivadas por la presencia de un nuevo elemento con el que había que convivir en los caminos, carreteras, pueblos y ciudades. La utilización negligente o peligrosa de los vehículos por parte de los conductores generaba situaciones de peligro y, en ocasiones, se producían lesiones y fallecimientos, siendo éstas unas consecuencias que la sociedad no estaba dispuesta a tolerar.

Debido al incremento de vehículos a motor y ciclomotores, y con el objetivo de intentar minimizar la materialización de los riesgos asociados a la utilización de los mismos, fue necesario regular su empleo a través de la aprobación de normas y límites que adecuaran su empleo al entorno. Para alcanzar dicho objetivo se dispuso una ordenación esencialmente administrativa complementada por el Derecho Penal, que estaba reservado para sancionar aquellos comportamientos más graves. Partiendo de esta génesis, hemos de señalar que algunas conductas realizadas con un vehículo a motor o ciclomotor, durante años, pudieron ser sancionadas bien por el Derecho Administrativo sancionador bien por el Derecho Penal. La coexistencia de este doble ámbito regulador y sancionador de la actividad vial determina que entre las cuestiones que necesariamente se abordan en este trabajo figure la de analizar los ámbitos propios de actuación del Derecho Administrativo sancionador en materia de seguridad vial y del Derecho Penal en lo relativo a los delitos cometidos con vehículos a motor y ciclomotores, en particular 
en relación con la regulación en ambas jurisdicciones de la privación temporal del derecho a conducir.

La intervención del Derecho Penal en el ámbito de la seguridad vial viene determinada por dos elementos sustanciales, a saber, la tipificación de determinadas conductas vinculadas con la conducción peligrosa, y, por otro lado, la creación de una sanción específica asociada a la conducción de vehículos de motor. Fue en el año 1958 cuando la privación del permiso de conducir se incorporó al catálogo de penas del Código Penal común para sancionar a los autores de determinados ilícitos cometidos con la utilización de un vehículo de motor. La elevación de esta sanción a la categoría de pena a través de su inclusión en el Código Penal común fue la constatación de un incremento de infracciones viales, así como de la ineficacia de las sanciones gubernativas que se imponían por la Administración en este tipo de acciones.

Nuevamente, en la primera década del S. XXI se produjo un punto de inflexión en la política criminal española relacionada con la seguridad vial. Después de unas décadas que se caracterizaron por un elevado número de fallecidos y lesionados en hechos relacionados con la utilización de vehículos a motor y ciclomotores, la sociedad pasó de una cierta resignación y aceptación de la siniestralidad vial a una posición de tolerancia cero hacia conductas peligrosas. Se acuñó el término violencia vial y ésta, junto a la violencia de género, pasó a ocupar un lugar prioritario en la agenda del legislador, que decidió incrementar la respuesta penal de forma contundente a través de una reforma en profundidad de lo que entonces se conocía como delitos contra la seguridad del tráfico, consolidando una mayor intervención del sistema penal en este ámbito. Con la entrada en vigor de la LO 15/2007 de 30 de noviembre, se reformó el Código Penal (en adelante $C P$ ) en el sentido de aumentar los delitos contra la seguridad vial y también las penas de privación del derecho a conducir. Ello conllevó, entre otras novedades, la elevación a la categoría de delitos de lo que hasta entonces eran meras sanciones administrativas con la finalidad de evitar que determinadas conductas relacionadas con la violencia vial quedaran impunes. Algunas de las consecuencias inmediatas de la reforma fueron el aumento de condenas por delitos relacionados con la seguridad vial y la consecuente aplicación de la privación del derecho a conducir vehículos a motor y ciclomotores.

A pesar de que el legislador siguió en la primera década del siglo XXI una férrea política criminal en materia de seguridad vial, lo cierto es que persisten algunas cuestiones concretas relacionadas con la pena de privación del derecho a conducir 
que no han sido suficientemente desarrolladas. Determinados aspectos relevantes de la misma, relativos tanto a su naturaleza y ámbito de aplicación como a su régimen de ejecución adolecen de déficits e inconcreciones importantes que repercuten, en demasiadas ocasiones, en un funcionamiento inadecuado. Hasta el momento, ni el legislador ni la jurisprudencia han abordado y resuelto algunas cuestiones que van a ser objeto de análisis pormenorizado en las próximas páginas. En este sentido, el principal objetivo de este trabajo es concretar el estado actual en el que se encuentra la pena de privación del derecho a conducir vehículos a motor y ciclomotores en el sistema penal español y detectar aquellos aspectos de su regulación que podrían ser mejorados en aras a optimizar su aplicación y ejecución.

El interés personal por la investigación de la pena de privación del derecho a conducir está estrechamente vinculado con la relevancia que la misma ha adquirido en la praxis judicial en los últimos años, especialmente tras la entrada en vigor de la LO 15/2007 de 30 de noviembre de reforma del CP. La pena objeto de estudio es una de las que más se impone, y ello se acredita con los datos de los últimos siete años recogidos en las Memorias de la Fiscalía General del Estado (en adelante FGE) así como por el Instituto Nacional de Estadística (en adelante INE). En el año 2012 fueron aproximadamente 71.000 las penas privativas del derecho a conducir impuestas; en el año 2013 fueron 58.637; en el año 2014 fueron 66.575; en el año 2015 fueron 57.313; en el año 2016 fueron 55.148; en el año 2017 fueron 55.890; en el año 2018 fueron 60.400 y en el año 2019 fueron 52.028. Cabe señalar que en dichos cómputos no aparecen las penas impuestas tanto en los delitos de homicidio y lesiones por imprudencia cometidas con vehículo a motor, por lo que los datos serían incluso más elevados ${ }^{1}$. Otra estadística, en este caso la elaborada por el Instituto Nacional de Estadística, difiere ligeramente de los datos anteriores y determina que las penas de privación del derecho a conducir impuestas en el año 2013 fueron 72.197; en el año 2014 fueron 68.017; en el año 2015 fueron 61.359; en el año 2016 fueron 61.163; en el año 2017 fueron 61.516; en el año 2018 fueron 61.441 y en el año 2019 se impusieron 62.088 penas $^{2}$. Si bien entre los años 2013 y

\footnotetext{
1 Vid. Memoria de la Fiscalía General del Estado del año 2013, p.405; del año 2014, p.432; del año 2015, p.483; del año 2016, pp.526-527; del año 2017, pp.583-584; del año 2018, p.665; del año 2019, p.876 y del año 2020, p.913.

2 Vid. la estadística en www.ine.es (último acceso: 1/11/2020). Además, partiendo de los datos publicados por el INE relativos a penas impuestas, se ha establecido el porcentaje que supone la pena de privación del derecho a conducir respecto el total de penas impuestas cada año. Así, en el año 2013, la pena analizada supuso el $11,8 \%$ de las penas impuestas; en el año 2014, el $11 \%$; en el año 2015, el 9,9 \%, en el año 2016 el 8,8\%; en el año 2017 el 8,37 \%; en el año 2018, el 8,2\% y en el año 2019, el $8 \%$. Tras el análisis de estos datos, parece evidenciarse que el peso de esta sanción en el conjunto de penas impuestas disminuye en los últimos años, pero a pesar ello sigue siendo la cuarta pena que más se aplica por los Juzgados y Tribunales.
} 
2015 hubo un pronunciado descenso en el número de penas de este tipo impuestas, lo cierto es que a partir del año 2015 existe una tendencia a la estabilización en las 61.000 penas de privación del derecho a conducir que se acuerdan cada año por los Juzgados y Tribunales.

A partir de los datos que aporta el informe "Seguridad Vial y su incidencia en el ámbito penitenciario"3 ${ }^{3}$ elaborado por el Ministerio del Interior y presentado en el mes de julio de 2020, se constata la relevancia de la delincuencia vial en la actualidad. En el año 2018, el 34\% del total de las sentencias dictadas por todos los delitos fueron sentencias relacionadas con la seguridad vial. Además, el referido informe verifica la importante reducción del número de víctimas mortales de accidentes de tráfico en los últimos treinta años, ya que se ha pasado de las 9.344 personas fallecidas en 1989 a 1.806 en el año 2018. Sin embargo, no es de justicia atribuir únicamente la reducción de víctimas a las reformas legislativas realizadas en el ámbito de la seguridad vial en los últimos quince años, ya que hay otros factores que han podido coadyuvar a este descenso (la mejora de la red viaria, las innovaciones tecnológicas en los vehículos y la renovación de los mismos, la realización de cursos de formación, mayor control policial, etc.).

El elevado número de casos relacionados con la seguridad vial que a diario se ven en los Juzgados, y en los que se aplica la pena de privación del derecho a conducir, no se corresponde con la escasa atención que ha recibido por parte de la doctrina y jurisprudencia. Como sucede con tantas otras penas no privativas de libertad, la pena de privación del derecho a conducir no ha sido objeto de un análisis pormenorizado como el que se ha dispensado a las penas privativas de libertad y a sus sustitutivos. Sin embargo, la praxis muestra que se trata de una pena que implica una importante afectación a las personas condenadas y que además puede desarrollar un papel relevante para la protección de todos los actores relacionados con la seguridad vial como conductores, peatones o ciclistas y que pueden resultar potencialmente afectados de forma grave por una conducción negligente o temeraria.

En cuanto a la metodología utilizada para llevar a cabo esta investigación, la misma se ha centrado en la búsqueda y análisis de la doctrina especializada en las penas privativas de derechos en general, y de forma particular de la que se ha ocupado de la pena de privación del derecho a conducir. También se ha acudido a la doctrina de

\footnotetext{
3 Vid. el informe en: http://www.dgt.es/Galerias/prensa/2020/07/INFORME-SEGURIDAD-VIAL-Y-SUINCIDENCIA-EN-EL-AMBITO-PENITENCIARIO ultimo.pdf (último acceso: 02/11/2020)
} 
referencia en el ámbito de los delitos contra la seguridad vial y los delitos contra la vida e integridad física o psíquica cometidos con vehículo a motor y ciclomotor, al ser las dos tipologías delictivas en las que se impone la pena objeto de este estudio. Asimismo, un aspecto importante a nivel metodológico ha sido el análisis pormenorizado de la jurisprudencia que ha examinado la pena de privación del derecho a conducir en aras a definir la aplicación de esta pena por nuestros tribunales. La revisión jurisprudencial ha sido especialmente relevante en sede de ejecución penal, atendiendo a cuestiones de gran incidencia práctica como son, entre otras, la posibilidad de suspensión, sustitución, fraccionamiento, e incluso el indulto. Hay que señalar que el trabajo se ha centrado en el estudio exhaustivo de la regulación española de la pena de privación del derecho a conducir, por lo que las referencias a la presencia de esta pena en otros ordenamientos jurídicos son puntuales.

Con relación a la estructura de la tesis, ésta se lleva a cabo en seis capítulos, que permiten una visión global de la pena de privación del derecho a conducir no sólo desde una vertiente teórica sino también dotando de una especial importancia al análisis de todo lo relativo a su aplicación. De esta forma, partiendo de los antecedentes históricos de la sanción, se realiza un estudio pormenorizado de todos los aspectos relacionados con la misma, con valoraciones de la política criminal en materia de seguridad vial instaurada por el legislador en las dos últimas décadas, todo ello con el objetivo de detectar aquellas cuestiones que pueden contribuir a mejorar la evolución que pueda tener dicha pena en un futuro.

El primer capítulo tiene como principal objetivo determinar la naturaleza jurídica de la privación del derecho a conducir. Para ello se analizan los diversos ámbitos en los que dicha privación tiene previsto su campo aplicativo, lo que obliga a referirnos, en primer lugar, a su configuración como sanción penal, a su previsión como pena privativa de derechos y como pena principal. Asimismo, en el capítulo se realizan otras dos referencias obligadas a la privación del derecho a conducir relativas a la posibilidad de ser aplicada como medida cautelar y como medida de seguridad. Con la finalidad de detallar en el ámbito penal todos los ámbitos en los que se contempla la privación del derecho a conducir, también se examina su regulación y aplicación en el Derecho Penal Juvenil y se realiza una comparativa con la regulación en adultos. En segundo lugar, me refiero a la privación del derecho a conducir como sanción administrativa, con una mención especial a la Ley 17/2005 de 19 de julio por la que se reguló el permiso y la licencia de conducción por puntos y a la influencia que esta norma pudo tener en la regulación y aplicación de la privación del derecho a conducir. A la vista de las consideraciones realizadas, el capítulo 
finaliza con la toma de posición respecto a la naturaleza jurídica que puede atribuírsele a la sanción en la actualidad.

El segundo capítulo de este trabajo se configura como elemento previo, si bien necesario, para un conocimiento en profundidad de esta sanción en cuanto pena privativa de derechos. Para ello, el capítulo se destina a analizar en qué medida la pena de privación del derecho a conducir participa de las doctrinas relativas a los fines de la pena. Se ha tratado de identificar los fines retributivos y preventivos que están asociados a la pena analizada. La investigación permite constatar como la pena participa de la finalidad retributiva y permite expresar el castigo al autor de la infracción en términos de proporcionalidad con la gravedad del delito cometido. Además, la pena puede ser configurada para dar respuesta a los fines de carácter preventivo pues con su aplicación pretende evitar que se cometan nuevos delitos relacionados con la seguridad vial tanto por parte del penado como por el resto de la ciudadanía.

El tercer capítulo de la tesis se dedica al análisis en profundidad del contenido de la pena de privación y del ámbito de aplicación de la misma en el CP. De ambas cuestiones se ofrece un estudio de las características esenciales que definen su contenido y duración precisando los aspectos que pueden resultar más problemáticos, entre los que destaca la determinación del concepto de vehículo a motor y ciclomotor. En este capítulo, adquiere una especial importancia la identificación de los tipos penales que actualmente prevén la aplicación de la pena de privación del derecho a conducir. Este análisis no comprende una revisión en profundidad de todos los delitos contra la seguridad vial, cuestión que ha sido ya abordada por otros autores y que no responde a los fines de este trabajo, sino que se centra en aquellos delitos contra la vida e integridad física o psíquica, así como contra la seguridad vial en los que se prevé la aplicación de la pena de privación del derecho a conducir. Para finalizar el capítulo, se estudia la consecuencia prevista en el art. 47.3 CP que supone la pérdida de vigencia del permiso o licencia para conducir y, que es una previsión de aplicación imperativa cuando la pena de privación del derecho a conducir supera los dos años de duración. Se trata de una previsión de gran importancia práctica y por ello se dedica un apartado completo en el que se realiza un exhaustivo estudio doctrinal y jurisprudencial del art.47.3 CP desde una visión eminentemente práctica.

El cuarto capítulo de esta investigación analiza las cuestiones vinculadas a la ejecución de la pena de privación del derecho a conducir vehículos a motor y ciclomotores. En primer lugar, se hace referencia a la ejecución ordinaria de la pena 
con especial énfasis en el control mixto penal-administrativo de la misma, detallándose los trámites previstos y la obligatoriedad de realizar el curso de sensibilización y reeducación vial. Asimismo, se analiza la ejecución de la pena de privación del derecho a conducir cuando concurre el art. 47.3 CP y la posibilidad que la pena quede en suspenso y no se ejecute mientras se tramitan tanto el recurso de amparo como la petición de indulto. De ambas cuestiones se ofrece un amplio análisis jurisprudencial. En la segunda parte del capítulo se examinan dos singularidades en el cumplimiento de la pena de privación del derecho a conducir. Por un lado, se dedica una especial atención desde una óptica doctrinal y jurisprudencial a un tema de gran incidencia práctica como es la posibilidad de solicitar su cumplimiento fraccionado. $Y$ por otro lado se analiza también la posibilidad del cumplimiento transnacional de la pena, centrando la cuestión en el ámbito de la Unión Europea dada la previsión de libre circulación y la movilidad que existe dentro del espacio comunitario. Uno de los aspectos esenciales de toda pena es que sea eficaz en relación con los fines que persigue su aplicación, y para ello, es necesario que se cumpla correctamente por parte de los penados. Por este motivo, el capítulo cuarto finaliza con el estudio del control de la ejecución y los posibles quebrantamientos relacionados con la pena de privación del derecho a conducir, y en especial la respuesta punitiva que el CP prevé para estas conductas.

Se dedica el quinto capítulo al análisis de los supuestos en que la pena de privación del derecho a conducir puede ser aplicada de forma acumulativa con otras sanciones penales, tales como la prisión, la multa o los trabajos en beneficio de la comunidad (en adelante TBC). Para ello, se determina el marco normativo en el que se producen estos supuestos y se analiza ampliamente la ejecución conjunta de las diversas sanciones penales con la pena objeto del estudio. Asimismo, se detallan los problemas que puede comportar la aplicación conjunta de la pena de privación del derecho a conducir y la pena de inhabilitación para la profesión u oficio cuando el delito cometido está relacionado con la utilización de vehículos a motor y ciclomotores. Por otra parte, en este capítulo se destina un apartado a analizar la posibilidad que la pena de privación del derecho a conducir concurra con una medida de seguridad, tanto las privativas de libertad como las no privativas de libertad, precisando en qué supuestos procederá la aplicación conjunta de ambas sanciones penales y cómo deberá afrontarse su ejecución. En el último apartado del capítulo quinto se aborda la aplicación conjunta de la pena de privación del derecho a conducir con la consecuencia accesoria del decomiso, dado que tiene especial incidencia en los delitos relacionados con la utilización de vehículos a motor y ciclomotores 
Finalmente, en el capítulo sexto se presentan diferentes propuestas de lege ferenda relacionadas con la pena de privación del derecho a conducir, con la finalidad de mejorar su regulación, aplicación, y ejecución. Las propuestas que se plantean son de diversa índole y se ha intentado que todas ellas puedan ser calificadas como factibles. Para implementar algunas se precisarían reformas legislativas sencillas. Sin embargo, otras sí necesitarían una dotación presupuestaria importante, lo que hace atisbar que tengan una mayor dificultad para que se puedan aprobar a corto 0 medio plazo. Entre las propuestas que se plantean destaca la de extender la pena de privación del derecho a conducir a otros delitos relacionados con la seguridad vial que en la actualidad no prevén su imposición, así como introducir su aplicación a posibles nuevos tipos penales. Por otra parte, también se explora en este capítulo la posibilidad de regular la pena objeto de estudio como pena accesoria con el fin de mejorar la aplicación de la misma, dado que en la actualidad sólo está prevista como pena principal. Asimismo, se formula una propuesta consistente en la inmovilización temporal del vehículo a motor o ciclomotor por tiempo igual a la condena de la pena de privación del derecho a conducir y en el ámbito de la ejecución penal, se proponen reformas legislativas en el sentido de profundizar en dos opciones como la sustitución y la suspensión de la pena de privación del derecho a conducir.

Las conclusiones más relevantes alcanzadas mediante la investigación se exponen en el último capítulo, al que se ha llegado tras el estudio integral de la pena de privación del derecho a conducir. 


\section{CAPÍTULO 1. NATURALEZA JURÍDICA DE LA PRIVACIÓN DEL DERECHO A CONDUCIR}

Este capítulo tiene como objetivo analizar la naturaleza jurídica de la privación del derecho a conducir. Para el desarrollo del mismo se tomará en consideración la presencia de esta sanción tanto en el Derecho Penal como en el Derecho Administrativo sancionador, al ser los dos ámbitos en los que ha sido aplicada. El debate relativo a la naturaleza jurídica de la privación del derecho a conducir ha estado presente desde el inicio de la cohabitación de esta sanción en los ámbitos administrativo y penal, con mayor intensidad tras las reformas operadas en la normativa relacionada con la seguridad vial desde hace más de una década.

El punto de partida para examinar la naturaleza jurídica de la privación del derecho a conducir será el análisis histórico de las normas administrativas y penales que han tipificado las diversas infracciones cometidas con vehículos a motor y ciclomotores, por lo que se realizará una breve referencia a la normativa esencial que ha regulado esta privación de derechos como sanción administrativa y como pena. Para ello, iniciaremos el estudio en el ámbito penal y determinaremos la naturaleza de la privación del derecho a conducir en tanto que pena privativa de derechos y pena principal. Además, definiremos la regulación de la medida cautelar de privación del permiso de conducir y su relación con la pena objeto del estudio, así como analizaremos la medida de seguridad que priva del derecho a conducir. El último ámbito penal que se estudia es la jurisdicción penal de menores, y a tal efecto se realiza un examen del funcionamiento de la privación del derecho a conducir y sus principales diferencias con la jurisdicción de adultos.

Después de examinar la privación del derecho a conducir en el ámbito penal, perfilaremos su contenido en el Derecho Administrativo sancionador. Para ello, se determinará su situación actual en el ámbito administrativo y se hará especial referencia a la Ley 17/2005, de 19 de julio por la que se regula el permiso y la licencia de conducción por puntos y se modifica el texto articulado de la ley sobre tráfico, circulación de vehículos a motor y seguridad vial, que regula el denominado "carnet por puntos", concretando la influencia que esta norma ha tenido en la interacción penal-administrativa en relación con la privación del derecho a conducir vehículos a motor y ciclomotores.

En último lugar, nos posicionaremos en relación con la naturaleza jurídica de la privación del derecho a conducir vehículos a motor o ciclomotores. 


\subsection{Antecedentes de la privación del derecho a conducir en la legislación penal y administrativa}

El primer apartado del capítulo está dedicado a realizar un breve análisis de la evolución histórica que ha tenido la privación del derecho a conducir en la legislación penal y administrativa española, con la finalidad de precisar la naturaleza penal y administrativa que tiene dicha privación en la actualidad. Para ello, destacaremos las principales normas, textos y Códigos en los que ha estado regulada dicha privación, bien como sanción administrativa bien como sanción penal, desde principios del siglo XX hasta la actualidad.

La normativa reguladora española en materia de tráfico se desarrolló entre final del siglo XIX y principios del siglo XX de forma exclusiva en el ámbito administrativo ${ }^{4}$, donde se reglamentaron las conductas relacionadas con la seguridad vial, careciendo de relevancia en este primer momento la ordenación a través del Derecho Penal ${ }^{5}$. No es hasta el Código Penal de 1928 cuando hallamos una primera referencia a los delitos relacionados con el tráfico viario ${ }^{6}$ aunque se produjo la derogación de este Código en el año 1932 y, posteriormente, el CP7 de 1944 no

\footnotetext{
${ }^{4}$ La normativa administrativa que reguló en sus inicios los temas viarios fue en primer lugar la Real Orden de 31 de julio de 1897 sobre la circulación por carreteras de vehículos no movidos por fuerza animal. Vid. DE VICENTE MARTÍNEZ, Rosario, Alcohol, drogas y delitos contra la seguridad vial, Ed. Reus, Madrid, 2018, p.13. Posteriormente entraron en vigor el Reglamento para el Servicio de Coches Automóviles por las Carreteras del Estado, aprobado el 17 de septiembre de 1900, el Reglamento para la Circulación de vehículos con motor mecánico por las vías públicas de España, de 23 de julio de 1918 y el Decreto de 25 de septiembre de 1934 por el que se aprueba el Código de la Circulación. Vid. HIDALGO DE MORILLO JIMÉNEZ, Agustín, "Aspectos comunes a los delitos contra la seguridad vial", La dogmática pena sobre el asfalto: un enfoque práctico de los delitos contra la seguridad vial, AGÜERO RAMÓN-LLIN, Elena/HIDALGO DE MORILLO JIMÉNEZ, Agustín/ LANZAROTE MARTíNEZ, Pablo/ PRIETO GONZÁLEZ, Helena María, Ed. Comares, Granada, 2012, p.5.

${ }^{5}$ Sobre la exclusividad del Derecho Administrativo para regular la seguridad del tráfico en la primera mitad del S.XX, vid. DE VICENTE MARTínEZ, Rosario, Derecho Penal de la Circulación, Ed. Bosch, Barcelona, 2008, 2ª edición revisada, p. 297.

6 Podemos citar a tal efecto el art.574 que sancionaba a quien "condujere los vehículos o aparatos de locomoción para cuya conducción se necesite aptitud determinada, sin certificación que acredite ésta", y el art.575, que penalizaba a los conductores:" $2^{\circ}$.- por marchar el vehículo por lugar no destinado al tránsito del mismo; $3^{\circ}$.- por marchar con velocidad excesiva; $4^{\circ}$ - por marchar conducido sin la debida atención de su conductor adecuada al peligro del tránsito". Vid. JARAMILLO GARCÍA, Antonio, Novísimo Código Penal comentado y cotejado con el de 1870, Volumen II, Imprenta Silvestre Ferreira, Salamanca, 1928, pp.242-243.

7 Fue aprobado por el Decreto de 23 de diciembre de 1944 por el que se aprueba y promulga el <<Código Penal, texto refundido de 1944>>, según la autorización otorgada por la Ley de 19 de julio de 1944.
} 
contemplaba esta materia ${ }^{8}$. En los años posteriores se intentó agrupar las conductas infractoras relacionadas con la conducción de vehículos a motor en un único texto legal, la Ley sobre Uso y Circulación de Vehículos a Motor de 9 de mayo de 1950, ley penal especial conocida como "Ley del Automóvil"9 que sirvió de base para la posterior Ley 122/1962 de 24 de diciembre de 1962, sobre uso y circulación de vehículos a motor ${ }^{10}$.

En lo que respecta a la primera referencia a la privación del permiso de conducir como pena ésta la hallamos en el año 1958 cuando se introdujo en el catálogo de penas del CP común como pena accesoria, a través de la Ley 24 de abril de 1958 por la que se modificaron determinados artículos del Código Penal ${ }^{11}$. Posteriormente, mediante la reforma del CP del año 1963, esta pena se configuró ya como pena principal y grave ${ }^{12}$, ex art.27 $\mathrm{CP}^{13}$.

\footnotetext{
${ }^{8}$ Sin embargo, sí existe en el art.565 CP de 1944 una referencia a la "... privación del permiso para conducirlos...", en referencia a los vehículos de motor, así como también se hace mención a la retirada definitiva del permiso de conducción. Vid. la Consulta de la FGE núm. 13/1985: La pena de privacion del permiso de conducir en concurrencia con las de arresto mayor o multa directa: su problematica degradabilidad.
}

Disponible en: https://www.fiscal.es/memorias/estudio2016/PDF/CONS/CON 13 1985.pdf (último acceso: 02/11/2020).

Acerca de la evolución de los delitos relacionados en el tráfico viario vid. VALLESPÍN PÉREZ, David, Aspectos procesales de los delitos contra la seguridad vial, Ed. Bosch, Barcelona, 2011, p.15.

${ }^{9}$ Esta ley penal especial es la primera que regula de forma específica los delitos relacionados con la utilización de vehículos a motor. En este sentido vid. MINGORANCE SÁNCHEZ, José Antonio, "La seguridad vial en el ordenamiento penal: justificación y crítica", Revista de Derecho UNED, no 202017, pp.431-422. Junto a esta ley penal especial se aplicaba de forma supletoria el Código Penal. Vid. CUELLO CALÓN, Eugenio, Ley penal del automóvil, Ed. Bosch, Barcelona, 1950, pp.22-23. También podemos destacar que el artículo 11 de la conocida como "Ley del Automóvil", hacía referencia a la privación del permiso de conducir, pero no a título de pena.

10 Vid. DE VICENTE MARTÍNEZ, Rosario, Alcohol, drogas..., op.cit., pp.15-16.

11 Referente a la introducción de la pena de privación del derecho a conducir, vid. TAMARIT SUMALLA, Josep/ LUQUE REINA, Mํㅡㄹ Eulàlia, Automóviles, delitos y penas. Estudio de la criminalidad y de las sanciones penales relacionadas con los vehículos a motor, Ed. Tirant lo Blanch, Valencia, 2007, p.127; RODRÍGUEZ MORO, Luis, "La pena de privación del derecho a conducir vehículos a motor y ciclomotores", en AA.VV. Las penas privativas de derechos y otras alternativas a la privación de libertad, FARALDO CABANA, Patricia/ PUENTE ABA, Luz María (Dirs.), Ed. Tirant lo Blanch, Valencia, 2013, p.229 y DE VICENTE MARTíNEZ, Rosario, Siniestralidad vial, delitos imprudentes y fuga, Ed. Reus, Madrid, 2019, p.90. Puede comprobarse el texto de la Ley en: https://www.boe.es/datos/pdfs/BOE//1958/099/A00738-00739.pdf (último acceso: 13/11/2020).

12 Vid. Decreto 691:1963, de 28 de marzo, por el que se aprueba el $<<$ Texto revisado de 1963>> del Código Penal. Vid. el texto de la Ley en: https://www.boe.es/boe/dias/1963/04/08/pdfs/A0587105907.pdf (último acceso: 13/11/2020).

13 Vid. MONER MUÑOZ, Eduardo, Aspectos y problemas de la pena de privación del permiso de conducir, Ed. Universidad de Valencia, Facultad de Derecho, Valencia, 1976, p.10 y CUELLO CONTRERAS, Joaquín/ MAPELLI CAFFARENA, Borja, Curso de derecho penal: Parte general, Ed. Tecnos, Madrid, 2015, p. 334. 
En el año 1967, la aprobación de la Ley 3/1967 de 8 de abril ${ }^{14}$, tuvo incidencia en la privación del derecho a conducir, ya que en el art.565 se establecía la pena de privación del derecho a conducir con una duración de tres meses y un día a diez años, así como la pérdida definitiva del permiso de conducción por acumular dos privaciones temporales ${ }^{15}$. Asimismo, se establecía que la pena sería calificada como grave o leve en función de su duración, si era mayor o menor de tres meses. En la propia exposición de motivos, se apuntaba la importancia que habían adquirido los hechos cometidos en la circulación de vehículos a motor y la necesidad de regulación en el CP en lugar de estar sancionados en leyes penales especiales $^{16}$.

El punto de inflexión que supuso la entrada en vigor de esta ley es fundamental para determinar la naturaleza jurídica de la actual pena de privación del derecho a conducir, ya que a partir de dicha fecha las conductas relacionadas con la circulación de vehículos no tenían su incardinación exclusiva en el Derecho Administrativo sancionador, sino que se implementaron también en el CP ${ }^{17}$. Tras la reforma operada en el año 1967, conductas que hasta ese momento estaban reguladas en una ley penal especial, la Ley sobre Uso y Circulación de Vehículos a Motor de 9 de mayo de 1950 o la Ley 122/1962 de 24 de diciembre de 1962, sobre uso y circulación de vehículos a motor, pasaron a estar integradas directamente en la estructura del CP. En este sentido, mediante la Ley 3/1967 de 8 de abril, se culminó la progresiva incorporación al CP de las conductas originadas con la circulación de vehículos a motor que hasta entonces en su mayor parte habitaban en la normativa administrativa viaria ${ }^{18}$. Por lo tanto, se produce una verdadera cohabitación de la privación del derecho a conducir tanto en el ámbito penal como

\footnotetext{
14 Ley sobre modificación de determinados artículos del Código Penal y de Ley de Enjuiciamiento Criminal, que derogó los apartados penal y procesal penal de la Ley 122/1962 de 24 de diciembre de 1962, sobre uso y circulación de vehículos a motor. A través de esta Ley se incorporaron al Código Penal los delitos contra la seguridad del tráfico. Vid. DE VICENTE MARTíNEZ, Rosario, Derecho... op.cit., p.301 y también HENRÍQUEZ RODRÍGUEZ, Francisco Javier, "Los accidentes de circulación y su relación con los delitos contra la seguridad del tráfico", en AA.VV. La reforma de la justicia penal (Estudios en homenaje al Prof. Klaus Tiedemann), GÓMEZ COLOMER, Juan Luis/ GONZÁLEZ CUSSAC, José Luis (Coords.) Publicacions de la Universitat Jaume I, Castelló de la Plana, 1997, p.520.

15 Vid. el texto de la Ley en: https://www.boe.es/diario boe/txt.php?id=BOE-A-1967-5578 (último acceso: 13/11/2020).

16 Vid. HIDALGO DE MORILLO JIMÉNEZ, Agustín, "Aspectos comunes a los delitos contra la seguridad vial", La dogmática penal..., op.cit., p.6.

17 En relación con la importancia de la reforma del año 1967, vid. FERNÁNDEZ PANTOJA, Pilar, "Delitos contra la seguridad del tráfico: la pena de privación del derecho a conducir", en AA.VV. Delincuencia en materia de tráfico y seguridad vial. Aspectos penales, civiles y procesales, MORILLAS CUEVA, Lorenzo (Coord.), Ed. Dykinson, Madrid, 2007, p.68.
} 
en el ámbito administrativo ${ }^{19}$. La pena de privación del derecho a conducir se mantuvo en el Texto Refundido del Código Penal, aprobado mediante el Decreto $3096 / 1973$ de 14 de septiembre ${ }^{20}$, donde aparece regulada en el art.42 párrafo 3‥ Posteriormente se incorporó al CP de 1995, aprobado mediante la LO 10/1995 de 23 de noviembre.

Los intentos por controlar los riesgos generados por el tráfico viario utilizando el CP han llegado hasta nuestros días y las reformas operadas en el CP por la LO 15/2007 de 30 de noviembre, la LO 5/2010 de 22 de junio y la LO 2/2019 de 1 de marzo, han seguido la tendencia de una mayor criminalización de las conductas que atentan contra la normativa viaria. En concreto, con la entrada en vigor de la LO 15/2007, de 30 de noviembre, la privación del derecho a conducir como pena adquirió mayor importancia debido al incremento punitivo de los delitos relacionados con la seguridad vial que conllevan su imposición imperativa por los Tribunales ${ }^{21}$. Por consiguiente, desde la incorporación de la pena de privación del permiso para conducir en el CP del año 1958 hasta la actualidad, la privación del derecho a conducir se ha mantenido en todos los CP posteriores y las diferentes modificaciones que se han efectuado en el catálogo de las penas privativas de derechos ${ }^{22}$.

A todo lo expuesto hemos de añadir que, en el ámbito administrativo, el texto de referencia en los últimos treinta años ha sido Ley de Tráfico y Seguridad Vial, aprobada por Real Decreto Legislativo (en adelante $R D L$ ) 339/1990 de 2 de marzo, por el que se aprueba el texto articulado de la Ley sobre Tráfico, Circulación de Vehículos a Motor y Seguridad Vial (en adelante LTSV). Dicha ley regula diversos

\footnotetext{
18 Vid. DE VICENTE MARTÍNEZ, Rosario, Derecho... op.cit., pp.38-39.

${ }^{19}$ Sobre la tipificación de las sanciones relacionadas con los vehículos a motor en el ámbito penal y administrativo y sus variaciones históricas, vid. VALLESPÍN PÉREZ, David, Aspectos procesales..., op.cit., p.15.

20 Recurso electrónico disponible en: http://www.boe.es/buscar/doc.php?id=BOE-A-1973-1715 (último acceso: 13/11/2020).

${ }^{21}$ El preámbulo de la LO 15/2007 de 30 de noviembre establece como finalidad de la reforma que: "...evitando que determinadas conductas calificadas como de violencia vial puedan quedar impunes", lo que originó que la pena de privación del derecho a conducir fuera una de las herramientas que el legislador utiliza para ello. Podemos señalar que la referida LO 1/2007 de 30 de noviembre ha sido considerado como uno de los instrumentos jurídicos más importantes para la mejora de la seguridad vial tal como ha destacado MINGORANCE SÁNCHEZ, José Antonio, "La seguridad vial...", op.cit., p.429.

22 En relación con la plena consolidación de dicha pena en el CP, vid. DÍEZ RIPOLLÉS, José Luis, "La evolución del sistema de penas en España 1975-2003", Revista Electrónica Ciencia Penal y Criminología, (RECPC), 08-07, (2006), p.5. Recurso electrónico disponible en: http://criminet.ugr.es/recpc/08/recpc08-07.pdf (último acceso: 02/11/2020).
} 
aspectos relacionados con la seguridad vial, entre otros, las competencias entre Administraciones, las normas de circulación, infracciones y sanciones. Esta ley ha sido sometida a dos reformas importantes. Por un lado, la efectuada mediante la Ley 17/2005 de 19 de julio por la que se regula el permiso y la licencia de conducción por puntos y por otro lado la Ley 18/2009 de 23 de noviembre en materia sancionadora ${ }^{23}$. Estas dos leyes determinaron la desaparición de la privación del derecho a conducir como sanción administrativa, tras muchos años en que la privación del derecho a conducir estuvo incardinada en dos órdenes jurídicos diferentes. La reforma de la normativa administrativa en los años 2005 y 2009 supuso que la privación del derecho a conducir quedara restringida al ámbito penal como sanción para los delitos relacionados con la seguridad vial.

Después de más de quince años de las reformas legales penales y administrativas implementadas en el ámbito de la seguridad vial desde el año 2005, el legislador español ha reafirmado el carácter delictivo de determinadas conductas relacionadas con la seguridad vial, lo que ha significado una mayor relevancia de la privación del derecho a conducir como sanción penal y que se haya diluido el carácter de sanción administrativa que aquella mantenía todavía en los albores del siglo $X_{X \mid}^{24}$. Esta estrategia del legislador consistente en reforzar la vía penal en detrimento de la vía administrativa ya fue en su día advertida por TAMARIT SUMALLA ${ }^{25}$.

\subsection{La privación del derecho a conducir como sanción penal}

El objetivo de este apartado es analizar la naturaleza penal de la privación del derecho a conducir, y para ello se detallarán las características esenciales de la pena de privación del derecho a conducir, su regulación en el $\mathrm{CP}$, los derechos de los que priva la misma, e invocaremos los criterios doctrinales favorables a su consideración como pena. Así, en primer lugar, estudiaremos la pena de privación

\footnotetext{
23 Vid. la Ley 18/2009, de 23 de noviembre, BOE número 283 de 24 de noviembre de 2009, y el enlace: http://www.boe.es/boe/dias/2009/11/24/pdfs/BOE-A-2009-18732.pdf (último acceso: 13/11/2020).

${ }^{24}$ Vid. POLAINO-ORTS, Miguel, "Delitos contra la seguridad vial: visión crítica de la nueva regulación española", en AA.VV. Entre libertad y castigo: dilemas del estado contemporáneo. Estudios en homenaje a la maestra Emma Mendoza Bremauntz. CAMPOS DOMÍNGUEZ, Fernando Gerardo/ CIENFUEGOS SALGADO, David/ RODRíGUEZ LOZANO, Luis Gerardo/ ZARAGOZA HUERTA, José (Coords.), Facultad de Derecho de la Universidad Nacional Autónoma de México, Centro de Investigación de Tecnología Jurídica y Criminológica de la Universidad Autónoma de Nuevo León, México, 2011, pp.694-695.
} 
del derecho a conducir, en tanto que pena privativa de derechos, ya que priva del derecho a conducir vehículos a motor y ciclomotores, y, en segundo lugar, se estudiará la privación del derecho a conducir en tanto que pena principal.

En cuanto a su regulación en el CP hemos de acudir a los artículos del 39 al 49, que regulan las penas privativas de derechos, siendo éstas un grupo de penas de carácter heterogéneo ${ }^{26}$, porque aparecen hasta diez penas tan diferentes como la inhabilitación absoluta, la privación del derecho a la tenencia y porte de armas o la privación de la patria potestad. La pena de privación del derecho a conducir se contempla en el art.39 d) CP.

La pena objeto de estudio, junto al resto de penas privativas de derechos, se caracteriza porque no priva de derechos que afectan directamente a la libertad deambulatoria, como la pena de prisión, ni tampoco al patrimonio, como la pena de multa ${ }^{27}$, aun cuando sí puede observarse que existe una afectación indirecta a estos derechos. Ello es así puesto que el penado, en cierto modo, puede ver limitada parcialmente su libertad de movimientos al ver reducida su movilidad con un vehículo a motor o ciclomotor ${ }^{28}$, así como ver afectado su patrimonio, en especial cuando la condena a la pena objeto de estudio pueda poner en riesgo su actividad laboral.

En cuanto a la naturaleza jurídica, la pena de privación del derecho a conducir constituye una pena tanto desde el punto de vista formal como material. En este sentido, siguiendo pautas estrictamente formales, cumple el criterio expresado por

\footnotetext{
25 Vid. TAMARIT SUMALLA, Josep, "De las penas privativas de derechos", en AA.VV. Comentarios al nuevo Código Penal, QUINTERO OLIVARES, Gonzalo (Dir.), MORALES PRATS, Fermín (Coord.), Ed. Aranzadi, Cizur Menor (Navarra), 2005, p.379.

${ }^{26}$ En relación con las penas privativas de derechos en el CP. Vid. ORTS BERENGUER, Enrique/ GONZÁLEZ CUSSAC, José.L. Compendio de Derecho Penal. Parte General, Ed. Tirant Lo Blanch, Valencia, 2017, p.471.

27 Acerca de las características de las penas privativas de derechos, vid. SANZ MULAS, Nieves, Alternativas a la pena privativa de libertad. Análisis crítico y perspectivas de futuro en las realidades española y centroamericana, Ed. Colex, Madrid, 2000, p.359 y también GUTIÉRREZ CASTAÑEDA, Ana, Las penas privativas de derechos políticos y profesionales. Bases para un nuevo modelo regulativo, Ed. Tirant lo Blanch, Valencia, 2012, pp.122 y 148.

28 Vid. MIR PUIG, Santiago, "El principio de proporcionalidad como fundamento constitucional de límites materiales del Derecho Penal", en AA.VV. Constitución y principios del Derecho Penal: algunas bases constitucionales, MIR PUIG, Santiago/ QUERALT JIMÉNEZ, Joan. (Dirs.), FERNÁNDEZ BAUTISTA, Silvia (Coord.), Ed. Tirant lo Blanch, Valencia, 2010, p.78; GUTIÉRREZ CASTAÑEDA, Ana, Las penas..., op.cit., p.192 y también MORENO CATENA, VÍctor, "Las medidas cautelares. La detención"; Derecho Procesal Penal, en MORENO CATENA, Víctor/CORTÉS DOMíNGUEZ Valentín, Ed. Tirant lo Blanch, Valencia, 2017, p.306.
} 
LANDROVE DÍAZ29 según el cual: "es pena lo que la ley califica como taf". Además, la pena examinada cumple los requisitos que exigen a tal categoría autores como ROCA AGAPITO ${ }^{30}$ requiriendo que: estén previstas y reguladas en el CP; que deriven de un hecho delictivo y que se impongan por Jueces y Tribunales penales. MAPELLI CAFFARENA/TERRADILLOS BASOCO también hacen referencia a las características de la pena en general: priva o restringe bienes jurídicos, es impuesta conforme a ley por los órganos jurisdiccionales y se impone al culpable de una infracción criminal ${ }^{31}$. Tales requisitos concurren sin lugar a dudas en relación con la pena estudiada, ya que se cumplen todos ellos, por lo que cabe sostener que nos hallamos ante una verdadera pena ${ }^{32}$.

\subsubsection{La privación del derecho a conducir como pena privativa de derechos y pena principal}

El primer dato a destacar de la privación del derecho a conducir, es que es una pena privativa de derechos. Con relación a las características de las penas privativas de derechos en general, MUÑOZ CONDE $^{33}$ ha señalado que se caracterizan por "... una privación, temporal o definitiva, de derechos distintos de la libertad deambulatoria...". También podemos destacar que GRACIA MARTíN ${ }^{34}$ sostenía acertadamente que todas las penas previstas en el CP privan de derechos y la descripción que realiza el art.32 CP, cuando hace referencia a penas privativas de otros derechos, sirve para determinar un determinado grupo de derechos que

${ }^{29}$ Referente al concepto formal de pena en base a lo preceptuado en el art.34 CP, vid. LANDROVE DÍAZ, Gerardo, Las consecuencias jurídicas del delito, Ed. Tecnos, Madrid, 2002, p.27.

30 Sobre los requisitos formales que debe cumplir una pena vid. ROCA AGAPITO, Luis, El sistema de sanciones en el derecho penal Español. JM Bosch Editor, Barcelona, 2007.p.64 y en "Las penas", en AA.VV. Las consecuencias jurídicas del delito, ROCA DE AGAPITO, Luis (Dir.), Ed. Tirant lo Blanch, Valencia, 2017, pp.27-28.

31 En relación con el concepto de pena, vid. MAPELLI CAFFARENA, Borja/ TERRADILLOS BASOCO Juan, Las consecuencias jurídicas del delito, Ed. Civitas, Madrid, 1993, 2ª edición, pp.2833.

${ }^{32}$ Respecto la naturaleza de pena de la privación del derecho a conducir también se ha mostrado favorable GÓMEZ PAVÓN, Pilar, El delito de conducción bajo la influencia del alcohol, drogas tóxicas o estupefacientes. $Y$ análisis del art.383 del C.Penal, Ed. Bosch, Barcelona, 2010, 4ª edición, p.223.

${ }^{33}$ Vid. MUÑOZ CONDE, Francisco/GARCíA ARAN, MERCEDES, Derecho Penal. Parte General, Ed. Tirant lo Blanch, Valencia, 2010, 8ª edición, p.515.

${ }^{34}$ En torno a las penas privativas de derechos, vid. GRACIA MARTÍN, Luis, "El sistema de penas", en AA.VV. Lecciones de consecuencias jurídicas del delito: el sistema de penas, de medidas de seguridad, de consecuencias accesorias y de responsabilidad civil derivada del delito, GRACIA MARTíN, Luis (Coord.)/ BOLDOVA PASAMAR, Miguel Ángel/ ALASTUEY DOBÓN, M.Carmen, Ed. Tirant lo Blanch, Valencia, 2012, 4ª edición, p.23. 
merecen un reproche penal específico, perteneciendo a ellos el derecho a conducir vehículos a motor y ciclomotores ${ }^{35}$. Las características que predominan en el resto de penas privativas de derechos las comparte la pena de privación del derecho a conducir, ya que en todas ellas se produce un menoscabo en la esfera personal, social, económica y en ocasiones laboral, de los penados ${ }^{36}$. Como podrá comprobarse a lo largo del trabajo, la pena de privación del derecho a conducir, de manera especial en los penados que ejercen este derecho para trabajar, generará un perjuicio económico importante en los mismos al poder causar la pérdida del puesto de trabajo.

La vigente denominación de la pena, a diferencia de su previsión en el CP de 1973, ya no insta a privar de una licencia o permiso, por lo que estaba vinculada con un documento administrativo ${ }^{37}$, sino que ahora de lo que se priva es de un derecho. El cambio en la denominación de pena de privación del derecho a conducir en lugar de privación del permiso ha sido acertado, ya que de lo que se priva con la pena impuesta es de la posibilidad de ejercitar el derecho a conducir, no del uso de la autorización o licencia ${ }^{38}$. El nombre actual de la pena reafirma el carácter de la privación del derecho a conducir como pena privativa de derechos, debido a que con la anterior regulación podía interpretarse que se privaba de una autorización administrativa siendo más clarificadora la redacción vigente, al no ser relevante que el penado posea el permiso o licencia ${ }^{39}$. Por consiguiente, y tras la sustitución de la denominación de privación del permiso o licencia por la de privación del derecho a conducir, no existe ningún género de dudas que esta pena puede ser aplicable tanto

35 Vid. DE URBANO CASTRILLO, Eduardo, "La privación del derecho a conducir", Boletín de Derecho de la Circulación, El Derecho Editores, no 4, Enero de 2007, p.9.

${ }^{36}$ En relación con las limitaciones que se derivan de la pena de privación del derecho a conducir, la misma comparte las características de las penas privativas de derechos en cuanto a las restricciones en la vida social y la posible pérdida de ingresos derivados del trabajo, Vid. MATUS ACUÑA, Jean Pierre, "Penas privativas de derechos", en AA.VV. Penas alternativas a la prisión, CID MOLINÉ, José/LARRAURI PIJOAN, Elena (Coords), Ed. Bosch, Barcelona, 1997, p.124, y también RíOS MARTíN, Julián Carlos/ SEGOVIA BERNABÉ, José Luis/ PASCUAL RODRÍGUEZ, Esther, Las penas y su aplicación. Contenido legal, doctrinal y jurisprudencial, Ed. Colex, Madrid, 2007, 3 edición, p.51, y GUTIÉRREZ CASTAÑEDA, Ana, Las penas, op.cit., pp.126-127.

37 Vid. MANZANARES SAMANIEGO, José Luis, Código Penal (Adaptado a la Ley Orgánica 5/2010 de 22 de junio) (Comentarios y jurisprudencia), I, Parte general (artículos 1 a 137), Ed. Comares, Granada, 2010, pp.457-458.

38 En relación con la denominación de la pena como de "privación del derecho a conducir", vid. RODRÍGUEZ FERNÁNDEZ, Ignacio, "Consideraciones metodológicas sobre el alcance de la privación del derecho a conducir vehículos a motor y ciclomotores en la legislación penal", Actualidad Penal, no 32, 2003, pp.791-818.

39 Acerca del cambio denominación de privación del permiso por privación del derecho, vid. POZUELO PÉREZ, Laura, Las penas privativas de derechos en el Código Penal, Ed. Colex, Madrid, 1998, p.62. 
a los penados que sí tenían el permiso o licencia como a aquellos que han cometido el delito careciendo de él ${ }^{40}$.

El segundo aspecto para destacar de la naturaleza penal de la privación del derecho a conducir es que el legislador ha previsto que tenga la consideración de pena principal ${ }^{41}$. El carácter de pena principal de la misma es histórico ya que se incorporó como tal en el CP tras la reforma ${ }^{42}$ de 1963. Por su parte, gran parte de la doctrina ha señalado que no puede ser impuesta como accesoria ${ }^{43}$, puesto que no se contempla en el artículo 54 y siguientes del CP relativos a las penas accesorias. Sin embargo, algunos autores como CARDENAL MONTRAVETA consideran que la pena que se analiza sí puede ser adoptada como pena accesoria al amparo del art. 56 CP ya que en dicho precepto se recoge la expresión "cualquier otro derecho" 44 en relación con la inhabilitación especial; en el mismo sentido, se manifiesta también DE LAMO RUBIO ${ }^{45}$. A pesar de la existencia de dicha línea doctrinal, no existe jurisprudencia en la que la pena que estudiamos se haya impuesto como pena accesoria, por lo que en mi opinión dicha opción debe descartarse a tenor de la actual regulación en el CP, sin perjuicio que pueda plantearse su incorporación en el elenco de penas accesorias. La propia Fiscalía del Tribunal Supremo en la Consulta 13/1985 de 19 de diciembre, destacaba que esta pena tenía la característica de ser siempre pena principal y que nunca podía ser impuesta como

40 Al respecto comparto plenamente el criterio de ROCA AGAPITO, Luis, El sistema..., op.cit., pp.215-216 y el de POZUELO PÉREZ, Laura., Las penas..., op.cit., p.63.

41 En relación con la previsión de la privación del derecho a conducir como pena principal, vid. MATUS ACUÑA, Jean Pierre, "Penas privativas de derechos", en AA.VV. Penas alternativas...op.cit., p.136, VALEIJE ÁLVAREZ, Inmaculada, "El sistema de penas en los delitos contra la seguridad vial", en AA.VV. Prevención y control de la siniestralidad vial. Un análisis jurídico y criminológico, ORTS BERENGUER, Enrique (Coord.), Ed. Tirant lo Blanch, Valencia, 2011, p.477 y FARALDO CABANA, Patricia/ PUENTE ABA, Luz María, "Concepto y funciones"; en AA.VV. Las penas privativas de derechos y otras alternativas a la privación de libertad, FARALDO CABANA, Patricia/ PUENTE ABA, Luz María (Dirs.), Ed. Tirant lo Blanch, Valencia, 2013, p.19.

42 Vid. LANDROVE DÍAZ, Gerardo, Las consecuencias..., op.cit., p.79.

43 Respecto de la configuración de la pena de privación del derecho a conducir vid. FARALDO CABANA, Patricia/ PUENTE ABA, Luz María, "Concepto y funciones", en AA.VV. Las penas... op.cit., p.19; RODRÍGUEZ MORO, Luis, La pena de privación del derecho a conducir vehículos a motor y ciclomotores; Ed. Tirant lo Blanch, Valencia, 2016, p.100 y GIL GIL, Alicia/ LACRUZ LÓPEZ, Juan Manuel/ MELENDO PARDOS, Mariano/ NÚÑEZ FERNÁNDEZ, José, Consecuencias jurídicas del delito. Regulación y datos de la respuesta a la infracción penal en España, Ed. Dykinson, Madrid, 2018, p. 180.

44 Vid. CARDENAL MONTRAVETA, Sergi,"Título III. De las penas", en AA.VV. Comentarios al Código Penal. Reforma LO 1/2015 y LO 2/2015, CORCOY BIDASOLO, Mirentxu/MIR PUIG, Santiago (Dirs.), VERA SÁNCHEZ, Juan Sebastián (Coord.), Ed. Tirant lo Blanch, Valencia, 2015, p.228.

45 Vid. DE LAMO RUBIO, Jaime, Penas y medidas de seguridad en el nuevo código, Ed. Bosch, Barcelona, 1997, p.143. 
pena accesoria ${ }^{46}$. Por ello considero que su naturaleza como pena principal está consolidada $^{47}$ y los supuestos de aplicación de la misma plenamente identificados en el CP, siendo una prueba más de su efectiva condición de pena.

Otra particularidad de la pena de privación del derecho a conducir es, que además de tener la naturaleza de principal ${ }^{48}$, nunca será la única que se imponga en la sentencia, pues siempre se aplica de forma conjunta con otra pena, bien sea de prisión, multa o la pena de TBC, lo que según VALEIJE ÁLVAREZ hace que pueda calificarse como "complementaria"49. Atendiendo a los motivos expuestos, aun siendo pena principal, la pena objeto del estudio puede destilar un cierto aroma de accesoriedad, al ser aplicada siempre de forma conjunta con otra pena ${ }^{50}$. Por este motivo algunos autores sugieren que es una pena que siempre queda en una posición de inferioridad en relación con la prisión, la multa o la pena de $\mathrm{TBC}^{51}$, aunque en su aplicación práctica está al mismo nivel que el resto de sanciones penales.

\subsubsection{La privación del derecho a conducir como medida de seguridad}

Una vez analizadas las características principales de la privación del derecho a conducir como pena privativa de derechos, nos referiremos a la privación del derecho a conducir como medida de seguridad no privativa de libertad. EI CP regula

\footnotetext{
46 Vid. Consulta 13/1985 de 19 de diciembre, sobre la pena de privación del permiso de conducir en concurrencia con las de arresto mayor o multa directa: su problemática degradabilidad. Recurso electrónico disponible en: https://www.fiscal.es/memorias/estudio2016/CONS/CON 13 1985.html (último acceso: 02/11/2020).

47 EI TS en una de las escasas ocasiones que ha analizado la naturaleza de la pena de privación del derecho a conducir, ha determinado que no es una pena accesoria y que es una pena principal, no aplicándose nunca sola. Vid. STS, núm. de recurso 1275/1994, Sala Segunda, de 14 de diciembre de 1994, ponente Excmo. Sr. Justo Carrero Ramos. (TOL403.798).

${ }^{48}$ El carácter de "pena principal y autónoma" de la pena de privación del derecho a conducir ha sido destacado por TAMARIT SUMALLA, Josep, "La pérdida definitiva del derecho de conducir o del derecho a la tenencia y porte de armas", en AA.VV. La adecuación del Derecho penal español al Ordenamiento de la Unión Europea. La política criminal europea en ÁLVAREZ GARCÍA, F.J. (Dir.), Tirant lo Blanch. Valencia, 2009, p.125.
}

49 Vid. VALEIJE ÁLVAREZ, Inmaculada, "El sistema de penas en los delitos contra la seguridad vial", en AA.VV. Prevención y control..., op.cit., p.477.

50 Aun cuando esta pena siempre se aplica de forma acumulativa con otras penas, existen sectores doctrinales que propugnaban su aplicación como pena única y principal para determinados delitos de peligro. La propuesta fue realizada por MATUS ACUÑA, Jean Pierre, "Penas privativas de derechos", en AA.VV. Penas alternativas...op.cit., pp.128-129.

51 Vid. TAMARIT SUMALLA, Josep/ LUQUE REINA, Maㅡ Eulàlia, Automóviles, delitos y penas... op.cit., p. 127. 
la privación del derecho a conducir como sanción firme en un doble sentido: como pena y como medida de seguridad, aplicándose ambas de forma diferente y bajo presupuestos totalmente distintos, enmarcadas en el sistema penal español que podemos calificar como dualista o de doble vía ${ }^{52}$.

En relación con esta doble regulación destacaremos el debate en torno a si la privación del derecho a conducir tenía que ser considerada una verdadera pena o por el contrario era merecedora de ser calificada como una medida de seguridad ${ }^{53}$. Ciertos sectores doctrinales mantenían que la privación del derecho a conducir en el sistema penal español tenía la naturaleza de medida de seguridad ya que tenía como finalidad proteger a la sociedad de los delincuentes peligrosos. La posición doctrinal contraria mantenía que no existía duda alguna que la privación del derecho a conducir tenía todos los requisitos exigibles a cualquier pena ${ }^{54}$. Al respecto considero que este debate hoy está superado desde el momento que el CP atribuye a la privación del derecho a conducir la doble naturaleza de pena y de medida de seguridad $^{55}$.

La regulación en el CP de la privación del derecho a conducir como pena y medida de seguridad evidencia que el legislador ha querido dejar sin margen de impunidad las conductas realizadas con vehículos a motor o ciclomotores por sujetos que revistan peligrosidad criminal ${ }^{56}$. En este sentido, la inclusión de la privación del derecho a conducir entre las medidas de seguridad tiene como objetivo asegurar

52 Vid. CORDERO LOZANO, Carlos, Ejecución penal, Ed. Bosch, Madrid, 2011, p.146. Sin embargo, por ciertos sectores doctrinales se ha calificado el sistema actual de $<<$ dualismo flexible $>0$ <<nuevo monismo>>, en base al acercamiento entre pena y medida de seguridad. Vid. GARCÍA ALBERO, Ramón, "De las medidas de seguridad", en AA.VV. Comentarios al Código Penal Español, Tomo I, (Artículos 1 a 233), QUINTERO OLIVARES, Gonzalo (Dir.), MORALES PRATS, Fermín (Coord.), Aranzadi-Thomson Reuters, Cizur-Menor (Navarra), 2011, 6ª edición, pp.636-638.

53 En torno al debate histórico en relación con la privación del derecho a conducir como pena o medida de seguridad, vid. el análisis histórico realizado por GÓMEZ PAVÓN, Pilar, El delito... op.cit., pp.222.

54 Vid. Ias dos posiciones doctrinales y los argumentos expuestos de manera más amplia en GÓMEZ PAVÓN, Pilar, El delito... op.cit., pp.222-223.

55 Sí es cierto que se ha producido un progresivo acercamiento entre las penas y las medidas de seguridad en general, cohabitando ambas en la actualidad en nuestro sistema penal. Vid. VAELLO ESQUERDO, Esperanza, Las consecuencias jurídicas del delito, Ed. Publicaciones Universidad de Alicante, Alicante, 2004, p.128 y ROCA DE AGAPITO, Luis, "Sistema de consecuencias jurídicas del delito", en AA.VV. Las consecuencias jurídicas del delito, ROCA DE AGAPITO, Luis (Dir.), Ed. Tirant lo Blanch, Valencia, 2017, pp.20-21.

56 A este respecto podemos relacionar la peligrosidad criminal del sujeto con el principio de necesidad de la pena del art.6.2 CP como indican RíOS MARTíN, Julián Carlos/ SEGOVIA BERNABÉ, José Luis/ PASCUAL RODRÍGUEZ, Esther, Las penas... op.cit., p.146. 
que el reo inimputable o semiimputable no desempeñe durante un tiempo el ejercicio de este derecho ${ }^{57}$.

Una vez realizado el juicio de peligrosidad, si objetivamente el individuo puede suponer un riesgo para la seguridad vial y para los usuarios de la vía ${ }^{58}$, parece adecuada la imposición de la medida de seguridad de privación del derecho a conducir. De esta forma, el Derecho Penal pretende evitar que se generen nuevos riesgos a la sociedad reduciendo la posibilidad que el sujeto pueda utilizar temporalmente determinados vehículos capaces de crear peligro para el tráfico viario ${ }^{59}$. La existencia de esta sanción penal en nuestro sistema penal es adecuada para minorar el peligro que personas a las que se les ha eximido de responsabilidad criminal por enajenaciones mentales u otras patologías puedan conducir vehículos a motor o ciclomotores sin ningún tipo de restricción ${ }^{60}$.

En lo relativo a los fines, para una parte de la doctrina, la medida de seguridad tiene una finalidad eminentemente reeducativa y en la que predomina la prevención general ${ }^{61}$. Desde otro sector de la doctrina se mantiene que la medida de seguridad tiene una finalidad de prevención especial, al tener específicamente un componente personal en el autor del hecho delictivo62. En el mismo sentido TAMARIT SUMALLA ${ }^{63}$ y LANDROVE DÍAZ ${ }^{64}$, destacan que la medida de seguridad tiene un

${ }^{57}$ En relación con la finalidad de la medida de seguridad de privación del derecho a conducir, vid. TAMARIT SUMALLA, Josep/ LUQUE REINA, Mํㅡㄹ Eulàlia, Automóviles, delitos y penas... op.cit., p.134 y también ha destacado una finalidad "asegurativa" de la medida de privación del derecho a conducir, RUBIO LARA, Pedro Ángel, Las medidas de seguridad tras la Reforma de la LO 5/2010 de 22 de junio, del Código Penal: Perspectivas Doctrinales y Jurisprudenciales. Problemas y soluciones, Revista Aranzadi de Derecho y Proceso Penal, Número 25, Ed. Aranzadi-Thomson Reuters, Cizur Menor (Navarra), 2011, p.74.

58 En torno a la finalidad de la medida de seguridad de privación del derecho a conducir, vid. DE URBANO CASTRILLO, Eduardo, “La privación...", op.cit., p.9.

59 En relación con la finalidad de la medida de seguridad de protección de la seguridad vial vid. LEAL MEDINA, Julio, Un Estudio de las Actuales Medidas de seguridad y los interrogantes que plantean en la moderna dogmática del Derecho Penal. Revista Aranzadi de Derecho y Proceso Penal. Número 20, Ed. Aranzadi-Thomson Reuters, Cizur Menor (Navarra), 2008, p.417.

60 Referente a la eficacia de las medidas de seguridad y actual funcionamiento de sanciones penales junto a la pena, vid. MUÑOZ CUESTA, Francisco Javier, "Estudios..." op.cit., pp.15-17.

61 Acerca de la finalidad de la medida de seguridad, vid. RíOS MARTíN, Julián Carlos/ SEGOVIA BERNABÉ, José Luis/ PASCUAL RODRÍGUEZ, Esther, Las penas... op.cit., p.145.

62 En torno a la naturaleza preventivo-especial de las medidas de seguridad vid. MUÑOZ CONDE, Francisco/GARCÍA ARÁN, Mercedes, Derecho... op.cit., p.52; LANDROVE DÍAZ, Gerardo, Las consecuencias..., op.cit., p.115 y RUBIO LARA, Pedro Ángel, Teoría de la pena y consecuencias jurídicas del delito. Análisis doctrinal y jurisprudencial, Ed. Tirant lo Blanch, Valencia 2017, pp.157159.

63 Vid. TAMARIT SUMALLA, Josep/ LUQUE REINA, Maㅡ Eulàlia, Automóviles, delitos y penas... op.cit., p.134. 
objetivo de intentar asegurar o evitar que el individuo catalogado como peligroso cometa nuevos hechos delictivos o genere nuevos riesgos para la seguridad vial, siendo la forma de llevarlo a cabo a través de la privación de su derecho a poder conducir vehículos a motor y ciclomotores. Además de los fines de prevención especial de la medida de seguridad de privación del derecho a conducir, se puede vislumbrar en ella cierta eficacia terapéutica o correctiva siempre que, por ejemplo, pueda ir acompañada de alguna otra medida como el tratamiento ambulatorio o sometimiento a programas formativos relacionados con los hechos cometidos, así como con las circunstancias personales del reo. Hay que destacar que las medidas de seguridad, igual que las penas, según lo preceptuado en el art.25.2 de la CE están orientadas a la reeducación y reinserción social, por lo que en ningún caso se podrán imponer si menoscaban las posibilidades que el penado pueda reeducarse o reinsertarse en la sociedad.

Por último, señalaremos los criterios utilizados por el Tribunal Supremo (en adelante TS) para delimitar los fines y funciones de la medida de seguridad que operan en un doble sentido65: protegiendo a la vez al propio acusado y a la sociedad, por lo que la jurisprudencia opta por destacar el carácter de prevención especial de la medida de seguridad. En similar sentido, LANDROVE DÍAZ ${ }^{66}$ destaca la ausencia del contenido retributivo en la medida de seguridad y preconiza una mayor relevancia de la protección de la sociedad ante la peligrosidad del autor de los hechos.

En mi opinión, la presencia en el CP de las dos modalidades sancionadoras, tanto la pena como la medida de seguridad de privación del derecho a conducir, es positiva si pensamos en la protección penal de bienes jurídicos, ya que el Derecho Penal trata de garantizar la seguridad a la sociedad a la vez que impone una sanción adecuada a los individuos que cometen hechos delictivos utilizando un vehículo a motor o ciclomotor ${ }^{67}$ sean o no imputables.

La privación del derecho a conducir como medida de seguridad, regulada en el Título IV, art.96.3.5 CP, forma parte del conjunto de las medidas no privativas de

\footnotetext{
64 Sobre la importancia de la prevención especial en las medidas de seguridad, vid. LANDROVE DÍAZ, Gerardo, Las consecuencias..., op.cit., p.113.

65 Vid. STS, núm. 1019/2010, Sala Segunda, de 2 de noviembre de 2010, ponente Excmo. Sr. Julián Artemio Sánchez Melgar. (TOL2.018.420).

66 Referente a la ausencia del componente de retribución en las medidas de seguridad, vid. LANDROVE DÍAZ, Gerardo, Las consecuencias..., op.cit., p.112.

${ }^{67}$ Respecto a la dualidad de sanciones penales y sus objetivos, vid. LANDROVE DíAZ, Gerardo, Las consecuencias..., op.cit., p.112.
} 
libertad, y está ubicada junto a otras como la privación del derecho a la tenencia al porte de armas o la inhabilitación profesional ${ }^{68}$. La medida de seguridad de privación del derecho a conducir se impondrá a aquellos sujetos respecto de los que se determine su inimputabilidad o semiimputabilidad ${ }^{69}$, siendo la base jurídica para que se acuerde lo previsto en los artículos 1.2 y $6 \mathrm{CP}^{70}$, cuando estos sujetos sean calificados como peligrosos tras haber cometido un hecho delictivo relacionado con la circulación de vehículos a motor o ciclomotores. El art.95 CP establece dos requisitos esenciales para que esta medida de seguridad se pueda adoptar, siendo uno de carácter objetivo consistente en la comisión de un hecho delictivo, y el otro de carácter subjetivo: la probabilidad que en el futuro se puedan cometer nuevos delitos, es decir, la peligrosidad criminal del sujeto ${ }^{71}$. A estos requisitos debe añadirse que al autor del delito se le haya apreciado la concurrencia de una causa de exención de la responsabilidad penal de las tipificadas en el art.20, apartados 1 , 2 y 3 del CP72.

Las vías por las que se puede imponer la medida de seguridad de privación del derecho a conducir son dos: como medida directa e inicial en la sentencia dictada o como medida sustitutiva en relación con el internamiento, al amparo del art.97 c) $\mathrm{CP}^{73}$.

El CP regula como han de aplicarse las medidas de seguridad en general, ex art.101 CP y siguientes, y define el marco normativo relativo a la medida de

68 Vid. VAELLO ESQUERDO, Esperanza, Las consecuencias..., op.cit., p.64; TRAPERO BARREALES, María.A., Los delitos contra la seguridad vial ¿Una reforma de ida y vuelta?, Ed. Tirant Lo Blanch, Valencia, 2011, p.574; RODRÍGUEZ MORO, Luis, "La pena de privación del derecho a conducir vehículos a motor y ciclomotores" en AA.VV. Las penas... op.cit., p.232 y RUBIO LARA, Pedro Ángel, Teoría de la pena..., op.cit., pp.186-187.

69 Vid. DE URBANO CASTRILLO, Eduardo, "La privación...", op.cit., pp.9-10.

70 Respecto a las garantías para aplicar la medida de seguridad, vid. el art.1.2 CP: Las medidas de seguridad sólo podrán aplicarse cuando concurran los presupuestos establecidos previamente por la Ley.

Art.6 CP: 1. Las medidas de seguridad se fundamentan en la peligrosidad criminal del sujeto al que se impongan, exteriorizada en la comisión de un hecho previsto como delito. 2. Las medidas de seguridad no pueden resultar ni más gravosas ni de mayor duración que la pena abstractamente aplicable al hecho cometido, ni exceder el límite de lo necesario para prevenir la peligrosidad del autor.

71 En relación con estos dos requisitos vid. GARCíA ALBERO, Ramón; "De las medidas de seguridad", en AA.VV. Comentarios..., QUINTERO OLIVARES, Gonzalo (Dir.), MORALES PRATS, Fermín (Coord.), op.cit., pp.639-642.

72 Vid. al respecto, TAMARIT SUMALLA, Josep/ LUQUE REINA, Mํa Eulàlia, Automóviles, delitos y penas... op.cit., p.134.

73 Vid. GARCÍA ALBERO, Ramón, "De las medidas de seguridad", en AA.VV. Comentarios..., QUINTERO OLIVARES, Gonzalo (Dir.), MORALES PRATS, Fermín (Coord.), op.cit., p.679. 
seguridad de privación del derecho a conducir en el art.105.2. c. Sin embargo, hay que destacar la orfandad de criterios para determinar cuándo procede acordar la medida de privación del derecho a conducir, quedando a la libre valoración del órgano judicial ${ }^{74}$, el cual tendrá que valorar, factores como la existencia de antecedentes penales, informes médicos o forenses, etc., contando con un amplio margen para decidir o no su imposición ${ }^{75}$. La ausencia de pautas para acordar la medida de seguridad de privación del derecho a conducir puede generar cierta inseguridad jurídica, por lo que probablemente fuera interesante contar con algunos parámetros en el propio $\mathrm{CP}$, como por ejemplo que fuera de aplicación en los mismos delitos en los que se prevé la pena de privación del derecho a conducir. Esta característica, por el contrario, no la hallamos en la privación del derecho a conducir como pena, puesto que en la mayoría de los delitos en los que se prevé, el juez penal tiene un menor margen de decisión al establecerse su aplicación de forma imperativa.

En relación con la duración de la medida de seguridad de privación del derecho a conducir esta puede tener una extensión temporal máxima de diez años ${ }^{76}$, según establece el art. 105.2.c CP. Para determinar el límite temporal de la medida, el juzgador debe regirse por dos parámetros objetivos. En primer lugar, el art.6.2 CP que determina que no puede tener mayor duración que la pena en abstracto que se pudiera aplicar al hecho cometido, así como que su duración ha de ser proporcional a la peligrosidad que revista el autor de los hechos. En segundo lugar, cuando se impone de forma conjunta con otra medida privativa de libertad el art.105.2.c CP, dispone que el umbral máximo de duración de la medida de seguridad será de diez años ${ }^{77}$.

\footnotetext{
74 Vid. DE URBANO CASTRILLO, Eduardo, “La privación...", op.cit., p.10.

75 Vid. TRAPERO BARREALES, María.A., Los delitos..., op.cit., p.576. En el ámbito jurisprudencial podemos señalar la SAP de Alicante, núm. 127/2019, Sección 2ª , de 29 de marzo de 2019, ponente Ilma.Sra. María Cristina Costa Hernández (TOL7.487.774), que enumera criterios para poder imponer la medida de seguridad de privación del derecho a conducir vehículos a motor y ciclomotores. En sentido contrario, la SAP de Tarragona, núm.538/2010, Sección 2a ${ }^{a}$, de 2 de diciembre de 2010, ponente IImo. Sr. Ángel Martínez Sáez (TOL2.061.030), determina los criterios para revocar la medida de seguridad de privación del derecho a conducir que había sido inicialmente impuesta por el juez a quo.

76 Vid. la STS, núm.1019/2010, Sala Segunda, de 2 de noviembre de 2010, ponente Excmo. Sr. Julián Artemio Sánchez Melgar. (TOL2.018.420), en la que se impuso la medida de seguridad de privación del derecho a conducir por un plazo de diez años y la SAP de Alicante, núm. 71/2010, Sección 1ạ, de 2 de febrero de 2010, ponente Ilmo. Sr. José Antonio Durá Carrillo, (TOL5.281.685), siendo esta última casada por el Tribunal Supremo, absolviendo al acusado por eximente completa.

77 Acerca de la duración de la medida de seguridad vid. GARCÍA ALBERO, Ramón, "De las medidas de seguridad", en AA.VV. Comentarios..., QUINTERO OLIVARES, Gonzalo (Dir.), MORALES PRATS, Fermín (Coord.), op.cit., pp.679-680. En el ámbito jurisprudencial podemos señalar la SAP de Guipúzcoa, núm. 436/1998, Sección 3a
} 
En la práctica, en cuanto a la duración de la medida de seguridad de privación del derecho a conducir, existe debate jurisprudencial acerca de si la misma ha de estar limitada por las peticiones efectuadas tanto por el Ministerio Fiscal y/o Acusación particular ${ }^{78}$, en virtud del principio acusatorio o, por el contrario, el Tribunal puede imponer una extensión temporal mayor que la solicitada por las acusaciones siempre que se mueva dentro del marco legal penológico previsto ${ }^{79}$.

A pesar de la reforma del CP operada por la LO 1/2015 de 30 de marzo ${ }^{80}$ y por la LO 2/2019 de 1 de marzo ${ }^{81}$, en relación con las medidas de seguridad no se ha producido modificación alguna respecto a los requisitos para su imposición, que en el caso de la privación del derecho a conducir hubiera sido sencillo. Podrían haberse instaurado parámetros objetivos como la reincidencia o la existencia de procedimientos penales incoados por delitos relacionados con la seguridad vial o bien con la vida o integridad física o psíquica de las personas cuando se hayan cometido utilizando un vehículo a motor o ciclomotor. Con la actual regulación sigue quedando a albur del juez la posibilidad de imponer la medida de seguridad de privación del derecho a conducir, generándose inseguridad al sujeto en relación con cuándo, cómo, por cuanto tiempo y en qué circunstancias se puede adoptar esta medida.

Tras determinar los fines de la privación del derecho a conducir como medida de seguridad, analizaremos en qué aspectos se distingue respecto la pena de privación

Piqueras Valls (EDJ 1998/37932), que establece que la medida de seguridad de privación del derecho a conducir puede tener una duración temporal superior a la medida de seguridad de internamiento en centro médico.

78 En este sentido hemos de citar la SAP de Tarragona, núm. 324/2008, Sección $2^{2}$, de 7 de julio de 2008, ponente IIma. Sra. Samantha Romero Adán (TOL1.372.790), en la que se considera vulnerado el principio acusatorio al imponer el Juzgado la medida de privación del derecho a conducir con una duración mayor de la solicitada por la acusación.

79 Vid. al respecto el ATS, núm 635/2017, Sala Segunda, de 23 de marzo de 2017, ponente Excmo. Sr. José Ramón Soriano Soriano (TOL6.090.209), SAP de Cuenca, núm. 55/2005, Sección 1ạ , de 25 de mayo de 2005, ponente IImo. Sr. Ernesto Casado Delgado, (TOL666.276); SAP de Alicante, núm. 289/2009 Sección 3a , de 27 de mayo de 2009, ponente Ilmo. Sr. José Daniel Mira-Perceval Verdú (TOL1.239.273). En las tres resoluciones se indican criterios como que el principio acusatorio no puede regir en las medidas de seguridad o que se puede imponer la medida con un límite superior al peticionado siempre que no se extienda por tiempo superior a la pena que se hubiera podido imponer en el caso de no mediar la eximente. En el ámbito doctrinal vid. MUÑOZ CUESTA, Francisco Javier, "Estudios de algunos aspectos sustantivos y procesales relevantes de las medidas de seguridad". Repertorio de jurisprudencia (Estudios doctrinales) no 6/2009, Ed. Aranzadi, pp.15-17.

80 Publicada en el BOE de fecha 31/03/2015. Recurso electrónico disponible en: http://www.boe.es/boe/dias/2015/03/31/pdfs/BOE-A-2015-3439.pdf (último acceso: 13/11/2020).

81 Publicada en el BOE de fecha 2 de marzo de 2019. Recurso electrónico disponible en: https://www.boe.es/diario boe/txt.php?id=BOE-A-2019-2973 (último acceso: 13/11/2020). 
del derecho a conducir. La ubicación de las consecuencias jurídicas en dos Títulos diferentes del CP, la pena de privación del derecho a conducir en el Título III y la medida de seguridad en el Título IV, acredita un contenido y aplicación heterogénea.

El fundamento y presupuestos objetivos y subjetivos de pena y medida de seguridad de privación del derecho a conducir son diferentes, aunque su contenido pueda ser equivalente ${ }^{82}$. En este sentido, ambas tienen premisas de aplicación distintas y si bien pueden tener en común alguna característica con relación a sus funciones preventivas, existen matices que las diferencian claramente y que relacionaremos a continuación.

1) Ambas sanciones poseen un fundamento diferente: la pena constituye la consecuencia jurídica aplicable a sujetos imputables y, por consiguiente, culpables, mientras que la justificación de todas las medidas de seguridad, incluida la privación del derecho a conducir, la encontramos en el art.6 CP. El cimiento de la medida de seguridad de privación del derecho a conducir, como del resto de medidas, es la peligrosidad criminal del sujeto ${ }^{83}$, bien sea inimputable o semiimputable, mientras que la pena de privación del derecho a conducir se rige por la culpabilidad del delincuente.

2) Existen diferencias en la regulación de la pena y la medida de seguridad de privación del derecho a conducir en lo relativo al art.47.3 $\mathrm{CP}$, que establece la pérdida de vigencia del permiso o licencia cuando aquella se impone por un periodo superior a los dos años de duración. Si nos ceñimos al tenor literal del art.47.3 CP, sus efectos no se pueden extender a los sujetos a quienes se les imponga la privación del derecho a conducir como medida de seguridad por un periodo superior a los dos años ${ }^{84}$. Además de ello, en la medida de seguridad de privación del derecho a conducir no está prevista la obligación de superar un curso de

\footnotetext{
${ }^{82} \mathrm{La}$ equivalencia del contenido de la pena y medida de seguridad de privación del derecho a conducir ha sido destacada por GARCÍA ALBERO, Ramón, "De las medidas de seguridad", en AA.VV. Comentarios..., QUINTERO OLIVARES, Gonzalo (Dir.), MORALES PRATS, Fermín (Coord.), op.cit., p.682.

${ }^{83}$ Sobre la peligrosidad criminal del sujeto como base de la medida de seguridad ha de invocarse el art.6.1 del C. Penal que establece: "Las medidas de seguridad se fundamentan en la peligrosidad criminal del sujeto al que se impongan, exteriorizada en la comisión de un hecho previsto como delito".

${ }^{84}$ El hecho que el legislador no haya previsto dicha consecuencia en las medidas de seguridad ha sido destacado por GONZÁLEZ CUSSAC, José Luis/VIDALES RODRÍGUEZ, Caty, "Los nuevos delitos contra la seguridad vial", en AA.VV. Seguridad Vial (Especial referencia a la reforma operada
} 
sensibilización y reeducación vial para poder volver a conducir, que sí ha de realizarse en la pena de privación del derecho a conducir cuando se aplique el art.47.3 CP, así como lo establecido en el art.73 de la LTSV85. La realización del curso sería interesante que también se impusiera de forma obligatoria en los casos en los que se acuerde la medida de seguridad de privación del derecho a conducir, ya que ésta se adopta por la peligrosidad del sujeto y el contenido del citado curso puede coadyuvar a reducir la misma.

3) También es destacable una singularidad procesal que puede afectar a la medida de seguridad de privación del derecho a conducir y la distingue de la pena. En el procedimiento judicial se puede acordar la privación cautelar del permiso de conducir y posteriormente que al acusado se le imponga la medida de seguridad de privación del derecho a conducir. En este caso, no existe un procedimiento de abono tal como sucede con la pena de privación del derecho a conducir ${ }^{86}$. La imposibilidad de un abono de la privación del derecho a conducir en la medida de seguridad deriva del hecho que ésta no pueda acordarse con carácter previo al dictado de la sentencia, sino que será ex post cuando en la misma se declaren los motivos que llevan al juzgador a aplicar la medida de seguridad. Probablemente resultaría interesante poder articular las reformas procesales oportunas para que en estos supuestos se pueda proceder al abono en la ulterior liquidación de condena, cuando se acuerde la medida de seguridad de privación del derecho a conducir, ello sin perjuicio, que en la praxis judicial este abono ya sea una realidad, por analogía a la pena objeto de estudio del tal modo que ya se pueda proceder al abono del tiempo sufrido como medida cautelar.

4) Especial mención merece la posibilidad de que ex arts.97 y 98 CP la medida de seguridad de privación del derecho a conducir pueda ser suspendida durante su ejecución, atendiendo al cumplimiento y evolución que del sujeto durante su

en el Código Penal mediante la Ley Orgánica 15/2007, de 30 de noviembre), VIDALES RODRÍGUEZ, Caty y MERA REDONDO, Antonio (Coords.), Tirant lo Blanch, 2008, Valencia, p.201.

${ }^{85}$ Art.73 LTSV. Obtención de un nuevo permiso o licencia de conducción posterior a la sentencia penal de privación del derecho a conducir vehículos a motor: 1. El titular de un permiso o licencia de conducción que haya perdido su vigencia de acuerdo con lo previsto en el artículo 47 del Código Penal, al haber sido condenado por sentencia firme a la pena de privación del derecho a conducir vehículos a motor y ciclomotores por tiempo superior a dos años, podrá obtener, una vez cumplida la condena, un permiso o licencia de conducción de la misma clase y con la misma antigüedad, de acuerdo con el procedimiento establecido en el artículo 71.2 para la pérdida de vigencia de la autorización por la pérdida total de los puntos asignados. El permiso que se obtenga dispondrá de un saldo de 8 puntos. 2. Si la condena es igual o inferior a dos años, para volver a conducir únicamente deberá acreditar haber superado con aprovechamiento el curso de reeducación y sensibilización vial al que hace referencia el primer párrafo del artículo 71.2. 
aplicación. Se trata de un aspecto positivo común a todas las medidas de seguridad y que concede al Juez o Tribunal la facultad de cesar, mantener o suspender la medida de seguridad ${ }^{87}$, lo que la diferencia de la pena de privación del derecho a conducir en la que únicamente cabe su cumplimiento íntegro.

5) Para finalizar destacaremos una diferencia que existió entre la pena y la medida de privación del derecho a conducir en su aplicación en las faltas por imprudencia leve cometidas con vehículo a motor o ciclomotor. La pena de privación del derecho a conducir se podía imponer en estos casos mientras que la medida de seguridad no se adoptaba al amparo del principio de proporcionalidad, y únicamente se aplicaba en los hechos delictivos ${ }^{88}$. Esta previsión estaba justificada al ser las faltas una infracción con relevancia penal, pero de escasa gravedad punitiva para el acusado. Sin embargo, tras la entrada en vigor de la LO 1/2015 de 30 de marzo, en los delitos leves de homicidio y lesiones por imprudencia menos grave, formalmente nada obstaría a que se pudiera imponer una medida de seguridad ya que el art. 95 $\mathrm{CP}$ únicamente requiere que se haya cometido un hecho previsto como delito, y el delito leve es un delito. Sin embargo, la investigación jurisprudencial que se ha efectuado a los efectos de este trabajo no ha permitido localizar ninguna resolución judicial en los procedimientos de delito leve en los que se haya aplicado la medida de seguridad de privación del derecho a conducir tras la entrada en vigor de la LO $1 / 2015$, por lo que parece seguirse la misma dinámica que las extintas faltas de no acordar la misma en los casos de menor gravedad delictiva.

\subsection{La privación del derecho a conducir como medida cautelar penal}

La privación del derecho a conducir se contempla también en el ordenamiento jurídico como medida cautelar, estando regulada en la LECrim, pudiéndose adoptar por la policía judicial y por el Juzgado. Si bien los requisitos de adopción y las finalidades de medida cautelar y pena de privación del derecho a conducir son distintas, la medida cautelar sí puede afectar a la pena por lo que estimo necesario analizar ambas conjuntamente.

\footnotetext{
${ }^{86}$ Acerca de la imposibilidad del abono cuando se impone la medida de privación del derecho a conducir, vid. GÓMEZ PAVÓN, Pilar, El delito... op.cit., p 223.

87 En relación con la diferente forma de aplicar la pena y la medida de seguridad, vid. LANDROVE DÍAZ, Gerardo, Las consecuencias..., op.cit., p.116.

${ }^{88}$ En torno al principio de proporcionalidad en la aplicación de las medidas de seguridad vid. RíOS MARTíN, Julián Carlos/ SEGOVIA BERNABÉ, José Luis/ PASCUAL RODRÍGUEZ, Esther, Las penas... op.cit., p.46.
} 
Nuestra Ley Rituaria prevé que se pueda acordar la privación del permiso a conducir como medida cautelar de carácter personal ${ }^{89}$ no privativa de libertad, lo que supone una privación temporal para poder ejercer el derecho a conducir a pesar de no existir sentencia condenatoria. Esta medida cautelar puede adoptarse cuando existen indicios racionales de criminalidad en la conducta del acusado, vinculada con un delito contra la seguridad vial o contra la vida o integridad física o psíquica de las personas habiéndose cometido el mismo con un vehículo a motor o ciclomotor ${ }^{90}$.

La regulación de la medida cautelar se halla contenida en los arts. 529 bis, 764.4 y 770.6을 de la LECrim. La primera referencia a la privación del permiso de conducir en sede de medida cautelar la encontramos en el art.529 bis de la LECrim ${ }^{91}$ que habilita al juez para privar cautelarmente de su permiso de conducir al procesado por un delito relacionado con la conducción de vehículos a motor. Ello equivale a no poder ejercitar su derecho a conducir desde el momento que se acuerde la medida cautelar. Dado que la adopción de la medida cautelar es una facultad discrecional del juez instructor, éste deberá evaluar la posibilidad que el sujeto vuelva a cometer hechos delictivos y también valorar la naturaleza del hecho cometido92. Para ello, será importante el atestado remitido por la Policía que deberá contener sólidos elementos incriminatorios. Si el atestado carece de estos indicios existirá una gran dificultad para que pueda privarse cautelarmente al conductor del permiso, por no poder considerarse tal medida ni necesaria ni proporcional a los hechos acaecidos. Curiosamente, el art. 529 bis de la LECrim únicamente hace referencia a los vehículos de motor, pero no cita explícitamente a los ciclomotores, por lo que sería

\footnotetext{
${ }^{89}$ Respecto de la medida cautelar de privación del permiso en la fase de instrucción Vid., CORTÉS DOMínGUEZ, Valentín, "La Fase de instrucción"; Derecho Procesal Penal, en MORENO CATENA, Víctor/CORTÉS DOMÍNGUEZ Valentín, Ed. Tirant lo Blanch, Valencia, 2017, p.217.

90 En relación con los requisitos de aplicación de la medida cautelar de privación del permiso de conducir vid. MORENO CATENA Víctor, "Otras medidas cautelares y medidas de protección", Derecho Procesal Penal, en MORENO CATENA, Víctor/CORTÉS DOMÍNGUEZ Valentín, Ed. Tirant lo Blanch, Valencia, 2017, p.346. También vid. ARMENTA DEU, Teresa, Lecciones de derecho procesal penal, Ed. Marcial Pons, Madrid 2018, p.239.

${ }^{91}$ Art. 529 bis LECrim. Cuando se decrete el procesamiento de persona autorizada para conducir vehículos de motor por delito cometido con motivo de su conducción, si el procesado ha de estar en libertad, el Juez, discrecionalmente, podrá privarle provisionalmente de usar el permiso, recogiendo e incorporando al proceso el documento en el que conste, y lo comunicará al organismo administrativo que lo haya expedido.

92 Vid. Grupo de Estudios de Política Criminal, Una propuesta alternativa al sistema de penas y su ejecución y a las medidas cautelares personales, Ed. Grupo de Estudios de Política Criminal, Valencia, 2005, p.73.
} 
recomendable que el legislador los incluyera y subsanara dicha omisión ${ }^{93}$. El precepto sí alude al procedimiento en caso de adopción de la medida, puesto que insta al Juzgado a comunicar a la Dirección General de Tráfico (en adelante DGT) la privación cautelar del permiso de conducir acordada. De esta forma, se evita que el investigado pueda solicitar un duplicado del permiso ante la Jefatura Provincial de Tráfico, siendo una muestra de la colaboración entre los ámbitos penal y administrativo para el efectivo cumplimiento de la privación del derecho a conducir.

El segundo supuesto que posibilita la adopción de la privación cautelar del permiso de conducir es el regulado en el art.764.4 de la LECrim ${ }^{94}$. En este caso, se faculta al Juez de Instrucción para intervenir el permiso de conducir privando cautelarmente al investigado del derecho a conducir cuando se haya procedido a la intervención judicial del vehículo para realizar una investigación sobre el mismo o para asegurar responsabilidades civiles. La jurisprudencia ha rechazado en diversas ocasiones que el art. 764.4 de la LECrim, funcione como una suerte de "pena anticipada"95.

La tercera vía para la adopción de la privación cautelar del permiso a conducir se recoge en el art.770.6 de la LECrim ${ }^{96}$ que regula la intervención por parte de la policía judicial del permiso de conducir de la persona imputada en un hecho delictivo. Esta medida cautelar será de aplicación en los delitos en que se emplee un vehículo a motor o ciclomotor y especialmente en los que se produzcan lesiones a bienes jurídicos como puede ser la vida o integridad física o psíquica de las personas.

93 La omisión a los ciclomotores en el art. 529 bis de la LECrim ha sido destacada por MANZANARES SAMANIEGO, José Luis, "El abono de las medidas cautelares en la duración de las penas", Diario la Ley, № 8293, 2014.

94 Art.764.4 LECrim: Se podrá acordar la intervención inmediata del vehículo y la retención del permiso de circulación del mismo, por el tiempo indispensable, cuando fuere necesario practicar alguna investigación en aquél o para asegurar las responsabilidades pecuniarias, en tanto no conste acreditada la solvencia del imputado o del tercero responsable civil. También podrá acordarse la intervención del permiso de conducción requiriendo al imputado para que se abstenga de conducir vehículos de motor, en tanto subsista la medida, con la prevención de lo dispuesto en el artículo 556 del Código Penal.

95 Vid. AAP de Barcelona, núm. recurso 215/2012, Sección 5a a de 20 de abril de 2012, ponente Ilma.Sra. María del Pilar Pérez de Rueda (TOL3.605.142) y AAP de Valencia, núm. 601/2018, Sección 2ª , de 14 de junio de 2018, ponente Ilmo. Sr. José Manuel Ortega Lorente (TOL6.669.817).

${ }^{96}$ Art.770.6ª LECrim. La Policía Judicial acudirá de inmediato al lugar de los hechos y realizará las siguientes diligencias: Intervendrá, de resultar procedente, el vehículo y retendrá el permiso de circulación del mismo y el permiso de conducir de la persona a la que se impute el hecho. 
La medida de intervención policial del permiso se caracteriza por cierta subjetividad de la autoridad policial a la hora de decidir la intervención del mismo ${ }^{97}$ puesto que el precepto no establece los parámetros concretos en los que puede plantearse su aplicación y remite solamente a la expresión: “...de resultar procedente”, existiendo una total ausencia de criterios normativos al respecto. Sin embargo, la intervención policial del permiso de conducir o licencia no implica que a partir de dicho momento el conductor no pueda hacer uso del derecho a conducir, ya que no existirá ninguna privación ni cautelar ni definitiva emanada de la autoridad judicial que le impida hacerlo ni tampoco se priva al conductor del ejercicio de un derecho fundamental.

Un dato singular de la medida cautelar de la privación de conducir es que su nombre no coincide con la pena impuesta en sentencia. En sede de medida cautelar, en la LECrim se sigue hablando de "privación del permiso o licencia" mientras que como pena se denomina "la privación del derecho a conducir", siendo el nombre de la medida cautelar una reminiscencia de la anterior denominación de la pena. A pesar de hacer referencia al permiso, nada obsta a identificar formal y materialmente la privación cautelar del permiso con la privación cautelar de ejercer el derecho a conducir ${ }^{98}$. Esta disfunción de la denominación podría haber sido corregida si hubiese entrado en vigor el Borrador de Código Procesal Penal del año 2013 (en adelante $B C P P)^{99}$ que regulaba en su artículo 195 la medida cautelar de privación del derecho a conducir. La modificación que planteaba el BCPP podemos calificarla como acertada, ya que armonizaría la denominación de la medida cautelar con la de la pena, privándose en ambas de la privación del derecho y no del documento físico como es el permiso o licencia. Por ello, sería recomendable que en la Ley Rituaria se estableciera que la privación recae sobre el ejercicio del derecho, para así homogeneizarlo con el nombre de la pena analizada en el estudio, lo que podría llevarse a cabo con una simple reforma de la LECrim.

97 En relación con la intervención policial cautelar del permiso de conducir vid. HIDALGO DE MORILLO JIMÉNEZ, Agustín, "Aspectos comunes a los delitos contra la seguridad vial"; La dogmática penal..., op.cit., p.45.

98 Acerca de la identidad entre privación del permiso y privación del derecho, vid. AAP de Madrid, núm. 393/2010, Sección 3ª̣, de 25 de mayo de 2010, ponente Ilmo. Sr. Juan Pelayo María García Llamas. (TOL3.572.214) y en la doctrina HIDALGO DE MORILLO JIMÉNEZ, Agustín, "Aspectos comunes a los delitos contra la seguridad vial", La dogmática penal..., op.cit., p.46.

99 Puede comprobarse el texto íntegro del borrador de Código Procesal Penal en: https://e00elmundo.uecdn.es/documentos/2013/06/04/codigo procesal penal.pdf (último acceso: 13/12/2020). 
En relación con la regulación de esta medida cautelar en el BCPP destaca, en primer lugar, que la misma se contemplaba en el art.181.c de dicho texto legal ${ }^{100}$, como alternativa a la prisión preventiva relacionadas con la peligrosidad del acusado. EI BCPP preveía la intervención y suspensión del permiso de conducción como medida cautelar para evitar la prisión provisional, de carácter mucho más gravoso para el investigado. También disponía expresamente el texto procesal penal que la privación cautelar del permiso se podía adoptar cuando la persona causante de los hechos fuera un conductor profesional ${ }^{101}$, lo que podría fomentar una mayor aplicación de esta medida cautelar en dichos casos. Por otro lado, el art.195, apartado 1 del BCPP, establecía la posibilidad de inhabilitación para el ejercicio del derecho a conducir vehículos a motor y ciclomotores cuando se detectara que podía existir por parte del encausado riesgo de reiteración delictiva mientras la causa se instruyera ${ }^{102}$. En último lugar, destacar que el BCPP recogía que cuando el permiso de conducir estuviese intervenido en la causa como medida cautelar no existiría problema alguno a la hora de realizar la posterior liquidación en la ejecución de la pena de privación del derecho a conducir, y abonar dicho periodo de privación cautelar, pues el art.687 del citado proyecto establecía dicha posibilidad $^{103}$.

Prosiguiendo con los caracteres de la medida cautelar de privación del permiso de conducir, cabe señalar que como sucede con el resto de medidas cautelares, y en particular con la prisión provisional, su aplicación debe someterse a criterios restrictivos, únicamente en aquellos casos que revistan gravedad y han de estar guiadas por el principio de proporcionalidad, al limitar la libertad deambulatoria del acusado en mayor o menor medida ${ }^{104}$.

En los casos que se acuerde la medida cautelar de privación del permiso, tanto policial como judicialmente, no existirá óbice para que, en caso de condena, en la

\footnotetext{
100 Art.181.c) 1a: Inhabilitación para el desempeño de determinadas actividades que ocasionen o faciliten la comisión de hechos delictivos de análoga naturaleza a los que están siendo objeto de la causa, interviniendo y suspendiendo en su caso el permiso de conducción, de tenencia de armas o cualquier otro que le autorice a realizar la actividad para la que se le inhabilite temporalmente.

101 Esta posibilidad ha sido destacada por MAGRO SERVET, Vicente, "Medidas que afectan a la seguridad vial incluidas en el nuevo Código Procesal Penal”, Tráfico y Seguridad Vial, no 177, 2013, pp.7-10.

102 Vid. art.195.1:“... el Tribunal, a instancia de parte, podrá acordar la medida cautelar de inhabilitación para el ejercicio de la correspondiente profesión, función o derecho, atendiendo las circunstancias personales, familiares, económicas, profesionales y laborales del encausado".

103 Vid. MAGRO SERVET, Vicente, "Medidas que afectan...., op.cit., pp.7-10.

104 Con relación a los requisitos para su adopción, vid. HIDALGO DE MORILLO JIMÉNEZ, Agustín, "Aspectos comunes a los delitos contra la seguridad vial", La dogmática penal..., op.cit., p.46.
} 
liquidación final de la misma se proceda al abono del tiempo en que de forma cautelar no se ha podido ejercer el derecho a conducir ${ }^{105}$. Los criterios que se siguen en relación al abono de la prisión provisional para la liquidación definitiva en el caso de condena, se aplican también a las penas privativas de derechos como la privación del derecho a conducir ya que el art.58.4 CP así lo preceptúa106. Sin embargo, para el caso que finalmente el acusado sea absuelto por la concurrencia de una circunstancia eximente o bien sea declarado inimputable, surge la duda respecto si cabe proceder al abono del periodo de la privación cautelar para el caso se le imponga la medida de seguridad de privación del derecho a conducir ${ }^{107}$. Al respecto cabe señalar que desde el tenor literal del art. $59 \mathrm{CP}$ no parece que pueda procederse a la liquidación, al referirse el precepto a la pena impuesta y no a la medida de seguridad ${ }^{108}$. No obstante, en la praxis judicial se acude a una interpretación analógica a la pena favorable al reo, procediéndose al abono de la medida cautelar a la liquidación definitiva de la medida de seguridad de privación del derecho a conducir, aun cuando pudiera resultar interesante que el propio legislador clarificara esta cuestión.

Uno de los principales problemas de la medida cautelar de privación del permiso de conducir es que no existe una normativa que limite su duración, al contrario de lo que se establece en la prisión provisional ex art. 504 de la LECrim ${ }^{109}$. Debido a la ausencia de un límite temporal, el conductor investigado podrá ver privado provisionalmente su derecho a conducir sine die. En cualquier caso, esta medida cautelar no podrá ser mantenida indefinidamente o con parámetros temporales

\footnotetext{
105 En lo relativo al abono del periodo en que se ha visto privado cautelarmente del ejercicio del derecho a conducir, vid. VALLESPÍN PÉREZ, David, Aspectos procesales..., op.cit., p.86. Hemos de señalar que el abono de la privación cautelar del permiso de conducir durante la tramitación de la causa, se reguló desde la Ley 24 de abril de 1958, por la que se modifican determinados artículos del Código Penal. En este sentido Vid. MANZANARES SAMANIEGO, José Luis, "El abono de las medidas cautelares en la duración de las penas", Diario La Ley, ํㅡ 8293, 2014.

106 Vid. HIDALGO DE MORILLO JIMÉNEZ, Agustín, "Aspectos comunes a los delitos contra la seguridad vial", La dogmática penal..., op.cit., p.82. La jurisprudencia que ha resuelto casos de abono del periodo de privación policial y judicial del permiso de conducir en la liquidación definitiva de condena, está citada en el epígrafe 4.1.1.

107 Vid. GÓMEZ PAVÓN, Pilar, El delito... op.cit., p 223.

108 Art.59 CP: Cuando las medidas cautelares sufridas y la pena impuesta sean de distinta naturaleza, el Juez o Tribunal ordenará que se tenga por ejecutada la pena impuesta en aquella parte que estime compensada.

109 Esta anomalía ha sido destacada por MORENO CATENA Víctor, "Otras medidas cautelares y medidas de protección", en MORENO CATENA, Víctor/CORTÉS DOMÍNGUEZ Valentín, Derecho..., op.cit., p.347.
} 
desproporcionados en relación con la pena final a imponer ${ }^{110}$. Serán las circunstancias concretas de cada caso las que coadyuven al cese de la medida cautelar, ya que habrá que valorar la duración de la instrucción del procedimiento, la posible pena a imponer y la previsión temporal para la celebración del juicio oral.

\subsubsection{Marco procesal y criterios jurisprudenciales}

A continuación, se determinará el marco procesal en el que se puede acordar la medida cautelar de privación del permiso de conducir, así como los criterios jurisprudenciales para su aplicación. En primer lugar, esta medida cautelar puede acordarse en los procedimientos tramitados como Juicio Rápido-Diligencias Urgentes en los que el investigado no se muestre conforme con la acusación y se deba celebrar la vista ante el Juzgado de lo Penal ${ }^{111}$. En estos supuestos el Juicio Oral tendrá lugar en un plazo aproximado de un mes, y la medida cautelar servirá para que el investigado no ejerza su derecho a conducir hasta la celebración del mismo, pudiéndose evitar así la reiteración delictiva. Si esto lo relacionamos con el hecho que se podrá dictar sentencia en un plazo breve de tiempo, la medida cautelar de privación de conducir adoptada en esta tipología procesal puede ser idónea para combatir la delincuencia vial. A todo ello se debe añadir que la sentencia que se dicte puede prorrogar la medida cautelar hasta que la resolución devenga firme. A sensu contrario, y para el hipotético caso que el investigado sea absuelto, en la misma sentencia absolutoria podrá dejarse sin efecto la medida cautelar acordada en su día en el Juzgado de Guardia.

En el resto de procedimientos, mayoritariamente los que se tramitan como Diligencias Previas, también puede acordarse la medida cautelar de privación del permiso de conducir si los hechos revisten especial importancia con la existencia fallecidos o lesionados de gravedad, o que pueda concurrir indiciariamente una conducción influenciada por alcohol o drogas, así como una conducción manifiestamente temeraria o velocidad excesiva, pues razones de proporcionalidad justificarían su adopción ${ }^{112}$.

\footnotetext{
110 Vid. dichos criterios en AAP de Barcelona, núm. recurso 202/2010, Sección 6ấ, de 22 de noviembre de 2010, ponente IImo.Sr. Miguel Ángel Gimeno Jubero (TOL3.551.959) y AAP de Murcia, núm. 1048/2017, Sección 3aㅡ, de 24 de noviembre de 2017, ponente Ilmo.Sr. José Luis García Fernández (TOL6.486.552).

111 Vid. RODRíGUEZ LEÓN, Luis Carlos, Seguridad Vial. Crónica de una reforma penal, Instituto Andaluz de Administración Pública. Sevilla, 2008, p.47.

$112 \mathrm{~A}$ tal efecto podemos señalar supuestos de atropellos mortales a peatones o ciclistas en los que se acordó la medida. Vid. las notas de prensa en:
} 
La adopción de la medida de privación cautelar del permiso a través de las dos vías señaladas sería recomendable que se acordara, de forma conjunta con la intervención judicial del vehículo para evitar que el investigado pueda seguir conduciendo ${ }^{113}$, y así minimizar uno de los principales hándicaps que tiene la adopción de la medida como es su quebrantamiento.

Entre los criterios esgrimidos por jueces y magistrados para la adopción de la medida cautelar consistente en la privación del permiso de conducir destaca el relativo a la gravedad de los hechos objeto de investigación, como podrían ser los supuestos de homicidio y/o conducción temeraria. En este contexto se enmarcan algunas resoluciones de diversas Audiencias Provinciales que instruyen casos de delitos contra la seguridad vial con resultado fatal para la vida o la integridad de las personas ${ }^{114}$.

El segundo parámetro que se constata en el análisis de la jurisprudencia es la percepción por parte del tribunal de un riesgo de reiteración delictiva, ya que la jurisprudencia ha considerado que la privación cautelar del permiso de conducir se debe adoptar en aquellos supuestos que exista riesgo de reiteración cuando existen

http://www.europapress.es/murcia/noticia-juez-ordena-retirada-cautelar-permiso-conducir-presuntoresponsable-atropello-mortal-murcia-20120607170818.html (último acceso: 02/11/2020).

https://www.segre.com/es/noticias/comarcas/2019/03/16/medidas cautelares para conductor deten ido por atropello mortal torres segre 70850 1091.html (último acceso: 02/11/2020).

113 En este sentido citar como destacado el AAP de Barcelona, núm. recurso 425/2012, Sección 6áa, de 26 de abril de 2012, ponente IImo.Sr. Eduardo Navarro Blasco (TOL3.553.670) en el que se ratifica la medida cautelar de intervención cautelar de vehículo y permiso de conducir en un procedimiento seguido por varios delitos contra la seguridad vial y atentado a agente de la autoridad. En la misma línea es interesante el AAP de Madrid, núm. 868/2018, Sección 4aㄹ, de 26 de noviembre de 2018, ponente IImo. Sr. José Joaquín Hervás Ortiz (TOL7.000.719) en el que además de ratificar la medida cautelar de intervención cautelar de vehículo y permiso de conducir, se complementa con la obligación de someterse a controles médicos por parte del investigado.

114 Vid. AAP de Madrid, núm.1045/2012, Sección 5ạ , de 12 de marzo de 2012, ponente Ilmo.Sr. Arturo Beltrán Núñez (TOL3.565.093) y AAP de Barcelona, núm. recurso 425/2012, Sección 6a , de 26 de abril de 2012, ponente IImo.Sr. Eduardo Navarro Blasco (TOL3.553.670). También podemos señalar el auto de fecha 27 de febrero de 2012 del Juzgado de Instrucción de Arévalo (Ávila), y en el que se retiró cautelarmente el permiso de conducir al conductor imputado durante toda la tramitación de la causa. Vid. la referencia al mismo en la SAP de Ávila, núm. 108/2016, Sección 1ạ, de 27 de octubre de 2016, ponente IImo.Sr. Jesús García García (TOL5.899.856). También podemos señalar la invocación de la jurisprudencia constitucional en relación con las medidas cautelares restrictivas de derechos, y de aplicación a supuestos de infracción grave de las normas viarias con resultado de personas fallecidas. Vid. AAP de Zaragoza, núm. 207/2019, Sección 1aㅡ, de 28 de marzo de 2019, ponente IImo. Sr. Alfonso Ballestín Miguel (TOL7.195.393). Incluso, en determinados supuestos, se ha decidido mantener la privación cautelar del permiso una vez se ha dictado el auto de transformación a Procedimiento Abreviado y escrito de acusación. Vid. AAP de Burgos, núm. 268/2019, Sección 1aㅡ, de 2 de abril de 2019, ponente Ilma. Sra. María Dolores Fresco Rodríguez (TOL7.210.739). 
indicios de que el investigado ha realizado conductas delictivas relacionadas con la circulación de vehículos a motor y ciclomotores ${ }^{115}$. En el mismo sentido se ha acordado la medida cautelar de privación del derecho a conducir en supuestos que el penado quebranta una previa condena a la privación del derecho a conducir pues es detectado conduciendo vehículos a motor y ciclomotores, estando vigente una pena o una medida de esta naturaleza, pudiendo con ello generar un peligro para el resto de usuarios de la vía desobedeciendo el mandato judiciall ${ }^{116}$.

En tercer lugar, se ha destacado por la jurisprudencia que la medida cautelar de privación del permiso combinada con otras medidas como la prestación de fianza y la comparecencia apud acta, puede ser utilizada para evitar la medida cautelar más restrictiva de derechos fundamentales como es la prisión provisional ${ }^{117}$. No obstante, también se observa como en ocasiones se ha acordado la medida cautelar de privación del permiso de conducir tras finalizar la medida cautelar de prisión provisional ${ }^{118}$, combinando de esta forma varias medidas cautelares con el objetivo de proteger la seguridad vial y guiadas por el principio de proporcionalidad. En estos casos, la medida cautelar de privación del permiso de conducir al ser impuesta junto con otras medidas, puede alcanzar los mismos fines que puede perseguir una medida más gravosa como es la prisión provisional ${ }^{119}$. De hecho, autores como GIMENO SENDRA, han destacado que la medida cautelar de privación del permiso de conducir únicamente se puede acordar en aquellos casos en los que la persona investigada por el delito se encuentre en libertad ${ }^{120}$.

\footnotetext{
115 Vid. AAP de Barcelona, núm. recurso 425/2012, Sección 6a , de 26 de abril de 2012, ponente IImo.Sr. Eduardo Navarro Blasco (TOL3.553.670); AAP de Burgos, núm. 60/2017 Sección 1르, de 31 de enero de 2017, ponente IIma. Sra. María Dolores Fresco Rodríguez (TOL6.002.556) y AAP de Girona, núm. 698/2017, Sección 4ª̣ , de 20 de diciembre de 2017, ponente IImo. Sr. Daniel Varona Gómez (TOL6.652.766).

116 Respecto de la existencia del requisito de "periculum in mora" para la adopción de la medida cautelar de privación del permiso de conducir, vid. AAP de Castellón, núm. 465/2010, Sección 2ª , de 30 de diciembre de 2010, ponente Ilma. Sra. Eloísa Gómez Santana (TOL3.608.679).

117 Este criterio ha sido expuesto en el AAP de Sevilla, núm. 316/2012, Sección 1aa de 2 de mayo de 2012, ponente Ilma. Sra. Ma Auxiliadora Echavarri García (TOL3.583.131) y el AAP de Lleida, núm. 236/2012, Sección 1ạ, de 17 de mayo de 2012, ponente Ilma. Sra. Mā Lucía Jiménez Márquez (TOL5.346.410).

118 Vid. SAP de Murcia, núm. 409/2011, Sección 2ª , de 29 de octubre de 2011, ponente llma.Sra. Beatriz Lourdes Carrillo Carrillo. (TOL2.278.059).

${ }^{119}$ Vid. AAP de Lleida, núm. 408/2019, Sección 1a, de 16 de julio de 2019, ponente Ilma.Sra. Mercé Juan Agustín. (TOL7.464.889).

120 Vid. GIMENO SENDRA, Vicente, Manual de Derecho Procesal Penal, Ediciones Jurídicas Castillo de Luna, Valencia, 2018, p.518
} 
Incluso, en alguna resolución se ha adoptado la privación cautelar del permiso de conducir con vigencia en toda la Unión Europea para evitar que el investigado por delitos contra la seguridad vial de cierta gravedad, conduzca en todo el ámbito comunitario y de esta forma dejar sin efecto una situación de prisión provisional ${ }^{121}$. Estas circunstancias pueden no ser relevantes para un ciudadano que no se dedique profesionalmente al transporte, pero para conductores profesionales la adopción de esta medida cautelar con alcance europeo tendrá un alto componente aflictivo.

En lo que respecta a los criterios jurisprudenciales para revocar la medida cautelar de privación del permiso de conducir, se observa en las resoluciones jurisprudenciales la referencia al hecho que el investigado haya cumplido ya como medida cautelar el tiempo mínimo de duración que prevé la pena de privación del derecho a conducir en el delito que se imputa ${ }^{122}$. Este criterio podemos valorarlo de forma positiva, ya que carecería de sentido que la medida cautelar excediera de la posible pena mínima que se le pudiera imponer al ulteriormente condenado. Otro de los parámetros seguidos por la jurisprudencia para dejar sin efecto la medida cautelar de privación del permiso de conducir ha sido el de compararla con la medida cautelar de prisión provisional, así como determinar que en modo alguno puede considerarse que sean una pena anticipada ${ }^{123}$, ya que únicamente deberá ser adoptada, o en su caso mantenida, cuando no existan otros mecanismos para garantizar el buen fin del proceso, ya que toda medida cautelar está unida a este objetivo. De igual modo, la ausencia de un pronóstico de peligrosidad del investigado, así como la inexistencia de antecedentes por delitos relacionados con la seguridad vial, han sido valorados como elementos para revocar la privación cautelar del permiso de conducir ${ }^{124}$. Por último, también podemos destacar que la modificación de circunstancias laborales del investigado unido a un cierto transcurso

\footnotetext{
121 En relación con la privación cautelar del permiso acordada en España y con eficacia en todo el ámbito de la Unión Europea, vid. AAP de Barcelona, núm. recurso 682/2011, Sección 10ª , de 12 de enero de 2012, ponente IImo. Sr. Santiago Vidal Marsal (TOL3.632.830).

122 Vid. AAP de Sevilla núm. 784/2011, Sección 3a a de 30 de diciembre de 2011, ponente llmo.Sr. Ángel Márquez Romero (TOL3.578.869) y AAP de Murcia, núm. 853/2017, Sección 3ª̣, de 9 de octubre de 2017, ponente Illmo. Sr. Álvaro Castaño Penalva (TOL6.418.507).

123 Vid. AAP de Pontevedra, núm. 448/2017, Sección 5a , de 21 de junio de 2017, ponente llma. Sra. María Mercedes Pérez Martín-Esperanza (TOL6.264.435) y AAP de Sevilla, núm. 614/2017, Sección 1르, de 30 de junio de 2017, ponente Ilmo. Sr. Juan Antonio Calle Peña (TOL6.364.525).

124 Vid. AAP de Zaragoza, núm. 215/2019, Sección 6ª , de 7 de mayo de 2019, ponente Ilma. Sra. María Victoria López Asín (TOL7.238.719) y AAP de Barcelona, núm. 180/2020, Sección 8ª de 3 de junio de 2020, ponente Ilma. Sra. Montserrat Arroyo Romagosa (TOL8.036.894).
} 
de tiempo de cumplimiento de la medida cautelar, también han sido argumentos utilizados para dejar sin efecto misma ${ }^{125}$.

Tras el análisis de los criterios jurisprudenciales para la adopción de la privación cautelar del permiso de conducir hemos de señalar que coinciden con los criterios que mantiene la Fiscalía de Seguridad Vial para la adopción de dicha medida cautelar que se caracterizan por acordarse en casos de gravedad, de reincidencia delictiva o que generen una determinada alarma social y siempre bajo el parámetro de la proporcionalidad ${ }^{126}$.

\subsubsection{Hacia una mayor aplicación de la medida cautelar}

Para finalizar el estudio de la privación del derecho a conducir como medida cautelar puede proponerse que los jueces tomen en mayor medida en consideración la posibilidad de aplicar esta medida en los procedimientos que puedan conllevar la imposición de la pena de privación del derecho a conducir, en cuanto medida alternativa a una medida de prisión provisional y valorando su utilidad en el ámbito de la delincuencia vial ${ }^{127}$.

La posibilidad de un mayor recurso a la medida cautelar de privación del permiso de conducir ya ha sido preconizado por la FGE, y específicamente la Fiscalía de Seguridad Vial, como uno de los mecanismos que pueden coadyuvar a una mejor aplicación de la pena de privación del derecho a conducir. A tal efecto es destacable la Instrucción 3/2006 de la FGE de 3 de julio "Sobre criterios de actuación del Ministerio Fiscal para una efectiva persecución de los ilícitos penales relacionados con la circulación de vehículos a motor"128 que en el capítulo dedicado a: "Otros recursos penales en materia de seguridad vial", apartado a), hacía referencia a la debida utilización de medidas cautelares penales en los casos más graves, siendo

\footnotetext{
125 Vid. AAP de Soria, núm. 146/2016, Sección 1ạ, de 28 de noviembre de 2016, ponente IImo. Sr. José Luis Rodríguez Greciano (TOL6.067.897).

126 Estos criterios han sido señalados por la FGE en la Memoria del año 2010, pp.941-942.

127 En este sentido vid. RODRíGUEZ LEÓN, Luis Carlos, Seguridad Vial..., op.cit., p.47 y BARONA VILAR, Silvia, "Especialidades procedimentales", en AA.VV. Derecho Jurisdiccional III. Proceso penal, MONTERO AROCA, Juan/GÓMEZ COLOMER, Juan Luis/BARONA VILAR, Silvia/ESPARZA LEIBAR, Iñaki/EXTEBERRÍA GURDI, José F., Ed.Tirant lo Blanch, Valencia, 2018, 26ª edición, p.612.

128 Documento disponible en formato electrónico en:

https://www.fiscal.es/memorias/estudio2016/INS/INS 03 2006.html (último acceso: 02/11/2020).
} 
uno de ellos el de la retención del permiso de conducir ${ }^{129}$. El diagnóstico realizado hace casi tres lustros por parte de la FGE hay que valorarlo como acertado, al destacar que nuestro ordenamiento penal ofrece mecanismos que han de ser desarrollados en aras a mejorar la seguridad vial ${ }^{130}$.

La preocupación de la Fiscalía de Seguridad Vial por un uso reducido de la privación cautelar del permiso de conducir también se puso de relieve en la Memoria de la FGE ${ }^{131}$ en el año 2007. La escasa utilización de esta medida cautelar se reiteró en la Memoria de la FGE del año 2010, al destacar que no se debe aplicar únicamente en los delitos contra la seguridad vial, sino que puede ser acordada en otro tipo de delitos siempre que en ellos se pueda imponer la pena de privación del derecho a conduciri ${ }^{132}$.

Entre los motivos que contribuyen a una escasa aplicación de la medida cautelar pueden apuntarse por lo menos los dos siguientes:

En primer lugar, es poco frecuente que la Fiscalía peticione la medida cautelar penal de privación del permiso de conducir en los delitos relacionados con la utilización de vehículos a motor o ciclomotor. Los supuestos en los que se insta suelen ser aquellos que son calificados como graves debido a la existencia de fallecidos lesionados de gravedad, generen lo que se denomina alarma social y/o exista una relevancia mediática ${ }^{133}$, y también en los casos en que los conductores sean reincidentes, conduzcan con tasas de alcohol elevadas, etc. ${ }^{134}$. Sin embargo, probablemente fuera adecuado que la medida cautelar no quedara restringida a conductores reincidentes o que han conducido con unas tasas elevadas de alcohol, ya que no existe impedimento para que aquella pueda ser también aplicada a los supuestos de exceso de velocidad con unos márgenes muy por encima de los

\footnotetext{
129 Vid. la Instrucción núm. 3/2006 de la FGE, p.17.

130 Esta propuesta de la FGE también ha sido destacada por DE VICENTE MARTÍNEZ, Rosario, Derecho..., op.cit., p.455.

131 Vid. la Memoria de la FGE, año 2007, p. 527 en la que se destaca su efecto preventivo.

132 Vid. la Memoria de la FGE, año 2010, p. 941.

133 En relación con la finalidad de la medida cautelar de privación del permiso, vid. HIDALGO DE MORILLO JIMÉNEZ, Agustín, "Aspectos comunes a los delitos contra la seguridad vial", La dogmática penal..., op.cit., p.46.

134 Vid. RODRíGUEZ LEÓN, Luis Carlos, Seguridad Vial..., op.cit., p.47 y también la Memoria del año 2010, pp.941-942, en relación a los criterios para la petición de la medida cautelar por parte de la FGE.
} 
permitidos $^{135}$, así como en supuestos en los que la tasa de alcohol no sea elevada pero se hayan producido lesiones de gravedad en peatones, conductores $u$ otros usuarios de la vía.

Un segundo factor que podemos asociar a la limitada aplicación de la privación cautelar del permiso de conducir, puede estar relacionado con los acuerdos de conformidad con la acusación formulada que se llevan a cabo a través del cauce procesal de Diligencias Urgentes-Juicio Rápido regulado en el art.801.2 de la LECrim en los procedimientos en los que se peticiona la pena de privación del derecho a conducir. En estos casos, al dictarse sentencia condenatoria firme, no es necesario adoptar medidas cautelares debido a que se inicia la ejecución de la pena de privación del derecho a conducir en el mismo Juzgado de Guardia.

Sin embargo, estas prácticas no deberían impedir el mayor recurso a esta medida cautelar, y en particular si tenemos en cuenta las siguientes ideas que justificarían un incremento del uso de la medida cautelar.

1) La medida cautelar de privación del permiso de conducir, tiene una gran potencialidad en su aplicación y puede ser equiparable con relación a los fines que persigue a la pena que priva del mismo derecho en cuanto a la prevención general y especial ${ }^{136}$. Una mayor aplicación de esta medida cautelar penal, y obviamente su aplicación tras una valoración de las circunstancias y los riesgos asociados al caso, podría ser beneficiosa a efectos de prevenir nuevos hechos delictivos por el investigado mientras dure la instrucción de la causa ${ }^{137}$, ya que existe un claro efecto disuasorio al estar regulada expresamente la posible imputación bien por el delito de quebrantamiento del art.384.2 bien por desobediencia grave ex art.556 CP. Si el conductor al que se le ha impuesto esta medida cautelar es descubierto conduciendo durante la vigencia de la misma, será investigado por un nuevo delito de quebrantamiento de condena del art.384 CP, derivándose unas consecuencias

\footnotetext{
135 Un ejemplo de ello es el caso que puede consultarse en: http://www.aragondigital.es/noticia.asp?notid=45377\&secid=9 (último acceso: 02/11/2020).

136 Vid. RODRíGUEZ LEÓN, Luis Carlos, Seguridad Vial..., op.cit., p.47, quien ha destacado que la medida cautelar de privación del permiso puede ser un mecanismo eficaz para evitar la comisión de nuevos delitos.

137 La finalidad de la medida como herramienta para evitar la comisión de nuevos delitos cometidos con un vehículo a motor o ciclomotor ha sido destacada por GIMENO SENDRA, Vicente, Manual..., op.cit., p.518.
} 
del incumplimiento que serán gravosas ya durante la tramitación del procedimiento que dio origen a la causa ${ }^{138}$.

En efecto, la consecuencia del incumplimiento de la medida cautelar había generado cierta controversia en el pasado por cuanto se planteaba si dichas acciones debían ser penalizadas al amparo del art. del art.468 CP, que establece la conducta típica del quebrantamiento de medida cautelar no privativa de libertad como es la privación cautelar del permiso de conducir o si tal conducta debía encauzarse a través del art. $556 \mathrm{CP}$ relativo al delito de desobediencia o bien por el art. $384 \mathrm{CP}$ sobre el delito de quebrantamiento ${ }^{139}$. Si observamos la posible eficacia disuasoria que pueda tener la privación cautelar del permiso o licencia, el art.468 establece una pena de multa de 12 a 24 meses, el art.556 establece una pena de prisión de seis meses a un año, mientras que el art.384 CP establece un régimen de alternatividad en la pena de prisión, multa o TBC. En la actualidad, los conductores que no respeten la medida cautelar de privación cautelar del permiso acordada judicialmente deberán ser sancionados por el art.384 CP, al ser un precepto penal especial que protege en el ámbito de la seguridad vial el efectivo cumplimiento de esta medida cautelar ${ }^{140}$. El tipo del art.384 puede contribuir a que el juzgador se muestre más proclive a la aplicación de la medida cautelar de privación del permiso ${ }^{141}$, pues si el conductor no la cumple, el juzgador tendrá una triple opción para sancionar dicha conducta a diferencia de los anteriores tipos de los arts.468 y 556 CP que estaban mucho más limitados. La medida cautelar de privación cautelar tendrá una respuesta más adecuada a su quebrantamiento, y en relación con la prevención especial del autor de los hechos el Juzgador podrá optar por la pena que se considere más ajustada a los hechos acaecidos.

\footnotetext{
138 Vid. REQUEJO CONDE, Carmen, Delitos relativos al tráfico viario, Ed. Tirant Lo Blanch, Valencia, 2011, pp.80-81.

139 En relación con la controversia vid. HERRERO ÁLVAREZ, Sergio, "Doce novedades en el procedimiento abreviado (reforma de octubre de 2002 de la ley de enjuiciamiento criminal)", Sala de Togas, Revista del llustre Colegio de Abogados de Gijón, número 45, abril 2003.

140 Sin embargo, existen opiniones doctrinales que mantienen que la finalidad de la medida cautelar de privación del permiso no está directamente relacionada con la protección de la seguridad vial. Vid. MONTANER FERNÁNDEZ, Raquel, "Los nuevos delitos contra la seguridad vial: una muestra de la Administración del Derecho Penal", Revista de Documentación Administrativa, № 284-285, mayodiciembre 2009, p.312.

141 Sobre la protección que proporciona el art.384 CP en los supuestos de quebrantamiento de medida cautelar de privación del permiso de conducir, vid. GARCÍA DEL BLANCO, Victoria, "EI nuevo artículo 384 del Código Penal: Quebrantamientos, desobediencias y conductas afines", en AA.VV. Protección Penal de la Seguridad Vial, en GUTIÉRREZ RODRíGUEZ, María (Coord.), Ed. Tirant lo Blanch, Valencia, 2009, p.446.
} 
2) La utilización de la medida cautelar debería plantearse en todos los supuestos en los que se hayan cometido acciones con vehículo a motor o ciclomotor con resultado de homicidio, lesiones graves, bien sea por conducciones temerarias o influencias por el alcohol, junto a supuestos de conductores que han sido sorprendidos circulando a una velocidad excesiva y que han de merecer una respuesta pronta y eficaz por parte de los Juzgados ${ }^{142}$. Ello puede canalizarse a través de la privación cautelar del permiso de conducir, al ser una herramienta que se atribuye al poder judicial para poder evitar la comisión de nuevos hechos delictivos sin que suponga una pena anticipada ni una vulneración de la presunción de inocencia, siendo además un mecanismo que puede evitar que se aplique otra medida mucho más restrictiva de derechos fundamentales como es la prisión provisional $^{143}$.

3) Otro efecto positivo que podría tener la aplicación de la medida cautelar de privación del derecho a conducir es que podría contribuir a mejorar incluso la propia ejecución de la pena de privación del derecho a conducir. En este sentido, cuando conste acordada la medida cautelar penal de intervención del permiso de conducir, para el caso de dictarse sentencia condenatoria firme, el Juzgado únicamente deberá realizar la liquidación de condena y requerimiento de abstención de conducir al tener ya el permiso del penado en su poder. Ello puede ser de utilidad en los supuestos que el penado no pueda ser ulteriormente localizado y no pueda ser requerido, por lo que existiría el riesgo que la pena de privación del derecho a conducir impuesta pudiera llegar incluso a prescribir. Si en estos casos está acordada la medida cautelar de privación del permiso de conducir, por lo menos una parte de la pena ya se habrá cumplido por lo que también puede reducirse la sensación de impunidad. Sin embargo, no se debe generalizar la adopción de la medida cautelar en todos los casos, ya que debe tenerse en cuenta los efectos perniciosos que puede tener su aplicación cuando no se ha demostrado la culpabilidad del sujeto, máxime cuando subyace la posibilidad que sea absuelto en el juicio.

\footnotetext{
142 Podemos señalar el supuesto de un conductor de la provincia de Valencia, acusado de homicidio por imprudencia y que triplicó la tasa de alcoholemia. Recurso disponible en: https://www.levanteemv.com/ribera/2019/03/26/jueza-deja-libertad-conductor-ebrio/1853184.html (último acceso: $02 / 11 / 2020)$.

143 La mayor utilización de la medida cautelar de privación del permiso a conducir, va en la línea de lo expresado en la Recomendación del Consejo de Europa CM/Rec (2107) 3, relativa a las Reglas europeas sobre las sanciones y medidas aplicadas en la comunidad, adoptada por el Comité de Ministros el 22 de marzo de 2017, en aras a reducir el uso de la prisión, tanto provisional como definitiva.
} 


\subsection{La medida de privación del derecho a conducir en el Derecho Penal Juvenil}

Una vez realizado el examen de la de privación del derecho a conducir en el ámbito de la legislación penal de adultos, definiremos cómo se aplica la privación del derecho a conducir en el ámbito del Derecho Penal Juvenil a través de la Ley Orgánica 5/2000, de 12 de enero, reguladora de la responsabilidad penal de los menores (en adelante LORPM), y desgranaremos las particularidades que presenta en relación con la jurisdicción de adultos. En cuanto a su duración, no existe en la un umbral mínimo y el límite temporal máximo es de dos años ex art. 9.3 de la LORPM $^{144}$.

A pesar de que la medida de privación del permiso o licencia de conducir está prevista en la legislación penal juvenil, su aplicación es mucho más reducida que la que se observa en la legislación penal de adultos ${ }^{145}$. En la última década las medidas de privación del permiso o licencia para conducir impuestas en el ámbito penal juvenil, según el INE, han sido las siguientes: 117 en el año 2011, 124 en el año 2012, 91 en el año 2013, 41 en el año 2014, 66 en el año 2015, 54 en el año 2016, 50 en el año 2017, 38 en el año 2018 y 41 en el año 2019, es decir, un número muy escaso mientras que en el ámbito de adultos en el año 2016 se han impuesto 55.148, en el año 2017, 55.890, en el año 2018, 60.400 y en el año 2019 fueron 52.028 penas de privación del derecho a conducir ${ }^{146}$. El motivo es obvio si tomamos en consideración la edad de los sujetos a quienes se aplica la medida, y sin embargo respecto a ello cabe hacer algunas precisiones.

La primera singularidad que presenta la jurisdicción de menores es que la LORPM establece en su art.1 que ésta únicamente es aplicable a las personas mayores de

\footnotetext{
${ }^{144}$ Art.9.3: La duración de las medidas no podrá exceder de dos años, computándose, en su caso, a estos efectos el tiempo ya cumplido por el menor en medida cautelar, conforme a lo dispuesto en el artículo 28.5 de la presente Ley. La medida de prestaciones en beneficio de la comunidad no podrá superar las cien horas. La medida de permanencia de fin de semana no podrá superar los ocho fines de semana.

145 Referente a la escasa aplicación de la privación del derecho a conducir en el Derecho Penal Juvenil vid. MUÑOZ RUIZ, Josefa, "Modalidades típicas del delito de conducción sin permiso y menores", en AA.VV. El delito..., MORILLAS FERNÁNDEZ, David Lorenzo (Coordinador), op.cit., p.113.

146 Vid. Memoria FGE año 2017 p. 576; año 2018, p. 665; año 2019, p.876 y año 2020, p, 913.
} 
14 de edad y menores de 18 años $^{147}$. Ello implica que los menores a los que se les puede imponer la medida que examinamos no poseen permiso de conducir automóviles y otros vehículos al carecer de la edad mínima para poder tenerlo, que son los 18 años $^{148}$. Sin embargo, sí pueden obtener el permiso para conducir ciclomotores, ya que en este caso la edad mínima requerida son los 15 años, así como motocicletas de cilindrada máxima de $125 \mathrm{~cm} 3$ tal como establecen el art.4.2.a) y b) Real Decreto (en adelante $R D$ ) 818/2009, de 8 de mayo, por el que se aprueba el Reglamento General de Conductores (en adelante RGCon) ${ }^{149}$. Además, los menores entre los 14 y 18 años también podrán ser titulares de licencia para conducir vehículos para personas de movilidad reducida y vehículos agrícolas especiales autopropulsados, como establece el art. 6 del RGCon ${ }^{150}$.

La segunda singularidad es la relativa a la finalidad de ambas, al tener la medida en el ámbito de la LORPM una clara función de reeducación del menor de manera

\footnotetext{
147 Art. 1 LORPM. Declaración general: Esta Ley se aplicará para exigir la responsabilidad de las personas mayores de catorce años y menores de dieciocho por la comisión de hechos tipificados como delitos o faltas en el Código Penal o las leyes penales especiales.

148 En relación a los permisos de conducir para los que se requiere una edad mínima de 18 años, vid. Art.4 del Real Decreto 818/2009, de 8 de mayo, por el que se aprueba el Reglamento General de Conductores. Recurso electrónico disponible en: http://www.boe.es/diario boe/txt.php?id=BOE-A2009-9481 (último acceso: 13/11/2020).

${ }^{149}$ El art.4 apartado 2 del RGCon, establece que el permiso de conducción de la clase AM autoriza para conducir ciclomotores de dos o tres ruedas y cuatriciclos ligeros, aunque podrá estar limitado a la conducción de ciclomotores de tres ruedas y cuatriciclos ligeros. La edad mínima para obtenerlo será de quince años cumplidos. Y en relación con el permiso de conducción de la clase A1, que éste autoriza para conducir motocicletas con una cilindrada máxima de $125 \mathrm{~cm}^{3}$, una potencia máxima de $11 \mathrm{~kW}$ y una relación potencia/peso máxima de $0,1 \mathrm{~kW} / \mathrm{kg}$ y triciclos de motor cuya potencia máxima no exceda de $15 \mathrm{~kW}$. La edad mínima para obtenerlo será de dieciséis años cumplidos.
}

150 Artículo 6 RGCon. Clases de licencia de conducción y edad requerida para obtenerla. 1. La licencia de conducción, teniendo en cuenta los vehículos cuya conducción autoriza, será de las siguientes clases: a) Para conducir vehículos para personas de movilidad reducida. La edad mínima para obtenerla será de catorce años cumplidos. No obstante, hasta los dieciséis años cumplidos no autorizará a transportar pasajeros en el vehículo. No se exigirá esta licencia a quien sea titular de un permiso de conducción de las clases $A 10 B$ en vigor y en el caso de que su titular obtenga un permiso de alguna de estas clases, la licencia de conducción dejará de ser válida. b) Para conducir vehículos especiales agrícolas autopropulsados y sus conjuntos cuya masa o dimensiones máximas autorizadas no excedan de los límites establecidos para los vehículos ordinarios o cuya velocidad máxima por construcción no exceda de $45 \mathrm{~km} / \mathrm{h}$. La edad mínima para obtenerla será de dieciséis años cumplidos. No se exigirá esta licencia a quien sea titular de un permiso de conducción de la clase $B$ en vigor y en el caso de que su titular obtenga un permiso de esta clase, la licencia de conducción dejará de ser válida. 2. Si una persona fuera titular de más de una clase de licencia de conducción, todas ellas deberán constar en un único documento. Respecto de los permisos y licencias para conducir vehículos a motor y ciclomotores que pueden obtener los menores de edad, vid. BENITTEZ ORTÚZAR, Ignacio F, "El bien jurídico en el delito de conducción sin permiso o licencia", y MUÑOZ RUIZ, Josefa, "Modalidades típicas del delito de conducción sin permiso y menores", en AA.VV. El delito de conducción de vehículos a motor o ciclomotores sin licencia administrativa cometido por menores de edad, MORILLAS FERNÁNDEZ, David Lorenzo (Coordinador), Ed. Dykinson, Madrid, 2018, pp.35-36 y 105. 
correlativa al espíritu que rige el Derecho Penal Juvenil ${ }^{151}$. El hecho que en el Derecho Penal Juvenil se hable de medidas y no de penas está relacionado con el espíritu de reeducación de los menores que han cometido actos delictivos ${ }^{152}$, al tratar de detraer el contenido criminal que destila el concepto de pena.

La tercera particularidad existente en el Derecho Penal Juvenil es la denominación de la sanción penal, que en el ámbito de adultos se identifica como pena mientras que en el Derecho Penal Juvenil recibe el nombre de medida ${ }^{153}$. A pesar de esta diferencia, los efectos de la privación del derecho a conducir en ambas jurisdicciones son idénticos y tanto la pena en adultos como la medida en menores, privan del ejercicio de un derecho durante el tiempo establecido en la sentencia.

En cuarto lugar, la LORPM contempla esta medida en el art.7.1. n) que alude a la privación del permiso para conducir ${ }^{154}$. Si lo comparamos con la pena privativa de derechos en el $\mathrm{CP}$, podemos comprobar que el contenido al que se alude en su denominación es distinto: en el ámbito de adultos se hace referencia a la privación del derecho a conducir y no se hace referencia el documento físico, excepto en el ámbito de la medida cautelar tal como hemos visto en el apartado 1.3 del trabajo. Si bien formalmente es una diferencia que apuntar, en términos prácticos los efectos son idénticos pues con la imposición de la medida el menor penado no podrá ejercitar su derecho a conducir ${ }^{155}$. En cuanto a esta disfunción nominativa, sería

151 Vid. IGLESIAS GARCÍA, María Concepción, "Derecho penal de menores", en AA.VV. Las consecuencias jurídicas del delito, ROCA DE AGAPITO, Luis (Dir.), Ed. Tirant lo Blanch, Valencia, 2017, p. 137. También podemos señalar que en general, el sistema penal juvenil se caracteriza porque las medidas como la privación del derecho a conducir tienen una finalidad de prevención especial positiva. En este sentido vid. GIL GIL, Alicia/ LACRUZ LÓPEZ, Juan Manuel/ MELENDO PARDOS, Mariano/ NÚÑ̃̃ FERNÁNDEZ, José, Consecuencias jurídicas..., op. cit., p. 473.

152 Vid. MUÑOZ CONDE, Francisco/GARCÍA ARÁN, Mercedes, Derecho..., op.cit., p.599 y GRACIA MARTíN, Luis, "La responsabilidad penal de los menores", Lecciones de consecuencias jurídicas del delito: el sistema de penas, de medidas de seguridad, de consecuencias accesorias y de responsabilidad civil derivada del delito, GRACIA MARTÍN/ BOLDOVA PASAMAR, ALASTUEY DOBÓN (Autores), GRACIA MARTíN, Luis (Coordinador), Ed. Tirant lo Blanch, Valencia, 2012, 4⿳亠丷a edición, pp.194-195.

153 En relación con la naturaleza de las consecuencias jurídicas en el ámbito de la LORPM, vid. VAELLO ESQUERDO, Esperanza, Las consecuencias..., op.cit., p.147 y GIL GIL, Alicia/ LACRUZ LÓPEZ, Juan Manuel/ MELENDO PARDOS, Mariano/ NÚÑEZ FERNÁNDEZ, José, Consecuencias jurídicas..., op.cit., p. 473.

${ }_{154}$ Art.7.1.n) LORPM: "Las medidas que pueden imponer los Jueces de Menores, ordenadas según la restricción de derechos que suponen, son las siguientes: $n$. Privación del permiso de conducir ciclomotores y vehículos a motor, o del derecho a obtenerlo, o de las licencias administrativas para caza o para uso de cualquier tipo de armas. Esta medida podrá imponerse como accesoria cuando el delito o falta se hubiere cometido utilizando un ciclomotor o un vehículo a motor, o un arma, respectivamente".

155 Respecto el tenor literal de la medida y sus efectos, vid. SERRANO TÁRRAGA, María Dolores, "Medidas susceptibles de imposición a los menores", en AA.VV. Derecho Penal Juvenil, VÁZQUEZ 
recomendable que se reformulara la denominación de la medida contenida en la LORPM como privación del derecho a conducir en lugar de privación del permiso de conducir. De hecho, se perdió una oportunidad para subsanar dicha disfunción a través de la modificación de la LORPM operada por LO 8/2006, de 4 diciembre.

Otra particularidad en la aplicación de la privación del derecho a conducir en la legislación de menores, es que la LORPM incluye en su redactado, art.7.1.n) el adverbio "respectivamente" en referencia al concreto objeto sobre el que recae la privación (ciclomotor, vehículo a motor o arma). Es decir, al contener el texto que recoge la medida de privación del permiso de conducir dicho adverbio, puede inferirse que el menor puede ser sancionado únicamente en relación con el vehículo con el que ha cometido la infracción, bien sea el ciclomotor o el vehículo a motor y no que la medida a imponer incluya ambos. De esta forma la LORPM mantiene un tenor que se alteró en el ámbito de adultos hace más de tres lustros, tras la entrada en vigor de la Ley 15/2003 de 25 de noviembre de reforma del CP, por la que se eliminó del texto del CP la referencia al adverbio "respectivamente"156 que existía en el art.379 CP. Lo procedente sería que se llevara a cabo una modificación en la LORPM y suprimir el adverbio "respectivamente" del texto que tipifica la medida de privación del permiso de conducir. Así, podrían evitarse interpretaciones divergentes en el ámbito de menores y en el de adultos, así como profundizar en la equiparación del contenido de la sanción penal en ambas jurisdicciones. Como opción alternativa, y en el caso que surgiesen dudas interpretativas acerca del contenido de la medida, los respectivos Juzgados de Menores siempre podrían utilizar como criterio orientador el seguido en la jurisdicción de adultos que determina que la pena de privación del derecho a conducir incluye tanto los vehículos a motor como los ciclomotores.

Existe una característica en la regulación de la privación del derecho a conducir en el Derecho Penal Juvenil, relacionada con el hecho que en el ámbito de menores la medida de privación del permiso de conducir puede ser aplicada como principal o como accesoria ${ }^{157}$. Resulta cuanto menos curiosa la actual ordenación de la privación del permiso de conducir en la LORPM pues, si se observa el catálogo de medidas tiene la consideración de medida principal, pero el propio art.7.1.n) prevé

GONZÁLEZ, Carlos/ SERRANO TÁRRAGA María Dolores (Editores), Ed. Dykinson, 2007, Madrid, 2ª edición, p.464.

156 Vid. la crítica efectuada por FERNÁNDEZ PANTOJA, Pilar," Delitos contra la seguridad del tráfico: la pena de privación del derecho a conducir", en AA.VV. Delincuencia..., op.cit., p.77.

157 Vid. MARTÍNEZ PARDO, Vicente José, La ejecución de las medidas en el proceso de menores, Ed. Tirant Lo Blanch, Valencia, 2012, p.202 y GARCíA PÉREZ, Octavio, Las medidas y su ejecución en el sistema de justicia penal juvenil, Ed. Tirant lo Blanch, Valencia, 2019, p.73. 
que esta medida podrá imponerse como accesoria cuando el delito o falta se hubiere cometido utilizando un ciclomotor o un vehículo a motor, y también la propia exposición de motivos de la LORPM ${ }^{158}$ determina que tiene naturaleza de medida accesoria ${ }^{159}$. Al respecto destacar que, en el ámbito de adultos no cabe imponer la pena de privación del derecho a conducir como pena accesoria ya que siempre se prevé la aplicación como pena principal. Cuando la medida de privación del derecho a conducir en el ámbito de menores se imponga como medida accesoria, parece acertada la posición de ROCA AGAPITO ${ }^{160}$ cuando apunta que la medida accesoria tendrá la misma duración que la medida principal y ello al amparo del art.33.6 CP161. Esta circunstancia nos permite constatar que la privación del derecho a conducir como medida en la jurisdicción de menores puede tener un ámbito de aplicación más amplio que el que tiene previsto la pena de privación del derecho a conducir en la jurisdicción de adultos donde únicamente puede ser impuesta como pena principal. La legislación penal de menores ha sido más proclive en extender dicha privación de derechos a los delitos que tengan relación con la utilización de un vehículo a motor o ciclomotor. En este sentido y tal como se indicará en el apartado de propuestas de lege ferenda que se incluye en este trabajo, considero que sería adecuado que el CP contemplara la misma posibilidad que existe en el ámbito de menores, en el sentido de poder extender la pena de privación del derecho a conducir a aquellos delitos que se hayan cometido con la utilización de un vehículo a motor o ciclomotor o tengan relación directa con la seguridad vial.

En otro orden de cosas, la supresión de las faltas con la reforma penal de 2015 ha contribuido a difuminar algunas incoherencias que se detectaban con la anterior

\footnotetext{
158 Motivo no 23. La privación del permiso de conducir ciclomotores o vehículos a motor, o del derecho a obtenerlo, o de licencias administrativas para caza o para el uso de cualquier tipo de armas, es una medida accesoria que se podrá imponer en aquellos casos en los que el hecho cometido tenga relación con la actividad que realiza el menor y que ésta necesite autorización administrativa.

159 Referente a la doble naturaleza como principal y accesoria de la medida, vid. SERRANO TÁRRAGA, María Dolores, "Medidas susceptibles de imposición a los menores", en AA.VV. Derecho..., op.cit., p.464, COLÁS TURÉGANO, Ascensión, Derecho Penal de Menores, Ed. Tirant lo Blanch, Valencia, 2011, p. 232 e IGLESIAS GARCÍA, María Concepción, "Derecho penal de menores", en AA.VV. Las consecuencias..., op. cit., p. 140. En relación con el artículo de la LOPRM que prevé esta medida como accesoria, vid. el art.7.1 n):" Privación del permiso de conducir ciclomotores y vehículos a motor, o del derecho a obtenerlo, o de las licencias administrativas para caza o para uso de cualquier tipo de armas. Esta medida podrá imponerse como accesoria cuando el delito o falta se hubiere cometido utilizando un ciclomotor o un vehículo a motor, o un arma, respectivamente".

160 Vid. ROCA AGAPITO, Luis, El sistema..., op.cit., p.457.

161 En la jurisdicción penal de menores, la privación del permiso de conducir se puede aplicar como medida principal o accesoria con una duración máxima de dos años como se establece en el art.9.3 de la LORPM.
} 
regulación en relación con la aplicación de la medida a menores autores de infracciones penales leves y que actualmente pueden considerarse zanjadas dada la supresión de las faltas en el CP. Entre estas cuestiones se había planteado por ejemplo que el tenor literal del art.9.1 de la LORPM ${ }^{162}$ en los supuestos de las faltas la medida de privación del permiso a conducir formalmente no incluía la prohibición de obtener dicho permiso como sí sucede en los delitos ${ }^{163}$. En este sentido BRAGE CENDÁN ${ }^{164}$, señalaba que en el ámbito de las faltas la medida prevista por la LORPM para los delitos no podía aplicarse analógicamente y nada impedía a un menor obtener el permiso o licencia durante el periodo de privación de la condena. Por otro lado, se planteaba también atendiendo a la anterior regulación cual era el plazo máximo por el que la medida se podía aplicar a las acciones cometidas por menores de edad consideradas como faltas ${ }^{165}$. El plazo de un año como límite máximo que establecía la medida de privación del permiso de conducir coincidía con el plazo máximo que preveía el CP en el art.621 para la pena de privación del derecho a conducir en las faltas y para los hechos cometidos por mayores de edad, por lo que en este aspecto sí existía una armonización en ambos órdenes jurisdiccionales. Sin embargo, tras la entrada en vigor de la LO 2/2019 de 1 de marzo, de modificación del Código Penal, en materia de imprudencia en la conducción de vehículos a motor y ciclomotor y sanción de abandono del lugar del accidente, dicho límite temporal en relación con la pena que analizamos no coincide, ya que en el delito leve del art. 142.2 CP la pena de privación del derecho a conducir puede alcanzar los dieciocho meses de duración, experimentando un incremento importante tras la reconversión de la conducta a delito leve.

\footnotetext{
162 Art.9. Régimen general de aplicación y duración de las medidas. No obstante lo establecido en los apartados 3 y 4 del artículo 7, la aplicación de las medidas se atendrá a las siguientes reglas: 1. Cuando los hechos cometidos sean calificados de falta, sólo se podrán imponer las medidas de libertad vigilada hasta un máximo de seis meses, amonestación, permanencia de fin de semana hasta un máximo de cuatro fines de semana, prestaciones en beneficio de la comunidad hasta cincuenta horas, privación del permiso de conducir o de otras licencias administrativas hasta un año, la prohibición de aproximarse o comunicarse con la víctima o con aquellos de sus familiares u otras personas que determine el Juez hasta seis meses, y la realización de tareas socio-educativas hasta seis meses.

163 Sobre esta circunstancia, vid. RODRÍGUEZ, FERNÁNDEZ, IGNACIO, "Consideraciones metodológicas...", op.cit., pp.791-818.

164 Vid. BRAGE CENDÁN, Santiago. B, "Algunas consideraciones en torno a las reglas para la aplicación de las medidas previstas en la ley reguladora de la responsabilidad penal de los menores", Revista Xuridica Galega, Rexurga, 2003, ㄲo 39, p.52. Recurso electrónico disponible en: http://www.rexurga.es/pdf/COL106.pdf (último acceso: 02/11/2020).

165 El plazo de un año de la medida de privación del derecho a conducir fue determinado a raíz de la reforma operada en la LO 8/2006, de 24 de diciembre por la que se modificó la LORPM. Asimismo, respecto el plazo de un año en los hechos calificado como falta, vid. DOLZ LAGO, Manuel Jesús, Comentarios a la legislación penal de menores, Ed. Tirant lo Blanch, Valencia, 2007, p.119.
} 
Por otro lado, debido al plazo máximo de dos años que puede tener la medida de privación del permiso de conducir en el ámbito de la LORPM ha de destacarse la inaplicabilidad de lo preceptuado en el art.47.3 CP que únicamente procedería en condenas superiores a los dos años, y dicha posibilidad no puede acaecer en el ámbito de menores ${ }^{166}$.

En la comparativa entre el Derecho Penal Juvenil y el Derecho Penal de adultos hallamos otra diferencia en el redactado de la medida de privación del derecho a conducir que se impone al menor de edad. En el art.7.1.n) de la LORPM se indica expresamente: "la privación del derecho a obtenerlo", en relación con el permiso de vehículos a motor o ciclomotores ${ }^{167}$. Como veremos en el Capítulo Tercero, en el CP la pena de privación del derecho a conducir no incluye de manera expresa la imposibilidad de obtenerlo, sino que dicha prohibición deberá ser aplicada en el ámbito administrativo a través de la Jefatura Provincial de Tráfico. El hecho que la jurisdicción de menores prohíba expresamente la obtención del permiso durante la condena, resulta indicativo de una falta de armonización entre el Derecho Penal de adultos y el Derecho Penal Juvenil en cuanto a la pena y a la medida de privación del derecho a conducir. Por ello, sería interesante que una futura reforma legal procediera a modificar la regulación prevista en la jurisdicción de menores de tal modo que se suprimiera de la LORPM la prohibición del derecho a obtener el permiso o licencia, puesto que ello ya lo regula la normativa administrativa. De este modo, la privación de derechos sería homogénea en ambas jurisdicciones y se determinaría de forma idéntica en la esfera penal el contenido tanto de la medida como de la pena de privación del derecho a conducir.

Igual que sucede en el ámbito de adultos, podemos hallarnos con la circunstancia que el menor sea absuelto del delito por concurrir causa de inimputabilidad de los arts.20.1, $2^{\circ}$ y $3^{\circ}$ CP. En estos supuestos se procederá a imponer las medidas terapéuticas establecidas en el art. 7.1.d) y e) de la LORPM $^{168}$, que serán complementadas con la medida accesoria de privación del derecho a conducir

\footnotetext{
166 Vid. TRAPERO BARREALES, María.A, Los delitos..., op.cit., p.581 y MUÑOZ RUIZ, Josefa, "Modalidades típicas del delito de conducción sin permiso y menores", en AA.VV. El delito..., MORILLAS FERNÁNDEZ, David Lorenzo (Coordinador), op.cit., p.115.

167 Acerca del contenido de la medida de privación del derecho a conducir en el ámbito de la jurisdicción de menores, vid. MARTíNEZ PARDO, Vicente José, La ejecución..., op.cit., p.202. Un ejemplo reciente en relación con la privación del derecho a obtener el permiso o licencia es la STS, núm. 64/2018, Sala Segunda, de 6 de febrero de 2018, ponente Excmo. Sr. Andrés Martínez Arrieta. (TOL6.508.915), que desestima el recurso de casación presentado por el menor condenado a la medida de privación de obtener el derecho a conducir vehículos a motor y ciclomotor durante el plazo de dos años.
}

168 Vid. MUÑOZ CONDE, Francisco/GARCÍA ARÁN, Mercedes, Derecho..., op.cit., p.602. 
vehículos a motor o ciclomotores, al poderse aplicar dicha medida en los casos relacionados con la utilización de un vehículo a motor o ciclomotor.

Por otra parte, el ámbito del Derecho Penal Juvenil posibilita, a diferencia de la regulación prevista para adultos, dejar sin efecto, reducir o sustituir la medida en cualquier momento si ello es beneficioso para el interés del menor al amparo del art.13 de la LORPM ${ }^{169}$. Esta alternativa no existe en el ámbito de adultos al no ser posible ni la suspensión ni la sustitución de la pena de privación del derecho a conducir, del mismo modo que no se contempla esta opción para el resto de penas privativas de derechos, ni tampoco existe posibilidad de dejar sin efecto la misma. La opción de modificar la medida de privación del permiso de conducir impuesta por el Juzgado de Menores puede ser eficaz para la generalidad de menores sancionados, y en especial, en aquellos casos en los que se inicie el cumplimiento siendo menor de edad y finalice cuando sea mayor de edad. En estos supuestos, al amparo de lo establecido en el art.14.1 de la LORPM $^{170}$, el mayor de edad debe cumplir con la medida impuesta derivada de unos hechos cometidos siendo menor de edad por lo que no podría ejercitar el derecho a conducir ni poder examinarse para la obtención del carnet de conducir. Es por ello, que la posibilidad regulada en el art.13 de la LORPM ${ }^{171}$ puede ser idónea para dejar sin efecto, o en su caso, sustituir la medida de privación del derecho a conducir atendiendo a las circunstancias personales, laborales o económicas del menor que ha sido condenado.

Una de las particularidades más relevantes que existen en la legislación de menores es la inexistencia de un artículo que permita acordar como medida cautelar la privación del permiso de conducir. No existe en el catálogo de medidas del art.28 d la LORPM ${ }^{172}$ la posibilidad de privar cautelarmente al menor del derecho a

\footnotetext{
169 Art. 13 LORPM. 1. El Juez competente para la ejecución, de oficio o a instancia del Ministerio Fiscal o del letrado del menor, previa audiencia de éstos e informe del equipo técnico y, en su caso, de la entidad pública de protección o reforma de menores, podrá en cualquier momento dejar sin efecto la medida impuesta, reducir su duración o sustituirla por otra, siempre que la modificación redunde en el interés del menor y se exprese suficientemente a éste el reproche merecido por su conducta.

170 Artículo 14 LORPM. 1. Cuando el menor a quien se le hubiere impuesto una medida de las establecidas en esta Ley alcanzase la mayoría de edad, continuará el cumplimiento de la medida hasta alcanzar los objetivos propuestos en la sentencia en que se le impuso conforme a los criterios expresados en los artículos anteriores.

171 En relación a la posibilidad de reducir o sustituir la medida, vid. IGLESIAS GARCÍA, María Concepción, "Derecho penal de menores", en AA.VV. Las consecuencias..., op cit., p. 142-143.

172 Respecto las medidas cautelares que se pueden adoptar en el proceso penal de menores, vid. MARTÍNEZ DÍAZ, Manuel/ LUACES GUTIÉRREZ ANA-ISABEL, "El proceso penal de Menores", en
} 
conducir, al contrario de lo que existe en la jurisdicción de adultos donde la LECrim si prevé la de forma expresa la opción de acordar dicha medida en los arts. 529 bis y 764.4. Sin embargo, la FGE ${ }^{173}$ mantiene que en el ámbito de la libertad vigilada podrían imponerse determinadas reglas de conducta, y una de estas obligaciones podría ser la de no poder conducir ciclomotores o motocicletas, al amparo del art. 7.1.h) $7^{\text {a }}$ de la LORPM. Esta posición también la mantiene MUÑOZ RUIZ174, para quien esta alternativa planteada por la FGE es posible. En efecto, en supuestos de conductas delictivas graves sería una medida que tendría eficacia para evitar la comisión de nuevos hechos similares hasta que se celebre el Juicio Oral, siendo además combinada con otro tipo de medidas de las que sí aparecen en el catálogo de la LORPM. Por ello, y dado que la cuestión suscita controversia, sí debería preverse la posibilidad de implementar la medida cautelar de privación del permiso de conducir en la propia LORPM.

Destaca por otro lado de la regulación en el ámbito de la legislación penal de menores la falta de previsión de la obligatoriedad de realización del curso de reeducación y sensibilización vial cuando el menor haya sido condenado por un delito contra la seguridad vial o contra la vida o integridad física o psíquica de las personas. En el ámbito de adultos existe la obligación de realizar dicho curso tras una condena a la privación del derecho a conducir según lo preceptuado en la LTSV $^{175}$. Sin embargo, debido a que en la LORPM la medida a imponer es la privación del permiso o licencia y no del derecho, entiendo igual que TRAPERO BARREALES ${ }^{176}$ que dicha obligación legal no existe. Por el contrario, MUÑOZ RUIZ considera que los menores condenados a la medida de privación del permiso de conducir igual o inferior a dos años sí han de realizar el curso de reeducación y sensibilización vial ${ }^{177}$. Mientras esta disfunción no sea resuelta, los Juzgados de Menores en todos aquellos casos que se dicte sentencia condenatoria por delitos que conlleven la privación del permiso o licencia para conducir, pueden imponer una medida similar como la realización de un curso de educación vial al estar prevista

AA.VV. Derecho Penal Juvenil, VÁZQUEZ GONZÁLEZ, Carlos/ SERRANO TÁRRAGA María Dolores (Editores), Ed. Dykinson, 2007, Madrid, 2ª edición, pp.373-385.

173 Esta posición la mantuvo el Fiscal de Sala Coordinador de Menores en el Dictamen 2/2013, acerca de las posibilidades de aplicación cautelar de determinadas medidas no mencionadas en el art. 28 de la LORPM.

174 Vid. MUÑOZ RUIZ, Josefa, "Modalidades típicas del delito de conducción sin permiso y menores", en AA.VV. El delito..., MORILLAS FERNÁNDEZ, David Lorenzo (Coordinador), op.cit., p.115.

175 Vid. al respecto arts. 71.2 y 73.1 y 2 de la LTSV.

176 Vid. TRAPERO BARREALES, María.A., Los delitos..., op.cit., p.582.

177 Vid. MUÑOZ RUIZ, Josefa, "Modalidades típicas del delito de conducción sin permiso y menores", en AA.VV. El delito..., MORILLAS FERNÁNDEZ, David Lorenzo (Coordinador), op.cit., p.115. 
en la LORPM en la medida de libertad vigilada ${ }^{178}$, y obligar al menor a realizar un curso similar al que se realiza en la jurisdicción de adultos.

Por otra parte, la ejecución de la privación del derecho a conducir en el ámbito de menores y en el ámbito de adultos también tiene aspectos similares, ya que en ambos existe el trámite de la entrega del permiso de conducir o licencia, el trámite de liquidación de la medida o pena, así como el control mixto judicial-administrativo del cumplimiento de la sanción impuesta ${ }^{179}$.

Por último, destacar que en el Derecho Penal Juvenil debido a las especificidades que rigen el mismo, en determinados supuestos delictivos, como son los delitos de homicidio y lesiones por imprudencia menos grave cometidos con vehículo a motor o ciclomotor, así como en los extintos Juicios de Faltas en los que podía aplicarse la medida de privación del permiso conducir, a través de procesos de mediación, se ha evitado la celebración de la vista y la imposición de la medida ${ }^{180}$. Dicha circunstancia ya fue destacada por la Fiscalía General de Seguridad Vial, que en la Memoria del año 2011 hizo referencia al buen funcionamiento de dichos procesos restaurativos en el ámbito de menores en relación con infracciones relacionadas con la seguridad vial ${ }^{181}$. Al amparo de los arts. 19 y 27 de la LORPM se han podido articular procesos de mediación y reparación entre el menor y la víctima, siempre según las circunstancias concurrentes en aras a evitar la celebración del Juicio y en aquellos casos que los hechos estaban considerados como delito menos grave 0 falta ${ }^{182}$. Con ello se exime al menor de la imposición de la medida de privación del

\footnotetext{
178 Vid. al respecto el art.7.1.h) $2^{\text {a }}$ de la LORPM.

179 Además de la LORPM, es de aplicación el Real Decreto 1774/2004, de 30 de julio, por el que se aprueba el Reglamento de la Ley Orgánica 5/2000, de 12 de enero, reguladora de la responsabilidad penal de los menores, especialmente los arts. 8.4 y 10.1.6.g), que hacen referencia a la medida de privación del permiso de conducir vehículos a motor o ciclomotores o del derecho a obtenerlo.
}

180 Acerca del marco jurídico procesal del Derecho Penal Juvenil, vid. PAREDES PORRO, Miguel Ángel, Tratamiento Policial de los Delitos contra la seguridad vial, Ed. Tecnos. 2010. Madrid, pp.279280. Uno de los principios que rige la justicia juvenil, es el de oportunidad, como ha destacado CRUZ BLANCA, María José, "Tratamiento penal y medidas aplicables a los menores de edad que condujeran sin la correspondiente licencia administrativa. Los resultados de un análisis empírico", en AA.VV. El delito de conducción de vehículos a motor o ciclomotores sin licencia administrativa cometido por menores de edad, MORILLAS FERNÁNDEZ, David Lorenzo (Coordinador), Ed. Dykinson, Madrid, 2018, pp.209-211.

181 Vid. la Memoria de la FGE del año 2011, apartado Fiscalía de Seguridad Vial, pp.1071-1072.

182 Relativo al procedimiento de conciliación en el Derecho Penal Juvenil vid. GIL GIL, Alicia/ LACRUZ LÓPEZ, Juan Manuel/ MELENDO PARDOS, Mariano/ NÚÑEZ FERNÁNDEZ, José, Consecuencias jurídicas..., op.cit., p. 501 y FERNÁNDEZ PANTOJA, Pilar, "La concurrencia delictiva en delitos contra la seguridad vial: especial referencia a las conductas relacionadas con los menores de edad", en AA.VV. El delito de conducción de vehículos a motor o ciclomotores sin licencia administrativa cometido por menores de edad, MORILLAS FERNÁNDEZ, David Lorenzo (Coordinador), Ed. Dykinson, Madrid, 2018, pp.189-191. 
derecho a conducir, opción que sería también interesante que se hubiera instaurado en la jurisdicción de adultos.

\subsection{La privación del derecho a conducir en el ámbito del Derecho Administrativo}

Tras haber analizado la naturaleza penal de la privación del derecho a conducir en los diversos ámbitos que puede aplicarse, a continuación, determinaremos los elementos esenciales de la privación del derecho a conducir como sanción administrativa.

\subsubsection{La regulación administrativa de la privación del derecho a conducir}

Si bien en la génesis de la privación del derecho a conducir, ésta tuvo una esencia administrativa, su trasvase a la esfera penal generó que durante décadas compartiera naturaleza tanto administrativa como penal. Después de un periodo de coexistencia de las sanciones temporales de privación del derecho a conducir en el ámbito penal y administrativo, la entrada en vigor de las leyes 17/2005 de 19 de julio, por la que se regula el permiso y la licencia de conducción por puntos, y 18/2009 de 23 de noviembre por la que se modifica la LTSV que supuso la supresión de la sanción administrativa de suspensión temporal del permiso de conducir $^{183}$ contribuyeron a diluir el debate en torno a la naturaleza jurídica de la privación temporal del derecho a conducir. Cuando esta sanción era aplicada con carácter temporal en el ámbito administrativo tenía una eficacia limitada para disuadir a los conductores de cometer infracciones, lo que generó su pérdida relevancia en el ámbito administrativo ${ }^{184}$ y que las sanciones administrativas se hayan centrado actualmente en pérdida de puntos y multas económicas.

\footnotetext{
183 Vid. MAGRO SERVET, Vicente, Análisis de las novedades legislativas en materia de seguridad vial, Ed. El Derecho Grupo Editorial, Madrid, 2010, p.267; MARZAL RAGA, Consuelo de los Reyes, "La nueva justicia administrativa de tráfico", en AA.VV. Prevención y control de la siniestralidad vial. Un análisis jurídico y criminológico, ORTS BERENGUER, Enrique (Coord.), Ed. Tirant lo Blanch, Valencia, 2011, p.556 y AA.VV. "Delitos contra la seguridad vial: cuestiones comunes", GUTIÉRREZ RODRÍGUEZ, María (Coordinadora): GARCÍA DEL BLANCO, Victoria / MARTÍN LORENZO, María y SANZ-DÍEZ DE ULZURRUN LLUCH, Marina, Protección Penal de la Seguridad Vial, Ed. Tirant lo Blanch, Valencia, 2013, p.46.

184 Vid. AA.VV. "Delitos contra la seguridad vial: cuestiones comunes", GUTIÉRREZ RODRÍGUEZ, María (Coordinadora), GARCÍA DEL BLANCO, Victoria/ MARTÍN LORENZO, María y SANZ-DíEZ
} 
De forma correlativa, desde el año 2007, se produjo un incremento del "Derecho Penal de la seguridad ciudadana"185, especialmente visible en el Derecho Penal de la seguridad vial, quedando el ámbito administrativo relegado a la imposición multas económicas y a la pérdida de puntos. Ello ha redundado en una mayor aplicación y reconocimiento de la privación del derecho a conducir como pena ${ }^{186}$, siendo una herramienta utilizada por el legislador para controlar los peligros que acechaban al tráfico viario ${ }^{187}$. En la actualidad, el ámbito penal ha quedado como único marco legal en el que se puede suspender temporalmente el derecho a conducir mediante una sanción directa, bien sea pena o medida de seguridad. Al no existir una sanción temporal administrativa equivalente a la pena de privación del derecho a conducir, también se ha eliminado la posibilidad de un posible solapamiento entre sanciones de dos órdenes jurisdiccionales diferentes como el penal y el administrativo ${ }^{188}$.

La mayor aplicación de la pena de privación del derecho a conducir tras la reforma operada por la LO 15/2007 de 30 de noviembre, de reforma del CP, unida a la tramitación de la mayoría de los delitos contra la seguridad vial por el cauce procesal de los Juicios Rápidos, incidió en los cambios que se emprendieron en la normativa administrativa ${ }^{189}$. El hecho que la privación del derecho a conducir se contemplara en el ámbito penal y a través de los Juicios Rápidos se posibilitara una respuesta pronta y efectiva a los supuestos de infracciones contra la seguridad vial, determinó la modificación de la legislación administrativa operada a través la Ley

DE ULZURRUN LLUCH, Marina, Protección Penal de la Seguridad Vial, Ed. Tirant lo Blanch, Valencia, 2009, p.31.

185 Vid. GARCÍA ALBERO, Ramón, "La nueva política criminal de la seguridad vial", Revista Electrónica de Ciencia Penal y Criminología (RECPC), 09-11, (2007), pp.2-3. Recurso electrónico disponible en: http://criminet.ugr.es/recpc/09/recpc09-11.pdf (último acceso: 02/11/2020).

186 Vid. HORTAL IBARRA, Juan Carlos, "La mutación del derecho penal vial. La criminalización de los excesos de velocidad como paradigma". La Ley penal, no 100, 2013, pp.4-5. Las conductas en las que se impone la pena de privación del derecho a conducir, a diferencia de otras, no tienen en el ámbito administrativo sancionador una sanción correlativa idéntica, como destacan AGUDO FERNÁNDEZ, Enrique/JAÉN VALLEJO, Manuel/PERRINO PÉREZ, Ángel Luis, Penas, medidas y otras consecuencias jurídicas del delito, Ed. Dykinson, Madrid, 2017, pp.17-18.

187 Ello podemos relacionarlo con la intervención del Derecho Penal en la sociedad del riesgo, como ha señalado DÍEZ RIPOLLES, JOSÉ LUIS, "De la sociedad del riesgo a la seguridad ciudadana: un debate desenfocado", Revista Electrónica de Ciencia Penal y Criminología (RECPC), 07-01, (2005), pp.3-4 y MINGORANCE SÁNCHEZ, José Antonio, "La seguridad vial...", op.cit., p.427.

188 En relación con el solapamiento entre el Derecho Penal y el Derecho Administrativo en el ámbito de la seguridad vial, vid. VALEIJE ÁLVAREZ, Inmaculada, "El sistema de penas en los delitos contra la seguridad vial", en AA.VV. Prevención y control..., op.cit., pp.458-460. Respecto la diferencia entre la pérdida de vigencia del permiso por pérdida de puntos y la pena de privación del derecho a conducir podemos destacar la SAP de Badajoz, núm. 422/2019, Sección 3ą, de 12 de diciembre de 2019, ponente Ilmo. Sr. Joaquín González Casso (TOL7.744.956).

189 Vid. la comparativa realizada por LEDESMA MUÑIZ, Ramón, "EI nuevo procedimiento sancionador de tráfico", DA, Revista de Derecho Administrativo, № 284-285, mayo-diciembre, 2009, pp.22-23, Ed. INAP, Madrid. 
18/2009, de 23 de noviembre por la que se reformó la LTSV en materia sancionadora y que supuso la supresión de la sanción temporal de privación del derecho a conducir en el ámbito administrativo. Es decir, el legislador valoró los resultados positivos del binomio delitos contra la seguridad vial y juicios rápidos con conformidad, que se caracterizan por la celeridad del procedimiento y la obtención de una respuesta rápida en forma de pena de privación del derecho a conducir. En estos casos, los penados al reducirse un tercio la pena solicitada, generalmente aceptan los hechos y se pueden beneficiar de la imposición de la pena mínima de privación del derecho a conducir que, por ejemplo, en los supuestos de alcoholemia en los que no existan lesionados ni anteriores condenas por delitos contra la seguridad vial en el penado, suele ser de ocho meses ${ }^{190}$.

Sin embargo, la recepción de la privación del derecho a conducir en el ámbito penal se hizo en ocasiones a consta de un exceso punitivo. Por ejemplo, el art. 379 del CP contemplaba la aplicación acumulativa de tres penas: prisión o multa, TBC y pena de privación del derecho a conducir, de modo similar a lo que se establecía en la normativa administrativa anterior al año 2009, donde el conductor infractor recibía una triple sanción administrativa: multa económica, pérdida de puntos y retirada del permiso de conducir ${ }^{191}$. Con la reforma operada por la LO 5/2010 de 22 de junio, y en aplicación del principio de proporcionalidad, se modificó el art. 379 del CP, existiendo desde entonces una penalidad alternativa a imponer con la pena de privación del derecho a conducir.

Por otro lado, existe en el Derecho Administrativo sancionador la previsión de una situación que puede ser similar a la pena de privación del derecho a conducir. Tal situación sucede cuando al conductor se le priva definitivamente del derecho a conducir tras seguirse un procedimiento de pérdida de vigencia, nulidad o lesividad, regulados en los arts.34 y siguientes del RD 818/2009, de 8 de mayo, por el que se

\footnotetext{
190 Respecto a la eficacia de la pena de privación del derecho a conducir en el ámbito penal, como parte de los mecanismos penales de la política criminal de seguridad vial, en detrimento a la escasa eficacia que tenía la sanción de privación del permiso de conducir en el ámbito administrativo, vid. MAGRO SERVET, Vicente, Análisis..., op.cit., p.263 y también VALEIJE ÁLVAREZ, Inmaculada, "EI sistema de penas en los delitos contra la seguridad vial", en AA.VV. Prevención y control..., op.cit., pp.459-460. Se ha determinado que aproximadamente el $90 \%$ de los procedimientos por delitos contra la seguridad vial tramitados ante el Juzgado de Guardia como Diligencias Urgentes-Juicio Rápido finaliza con una sentencia de conformidad. Vid. Memoria FGE año 2020 p. 907.

191 En relación con la supresión de la sanción de retirada del permiso de conducir, vid. LEDESMA MUÑIZ, Ramón, "El nuevo...", op.cit., pp.19-20.
} 
aprueba el RGCon ${ }^{192}$. Se trata de supuestos en los que se constate que el conductor no reúne los requisitos para el otorgamiento de la licencia administrativa o bien haya perdido totalmente la asignación de puntos. El procedimiento administrativo que se incoe puede finalizar determinando que el sujeto no tiene derecho a conducir, y, si bien no existe una resolución expresa que acuerde la suspensión temporal del referido derecho, el sujeto estará durante un determinado lapso temporal sin poder conducir hasta que obtenga de nuevo el permiso. En estos casos no estamos ante una sanción que se imponga de forma directa como sucedía con anterioridad a la entrada en vigor de la Ley 18/2009 de 23 de noviembre de reforma de la LTSV en materia sancionadora, sino que se priva del derecho a conducir de manera indirecta dejando sin efecto la autorización administrativa para conducir. Tanto si ello ha acaecido por una declaración de nulidad o lesividad, no concurrencia de los requisitos para otorgar la autorización o se haya decretado la pérdida de vigencia del permiso o licencia por pérdida de puntos, los interesados en volver a conducir deberán seguir los procedimientos administrativos para su obtención, que incluyen, entre otros, los siguientes requisitos: el transcurso de unos determinados plazos temporales, realizar pruebas de aptitudes o la realización de un curso de sensibilización y reeducación vial.

Persiste, no obstante, en el ámbito administrativo la posibilidad de suspensión cautelar del permiso, tipificada en el art.72 de la LTSV ${ }^{193}$ y el art. 39 del RGCon ${ }^{194}$, aun cuando únicamente en determinados supuestos de nulidad o lesividad y pérdida de vigencia de las autorizaciones administrativas cuando su mantenimiento suponga un peligro grave para la seguridad del tráfico o perjudique notoriamente el interés público. Sin embargo, no se impone como una sanción directa y con los mismos efectos que en el ámbito penal sin que para su aplicación se requiera obligatoriamente haber cometido una infracción. La existencia de esta modalidad de suspensión cautelar del permiso en el ámbito administrativo no puede utilizarse

\footnotetext{
192 Vid. art. 34 y ss. del Real Decreto 818/2009, de 8 de mayo, por el que se aprueba el Reglamento General de Conductores en: http://www.boe.es/diario boe/txt.php?id=BOE-A-2009-9481 (último acceso: 13/11/2020).

193 Art.72. Suspensión cautelar: En el curso de los procedimientos de declaración de nulidad o lesividad y pérdida de vigencia de las autorizaciones administrativas se acordará la suspensión cautelar de la autorización en cuestión cuando su mantenimiento entrañe un grave peligro para la seguridad del tráfico, en cuyo caso la autoridad que conozca del expediente ordenará, mediante resolución motivada, la intervención inmediata de la autorización y la práctica de cuantas medidas sean necesarias para impedir el efectivo ejercicio de la misma.

194 Art.39. Suspensión cautelar de la vigencia del permiso o de la licencia de conducción. 1. En el curso de los procedimientos de declaración de nulidad o lesividad o de pérdida de vigencia de las autorizaciones administrativas, se acordará la suspensión cautelar de la vigencia de la autorización de que se trate cuando su mantenimiento entrañe un grave peligro para la seguridad del tráfico o perjudique notoriamente el interés público.
} 
como argumento para invocar la naturaleza administrativa de la privación del derecho a conducir, puesto que se trata de una posibilidad de carácter residual, en detrimento de la amplísima aplicación que tiene la pena de privación del derecho a conducir $^{195}$.

La medida cautelar de privación del derecho a conducir en el ámbito penal y la suspensión cautelar del permiso en el ámbito administrativo pueden perseguir un mismo fin: evitar que determinados conductores puedan ejercer un derecho reconocido administrativamente dado el peligro que pueden suponer para la seguridad vial. Este contexto en sede de medidas cautelares puede ser el único ámbito en el que confluyan de manera parcial los dos ámbitos normativos ya que tras la entrada en vigor de la Ley 18/2009 de 23 de noviembre por la que se reformó la LTSV en materia sancionadora, la naturaleza de pena de la privación del derecho a conducir ha quedado absolutamente reforzada. En definitiva, la aplicación de la privación del derecho a conducir como medida cautelar constituye el único ámbito en el que parecen confluir el Derecho Penal y el Derecho Administrativo sancionador.

\subsubsection{La entrada en vigor del "carnet por puntos" y su influencia en la pena de privación del derecho a conducir}

El presente epígrafe tiene por objeto analizar en qué medida los cambios introducidos mediante la Ley 17/2005 de 19 de julio por la que se reguló el permiso y la licencia de conducción por puntos y se modificó el texto articulado de la LTSV, influyeron en la política criminal de seguridad vial, y en concreto en el desarrollo de la pena de privación del derecho a conducir. Es menester decir que dicha Ley estuvo en vigor hasta el 31 de enero de 2016, ya que a partir de dicha fecha está vigente el RDL 6/2015 de 30 de octubre por el que se aprueba el texto refundido de la LTSV.

La Ley 17/2005 de 19 de julio, tenía una aplicación exclusivamente administrativa pero el legislador se topó con un problema: para que el sistema instaurado fuera efectivo debía crearse algún tipo de amenaza severa para evitar que los conductores sancionados persistieran en la conducción. Para ello se optó por la creación de un tipo delictivo que sancionara la conducción de un vehículo tras la

\footnotetext{
195 Comparto la opinión de RODRÍGUEZ MORO en el sentido que no está prevista la suspensión temporal del permiso de conducir como sanción administrativa. Vid. RODRíGUEZ MORO, Luis, La
} 
pérdida de todos los puntos asignados, con el que se esperaba obtener mayor eficacia que la conseguida con la única amenaza de sanciones administrativas que, a la vista de los hechos, habían tenido escasa capacidad disuasoria para el concreto infractor. En este sentido considero que la opción de política criminal de penalizar como delito dicha conducta fue correcta, ya que en caso contrario la Ley $17 / 2005$ de 19 de julio hubiera quedado sin efectos intimidatorios entre los conductores $^{196}$. La conducción tras la pérdida de todos los puntos se tipificó como delito en el art.384 CP junto a otras conductas, como la de conducir sin haber obtenido nunca el permiso o licencia o la conducción tras ser privado del derecho a conducir, tanto de manera temporal como de manera definitiva por la pérdida de vigencia de su permiso o licencia.

La influencia de la Ley 17/2005 de 19 de julio en el ámbito de la pena de privación del derecho a conducir ha sido reconocida por diversos autores, como TAMARIT SUMALLA ${ }^{197}$. A pesar de esta influencia de la normativa administrativa en la pena de privación del derecho a conducir no podemos afirmar que la entrada en vigor de la Ley 17/2005 de 19 de julio, modificara el contenido de esta pena ${ }^{198}$, sino que tuvo consecuencias administrativas de carácter extrapenal por lo que identificaremos las más relevantes. La primera está relacionada con la Disposición Adicional (en adelante DA) 13 a de la LTSV que fue modificada por la Ley 17/2005 de 19 de julio ${ }^{199}$, que regulaba los efectos administrativos de las condenas penales que conllevan la privación del derecho a conducir, y según la cual: $<<E l$ titular del permiso o licencia de conducción que haya sido condenado por sentencia firme por la comisión de un delito castigado con la privación del derecho a conducir un vehículo a motor o ciclomotor, para volver a conducir, deberá acreditar el haber superado con aprovechamiento el curso de reeducación y sensibilización vial al que

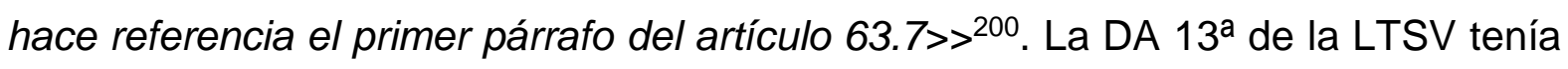

pena de privación..., op.cit., pp.50-51.

196 En este sentido coincido con que la Ley 17/2005 requería de un desarrollo penal para aquellas conductas del que conducía tras haber perdido la totalidad de los puntos, PIPAÓN PULIDO, Jorge Guillermo/ PEDREÑO NAVARRO, Lucía/ BAL FRANCES, Edmundo, Los delitos contra la seguridad vial. Análisis práctico y formularios de aplicación, Ed. Lex Nova, Valladolid, 2009, 1a edición, p.17.

197 Vid. TAMARIT SUMALLA, Josep/ LUQUE REINA, Mํㅡㄹ Eulàlia, Automóviles, delitos y penas..., op.cit., p.128.

198 Al respecto podemos citar a TAMARIT SUMALLA, Josep," La pérdida definitiva del derecho de conducir o del derecho a la tenencia y porte de armas", en AA.VV. La adecuación..., op.cit., p.124.

199 Vid. en: https://www.boe.es/buscar/doc.php?id=BOE-A-2005-12458 (último acceso: 13/11/2020).

200 Acerca de los efectos en el ámbito penal de los cursos de sensibilización y reeducación vial previstos en la normativa administrativa, vid. TORRES FERNÁNDEZ, Ma Elena, "Reflexiones sobre algunos efectos administrativos del llamado "carnet por puntos" en las consecuencias penales de los delitos contra la seguridad en el tráfico", en AA.VV. Delincuencia en materia de tráfico y seguridad 
por título: "Efectos administrativos de las condenas penales que conlleven la privación del derecho a conducir'201, lo que acreditaba la vinculación entre la Ley 17/2005 y la pena estudiada, y esta relación se vio ampliada a otro ámbito en el que se podía aplicar la pena de privación del derecho a conducir y que eran las faltas, pues inicialmente no se hacía una referencia a las mismas ${ }^{202}$.

Otra evidencia de la interacción entre la Ley 17/2005 de 19 de julio y la pena de privación del derecho a conducir está relacionada con el redactado del antiguo art.82 de la LTSV $^{203}$, que exigía que cuando en una sentencia se imponía la pena de privación del derecho a conducir ésta debía ser anotada en el Registro de conductores e infractores de la DGT. Con ello, el art.82 de la LTSV obligaba a las autoridades judiciales penales a comunicar al Registro todas las condenas que incluyeran la pena citada. La incorporación de esta medida mediante la modificación llevada a cabo por la Ley 17/2005 de 19 de julio fue positiva para la correcta ejecución de la pena de privación del derecho a conducir, al impedir, entre otras cosas, que el penado pudiera solicitar un duplicado del permiso o licencia tras haber sido condenado a la pena de privación del derecho a conducir ${ }^{204}$. El redactado del precepto citado, probablemente estuvo influenciado por dos artículos de la LECrim que regulaban cuestiones relacionadas con la privación del permiso de conducir bien de manera cautelar bien de manera definitiva como pena. En primer lugar, el

vial. Aspectos penales, civiles y procesales, MORILLAS CUEVA, Lorenzo (Coord.), Ed. Dykinson, Madrid, 2007, p.100.

201 Ibídem.p.102.

202 En el contenido de la DA 13a de la LTSV que entró en vigor por la Ley 17/2005 de 19 de julio, únicamente se hacía referencia a los efectos respecto a los delitos en los que se aplicaba la pena de privación del derecho a conducir, obviándose las faltas cometidas por imprudencia leve y constitutivas de homicidio o lesiones, en los que esta pena se podía imponer con una duración de hasta un año. La omisión relativa a las faltas, fue subsanada por la Ley 18/2009 de 23 de noviembre por la que se modificó el texto de la LTSV en materia sancionadora. El cambio realizado por esta norma afectó al título de la DA $13^{\text {a }}$ de la LTSV que pasó a denominarse: "Obtención del permiso o licencia de conducción cuando su titular haya sido condenado por sentencia penal con la privación del derecho a conducir". Con la nueva denominación ya no se hacía referencia únicamente a la condena por delito por lo que entiendo que se dejaba la puerta abierta a que también los condenados a esta pena en juicios de faltas tuvieran que realizar el curso de sensibilización y reeducación vial.

203 Vid. el redactado del art.82, párrafo 2ํㅡㄹ de la LTSV según la Ley 17/2005: Las autoridades judiciales comunicarán a la Dirección General de Tráfico, en el plazo de 15 días siguientes a su firmeza, las sentencias que condenen a la privación del derecho a conducir vehículos a motor y ciclomotores, a efectos de su anotación en el referido Registro.

204 Actualmente, el art. 113.2 de la LTSV, vigente tras la aprobación del RDL 6/2015 de 30 de octubre por el que se aprueba el texto refundido de la LTSV, es el que regula en la normativa administrativa las anotaciones en la DGT de las penas de privación del derecho a conducir. Art.113.2 LTSV: Las autoridades judiciales comunicarán al Registro de Conductores e Infractores del organismo autónomo Jefatura Central de Tráfico, en el plazo de los quince días naturales siguientes a su firmeza, las penas de privación del derecho a conducir vehículos a motor y ciclomotores que se impongan por la comisión de delitos contra la seguridad vial. 
art.794 de la LECrim ${ }^{205}$ por el que se regulaba la ejecución de sentencias que incluyeran la pena de privación del derecho a conducir. En segundo lugar, el art.764.4 de la LECrim ${ }^{206}$ relativo a la medida cautelar de intervención del permiso de conducción por el Juez o Tribunal con la prohibición que el investigado pueda conducir un vehículo de motor mientras subsista la medida.

Otro de los datos que acreditan la relación que ha existido entre la Ley 17/2005 de 19 de julio y la pena de privación del derecho a conducir, es que aquella ha contribuido a reforzar el carácter penal de esta privación de derechos. Con la entrada en vigor de la Ley 17/2005 de 19 de julio en determinadas infracciones los conductores podían recibir en vía administrativa tres tipos de sanciones: multa económica, pérdida de puntos y privación del derecho/permiso a conducir ${ }^{207}$. Debido a la articulación de la Ley 17/2005 de 19 de julio, desde la DGT se determinó dejar sin efecto la sanción de suspensión temporal del permiso en infracciones graves, manteniéndose para las infracciones muy graves ${ }^{208}$. No sólo eso, sino que tras la entrada en vigor de la Ley 18/2009, de 23 de noviembre, por la que se modifica el texto articulado de la LTSV en materia sancionadora ${ }^{209}$ y tras la experiencia de tres años de vigencia de la Ley 17/2005 de 19 de julio, el legislador concluyó que no tenía sentido seguir aplicando la suspensión temporal del permiso a conducir en el ámbito administrativo ${ }^{210}$. Con motivo de dicha supresión como sanción administrativa, la privación temporal del derecho a conducir como sanción

\footnotetext{
205 Art.794.2 LECrim: En los casos en que se haya impuesto la pena de privación del derecho a conducir vehículos a motor y ciclomotores, el Secretario judicial procederá a la inmediata retirada del permiso y licencia habilitante, si tal medida no estuviera ya acordada, dejando unido el documento a los autos y remitirá mandamiento a la Jefatura Central de Tráfico para que lo deje sin efecto y no expida otro nuevo hasta la extinción de la condena.
}

206 Art.764.4 LECrim. Se podrá acordar la intervención inmediata del vehículo y la retención del permiso de circulación del mismo, por el tiempo indispensable, cuando fuere necesario practicar alguna investigación en aquél o para asegurar las responsabilidades pecuniarias, en tanto no conste acreditada la solvencia del investigado o encausado o del tercero responsable civil. También podrá acordarse la intervención del permiso de conducción requiriendo al investigado o encausado para que se abstenga de conducir vehículos de motor, en tanto subsista la medida, con la prevención de lo dispuesto en el artículo 556 del Código Penal. Las medidas anteriores, una vez adoptadas, llevarán consigo la retirada de los documentos respectivos y su comunicación a los organismos administrativos correspondientes.

207 Vid. LEDESMA MUÑIZ, Ramón, "El nuevo...., op.cit., pp.19-20.

208 Vid. la Instrucción no 09/s- 105 de la Dirección General de Tráfico de 10 de febrero de 2009. Recurso electrónico disponible en: http://siplainfo.files.wordpress.com/2009/03/instruccion-dgt-09-s105.pdf (último acceso: 02/11/2020).

${ }^{209}$ Recurso electrónico disponible en: https://www.boe.es/buscar/act.php?id=BOE-A-2009-18732 (último acceso: 13/12/2020).

210 En relación con la suspensión administrativa de la autorización administrativa para conducir, vid. Ley 18/2009, de 23 de noviembre, Preámbulo, apartado IV y también MAGRO SERVET, Vicente, Análisis..., op.cit., p.267. 
directa únicamente la tenemos en la esfera penal a través de la pena o medida de seguridad de privación del derecho a conducir.

Del examen efectuado inferimos que existe una clara similitud entre aquellos penados que cumplen con una privación del derecho a conducir superior a los dos años y aquellos conductores que en el ámbito administrativo pierden la totalidad de sus puntos en el permiso de conducir. En el primer caso nos hallamos ante una pérdida de vigencia del permiso o licencia derivada de una sentencia penal al amparo del art.47.3 CP y en el segundo supuesto, una pérdida de vigencia administrativa al haber perdido la totalidad de los puntos. Las dos situaciones pueden ser consideradas "equivalentes", derivadas de génesis diferentes, pero con consecuencias similares. En los dos supuestos, los conductores deberán realizar el curso de sensibilización y reeducación vial, así como el posterior examen teórico para poder volver a ejercer el derecho a conducir, que en unos casos habrán perdido por resolución penal y en el otro por resolución administrativa, aunque comparten los efectos ${ }^{211}$. En ambas situaciones para recuperar el derecho a conducir se exige el mismo procedimiento, ya que debe realizarse lo establecido en el art.71.2 de la LTSV212. Ello acredita la influencia que ha tenido la Ley 17/2005 de 19 de julio en el ámbito penal cuando se impone al conductor la pena de privación del derecho a conducir ${ }^{213}$, y que se ha mantenido en el RDL 6/2015 de 30 de octubre por el que se aprueba el texto refundido de la LTSV.

Tras el análisis de la Ley 17/2005 de 19 de julio, estimo acreditada su influencia tanto directa como indirecta en la pena de privación del derecho a conducir, motivada por la necesidad de articular un correcto sistema penal-administrativo. A pesar del peso que ha tenido la Ley 17/2005 de 19 de julio en la pena de privación del derecho a conducir, ésta sigue teniendo autonomía propia respecto cualquier norma administrativa pero no podemos obviar las conexiones entre los dos ámbitos normativos. De forma contraria a lo que podría imaginarse, la Ley 17/2005 de 19 de julio ha contribuido también a reforzar la naturaleza jurídica de la privación del

\footnotetext{
211 Sobre la privación definitiva del derecho a conducir y la relación con la Ley 17/2005, vid. CUESTA PASTOR, Pablo.J., El delito de conducción bajo la influencia de bebidas alcohólicas y el sistema de sanción por puntos de la Ley 17/2005, de 19 de julio, Ed. Dykinson, Madrid, 2012, p.85.

${ }^{212}$ Art.71.2 LTSV. El titular de un permiso o licencia de conducción, cuya pérdida de vigencia haya sido declarada como consecuencia de la pérdida total de los puntos asignados podrá obtener nuevamente un permiso o licencia de conducción de la misma clase de la que era titular, transcurridos los plazos señalados en el apartado anterior, previa realización y superación con aprovechamiento de un curso de sensibilización y reeducación vial y posterior superación de las pruebas que reglamentariamente se determinen.

${ }^{213}$ Respecto a la interacción entre la Ley 17/2005 y las condenas penales a privación del derecho a conducir, vid. TRAPERO BARREALES, María.A., Los delitos..., op.cit., pp.571-572.
} 
derecho a conducir como pena en detrimento de su naturaleza cómo sanción administrativa. La precitada Ley introdujo sanciones que acarreaban pérdida de puntos y sanción pecuniaria, pero con el paso de los años se ha establecido en el ámbito administrativo un sistema en el cual han desaparecido las privaciones temporales del derecho a conducir que existían con anterioridad. Ello ha generado que en la actualidad el Derecho Administrativo sancionador en materia de tráfico se caracterice por el binomio puntos/sanción pecuniaria, en detrimento de la sanción de privación del derecho a conducir que ha quedado circunscrita al ámbito penal.

\subsection{Toma de posición respecto la naturaleza jurídica de la privación del derecho a conducir}

Tras haber analizado la naturaleza jurídica de la privación del derecho a conducir desde la óptica penal y administrativa, finalizará el capítulo con la toma de posición respecto si nos hallamos ante una naturaleza penal o administrativa ${ }^{214}$.

Se ha constatado en el trabajo, que en sus inicios la privación del derecho a conducir estaba regulada mayoritariamente por el Derecho Administrativo sancionador, y tanto éste como el Derecho Penal tenían la finalidad a través de la privación del derecho a conducir de proteger bienes jurídicos como la seguridad vial y la vida e integridad física de las personas usuarias de la vía ${ }^{215}$. La coexistencia durante años de la protección de bienes jurídicos en el ámbito administrativo y penal tenía fundamento constitucional| ${ }^{216}$, pues en ambos se ejercía el poder punitivo del Estado, siendo válidos ambos órdenes para la protección que merecen bienes jurídicos como la seguridad vial ${ }^{217}$. La tutela de la seguridad vial por el Derecho

\footnotetext{
214 En relación con el debate en general entre sanción penal-sanción administrativa, vid. MAPELLI CAFFARENA, Borja/ TERRADILLOS BASOCO Juan, Las consecuencias..., op.cit., pp.20-21.

${ }^{215}$ Acerca de las relaciones entre el Derecho Penal y el Derecho Administrativo sancionador, vid. RANDO CASERMEIRO, PABLO, "El modelo penal de la seguridad ciudadana en el Derecho administrativo sancionador", Indret, Revista para el análisis del Derecho, oㅡ 1, 2010, p.7.
}

Recurso electrónico disponible en: http://www.indret.com/pdf/rando casermeiro.pdf (último acceso: 02/11/2020).

216 En relación con la protección de bienes jurídicos en dos órdenes normativos diferentes, vid. la STC, núm.18/1981, Sala Primera, de 8 de junio de 1981, ponente Excmo. Sr. Rafael Gómez-Ferrer Morant (TOL110.823).

217 En torno a las relaciones entre el Derecho Administrativo sancionador y el Derecho Penal, vid. RANDO CASERMEIRO, Pablo, "EI modelo...", op.cit., p.7 y 16. También podemos citar la STC de 21 de diciembre de 1987 como prueba de la convergencia entre ambas jurisdicciones, en la que se establecía que los principios que rigen en el orden penal podrían ser traspuestos, con matizaciones al Derecho Administrativo sancionador. Vid. STC, núm. 2/1987, Sala Primera, de 21 de enero de 1987, ponente Excmo. Sr. Miguel Rodríguez-Piñero y Bravo-Ferrer (TOL340.205). 
Administrativo y el Derecho Penal afectaba directamente a la privación del derecho a conducir que se imponía indistintamente en ambos órdenes jurisdiccionales. Un ejemplo evidente de la relación entre el Derecho Penal y el Derecho Administrativo sancionador fueron las diversas sentencias dictadas por el TC ${ }^{218}$, en las que se analizaba el principio non bis in idem y su incidencia en los órdenes penal y administrativo. La jurisprudencia constitucional encauzó lo acaecido años más tarde, y que se ha concretado en la preeminencia del orden penal en lo relativo a la aplicación de la privación del derecho a conducir bien como pena, medida de seguridad o medida cautelar.

Las reformas operadas desde la LO 15/2007 de 30 de noviembre de 2007 en los delitos relacionados con la seguridad vial han reforzado el carácter penal de la privación del derecho a conducir. El poder legislativo a través de lo que se conoce como "leyes apaciguadoras" 219 , intentó calmar a determinados sectores sociales que peticionaban mayor utilización del $\mathrm{CP}$, transmitiendo la sensación de un cierto populismo punitivo y de una utilización simbólica del Derecho Penal ${ }^{220}$. Esta situación podemos vincularla con el fenómeno de la “'administrativización"221 del Derecho Penal, ya que tras haberse producido la expansión de éste al ámbito de la seguridad vial ${ }^{222}$ quedó huérfana de aplicación la sanción temporal de privación del derecho a conducir en el ámbito administrativo, en el que ahora se imponen sanciones pecuniarias o bien pérdida de los $\operatorname{puntos}^{223}$. El legislador, al dirigir la

218 Vid. STC, núm. 77/1983, Sala Segunda, de 3 de octubre de 1983, ponente Excmo. Sr. Luis DíezPicazo (TOL79.242), STC, núm. 177/1999, Sala Segunda, de 11 de octubre de 1999, ponente Excmo. Sr. Pablo García Manzano (TOL81.219), y STC, núm. 2/2003, dictada por el Pleno del Tribunal Constitucional de 16 de enero de 2003, ponente Excma. Sra. María Emilia Casas Bahamonde (TOL228.958).

${ }^{219}$ Acerca de dicha denominación vid. DÍEZ RIPOLLÉS, José Luis, "El Derecho penal simbólico y los efectos de la pena", en AA.VV. Crítica y justificación del Derecho penal en el cambio de siglo, ARROYO ZAPATERO, Luis /NEUMANN, Ulfrid /NIETO MARTíN, Adán (Coords.), Ediciones de la Universidad de Castilla-La Mancha, Cuenca, 2003, p.168.

220 Respecto de la función simbólica del Derecho Penal en la reforma operada por la LO 15/2007 de 30 de noviembre de 2007, vid. TENA SÁNCHEZ, Jordi, "Cambios en la política criminal de seguridad vial en España entre 2004 y 2010: Un análisis centrado en el diseño institucional". Estudios de Deusto, julio-diciembre 2010, volumen 58, oㅡ 2, 2010, p.276. Recurso electrónico disponible en: http://revista-estudios.revistas.deusto.es/article/viewFile/352/514 (último acceso: 02/11/2020).

${ }^{221}$ En torno a la movilidad del límite entre ambos órdenes normativos, vid. NAVARRO CARDOSO, Fernando, Infracción Administrativa y Delito: Límites a la intervención del derecho penal, Ed. Colex, Madrid, 2001, pp.80-81.

222 Sobre el incremento de la privación del derecho a conducir en el ámbito penal entre los años 2005-2010 al haberse se elevado a delito lo que eran meras infracciones administrativas, vid. CUESTA PASTOR, Pablo.J., El delito..., op.cit., p.13.

223 Difiero de la opinión de ROCA DE AGAPITO que mantiene que existe una sanción administrativa correlativa a la pena de privación del derecho a conducir, cuando en la actualidad, no existe una sanción en el ámbito del Derecho Administrativo sancionador que temporalmente imponga al 
punición de determinadas conductas hacia el $\mathrm{CP}$, ha potenciado la naturaleza penal de la privación del derecho a conducir y el incremento del uso de la pena de privación del derecho a conducir es correlativo a la opción de política criminal por los delitos de peligro abstracto en la seguridad vial. Ello motivó que actualmente la privación del derecho a conducir aparezca de forma residual en la normativa administrativa en forma de medida cautelar, mientras que tiene su aplicación mayoritaria en sede penal ${ }^{224}$.

Asimismo, al concentrarse exclusivamente en la jurisdicción penal esta privación de carácter temporal, se evita el solapamiento que podía producirse cuando se aplicaba en los dos ámbitos ${ }^{225}$ y se ha reducido la dificultad para determinar si nos hallamos ante una sanción propia del Derecho Administrativo sancionador o bien, propia del ámbito penal o incluso de ambos. En este sentido, la tendencia del legislador español en los últimos años en relación con los delitos relativos al tráfico viario, así como en la aplicación de la privación del derecho a conducir parece consolidada en el ámbito penal en detrimento de la LTSV ${ }^{226}$. Con la actual regulación penal, la naturaleza de la privación del derecho a conducir puede ser considerada como múltiple (pena, medida cautelar y medida de seguridad) ${ }^{227}$. El hecho que en el CP exista la privación del derecho a conducir de forma triple, reafirma su importancia al poder imponerse tanto a los sujetos penalmente responsables como a aquellos infractores que hayan sido declarados inimputables o semiimputables. Esta circunstancia, en mi opinión refuerza la naturaleza de la privación del derecho a conducir como sanción penal, ya que nuestro sistema penal posibilita que aquellos que cometan un delito, aún en el caso de resultar absueltos por concurrencia de una circunstancia eximente no puedan hacer uso de su derecho a conducir.

conductor la privación del derecho a conducir. Vid. ROCA DE AGAPITO, Luis, "Las penas", en AA.VV. Las consecuencias..., op.cit., p. 27. En el mismo sentido se expresa RODRÍGUEZ MORO, Luis, La pena de privación..., op.cit., pp.34-35.

${ }^{224}$ En relación con la eficacia preventivo-sancionadora del Derecho Penal, vid. HORTAL IBARRA, Juan Carlos, "La mutación...., op.cit., p.4.

225 En relación con el solapamiento entre el ámbito penal y administrativo en materia de seguridad vial vid. MIRÓ LLINARES, Fernando, "El "moderno" Derecho Penal Vial y la penalización de la conducción sin permiso", en AA.VV. Protección Penal de la Seguridad Vial, OLMEDO CARDENETE, Miguel/ARÁNGUEZ SÁNCHEZ, Carlos (Eds.), Ed. Alea Blanca 2010, Granada, 2010, pp.160-161.

226 En la actualidad el Derecho Penal tiene preeminencia respecto el Derecho Administrativo sancionador, que básicamente se circunscribe a las sanciones pecuniarias y a la pérdida de puntos, como ha señalado MIRÓ LLINARES, Fernando, "El "moderno" Derecho Penal Vial y la penalización de la conducción sin permiso", en AA.VV. Protección Penal..., op.cit., pp.160-161.

227 Vid. GÓMEZ PAVÓN, Pilar, El delito..., op.cit., p.221. 
A pesar de la tradición de la pena de privación del derecho a conducir en nuestro sistema penal, y el incremento que supuso su aplicación en los últimos años, no podemos obviar el debate acerca de si la privación del derecho a conducir como pena temporal privativa de derechos ha de estar únicamente regulada en el CP o por el contrario se ha reintroducir como sanción temporal en el Derecho Administrativo sancionador. En el CP existen diversos tipos delictivos relacionados con la seguridad vial, en los que se prevé la aplicación de la pena de privación del derecho a conducir, que por meras razones de política criminal se les ha revestido de tal categoría, cuando podrían ser sancionados en la vía administrativa ${ }^{228}$. Por ello, no sería descartable que en ulteriores reformas penales-administrativas se procediera a la instauración de la privación del derecho a conducir como suspensión temporal de nuevo en la LTSV ${ }^{229}$, al amparo de los principios que rigen nuestro Derecho Penal y en especial el principio de mínima intervención y el de fragmentariedad. Actualmente, la naturaleza penal de la privación del derecho a conducir está consolidada ${ }^{230}$, bien como pena, medida de seguridad o medida cautelar, aunque sí sería conveniente que existiera la sanción en el ámbito administrativo para aquellos casos que finalicen bien con archivo bien con sentencia absolutoria en el ámbito penal, a pesar de observarse una infracción grave a la normativa administrativa.

\footnotetext{
228 En este sentido comparto lo expresado por MONTANER FERNÁNDEZ, Raquel, "Los nuevos...", op.cit., p.316 y VALEIJE ÁLVAREZ, Inmaculada," El sistema de penas en los delitos contra la seguridad vial", en AA.VV. Prevención y control...,

op.cit., p.459.

229 En este sentido comparto la expresión de HORTAL IBARRA, Juan Carlos, de: "desandar el camino realizado y repensar la intervención penal en este ámbito", en "La mutación...", op.cit., pp.45.

230 Respecto del carácter penal de la privación del derecho a conducir, vid. TAMARIT SUMALLA, Josep, "La prohibición de conducir y otras sanciones penales relacionadas con los vehículos" en AA.VV. Las sanciones penales en Europa, Revista Aranzadi de Derecho y Proceso Penal, TAMARIT SUMALLA, Josep (Coord.), núm. 21, Ed. Aranzadi, Cizur Menor (Navarra), 2009, p. 326.
} 


\section{CAPítulo 2. Fines de la PENA de PRIVACIÓN DEL DERECHO A CONDUCIR}

El Derecho Penal tiene como una de sus principales metas garantizar la convivencia en una sociedad ${ }^{231}$ y las penas constituyen uno de los mecanismos utilizados para alcanzarla. A tales efectos, los objetivos de este capítulo son precisar los fines que cumple en la actualidad la pena de privación del derecho a conducir vehículos a motor y ciclomotores, determinar su sentido en el catálogo de penas del $\mathrm{CP}^{232}$ y analizar si es un medio idóneo para contribuir a la estabilidad de la sociedad en el ámbito de la seguridad vial ${ }^{233}$.

Para definir los fines de la pena objeto de análisis, seguiremos la doctrina clásica sobre los fines de la pena. En primer lugar, se estudiarán los fines retributivos de la pena de privación del derecho a conducir, para después examinar la misma en relación con los fines que se derivan de las llamadas teorías relativas o utilitaristas, es decir, concretando sus fines preventivos, tanto preventivo-generales y preventivo-especiales en su vertiente negativa y positiva. En tercer lugar, nos adentraremos en las llamadas Teorías Eclécticas para determinar si la pena que se examina puede desarrollar una finalidad mixta. El último apartado del Capítulo está dedicado a plasmar la toma de posición en relación con los fines actuales de la pena de privación del derecho a conducir, que irá acompañada de referencias jurisprudenciales en las que se ha tratado esta cuestión.

\subsection{La realización de fines retributivos en la pena de privación del derecho a conducir}

El objetivo del apartado es determinar si la pena de privación del derecho a conducir tiene en la actualidad fines retributivos, por lo que analizaremos los aspectos más destacados de las teorías absolutas o de la retribución y los pondremos en relación

\footnotetext{
231 Relativo al fundamento de la pena vid. QUINTERO OLIVARES, Gonzalo, "El derecho penal: concepto, principios informadores y evolución", Parte General del Derecho Penal, QUINTERO OLIVARES, Gonzalo (Dir.), Ed.Thomson-Aranzadi, Cizur Menor (Navarra), 2007, pp-93-95; DíEZ RIPOLLÉS, José Luis, "El Derecho penal simbólico y los efectos de la pena", en AA.VV. Crítica..., op.cit., p.153 y también ROCA AGAPITO, Luis, El sistema..., op.cit., p.71.

${ }^{232}$ Acerca de la justificación de la pena, vid. CARBONELL MATEU, Juan Carlos, "La reforma del tratamiento penal de la seguridad vial", en AA.VV. Delincuencia en materia de tráfico y seguridad vial. Aspectos penales, civiles y procesales, MORILLAS CUEVA, Lorenzo (Coord.), Ed. Dykinson, Madrid 2007, p.386.

${ }^{233}$ En relación con la justificación de las penas en general, vid. VAELLO ESQUERDO, Esperanza, Las consecuencias..., op.cit., p.18.
} 
con esta pena. A tal efecto, desgranaremos las características esenciales de las teorías absolutas, tanto desde la óptica del retribucionismo clásico como de la teoría de la expiación con la finalidad de precisar si la pena de privación del derecho a conducir está guiada, o no, por fines retributivos y en qué medida.

Expresiones como "punitur quia peccatum est"234 y "Si imponéis-con los criterios que sea- una pena, con ella se ha de retribuir un delito"235, contribuyen a fijar la esencia de las teorías absolutas. Según estas ideas, se considera que la pena es una retribución o una suerte de compensación por el mal causado por el autor del delito, descartando cualquier tipo de fines extrínsecos a la misma pena ${ }^{236}$.

Las teorías absolutas mantienen que la pena no debe de tener ni objetivos ni finalidad y únicamente se procede a castigar porque se ha delinquido ${ }^{237}$, siendo este castigo una compensación por el daño causado ${ }^{238}$, despojándola de cualquier fin al estimar que es un fin en sí misma y no un mecanismo para alcanzar otro fin ${ }^{239}$. En este sentido, las posiciones de KANT y HEGEL preconizan que la pena no va más allá del castigo por el hecho que ha cometido el delincuente, careciendo de cualquier fin ${ }^{240}$. En la misma línea, los postulados retribucionistas clásicos destacan que la pena no debe perseguir finalidades para prevenir delitos ${ }^{241}$, al ser sólo una

\footnotetext{
234 Traducido al castellano significa que se impone la pena porque se ha cometido un delito. Vid. SANZ MULAS, Nieves, Alternativas..., op.cit., p.39.

235 Vid. la frase de ROXIN citada por ROCA AGAPITO, Luis, El sistema..., op.cit., p.84.

${ }^{236}$ Con relación a la inexistencia de fines fuera de la propia pena en las teorías absolutas vid. SANZ MULAS, Nieves, Alternativas..., op.cit., p.39 y CUTINO RAYA, Salvador, Fines de la pena, sistema penitenciario y política criminal, Ed. Tirant lo Blanch, Valencia, 2017, p.15.
}

${ }^{237}$ Acerca de los caracteres de las teorías absolutas vid. VAELLO ESQUERDO, Esperanza, Las consecuencias..., op.cit., p.18.

238 En torno a las teorías absolutas y los fines retributivos de la pena, vid. ÁLVAREZ GARCíA, Francisco Javier, Consideraciones..., op.cit., p.89, y FERRAJOLI, Luigi, Derecho y razón, Ed. Trotta, Madrid, 2011, p.253.

239 En relación con la consideración de la pena como fin en sí misma, vid. LANDROVE DÍAZ, Gerardo, Las consecuencias..., op.cit., p.19 y ROCA AGAPITO, Luis, El sistema..., op.cit., p.83.

240 Con relación a KANT destacar que el castigo que se impone al delincuente es <<fin en sí mismo >> y determina que la pena no puede tener fines preventivos. Con relación a HEGEL, podemos destacar que estima que la pena es utilizada para que el orden jurídico que se ha lesionado vuelva a la normalidad. En relación con los postulados realizados por ambos autores vid. QUINTERO OLIVARES, Gonzalo, "El derecho penal: concepto, principios informadores y evolución", Parte General..., QUINTERO OLIVARES, Gonzalo (Dir.), op.cit., p.95; MAPELLI CAFFARENA, Borja/ TERRADILLOS BASOCO Juan, Las consecuencias..., op.cit., pp.33-34; SANZ MULAS, Nieves, Alternativas..., op.cit., pp.40-42; ÁLVAREZ GARCÍA, Francisco Javier, Consideraciones sobre los fines de la pena en el ordenamiento constitucional español, Ed. Tomares, Granada, 2001, p.92, y CUTIÑO RAYA, Salvador, Fines de la pena..., op.cit., pp.18-20.

241 Con relación a dichos fines vid. ROCA AGAPITO, Luis, El sistema..., op.cit., p.83. 
respuesta al delito cometido y la misma no tiene relación con los efectos que pueda provocar en el penado 242 .

La opción de relacionar estos principios con la pena de privación del derecho a conducir puede ser limitada, ya que ello significaría que la misma en modo alguno buscaría que el conductor penado en el futuro volviera a delinquir, así como que estaría desposeída de fines con relación al resto de la sociedad, y específicamente al resto de conductores ${ }^{243}$. Asociar esta idea a la pena que analizamos representaría que ésta no tiene ninguna finalidad y únicamente se impone para que la responsabilidad del delincuente en los hechos delictivos cometidos sea compensada de manera justa ${ }^{244}$. A su vez, los postulados retributivos pueden colisionar con el marco constitucional español que se rige por la función de reinserción y resocialización de las penas privativas de libertad reconocido en el art.25.2 de la CE y que pueden ser aplicables a la privación del derecho a conducir. Un principio relacionado con el retribucionismo es el de la "irrenunciabilidad de la pena"245, que es de difícil vinculación a la pena de privación del derecho a conducir. Aun cuando ésta no pueda ser suspendida ni sustituida, sí existen en nuestro ordenamiento penal tanto la prescripción de la pena o el indulto ${ }^{246}$, que harán que la pena objeto de examen sea "renunciable" y el Estado no pueda ejecutarla 247.

La posibilidad de aplicar los principios retribucionistas a la pena de privación del derecho a conducir hemos de conectarla con los diversos efectos negativos que para el penado derivan de su imposición. Así, en primer lugar, la imposibilidad de ejercer el derecho a conducir vehículos e, implícitamente, una afectación a la libertad ambulatoria del individuo, así como el efecto económico derivado del

242 Vid. RíOS MARTíN, Julián Carlos/ SEGOVIA BERNABÉ, José Luis/ PASCUAL RODRíGUEZ, Esther, Las penas..., op.cit., p.26.

243 En el ámbito doctrinal TAMARIT SUMALLA considera que la pena de privación del derecho a conducir no tiene fines retributivos. Vid. TAMARIT SUMALLA, Josep, "La prohibición de conducir y otras sanciones penales relacionadas con los vehículos", en AA.VV. Las sanciones..., op.cit., p.327.

244 Podemos señalar tres conceptos relacionados con la pena y los fines retributivos que guían las teorías absolutas o retributivas, y que son: <<venganza >>, <<expiación >> y <<reequilibrio >> entre pena y delito, citados por FERRAJOLI, Luigi, op.cit., p.254.

245 En relación con el principio de irrenunciabilidad de la pena, vid. ÁLVAREZ GARCÍA, Francisco Javier, Consideraciones..., op.cit., pp.92-94.

246 Sobre el derecho de gracia vid. QUINTERO OLIVARES, GONZALO, "Aspectos generales", en AA.VV, Derecho Penal Constitucional, QUINTERO OLIVARES, GONZALO (Dir.)/ JARIA I MANZANO, Jordi (Coord.), Ed. Tirant lo Blanch, Valencia, 2015, pp. 38-39.

247 Con relación a este aspecto, en el apartado de propuestas de mejora se propondrá tanto la opción de la suspensión como la sustitución de la pena de privación del derecho a conducir, soluciones que gravitan en una dirección diferente a las posiciones retribucionistas, ya que ambas favorecen que el Estado pueda "renunciar a la pena". 
decomiso del vehículo, posibilidad de pérdida del puesto de trabajo, e incluso la carga consistente en la pérdida definitiva de la vigencia del permiso o licencia y la necesidad que el individuo supere las pruebas pertinentes si quiere recuperar este derecho.

A su vez, podemos destacar la obligatoriedad que los penados a los que se le impone la pena de privación del derecho a conducir realicen antes de poder ejercitar de nuevo su derecho a conducir, el curso de sensibilización y reeducación vial ${ }^{248}$. Que la pena objeto de análisis tenga como consecuencia administrativa la obligatoriedad de realizar este curso no casa con el sentido expiatorio o retributivo que pudiera tener según las teorías absolutas. Por el contrario, es congruente con una finalidad de obtener una reeducación en el conductor infractor que le haga conocedor de la infracción cometida y prevenga de la comisión de futuros delitos al conocer el propio contenido de la norma anteriormente infringida.

En el ámbito doctrinal, en el sistema penal español hemos de destacar la opinión de QUINTERO OLIVARES ${ }^{249}$ quien considera que la teoría retribucionista tiene un difícil encaje en una sociedad y en un estado moderno como el actual. Por su parte, MORILLAS CUEVA, mantiene que la nueva política criminal de seguridad vial que se ha instaurado en España a partir del año 2007 formaría parte de un "renacer del retribucionismo o prevención general fustigadora para los ciudadanos"250. Con esta afirmación podemos inferir que sitúa a las penas relacionadas con la seguridad vial, como lo es la privación del derecho a conducir, en un neoretribucionismo ${ }^{251}$. Del mismo modo, RODRÍGUEZ MORO ${ }^{252}$ estima que la pena de privación del derecho a conducir tiene fines retributivos que se unen a los de prevención especial, por lo que parece descartar unos fines retribucionistas puros.

\footnotetext{
248 Vid. al respecto el art. 73 de la LTSV, para las condenas a la privación del derecho a conducir inferiores a dos años.

249 Vid. la crítica al retribucionismo de QUINTERO OLIVARES, Gonzalo, "El derecho penal: concepto, principios informadores y evolución”, Parte General..., QUINTERO OLIVARES, Gonzalo (Dir.), op.cit., p.96.

250 Vid. al respecto la opinión contra las nuevas políticas de seguridad vial de MORILLAS CUEVA, Lorenzo,"Delitos contra la seguridad del tráfico: una preocupada reflexión global", en AA.VV. Delincuencia en materia de tráfico y seguridad vial. Aspectos penales, civiles y procesales, MORILLAS CUEVA, Lorenzo (Coord.) Ed. Dykinson, Madrid, 2007, p.408.

251 En torno al resurgir del retribucionismo en los últimos años vid. MAPELLI CAFFARENA, Borja/ TERRADILLOS BASOCO Juan, Las consecuencias..., op.cit., pp.48-49.

252 Vid. RODRÍGUEZ MORO, Luis, "La pena de privación del derecho a conducir vehículos a motor y ciclomotores", en AA.VV. Las penas..., op.cit., p.231.
} 


\subsection{La realización de fines preventivos en la pena de privación del derecho a conducir}

Tras haber analizado los fines retributivos en la pena de privación del derecho a conducir, examinaremos los fines preventivos asociados en la actualidad con esta pena. Para ello se partirá de las llamadas teorías relativas, que a diferencia a las teorías absolutas sí estiman que la pena ha de tener fines claramente orientados a la prevención de delitos en el futuro ${ }^{253}$.

Uno de los principios relevantes en los fines preventivos de las teorías relativas es: "punitur, ut ne peccetur" (castiga para que no se delinca). A través del contenido de este aforismo se pretende transmitir la idea de la imposición de un castigo, para que no se delinca. Con esta afirmación, las teorías relativas mantienen que la pena es un medio para alcanzar el objetivo que no se cometan delitos ${ }^{254}$ y tienen un propósito en el futuro ${ }^{255}$, diferencia esencial con las teorías absolutas que despojan a la pena de cualquier finalidad. BECCARIA, sostuvo: "El fin de las penas no es atormentar ni afligir, sino impedir al reo causar nuevos daños a sus ciudadanos y retraer a los demás de la comisión de otros iguales" ${ }^{256}$, de donde podemos inferir los fines de prevención general y especial que defienden las teorías relativas. También en relación con los fines preventivos de las penas hemos de citar la descripción realizada por LESCH ${ }^{257}$, quien considera que se corresponden con el efecto intimidatorio y, la corrección, así como intentar que el autor se convierta en inofensivo para la sociedad, siendo éstos compatibles con la prevención general y especial.

Las teorías relativas postulan la finalidad de evitación de delitos a través de la pena, y ello se puede llevar a cabo a través de dos vías. En primer lugar, la pena ha de

\footnotetext{
253 Con relación a los postulados de las teorías relativas, vid. MAPELLI CAFFARENA, Borja/ TERRADILLOS BASOCO Juan, Las consecuencias..., op.cit., p.36.

254 En relación con las características que posee la pena para las teorías relativas o utilitaristas, vid. FERRAJOLI, Luigi, op.cit., pp.258-262.

255 Respecto de la orientación hacia el futuro de las teorías relativas vid. QUINTERO OLIVARES, Gonzalo, "El derecho penal: concepto, principios informadores y evolución", Parte General..., QUINTERO OLIVARES, Gonzalo (Dir.), op.cit., p.96 y MAPELLI CAFFARENA, Borja/ TERRADILLOS BASOCO Juan, Las consecuencias...op.cit., p.36.

${ }^{256} \mathrm{Vid}$. la referencia efectuada por DE BECCARIA, Cesare, De los delitos y de las penas, Ed. Alianza Editorial, Madrid, 1968, pp.45-46, traducción de Juan Antonio de las Casas.

257 Acerca de los fines de la pena vid. LESCH, Heiko.H, La función de la pena, Cuadernos Luis Jiménez de Asúa, núm.4, Ed. Dykinson, Madrid, 1999, p .21, traducción de Javier Sánchez-Vera Gómez Trelles.
} 
actuar sobre el sujeto que ha cometido el delito para evitar la reiteración delictiva, siendo ésta la finalidad conocida como prevención especial. En segundo lugar, cuando la pena se dirige a la sociedad en general, con el objetivo que sus miembros no cometan en el futuro delitos, hablamos de la prevención general. Ambos fines preventivos de la pena han sido destacados por VON HIRSCH${ }^{258}$, y si realizamos un análisis de la esencia del Derecho Penal no podemos obviar que la finalidad de prevención general y especial constituye hoy la orientación primordial de todas las penas en mayor o menor medida.

Si aplicamos los fines preventivos a la pena de privación del derecho a conducir resulta obvio que la misma tiene efectivamente a evitar la comisión de futuros delitos $^{259}$, tanto por parte del conductor que ya ha sido penado como por parte de aquellos que no lo han sido todavía pero que podrían convertirse en potenciales infractores. El Estado ejercita el ius puniendi a través de la pena como mecanismo para que en el futuro tanto el sujeto que ha quebrantado el CP como el resto de sujetos que conducen vehículos a motor y ciclomotores no cometan conductas delictivas, lo que supone que la finalidad esencial de la pena está guiada tanto prevención general como de prevención especial ${ }^{260}$.

La pena de privación del derecho a conducir tiene una gran aplicación en nuestra sociedad y sus consecuencias son vistas en ocasiones con temor por la generalidad de conductores por los perjuicios que se derivan de la misma ${ }^{261}$. El ámbito de la seguridad vial es uno en los que mayor eficacia tienen las penas privativas de derechos como la que estudiamos, al poder extrapolar sus fines y eficacia tanto a los penados como a aquellos no penados pero que sí pueden devenir potenciales delincuentes ${ }^{262}$.

\footnotetext{
258 Vid. VON HIRSCH, Andrew, Censurar y castigar, Ed. Trotta, Madrid, 1998, p.39, traducción de Elena Larrauri.

259 Referente a la utilidad de la pena para alcanzar los fines preventivos, vid. QUINTERO OLIVARES, Gonzalo, "El derecho penal: concepto, principios informadores y evolución", Parte General..., QUINTERO OLIVARES, Gonzalo (Dir.), op.cit., p.97 así como ROCA AGAPITO, Luis, El sistema..., op.cit., p.85.

260 En relación con el fundamento de la sanción penal en las teorías relativas, vid. LANDROVE DÍAZ, Gerardo, Las consecuencias..., op.cit., p.19.

261 Acerca de las consecuencias que genera la imposición de la pena de privación del derecho a conducir y el miedo a su imposición que tienen los conductores vid. DE VICENTE MARTíNEZ, Rosario, Siniestralidad vial..., op.cit., p.91.

262 Respecto de la eficacia de las sanciones relacionadas con la utilización de vehículos a motor, vid. VALLESPÍN PÉREZ, David, Aspectos procesales..., op.cit., p.18.
} 
Por todas las razones apuntadas podemos inferir que la finalidad actual de la pena objeto de este análisis, es evitar que el penado vuelva a cometer infracciones a la normativa de tráfico y que el resto de conductores tomen conciencia de las penas que se les puedan imponer ${ }^{263}$. De esta forma se intenta que respeten la normativa de seguridad vial en los delitos que la contemplan, por lo que puede colegirse que la pena de privación del derecho a conducir sí tiene unos fines de carácter preventivo 264 .

\subsubsection{La prevención general en la pena de privación del derecho a conducir}

Si realizamos el estudio de los fines de la pena de privación del derecho a conducir desde la óptica preventiva, hemos de determinar en primer lugar si puede revestir unos objetivos de prevención general, tanto negativa como positiva, y definir los aspectos en los que se implementan.

Según las teorías relativas, las penas que están orientadas hacia unos fines preventivo-generales tienen como finalidad que los ciudadanos cuando realizan una conducta sepan que, en el caso de no ajustarse a las normas establecidas en el CP, puede recaer sobre ellos una pena y ello les haga renunciar a la comisión de delitos $^{265}$. Esta finalidad, hemos de vincularla con la conducción de vehículos a motor y ciclomotores y determinar la influencia que en dichos comportamientos puede tener la pena de privación del derecho a conducir. Los fines de prevención general que puede desarrollar la pena de privación del derecho a conducir están dirigidos a que la mayoría de conductores sean conocedores de su existencia, de las consecuencias jurídicas que acarrea una acción delictiva, y lleguen a la convicción de que no han de delinquir. Estos fines no son exclusivos de las penas

\footnotetext{
263 En este sentido KAISER señaló que “....todo conductor está próximo a la situación delictiva”, por lo que considero que la pena de privación del derecho a conducir sí puede tener fines preventivos generales. Vid. KAISER Günther, Delincuencia de tráfico y prevención general. Investigaciones sobre la Criminología y el Derecho Penal del tráfico. (trad. J.M. Rodríguez Devesa), Ed. Espasa Calpe, Madrid, 1979, p.28.

${ }^{264}$ Con relación a los fines preventivos de la pena, vid. ROCA AGAPITO, Luis, El sistema..., op.cit., p.85 y FERRAJOLI, Luigi, op.cit., p.263.

265 Los fines de prevención general de las penas, podemos inferirlos en QUINTERO OLIVARES, Gonzalo, "El derecho penal: concepto, principios informadores y evolución", Parte General..., QUINTERO OLIVARES, Gonzalo (Dir.), op.cit., p.97; VON HIRSCH, Andrew, Censurar y castigar, op.cit., p.81 y también MAPELLI CAFFARENA, Borja/ TERRADILLOS BASOCO, Juan, Las consecuencias..., op.cit., p.37.
} 
privativas de libertad y las propias penas privativas de derechos ${ }^{266}$, como es la privación del derecho a conducir, pueden realizar tales fines, en particular en la medida en que su previsión o su aplicación contribuyen a conseguir que los conductores desistan de realizar determinadas conductas sino quieren que el derecho a conducir que han adquirido se vea restringido ${ }^{267}$.

Los fines de prevención general sí pueden ser visibles en la pena que se analiza, al estar destinada a la prevención de la comisión de futuros delitos por los ciudadanos en general, y en particular en aquellos poseedores de un permiso o licencia de conducir $^{268}$. Sin embargo, los fines de prevención general no deben ceñirse únicamente a aquellos conductores que sí poseen el permiso o licencia, sino que también han de dirigirse hacia ciudadanos que sin disponer del necesario permiso pueden también ser potencialmente condenados por algunos de los delitos tipificados en el CP como, por ejemplo, los tipificados en los actuales arts. 379, 382 bis y $383 \mathrm{CP}$. Esto es, aquellos que realizan la conducción bajo la influencia de alcohol o drogas; que conducen a velocidad rebasando los límites establecidos, los que abandonan el lugar donde se ha producido un accidente y los que se niegan a someterse a las pruebas de detección de alcohol y drogas. Debido a que en estos tipos delictivos se puede imponer la pena de privación del derecho a conducir a conductores que carezcan del permiso o licencia, destacaremos en ella los fines de prevención general de manera amplia, al dirigirse a todos los potenciales conductores con independencia que tengan o no permiso o licencia que les habilite para conducir.

La proyección de la pena que se analiza en la sociedad hay que relacionarla con la prevención general, ya que numerosos ciudadanos utilizan el vehículo a motor o

266 En relación con los fines de prevención general de las penas privativas de derechos, vid. CHOCLÁN MONTALVO, José Antonio, "Las penas privativas de derechos en la reforma penal", Actualidad Penal, no 8, 1997, p.148 y también Grupo de Estudios de Política Criminal, Una propuesta..., op.cit., p.33.

267 Podemos destacar que un estudio realizado entre conductores españoles llegó a la conclusión que el $96,4 \%$ de los conductores entrevistados sabía que si conducían un vehículo a motor o ciclomotor bajo los efectos del alcohol se les podía privar de su derecho a conducir. Vid. ALONSO, Francisco/, PASTOR, Juan Carlos/, MONTORO Luis/, ESTEBAN, Cristina, "Driving under the influence of alcohol: frequency, reasons, perceived risk and punishment", Substance Abuse Treatment, Prevention, and Policy, 2015, 10:11. Recurso electrónico disponible en: https://substanceabusepolicy.biomedcentral.com/track/pdf/10.1186/s13011-015-0007-4 (último acceso: 02/11/2020).

268 Los fines de prevención ya fueron puestos de manifiesto por el Excmo. Sr. Fiscal General del Estado, Sr. Cándido Conde-Pumpido, en su comparecencia efectuada en fecha 23-11-2005, ante la Comisión no permanente sobre Seguridad Vial y Prevención de accidentes de tráfico del Congreso. 
ciclomotor de manera diaria. Con ello, quiero destacar que una hipotética condena a la pena de privación del derecho a conducir recaerá indirectamente sobre el vehículo a motor y ciclomotor por lo que su eficacia dentro de la esfera de la sociedad será elevada, rebasando los límites del propio penado.

Una vez delimitados los fines de prevención general, examinaremos sus dos vertientes: la prevención general negativa y la prevención general positiva. En ambos casos determinaremos la relación con la pena de privación del derecho a conducir vehículos a motor y ciclomotores, así como los caracteres con los que dichos fines se manifiestan en la misma en la actualidad para finalmente determinar cuál predomina con mayor claridad.

\section{a) La prevención general negativa}

La finalidad de prevención general negativa de las penas ha de ser puesta en relación con el efecto intimidatorio que proyectan en la población, convirtiéndose esta amenaza en el motivo para no cometer delitos, al inferirse un respeto al CP a través el temor que se ha inoculado en los ciudadanos ${ }^{269}$.

Partiendo de estas premisas, analizaremos los fines de prevención general negativa de la pena objeto de este trabajo, al poder realizar una función de intimidación respecto a la ciudadanía en general y los conductores en particular ${ }^{270}$. La existencia de la pena de privación del derecho a conducir en el CP como consecuencia jurídica que se puede imponer en determinados delitos puede influenciar a la ciudadanía, formar en ella una convicción de respeto hacia las normas y disuadir a los conductores de la comisión de hechos delictivos. Con la pena de privación del derecho a conducir se pretende que todos los ciudadanos tengan presente en su fuero interno una amenaza en forma de pena para el caso que piensen llevar a cabo la comisión de un delito ${ }^{271}$.

269 Sobre la prevención general negativa, vid. ÁLVAREZ GARCÍA, Francisco Javier, Consideraciones..., op.cit., p.110, ROCA AGAPITO, Luis, El sistema..., op.cit., p.85 y también FERRAJOLI, Luigi, op.cit., p.263.

270 La función de prevención general desde la intimidación ha sido destacada por ÁLVAREZ GARCÍA, Francisco Javier, Consideraciones..., op.cit., p.117. También relación a los efectos de la intimidación de las penas en general sobre la generalidad de ciudadanos y sobre el delincuente en particular, vid. DÍEZ RIPOLLÉS, José Luis, "El Derecho penal simbólico y los efectos de la pena", en AA.VV. Crítica...op.cit., p.156.

271 En relación con la prevención general negativa, hemos de recordar la frase: "el miedo guarda la viña", que ejemplifica el sentido de dicho fin de la pena, vid. RíOS MARTíN, Julián Carlos/ SEGOVIA BERNABÉ, José Luis/ PASCUAL RODRÍGUEZ, Esther, Las penas..., op.cit., p.26. 
En el sistema penal español, la LO 15/2007 de 30 de noviembre supuso un incremento de la utilización del Derecho Penal en general y de la pena de privación del derecho a conducir en particular. Esta reforma se vincula a los fines de prevención general negativa de la pena que analizamos, especialmente con las modificaciones introducidas en el art.379 CP, que impuso una "intimidación o amenaza" cierta para los conductores ${ }^{272}$. En el mismo sentido, la aplicación de la pena de privación del derecho a conducir conjuntamente con la pena de privación de libertad, en algunos delitos reformados por la LO 15/2007 de 30 de noviembre pudo tener inicialmente unos fines de prevención general negativa. El motivo es que, para disuadir a la población de infringir la normativa de tráfico a través de la intimidación, podía existir la pretensión de asociar la pena de prisión a la pena privativa del derecho a conducir. De esta forma se producía un doble castigo y se trasladaba el mensaje de dureza punitiva hacia los potenciales delincuentes en aras de provocar en los mismos un efecto intimidatorio, claramente asociado a la prevención general negativa.

MORILLAS CUEVA vincula la pena de privación del derecho a conducir a la política criminal de seguridad vial que se caracteriza por una "prevención general fustigadora para los ciudadanos"273. La definición de fustigadora podría asociarse a la prevención general negativa, pues parece desprender un aroma de temor o intimidación hacia la ciudadanía. Si aplicamos dichos postulados a la pena que se analiza, ésta sí puede cumplir los fines de prevención general negativa, aunque de forma no explícita ni claramente constatable, aunque es cierto que gran parte de la sociedad sabe los graves efectos que pueden implicar para los conductores la comisión de un delito contra la seguridad vial. En este sentido, uno de los fines de prevención general negativa que podemos atribuir a la pena que analizamos puede vincularse con el aumento de sentencias condenatorias que incluyen la misma que han favorecido un mayor conocimiento de esta pena entre la sociedad. En los últimos años se ha difundido entre la sociedad en general, y entre los conductores en particular, la convicción que determinadas conductas realizadas con un vehículo

\footnotetext{
272 Acerca de la finalidad de prevención general negativa del art.379 CP, y por ende de la pena de privación del derecho a conducir tras la reforma del año 2007, vid. MIRÓ LLINARES, Fernando/ BAUTISTA ORTUÑO, Rebeca, “¿Por qué cumplimos las normas penales? Sobre la disuasión en materia de seguridad vial", Indret, Revista para el análisis del Derecho, no 4, 2013, p.5. Recurso electrónico disponible en: http://www.indret.com/pdf/1001.pdf (último acceso: 02/11/2020).

273 Vid. la opinión contra las nuevas políticas de seguridad vial, MORILLAS CUEVA, Lorenzo,"Delitos contra la seguridad del tráfico: una preocupada reflexión global", en AA.VV. Delincuencia..., op.cit., p.408.
} 
a motor o ciclomotor son merecedoras de una sanción penal que comporta la imposibilidad de conducir durante largos periodos de tiempo ${ }^{274}$.

Una de las críticas dirigidas a las teorías de la prevención general negativa, es que la pena no puede ser impuesta única y exclusivamente al penado para que recaiga una intimidación en terceros que conlleve el respeto hacia el $\mathrm{CP}^{275}$, pues ello supondría la utilización del individuo que podría incluso conducir a una situación del llamado terror penal que pueden percibir los ciudadanos cuando el Estado a través de la pena, pretende atemorizar para mantener el orden penal. En materia de seguridad vial, en la política criminal seguida en los últimos trece años, sí puede llegar a percibirse una clara orientación preventivo general.

Como crítica a los fines de prevención general negativa que pueden existir en la pena de privación del derecho a conducir, señalar que no están debidamente insertados en el disco duro de la sociedad los límites temporales sin poder conducir que implican los tipos delictivos. Sin embargo, sí puede considerarse acreditada la existencia de un cierto temor a combinar factores como alcohol/drogas y conducción o también el binomio exceso de velocidad/conducción ${ }^{276}$. En este sentido es destacable que la creación de tipos delictivos como el del art.383 CP, que comporta la pena de privación del derecho a conducir, ha podido trasladar cierta sensación de amenaza respecto a la negativa a someterse a las pruebas legalmente establecidas y las consecuencias que se derivan, siendo una muestra de los fines de prevención general negativa asociados a la pena de privación del derecho a conducir.

A la vista de las consideraciones realizadas sobre la identificación de los fines de la prevención general negativa en la pena de privación del derecho a conducir, indicar que aquella tiene un papel secundario tanto respecto la prevención general positiva como en relación con la prevención especial que se detallarán posteriormente. La finalidad $u$ objetivo que puede subyacer en la prevención general negativa es la

\footnotetext{
${ }^{274}$ El mayor conocimiento de la pena de privación del derecho a conducir a través de un mayor número de sentencias que incluyan la misma sí puede tener relación con la finalidad de prevención general intimidatoria, ya que su existencia es conocida por un mayor número de personas. En relación con la función de prevención general de la pena, como amenaza a la sociedad si lleva a cabo una conducta que trasgrede las normas, vid. MIRÓ LLINARES, Fernando/ BAUTISTA ORTUÑO, Rebeca, “¿Por qué...”, op.cit., p.6

275 En este sentido comparto la opinión de VON HIRSCH, Andrew, "Retribución y prevención como elementos de justificación de la pena", en AA.VV. Crítica y justificación del Derecho penal en el cambio de siglo, ARROYO ZAPATERO, Luis /NEUMANN, Ulfrid /NIETO MARTíN, Adán (Coords.), Ediciones de la Universidad de Castilla-La Mancha, Cuenca, 2003, p.128.
} 
amenaza o causar temor en terceros, y estos fines no se identifican claramente en la pena de privación del derecho a conducir, a pesar de que sectores doctrinales sí defienden que las penas privativas de derechos como la analizada cumplen dicho fin $^{277}$. Considero que los efectos de prevención general negativa son limitados, ya que la mayor parte de conductores desconocen la existencia de determinados tipo delictivos, así como las repercusiones.

\section{b) La prevención general positiva}

Nos referiremos a continuación a las doctrinas de la prevención general positiva y su relación con la pena de privación del derecho a conducir. La particularidad de la prevención general positiva es que considera que la pena ha de servir para proteger al ordenamiento jurídico, reforzar la creencia de los ciudadanos en el sistema penal existente y fortalecer la confianza de éstos en las normas ${ }^{278}$. A diferencia de la prevención general negativa, los fines asociados a la prevención general positiva pretenden que la ciudadanía conozca, entienda, asuma el CP vigente y se genere un respeto al ordenamiento jurídico a través del conocimiento de las normas que lo rigen $^{279}$. Este objetivo no se ha de realizar con amedrentamiento o utilizando mecanismos penales que puedan o pretendan atemorizar a los ciudadanos sino, en palabras de LESCH, incidiendo en: "producir un reforzamiento de la conciencia colectiva por parte de la ciudadanía" ${ }^{280}$.

Cuando por parte de un sujeto se produce la comisión de un hecho delictivo, la función que ha de realizar la pena es reaccionar contra dicha acción poniendo de manifiesto que sigue siendo válida la norma penal que estaba vigente ${ }^{281}$. Los fines citados que se desprenden de la prevención general positiva sí pueden

\footnotetext{
276 En sentido contrario, autores como MIRÓ LLINARES, Fernando/ BAUTISTA ORTUÑO, Rebeca, estiman que las normas penales de tráfico no tienen una capacidad de disuasión acreditada desde los fines de prevención especial negativa. Ibídem, p.46.

277 En este sentido se expresan, FARALDO CABANA, Patricia/ PUENTE ABA, Luz María, "Concepto y funciones", en AA.VV. Las penas..., op.cit., p.31.

278 En lo relativo a los caracteres esenciales de la prevención general positiva, vid. FERRAJOLI, Luigi, op.cit., 2011, p.263 y también VON HIRSCH, Andrew, "Retribución y prevención como elementos de justificación de la pena", en Crítica y justificación..., op.cit., p.129.

279 En torno a la definición de prevención general positiva, vid. SANZ MULAS, Nleves, Alternativas..., op.cit., p.59.

${ }^{280}$ Respecto a la prevención general positiva, vid. LESCH, Heiko.H, La función..., op.cit., p.28.

${ }^{281}$ Acerca de la prevención general positiva, vid. CANCIO MELIÁ, Manuel, "De nuevo: $i<$ Derecho penal>> del enemigo?, Derecho Penal del enemigo, JAKOBS, Günter/ CANCIO MELIÀ, Manuel, Ed. Thomson Civitas, Cizur Menor (Navarra), 2006, 2ª edición, p. 130.
} 
vislumbrarse en la pena de privación del derecho a conducir, al ser una de las formas a través de las que el CP reacciona ante la vulneración de bienes jurídicos relacionados con el tráfico viario. Con relación a la pena que analizamos, se pueden aplicar dichos postulados a lo que expresó en su día sobre la reforma penal operada por la LO 15/2007 de 30 de noviembre por el Director General de Tráfico Sr. Pere Navarro ${ }^{282}$, que textualmente indicó: "El nuevo Código Penal no tiene intención de meter a nadie en prisión, tiene un carácter preventivo". Estas manifestaciones del entonces máximo responsable de la DGT fueron una muestra de los fines de prevención general integradora del CP. Es decir, la reforma de 2007 pretendía también influir en la conciencia social en lo relacionado con los delitos contra la seguridad del tráfico (hoy en día delitos contra la seguridad vial), a lo que sin duda contribuyó un suceso con fuerte repercusión mediática conocido como el "Caso Farruquito"283. Desde esta perspectiva, los ciudadanos que acostumbran a respetar las normas han podido comprobar cómo el sistema penal ha sido reforzado y actualmente es más difícil que resten impunes determinadas conductas delictivas que se ejecutan con un vehículo a motor o ciclomotor ${ }^{284}$.

A través de la prevención general positiva, ROCA AGAPITO 285 manifiesta que se produce un triple efecto: didáctico, de confianza y satisfacción, por lo que definiremos si estos efectos pueden ser aplicables a la pena de privación del derecho a conducir. De las tres consecuencias descritas, el efecto didáctico es el que menos puede identificarse en la ciudadanía, aunque sí podemos vincularlo la pena de privación del derecho a conducir, aunque con mayor dificultad, debido a que combinar una pena con la didáctica no es sencillo. Los efectos de confianza y satisfacción pueden ser más fácilmente reconocibles en la pena de privación del derecho a conducir, y la generalidad de la ciudadanía puede percibir que, si se realizan determinadas conductas, serán penados. Por otra parte, a través de la imposición de la pena que analizamos, los ciudadanos pueden percibir que el sistema penal funciona, lo que puede generar un grado de satisfacción en la respuesta del estado ante determinadas conductas utilizando un vehículo a motor o ciclomotor.

\footnotetext{
282 En relación con la prevención general positiva, podemos citar las declaraciones del Sr. PERE NAVARRO, Infotrànsit, № 12, Ed. Servei Català de Trànsit, Desembre 2007, pp.27-28.

283 Suceso conocido como el llamado "Caso Farruquito". Sentencia AP Sevilla, de 4/9/2006, Sección $7^{\mathrm{a}}$, ponente Ilmo.Sr. Antonio Gil Merino. (TOL981.108).

284 Referente a la prevención general positiva, vid. MONTANER FERNÁNDEZ, Raquel, "Los nuevos...", op.cit., p.319.

285 Acerca del triple efecto de la prevención general positiva, vid. ROCA AGAPITO, Luis, El sistema..., op.cit., p.86.
} 
En el ámbito de los fines de prevención general positiva, la pena de privación del derecho a conducir cumple con los fines enunciados por VON HIRSCH ${ }^{286}$ para fortalecer la conciencia normativa de los ciudadanos. Uno de los fines relacionados con la prevención general positiva que pueden inferirse en la aplicación a la pena objeto de nuestro estudio, es que se puedan aumentar los estándares de calidad de vida de los ciudadanos. Los conductores a los que se les imponga la pena objeto del trabajo se verán privados de ejercer su derecho a conducir. De esta forma se puede incrementar la seguridad en las vías por las que circulan el resto de ciudadanos que han respetado el CP, y los penados con la privación del derecho a conducir tendrán prohibido hacerlo ya que para el caso que conduzcan y sean descubiertos, podrán ser acusados por un posible delito de quebrantamiento de condena.

GARCÍA ALBERO287 indicaba que la prevención general positiva era uno de los fines de la política criminal de seguridad vial, aun cuando quepa considerar que este no es el fin principal de la misma. Al formar parte la pena de privación del derecho a conducir del nuevo Derecho Penal vial, podemos mantener que cumple fines de prevención general positiva como mecanismo previsto por el legislador para preservar los bienes jurídicos relacionados con la seguridad vial.

Después haber analizado los fines de la pena de privación del derecho a conducir desde la óptica de la prevención general positiva y negativa, uno de los principales óbices para afirmar la existencia de unos fines de prevención general en dicha pena es el posible desconocimiento por parte de la población tanto de los delitos que acarrean su imposición, así como de la propia pena ${ }^{288}$. El motivo es que, si la mayoría de la población no conoce los delitos en los que se prevé la aplicación de la pena, así como sus consecuencias y duración, los posibles efectos intimidatorios pueden quedar restringidos. Otro de los déficits detectados es que el hecho que la pena y sus efectos se dirijan hacia la generalidad de la ciudadanía tiene la limitación que cada persona puede interpretar el temor o amenaza de forma distinta, por lo que el fin de prevención general, tanto positiva como negativa, puede ser de difícil

\footnotetext{
286 Sobre la función integradora de la prevención general positiva, vid. VON HIRSCH, Andrew, "Retribución y prevención como elementos de justificación de la pena", en AA.VV. Crítica y justificación..., 2003, op.cit., p.125.

287 Vid. GARCÍA ALBERO, Ramón, "La nueva política criminal...", op.cit., p.13.

288 En relación con el desconocimiento de la norma, de la pena y sus efectos y su aplicación en la prevención general, vid. ÁLVAREZ GARCÍA, Francisco Javier, Consideraciones..., op.cit., pp.126127.
} 
acreditación y quedar reducido ${ }^{289}$. Por ello, desde la visión de la prevención general, la pena de privación del derecho a conducir sí puede tener fines preventivogenerales, pero son limitados, especialmente los relacionados con la prevención general negativa. En cualquier caso, no hemos de desdeñar el efecto intimidatorio de la pena estudiada en una sociedad como la actual que se rige por el uso extenso del vehículo privado, y puede verse amenazada por la pena de privación del derecho a conducir. Sin embargo, sí puede estimarse que dentro de la prevención general tiene más relevancia la vertiente positiva que la intimidatoria o negativa.

\subsubsection{La prevención especial en la pena de privación del derecho a conducir}

A continuación, procederemos a estudiar la existencia de fines preventivoespeciales en la pena de privación del derecho a conducir. El principio básico de la prevención especial, tanto en su vertiente negativa como positiva, es la capacidad de la pena para evitar la comisión de nuevos delitos por parte del penado ${ }^{290}$, en nuestro caso impedir que atente contra la seguridad vial, así como contra la vida y la integridad física o psíquica de las personas. Esta función preventivo especial podría desplegarse tanto en el sentido de que la aplicación de la pena impida o incapacite al penado para la comisión de nuevos delitos, como en el sentido de que aquella contribuya, de forma positiva, a que el penado emprenda una vida alejada de la criminalidad. Nos preguntamos pues, en definitiva, si la pena de privación del derecho a conducir opera o puede operar en términos de prevención especial.

Asimismo, la eficacia en el cumplimiento de esta pena contribuye a realizar los fines de prevención especial. Si en la ejecución penal se cumple correctamente la pena que se analiza y el penado no conduce durante el tiempo de la misma, ésta habrá cumplido unas finalidades preventivo-especiales al no poder ejercer la actividad que fue la generadora de un delito ${ }^{291}$. En la fase ejecutiva es importante la diferencia entre aquellos penados que no necesitan el derecho a conducir para su trabajo habitual y aquellos que sí lo requieren e incluso son conductores profesionales. Si bien esta distinción en los fines de prevención general es difícil que produzca

\footnotetext{
${ }^{289}$ Referente las críticas a la eficacia de la prevención general positiva, vid. SANZ MULAS, Nieves, Alternativas..., op.cit., p .59.

290 Relativo a la finalidad de la prevención especial vid. QUINTERO OLIVARES, Gonzalo, "EI derecho penal: concepto, principios informadores y evolución", Parte General..., QUINTERO OLIVARES, Gonzalo (Dir.), op.cit., p.98; LESCH, Heiko.H, La función..., op.cit., p.31 y también SANZ MULAS, Nieves, Alternativas..., op.cit., p.72.

291 En torno a la finalidad preventivo-especial de las penas privativas de derechos, vid. Grupo de Estudios de Política Criminal, Una propuesta... op.cit., p.33.
} 
efectos, sin embargo, en los fines de prevención especial sí existen situaciones antagónicas entre los penados para los que el derecho a conducir sea su medio de vida, y aquellos que pueden seguir realizando su actividad laboral a pesar de no poder conducir292.

En el análisis de los fines preventivo-especiales de la pena analizada hemos de hacer referencia a su aflictividad, debido a que el uso de vehículos a motor y ciclomotores es muy elevado en la sociedad del S.XXI. Aquellos penados que se ven privados del derecho a conducir ven afectado su modus vivendi, trasladándose de forma personalísima las consecuencias de la pena a su vida diaria ${ }^{293}$, lo que pone de manifiesto el contenido aflictivo. Por estos motivos la pena de privación del derecho a conducir puede tener fines de prevención especial más evidentes que los fines preventivo-generales que son más difusos.

Una de las características de la pena objeto de este análisis es la celeridad con la que ésta se puede imponer, así como la rapidez con la que da inicio su ejecución desde que se ha cometido el hecho delictivo. En este aspecto, la pena que examinamos casa con uno de los fines históricos que citaba BECCARIA como es el de "la prontitud de las penas"294, relacionándolo además con el conocido aforismo vinculado a al mundo del derecho que indica que: "La justicia si es lenta, no es justicia". Los delitos contra la seguridad vial, ámbito en el que se aplica mayoritariamente la pena objeto de nuestro estudio, son tramitados en un porcentaje elevado como Diligencias Urgentes-Juicio Rápido, por lo que entre el hecho delictivo y la comparecencia del investigado ante el Juzgado de Guardia transcurre un breve lapso de tiempo. Son numerosas las ocasiones que en un periodo de tres o cuatro días desde la comisión del hecho delictivo el penado ya obtiene la sentencia condenatoria de conformidad en el Juzgado de Guardia e inicia el cumplimiento de la pena de privación del derecho a conducir ${ }^{295}$. Con este marco procesal, el fin de prevención especial positiva de esta pena se ha fortalecido en las

\footnotetext{
292 Sobre los diferentes efectos de la pena de privación del derecho a conducir, ya se manifestó el Excmo. Sr. Fiscal General del Estado, Sr. Cándido Conde-Pumpido, en su comparecencia efectuada en fecha 23-11-2005, ante la Comisión no permanente sobre Seguridad Vial y Prevención de accidentes de tráfico del Congreso.

293 En relación con la aflictividad de la pena, vid. RODRÍGUEZ MORO, Luis, "La pena de privación del derecho a conducir vehículos a motor y ciclomotores", en AA.VV. Las penas..., op.cit., p.231 y también LANDROVE DÍAZ, Gerardo, Las consecuencias..., op.cit., p.79.

${ }^{294}$ En relación con la prontitud de la pena, vid. DE BECCARIA, Cesare, De los delitos..., op.cit., pp. 60-61.

295 El breve espacio temporal entre el hecho delictivo, la sentencia y el inicio de la ejecución en los Juicios Rápidos de delincuencia vial ha sido destacado por la FGE en su Memoria año 2014, p. 423. En el mismo sentido vid. TENA SÁNCHEZ, Jordi, "Cambios en la política criminal...", op.cit., p.292.
} 
dos últimas décadas al percibir el penado una respuesta rápida y eficaz tras haber trasgredido el CP. La prontitud en la respuesta del Estado ante un delito cometido con un vehículo a motor o ciclomotor, no podemos hallarla en el ámbito administrativo, ya que carece de la agilidad que actualmente caracteriza al proceso penal en el caso de los delitos contra la seguridad vial.

Todo lo expuesto pone de relieve que los fines preventivo-especiales son relevantes en la pena de privación del derecho a conducir tal como mantiene RODRíGUEZ $\mathrm{MORO}^{296}$ y ésta sí puede ser una pena adecuada al tener una vinculación directa con los hechos que han provocado la condena 297 , por lo que concretaremos si en la pena de privación del derecho a conducir predominan los preventivo-especiales positivos o negativos.

\section{a) La prevención especial negativa}

A continuación, siguiendo la clasificación de los fines de la pena en el ámbito de la prevención especial, analizaremos la pena de privación del derecho a conducir desde la perspectiva de la prevención especial negativa. En este plano, uno de los principales retos es que el condenado no genere un nuevo riesgo para la sociedad y ello puede conseguirse a través de la "inocuización" del delincuente ${ }^{298}$. En la pena de prisión, la prevención especial negativa se ha articulado en torno a la reclusión del penado y si lo aplicamos a la pena objeto de este trabajo la finalidad sería la de evitar que el penado conduzca durante el tiempo de la condena. En efecto, este es precisamente el objetivo de dicha sanción, evitar que el penado conduzca durante el tiempo de ejecución de la sentencia y evitar, con ello, la comisión de nuevos delitos contra la seguridad vial.

No obstante, este objetivo puede resultar difícil de alcanzar si el sujeto decide volver a ponerse al frente de un vehículo durante el periodo de ejecución de la pena,

\footnotetext{
296 Vid. RODRÍGUEZ MORO, Luis, "La pena de privación del derecho a conducir vehículos a motor y ciclomotores", en AA.VV. Las penas..., op.cit., p.233.

297 Sobre los fines de prevención especial de la pena de privación del derecho a conducir, vid. FARALDO CABANA, Patricia/ PUENTE ABA, Luz María, "Concepto y funciones", en AA.VV. Las penas..., op.cit., p.20.

298 En relación con los fines de la prevención especial negativa, vid. SANZ MULAS, Nieves, Alternativas..., op.cit., p.84 y RíOS MARTíN, Julián Carlos/ SEGOVIA BERNABÉ, José Luis/ PASCUAL RODRÍGUEZ, Esther, Las penas..., op.cit., p.26. También se hace referencia a los efectos que produce la pena, especialmente las privativas de derechos, sobre el delincuente a través de la llamada inocuización por parte de DIEZ RIPOLLÉS, José Luis, "El Derecho penal simbólico y los efectos de la pena", en AA.VV. Crítica...op.cit., p.155.
} 
puesto que la misma no comporta una privación física de cumplimiento. La incorporación de algunas medidas para garantizar que el penado no acceda a la conducción podría ayudar a realizar de forma más eficaz los fines de prevención especial negativa. Entre tales medidas, podría plantearse, por ejemplo, el decomiso del vehículo a motor o ciclomotor con el que se ha cometido el hecho delictivo. Con la aplicación conjunta de la pena de privación del derecho a conducir y el decomiso del vehículo aumentan las dificultades para que el penado pueda delinquir de nuevo al privarle judicialmente del derecho a conducir, así como del instrumento con el que puede ejercerlo ${ }^{299}$. Cuando esto suceda, puede existir una finalidad de prevención especial negativa al excluir, aunque sea formalmente, al penado del derecho a conducir y de la utilización del vehículo a motor o ciclomotor con el que se cometió el delito. Sin embargo, el penado siempre tendría a su alcance utilizar un vehículo a motor o ciclomotor de un tercero para quebrantar la pena impuesta y de esta forma seguir conduciendo, por lo que los fines de prevención especial negativa de la pena quedarían sin sentido.

La incorporación del ciclomotor junto a los vehículos a motor como instrumento del que se priva al penado contribuye también a evitar la reiteración delictiva. En este sentido, durante un cierto tiempo la jurisprudencia se mostró contradictoria con relación a si la pena de privación del derecho a conducir debía aplicarse tanto a vehículos a motor y a ciclomotores, o únicamente a uno de ellos con el que se había cometido el delito. La LO 15/2003 contribuyó a clarificar los fines de la pena de privación del derecho a conducir pues carecía de sentido que ésta únicamente fuera aplicada a uno de los vehículos. El motivo era que el bien jurídico protegido seguridad del tráfico (hoy seguridad vial) se había violentado y era contrario a los propios fines de la pena que el penado tuviera la posibilidad de poder conducir con otro vehículo distinto al que se cometió el delito ${ }^{300}$. Desde la doctrina, TAMARIT SUMALLA 301 valoró de forma positiva la previsión que el penado no pueda utilizar ningún vehículo a motor ni ciclomotor para que la pena de privación del derecho a conducir pueda ser eficaz, motivo por el que a partir del año 2003 con la supresión del adverbio "respectivamente" considero que se reforzó la finalidad de prevención

\footnotetext{
299 Referente a la prevención especial relacionada con el decomiso, vid. TAMARIT SUMALLA, Josep, "La prohibición de conducir y otras sanciones penales relacionadas con los vehículos", en AA.VV. Las sanciones..., op.cit., p.330.

300 Con relación a los fines preventivos de la pena privación del derecho a conducir, vid. RODRÍGUEZ FERNÁNDEZ, Ignacio, “Consideraciones metodológicas...”, op.cit., pp.791-818.

301 Vid. TAMARIT SUMALLA, Josep/ LUQUE REINA, Mํㅡㄹ Eulàia, Automóviles, delitos y penas... op.cit., p.132.
} 
especial negativa de esta pena, ya que se limitan aún más las opciones que el penado pueda conducir.

Para finalizar el estudio de los objetivos que pueden tener relación con los fines de prevención especial negativa de la pena de privación del derecho a conducir haremos referencia a su aplicación en varios tipos penales. El motivo principal para que se imponga la pena que analizamos en este trabajo es que por parte del penado se haya producido un ejercicio del derecho no adecuado a las normas viales establecidas y, aunque sea de forma abstracta, se haya generado un riesgo para la seguridad vial ${ }^{302}$. Debido a la tipología actual de los delitos contra la seguridad vial, en muchas ocasiones se impondrá la pena que hemos estudiado sin necesidad de causar ni daños materiales ni personales, como sucede con los tipos delictivos del art.379.1 y 2. Incluso una persona que no hubiera consumido ni alcohol ni drogas ni hubiese circulado a una velocidad excesiva, simplemente por negarse a realizar a las pruebas de detección establecidas puede ser condenada por mor del art.383 CP a la pena de privación del derecho a conducir. El análisis de tipos penales como los del art.379.1 y 2 o art. 383 ha de relacionarse con una función de prevención especial negativa debido a que, al imponer la pena de privación del derecho a conducir se pretende reducir el riesgo concreto que el conductor puede generar para la sociedad.

Una vez identificados los objetivos relacionados con la prevención especial negativa en la pena de privación del derecho a conducir, señalaremos que los fines preventivo especiales son incompatibles el objetivo de eliminar y excluir de la sociedad al conductor penado por el mero hecho de haber cometido un delito y que se le imponga una pena privativa de derechos como la que se analiza ${ }^{303}$. Ha de procurarse que al conductor penado se le faciliten los mecanismos para evitar que quebrante la pena impuesta, para impedir la reiteración delictiva, que asuma el quebranto infringido a la norma penal y en modo alguno eliminarle socialmente ${ }^{304}$. Al conductor que se le priva del derecho a conducir se le impone la pena con la finalidad que durante un lapso determinado de tiempo no ejercite dicho derecho,

\footnotetext{
302 Sobre el fundamento de la pena de privación del derecho a conducir, comparto que se basa en una utilización deficiente de dicho derecho que puede generar peligro para la seguridad vial, como sostienen RíOS MARTíN, Julián Carlos/ SEGOVIA BERNABÉ, José Luis/ PASCUAL RODRÍGUEZ, Esther, Las penas..., op.cit., p.55.

303 En relación con los fines de prevención especial negativa a través de la neutralización del delincuente en relación con las penas privativas de derechos políticos y profesionales vid. GUTIÉRREZ DE AGAPITO, ANA, Las penas..., op.cit., p.404.

${ }^{304}$ Con relación a las características de la prevención especial negativa, vid. RíOS MARTíN, Julián Carlos/ SEGOVIA BERNABÉ, José Luis/ PASCUAL RODRíGUEZ, Esther, Las penas..., op.cit., p.26.
} 
pero una vez pasado este periodo temporal se considera que estará de nuevo capacitado para utilizar un vehículo a motor o ciclomotor de manera correcta ${ }^{305}$.

Si analizamos la pena desde los fines de la prevención especial negativa es necesario cuestionarlos en los casos que el penado sea un conductor profesional y ello pueda utilizarse como criterio para aumentar la pena de privación del derecho a conducir. La finalidad de esta pena es sancionar la conducta de un sujeto que ha infringido el tipo penal para evitar la comisión de nuevos delitos, pero no castigar con una mayor severidad a los conductores profesionales con el pretexto que a éstos se les debe exigir un plus en la conducción ${ }^{306}$. En estos casos, si admitiéramos la prevención especial negativa como fin de la pena de privación del derecho a conducir aquella puede quedar rebasada, ya que el penado conductor profesional recibirá un castigo más severo personal y laboralmente que un tercero que no requiera el ejercicio del derecho para desarrollar su trabajo.

La finalidad de la pena de privación del derecho a conducir no puede ser la de causar al penado perjuicios más graves de los que está obligado a cumplir, es decir, carece de sentido que la aplicación de la pena provoque en el penado unos perjuicios que el legislador no quiso y que seguramente, la sociedad, a la que en último lugar protege la pena, tampoco. Por ello es necesario articular mecanismos que se examinarán en el Capítulo Sexto como la suspensión y sustitución de la pena de privación del derecho a conducir, que en determinados supuestos sirvan para compatibilizar el fin y contenido de la pena con la situación personal y laboral del penado.

\section{b) La prevención especial positiva}

Los fines de prevención especial positiva de la pena de privación del derecho a conducir se vinculan a la posibilidad que la aplicación y la ejecución de esta pena contribuyan a que el penado no reincida en su conducta delictiva. A través de la imposición de esta pena, el reo se verá afectado de forma personalísima al no

\footnotetext{
305 Por este motivo estimo que la pena de privación del derecho a conducir no ha de tener unos fines de prevención especial negativa relacionados con la incapacitación del conductor, no estando conforme con la opinión al respecto de TAMARIT SUMALLA, Josep" La pérdida definitiva del derecho de conducir o del derecho a la tenencia y porte de armas", en AA.VV. La adecuación..., op.cit., p.125.

306 En estos casos, considero que la pena de privación del derecho a conducir también ha de estar guiada por el principio de proporcionalidad. Sobre los fines de la prevención especial negativa en la pena vid. CUTIÑO RAYA, Salvador, Fines de la pena..., op.cit. p.94.
} 
poder ejercer un derecho esencial para muchas personas en el siglo XXI. A su vez, al cumplir la pena, el conductor podrá asumir los hechos, aprender a respetar la normativa que ha infringido con el delito cometido ${ }^{307}$, y las consecuencias del mismo. Asimismo, la pena puede brindar al penado la posibilidad de mejorar en sus conocimientos o habilidades sobre conducción de forma que pueda volver a conducir de acuerdo con las normas que la sociedad se ha proporcionado ${ }^{308}$. En el ámbito de la prevención especial positiva, la pena que se examina puede ser más eficaz que una pena de prisión como respuesta al delito cometido con un vehículo a motor o ciclomotor ${ }^{309}$. La pena que analizamos tiene un elevado grado de cumplimiento, una estrecha relación con el delito cometido y casi siempre se cumple en libertad, lo que hace que sea adecuada para unos fines de prevención especial positiva, y apta para la resocialización del penado ${ }^{310}$.

En los delitos que conllevan la imposición de la pena de privación del derecho a conducir existe un requisito obligatorio para poder volver a conducir que podemos conectarlo con los fines de la prevención especial positiva, que es la realización del curso de sensibilización y reeducación vial previsto en el art. 73 de la LTSV. Esta obligación es una constatación extrapenal de la finalidad de prevención especial positiva que tiene la pena que analizamos. El penado al realizar el citado curso asumirá durante unas horas una serie de vivencias y experiencias teóricaspersonales con la finalidad de reflexionar acerca del delito cometido e identificar las conductas que no ha de repetir al volver a conducir. De esta forma, podrá trasladar dichos conocimientos a su práctica en la conducción diaria, realizarla con respeto al $\mathrm{CP}$, tener una potencialidad delictiva inferior a la que atesoraba antes de realizar el mismo y existir menos riesgo para la seguridad vial ${ }^{311}$. Si atendemos a la tipología

\footnotetext{
307 En este sentido, vid. TAMARIT SUMALLA, Josep/ LUQUE REINA, Mํㅡㄹ Eulàlia, Automóviles, delitos y penas..., op.cit., p.100, así como TAMARIT SUMALLA, Josep, "La prohibición de conducir y otras sanciones penales relacionadas con los vehículos", en AA.VV. Las sanciones..., op.cit., p.327.

308 Relacionado con los fines que tiene la pena en la <<resocialización>> podemos vid. DíEZ RIPOLLÉS, José Luis, "El Derecho penal simbólico y los efectos de la pena", en AA.VV. Crítica..., op.cit., p.156.
}

En relación con la teoría respecto a la prevención especial positiva, vid. RíOS MARTíN, Julián Carlos/ SEGOVIA BERNABÉ, José Luis/ PASCUAL RODRÍGUEZ, Esther, Las penas..., op.cit., p.26. 309 Vid. GÓMEZ PAVÓN, Pilar, El delito..., op.cit., p.227.

${ }^{310}$ Acerca de la resocialización del penado, vid. SANZ MULAS, Nieves, Alternativas..., op.cit., p.76 y también DÍEZ RIPOLLÉS, José Luis, "El Derecho penal simbólico y los efectos de la pena", en AA.VV. Crítica..., op.cit., p.156.

311 En este sentido podemos señalar que desde la doctrina se ha señalado que la privación del derecho a conducir y las medidas educativas para que sean eficaces se han de aplicar de forma conjunta. Vid. LAURELL, H, "Hacia unas carreteras sin alcohol en Europa", Revista de Trastornos adictivos, 2004; Volumen 6, núm. 4, p. 45. Recurso electrónico disponible en: 
de los delincuentes viales, la pena que se analiza debería vincularse hacia la agitación de la conciencia del penado para que pueda recapacitar sobre el porqué de su conducta. Ello se sustenta en el hecho que los delincuentes viales a los que se les impone la pena de privación del derecho a conducir suelen tener una tasa de reincidencia inferior a los delincuentes que cometen otros delitos ${ }^{312}$, diferenciándose del resto de delincuentes estereotipados ya que muchos de ellos únicamente delinquen en una ocasión. El hecho que los conductores penados presenten una baja tasa de reincidencia ${ }^{313}$ puede atribuirse a la capacidad de la pena de privación del derecho a conducir para desplegar efectos rehabilitadores. Al respecto cabe tener en cuenta que, numerosos penados han cometido el delito por "azar"314, simplemente por el hecho que una noche se habían tomado varias copas de alcohol o condujeron a una velocidad excesiva, lo que aconseja que la pena de privación del derecho a conducir tenga unos fines preventivos y no represivos ${ }^{315}$. Para que esto suceda con más frecuencia es necesario que se mantengan y mejoren penas como los TBC y la realización del curso de sensibilización y reeducación vial, que se aplicarán de forma conjunta con la pena de privación del derecho a conducir, lo que coadyuva a la finalidad de prevención especial positiva de esta pena.

http://www.elsevier.es/es-revista-trastornos-adictivos-182-articulo-hacia-unas-carreteras-sin-alcohol13069837 (último acceso: 02/11/2020).

312 En relación con la tasa de reincidencia de los delincuentes viales, vid. TAMARIT SUMALLA, Josep/ LUQUE REINA, Mํㅡㄹ Eulàlia, Automóviles, delitos y penas..., op.cit., p.155.

313 En uno de los pocos estudios realizados al respecto, en concreto en la provincia de Alicante, se estableció una tasa de reincidencia inferior al $20 \%$. Dicha tasa, estimo que se ha de relativizar ya que no engloba todos los delitos que conllevan la pena de privación del derecho a conducir y únicamente se circunscribe a una provincia y a unos meses.

El citado estudio puede consultarse en: http://www.dgt.es/Galerias/seguridadvial/investigacion/estudios-e-informes/2013/so-8859-

1 Q 0100dgt234785F Delincuencia Vial2C Reincidencia y Delinc -uencia-Comun -INFORMEPARA-WEB.pdf (último acceso: 01/11/2020).

314 En relación con la visión criminológica de los delincuentes viales, vid. CARRERAS ESPALLARDO, Juan Antonio, "Visión criminológica de los delitos contra la seguridad vial en España", Archivos de Criminología, Criminalística y Seguridad Privada, Vol.VII, enero-julio 2012, pp.1-2 y PALLíN IBÁÑEZ, Gabriela, El impacto de las últimas reformas legales en la delincuencia vial en España. Especial referencia a la LO 1/2015 y su nueva clasificación de la imprudencia, Ed. Thomson-Aranzadi, Cizur Menor (Navarra), 2017, pp.40-42.

315 En este sentido podemos destacar el estudio realizado por BAUTISTA ORTUÑO/MIRÓ LLINARES, que determinan que los infractores viales que saben de la existencia de una tasa penal de alcoholemia infringen menos las normas. De ello podemos inferir una prevención especial positiva de las penas asociadas a los delitos contra la seguridad vial como la pena de privación del derecho a conducir. Vid. BAUTISTA ORTUÑO, Rebeca/ MIRÓ LLINARES, Fernando, "¿Por qué algunos siempre incumplen? Infractores y multi-infractores en seguridad vial", Indret, Revista para el análisis del Derecho, no 4, 2015, p.19-20.

Recurso electrónico disponible en: http://www.indret.com/pdf/1167 baut miro.pdf (último acceso: 01/11/2020). 
Por otro lado, se considera más acorde con los fines rehabilitadores de la pena que la privación recaiga sobre el derecho a conducir, y no sobre el permiso o licencia, como se venía haciendo con la anterior regulación.

Para mantener una coherencia con los fines de la pena, es procedente que en los casos que no existan daños personales ni materiales ésta se pueda moderar, atendiendo a la repercusión que su aplicación pueda tener en el entorno laboral del penado, máxime si es conductor profesional. Si uno de los fines de la pena de privación del derecho a conducir ha de ser la resocialización y rehabilitación del penado, en determinados supuestos como pudiera ser el de conductores profesionales, imponer la pena en su umbral mínimo no iría contra sus propios fines, ni la misma quedaría desnaturalizada. Este criterio fue introducido en diversas sentencias $^{316}$, reconociéndose que la pena que se analiza produce en los penados conductores profesionales mayores perjuicios que para la generalidad de penados al verse limitada su actividad laboral, por lo que puede moderarse judicialmente la pena. Dicha línea jurisprudencial es adecuada ya que las consecuencias que acarrea la pena para este tipo de penados son más gravosas que para el resto, y respetando el principio de legalidad es lógico que se modere la pena hasta su grado mínimo. Ante la imposibilidad actual de suspender o sustituir la pena de privación del derecho a conducir, esta línea jurisprudencial podría ser una vía para reducir los perjuicios que pudieran causarse a conductores profesionales y mantener unos fines de prevención especial positiva que no sean contrarios a la pena. Sin embargo, esta opción merece un reproche y es que nos hallaríamos ante una especie de atenuante encubierta, que se aplicaría exclusivamente a conductores profesionales motivo por el que se puede estar produciendo una vulneración del principio de legalidad, así como el principio de igualdad.

Para finalizar, destacaremos que los fines de prevención especial positiva de la pena que estudiamos también se detectan en la vinculación directa entre el medio utilizado para cometer el delito y la pena que se impone, pues ésta siempre se impondrá cuando se haya producido una vulneración del bien jurídico seguridad vial

\footnotetext{
316 Vid. SAP de Tarragona, núm. 410/2001 de 12 de noviembre de 2001, Sección 2ª, ponente Ilmo.Sr.Eduardo López Causapé (JUR 2002/20313) y SAP de Cantabria, núm. 61/1997, Sección 2ª de 13 de mayo de 1997, ponente llmo.Sr.Javier de la Hoz de la Escalera (ARP 1997/707), en las que se impone el umbral mínimo de un año y día de privación del derecho a conducir atendiendo a la condición de chófer y repartidor respectivamente de ambos penados.
} 
o bien se haya realizado una agresión contra la vida o la integridad física o psíquica de las personas utilizando un vehículo a motor o ciclomotor ${ }^{317}$.

\subsection{La realización de fines mixtos en la pena de privación del derecho a conducir}

En tercer lugar, tras haber analizado las teorías absolutas y las teorías relativas estudiaremos la pena de privación del derecho a conducir desde el prisma de las teorías mixtas o eclécticas, para determinar si los fines de dicha pena tienen encaje en estas teorías que para una parte de la doctrina son las teorías dominantes actualmente $^{318}$. Uno de los aspectos relevantes de las teorías mixtas en relación con los fines de la pena es que combinan los fines retributivos y preventivos, y defienden que las penas responden a ambos fines, descartando así los dogmas retribucionistas puros que detraían cualquier finalidad o sentido a la pena ${ }^{319}$.

En el ámbito de las teorías mixtas nos referiremos en primer lugar las teorías de la unión o aditivas, que tratan de combinar diferentes finalidades en la pena huyendo de posicionamientos puros. Desde las teorías de la unión se mantiene que el embrión de la pena está relacionado con la retribución y que, partiendo de este origen, la pena puede derivar hacia finalidades preventivas. Es decir, se trata de fijar en una misma construcción jurídica las teorías absolutas y las relativas, y desde el retribucionismo llegar a la prevención. Como puede observarse es una construcción dogmática de difícil concreción y LESCH ha indicado que no pueden ir más allá de ser "propuestas y de carácter teórico"320, al ser de difícil utilidad práctica y en nuestro caso, de difícil aplicación a la pena de privación del derecho a conducir.

\footnotetext{
317 La relación entre la pena de privación del derecho a conducir y el delito cometido, que siempre se lleva a cabo utilizando un vehículo a motor o ciclomotor, ha sido destacada por GIL GIL, Alicia/ LACRUZ LÓPEZ, Juan Manuel/ MELENDO PARDOS, Mariano/ NÚÑEZ FERNÁNDEZ, José, Consecuencias jurídicas..., op.cit., p. 182.

318 Vid. QUINTERO OLIVARES, Gonzalo, "EI derecho penal: concepto, principios informadores y evolución", Parte General..., QUINTERO OLIVARES, Gonzalo (Dir.), op.cit., p.102; SANZ MULAS, Nieves, Alternativas..., op.cit.p.79, VAELLO ESQUERDO, Esperanza, Las consecuencias..., op.cit., p. 20 y ROCA AGAPITO, Luis, El sistema..., op.cit., p.92.

319 En relación con la combinación de los fines retributivos y preventivos en las teorías mixtas o eclécticas, vid. SANZ MULAS, Nieves, Alternativas..., op.cit., p.80 y AGUDO FERNÁNDEZ, Enrique/ JAÉN VALLEJO, Manuel/ PERRINO PÉREZ, Ángel Luis, Penas..., op.cit., p.27.

${ }^{320}$ Acerca de las Teorías de la Unión, vid. LESCH, Heiko.H, La función ..., op.cit., p.42.
} 
Una de las aportaciones más reconocidas a las teorías mixtas es la construcción doctrinal llevada a cabo por ROXIN321 en la Teoría Unificadora Dialéctica. La formulación de ROXIN está basada en determinar la relación entre los fines de la pena durante los tres estadios o fases por las que discurre la pena que son: amenaza, concreción o imposición de la pena y la fase de ejecución o cumplimiento; constatando que en cada uno de estos tres momentos existen distintas exigencias derivadas de los fines de la pena. Esta construcción doctrinal realiza una combinación de los fines retributivos de la pena con los fines preventivos, generales y especiales, y los engarza en las tres fases citadas. En la fase inicial de amenaza formulada mediante la conminación de una conducta con una determinada sanción penal, ROXIN ${ }^{322}$ considera que ha de prevalecer la prevención general debido a que se percibe la amenaza de la pena en aquellos que puedan cometer el delito. $\mathrm{Si}$ aplicamos dicha afirmación a la pena de privación del derecho a conducir sí puede estar relacionada con los fines de ésta, debido a que los ciudadanos a los que va dirigida la pena pueden percibir la misma como una amenaza para el caso que cometan una conducta delictiva con un vehículo a motor o ciclomotor.

En la segunda fase, esto es, la de la imposición judicial de la pena al sujeto que ha cometido un delito, es donde podemos identificar ciertos fines retributivos, ya que cada individuo recibe la pena como un mal y una limitación de sus derechos. Además, esta pena contribuye en términos de prevención general positiva a mantener la vigencia del ordenamiento jurídico ${ }^{323}$. Esta fase es en la que se concreta la amenaza que existía en la primera fase de conminación, y en ella se despliegan también fines de prevención general ${ }^{324}$ y especial ${ }^{325}$. Pueden concurrir en esta fase los dos fines preventivos en la pena de privación del derecho a conducir, puesto que desde el prisma de la prevención general los ciudadanos podrán percibir que la amenaza previa se materializa cuando un ciudadano realiza

\footnotetext{
${ }^{321}$ En relación con la referencia a la $<<$ teoría dialéctica de la unión >> de ROXIN vid. QUINTERO OLIVARES, Gonzalo, "El derecho penal: concepto, principios informadores y evolución", Parte General..., QUINTERO OLIVARES, Gonzalo (Dir.), op.cit., p.103. En relación con la construcción doctrinal realizada por ROXIN respecto de las teorías de la unión, vid. SANZ MULAS, Nieves, Alternativas..., op.cit., p.79 y ROCA AGAPITO, Luis, El sistema..., op.cit., pp.93-96. Asimismo, relativo a la Teoría Unificadora de Roxin.

322 Vid. ROXIN, Claus, Problemas básicos del derecho penal, Ed. Reus, Madrid, 1976, p.24, traducción Diego-Manuel Luzón Peña.

323 En lo relativo a los fines retributivos en la fase de imposición de la pena, vid. ROXIN, Claus, Problemas..., op.cit., pp.26-27 así como VAELLO ESQUERDO, Esperanza, Las consecuencias..., op.cit., p. 20.

${ }^{324}$ En torno a los fines de prevención general que predominan en esta fase intermedia, vid. ROXIN, Claus, Problemas..., op.cit., pp.24-25 y 31.

325 Vid. SANZ MULAS, Nieves, Alternativas..., op.cit., p.86.
} 
una acción que vulnera la seguridad vial. Al imponerse la pena podemos hablar de una reafirmación de cara a la ciudadanía y al propio sujeto que el sistema penaliza las conductas prohibidas. En esta fase intermedia también concurre junto con la prevención general la prevención especial, al concretarse la imposición de la pena en el individuo que la recibe en forma de sentencia condenatoria.

En la tercera fase, relativa a la ejecución de la pena, la finalidad que predomina de manera más notoria es la prevención especial, siendo el momento en que el penado cumple directamente la pena, conoce motu propio el contenido de la misma y todos sus efectos posibilitando que el mismo se reinserte y vuelva a desarrollar su vida en sociedad a pesar del delito cometido ${ }^{326}$.

Se ha pretendido mantener la vigencia de las teorías mixtas argumentando que tratan de conciliar los aspectos de las teorías absolutas y las relativas diferenciando por fases las distintas funciones de la pena, y como indica LANDROVE ${ }^{327}$, las teorías mixtas determinan claramente en cada una de las fases los fines que tiene la pena, por lo que puede inferirse que ésta ha de cumplir en las tres fases diferentes finalidades. En el mismo sentido otras posiciones doctrinales ${ }^{328}$, mantienen que las teorías eclécticas no pueden considerarse como una mera suma de teorías, como pueden ser las retributivas y las relativas, sino que en cada uno de los tres momentos se prioriza una finalidad.

Respecto la vigencia y utilidad de las teorías mixtas, al intentar aglutinar diversos fines en una misma teoría provocan que al final no quede determinado qué es lo que se propone, al ser una misión de difícil arquitectura jurídica la unión de los fines retributivos y de prevención ${ }^{329}$. A pesar de intentar diferenciar en las tres fases los fines retributivos y preventivos, al aplicarlos a una pena privativa de derechos siempre ha de quedar diluido uno de ellos en detrimento del fin que predomina en todas las fases de la pena ${ }^{330}$. En las tres fases expuestas por estas teorías

\footnotetext{
${ }^{326}$ Respecto a la finalidad de la pena en cada una de las tres fases vid. CUTIÑO RAYA, Salvador, Fines de la pena..., op.cit., p.97.

327 Acerca de las diferentes fases de la pena según la Teoría de la unión, vid. LANDROVE DíAZ, Gerardo, Las consecuencias..., op.cit., pp.20-21.

328 Vid. RíOS MARTíN, Julián Carlos/ SEGOVIA BERNABÉ, José Luis/ PASCUAL RODRíGUEZ, Esther, Las penas..., op.cit., p.26.

329 Vid. JAKOBS, Günter, Sobre la teoría de la pena, Cuadernos de conferencias y artículos № 16 . Universidad Externado de Colombia, Centro de Investigaciones de Derecho Penal y Filosofía del Derecho. Bogotá (Colombia) 1998, p. 9, traducción de Manuel Cancio Meliá.

330 Acerca de la no idoneidad de las Teorías de la Unión, vid. JAKOBS, Günter, Sobre la teoría..., op.cit., p.33.
} 
predominan los fines preventivos tanto general como especial y no parece concurrir una mayor influencia de los fines retributivos en los preventivos en ninguna de ellas, estando de acuerdo con QUINTERO OLIVARES ${ }^{331}$ para quien dichas teorías hacen gravitar los fines de la pena en la noción de prevención.

Por otro lado, autores como RODRÍGUEZ MORO ${ }^{332}$ han señalado que la pena de privación del derecho a conducir tiene finalidades retributivas a la vez que de prevención general y especial. También VAELLO ESQUERDO ${ }^{333}$ ha reconocido el éxito de la triple finalidad de la pena según el momento en el que la misma se aplica por lo que se concede a las teorías mixtas plena vigencia en la actualidad. En términos similares se ha posicionado MOLINA BLÁZQUEZ para quien la pena ha de estar guiada tanto por los fines retributivos, como de prevención general y especial ${ }^{334}$.

Un supuesto que podría relacionar las teorías mixtas y la pena de privación del derecho a conducir sería la posibilidad de dejar en suspenso la misma por un plazo determinado siempre con sujeción a determinados requisitos. Dicha propuesta podría ser una constatación de los fines de la pena según las teorías mixtas, y se podría dejar en suspenso la pena en aras a combinar los fines de prevención especial en aquellos casos de conductores profesionales a los que la pena les perjudicaría social, laboral, económica y familiarmente. Con este planteamiento podríamos inferir un cierto retribucionismo en la pena y a la vez dotarla de fines preventivo-especiales, aunque la finalidad mayoritaria seguiría siendo la preventiva en detrimento de la retributiva.

\footnotetext{
331 Vid. QUINTERO OLIVARES, Gonzalo, "EI derecho penal: concepto, principios informadores y evolución", Parte General..., QUINTERO OLIVARES, Gonzalo (Dir.), op.cit., p.103.

332 Vid. RODRÍGUEZ MORO, Luis, "La pena de privación del derecho a conducir vehículos a motor y ciclomotores", en AA.VV. Las penas..., op.cit., pp.231 y 251.

333 Vid. VAELLO ESQUERDO, Esperanza, Las consecuencias..., op.cit., p. 20.

334 Los tres fines de la pena han de ser: retribución, prevención general y especial según lo expresado por MOLINA BLÁZQUEZ Mํㅡㄹ Concepción, La aplicación de la pena, Ed. Bosch, Barcelona, 2002, 3를 edición, pp.24-25.
} 


\subsection{Toma de posición sobre los fines de la pena de privación del derecho a conducir}

Hoy en día resulta complejo aceptar un modelo basado en los fines retributivos puros que otorgan a las penas las teorías absolutas ${ }^{335}$, y también ha de descartarse cualquier tipo de vinculación de la pena analizada con fines expiatorios al ser éstos incompatibles con el Estado de derecho ${ }^{336}$. Sin embargo, sí considero que la pena que se analiza en el trabajo tiene fines retributivos aunque reducidos, ya que cuando se impone la misma por parte del Juzgado o Tribunal se da una respuesta aflictiva y que debe resultar proporcional al delito cometido.

A su vez, estimo que la pena de privación del derecho a conducir cumple unos fines para evitar la reiteración delictiva del penado y la comisión de delitos por el resto de ciudadanos, lo que la relaciona directamente con los fines preventivos ${ }^{337}$. Si bien las especificidades de una pena privativa de derechos como la que examinamos se orientan principalmente a unos fines preventivos especiales ${ }^{338}$, no puede obviarse los fines de prevención general que también existen en la misma ${ }^{339}$, aunque en mi opinión, en un plano de inferioridad. Las posibilidades para disuadir de la comisión de nuevos delitos que puede tener la pena que estudiamos a través de sus fines

\footnotetext{
335 En el actual contexto de la política criminal de seguridad vial, en el que la pena de privación del derecho a conducir ha sido desarrollada con mayor amplitud en estos últimos diez años, entiendo que es difícil que la misma pueda ser compatible con los postulados que preconizan las teorías absolutas. Además, estimo que éstas han podido quedar superadas por las teorías relativas que son más adecuadas a un sentido moderno del sistema de penas, en el que se encuadra la pena de privación del derecho a conducir. En torno a las características de las teorías absolutas, vid. MUÑOZ CONDE, Francisco/GARCÍA ARÁN, Mercedes, Derecho... op.cit., p.47.

336 Vid. ÁLVAREZ GARCÍA, Francisco Javier, Consideraciones..., op.cit., p.109. En relación con los motivos por los que los fines de la pena que guían las teorías absolutas no pueden ser aplicables a un ordenamiento constitucional aconfesional en el que se encuadra la pena de privación del derecho a conducir, valoro como acertados los argumentos citados por FERRAJOLI, Luigi, op.cit., pp.257258.

337 Vid. TOLEDO CASTILLO, Francisco/ CAMPÓN DOMÍNGUEZ, José Andrés/ MARTÍN UCLÉS, Francisco, Manual de Seguridad Vial: El factor alcohol. Adaptado a la LO 15/2007 de 30 de noviembre por la que se modifica el Código Penal en materia de seguridad vial, Ed. Thomson Reuters-Aranzadi, Cizur Menor (Navarra), 2009, $1^{\text {a }}$ edición, p.295.

338 En relación con la prevención especial como aspecto relevante de la pena de privación del derecho a conducir, vid. TAMARIT SUMALLA, Josep/ LUQUE REINA, M를 Eulàlia, Automóviles, delitos y penas..., op.cit., p.132, así como TAMARIT SUMALLA, Josep, "La prohibición de conducir y otras sanciones penales relacionadas con los vehículos", en AA.VV. Las sanciones..., op.cit., p.321.

339 Los fines preventivos especiales y generales de la privación del derecho a conducir ya fueron destacados por KAISER. Vid. KAISER Günther, Delincuencia de tráfico..., op.cit., p.475. Relativo a los fines de prevención general de las penas en la actualidad, Vid. MORALES PRATS, Fermín,"La vuelta a la prevención general", Parte General del Derecho Penal, QUINTERO OLIVARES, Gonzalo (Director), Ed.Thomson-Aranzadi, Cizur Menor (Navarra), 2007, pp.106-107.
} 
intimidatorios son idóneos en aquellos delincuentes ocasionales ${ }^{340}$, que son mayoría entre los que se impone la pena de privación del derecho a conducir. Sin embargo, esta eficacia intimidatoria de la pena puede resultar menos evidente en el caso de delincuentes impulsivos, para los cuales tendrá una nula eficacia al no pensar éstos en las consecuencias de su acción delictiva ${ }^{341}$. Todo lo expuesto pone de relieve las dificultades para determinar claramente los fines de prevención general negativa en la pena examinada al encontrarnos en el ámbito de la psicología de los individuos y junto a ello, la dificultad de acreditar que determinados sujetos no delincan por el temor que les puede producir la existencia de una pena, al no existir forma objetiva de poder demostrar empíricamente dicha circunstancia.

Debido al aumento en las dos últimas décadas de los procedimientos en los que se puede imponer la pena de privación del derecho a conducir, se ha producido también necesariamente una mayor difusión y conocimiento de la misma lo que ha redundado en la capacidad disuasoria de la misma, tanto en términos de prevención general como especial ${ }^{342}$. Por esta causa, una de las consecuencias derivadas de su aplicación en la práctica judicial diaria es que también se ha podido incrementar el conocimiento de las consecuencias que se derivan de la misma, especialmente en lo relativo a su ejecución, aunque carecemos de estadísticas o datos que acrediten este extremo.

Los fines de prevención se asocian al hecho que a través de la pena no se privará únicamente del derecho a conducir el vehículo con el que se ha cometido el delito, sino que se privará la conducción de todos los vehículos a motor o ciclomotores. A ello hemos de añadir que debido a la imposibilidad que la pena de privación del derecho a conducir sea suspendida o sustituida comporta que siempre va a ser ejecutada. De no ejecutarse correctamente la pena impuesta se corre el riesgo que sus fines dejen de tener sentido, por lo que en mi opinión y como criterio general, la pena ha de ser cumplida, salvo excepciones como se detallará posteriormente, en

\footnotetext{
340 En relación al perfil de los delincuentes viarios podemos destacar que KAISER ya en la década de los años 70 destacaba que: "...en la circulación viaria casi <<todo el mundo > se convierte en delincuente.... Vid. KAISER Günther, Delincuencia

de tráfico..., op.cit., p.35.

${ }^{341}$ En cuanto a la eficacia intimidatoria de las penas en delincuentes impulsivos y ocasionales, vid. ÁLVAREZ GARCÍA, Francisco Javier, Consideraciones..., op.cit., p.134.

${ }^{342} \mathrm{~A}$ título ilustrativo puede comprobarse el incremento de los delitos que conllevan la pena de privación del derecho a conducir en el periodo 2005-2011 en la nota de prensa de la Fiscalía de Seguridad Vial de 26 de septiembre de 2012, Tabla I, p.3. Recurso electrónico disponible en: https://www.fiscal.es/documents/20142/159534/DOSSIER DE PRENSA FSV SEPTIEMBRE 2012. pdf/078d3bde-f1ae-3a0b-0f29-751b5542894d (último acceso: 01/11/2020).
} 
los términos que se fije en la sentencia dictada para que la misma pueda ser eficiente y no sea desvirtuada ${ }^{343}$.

El cumplimiento efectivo de la pena de privación del derecho a conducir, también hemos de vincularlo con el contenido aflictivo de la misma, lo que ha sido reconocido por la doctrina ${ }^{344}$. La aflictividad, inherente a todas las penas y a las privativas de derechos especialmente ${ }^{345}$, se plasma en nuestro caso en el hecho que el penado sufre directamente la imposibilidad de poder ejercer su derecho a conducir con una duración mínima de tres meses con las derivadas sociales, económicas, familiares y laborales que ello supone ${ }^{346}$, lo que coadyuva a que la pena de privación del derecho a conducir pueda cumplir los fines preventivos que persigue, y especialmente los preventivo-especiales.

Estimo que los fines preventivos como los que se preconizan desde las teorías relativas, tanto especiales como generales ${ }^{347}$, son los que predominan en la pena que hemos estudiado, aunque, tal como se ha señalado desde posiciones jurisprudenciales son más relevantes los fines de prevención especial ${ }^{348}$. Ello no excluye que también existan fines retributivos en la pena de privación del derecho a conducir, aunque siempre van unidos a los fines de prevención especial y general.

\footnotetext{
343 En relación con el contenido aflictivo de la pena y los fines de la misma, que son incompatibles con un cumplimiento fraccionado de la misma, vid. el AAP de Barcelona, núm. 346/2007, Sección 6ª de 17 de julio de 2007, ponente Ilma. Sra. Bibiana Segura Cros (JUR 2007/284515) y el AAP de Madrid, núm. 363/07, Sección 17ª̣, de 29 de marzo de 2007, ponente Ilma.Sra. Rosa Mª Brobia Varona (TOL2.435.925).
}

344 El contenido aflictivo de la pena de privación del derecho a conducir ha sido destacado por TAMARIT SUMALLA, Josep M., "La pérdida definitiva del derecho de conducir o del derecho a la tenencia y porte de armas", en AA.VV. La adecuación..., op.cit., p., 125 y también por RODRíGUEZ MORO, Luis, "La pena de privación del derecho a conducir vehículos a motor y ciclomotores", en AA.VV. Las penas..., op.cit., p.231.

345 El contenido aflictivo que poseen las penas privativas de derechos ha sido destacado por GUTIÉRREZ CASTAÑEDA, Ana, Las penas..., op.cit., p.429.

${ }^{346}$ Se ha destacado por la jurisprudencia el contenido aflictivo de la pena de privación del derecho a conducir en: AAP de Córdoba, núm. 200/2005, Sección 3ä, de 30 de noviembre de 2005, ponente Ilmo. Sr. Felipe Luis Moreno Gómez, (EDJ 2005/298496); SAP de Huelva, Sección 1ª , de 17 de diciembre de 2002, ponente IImo.Sr. Santiago García García (EDJ 2002/70847) y SAP de Guipúzcoa, núm. 100/2010, Sección 1ạ, de 22 de febrero de 2010, ponente IImo.Sr. Ignacio José Subijana Zunzunegui (EDJ 2010/259973)

347 Los fines de prevención general y especial en la pena de privación del derecho a conducir han sido destacados en el AAP de Madrid, núm. 603/2012, Sección 6ạ, de 13 de septiembre de 2012, ponente IIma. Sra. María Luz Almeida Castro (TOL3.546.629) / AAP de Madrid, núm. 735/12, Sección 1aㅡ, de 18 de octubre de 2012, ponente Ilmo.Sr. Eduardo de Porres Ortiz de Urbina (TOL3.631.316).

348 Los fines predominantes de prevención especial de la pena de privación del derecho a conducir han sido destacados en el AAP de Vizcaya, núm. 775/11 Sección 2ª , de 26 de octubre de 2011, 
En cierto modo podemos relacionarlo con los postulados de las teorías mixtas o eclécticas en la pena que examinamos, ya que existen numerosas resoluciones ${ }^{349}$ que destacan los fines retributivos y preventivos de forma conjunta en la pena de privación del derecho a conducir.

Los fines preventivos especiales y generales de la pena privación del derecho a conducir, se han de valorar positivamente en comparación con otras penas con las que se prevé la aplicación de forma conjunta como la pena de prisión. Por ello, sería partidario de imponer únicamente la pena de prisión junto a la pena objeto de este trabajo en los casos de especial gravedad o reincidencia delictiva ${ }^{350}$, y en el resto de supuestos aplicar bien la pena de TBC bien la pena de multa que tiene unos fines preventivo-especiales similares a la pena que estudiamos en el presente trabajo ${ }^{351}$.

Finalmente, en los supuestos que la pena de privación del derecho a conducir se impone a conductores profesionales o personas que su trabajo depende de la utilización del vehículo a motor o ciclomotor, los fines asociados a la pena se pueden ver desplazados a un segundo plano al generarse una mayor punición al penado que los fines de protección de bienes jurídicos y preventivos que puede buscar la pena. Cuando concurran dichas circunstancias, los fines de prevención de la pena de privación del derecho a conducir pueden cuestionarse y dicha situación debería ser corregida por el legislador a través de algún mecanismo existente en nuestro sistema procesal penal, como la posibilidad de un cumplimiento fraccionado

ponente Ilma. Sra. María José Martínez Sáinz (TOL3.582.599) y en la SAP de León, núm. 474/13, Sección 3aa, de 17 de junio de 2013, ponente Ilmo. Sr. Teodoro González Sandoval (TOL3.849.234).

349 En cuanto a resoluciones que han reconocido tanto fines preventivos y retributivos a la pena de privación del derecho a conducir podemos citar: AAP de Las Palmas, núm. 667/2008, Sección 1a 24 de octubre de 2008, ponente Ilmo. Sr. Secundino Alemán Almeida (EDJ 2008/279696); SAP de Cuenca, núm. 9/2009, Sección 1aㅡ, de 29 de enero de 2009, ponente Ilmo. Antonio Díaz Delgado, (TOL1.561.043); SAP de la Coruña, núm.115/2009, Sección 6aㅡ, de 18 de diciembre de 2009, ponente Ilmo.Sr. José Gómez Rey (TOL1.964.241); AAP de Vizcaya, núm. 267/10, Sección 1ạ , de 8 de abril de 2010, ponente, IIma. Sra. Reyes Goenaga Olaizaola (TOL3.653.824); SAP de Vizcaya, núm. 103/2011, Sección 2a ${ }^{-}$, de 18 de febrero de 2011, ponente llma. Sra. María José Martínez Sáinz (TOL2.214.536); SAP de Almería, núm. 126/2012, Sección 3ạ, de 13 de abril de 2012, ponente Ilmo.Sr. Jesús Martínez Abad (TOL3.665.790) y AAP de Madrid, núm. 39/ 2013, Sección 2ª , de 23 de enero de 2013, ponente Ilma.Sra. Lucía María Torroja Ribera (TOL3.880.078).

350 En relación con la finalidad de la pena de privación del derecho a conducir, vid. GÓMEZ PAVÓN, Pilar, El delito..., op.cit., p. 228.

351 La FGE exponía que las penas en materia de delincuencia de tráfico (hoy día seguridad vial), tenían un fin disuasorio, por lo que se posicionaba con unos fines preventivos-generales y especiales de la pena frente a los fines retributivos. Vid. la Memoria de la FGE del año 2007, p.536. 
para de evitar un conflicto entre la vida personal del penado y el cumplimiento de la pena ${ }^{352}$.

352 Vid. GARCÍA DEL BLANCO, Victoria, "El nuevo artículo 384 del Código Penal: Quebrantamientos, desobediencias y conductas afines", en AA.VV. Protección Penal..., op.cit., p.445. 


\section{CAPÍTULO 3. CONTENIDO Y ÁMBITO DE APLICACIÓN DE LA PENA DE PRIVACIÓN DEL DERECHO A CONDUCIR}

El tercer capítulo del trabajo tiene por objetivo analizar el contenido y ámbito de aplicación de la pena de privación del derecho a conducir. En primer lugar, se examinará el contenido de esta pena, desgranando aspectos esenciales como el relativo a su duración, el concepto de vehículo a motor y ciclomotor y el alcance de la prohibición, poniendo énfasis en la imposibilidad de obtener el permiso de conducir tras la sentencia.

En segundo lugar, se delimitará el ámbito de aplicación de la pena de privación del derecho a conducir en la parte especial del CP, especificando los tipos delictivos en los que se puede imponer, que son los delitos contra la seguridad vial, así como los delitos contra la vida e integridad física o psíquica de las personas. El análisis se centra en los tipos constitutivos de delito si bien se incluye también una referencia a los supuestos de comisión de faltas de lesiones y homicidio imprudentes cometidos con vehículo a motor y ciclomotor, que estuvieron en vigor hasta la reforma del CP del año 2015 operada por la LO 1/2015 de 30 de marzo.

El tercer aspecto relacionado con la pena de privación del derecho a conducir que se estudiará en este capítulo es el de las consecuencias derivadas de la aplicación del art.47.3 CP, cuando dicha pena se impone por un periodo de más de dos años, hecho que acarrea la pérdida de vigencia del permiso o licencia.

\subsection{Contenido de la pena de privación del derecho a conducir vehículos a motor y ciclomotores}

A continuación, determinaremos el contenido de la pena de privación del derecho a conducir y para ello se estudiarán los diferentes aspectos que pueden coadyuvar a perfilar el mismo. Definiremos las características que delimitan el contenido de la pena objeto de estudio para posteriormente realizar una referencia a dos aspectos importantes: el concepto de vehículo a motor o ciclomotor al que se aplica la pena y la repercusión de la pena en la posibilidad obtener el permiso o licencia de conducir.

La pena de privación del derecho a conducir comporta una principal consecuencia para el conductor y es que el sujeto que resulte penado no podrá conducir durante 
un tiempo determinado ningún vehículo a motor ni ciclomotor ${ }^{353}$, siendo éste el contenido esencial de la misma. Asimismo, podemos destacar que respecto lo que ha de entenderse por conducción de un vehículo a motor o ciclomotor, pese a no existir un concepto jurídico penal de dicha acción, la jurisprudencia lo ha determinado asociándolo al desplazamiento o movimiento sin exigir una distancia determinada ${ }^{354}$.

El contenido de la pena tras la reforma del CP de 1995 se refiere únicamente a la privación del derecho a conducir, suprimiendo la anterior referencia a la privación del permiso, al no existir actualmente en el catálogo de penas del art.33 la pena de privación del permiso de conduciris5. En relación con este aspecto, técnicamente es más apropiada la formulación actual de la pena que hace referencia al derecho y no al permiso ${ }^{356}$, al no realizar distinciones en su imposición entre los autores del delito que poseían el permiso y quienes carecían del mismo. Por consiguiente, podemos afirmar que el ámbito de aplicación personal de la pena se extiende tanto a quienes poseen el permiso de conducir en el momento de cometer el delito como a los que no ${ }^{357}$. Como veremos, en aquellos penados que sí poseían el permiso, la pena genera una limitación de la facultad que les fue concedida administrativamente mediante la expedición del permiso o licencia ${ }^{358}$ y provocará la inhabilitación del penado para el ejercicio del derecho a conducir durante el tiempo de la misma ${ }^{359}$.

\footnotetext{
353 Acerca del contenido de la pena, vid. RODRÍGUEZ MORO, Luis, "La pena de privación del derecho a conducir vehículos a motor y ciclomotores", en AA.VV. Las penas..., op.cit., p.239.

354 Sobre el concepto de conducción, vid. la STS, núm.436/2017, Sala Segunda, de 15 de junio de 2017, ponente Excmo. Sr. Antonio del Moral García. (TOL6.185.691).

355 Respecto a la erradicación de la referencia al permiso de conducir tras la entrada en vigor del CP de 1995, vid. CORDERO LOZANO, Carlos, Ejecución..., op.cit., p.196 y también RODRíGUEZ MORO, Luis, "La pena de privación del derecho a conducir vehículos a motor y ciclomotores", en AA.VV. Las penas..., op.cit., p.229. También en el ámbito de la jurisprudencia SAP de Barcelona, núm. 25/2009, Sección 2ª , de 21 de enero de 2009, ponente Ilmo. Sr. Pedro Martín García (TOL1.487.893).

356 Vid. LÓPEZ BARJA DE QUIROGA, Jacobo, "Las penas privativas de derechos", Revista del Poder Judicial, no 53, Primer Trimestre 1999, Consejo General del Poder Judicial, pp.127-152, MANZANARES SAMANIEGO, José Luis, Código Penal...op.cit.,p.458 y también VALEIJE ÁLVAREZ, Inmaculada," El sistema de penas en los delitos contra la seguridad vial", en AA.VV. Prevención y control..., op.cit., p.479.

357 En este sentido vid. ROCA AGAPITO, Luis, El sistema..., op.cit., p.215; CORDERO LOZANO, Carlos, Condenas penales privativas de libertad y de derechos. Actualizado a la reforma del C.P 2010 (LO 5/2010), Biblioteca Básica de Práctica Procesal, Ed. Bosch, Barcelona, 2010, p.44; DíAZ SASTRE, CRISTINA, "Tratamiento jurídico-penal de las conductas atentatorias contra la seguridad vial", Actualidad Jurídica Aranzadi, ㄲo 792, de 11 de febrero de 2010 y VALEIJE ÁLVAREZ, Inmaculada," El sistema de penas en los delitos contra la seguridad vial", en AA.VV. Prevención y control..., op.cit., p.478.

358 Los permisos y licencias de conducción son emitidos por la DGT tras la superación de pruebas teórico-prácticas. El procedimiento de obtención de los permisos y licencias puede consultarse en:
} 
En relación con esta cuestión debe tenerse en cuenta que cuando la LECrim hace referencia a la entrega del permiso, en los artículos 529 bis, 764.4 párrafo $2^{\circ}$ y 794.2, lo podemos asimilar a la privación del derecho a conducir pues la entrega únicamente se circunscribe a la acción física de entregar el permiso o licencia. Los reductos de la LECrim que hablan del permiso ${ }^{360}$ así como la referencia al mismo en la parte especial del CP, en el art.384, apartado segundo ${ }^{361}$, pueden generar confusión con relación al posible contenido de la pena pues pueden llevar a pensar que de lo que se priva es del permiso del que se dispone. Esta disfunción ha sido destacada por autores como LANZAROTE MARTÍNEZ ${ }^{362}$, y estimo acertada la propuesta de erradicar la referencia al permiso de conducir y sustituirla por el derecho a conducir al ser el verdadero derecho sobre el que recae la pena.

Debido a la penalidad de los delitos en los que se prevé la aplicación de la pena de privación del derecho a conducir, hasta la reforma operada por la Ley 41/2015, de 5 de octubre, de modificación de la Ley de Enjuiciamiento Criminal para la agilización de la justicia penal y el fortalecimiento de las garantías procesales en los procedimientos judiciales, estos casos difícilmente accedían ni a los Tribunales Superiores de Justicia ni al Tribunal Supremo ya que mayoritariamente la última instancia ordinaria era la Audiencia Provincial, siendo escasa la jurisprudencia del TS que ha delimitado el contenido y alcance de la pena ${ }^{363}$. Una de las resoluciones que sí abordan esta cuestión es la STS de 13 de diciembre de 1993, en la que se determina que el contenido de la pena de privación del derecho a conducir no radica de forma predominante en la acción de retirada física del permiso, sino que tiene

https://sede.dgt.gob.es/es/permisos-de-conducir/obtencion-renovacion-duplicados-permiso/permisoconducir/index.shtml (último acceso: (13/11/2020).

359 Referente al contenido de la pena de privación del permiso de conducir, actualmente privación del derecho, vid. GÓMEZ PAVÓN, Pilar, El delito..., op.cit., pp.221-227.

$360 \mathrm{Vid}$. la triple referencia al permiso en la LECrim en los arts. 529 bis, 764.4 párrafo $2^{\circ}$ y 794.2.

${ }^{361}$ Art.384, aptdo $2^{0}$ : "La misma pena se impondrá al que realizare la conducción tras haber sido privado cautelar o definitivamente del permiso o licencia por decisión judicial...".

362 Vid. LANZAROTE MARTíNEZ, Pablo, "Algunas cuestiones discutidas en el delito de conducción punible del art.384 del Código Penal”, La dogmática penal sobre el asfalto: un enfoque práctico de los delitos contra la seguridad vial, AGÜERO RAMÓN-LLIN, Elena/HIDALGO DE MORILLO JIMÉNEZ, Agustín/ LANZAROTE MARTíNEZ, Pablo/ PRIETO GONZÁLEZ, Helena María, Ed. Comares, Granada, 2012, p.217.

363 Tras la reforma de la LECrim operada en el año 2015, los casos que a través del recurso de casación se pueda examinar la pena de privación del derecho a conducir por el Tribunal Supremo han aumentado y ello puede servir para que se aborden cuestiones sobre las que no existía, ni existe, unanimidad en las diversas Audiencias Provinciales y pueda obtenerse un criterio que clarifique posibles interpretaciones divergentes. 
una mayor relevancia la inhabilitación para conducir ${ }^{364}$. Este criterio se ha mantenido hasta nuestros días y el contenido actual ha dejado en un segundo plano la entrega del permiso y ha adquirido importancia la imposibilidad de ejercer el derecho a conducir vehículos a motor y ciclomotores, interpretación que también se ha incorporado al CP desde 1995 en la propia denominación de la pena.

En segundo lugar, como aspecto relevante del contenido de la pena de privación del derecho a conducir vehículos a motor y ciclomotores hemos de señalar que no son dos penas diferenciadas, sino que es una única pena "que tiene el doble efecto de afectar a ambos derechos" 365 , ya que afecta tanto a la conducción de los vehículos a motor como de los ciclomotores. La prueba de ello es que los arts.33, 39 y 47 CP hablan de una única pena con doble afectación no de dos penas con afectación de derechos independientes. Si bien el art.47 $\mathrm{CP}^{366}$ puede sugerir una cierta división de derechos al indicar que: "inhabilitará al penado para el ejercicio de ambos derechos...", la pena es única debido a que el artículo se refiere a la misma en singular por lo que realizando una interpretación gramatical y stricto sensu, debe ser calificada como una pena única con contenido doble ${ }^{367}$.

En tercer lugar, en el análisis del contenido de la pena de privación del derecho a conducir destaca especialmente que se trata de una pena que incorpora consecuencias administrativas que se derivan de su imposición. Entre ellas, es relevante la obligatoriedad de realizar el curso de reeducación y sensibilización vial, regulado en el vigente art. 73 de la LTSV368 (antigua DA 13 ${ }^{\underline{a}}$ de LTSV), como requisito administrativo para poder volver a conducir, y que algunos autores ${ }^{369}$ consideran que forma parte del contenido de la pena de privación del derecho a conducir. No obstante, cierta parte de la doctrina considera que este curso no forma

364 Vid. STS, Sala Segunda, de 13 de diciembre de 1993, ponente Excmo. Sr. Cándido CondePumpido Ferreiro (TOL401.968).

365 En este sentido ya se pronunció la SAP de Madrid, Sección 23ª , de 25 de enero de 2002, ponente Ilmo. Sr. Ángel Luis Hurtado Adrián (TOL161.181).

366 La imposición de la pena de privación del derecho a conducir vehículos a motor y ciclomotores inhabilitará al penado para el ejercicio de ambos derechos durante el tiempo fijado en la sentencia.

367 Relativo al contenido doble de la pena vid. TAMARIT SUMALLA, Josep; "De las penas privativas de derechos", en AA.VV. Comentarios al Código Penal Español, Tomo I, (Artículos 1 a 233), QUINTERO OLIVARES, Gonzalo (Dir.), MORALES PRATS, Fermín (Coord.), 6a edición, AranzadiThomson Reuters, Cizur-Menor (Navarra), 2011, p.440.

368 Vid. Art. 73 LTSV en: https://www.boe.es/buscar/act.php?id=BOE-A-2015-11722 (último acceso: 13/11/2020).

369 Vid. TORRES FERNÁNDEZ, Ma Elena, "Reflexiones sobre algunos efectos administrativos del llamado "carnet por puntos" en las consecuencias penales de los delitos contra la seguridad en el tráfico", en AA.VV. Delincuencia... op.cit., p.102. 
parte del contenido de la pena que estudiamos. En este sentido se mantiene que el penado a la privación del derecho a conducir por menos de dos años que vuelve a conducir tras cumplir la pena, pero sin haber realizado el curso, no incurre en delito de quebrantamiento de condena del art.384 $\mathrm{CP}$, sino que únicamente podría recibir una sanción administrativa ${ }^{370}$, lo que excluye que el curso forme parte del contenido de la pena estudiada. En la misma línea se ha manifestado la FGE ${ }^{371}$, que en su memoria del año 2008 considera dicho curso un simple efecto administrativo de la pena, y la obligatoriedad de realizarlo está directamente relacionada con la pena de privación del derecho a conducir, no formando parte de su contenido al no aparecer en la sentencia, sino que tiene su génesis en la norma administrativa. Otro de los argumentos que refuerza la idea que el curso de sensibilización y reeducación vial no forma parte del contenido de la pena que analizamos es que la DGT dictó la Instrucción 08/S-96, de fecha 18 de abril de 2008, que llevaba por nombre: "efectos administrativos de las condenas penales" y en la que dejaba patente que se trata de un efecto de naturaleza administrativa. Del contenido de la citada Instrucción podemos concluir que el curso de sensibilización y reeducación vial puede tener una similitud con las consecuencias del art.47.3 CP, esto es, la pérdida de vigencia del permiso en caso de imposición de la pena por tiempo superior a dos años, pues a pesar de que ambos derivan de una sentencia penal despliegan su eficacia exclusivamente en el ámbito administrativo. En definitiva, y siguiendo la posición mayoritaria, estimo, como ya he señalado en el epígrafe 1.5.2, que la obligación de realizar el curso de sensibilización y reeducación vial no forma parte del contenido de la pena de privación del derecho a conducir, y me inclino por mantener la atipicidad de la conducta de conducir tras cumplir la pena, pero sin haber realizado el curso de sensibilización y su remisión como infracción a la vía administrativa ${ }^{372}$. Por lo tanto, en tal caso, la condena de privación del derecho a conducir estaría íntegramente cumplida y lo único que no habrá realizado el penado es el curso exigible en la normativa administrativa. Puesto que la exigencia de realización del

\footnotetext{
370 En torno a dicha situación coincido con lo expresado por GARCíA DEL BLANCO, Victoria, "EI nuevo artículo 384 del Código Penal: Quebrantamientos, desobediencias y conductas afines", en AA.VV. Protección Penal..., op.cit., pp.445-446; DE VICENTE MARTíNEZ, Rosario, "La conducción con pérdida de la totalidad de los puntos transcurrido el plazo de la sanción pero sin la realización del curso de sensibilización y reeducación vial ¿es típica a los efectos del art.384.1 del CP?", Revista Aranzadi Doctrinal, núm. 8/2012, Ed. Aranzadi, 2012 y también REQUEJO CONDE, Carmen, El delito..., op.cit., pp.85-86.

${ }^{371}$ Acerca de su consideración como "mero efecto administrativo", vid. la Memoria de la FGE del año 2008, p. 682.

372 En este sentido destacar la posición de PRIETO GONZÁLEZ, Helena María, "El delito de conducción sin permiso en la reforma de los delitos contra "la seguridad vial", en AA.VV. Seguridad Vial y Derecho Penal. Análisis de la LO 15/2007, que modifica el Código Penal en materia de Seguridad Vial, MIR PUIG, Santiago y CORCOY BIDASOLO, Mirentxu (Dirs.) / CARDENAL MONTRAVETA, Sergi (Coord.), Ed. Tirant lo Blanch, Valencia, 2008, p. 264.
} 
curso no se incluye en la sentencia dictada y tampoco existe disposición en el CP que integre su realización como parte de la condena de privación del derecho a conducir, únicamente podemos referirnos a una infracción de carácter administrativa pero no a un quebrantamiento de pena.

En cuarto lugar, citaremos un debate existente durante varios años que contribuyó a delimitar el contenido actual de la pena de privación del derecho a conducir, y que giró en torno a si la misma debía afectar únicamente al vehículo con el que se cometía el delito o bien si alcanzaba tanto al vehículo a motor como al ciclomotor, con independencia del instrumento utilizado para la comisión del delito. La génesis del debate podemos datarla en la entrada en vigor de la LO 17/1994 de 23 de diciembre de modificación de diversos artículos del $\mathrm{CP}$, que aprobó incluir la conducción de ciclomotores en los delitos contra la seguridad del tráfico, que hasta entonces no estaba contemplada en la conducción bajo la influencia del alcohol, drogas tóxicas, estupefacientes o sustancias psicotrópicas ${ }^{373}$. La exposición de motivos de la LO 17/1994 de 23 de diciembre de modificación de diversos artículos del CP, destacaba que carecía de sentido que la conducción de ciclomotores estuviera excluida del ámbito penal, por lo que a partir de dicha modificación se añadía a la pena existente de privación del derecho a conducir vehículos a motor, que se ha mantenido de lege lata hasta la actualidad.

En 1995, el CP incluyó en el redactado del art.379 CP el adverbio "respectivamente" con el fin de plasmar la referencia a los ciclomotores tal como se había realizado meses antes con la LO 17/1994 de 23 de diciembre de modificación de diversos artículos del CP374. Al incluir en el art.379 CP el adverbio "respectivamente" se generaron interpretaciones doctrinales y jurisprudenciales que entendieron que la pena de privación del derecho a conducir tan sólo afectaba al vehículo con el que se

\footnotetext{
373 Respecto a la génesis del problema, vid. la referencia de DÍEZ RIPOLLÉS, José Luis "La evolución...", op.cit., p.4; FERNÁNDEZ PANTOJA, Pilar, "Delitos contra la seguridad del tráfico: la pena de privación del derecho a conducir", en AA.VV. Delincuencia... op.cit., pp.75-76 y también AGÚERO RAMÓN-LLÍN, ELENA, "Aspectos Comunes a los delitos contra la Seguridad Vial", La dogmática penal sobre el asfalto: un enfoque práctico de los delitos contra la seguridad vial, AGÜERO RAMÓN-LLIN, Elena/HIDALGO DE MORILLO JIMÉNEZ, Agustín/ LANZAROTE MARTíNEZ, Pablo/ PRIETO GONZÁLEZ, Helena María, Ed.Comares, Granada, 2012, pp.28-29.

374 Artículo 379 CP de 1995: El que condujere un vehículo a motor o un ciclomotor bajo la influencia de drogas tóxicas, estupefacientes, sustancias psicotrópicas o de bebidas alcohólicas, será castigado con la pena de arresto de ocho a doce fines de semana o multa de tres a ocho meses $y$, en cualquier caso, privación del derecho a conducir vehículos a motor y ciclomotores, respectivamente, por tiempo superior a uno y hasta cuatro años.
} 
había cometido el delito y no indistintamente a todo vehículo a motor y ciclomotor ${ }^{375}$. Posiciones doctrinales que, en aquel momento, mantuvieron que la pena de privación del derecho a conducir cuando se aplicaba por mor del art.379 CP, únicamente afectaba al vehículo con el que se cometía el delito fueron las de OLMEDO CARDENETE ${ }^{376}$ y POZUELO PÉREZ ${ }^{377}$ que defendían una interpretación restrictiva del adverbio "respectivamente" en el art.379 CP.

En cuanto a la jurisprudencia, la interpretación del art.379 CP en lo relativo a la pena de privación del derecho a conducir y su contenido, quedó restringida al ámbito de los Juzgados de lo Penal, así como a las diversas Audiencias Provinciales, pues dicho tipo delictivo raramente accedía al TS. Unas Audiencias Provinciales estimaban que el adverbio "respectivamente" en la pena de privación del derecho a conducir únicamente afectaba al vehículo con el que se cometía el delito, aplicando tanto el principio in dubio pro reo como la interpretación in bonam partem que rige el Derecho Penal con relación al art.379 $\mathrm{CP}^{378}$. A través de estos criterios se interpretaba la pena de privación del derecho a conducir de forma restrictiva y de manera favorable al acusado, en el sentido que la misma únicamente afectara al vehículo con el que se cometió el delito. También se argumentaron criterios relacionados con el principio de legalidad penal, así como en relación con una interpretación literal y taxativa del adverbio "respectivamente" que impedía ampliar la condena a todos los vehículos a motor y ciclomotores ${ }^{379}$. Algunas Audiencias Provinciales ${ }^{380}$ mantenían que las conductas de conducir un vehículo a motor y un ciclomotor no eran acciones idénticas y que por ello no podía utilizarse la analogía para aplicar la pena de privación del derecho a conducir a ambos vehículos de manera indistinta, optándose también porque la pena

\footnotetext{
375 Vid. FERNÁNDEZ PANTOJA, Pilar, "Delitos contra la seguridad del tráfico: la pena de privación del derecho a conducir", en AA.VV. Delincuencia..., op.cit., p. 76 y ARMENTEROS LEÓN, Miguel, Las faltas: derecho sustantivo y procesal, Ed. Tirant lo Blanch, Valencia, 2007, p.36.

376 Vid. la postura doctrinal en: OLMEDO CARDENETE, Miguel, "Aspectos prácticos de los delitos contra la seguridad del tráfico tipificados en los arts.379 y 380 del C.Penal", Revista Electrónica de Ciencia Penal y Criminología (RECPC), 04-02, (2002). Recurso electrónico disponible en: http ://criminet.ugr.es/recpc/recpc 04-02.html (último acceso: 01/11/2020).
}

377 En el mismo sentido, POZUELO PÉREZ mantenía que en el art.379 CP la pena de privación del derecho a conducir únicamente al vehículo con el que se había cometido el delito. Vid. POZUELO PÉREZ, Laura., Las penas..., op.cit., pp.61-62

378 Con relación a dicho criterio vid. la SAP de Badajoz, núm. 27/1998, Sección 1ạ, de 26 de marzo de 1998 (ARP 1998/1148).

379 En este sentido podemos citar la SAP de Alicante, Sección 2a ${ }^{2}$, de 16 de noviembre de 1998, ponente Ilmo.Sr. Faustino de Urquía Gómez (ARP 1998/4831).

380 Vid. la SAP de Huesca, de 16 de abril de 1997, ponente IImo.Sr. Antonio Angos Ullate (TOL389.167) y SAP de Huesca, de 28 de abril de 1997, ponente Ilmo.Sr. Gonzalo Gutiérrez Celma (TOL389.179). 
únicamente se debía imponer en relación con el vehículo con el que se cometió el delito. A sensu contrario, otras Audiencias Provinciales establecían un doble contenido para la pena de privación del derecho a conducir y negaban la eficacia del adverbio "respectivamente" para imponer la pena de privación únicamente en relación al vehículo con el que se cometía el delito ${ }^{381}$.

Debido a las divergencias existentes entre las distintas Audiencias Provinciales, se plantearon estas dudas interpretativas ante la FGE quien resolvió en la Consulta 4/1998 de 14 de julio de 1998 que la pena de privación del derecho a conducir incluía a los vehículos a motor, así como los ciclomotores ${ }^{382}$, siendo esta consulta la base de la ulterior reforma operada en el CP por la LO 15/2003 de 25 de noviembre. Esta ley aclaró que la pena de privación del derecho a conducir afectaba a vehículos a motor y ciclomotores ${ }^{383}$, determinándose en el propio CP el contenido y alcance de la misma ${ }^{384}$. La solución que se adoptó fue sencilla: eliminar el adverbio "respectivamente" del art.379 CP, debido a que éste había sido el origen de la disparidad de criterios interpretativos doctrinales y jurisprudenciales. En consecuencia, hoy día no existe discusión doctrinal ni jurisprudencia al respecto del alcance y contenido de la pena que priva del derecho a conducir vehículos a motor y ciclomotores ${ }^{385}$, no sólo por la supresión del referido adverbio sino porque uno de los objetivos de la pena es que el conductor no haga uso de su permiso o licencia con ningún tipo de vehículo. Esta interpretación podemos calificarla como acertada al adecuar el alcance y contenido de la pena de privación del derecho a conducir al

381 Vid.la SAP de Madrid, Sección 23a a de 25 de enero de 2002, ponente Ilmo.Sr. Ángel Luis Hurtado Adrián (TOL161.181) y la SAP de Asturias, Sección 8aㅡ, de 3 de abril de 2002, ponente Ilma Sra. Alicia Martínez Serrano (TOL212.728).

382 Recurso electrónico disponible en:

https://www.fiscal.es/memorias/estudio2016/CONS/CON 04 1998.html (último acceso: 02/11/2020).

La posición de la Fiscalía quedó determinada a raíz de la Circular 4/1998 ya que la conclusión segunda obligaba a los representantes del Ministerio Público a interponer recurso contra las resoluciones que únicamente hicieran referencia bien al vehículo a motor o al ciclomotor.

${ }^{383}$ Vid.GANZENMÜLLER ROIG, Carlos/ DE LAMO RUBIO, Jaime/ ROBLEDO VILLAR, Antonio, ESCUDERO MORATALLA, José Francisco y FRIGOLA VALLINA, Joaquín, Delitos contra la seguridad del tráfico. Los delitos cometidos con ocasión de la conducción de vehículos a motor y ciclomotores, Ed. Bosch, Sabadell, (Barcelona), 2005, p.53 y la opinión de TAMARIT SUMALLA, Josep/ LUQUE REINA, Ma Eulàlia, Automóviles, delitos y penas... op.cit., p.130 y ROCA AGAPITO, Luis, El sistema..., op.cit., p.216. Asímismo vid. la referencia de VALEIJE ÁLVAREZ, Inmaculada,"El sistema de penas en los delitos contra la seguridad vial", en AA.VV. Prevención y control..., op.cit., p.478.

384 En el mismo sentido se expresó la FGE en la Circular 2/2004 sobre aplicación de la reforma del C. Penal operada por la ley orgánica 15/2003, de 25 de noviembre. Vid. la Circular en: https://www.fiscal.es/memorias/estudio2016/CIR/CIR 02 2004.html (último acceso: 02/11/2020).

385 Vid. DE URBANO CASTRILLO, Eduardo, "La privación...", op.cit., p.9 y a TAMARIT SUMALLA, Josep; "De las penas privativas de derechos", en AA.VV. Comentarios..., QUINTERO OLIVARES, Gonzalo (Dir.), MORALES PRATS, Fermín (Coord.), op.cit., p.440. 
sentido actual de la política criminal de seguridad vial ${ }^{386}$. No hubiese sido coherente con el art.47 CP ni con los fines de esta pena ${ }^{387}$ que el conductor que ha creado un riesgo para la circulación al ser condenado por el art.379 CP, pudiese seguir creando riesgos idénticos, o incluso mayores, y ello para el caso que la pena se entendiera que únicamente afecta a uno de ellos y no a ambos ${ }^{388}$. Como conclusión, destacaremos que a raíz de la solución concreta del art.379 CP relacionada con el adverbio "respectivamente" se produjo una influencia en todos los tipos delictivos que aparece regulada la pena de privación del derecho a conducir vehículos a motor a ciclomotores ${ }^{389}$.

A pesar de la erradicación del debate sobre el contenido de la pena analizada y el adverbio "respectivamente", el legislador dejó un ámbito por homogeneizar. Es la jurisdicción de Menores, donde la LORPM en el apartado de medidas se sigue utilizando el adverbio "respectivamente" en el art. 7.1.n) ${ }^{390}$ en el que se hace referencia al vehículo a motor o ciclomotor. Por ello, sería recomendable que el legislador subsanara esta disfunción residual que existe en la pena de privación del derecho a conducir ${ }^{391}$ y armonizara el contenido de la pena y medida de privación del derecho a conducir en ambas jurisdicciones.

Una vez perfilados aspectos generales relativos al contenido de la pena que hemos estudiado haremos referencia a su duración. La pena de privación del derecho a conducir está tipificada en el CP como grave, menos grave y leve, en función del tiempo por el que la misma se ha impuesto en la sentencia dictada. Se califica como grave según el art.33.2 e) CP cuando se acuerda por un plazo superior a ocho años; como pena menos grave según el art.33.3 d) CP cuando se impone con una duración entre un año y un día y ocho años y como pena leve según el art.33.4.a)

\footnotetext{
386 En este sentido, vid., GUTIÉRREZ RODRÍGUEZ, María, "Excesos de velocidad e intoxicaciones punibles", en AA.VV. Protección Penal de la Seguridad Vial, GUTIÉRREZ RODRÍGUEZ, María (Coord.), Ed. Tirant lo Blanch, Valencia, 2009, pp.128-129.

387 Respecto a la finalidad de la pena, vid. GARCÍA DEL BLANCO, Victoria, "El nuevo artículo 384 del Código Penal: Quebrantamientos, desobediencias y conductas afines", en AA.VV. Protección Penal... op.cit., p.444.

388 Vid. RODRÍGUEZ FERNÁNDEZ, Ignacio, "Consideraciones metodológicas...", op.cit., pp.791818.

389 Dicha circunstancia la señala FERNÁNDEZ PANTOJA, Pilar, "Delitos contra la seguridad del tráfico: la pena de privación del derecho a conducir", en AA.VV. Delincuencia..., op.cit., p.76.

390 Art.7.1.n) in fine LORPM: Esta medida podrá imponerse como accesoria cuando el delito o falta se hubiere cometido utilizando un ciclomotor o un vehículo a motor, o un arma, respectivamente.

391 Vid. la crítica efectuada FERNÁNDEZ PANTOJA, Pilar, "Delitos contra la seguridad del tráfico: la pena de privación del derecho a conducir", en AA.VV. Delincuencia..., op.cit., p. 77.
} 
CP cuando es por un lapso de tiempo de tres meses a un año ${ }^{392}$, clasificación que no ha sido modificada tras la reforma del CP operada ni por la LO 1/2015 de 30 de marzo ni por la LO 2/2019 de 1 de marzo.

En cuanto a la duración de la pena de privación del derecho a conducir el art.33 CP establece una duración mínima de 3 meses y el umbral superior lo hallamos en los 10 años de duración que la pena puede alcanzar a tenor de lo previsto en el art.381.1 CP. Además, en determinados casos puede alcanzar los 15 años $^{393}$, al amparo de lo establecido en el art.70.3.4 CP. La duración de la pena determina también los plazos de prescripción de la misma, que están regulados en el art.133 CP y según el cual cuando la pena de privación del derecho a conducir tenga la consideración de grave, prescribirá a los 10 años; cuando sea menos grave prescribirá a los 5 años y cuando sea pena leve prescribirá al año.

En los siguientes epígrafes se analizarán dos aspectos relacionados con la pena que coadyuvarán a definir su contenido. Estudiaremos el concepto de vehículo a motor y ciclomotor al que se ha de aplicar la pena impuesta, para posteriormente determinar el alcance de la pena y si su contenido incluye la prohibición de obtener el permiso o licencia.

\subsubsection{Concepto de vehículo a motor y ciclomotor}

Un aspecto esencial de la pena de privación del derecho a conducir es lo que hemos de entender por vehículo a motor y ciclomotor, al ser los dos tipos de vehículos en los que se aplicará. La definición conceptual de ambos nos servirá para determinar el contenido y los vehículos a los que afecta esta pena ${ }^{394}$. Avanzamos que la definición no es tan clara como sería necesario, en particular, en relación con determinados artilugios y objetos empleados para el desplazamiento en el espacio y que no encajan totalmente en las definiciones contenidas en normas de naturaleza administrativa. El objeto de estas páginas es el de determinar donde se

\footnotetext{
392 En relación con la clasificación de la pena de privación del derecho a conducir según su naturaleza y duración vid. el cuadro explicativo de ROCA AGAPITO, Luis, El sistema..., op.cit., p.105.

393 En relación con el periodo máximo de duración, puede alcanzar los 15 años si se aplica el art.70 CP. Vid. VALEIJE ÁLVAREZ, Inmaculada," El sistema de penas en los delitos contra la seguridad vial", en AA.VV. Prevención y control..., op.cit., p.477 y también CORDERO LOZANO, Carlos, Ejecución..., op.cit., p.147.

394 Vid. AGUERO RAMÓN-LLÍN, ELENA, "Aspectos comunes a los delitos contra la seguridad vial", La dogmática penal..., op.cit., p.29.
} 
hallan conceptualizados normativamente los términos vehículo a motor y ciclomotor y señalar algunos casos de difícil encaje.

La referencia al vehículo a motor y ciclomotor en el contenido de la pena objeto de estudio data de la reforma operada por la LO 17/1994 de 23 de diciembre sobre modificación de diversos artículos del Código Penal, a la que hemos hecho referencia en el epígrafe anterior, y por la que se amplió el contenido a la licencia de conducción de ciclomotores ${ }^{395}$. Según la exposición de motivos de la LO 17/1994 sería ilógico mantener la exclusión de los ciclomotores de la aplicación de la pena ${ }^{396}$ atendiendo a los fines de prevención que tiene la misma ${ }^{397}$.

El principal problema que actualmente identificamos en lo referente a los vehículos a los que se ha de aplicar la pena es la omisión en el CP de un concepto de vehículo a motor y ciclomotor ${ }^{398}$. La falta de una definición legal del concepto nos lleva a explorar a continuación las opciones que existen para determinar el concepto de vehículo a motor y ciclomotor aplicable en el ámbito penal.

La primera opción para delimitar los vehículos objeto de la pena es aplicar la norma administrativa ${ }^{399}$. Para ello hemos de acudir a la calificación jurídica del vehículo a motor y ciclomotor que establece la LTSV, en su Anexo I400, números 9 y 12 , en la

\footnotetext{
395 Vid. DÍEZ RIPOLLÉS, José Luis, "La evolución...", op.cit., p.4 y también CERVELLÓ DONDERIS, Vicenta, Derecho Penitenciario, Ed. Tirant lo Blanch, Valencia, 2012, 3ª edición, p.88.

396 Vid. en: http://www.boe.es/boe/dias/1994/12/24/pdfs/A38668-38669.pdf (último acceso: 13/11/2020).

397 Vid. RODRÍGUEZ FERNÁNDEZ, Ignacio, “Consideraciones metodológicas...", op.cit., pp.791-818.

398 Sin embargo, podemos destacar que el legislador alemán sí que ha previsto en el Código Penal alemán un concepto jurídico-penal de lo que se considera vehículo a motor, en concreto en el art. 248.b.4.
}

399 Con relación a este criterio vid. AA.VV, "Delitos contra la seguridad vial: cuestiones comunes", GUTIÉRREZ RODRÍGUEZ, María (Coordinadora), GARCÍA DEL BLANCO, Victoria / MARTíN LORENZO, María y SANZ-DíEZ DE ULZURRUN LLUCH, Marina, Protección Penal de la Seguridad Vial, Ed. Tirant lo Blanch, Valencia, 2009, p.39 y RODRÍGUEZ MORO, Luis, "La pena de privación del derecho a conducir vehículos a motor y ciclomotores", en AA.VV. Las penas... op.cit., pp.246247.

400 Anexo I LTSV, número 9: Ciclomotor: Tienen la condición de ciclomotores los vehículos que se definen a continuación: a) Vehículo de dos ruedas, con una velocidad máxima por construcción no superior a $45 \mathrm{~km} / \mathrm{h}$ y con un motor de cilindrada igual o inferior a $50 \mathrm{~cm} 3$, si es de combustión interna, o bien con una potencia continua nominal máxima inferior o igual a $4 \mathrm{kw}$ si es de motor eléctrico. b) Vehículo de tres ruedas, con una velocidad máxima por construcción no superior a 45 $\mathrm{km} / \mathrm{h}$ y con un motor cuya cilindrada sea inferior o igual a $50 \mathrm{~cm} 3$ para los motores de encendido por chispa (positiva) o bien cuya potencia máxima neta sea inferior o igual a $4 \mathrm{kw}$ para los demás motores de combustión interna, o bien cuya potencia continua nominal máxima sea inferior o igual a $4 \mathrm{kw}$ para los motores eléctricos c) Vehículos de cuatro ruedas cuya masa en vacío sea inferior o igual a 350 kilogramos no incluida la masa de las baterías para los vehículos eléctricos, cuya velocidad máxima por construcción sea inferior o igual a $45 \mathrm{~km} / \mathrm{h}$ y cuya cilindrada del motor sea 
que se definen ambos términos ${ }^{401}$. Además, con relación al concepto de ciclomotor, la LTSV tras su redactado operado por el RDL 6/2015, de 30 de octubre, tiene una definición más amplia y precisa de este concepto y que sin duda está influenciada por el redactado del artículo 7 de la Ley 43/1999 de 25 de noviembre sobre adaptación de las normas de circulación a la práctica del ciclismo, que estuvo vigente hasta el 31 de enero de 2016.

Además de las leyes administrativas citadas, podemos invocar otras normativas que nos facilitan conceptos administrativos de lo que puede entenderse por vehículo a motor y que no coinciden totalmente con el concepto que se establece en la LTSV. En primer lugar, la Directiva 2002/24/CE y el Reglamento (UE) núm. 168/2013 del Parlamento Europeo y del Consejo, de 15 de enero de 2013, relativos a la homologación de los vehículos de motor de dos y tres ruedas ${ }^{402}$. En segundo, lugar, la Directiva 2015/413/UE del Parlamento y del Consejo de 11 de marzo de 2015 por la que se facilita el intercambio transfronterizo de información sobre infracciones de tráfico en materia de seguridad vial. En el art. 3 establece que ha de considerarse vehículo: todo vehículo de motor, incluidas las motocicletas, utilizado normalmente para el transporte de personas o bienes por carretera ${ }^{403}$. En tercer lugar, a nivel nacional, otra normativa que se puede utilizar como referencia para precisar lo que es un vehículo a motor y un ciclomotor es el Real Decreto 282/1988, de 23 de diciembre, por el que se aprueba Reglamento General de Vehículos, que en su anexo II realiza un listado de definiciones de los diferentes vehículos ${ }^{404}$. En cuarto lugar, el RD 1507/2008 de 12 de septiembre por el que se aprueba Reglamento del Seguro Obligatorio de Responsabilidad Civil en la Circulación de Vehículos a

inferior o igual a $50 \mathrm{~cm} 3$ para los motores de encendido por chispa (positiva), o cuya potencia máxima neta sea inferior o igual a $4 \mathrm{~kW}$, para los demás motores de combustión interna, o cuya potencia continua nominal máxima sea inferior o igual a $4 \mathrm{kw}$ para los motores eléctricos.

Anexo I LTSV, número 12: Vehículo de motor: Vehículo provisto de motor para su propulsión. Se excluyen de esta definición los ciclomotores, los tranvías y los vehículos para personas de movilidad reducida.

401 Acerca de la definición del vehículo a motor y ciclomotor partiendo de la regulación administrativa de la LTSV, GUTIÉRREZ RODRÍGUEZ se ha mostrado partidaria de dicha opción. Vid. GUTIÉRREZ RODRíGUEZ, María, "Dos años tras la reforma penal: cuestiones comunes sobre los delitos contra la seguridad vial y aplicación del artículo 379 del Código Penal" Tráfico y Seguridad Vial, no 136, 2010. También vid. GANZENMÜLLER ROIG, Carlos/ DE LAMO RUBIO, Jaime/ ROBLEDO VILLAR, Antonio, ESCUDERO MORATALLA, José Francisco y FRIGOLA VALLINA, Joaquín; Delitos..., op.cit., pp.78-82.

402 Vid. https://eur-lex.europa.eu/legal-content/ES/TXT/PDF/?uri=CELEX:32013R0168\&from=ES (último acceso: 02/11/2020).

403 Vid. https://www.boe.es/doue/2015/068/L00009-00025.pdf (último acceso: 13/11/2020).

$404 \mathrm{Vid}$. https://www.boe.es/buscar/act.php?id=BOE-A-1999-1826 (último acceso: 13/12/2020). 
Motor ${ }^{405}$, en su art.1 determina de forma amplia lo que puede considerarse un vehículo a motor ${ }^{406}$. Este elenco normativo contribuye a definir el objeto sobre el que recae la prohibición de conducir y sobre todo a diferenciar el vehículo a motor del ciclomotor. No obstante, como veremos, surgen algunas áreas grises en relación con determinados artilugios, en las que todavía no es fácil determinar si encajan en la definición de vehículo a motor o de ciclomotor.

A todo ello debe añadirse que cierto sector doctrinal es contrario a someterse a las normas administrativas para configurar un concepto penal de vehículo a motor, siendo partidario de concretar lo que es un vehículo a motor de un modo amplio ${ }^{407}$ e incluso REQUEJO CONDE se inclina por crear un concepto penal de vehículo a motor con las características de: "estar provisto de motor y destinado al transporte de personas o cosas" ${ }^{408}$. También se muestran críticos con la utilización de criterios administrativos para definir el concepto de vehículo a motor y ciclomotor ORTS BERENGUER y FERRANDIS CIPRIÁN ${ }^{409}$, con el argumento que el Derecho Penal estaría en una posición de inferioridad respecto al Derecho Administrativo, que sería quien determinaría lo que es un vehículo a motor y un ciclomotor. En la misma línea, MORELL ALDANA considera que debe existir un concepto penal propio de lo que es un vehículo a motor o ciclomotor, aunque sin olvidar los criterios administrativos que pueden ser útiles como orientación ${ }^{410}$.

Otro criterio que podría utilizarse para determinar un concepto jurídico-penal de vehículo estaría vinculado con aquellos que requieren necesariamente para su conducción el permiso o licencia, lo que también infiere una importancia de la

\footnotetext{
405 Referente a la aplicación de este texto legal para determinar la aplicación del concepto de vehículo a motor se ha manifestado PAREDES PORRO, Miguel Ángel, Tratamiento... op.cit., p. 65.

406 Vid. el contenido del Real Decreto 1507/2008 de 12 de septiembre, en especial su artículo 1. Recurso electrónico disponible en: http://www.boe.es/buscar/doc.php?id=BOE-A-2008-14915 (último acceso: 13/11/2020).

407 Vid. AA.VV, "Delitos contra la seguridad vial: cuestiones comunes", GUTIÉRREZ RODRÍGUEZ, María (Coord.): GARCÍA DEL BLANCO, Victoria / MARTÍN LORENZO, María y SANZ-DÍEZ DE ULZURRUN LLUCH, Marina, Protección Penal de la Seguridad Vial, Ed. Tirant lo Blanch, Valencia, 2009, p.40.

408 Vid. las propuestas doctrinales realizadas por REQUEJO CONDE, Carmen, El delito..., op.cit., p.58.

409 En relación con la crítica a la utilización de la normativa administrativa para determinar los conceptos penales de vehículo a motor y ciclomotor, vid. ORTS BERENGUER Enrique/ FERRANDIS CIPRIÁN, Daniel, "Elementos comunes de todos o de algunos de los delitos contra la seguridad vial", en AA.VV. Prevención y control de la siniestralidad vial. Un análisis jurídico y criminológico, ORTS BERENGUER, Enrique (Coord.), p.238.

410 Vid. MORELL ALDANA, Laura Cristina, Delitos contra la seguridad vial y siniestralidad de los nuevos tipos de vehículo, Ed. Bosch, Wolters Kluwer, Las Rozas (Madrid), 2019, p.120.
} 
regulación administrativa, aunque existen opiniones doctrinales contrarias a esta opción con el argumento que el propio legislador ha suprimido la referencia al permiso o licencia en la pena de privación del derecho a conducir ${ }^{411}$.

En todo caso, existe cierto consenso entre la doctrina y la jurisprudencia en aras a delimitar los vehículos que están afectados por la pena de privación del derecho a conducir, a considerar que la misma se restringe a vehículos a motor y ciclomotores que circulan por tierra. El contenido de la pena no incluye la conducción de lanchas, barcos, motos de agua, así como general todo vehículo a motor que circule por mar, así como tampoco se incluyen todos los aviones, avionetas y demás aparatos con naturaleza aérea ${ }^{412}$. Asimismo, se excluyen los tranvías al no ser considerados un vehículo a motor ni ciclomotor ${ }^{413}$ y también las bicicletas, los vehículos arrastrados por animales, pues no disponen de motor ${ }^{414}$, y los ferrocarriles ya que estos últimos no circulan por vías públicas, sino que lo hacen por unas vías férreas destinadas a tal efecto. Otro grupo de vehículos que según la normativa administrativa también ha de quedar excluido son las sillas de ruedas ${ }^{415}$.

Más interesante resulta la determinación del alcance del concepto de vehículo a motor respecto de nuevos vehículos debido a los avances tecnológicos que han originado la aparición de vehículos de difícil encaje en dicho concepto. Resulta difícil incluir nuevos vehículos en el concepto de vehículo a motor tales como las bicicletas eléctricas, las minimotos ${ }^{416}$ o los conocidos como segways ${ }^{417}$ al no

\footnotetext{
411 Vid. AA.VV. "Delitos contra la seguridad vial: cuestiones comunes", GUTIÉRREZ RODRÍGUEZ, María (Coord.), GARCÍA DEL BLANCO, Victoria / MARTÍN LORENZO, María y SANZ-DÍEZ DE ULZURRUN LLUCH, Marina, Protección Penal de la Seguridad Vial, Ed. Tirant lo Blanch, Valencia, 2009, p.40 y MORELL ALDANA, Laura Cristina, Delitos..., op.cit., p. 122.

412 Respecto a la no aplicación a barcos y aeronaves, vid. ROCA AGAPITO, Luis, El sistema..., op.cit., p.217 y GIL GIL, Alicia/ LACRUZ LÓPEZ, Juan Manuel/ MELENDO PARDOS, Mariano/ NÚÑEZ FERNÁNDEZ, José, Consecuencias jurídicas..., op.cit., p. 181 así como la no aplicación a aviones y motos acuáticas vid. ORTS BERENGUER, Enrique/ FERRANDIS CIPRIÁN, Daniel, "Elementos comunes de todos o de algunos de los delitos contra la seguridad vial", en AA.VV. Prevención..., op.cit., p.240. También relativo a su no aplicación a los vehículos que no sean terrestres destacar la opinión de VELASCO NÚÑEZ, Eloy, "Privación del derecho a conducir vehículos a motor y ciclomotores", Boletín de Derecho de la Circulación, El Derecho Editores, ㄲo 9, junio de 2007, p.1.

${ }^{413} \mathrm{Al}$ respecto de la exclusión de los tranvías también se manifiesta REQUEJO CONDE, Carmen, El delito..., op.cit., p.59 y MORELL ALDANA, Laura Cristina, Delitos..., op.cit., p. 49.

414 Vid. PALLÍN IBÁÑEZ, Gabriela, El impacto..., op.cit., p.75.

415 Vid. PAREDES PORRO, Miguel Ángel, Tratamiento..., op.cit., pp.64-65.

416 En concreto, el caso de las minimotos fue objeto de análisis detallado por la FGE en la Circular 10/2011 determinándose que no tenían la consideración de vehículo a motor. Vid. la Circular 10/2011 de la FGE "Sobre criterios para la unidad de actuación especializada del Ministerio Fiscal en materia de seguridad vial, pp.67-68.
} 
coincidir con ninguno de los conceptos de vehículo a motor y por lo tanto tampoco pueden ser susceptibles que se les pueda aplicar a su conducción la pena de privación del derecho a conducir vehículos a motor y ciclomotores. Por este motivo se tiene que ir determinando jurisprudencialmente el contenido de la pena en lo relativo a los vehículos que afecta. Se ha generado controversia doctrinal en torno a si debían ser considerados o no vehículo a motor los quads, las llamadas minimotos, los tractores o los coches de minusválido ${ }^{418}$. En relación a los quads, la jurisprudencia de diversas Audiencias Provinciales ha considerado que dichos vehículos requieren de autorización administrativa para conducirlos y deben contar con matrículas ${ }^{419}$, por lo que aquellos que los conduzcan sí podrán ser acusados por el delito del art. $384.2 \mathrm{CP}$ si lo hacen estando privados cautelar o definitivamente del derecho a conducir. Además, aquellos que conduzcan los llamados quads están obligados a someterse a las pruebas de alcohol o drogas legalmente establecidas ${ }^{420}$ y pueden ser considerados como autores de los delitos de conducción bajo la influencia del alcohol del art.379.2 CP $^{421}$ o de conducción temeraria del art. 381 si realizan la conducta típica ${ }^{422}$.

Por lo que respecta a las llamadas minimotos, la jurisprudencia de diversas Audiencias Provinciales ha establecido que generalmente son vehículos no aptos para circular por vías públicas y que no requieren para su conducción permiso o licencia, aunque en determinados supuestos sí que pueden ser considerados vehículos a motor y por lo tanto su utilización sí puede ser constitutiva de un delito

\footnotetext{
417 En relación con los segways, se dictó por parte de la DGT la Instrucción 16/V-124 de fecha 3 de noviembre de 2016 que determinaba que no tenían la consideración de vehículo a motor, sino que son calificados como vehículo de movilidad personal (VMP). Asimismo, no se ha dictado ninguna sentencia que haga referencia a dichos vehículos en el ámbito penal.

418 Referente a la inclusión de determinados vehículos en el concepto de vehículo a motor, vid. REQUEJO CONDE, Carmen, El delito..., op.cit., pp.59-60 y MOLINA FERNÁNDEZ, Fernando, Delitos contra la seguridad vial: su aplicación jurisprudencial. Ediciones Francis Lefebvre, Madrid, 2014, p.17-18, en relación con determinados vehículos a motor y ciclomotor.

419 En este sentido vid. SAP de Teruel, núm. 4/2013, Sección 1ä, de 19 de febrero de 2013, ponente IIma. Sra. María Teresa Rivera Blasco (TOL3.667.572); SAP de Madrid, núm. 976/2014, Sección 30ª̆, de 10 de diciembre de 2014, ponente Ilmo. Sr. Carlos Martín Meizoso (TOL4.713.426) y SAP de Las Palmas, núm. 238/2019, Sección 6ª , de 29 de julio de 2019, ponente llma. Sra. Oscarina Inmaculada Naranjo García (TOL7.543.377).

420 Vid. la SAP de Tenerife, núm. 617/2011, Sección 2a , de 25 de noviembre de 2011, ponente llma. Sra. Francisca Soriano Vela (TOL2.473.712).

421 Vid. la SAP de Pontevedra, núm. 231/2011, Sección 2a ${ }^{\underline{a}}$, de 28 de julio de 2011, ponente llmo. Sr. Celso Joaquín Montenegro Viéitez (TOL2.226.077).

422 Vid. la SAP de Sevilla, núm. 553/2006, Sección 1ạ , de 5 de octubre de 2006, ponente llma. Sra. Inmaculada Adelaida Jurado Hortelano (TOL6.103.132) y SAP de Cáceres, núm. 329/2019, Sección $2^{2}$, de 28 de noviembre de 2019, ponente Ilma. Sra. Julia Domínguez Domínguez (TOL7.742.072).
} 
contra la seguridad vial de los arts. 379, 380 o $381 \mathrm{CP}^{423}$, que conllevan la pena de privación del derecho a conducir. También podemos destacar que tras la entrada en vigor de la LO 2/2019 de 1 de marzo, de modificación del Código Penal, los conductores de los quads y las llamadas minimotos también podrían ser, en determinados supuestos, autores de un delito de abandono del lugar del accidente del art. 382 bis que acarrea la pena de privación del derecho a conducir. Sin embargo, en los escasos supuestos que han sido resueltos por las Audiencias Provinciales no existe unanimidad en la aplicación del art. 384.2 CP a las minimotos. Así, por ejemplo, la Audiencia Provincial de Córdoba determinó que la conducción de una minimoto estando privado del derecho a conducir vehículos a motor y ciclomotores no constituye delito de quebrantamiento del art. $384.2 \mathrm{CP}^{424}$. Por el contrario, la Audiencia Provincial de Málaga sí ha considerado como delito del art. 384.2 CP la conducción de una minimoto sin haber obtenido nunca el correspondiente permiso o licencia ${ }^{425}$, mientras que la Audiencia Provincial de Barcelona considera que no es delito, al no precisar estos vehículos el correspondiente permiso o licencia, aún en el caso que sean asimilables a un ciclomotor $^{426}$. En el mismo sentido, la Audiencia Provincial de Murcia determinó que, dado que las minimotos no están homologadas para ser utilizadas en las vías públicas, no es preceptivo el correspondiente permiso o licencia para su conducción ${ }^{427}$. En relación con los patinetes, podemos destacar a la Audiencia Provincial de Cáceres, que una novedosa sentencia, ha concluido que determinados modelos de patinetes, como por ejemplo los que tengan una potencia de $1.500 \mathrm{~W}$ y alcancen una velocidad máxima de $45 \mathrm{~km} / \mathrm{h}$ han de ser considerados ciclomotores, y por ende precisan el correspondiente permiso o licencia ${ }^{428}$.

\footnotetext{
${ }^{423}$ Vid. la SAP de Valencia, núm. 355/2006, Sección 2a Carlos Turiel Sandín (TOL1.029.305); SAP de Vizcaya, núm. 557/2006, Sección 1aㅡ, de 13 de octubre de 2006, ponente Ilmo. Sr. Rafael Yangüela Criado (TOL1.061.486); SAP de Madrid, núm. 893/2007, Sección 17a , de 3 de septiembre de 2007, ponente IIma. Sra. Manuela Carmena Castrillo (TOL1.179.522); SAP de Valencia, núm. 389/2009, Sección 2a , de 10 de junio de 2009, ponente Ilmo. Sr. José María Tomás y Tio (TOL1.859.602) y la SAP de Valencia, núm. 514/2016, Sección 3ª de 29 de julio de 2016, ponente Ilmo. Sr. Lamberto Juan Rodríguez Martínez (TOL5.829.577).

424 Vid. la SAP de Córdoba, núm. 559/2010, Sección 1ạ, de 6 de julio de 2010, ponente Ilmo. Sr. José María Magaña Calle (TOL2.110.509).

425 Vid. la SAP de Málaga, núm. 67/2016, Sección 8ª , de 4 de febrero de 2016, ponente Ilmo. Sr. Pedro Molero Gómez (TOL5.777.575).

426 Vid. la SAP de Barcelona, núm. 802/2010, Sección 7ª̣, de 19 de octubre de 2010, ponente llma. Sra. Ana Ingelmo Fernández (TOL2.058.920).

427 Vid. la SAP de Murcia, núm. 21/2009, Sección 5a , de 12 de marzo de 2009, ponente Ilmo. Sr. José Manuel Nicolás Manzanares (TOL6.758.464).

428 Vid. la SAP de Cáceres, núm. 44/2020, Sección 2aa de 7 de febrero de 2020, ponente IImo. Sr. Valentín Pérez Aparicio (TOL7.791.823).
} 
La conducción de los denominados vehículos de movilidad personal (en adelante $V M P$ ), como segways, patinetes eléctricos o ruedas eléctricas, ha generado debate en torno a por donde han de circular y si ha de requerirse permiso o licencia para su conducción ${ }^{429}$, así como si han de ser considerados vehículos a motor ${ }^{430} \mathrm{o}$ ciclomotor ${ }^{431}$. Si bien en los últimos meses se han aprobado normativas de carácter local e incluso se promulgó por la DGT una instrucción en el año $2019^{432}$, no ha sido hasta el mes de noviembre del año 2020 cuando se ha reformado el Reglamento General de Vehículos. Ello se ha realizado a través del Real Decreto 970/2020 de 10 de noviembre ${ }^{433}$, cuya entrada en vigor está prevista para el 2 de enero de 2021, en el que se determina, entre otras cosas, que los VMP no se consideran vehículos de motor ${ }^{434}$ así como que han de poseer un certificado para la circulación. Sin embargo, considero que, a pesar de esta reforma legislativa, podrían subsistir las dificultades respecto a la naturaleza y requisitos legales de los VMP, lo que podría

\begin{abstract}
${ }^{429}$ Acerca de la problemática de los VMP, vid. Memoria FGE, 2018, pp.650-651. En concreto, en relación con los patinetes eléctricos, SAP de Girona, núm. 59/2016, Sección 3ª , de 29 de enero de 2016, ponente Ilma. Sra. Fátima Ramírez Souto (TOL5.676.401), que absuelve a un acusado que había sido condenado por conducir bajo la influencia del alcohol, al considerar que un patinete no puede tener la consideración de ciclomotor. También es interesante la SAP de Pontevedra, núm. 228/2019, Sección 4a , de 30 de diciembre de 2019, ponente Ilma. Sra. María Cristina Navares Villar (TOL7.814.554), en la que se analiza la conducción de un VMP tipo scooter/moto eléctrica, la problemática de sus condiciones técnicas, requisitos de conducción y matriculación, así como su no consideración como ciclomotor.
\end{abstract}

430 Vid. MORELL ALDANA, Laura Cristina, Delitos..., op.cit., p. 123 y ANDRÉS DOMíNGUEZ, Ana Cristina, "Cuestión controvertida: Los vehículos de movilidad personal, ¿Instrumento típico de un delito contra la seguridad vial?". Estudios penales y criminológicos. Vol. XL, 2020, Universidad Santiago de Compostela, pp.17-18.

431 Vid. SAP de Murcia, núm. 81/2020, Sección 2a , de 24 de marzo de 2020, ponente Ilmo. Sr. Enrique Domínguez López (TOL7.945.600), en la que se absuelve al acusado de un delito de conducción sin permiso por conducir un patinete/ciclo, al no estar acreditada su consideración como ciclomotor.

432 Con relación a dicha problemática, vid., ANDRÉS DOMÍNGUEZ, Ana Cristina, "Cuestión...,", op.cit., pp.19-20.

Hasta que entre en vigor la modificación del Reglamento General de vehículos, podemos tener como referencia la Instrucción 2019/S-149 TV-108 de 3 de diciembre de 2019 de la DGT, sobre vehículos ligeros propulsados por motores eléctricos.

Vid. en: http://www.dgt.es/Galerias/seguridad-vial/normativa-legislacion/otras-normas/normasbasicas/Intruccion-VMP-y-otros-vehiculos-ligeros.pdf (último acceso: 02/11/2020).

433 Vid. Real Decreto 970/2020, de 10 de noviembre, por el que se modifican el Reglamento General de Circulación, aprobado por el Real Decreto 1428/2003, de 21 de noviembre y el Reglamento General de Vehículos, aprobado por Real Decreto 2822/1998, de 23 de diciembre, en materia de medidas urbanas de tráfico.

Recurso electrónico disponible en: https://www.boe.es/boe/dias/2020/11/11/pdfs/BOE-A-202013969.pdf (último acceso 13/11/2020).

434 Vid. Apartado A <<Definiciones>> del Anexo II del Reglamento General de vehículos en el que se establece que $<<$ Vehículo a motor: Vehículo provisto de motor para su propulsión. Se excluyen de esta definición los ciclomotores, los tranvías, los vehículos para personas de movilidad reducida, bicicletas de pedales con pedaleo asistido y los vehículos de movilidad personal>>. 
comportar que en algún caso tuviera repercusión en la pena de privación del derecho a conducir. Un mecanismo para acabar con estas dificultades podría ser el establecer un concepto jurídico-penal de lo que es un vehículo a motor a los efectos de la aplicación de la pena estudiada, y sería partidario de una acepción amplia utilizando como referencia las normas administrativas ${ }^{435}$.

\subsubsection{Alcance de la privación del derecho a conducir vehículos a motor y ciclomotores}

A continuación, se analizará si en el contenido de la pena de privación del derecho a conducir debe incluirse o no la prohibición de obtener el permiso o licencia durante el tiempo de cumplimiento de la misma. Formalmente no consta en el CP que la pena prive de la posibilidad que el penado pueda obtener el permiso de conducir. El contenido literal de la pena únicamente alcanza al derecho a conducir vehículos a motor y ciclomotores por lo que trataremos de determinar si una vez se ha producido la condena ésta también inhabilita para obtener el permiso o licencia para conducir durante el tiempo de la condena.

La problemática que se plantea ya fue estudiada antaño por la doctrina, aunque en relación a los penados que no tuviesen el permiso o licencia en el momento de la comisión del delito. MAPELLI CAFFARENA/TERRADILLOS BASOCO ${ }^{436}$ destacaron la controversia existente con la reforma del CP de 1983 en su arts. 42.3, 27 y 516 bis, en relación al alcance de la pena de privación del derecho a conducir y si ésta incluía la prohibición de obtenerlo por parte de aquellos penados que no lo poseían durante el tiempo de la condena. En el ámbito jurisprudencial, el Tribunal Supremo en las escasas resoluciones dictadas con anterioridad a la entrada en vigor de la reforma del CP de 1995 en las que examinó el contenido de la pena de privación del permiso a conducir, mantuvo que la pena incluía la prohibición de obtener el permiso o licencia a aquellos penados que carecían del mismo ${ }^{437}$.

\footnotetext{
435 En este sentido me parece acertada la posición de ORTS BERENGUER, Enrique/ FERRANDIS CIPRIÁN, Daniel, "Elementos comunes de todos o de algunos de los delitos contra la seguridad vial", en AA.VV. Prevención..., op.cit., p.240, quienes son partidarios que el concepto de vehículo a motor sea más amplio que el que se establece en la LTSV.

436 Con relación a la referencia de este debate doctrinal vid. MAPELLI CAFFARENA, Borja/ TERRADILLOS BASOCO Juan, Las consecuencias..., op.cit., p.162.

437 Vid. STS, Sección 1aㅡ, de 5 de junio de 1972, ponente Excmo. Sr. Fernando Díaz Palos (TOL4.263.271) que se posiciona por la opción de impedir que se pueda obtener el permiso de conducir durante el tiempo de la condena, STS, Sala Segunda, de 3 de julio de 1985, ponente Excmo. Sr. José Augusto De Vega Ruiz (TOL2.313.893), en la que se delimita el contenido de la
} 
Tras la reforma del CP del año 1995 la antigua pena de privación del permiso a conducir pasó a denominarse pena de privación del derecho a conducir, calificación que no ha cambiado. En la actualidad, al sujeto al que se le impone la pena de privación del derecho a conducir, tanto si posee o no el permiso o licencia, no se le sancionará en la sentencia condenatoria con la prohibición expresa de obtenerlo. El juez penal no puede acordar esta prohibición ante la inexistencia de una pena de prohibición de obtener el permiso de conducir dentro del catálogo de penas del $\mathrm{CP}^{438}$. Ello no excluye, no obstante, que al penado le quede vedado por la vía administrativa la obtención del permiso en caso de que no lo poseyera en el momento de la comisión de los hechos delictivos. En este sentido, el art. 794.2 ${ }^{\mathrm{a}}$ de la LECrim ${ }^{439}$ establece que se comunicará a la Jefatura de Tráfico la sentencia condenatoria que conlleve la pena de privación del derecho a conducir a los efectos que no pueda expedir el permiso de conducir hasta que finalice la condena ${ }^{440}$. Sin embargo, esta traba para la obtención del permiso al hallarse en el ámbito de la LECrim no puede ser equiparable a una pena, ya que la Ley Rituaria no puede crear nuevas penas como podría ser la de imposibilidad de obtener el permiso o licencia durante el tiempo de la condena ${ }^{441}$.

A efectos prácticos el funcionamiento de lo previsto en el art. 794.2 LECrim supone que una vez recibida la sentencia condenatoria que incluye la pena de privación del derecho a conducir, la Jefatura Central de Tráfico inscribe en sus ficheros la condena, así como la duración y plazo en el que la pena quedará completamente ejecutada. Esta previsión concurre con lo establecido en el RGCon, aprobado por RD 818/2009 de 8 de mayo, donde se establecen los requisitos para obtener el permiso o licencia para conducir y entre los que se incluye el no estar privado por

antigua pena de privación del permiso a conducir, y la STS, Sala Segunda, de 13 de diciembre de 1993, ponente Excmo. Sr. Cándido Conde-Pumpido Ferreiro (TOL401.968).

438 Vid. VALLESPÍN PÉREZ, David, Aspectos procesales..., op.cit., p.85.

439 Art.794.2 ${ }^{\text {a }}$ LECrim: En los casos en que se haya impuesto la pena de privación del derecho a conducir vehículos a motor y ciclomotores, el Secretario judicial procederá a la inmediata retirada del permiso y licencia habilitante, si tal medida no estuviera ya acordada, dejando unido el documento a los autos y remitirá mandamiento a la Jefatura Central de Tráfico para que lo deje sin efecto y no expida otro nuevo hasta la extinción de la condena.

$440 \mathrm{Al}$ respecto señalar que en el año 2015 se aprobó el nuevo protocolo de funcionamiento en el que directamente se remiten por el Juzgado a la Dirección General de Tráfico las sentencias que incluyen la pena de privación del derecho a conducir. Vid. la noticia en: http://www.dgt.es/es/prensa/notas-deprensa/2015/20150211-justicia-enviara-a-trafico-automaticamente-las-condenas-por-delitos-contrala-seguridad-vial.shtml (último acceso: 13/12/2020).

${ }^{441}$ En este sentido también se expresó ROMEO CASABONA, quien considera que la ley procesal no puede modificar una ley sustantiva como es el CP. Vid. ROMEO CASABONA, Carlos María, 
resolución judicial del derecho a conducir vehículos a motor y ciclomotor (art. 7.1.b) ${ }^{442}$ ), así como la prohibición de obtener un nuevo permiso o duplicado (art. $14.2^{443}$ ). Es por ello que una vez dictada por un juzgado la sentencia firme que incluya la pena de privación del derecho a conducir, de manera indirecta y a través de la norma administrativa se estará privando al penado, posea o no permiso o licencia, de la posibilidad de obtenerlos.

En el ámbito doctrinal existe también discusión en torno a si la aplicación de la pena impide o no al penado la obtención del permiso durante el tiempo de ejecución de aquella. Algunos autores, como URBANO CASTRILLO ${ }^{444}$, ORTS BERENGUER y GONZÁLEZ CUSSAC ${ }^{445}$, mantienen que la imposición de la pena de privación del derecho a conducir comporta además la prohibición que aquellos condenados que no poseyeran el permiso o licencia puedan obtenerlo durante el tiempo que dure la condena. En el mismo sentido se expresan GUTIÉRREZ RODRÍGUEZ y VAELLO ESQUERDO 446 para quienes la pena impide obtener el permiso o licencia a las personas que no lo poseían y se utiliza como argumento que el redactado de la pena tras la entrada en vigor del CP de 1995 se refiere al derecho y no al permiso. También en términos similares se postulan POZUELO PÉREZ, AYO FERNÁNDEZ y BOLDOVA PASAMAR ${ }^{447}$ al mantener que aquellos penados que no poseyeran el

Conducta peligrosa e imprudencia en la sociedad del riesgo, Ed. Comares, Granada, 2005, pp.262263.

442 Art. 7 RGCon. Requisitos para obtener un permiso o una licencia de conducción. 1. b) No estar privado por resolución judicial del derecho a conducir vehículos de motor y ciclomotores, ni hallarse sometido a suspensión o intervención administrativa del permiso o licencia de conducción que se posea.

443 Art.14.2 RGCon. En todo caso, la privación por resolución judicial del derecho a conducir vehículos de motor y ciclomotores, la declaración de pérdida de vigencia a que se refiere el artículo 37, la intervención, medida cautelar o suspensión del permiso o licencia que se posea, tanto se hayan acordado en vía judicial o administrativa, serán causa para denegar el trámite solicitado, que no procederá hasta que se haya cumplido la pena o sanción, levantado la intervención o medida cautelar, o hayan transcurrido los plazos o acreditado los requisitos legalmente establecidos, según el trámite de que se trate.

444 Vid. DE URBANO CASTRILLO, Eduardo, "La privación...", op.cit., p.9.

445 Vid. ORTS BERENGUER, Enrique/ GONZÁLEZ CUSSAC, José.L. Compendio..., op.cit., p.474.

446 Vid. VAELLO ESQUERDO, Esperanza, Las consecuencias..., op.cit.p. 71 y también GUTIÉRREZ RODRÍGUEZ, María, "Excesos de velocidad e intoxicaciones punibles", en AA.VV. Protección Penal..., op.cit., p.128

447 Vid. POZUELO PÉREZ, Laura., Las penas..., op.cit., p.63, también AYO FERNÁNDEZ, Manuel, Las penas, medidas de seguridad y consecuencias accesorias. Manual de determinación de las penas y de las demás consecuencias jurídico-penales del delito, Ed. Aranzadi, Pamplona, 1997, p. 151 y BOLDOVA PASAMAR, Miguel Ángel, "Penas Privativas de Derechos", en AA.VV. Lecciones de consecuencias jurídicas del delito: el sistema de penas, de medidas de seguridad, de consecuencias accesorias y de responsabilidad civil derivada del delito, GRACIA MARTíN, Luis (Coord.)/ BOLDOVA PASAMAR, Miguel Ángel/ ALASTUEY DOBÓN, M.Carmen, Ed. Tirant lo Blanch, Valencia, 2012, 4ª edición, p.69. 
permiso no podrán obtenerlo durante el tiempo de la condena. En la misma línea doctrinal se posiciona MOLINA BLÁZQUEZ ${ }^{448}$ al indicar que tras la entrada en vigor del C.P de 1995 la pena tiene un doble contenido: la privación del derecho a conducir y la prohibición de obtener el permiso durante el tiempo de la condena impuesta, por lo que esta segunda consecuencia afectará tanto a penados que lo poseyeran como aquellos que carecieran en el momento de la comisión del hecho delictivo.

En sentido contrario, destaca la opinión de TAMARIT SUMALLA ${ }^{449}$ para quien la pena de privación del derecho a conducir no constituye un óbice para que el penado pueda superar las pruebas para obtener el permiso. En el mismo sentido GÓMEZ PAVÓN ${ }^{450}$ mantenía que la pena no incluye la imposibilidad de obtener el permiso durante el tiempo de la condena porque si observamos el texto de la pena en el CP en ningún momento consta que se impida la obtención del permiso o licencia para aquellos penados que no la posean y además el contenido de la pena es de una inhabilitación ${ }^{451}$. En las posiciones favorables a que la pena analizada no priva de la obtención del permiso o licencia, podemos señalar también a LÓPEZ BARJA DE QUIROJA O VELASCO NÚÑEZ, para quienes los penados sí podrían obtenerlo, pero no podrían ejercer su derecho una vez obtenido ${ }^{452}$.

Tras lo expuesto podemos determinar que formalmente la pena de privación del derecho a conducir únicamente priva del ejercicio del derecho, pero no afecta al permiso o licencia ${ }^{453}$, que se mantiene vigente excepto en los casos que se aplica las consecuencias del art.47.3 CP, ni tampoco prohíbe su obtención ya que no

\footnotetext{
448 Vid. MOLINA BLÁZQUEZ Mª Concepción, La aplicación..., op.cit., p 37.

449 Vid.TAMARIT SUMALLA, Josep, "De las penas privativas de derechos", en AA.VV. Comentarios..., QUINTERO OLIVARES, Gonzalo (Dir.), MORALES PRATS, Fermín (Coord.), op.cit., p.440.

450 Vid. GÓMEZ PAVÓN, Pilar, El delito..., op.cit., p. 226.

451 Respecto a dicho debate doctrinal, vid. RODRíGUEZ MORO, Luis, "La pena de privación del derecho a conducir vehículos a motor y ciclomotores", en AA.VV. Las penas... op.cit., p.241 y La pena de privación..., op.cit., pp.185-188.

452 Vid. LÓPEZ BARJA DE QUIROGA, Jacobo, "Las penas..." op.cit., pp.127-152 y VELASCO NÚÑEZ, Eloy, "Privación del derecho...., op.cit., p.3.

453 Referente al hecho que la pena no afecte a la autorización administrativa, vid. TAMARIT SUMALLA, Josep/ LUQUE REINA, Mํㅡㄹ Eulàlia, Automóviles, delitos y penas..., op.cit., p.127 y GUTIÉRREZ CASTAÑEDA, Ana en "Penas privativas y restrictivas de derechos", en AA.VV. Las consecuencias jurídicas del delito, ROCA DE AGAPITO, Luis (Dir.), Ed. Tirant lo Blanch, Valencia, 2017, p. 57.
} 
existe prohibición expresa a tal efecto ${ }^{454}$. Sin embargo, el penado no podrá examinarse para obtener el permiso ya que en la base de datos de la DGT aparecerá la pena de prohibición del derecho a conducir, lo que imposibilitará la obtención del permiso o licencia, proyectándose en el ámbito administrativo unas consecuencias jurídicas de la pena que no recoge ni la sentencia dictada ni el CP. Además, existen numerosas resoluciones judiciales que en la última década han impuesto la pena de privación del derecho a conducir o la prohibición del derecho a obtenerlo, y ello aun cuando dicha prohibición no aparece en el catálogo de penas o medidas de seguridad del CP, por lo que es evidente que existe una disfunción que ha de ser corregida ${ }^{455}$.

Tal vez por ello, y con el objetivo que el CP delimite el contenido exacto de la pena de privación del derecho a conducir debería añadirse en su parte final: “...y la prohibición de obtener el correspondiente permiso o licencia durante el tiempo de duración de la pena", en el mismo sentido que aparece regulado en el art.7.1.n) en la LORPM la medida de privación del derecho a conducir y que expresamente prevé en el contenido de la medida la imposibilidad de obtenerlo456. Así se trasladaría al ámbito penal lo que en el ámbito administrativo ya está clarificado desde la entrada en vigor del RD 818/2009 de 8 de mayo por el que se aprueba el RGCon, ya que uno de los requisitos para la obtención del permiso o licencia según el art.7.1.b) ${ }^{457}$ del citado Reglamento es la ausencia de resoluciones judiciales que priven del derecho a conducir por lo que la norma administrativa veda cualquier posibilidad al respecto en el caso de condena a la pena de privación del derecho a conducir. Con

454 Acerca de la imposibilidad de obtener el permiso durante el tiempo de la condena vid. RODRÍGUEZ MORO, Luis, "La pena de privación del derecho a conducir vehículos a motor y ciclomotores", en AA.VV. Las penas..., op.cit., p.241.

$455 \mathrm{~A}$ tal efecto citaremos sentencias de diferentes Audiencias Provinciales en las que se impone la prohibición del derecho a obtener el permiso de conducir, a pesar de no estar presente dentro del catálogo de penas del CP. Vid. la SAP de Navarra, núm. 259/2012, Sección 2a , de 21 de diciembre de 2012, ponente IImo. Sr. Francisco José Goyena Salgado (TOL3.916.016), SAP de Badajoz, núm. 144/2013, Sección 1ạ, de 20 de diciembre de 2013, ponente Ilmo. Sr. Emilio Francisco José Serrano Molera (TOL4.095.015), SAP de Barcelona, núm. recurso 241/2014, Sección 10ª , de 30 de diciembre de 2013, ponente IIma. Sra. Montserrat Comas de Argemir Cendra (TOL5.002.062), SAP de Santander, núm. 345/2015, Sección 3ạ, de 24 de julio de 2015, ponente Ilmo. Sr. Agustín Alonso Roca (TOL5.559.800), SAP de Sevilla, núm. 451/2016, Sección 7ạ, de 8 de noviembre de 2016, ponente Ilma. Sra. Mercedes Alaya Rodríguez (TOL6.145.679), SAP de Barcelona, núm. 478/2017, Sección 7ạ, de 11 de julio de 2017, ponente llma. Sra. Ana Rodríguez Santamaría (TOL6.443.716) y SAP de Illes Balears, núm.1/2018, Sección 1르, de 8 de enero de 2018, ponente llma. Sra. Eleonor Moya Rossello (TOL6.528.276).

456 Art.7.1.n) LORPM: "Privación del permiso de conducir ciclomotores y vehículos a motor, o del derecho a obtenerlo...".

457 Art.7.1.b) RGCon: No estar privado por resolución judicial del derecho a conducir vehículos de motor y ciclomotores, ni hallarse sometido a suspensión o intervención administrativa del permiso o licencia de conducción que se posea. 
dicha reforma se clarificaría el contenido de esta pena, especialmente para aquellos penados que no poseen el permiso, pero han sido condenados a la pena de privación del derecho a conducir, así como para los penados a los que se les ha aplicado el art.47.3 CP y han perdido la vigencia del permiso.

\section{2. Ámbito de aplicación de la pena de privación del derecho a conducir vehículos a motor y ciclomotores}

En el segundo apartado del capítulo determinaremos el ámbito de aplicación de la pena de privación del derecho a conducir en los diversos tipos penales del libro II del CP. La pena de privación del derecho a conducir es la respuesta del legislador en el CP a las acciones que realizan determinados sujetos habiendo utilizado un vehículo a motor o ciclomotor, poniendo en riesgo distintos bienes jurídicos: la seguridad vial, la vida o la integridad física o psíquica de las personas. De esta forma, se detallan una serie de conductas en el CP que generarán una consecuencia jurídica que es la pena de privación del derecho a conducir, que al imponerse puede evitar que el sujeto condenado conduzca durante un periodo determinado de tiempo y así garantizar durante ese lapso temporal el mejor funcionamiento de la seguridad vial ${ }^{458}$.

El ámbito de aplicación de la pena de privación del derecho a conducir se vio ampliado tras la entrada en vigor de la LO 15/2007 de 30 de noviembre, bien sea por la instauración de la pena de privación del derecho a conducir en tipos penales que hasta entonces no comportaban su aplicación, bien sea por la ampliación en otros supuestos de tipos penales en los que sí estaba prevista ${ }^{459}$. El legislador optó por la pena analizada en el presente trabajo como uno de los mecanismos para combatir la delincuencia vial, y desde hace más de una década se han incrementado los delitos que acarrean dicha pena, así como las consecuencias jurídicas relacionadas con la misma ${ }^{460}$. La posterior reforma operada en la LO

\footnotetext{
458 Relativo al fundamento de la pena de privación del derecho a conducir, vid. POZUELO PÉREZ, Laura., Las penas..., op.cit., p. 64.

459 Vid. al respecto la exposición de motivos de la LO 15/2007 de 30 de noviembre donde se indica: "...las penas y consecuencias se incrementan notablemente, en especial, en lo concerniente a la privación del permiso de conducir".

460 La mayor protección de los bienes jurídicos relacionados con la seguridad vial y la vida e integridad física y psíquica de las personas ha conllevado un incremento que ha tenido la utilización de la pena de privación del derecho a conducir en nuestro sistema penal, destacar el incremento de tipos delictivos que acarrean la pena de privación del derecho a conducir (art.379.1, 379.2 y art.383 $\mathrm{CP}$ ) así como las consecuencias derivadas del art.47.3 CP y que han sido destacadas en la Circular
} 
5/2010 de 22 de junio perfiló el ámbito de aplicación de la pena de privación del derecho a conducir, al solucionar uno de los problemas existentes en los delitos contra la seguridad vial en los que se imponía la misma, que era el de la acumulación de penas. A pesar de que en el CP esta circunstancia no era un problema muy extendido coincido con TAMARIT SUMALLA ${ }^{461}$ que era especialmente relevante en los delitos contra la seguridad vial en los que existía una excesiva punición con la imposición de tres penas, siendo siempre imperativa la aplicación de la pena de privación del derecho a conducir ${ }^{462}$.

En el ámbito de los delitos, examinaremos la implementación de la pena de privación del derecho a conducir en los delitos contra la vida e integridad física o psíquica de las personas, así como los delitos contra la seguridad vial. Otro ámbito que nos servirá para determinar la aplicación de la pena de privación del derecho a conducir, es el de las faltas, que tras la reforma operada por la LO 1/2015 de 30 de marzo de reforma del $\mathrm{CP}$ han desparecido por lo que se hará referencia a dicha circunstancia.

\subsubsection{Delitos que conllevan la pena de privación del derecho a conducir vehículos a motor y ciclomotores}

El objetivo de este apartado es identificar los tipos penales que prevén la aplicación de la pena objeto de estudio. No se trata de un análisis pormenorizado de los tipos penales, sino de configurar un mapa de los delitos para los que el legislador ha valorado la adecuación de ser conminados con una pena de privación del derecho a conducir. Interesa pues identificar tales tipos penales e indicar si la aplicación de la pena es facultativa o imperativa, así como la duración de la misma. En primer lugar, analizaremos la aplicación de la pena de privación del derecho a conducir en los delitos contra la vida e integridad física o psíquica de las personas, siendo estos supuestos en los que se habrán producido bien homicidios o lesiones por

10/2011 de la FGE "Sobre criterios para la unidad de actuación especializada del Ministerio Fiscal en materia de seguridad vial", pp.3-4.

${ }^{461}$ En torno a la acumulación de penas vid. TAMARIT SUMALLA, Josep, "Sistema de Sanciones y Política Criminal. Un estudio de Derecho comparado europeo", Revista Electrónica de Ciencia Penal y Criminología (RECPC), 09-06, (2007), p.11, Recurso electrónico disponible en: http://criminet.ugr.es/recpc/09/recpc09-06.pdf (último acceso: 02/11/2020).

462 Señalar que la aplicación de la pena de privación del derecho a conducir actualmente es más adecuada sobre todo en el delito del art.379 CP, al haberse reducido a través de la fórmula de la alternatividad lo que podía considerarse como una excesiva punición. 
imprudencia cometidos con la utilización de un vehículo a motor o ciclomotor ${ }^{463}$. En segundo lugar, estudiaremos los delitos contra la seguridad vial (antes denominados contra la seguridad del tráfico), que con anterioridad a la modificación legislativa del CP operada por la LO 15/2007 de 30 de noviembre, recogían tres conductas en las que se podía imponer la pena de privación del derecho a conducir. Tras la reforma del CP del año 2007, se produjo la modificación de varios tipos penales aumentando los tipos delictivos en los que se aplica la pena de privación del derecho a conducir, y por ende un aumento en el número de sentencias condenatorias que incluyen esta pena. También se hará referencia al nuevo delito de abandono del lugar del accidente que ha entrado en vigor con la LO 2/2019 de 1 de marzo.

\section{a) Delitos contra la vida e integridad física y psíquica}

Los delitos vinculados con la protección de la vida y la integridad física y psíquica de las personas que actualmente prevén la pena de privación del derecho a conducir son el homicidio por imprudencia grave del art.142.1 y menos grave del art.142.2 $\mathrm{CP}$, así como las lesiones por imprudencia grave del art.152.1 CP e imprudencia menos grave del art.152.2 CP, todos ellos cometidos con vehículos a motor o ciclomotor.

El primer delito que estudiaremos es el tipificado en el art.142.1 CP, que regula el homicidio por imprudencia grave cometido con la utilización de un vehículo a motor o ciclomotor ${ }^{464}$. La pena de privación del derecho a conducir en este tipo delictivo tiene un umbral de uno a seis años de duración, siendo idéntica a la prevista en el delito de conducción temeraria del art.380 $\mathrm{CP}^{465}$. La comparativa de ambos tipos penales es interesante en relación con la pena de privación del derecho a conducir, pues su duración es la misma en los casos de homicidio imprudente y en los supuestos de una conducta dolosa como es la conducción temeraria.

\footnotetext{
463 En relación con el ámbito de aplicación de la pena de privación del derecho a conducir, vid. VALEIJE ÁLVAREZ, Inmaculada,"El sistema de penas en los delitos contra la seguridad vial", en AA.VV. Prevención y control..., op.cit., pp.477-478 y especialmente la nota al pie oㅜ 27.

464 Vid. MORALES PRATS, Fermín, "Del homicidio y sus formas", en AA.VV. Comentarios a la Parte Especial del Derecho Penal, QUINTERO OLIVARES, Gonzalo (Dir.), MORALES PRATS, Fermín (Coord.), Ed. Thomson-Aranzadi, Cizur Menor (Navarra), 2011, p. 68-72.

465 En el delito de homicidio por imprudencia grave hemos de señalar que sectores doctrinales propugnan la elevación del umbral mínimo de la pena de privación del derecho a conducir hasta los diez años, aunque personalmente considero dicha propuesta como contraria al principio de proporcionalidad. Vid. MAGRO SERVET, Vicente, "Ciclistas: víctimas de delitos contra la seguridad vial sobre todo en vacaciones", Tráfico y Seguridad Vial, ํㅡ. 219, 2017.
} 
El art. 142.1 CP se ha visto afectado por la reforma operada por la LO 2/2019 de 1 de marzo, ya que el legislador en aras a clarificar lo que ha de considerarse penalmente como imprudencia grave ha determinado que las conductas imprudentes cometidas con vehículo que afecten a la vida o a la integridad de las personas serán consideradas graves cuando concurran alguna de las circunstancias del art. $379 \mathrm{CP}$, es decir, conducción con consumo de alcohol, drogas o con exceso de velocidad en los términos previstos en este precepto ${ }^{466}$. Este cambio legislativo, que objetiviza cuando una imprudencia debe ser considerada como grave, puede acabar comportando a efectos prácticos un aumento las condenas por este tipo penal lo que puede suponer también un incremento de las condenas a la pena de privación del derecho a conducir ya que ésta se ha de imponer de forma preceptiva por el Juzgado o Tribunal si existe una sentencia condenatoria.

Por su parte, el apartado 2이 del art.142, introducido por LO 1/2015 de 30 de marzo, es un subtipo atenuado que castiga el homicidio cometido con vehículo a motor o ciclomotor, por una imprudencia menos grave ${ }^{467}$. Este tipo penal, inicialmente podía pensarse que ocuparía parte del espacio que dejó la despenalización de la falta de homicidio por imprudencia leve del art.621.2 $\mathrm{CP}^{468}$, al compartir alguna característica con esta, como es que la pena de privación del derecho a conducir será de imposición facultativa por el Juzgador, que se aplicará con la pena de multa, así como que únicamente será perseguible a instancia de parte ${ }^{469}$. Sin embargo, se

\footnotetext{
466 Vid. LANZAROTE MARTÍNEZ, Pablo, "El nuevo delito de abandono del lugar del accidente y otras importantes novedades de la inminente reforma del Código Penal en materia de imprudencia", Diario La Ley, no 2650, 2019 y DE VICENTE MARTÍNEZ, Rosario, Siniestralidad vial..., op.cit., pp.59-60 y TAMARIT SUMALLA, Josep Maria, "El nuevo tratamiento legal de la imprudencia y el delito de abandono del lugar del accidente"; Las reformas penales de 2019, QUINTERO OLIVARES, Gonzalo/ MORALES PRATS, Fermín/ TAMARIT SUMALLA, Josep Maria/ GARCíA ALBERO, Ramón, Ed. Aranzadi, Cizur Menor (Navarra), 2019, p.19.

${ }^{467}$ Art.142.2 CP: El que por imprudencia menos grave causare la muerte de otro, será castigado con la pena de multa de tres meses a dieciocho meses. Si el homicidio se hubiera cometido utilizando un vehículo a motor o un ciclomotor, se podrá imponer también la pena de privación del derecho a conducir vehículos a motor y ciclomotores de tres a dieciocho meses.

468 En relación con el debate respecto de la despenalización del homicidio por imprudencia leve cometido con vehículo a motor o ciclomotor en el Proyecto de Reforma del C. Penal del año 2013, vid. VIZUETA FERNÁNDEZ, Jorge, "Novedades del Proyecto de reforma del Código Penal de 2013 en algunos delitos contra bienes jurídicos fundamentales", Diario La Ley, no 8311, 2014.

469 Se ha considerado por un sector doctrinal que el art.142.2 puede ser el "heredero natural" de la antigua falta de homicidio por imprudencia leve del art.621.2. Vid. SUÁREZ-MIRA RODRÍGUEZ, Carlos, "Del homicidio y sus formas", en AA.VV. Comentarios a la Reforma del Código Penal de 2015, GONZÁLEZ CUSSAC, José.L (Dir.), MATALLÍN EVANGELIO, Ángela/ GÓRRIZ ROYO, Elena (Coords.), Ed. Tirant Lo Blanch, Valencia, 2015, pp.485-486. Por el contrario, otro sector doctrinal estima que no está claro que el delito de homicidio por imprudencia menos grave vaya a ocupar el
} 
incrementó el umbral punitivo de este delito en relación con la antigua falta de homicidio por imprudencia leve 470 , dado que la pena de privación del derecho a conducir en el art.142.2 CP tiene una duración de tres a dieciocho meses, en lugar de los tres meses a un año que preveía la falta del art. 621.2 y $4 \mathrm{CP}^{471}$. El tipo del art.142.2 CP siguió la propuesta contenida en el Proyecto de Reforma del Código Penal de 15 de enero de 2007 que propuso la eliminación de la falta de homicidio ${ }^{472}$ y su calificación como delito, y en la configuración que le dio la Ley de 2015 mantiene en el ámbito penal conductas similares a las que estaban reguladas como faltas de homicidio por imprudencia no grave causadas con vehículo a motor o ciclomotor.

Uno de los problemas que suscitó el art.142.2 CP fue la incerteza que generó ab initio la interpretación del tipo penal, pues su redactado introdujo un concepto jurídico novedoso como es la imprudencia menos grave, que es una categoría intermedia entre la imprudencia grave y la leve. Ante la inexistencia de un criterio normativo objetivo de lo que era la imprudencia menos grave, los Juzgados y Tribunales acudieron, además de a la jurisprudencia relacionada, a la Circular 10/2011 y la Instrucción no 3/2006 de la FGE ${ }^{473}$ como criterios para calificar la imprudencia como grave o menos grave y poder aplicar el art.142.2 CP. La estructura del tipo penal del art.142.2 CP y la indefinición para su aplicación, considero que han sido óbices para una mayor aplicación de dicho artículo, lo que ha significado que también se vea reducida la aplicación de la pena de privación del

espacio de la falta de homicidio por imprudencia leve. Vid. FERNÁNDEZ HERNÁNDEZ, Antonio, "Supresión de las faltas y creación de delitos leves", en AA.VV. Comentarios a la Reforma del Código Penal de 2015, GONZÁLEZ CUSSAC, José.L (Dir.), MATALLíN EVANGELIO, Ángela/ GÓRRIZ ROYO, Elena (Coords.), Ed. Tirant Lo Blanch, Valencia, 2015, pp.68-69. En relación a la dificultad para determinar el tipo de imprudencia, vid. DOVAL PAIS, Antonio "El nuevo régimen penal de las imprudencias menos graves y leves", en AA.VV. Comentario a la reforma penal de 2015, QUINTERO OLIVARES, Gonzalo (Dir.), Ed. Thomson Reuters- Aranzadi, Cizur Menor (Navarra), 2015, pp.339340 y RODRÍGUEZ LAINZ, José Luis, "Los nuevos delitos leves de imprudencia menos grave en materia de tráfico: aspectos sustantivos y procesales". Diario La Ley, oㅡ 9392, 2019, pp.4-5.

470 Vid. FERNÁNDEZ HERNÁNDEZ, Antonio, "Supresión de las 152 y creación de delitos leves", en AA.VV. Comentarios..., GONZÁLEZ CUSSAC, José.L (Dir.), MATALLíN EVANGELIO, Ángela/ GÓRRIZ ROYO, Elena (Coords.), op.cit., p.69.

471 Art.621.4 CP: Si el hecho se cometiera con vehículo a motor o ciclomotor, podrá imponerse además la pena de privación del derecho a conducir vehículos a motor y ciclomotores por tiempo de tres meses a un año.

472 Vid. REQUEJO CONDE, Carmen, Delitos relativos..., op.cit., p.148.

473 Circular 10/2011 de la FGE "Sobre criterios para la unidad de actuación especializada del Ministerio Fiscal en materia de seguridad vial", pp.83-89 e Instrucción 3/2006 sobre criterios de actuación del Ministerio Fiscal para una efectiva persecución de los ilícitos penales relacionados con la circulación de vehículos a motor, pp.7-10. 
derecho a conducir en este tipo de conductas ${ }^{474}$. En este sentido hemos de señalar que si bien existen sentencias en las que se ha aplicado el delito del art. 142.2 CP, éstas no son muy numerosas ${ }^{475}$.

La prueba que el art. 142.2 tuvo dificultades para su aplicación ya desde su introducción en el año 2015 es que el legislador ha modificado su redactado a través de la LO 2/2019 de 1 de marzo de reforma del Código Penal en el sentido de asimilar el concepto de imprudencia menos grave a que la acción cometida con el vehículo a motor o ciclomotor sea considerada grave por la LTSV ${ }^{476}$, coincidiendo en concreto de las descritas en el art. 76 de esta norma ${ }^{477}$. Con la modificación realizada considero que puede producirse una mayor aplicación del tipo penal del art. 142.2 CP, lo que redundaría en una extensión de la pena de privación del derecho a conducir, siempre con el hándicap que en dicho precepto su aplicación es facultativa y no preceptiva, lo que ha motivado críticas en el sentido de considerar que su imposición debería ser obligatoria siempre y no quedar al criterio del juzgador $^{478}$.

Por otro lado, la LO 2/2019 de 1 de marzo de reforma del Código Penal ha comportado la introducción de un nuevo artículo que guarda relación con la pena de

\footnotetext{
474 Un ejemplo es la SAP de Madrid, núm. 685/2018, Sección 16a IImo.Sr. Francisco Javier Teijeiro Dacal (TOL6.927.475), en la que se ratifica la condena por un delito de lesiones por imprudencia menos grave pero no se impone la pena de privación del derecho a conducir.
}

475 Vid. SAP de Cádiz, núm. 100/2017, Sección 8ạ, de 23 de marzo de 2017, ponente llmo. Sr. Blas Rafael Lope Vega (TOL6.115.378); SAP de Cantabria, núm. 123/2018, Sección 1ạ, de 23 de marzo de 2017, ponente IIma. Sra. María Gallardo Monje (TOL6.625.867); SAP de La Coruña, núm. 458/2018, Sección 1a , de 27 de septiembre de 2018, ponente IImo. Sr. Alejandro Moran Llorden (TOL6.918.812); SAP de Guipúzcoa, núm. 292/2018, Sección 3á, de 12 de diciembre de 2018, ponente Ilma. Sra. Juana María Unanue Arratibel (TOL7.068.411). En el ámbito del Tribunal Supremo es interesante la STS, núm. 41/2020, Sala Segunda, de 22 de julio de 2020, ponente Excmo. Sr. Antonio Del Moral García (TOL8.036.243), en la que se analiza el concepto de imprudencia menos grave y se acuerda no imponer la pena de privación del derecho a conducir al ser facultativa en el delito tipificado en el art. 142.2 del CP.

476 Vid. MAGRO SERVET, Vicente, “¿Cómo se van a tramitar ahora las reclamaciones por accidente de tráfico en vía penal?”, Diario La Ley no 9370, Sección Doctrina, 5 de marzo de 2019 y DE VICENTE MARTÍNEZ, Rosario, Siniestralidad vial..., op.cit., pp.93-94 y TAMARIT SUMALLA, Josep Maria, "El nuevo tratamiento legal de la imprudencia y el delito de abandono del lugar del accidente"; en Las reformas penales de 2019, op.cit., p.21-22.

477 En este sentido, el criterio del legislador es acudir al art. 76 de la LTSV para determinar cuándo nos hallamos ante una imprudencia menos grave, por lo que considero que la jurisprudencia puede utilizar la norma administrativa para determinar posibles condenas penales. La remisión al art. 76 de la LTSV ha sido criticada por RODRÍGUEZ LAINZ, ya que considera que van a producirse "extensos espacios de impunidad", ya que no todas las posibles imprudencias que puedan ser calificadas penalmente como menos graves están reguladas en el art. 76 o en el art. 77 de la LTSV. Vid. RODRÍGUEZ LAINZ, José Luis, "Los nuevos delitos leves...", op.cit., pp.9-14.

478 Sobre tales críticas véase, DE VICENTE MARTÍNEZ, Rosario, Siniestralidad vial..., op.cit., p.97. 
privación del derecho a conducir. Se trata del art. 142 bis $\mathrm{CP}^{479}$ que establece unas penas agravadas en aquellos supuestos en los que se haya producido una imprudencia grave con el resultado de muerte, permitiendo incrementar en un grado las penas del art. 142.1 CP cuando concurran los requisitos que se determinan en el precepto (muerte de dos o más personas, muerte de una persona y lesiones graves en otras) e incluso el incremento hasta dos grados cuando se cause la muerte de un elevado número de personas. Sin embargo, tal como se ha puesto de manifiesto desde sectores doctrinales, la deficiente redacción del artículo puede generar enormes dificultades para su aplicación, al existir en el mismo diversos conceptos jurídicos indeterminados ${ }^{480}$.

Aparte de en los delitos contra la vida, la reforma de 2019 incide también en los delitos contra la salud. En este sentido, el segundo tipo delictivo relacionado con la vida e integridad física o psíquica de las personas en el que se aplica la pena de privación del derecho a conducir es el regulado en el art.152.1 CP. Este artículo tipifica como delito las lesiones causadas por imprudencia grave en la conducción de un vehículo a motor o ciclomotor. Para estos supuestos la pena de privación del derecho a conducir será impuesta de uno a cuatro años. La duración de la pena de privación del derecho a conducir prevista en el art.152.1 CP es idéntica a la que se establece en los delitos tipificados en los delitos 379 y $383 \mathrm{CP}$, que son de comisión dolosa en contraposición al art.152.1 CP que es de comisión imprudente.

La estructura del delito de lesiones por imprudencia con la entrada en vigor de la LO $1 / 2015$ de 30 de marzo introdujo como novedad el art.152.2, que tipifica las acciones cometidas por imprudencia menos grave con un vehículo a motor 0 ciclomotor y que originen las lesiones de los arts.149 o $150 \mathrm{CP}^{481}$. Del mismo modo que se ha expuesto la dificultad para determinar el alcance de la imprudencia menos grave en el tipo del art.142.2, también el art. 152.2 CP presentó ab initio la

\footnotetext{
479 Art. 142 bis: En los casos previstos en el número 1 del artículo anterior, el Juez o Tribunal podrá imponer motivadamente la pena superior en un grado, en la extensión que estime conveniente, si el hecho revistiere notoria gravedad, en atención a la singular entidad y relevancia del riesgo creado y del deber normativo de cuidado infringido, y hubiere provocado la muerte de dos o más personas o la muerte de una y lesiones constitutivas de delito del artículo 152.1.2.o 3.ำ en las demás, y en dos grados si el número de fallecidos fuere muy elevado.

480 Vid. MAGRO SERVET, Vicente, “¿Cómo se van a tramitar ahora...?. Diario La Ley no 9370, Sección Doctrina, 5 de marzo de 2019 y DE VICENTE MARTíNEZ, Rosario, Siniestralidad vial..., op.cit., pp.101-103.

481 Art.152.2 CP: El que por imprudencia menos grave causare alguna de las lesiones a que se refieren los artículos 149 y 150 será castigado con una pena de multa de tres meses a doce meses. Si los hechos se hubieran cometido utilizando un vehículo a motor o un ciclomotor, se podrá imponer también la pena de privación del derecho a conducir vehículos a motor y ciclomotores de tres meses a un año.
} 
dificultad para concretar jurisprudencialmente el concepto de imprudencia menos grave $^{482}$. En relación con este tipo delictivo es importante destacar que tras la entrada en vigor de la LO 2/2019 de 1 de marzo, la pena que analizamos puede ver ampliada su aplicación, ya que ahora incluye las lesiones del art. $147.1 \mathrm{CP}^{483}$ entre aquellas que pueden dar lugar a observar la concurrencia de una imprudencia menos grave. El art. 152.2 CP prevé la pena de privación del derecho a conducir tiene un umbral de tres meses a un año, duración que coincide con la de las extintas faltas del antiguo art.621 CP.

El tipo del art. 152.2 CP tiene, en relación con la pena de privación del derecho a conducir, la misma estructura que el art. 142.2 CP, ya que en ambos la imposición de dicha pena es de carácter facultativo por el juzgador, equiparándose las dos situaciones en lo relativo a la imprudencia calificada como menos grave.

La LO 2/2019 de 1 de marzo de reforma del Código Penal también ha significado la introducción de un nuevo artículo que guarda relación con la pena de privación del derecho a conducir. Es el art. 152 bis CP, que sigue la misma estructura que el art. 142 bis ya que las penas del art. 152.2 CP se podrán incrementar en uno o dos grados, según concurran los requisitos que se determinan en el precepto.

Considero acertada la previsión de aplicar la pena de privación del derecho a conducir en los delitos tipificados en los arts.142 y 152 CP de lesiones y homicidio imprudente atendiendo a los fines de la misma, ya que el conductor habrá mostrado un desconocimiento de la normativa de tráfico o un mal uso del vehículo a motor o ciclomotor que ha provocado un resultado lesivo o mortal para los usuarios de la vía ${ }^{484}$. La posibilidad de imponer la pena de privación del derecho a conducir es adecuada ya que tanto el homicidio como las lesiones imprudentes que se cometen

\footnotetext{
482 En relación con la problemática de lo que deberá entenderse por imprudencia menos grave, y la necesidad de acudir al auxilio judicial para su determinación vid. DOVAL PAIS, Antonio, "EI nuevo régimen penal de las imprudencias menos graves y leves", en AA.VV. Comentario..., QUINTERO OLIVARES, Gonzalo (Dir.), op.cit., p.343. También un sector doctrinal mantiene que la reforma operada no tiene por objetivo equiparar en términos nominativos la imprudencia menos grave con la imprudencia leve. Vid. CASTRO CORREDOIRA, María/ GUINARTE CABADA, Gumersindo, "La reforma de los delitos de lesiones (arts.147, 152 y 156 CP)", en AA.VV. Comentarios a la Reforma del Código Penal de 2015, GONZÁLEZ CUSSAC, José.L (Dir.), MATALLín EVANGELIO, Ángela/ GÓRRIZ ROYO, Elena (Coords.), Ed. Tirant Lo Blanch, Valencia, 2015, p.494.

$483 \mathrm{La}$ incorporación de las lesiones del art. 147.1 ha merecido la crítica negativa de RODRíGUEZ LAINZ que considera que con la reforma operada los Juzgados de Instrucción pasarán a ser "herramientas de tramitación de siniestros", Vid.RODRÍGUEZ LAINZ, José Luis, "Los nuevos delitos leves...", op.cit., p.3.

${ }^{484}$ En este sentido estoy de acuerdo con lo expresado por TRAPERO BARREALES, María.A., Los delitos..., op.cit., p.560.
} 
con un vehículo a motor o ciclomotor deben ser diferenciados del homicidio y lesiones genéricas y la pena de privación del derecho a conducir tiene que ser aplicada para obtener una respuesta más ajustada a la naturaleza del hecho cometido.

\section{b) Delitos contra la seguridad vial}

En este epígrafe detallaremos los tipos penales previstos en los delitos contra la seguridad vial, tipificados en el Capítulo IV del Título XVII del CP, que acarrean la pena de privación del derecho a conducir.

El primero de los delitos previstos en el Capítulo IV del Título XVII en el que se sanciona con la pena de privación del derecho a conducir es el art.379 CP. El art.379 CP protege la seguridad vial a través de la punición de la conducción con exceso de velocidad, así como la conducción bajo la influencia de alcohol o drogas. La pena de privación del derecho a conducir prevista para ambas conductas es idéntica, por tiempo superior a uno y hasta cuatro años, situando el legislador en plano de igualdad la conducción bajo el consumo de drogas/alcohol y la conducción a velocidad excesiva.

El delito tipificado en el art.379.1 CP, sanciona las conducciones con una velocidad excesiva ${ }^{485}$ y su aprobación con la LO 15/2007, de 30 de noviembre, de reforma del $\mathrm{CP}$, conllevó que se ampliara el ámbito de aplicación de la pena de privación del derecho a conducir a los supuestos de velocidad excesiva. Desde su inicial redactado en el año 2007, el art.379.1 CP determina cuándo una velocidad es considerada delictiva, y para el caso que se rebasen los estándares de velocidad indicados en el tipo, la conducta será merecedora de condena y se impondrá la pena de privación del derecho a conducir por un periodo entre uno y cuatro años. En el momento que conste acreditada dicha conducción superando los límites legales de velocidad establecidos, tras la incoación del procedimiento penal y el

\footnotetext{
485 Art. 379 CP: 1. El que condujere un vehículo de motor o un ciclomotor a velocidad superior en sesenta kilómetros por hora en vía urbana o en ochenta kilómetros por hora en vía interurbana a la permitida reglamentariamente, será castigado con la pena de prisión de tres a seis meses o con la de multa de seis a doce meses o con la de trabajos en beneficio de la comunidad de treinta y uno a noventa días, $y$, en cualquier caso, con la de privación del derecho a conducir vehículos a motor y ciclomotores por tiempo superior a uno y hasta cuatro años. 2. Con las mismas penas será castigado el que condujere un vehículo de motor o ciclomotor bajo la influencia de drogas tóxicas, estupefacientes, sustancias psicotrópicas o de bebidas alcohólicas. En todo caso será condenado con dichas penas el que condujere con una tasa de alcohol en aire espirado superior a 0,60 miligramos por litro o con una tasa de alcohol en sangre superior a 1,2 gramos por litro.
} 
dictado de la sentencia condenatoria se impondrá de forma obligatoria la pena privativa del derecho a conducir puesto que la pena no se contempla en esta ocasión como facultativa. En este tipo penal existe una presunción iuris et de iure ya que el legislador ha considerado que, rebasándose los límites de velocidad establecidos, el bien jurídico seguridad vial ya estará vulnerado ${ }^{486}$.

Después de tres años de la entrada en vigor del tipo del art.379.1 CP, la LO 5/2010 de 22 de junio de reforma del CP, con el objetivo de dotar de una mayor proporcionalidad a las consecuencias penales que se derivan de la comisión de determinados delitos de peligro abstracto ${ }^{487}$, flexibilizó el castigo para los conductores que cometen infracciones menos graves, en las que no se causen accidentes. Para ello el legislador introdujo un criterio de alternatividad en las penas que acompañan a la pena de privación del derecho a conducir, pero en modo alguno ha modificado esta pena que se ha mantenido desde 2007 como de aplicación preceptiva.

La siguiente conducta a la que nos referiremos es la descrita en el art. $379.2 \mathrm{CP}$, que tipifica como delito la conducción bajo la influencia de bebidas alcohólicas o drogas y comporta la aplicación de la pena de privación del derecho a conducir. Este tipo delictivo es por el que más condenas se han producido en los años 2013, 2014, 2015, 2016, 2017, 2018, 2019 y 2020, y por ende en el que se impone en mayor número de ocasiones la pena de privación del derecho a conducir ya que su imposición siempre es imperativa ${ }^{488}$. El art. 379.2 CP, a su vez, se subdivide en dos apartados, detallándose conductas delictivas diferentes y en ambas se acuerda de forma idéntica la pena de privación del derecho a conducir. El primer apartado del art.379.2 CP regula la conducción bajo influencia de bebidas alcohólicas o de drogas, mientras que en el segundo apartado se sanciona la conducción bajo unas tasas objetivas de alcohol en sangre o en aire espirado. Esta estructura ha llevado a considerar el tipo como paradigma de delito formal en el que la pena de privación del derecho a conducir se aplica en todo caso.

\footnotetext{
486 Vid. POLAINO-ORTS, Miguel, "Delitos contra la seguridad vial: visión crítica de la nueva regulación española", en AA.VV. Entre libertad..., op.cit., p.685.

487 Vid. la Exposición de Motivos XXV de la LO 5/2010 de 22 de junio de reforma del CP.

488 En los años 2013, 2014, 2015, 2016, 2017, 2018, 2019 y 2020 se dictaron respectivamente $53.793,58.607,52.523,50.552,51.085,56.173$ y 48.078 sentencias condenatorias por el art.379.2 $\mathrm{CP}$, aunque estadísticamente no se diferencia en los dos subapartados que tiene dicho artículo. En relación con la estadística de sentencias condenatorias por los delitos contra la seguridad vial. Vid. Memoria FGE del año 2014, pp.421-422, Memoria FGE del año 2015, p. 474, Memoria FGE del año 2016, p. 524, Memoria FGE del año 2017, p. 580, Memoria FGE del año 2018, p. 659, Memoria FGE del año 2019, p. 870 y Memoria FGE del año 2020, p. 909.
} 
La aplicación práctica de la pena de privación del derecho a conducir en el tipo penal del art.379.2 CP, apartado primero, que sanciona la conducción con la influencia de drogas tóxicas, sustancias psicotrópicas o estupefacientes, es muy limitada debido a dos factores: el reducido número de controles de drogas que se realizan por los cuerpos policiales y la dificultad de acreditar la influencia de las drogas en la conducción que requiere el tipo penal ${ }^{489}$. En contraposición, en el art.379.2 CP apartado segundo hallamos el ámbito de mayor aplicabilidad de la pena de privación del derecho a conducir, al imponerse en supuestos de conducción con una tasa de alcohol objetivada en aire espirado o en sangre ${ }^{490}$. Del mismo modo que sucede con el tipo del art.379.1 CP, en el tipo del art.379.2 apartado segundo del CP rige una presunción iuris et de iure ya que únicamente acreditando una conducción rebasando la tasa de alcohol establecida para considerar que el conductor está afectado por el alcohol, se puede condenar por este tipo penal e imponer la pena de privación del derecho a conducir.

El segundo de los tipos delictivos relacionados con la seguridad vial en el que se puede imponer la pena estudiada es el art. $380 \mathrm{CP}$, que tipifica como delito la conducción temeraria. La regulación del art.380 CP fue modificada por la LO $15 / 2007$ de 30 de noviembre, ya que anteriormente dicha conducta estaba regulada en el art.381 CP. La modificación más relevante que realizó la LO 15/2007 en el delito de conducción temeraria fue introducir la objetivación del concepto de conducción manifiestamente temeraria, afectando dicho cambio a la aplicación práctica de la pena de privación del derecho a conducir, al producirse una mayor aplicación de la misma ${ }^{491}$. En el apartado segundo del art.380 CP se produce una

489 Vid. PRIETO GONZÁLEZ, Helena María, "Los controles preventivos de drogas: estado de la cuestión", La dogmática penal sobre el asfalto: un enfoque práctico de los delitos contra la seguridad vial, AGÜERO RAMÓN-LLIN, Elena/HIDALGO DE MORILLO JIMÉNEZ, Agustín/ LANZAROTE MARTíNEZ, Pablo/ PRIETO GONZÁLEZ, Helena María, Ed. Comares, Granada, 2012, pp.103-104. Por este motivo por parte del Fiscal de Sala Coordinador de Seguridad Vial se ha remitido en fecha 18 de julio de 2019 un oficio a las Policías Judiciales a los efectos de clarificar los criterios de elaboración de los atestados por presuntos delitos del art. 379.2 CP por conducción bajo la influencia de drogas tóxicas, estupefacientes y sustancias psicotrópicas. Vid. el oficio en: http://siprojefes.com/wp-content/uploads/2019/07/OFICIO A LAS POLICÍAS JUDICIALES.pdf (último acceso: 01/11/2020).

490 En relación a este tipo penal no se puede determinar el número de sentencias que se dictan anualmente por cada apartado, ya que ni las estadísticas del Consejo General del Poder Judicial (en adelante CGPJ) ni de las Memorias de la Fiscalía General del Estado diferencian los dos apartados del art. $379.2 \mathrm{CP}$.

491 A título de ejemplo podemos señalar que, en el año 2006, se incoaron 1514 procedimientos en relación a este delito, mientras que cinco años después, en el año 2011, fueron 3058, es decir, se duplicaron. Vid. Memoria FGE año 2012, p.914. Con posterioridad, el número de procedimientos 
remisión al art.379 CP para objetivar una conducción manifiestamente temeraria en el sentido de que cuando se produzca una conducción con una velocidad excesiva en los términos establecidos en el art. 379.1 y además una tasa de alcohol por encima de 0, $60 \mathrm{mg} / \mathrm{l}$ en aire espirado o 1,2 g/l en sangre. Cuando esta conducción se realice en los términos expuestos anteriormente se podrá imponer la pena de privación del derecho a conducir en los límites establecidos en el apartado primero del art.380, existiendo una presunción iuris et de iure como destaca HIDALGO DE MORILLO ${ }^{492}$. En lo que a la pena objeto de estudio respecta, la misma se configura en el art. 380 como una pena de aplicación prescriptiva y por un tiempo de entre uno y seis años. El vigente art. $380 \mathrm{CP}$, supone un plus punitivo en comparación a las conductas tipificadas en el art.379 CP, ya que la conducción temeraria descrita en el art.380 CP comporta la pena de privación del derecho a conducir por un plazo superior a un año y hasta un máximo de seis por lo que se incrementa en dos años el plazo máximo por el que puede ser impuesta esta pena respecto del art.379 CP.

El tercer tipo delictivo relacionado con la seguridad vial en el que se aplica la pena de privación del derecho a conducir es el art.381 CP, que se corresponde con un tipo especial o agravado de conducción temeraria. En este caso, la conducción se lleva a cabo con desprecio a la vida ajena, lo que supone un mayor desvalor de la conducta descrita en el precedente art. 380 CP. La conducción temeraria agravada del art.381 CP se subdivide en dos apartados. El primero exige, además de la conducta descrita en el art.380 CP, que se haya realizado con manifiesto desprecio hacia la vida ajena, en cuyo caso la pena de privación del derecho a conducir será impuesta por un periodo de entre seis a diez años. El segundo apartado del art.381 CP también sanciona una conducción temeraria con desprecio hacia la vida ajena, pero con una ausencia de peligro concreto para la vida o integridad de las personas, hallándonos ante un subtipo atenuado al reducirse la pena de prisión y de multa a imponer. Este subtipo del art.381 CP es interesante ya que atenúa las penas con las que conmina el delito, a excepción de la duración prevista para la pena de privación del derecho a conducir que coincide con la del apartado primero. La aplicación de la pena de privación del derecho a conducir en el segundo apartado del art.381 CP entiendo que no es acorde con lo establecido en el primer apartado del art.381 CP, ya que, si nos hallamos ante una acción en la que ni la vida ni la integridad de las personas han estado en peligro, la pena de privación del derecho a

incoados por este delito han oscilado entre los 2310 y 2799 , y en el año 2018 han vuelto a niveles del año 2006, incoándose 1553. Vid. Memoria FGE año 2019, p. 869.

492 Vid. HIDALGO DE MORILLO JIMÉNEZ, Agustín, "El delito de conducción temeraria", La dogmática penal sobre el asfalto: un enfoque práctico de los delitos contra la seguridad vial, 
conducir también debería atenuarse. Tras las reformas operadas en el CP en los años 2007, 2010, 2015 y 2019, dicho tipo penal no ha sido modificado a pesar de que en aplicación del principio de proporcionalidad la pena de privación del derecho a conducir también debería haber visto reducido su periodo de imposición. Por lo expuesto, en lo que afecta estrictamente a dicha pena, sí debería procederse a la reforma del apartado segundo del art.381 $\mathrm{CP}^{493}$.

El siguiente artículo del CP que afecta a la pena de privación del derecho a conducir es el art.382 CP, que tras su entrada en vigor en el año 2007 no se correspondía con ningún tipo delictivo concreto, sino que era únicamente una regla concursal, y constaba de un único apartado ${ }^{494}$. Posteriormente, tras la LO 2/2019 de 1 de marzo de modificación del Código Penal, se ha añadido un segundo apartado que es relevante para la aplicación de la pena de privación del derecho a conducir

En lo que se refiere al apartado primero de este artículo, el mismo será aplicable cuando concurran las conductas descritas en los arts.379, 380 o 381 CP y además exista un resultado lesivo, bien sea homicidio o lesiones, en cuyo caso se sanciona la infracción más grave en su mitad superior ${ }^{495}$. La regla concursal del art.382 CP sí afecta a la pena objeto de estudio ya que para calcular la pena a imponer siempre se partirá de la infracción que tenga la pena más grave, en cuyo caso la pena de privación del derecho a conducir también deberá ser impuesta en la mitad superior con el riesgo de aplicación del art.47.3 CP y la posible pérdida definitiva del permiso o licencia ${ }^{496}$.

AGÜERO RAMÓN-LLIN, Elena/HIDALGO DE MORILLO JIMÉNEZ, Agustín/ LANZAROTE MARTíNEZ, Pablo/ PRIETO GONZÁLEZ, HELENA M, Ed. Comares, Granada, 2012, pp.129-131.

493 Sin embargo, CARBONELL MATEU se muestra contrario a una rebaja punitiva del art.381 apartado segundo, ya que estima que debido a la gravedad de la acción que se ha llevado a cabo con el vehículo a motor o ciclomotor, permite que se pueda condenar aún en el caso que no se materialice el peligro concreto, vid. CARBONELL MATEU, Juan Carlos, "La Ley Orgánica de Reforma del Código Penal en materia de seguridad vial: un comentario de urgencia" en AA.VV. Reforma del Código Penal: Respuestas para una sociedad del siglo XXI, BENÍTEZ ORTÚZAR, Ignacio Francisco (Coord.), Ed.Dykinson, Madrid, 2008, p.192.

${ }^{494}$ Acerca de la génesis del art. 382 CP, vid. DE VICENTE MARTíNEZ, Rosario, Siniestralidad vial..., op.cit., pp.113-114.

495 Art.382 CP: Cuando con los actos sancionados en los artículos 379, 380 y 381 se ocasionare, además del riesgo prevenido, un resultado lesivo constitutivo de delito, cualquiera que sea su gravedad, los Jueces o Tribunales apreciarán tan sólo la infracción más gravemente penada, aplicando la pena en su mitad superior y condenando, en todo caso, al resarcimiento de la responsabilidad civil que se hubiera originado.

${ }^{496}$ En relación con el art.382 CP, incluso autores consideran que el citado artículo vulnera el principio "ne bis in idem", al existir una exasperación punitiva en su aplicación, como ha señalado GRIMA LIZANDRA, Vicente, "Los delitos contra la seguridad vial: lectura desde los principios penales", en AA.VV. Prevención y control de la siniestralidad vial. Un análisis jurídico y criminológico, ORTS BERENGUER, Enrique (Coord.), Ed. Tirant lo Blanch, Valencia, 2011, p.136. 
Un aspecto destacable de la regla concursal del art.382 CP es que entrará en juego bien cuando las lesiones hayan sido causadas de forma dolosa con el vehículo a motor o ciclomotor en una conducción temeraria ${ }^{497}$ bien cuando se haya producido un homicidio o lesiones por imprudencia cometidas con la utilización de vehículos a motor o ciclomotores ${ }^{498}$ junto con un delito contra la seguridad vial del art. 379, 380 o 381, por lo que siempre concurrirá un tipo delictivo que prevé la pena de privación del derecho a conducir. Respecto la aplicación del art. 382, el TS en una sentencia del año $2020^{499}$ ha determinado que cuando el resultado lesivo constitutivo de delito sea causado por dolo directo no será de aplicación esta norma concursal y deberán penarse los delitos cometidos en concurso real. El art.382 CP es importante ya que se pueden imponer penas que no sean homogéneas en la regla concursal y en tipos delictivos en los que puede concurrir la pena de privación del derecho a conducir, junto a penas privativas de libertad y que dichas penas se apliquen en todos los tipos delictivos concursados ${ }^{500}$. En estos supuestos, para determinar el tipo penal más grave considero que debe primar como pena más grave aquella que acarrea la pena de prisión más elevada y para el caso que ésta sea idéntica, aquel tipo que conlleve más penas aparejadas a aquella ${ }^{501}$.

Con la entrada en vigor de la LO 2/2019 de 1 de marzo de modificación del Código Penal, el precepto experimentó la introducción de un segundo apartado en el que específicamente se determina que cuando el resultado lesivo concurra con un delito del art. $381 \mathrm{CP}$ se impondrá la pena de privación del derecho a conducir en su mitad superior ${ }^{502}$. En relación a este segundo apartado, si bien las sentencias que

\footnotetext{
497 Vid. la SAP de Barcelona, núm. 336/2013, Sección 6a María Carmen Domínguez Naranjo (TOL3.757.514) y SAP de Madrid, núm. 452/2014, Sección 17ª̣, de 21 de marzo de 2014, ponente Ilma. Sra. Carmen Lamela Díaz (TOL4.360.790).

498 Referente al ámbito de aplicación del art.382 CP, vid. DE VICENTE MARTíNEZ, Rosario, Derecho..., op.cit., p.646 y TRAPERO BARREALES, María.A, "Comentario urgente sobre la reforma penal vial y otros aspectos controvertidos", Revista Electrónica de Ciencia Penal y Criminología (RECPC), 21-11, (2019), p.24.

499 Vid. STS, núm. 350/2020, Sala Segunda, de 25 de junio de 2020, ponente Excmo. Sr. Julián Artemio Sánchez Melgar. (TOL8.001.069).

500 En relación con la forma de aplicar la regla concursal, Ibídem, p. 663 así como la STS, núm. 64/2018, Sala Segunda, de 6 de febrero de 2018, ponente Excmo. Sr. Andrés Martínez Arrieta. (TOL6.508.915).

501 En torno al criterio para determinar la infracción con pena más grave, vid. PALLíN IBÁÑEZ, Gabriela, El impacto..., op.cit., p.175.

502 Art.382, párrafo segundo: Cuando el resultado lesivo concurra con un delito del artículo 381, se impondrá en todo caso la pena de privación del derecho a conducir vehículos a motor y ciclomotores prevista en este precepto en su mitad superior.
} 
se dictan en relación con el artículo 381 son muy reducidas ${ }^{503}$, son casos que sí generan una gran alarma social al ser hechos de mucha gravedad cometidos con vehículo a motor o ciclomotor, motivo por el que puede estar justificada esta reforma que afecta de forma específica a la pena analizada. Sin embargo, algunos autores se han mostrado críticos con la reforma operada, ya que supone un "endurecimiento penológico" y existen otros mecanismos para reducir la siniestralidad ${ }^{504}$.

La finalidad del legislador con la entrada en vigor del apartado segundo del art. 382 $\mathrm{CP}$ es que en determinados supuestos no quede sin aplicar la pena de privación del derecho a conducir. Ello podría suceder en los casos en los que por aplicación del art. $381 \mathrm{CP}$, que requiere dolo eventual, se considerase que el homicidio o lesiones causadas también lo han sido con dolo, por lo que, al remitirnos al tipo doloso de homicidio o lesiones, éste sería el tipo penal más grave y al no conllevar la pena de privación del derecho a conducir ni como pena principal ni como pena accesoria, ésta no se podría imponer en un supuesto que es de gravedad en el ámbito de la seguridad vial ${ }^{505}$. Sin embargo, estimo que este apartado puede ser contrario al principio de proporcionalidad ya que al establecer el tipo penal el término "resultado lesivo", entiendo que puede hacer referencia, bien a lesiones constitutivas de delito leve del 147.2 como cualquier otra lesión de mucha mayor gravedad.

Por otro lado, cabe poner de relieve que ciertos autores han puesto de manifiesto una posible incongruencia en la aplicación práctica de dicho artículo con la finalidad de la reforma operada ${ }^{506}$. Ello sucedería en el caso que se incrementara la pena de privación del derecho a conducir en dos grados en el art. 142 bis CP, y que podría oscilar entre los nueve años y los trece años y medio, mientras que por mor de la aplicación de la regla concursal del art.382 apartado segundo, se debería imponer la pena de privación del art. 381.1 CP que prevé entre los seis y diez años de duración, sensiblemente inferior a la prevista en el art. 142 bis CP.

\footnotetext{
503 Las sentencias condenatorias por el art. 381 CP fueron 101 en el año 2016, 102 en el año 2017, 60 en el año 2018 y 79 en el año 2019. Vid. Memoria FGE, año 2020, p. 870.

504 Vid. MORELL ALDANA, Laura Cristina, Delitos..., op.cit., p. 79.

505 Con relación al apartado segundo del art. 382 CP y la justificación de su entrada en vigor, vid. DE VICENTE MARTÍNEZ, Rosario, Siniestralidad vial..., op.cit., pp.121-122; CASTRO MORENO, Abraham, "Comentario crítico a la LO 2/2019, de 1 de marzo, de reforma del Código Penal, en materia de imprudencia en la conducción de vehículos a motor y ciclomotores: nuevo delito de abandono del lugar del accidente", La Ley Penal, no 138, 2019, pp.18-19 y TRAPERO BARREALES, María. A, "Comentario urgente...", op.cit., p.24-25.

506 La disfunción ha sido destacada por TRAPERO BARREALES, María. A, "Comentario urgente...", op.cit., pp.25-26 y CASTRO MORENO, Abraham, "Comentario crítico...", op.cit., pp.19-20.
} 
Respecto a la posible aplicación de la regla concursal del art.382 CP en relación con las infracciones que eran calificadas como faltas del art. 617 y $621 \mathrm{CP}$ cuando se llevaban a cabo con vehículo a motor o ciclomotor, diversos sectores doctrinales abogaban con acierto su exclusión ${ }^{507}$. En el mismo sentido la FGE en la Circular 10/2011 consideraba que debían excluirse las faltas de la aplicación de la regla concursal del art.382 CP atendiendo a un criterio de gravedad 508 .

El siguiente artículo al que hemos de hacer referencia es el art. 382 bis CP, de aplicación tras la entrada en vigor de la LO 2/2019 de 1 de marzo que tipifica un nuevo delito que se conoce como abandono del lugar del accidente, en el que se pueden imponer como penas principales de forma acumulativa la pena de prisión y la pena de privación del derecho a conducir. La duración máxima de ésta para los hechos causados de forma fortuita es de dos años y de cuatro años para los que sean causados por imprudencia. El nuevo art. 382 bis CP es la culminación de la toma en consideración de la proposición de ley de fecha 30 de junio de 2017, por el Congreso de los Diputados 509 , tras las reclamaciones de algunas asociaciones de víctimas de accidentes de tráfico que habían propugnado la creación de esta figura delictiva desde hace unos años ${ }^{510}$. El delito del art. 382 bis CP tiene un precedente similar en la Ley 122/1962 de 24 de diciembre sobre uso y circulación de vehículos a motor, que en el art. $7^{\circ}$ hacía referencia a la omisión de socorro de los conductores de vehículo a motor ${ }^{511}$, estableciéndose una pena de privación del permiso de

\begin{abstract}
507 Vid. PRIETO GONZÁLEZ, Helena María, "Otros temas de interés", La dogmática penal sobre el asfalto: un enfoque práctico de los delitos contra la seguridad vial, AGÜERO RAMÓN-LLIN, Elena/HIDALGO DE MORILLO JIMÉNEZ, Agustín/ LANZAROTE MARTíNEZ, Pablo/ PRIETO GONZÁLEZ, HELENA M, Ed. Comares, Granada, 2012, p.242; REQUEJO CONDE, Carmen, Delitos relativos... op.cit., p.148 y PALLÍN IBÁÑEZ, Gabriela, El impacto..., op.cit., p.174 y p.207.

508 Vid. en relación con la regla concursal la Circular 10/2011 de la FGE "Sobre criterios para la unidad de actuación especializada del Ministerio Fiscal en materia de seguridad vial". p 36.
\end{abstract}

509 Vid. la proposición de ley en: http://www.congreso.es/public oficiales/L12/CONG/BOCG/B/BOCG12-B-142-1.PDF (último acceso: 14/04/2020).

510 Recurso electrónico disponible en: https://www.europapress.es/sociedad/noticia-ministra-justiciarecibe-lunes-promotora-campana-porunaleyjusta-exciclista-alberto-contador-20180824121641.html (último acceso: 13/12/2020).

En este punto, quiero destacar que en la proposición de ley presentada tuvo una especial relevancia la figura de la Sra. Anna González quien a través de la plataforma change.org, presentó más de 200.000 firmas ante el Congreso de los Diputados. La génesis del artículo vinculada a asociaciones de ciclistas ha sido destacada por RODRÍGUEZ LAINZ, José Luis, "Los nuevos delitos leves...", op.cit., p.1.

511 Recurso electrónico disponible en: http://www.boe.es/boe/dias/1962/12/27/pdfs/A18306-18312.pdf (último acceso: 13/11/2020).

Asimismo, respecto a los antecedentes históricos relacionados con el nuevo delito del art. 382 bis CP, Vid. LANZAROTE MARTÍNEZ, PABLO, "El nuevo delito de abandono...", Diario La Ley, ํㅡ 2650, 2019; TAMARIT SUMALLA, Josep Maria, "El nuevo tratamiento legal de la imprudencia y el delito de 
conducir de dos a diez años ${ }^{512}$, aunque tras la entrada en vigor de la Ley 3/1967 de 8 de abril, sobre modificación de determinados artículos del Código Penal y de la Ley de Enjuiciamiento Criminal, se suprimió el "delito de fuga".

A pesar de que en la doctrina penal española mayoritaria no se había propugnado la incorporación de dicho tipo delictivo al $\mathrm{CP}^{513}$, el TS sí propuso antaño la inclusión de un delito similar, como era el denominado "delito de fuga"514. El Alto Tribunal había establecido que en el Código Penal español no era posible sancionar penalmente a quien deja de auxiliar a una persona ya muerta y huye en busca de la impunidad, por lo que se proponía de lege ferenda sancionar penalmente la fuga del lugar del accidente. Esta propuesta no estaba regulada en el CP ya que éste carecía de una conducta tipificada como "delito de fuga" tal como se hizo referencia desde la doctrina ${ }^{515}$ y existía un vacío sancionador entre el delito de omisión del deber de socorro y el "delito de fuga" ${ }^{516}$. La creación de este tipo delictivo estaría justificada ya que en determinados supuestos en los que el accidente se producía en una zona donde existen personas, no existía una situación de desamparo de la víctima y atendiendo a la jurisprudencia ${ }^{517}$ no se podía imputar al conductor del

abandono del lugar del accidente"; en Las reformas penales de 2019, op.cit., p.27-28 y TRAPERO BARREALES, María. A, "Comentario urgente...", op.cit., pp.37-38.

512 Vid. DÍAZ y GARCíA CONLLEDO, Miguel, "Omisión de socorro a la propia víctima", en AA.VV. Derecho Penal y Seguridad Vial, DE VICENTE MARTínEZ, Rosario (Dir.), Estudios de Derecho Judicial no 114, Ed. Centro de Documentación Consejo General del Poder Judicial, Madrid, 2007, p.21.

513 Sin embargo, existía doctrina minoritaria que sí proponía la inclusión de un "delito de fuga" en el CP. Vid. ROSÓN FERNÁNDEZ, Antonio, "La reforma de los delitos contra la seguridad vial. La L.O. 15/2007", Noticias Jurídicas, (www.noticias.juridicas.com) Julio 2009.

514 Vid. STS, Sección 1ạ, de 5 de abril de 1974, ponente Excmo. Sr. Jesús Sáez Jiménez (TOL4.254.191) y STS, Sala Segunda, de 27 de marzo de 1987, ponente Excmo. Sr. José Hermenegildo Moyna Menguez (TOL2.333.203).

515 En relación con el "delito de fuga" vid. OLMEDO CARDENETE, Miguel, "Omisión del deber de socorro", en AA.VV. Delincuencia en materia de tráfico y seguridad vial. Aspectos penales, civiles y procesales, MORILLAS CUEVA, Lorenzo (Coord.), Ed. Dykinson, Madrid 2007, p.169; DÍAZ y GARCÍA CONLLEDO, Miguel, "Omisión de socorro a la propia víctima", en AA.VV. Derecho Penal..., op. cit., p.56 y también DE URBANO CASTRILLO, Eduardo, "La fuga del lugar del accidente", Revista de Derecho de la Circulación, El Derecho Editores, no 5, Febrero de 2013, pp. 3-7.

516 El llamado "delito de fuga" y sus consecuencias penológicas también fue analizado por el Comité de Ministros del Consejo de Europa. Vid. Recomendaciones y resoluciones del Comité de Ministros del Consejo de Europa en Materia de Justicia. Ministerio de Justicia. Secretaria General Técnica. Centro de Publicaciones, Madrid, 1992, pp.231-232. La relación entre el delito de omisión del deber de socorro y el "delito de fuga" ha sido destacada por GÓMEZ PAVÓN, Pilar, "La reforma de los delitos contra la seguridad vial", Revista Jurídica de la Comunidad Autónoma de Madrid, № 25, 2012, p. 121.

517 Vid. STS, núm. 706/2012, Sala Segunda, de 24 de septiembre de 2012, ponente Excmo. Sr. Antonio del Moral García (TOL2.651.939). 
vehículo la comisión de un delito de omisión del deber de socorro del art. 195 CP, generándose situaciones de atipicidad de estas conductas ${ }^{518}$.

El hecho que el legislador haya previsto en el delito del art. 382 bis CP, la aplicación conjunta de la pena de prisión y la pena de privación del derecho a conducir refuerza la utilidad de ésta en la esfera penal como mecanismo de protección tanto de la seguridad vial como de la vida e integridad física y psíquica de las personas, ya que la conducta del autor de los hechos, que siempre se llevará a cabo con un vehículo a motor o ciclomotor, en mi opinión justifica que dicha acción tenga un reproche penal en su derecho a conducir. En los casos que se aplique, estimo que el nuevo delito de abandono del lugar del accidente en relación a la pena de privación del derecho a conducir tendría fines punitivos y a la vez cumpliría una función preventiva, ya que sancionaría individualmente al conductor que realiza la conducta y además serviría como prevención para que los conductores no realizaran en el futuro la misma acción. En relación con los fines preventivos, TRAPERO BARREALES se muestra crítica con la aplicación de la pena de privación del derecho a conducir en el art. 382 bis $\mathrm{CP}$, en aquellos casos de imprudencia leve o caso fortuito al mantener que no estaría justificada su imposición ${ }^{519}$.

La valoración del nuevo delito del art. 382 bis CP, a priori puede ser positiva, ya que, al ser complementario del delito de omisión del deber de socorro, cubrirá un vacío existente y servirá para ampliar el ámbito de aplicación de la pena de privación del derecho a conducir en los casos en que no quepa la condena por el delito de omisión del deber de socorro ${ }^{520}$. Sin embargo, la mayor aplicación de la pena de privación del derecho a conducir no ha de ir asociada a una mayor aplicación de la pena de prisión, como consideramos que sucede con el nuevo delito del art. 382 bis $\mathrm{CP}$, en el que únicamente se prevé la pena de prisión como pena principal junto a la privación del derecho a conducir. Al haberse inclinado el legislador por esta opción, el sistema penal español puede estar cerrando

\footnotetext{
518 En este sentido vid. MAGRO SERVET, Vicente, "El nuevo delito de fuga del art. 382 CP en la siniestralidad vial", Diario La Ley n 9346, Sección Doctrina, 28 de enero de 2019; LANZAROTE MARTíNEZ, Pablo, "El nuevo delito de abandono...", Diario La Ley, no 2650, 2019 y DE VICENTE MARTÍNEZ, Rosario, Siniestralidad vial..., op.cit., p. 133.

519 Vid. TRAPERO BARREALES, María. A, "Comentario urgente...", op.cit., p.55-56.

520 Destacar que TAMARIT SUMALLA, considera "desafortunado" el nuevo tipo penal del art. 382 bis CP. Vid. TAMARIT SUMALLA, Josep Maria, "El nuevo tratamiento legal de la imprudencia y el delito de abandono del lugar del accidente"; en Las reformas penales de 2019, op.cit., p.34. En la misma línea se muestra muy crítica con el nuevo tipo penal TRAPERO BARREALES, María. A, "Comentario urgente...., op.cit., p.38-56.
} 
alternativas distintas a la pena de prisión, que podrían articularse a través de la pena de privación del derecho a conducir ${ }^{521}$. La combinación de ésta y otras penas restrictivas de derechos, podría devenir un mecanismo idóneo para reducir el uso de la pena de prisión en los delitos relacionados con la utilización de vehículo a motor y ciclomotores ${ }^{522}$.

A continuación, nos referiremos al art.383 CP, que tipifica la conducta relativa a la negativa a someterse a las pruebas de comprobación de tasas de alcoholemia y presencia de drogas. Se trata del segundo tipo de los delitos contra la seguridad vial conminados con la pena de privación del derecho a conducir por el que más sentencias condenatorias se dictan ${ }^{523}$. En mi opinión, el art.383 y el art.47.3 CP fueron la novedad más importante que se produjo en relación con la pena de privación del derecho a conducir tras la reforma operada por la LO 15/2007 de 30 de noviembre. El art. 383 comporta la imposición de la pena de privación del derecho a conducir ${ }^{524}$ por tiempo de entre uno y cuatro años. Este tipo penal podrá aplicarse de forma conjunta con otros delitos contra la seguridad vial que actualmente prevén la pena de privación del derecho a conducir como el art.379 $\mathrm{CP}^{525}$ o el delito del art.380 CP526 concurriendo en ambos en concurso real.

\footnotetext{
521 En este sentido se ha expresado TAMARIT SUMALLA, Josep, "La pérdida definitiva del derecho de conducir o del derecho a la tenencia y porte de armas", en AA.VV. La adecuación..., op.cit.,
} p.125.

522 Acerca de la utilización de la pena de prisión en la criminalidad no violenta, vid. QUINTERO OLIVARES, Gonzalo, "La progresiva renuncia a la prisión y la respuesta ante el delincuente violento y peligroso", en AA.VV. Las sanciones penales en Europa, Revista Aranzadi de Derecho y Proceso Penal, TAMARIT SUMALLA, Josep (Coord.), Ed. Aranzadi, Cizur Menor (Navarra), 2009, pp.105106.

523 En el año 2013 se dictaron 2.553 sentencias condenatorias, en el año 2014, 5.554, en el año 2015, fueron 2.501, en el año 2016 el número fue de 2.384, en el año 2017 fueron 2441 y en el año 2018 fueron 2.797. En relación con la estadística de sentencias condenatorias por los delitos contra la seguridad vial. Vid. Memoria FGE del año 2014, pp.421-422, Memoria de la FGE del año 2015, p. 474, Memoria de la FGE del año 2016, p. 524, Memoria de la FGE del año 2017, p. 581, Memoria de la FGE del año 2018, p. 659 y Memoria de la FGE del año 2019, p. 870.

524 En relación con el incremento de las penas que conllevó la reforma operada por la LO 15/2007, vid. SOLA RECHE, Esteban, "Los viejos problemas de los nuevos delitos contra la seguridad vial", Revista General de Derecho Penal, 10 (2008), p.5. En concreto con el incremento punitivo del art.383 vid. LANDROVE DÍAZ, Gerardo, El nuevo derecho penal, Ed. Tirant lo Blanch, Valencia, 2009 , p.114.

${ }^{525}$ Vid. STS, núm.1/2014, Sala Segunda, de 21 de enero de 2014, ponente Excmo. Sr. Joaquín Giménez García (TOL4.082.880), STS, núm.138/2017, Sala Segunda, de 28 de marzo de 2017, ponente Excmo. Sr. Julián Artemio Sánchez Melgar (TOL5.967.909) y STS, núm. 419/2017, Sala Segunda, de 8 de junio de 2017, ponente Excmo. Sr. Alberto Gumersindo Jorge Barreiro (TOL6.172.049).

526 Vid. la SAP de Asturias, núm. 223/2014, Sección 2ạa de 28 de abril de 2014, ponente Ilmo. Sr. Agustín Pedro Lobejón Martínez (TOL4.406.332). 
La conducta descrita en el actual art.383 CP antes de la entrada en vigor de la LO 15/2007 de 30 de noviembre, estaba ubicada en el antiguo art.380 CP, artículo que realizaba una remisión expresa al delito de desobediencia genérica del art.556 CP y que tipificaba los delitos de desobediencia, en el que no se imponía la pena de privación del derecho a conducir. La actual ubicación permite dotar de coherencia a la reforma operada en el año 2007 y considero lógico que se imponga a los autores del tipo penal la pena de privación del derecho a conducir. Ello es debido a que el tipo delictivo está ubicado con el resto de conductas considerados delitos viarios, a diferencia del antiguo art.380 CP que por remisión al art.556 CP no comportaba la imposición de la pena de privación del derecho a conducir ${ }^{527}$.

El art.383 CP conlleva la imposición de la pena de privación del derecho a conducir a todos los conductores que se negaren a la realización de las pruebas ${ }^{528}$. Si estudiamos el contenido del art.383 $\mathrm{CP}^{529}$, se puede imponer la pena de privación del derecho a conducir por un periodo de uno a cuatro años, siendo idéntico al previsto para la conducta de conducir un vehículo bajo la influencia de alcohol o drogas, con tasas positivas de alcoholemia o rebasando los límites de velocidad legalmente establecidos del art.379 CP. La pena de privación del derecho a conducir salió reforzada después de la reforma operada por la LO 15/2007 de 30 de noviembre, al ser utilizada por el legislador como herramienta para prevenir futuras conductas de negativa a someterse a las pruebas legalmente establecidas. Al equipararse la duración de la pena de privación del derecho a conducir en el art.383 $\mathrm{CP}$ con la establecida en el art.379.2 CP, significa que tiene la misma duración la pena de privación del derecho a conducir en las conductas de circular bajo la influencia de alcohol, con determinadas tasas o bajo la influencia de drogas, que la conducta de negarse a someterse a las pruebas para detectar las mismas.

La regulación y aplicación de la pena de privación del derecho a conducir en el art.383 CP ha sido criticada por TRAPERO BARREALES ${ }^{530}$, al considerar que lo

\footnotetext{
527 Sobre la reforma efectuada en relación con el art. 383 por la LO 15/2007, vid. GONZÁLEZ CUSSAC, José Luis/VIDALES RODRíGUEZ, Caty, "La reforma del Código Penal en materia de seguridad vial", Revista Xuridica Galega, Rexurga, 2007, no 55, pp. 55-56.

528 Relativo a la modificación operada en el art.383 por la LO 15/2007, vid. DE VICENTE MARTíNEZ, Rosario, Derecho..., op.cit., pp.738-740.

529 Art. 383 C.P: El conductor que, requerido por un agente de la autoridad, se negare a someterse a las pruebas legalmente establecidas para la comprobación de las tasas de alcoholemia y la presencia de las drogas tóxicas, estupefacientes y sustancias psicotrópicas a que se refieren los artículos anteriores, será castigado con la pena de prisión de seis meses a un año y privación del derecho a conducir vehículos a motor y ciclomotores por tiempo superior a uno y hasta cuatro años.

530 Vid. TRAPERO BARREALES, María.A., Los delitos..., op.cit., pp.558-560.
} 
que se está llevando a cabo con la conducta del art.383 CP es una desobediencia a los agentes de la autoridad negándose a realizar las pruebas legalmente establecidas. Esta posición doctrinal justifica un mejor acomodo de dicha conducta bien en el art.556 CP, cuya remisión penológica efectuaba el CP con anterioridad a la reforma del CP del año 2007 o bien mantener el actual tipo del art.383 CP suprimiendo la imposición de la pena de privación del derecho a conducir. No obstante, en mi opinión la actual ubicación del precepto resulta más coherente que la existente con anterioridad al año 2007, al regularse todas las conductas que atentan contra la seguridad vial en el mismo Capítulo. Asimismo, considero adecuado que la pena de privación del derecho a conducir se imponga en el tipo del art.383 CP, al tener relación directa con el bien jurídico que protege que es primordialmente la seguridad vial y siempre será impuesta a la persona que estaba haciendo uso de un vehículo a motor o ciclomotor ${ }^{531}$.

Tras las reformas del CP en los años 2007, 2010, 2015 y 2019, la pena de privación del derecho a conducir en el ámbito de los delitos contra la seguridad vial no ha visto reducido su ámbito de aplicación, sino que se ha incrementado, a pesar de que ciertos sectores doctrinales han puesto de manifiesto la necesidad que determinados tipos delictivos sean despenalizados y se remita su sanción al Derecho Administrativo sancionador ${ }^{532}$. Personalmente, soy partidario de mantener los actuales tipos delictivos de los arts. 379, 380, 381, 382 bis y $383 \mathrm{CP}$, ya que atendiendo al principio de ofensividad y a los bienes jurídicos que protegen han de estar en la esfera penal, ya que la respuesta punitiva que se ofrece a través de la aplicación de la pena de privación del derecho a conducir es adecuada. La pena analizada, cuya aplicación se prevé de forma obligatoria en delitos como los anteriormente citados, es una respuesta penal adecuada atendiendo a que las infracciones cometidas con estos delitos atentan a bienes jurídicos de carácter colectivo pero que en numerosas ocasiones también se concretan en bienes jurídicos personales en aquellos casos en los que se produce el resultado final de fallecimiento o de lesionados derivados de la conducción de un vehículo a motor o ciclomotor. El Derecho Penal ha de actuar ante los ataques a los derechos y bienes jurídicos más relevantes de la sociedad, y en los casos en los que se puede

\footnotetext{
531 Vid. TRABADO ÁLVAREZ, Concepción, "Non bis in idem por la condena contra la seguridad del tráfico, alcoholemia y de negativa a someterse a las pruebas de alcoholemia". Diario La Ley, no 7681, 26 de julio de 2011, año XXXII, Ref.D-315.

532 En torno al debate de si las infracciones de tráfico deben recibir sanción penal o administrativa, vid. GANZENMÜLLER ROIG, Carlos/ DE LAMO RUBIO, Jaime/ ROBLEDO VILLAR, Antonio, ESCUDERO MORATALLA, José Francisco y FRIGOLA VALLINA, Joaquín; Delitos..., op.cit., pp.4648.
} 
imponer la pena de privación del derecho a conducir su presencia en el CP estimo que está justificada.

\subsubsection{La despenalización de las faltas por imprudencia e incidencia en la pena de privación del derecho a conducir vehículos a motor y ciclomotores}

Para finalizar el análisis del ámbito de aplicación de la pena de privación del derecho a conducir explicaré los motivos que considero llevaron a la despenalización de las faltas consistentes en lesiones y homicidio por imprudencia leve cometidas con la utilización del vehículo a motor o ciclomotor, tipificadas en el antiguo art. $621 \mathrm{CP}^{533}$, así como también se estudiarán las consecuencias que ello pudo comportar. Ambas faltas estuvieron vigentes hasta la entrada en vigor de la LO 1/2015 de 30 de marzo de reforma del CP, que al suprimir el Libro III del CP supone la despenalización las faltas cometidas por imprudencia leve en las que se imponía la pena que hemos analizado. El legislador parece que ha vuelto al sistema vigente hasta el año 2015 con las faltas de lesiones por imprudencia, ya que tras la entrada en vigor de la LO 2/2019 de 1 de marzo, el art. 152.2 CP, prevé que a título de delito leve puedan sancionarse penalmente las lesiones del art. 147.1 CP causadas por imprudencia menos grave con vehículo a motor o ciclomotor ${ }^{534}$.

Las faltas eran los procedimientos en los que se tramitaban el grupo más numeroso de lesiones y homicidios por imprudencia cometidos con vehículo a motor o ciclomotor, y se podían ventilar conductas imprudentes de carácter leve pero que causaban el fallecimiento de una persona o lesiones de gravedad $^{535}$. La pena de privación del derecho a conducir vehículos a motor y ciclomotores en el ámbito de las faltas tenía una extensión temporal de tres meses a un año de duración, comparativamente inferior con las conductas delictivas, ya que en todos ellos la pena mínima era de un año. A pesar de existir la posibilidad de imponer la pena en

\footnotetext{
533 Artículo 621. 1 CP. Los que por imprudencia grave causaren alguna de las lesiones previstas en el apartado 2 del artículo 147, serán castigados con la pena de multa de uno a dos meses. 2. Los que por imprudencia leve causaren la muerte de otra persona, serán castigados con la pena de multa de uno a dos meses. 3. Los que por imprudencia leve causaran lesión constitutiva de delito serán castigados con pena de multa de 10 a 30 días. 4. Si el hecho se cometiera con vehículo a motor o ciclomotor, podrá imponerse además la pena de privación del derecho a conducir vehículos a motor y ciclomotores por tiempo de tres meses a un año.

534 En este sentido vid. TAMARIT SUMALLA, Josep Maria, "El nuevo tratamiento legal de la imprudencia y el delito de abandono del lugar del accidente"; en Las reformas penales de 2019, op.cit., p.27.
} 
las faltas, la praxis judicial constataba que difícilmente se imponían penas de privación del derecho a conducir que rebasaran el umbral mínimo de los tres meses de duración, aunque se podían juzgar acciones relevantes a los fines de prevención general y especial.

La justificación de dicha despenalización estuvo motivada por la remisión de dichas reclamaciones a la vía civil como se establecía en la exposición de motivos XXII del Proyecto de Reforma del CP donde se desgranaban las causas para la supresión de los Juicios de Faltas ${ }^{536}$. Dicha opción de política criminal ha de ser objeto de crítica, máxime desde el punto de vista de las víctimas de los hechos cometidos con un vehículo a motor o ciclomotor, que vieron como determinadas imprudencias quedaron impunes penalmente y únicamente se ventilaron en un procedimiento civil cuya única finalidad era la económica ${ }^{537}$, donde está vedada la posibilidad de peticionar la pena de privación del derecho a conductor. La conducta que generaba la condena en las faltas de lesiones y homicidio por imprudencia leve siempre se realizaba con un vehículo a motor o ciclomotor, por lo que la pena de privación del derecho a conducir en dichos supuestos tenía una vinculación con los hechos acaecidos y estaba justificada.

Aunque valoro negativamente la despenalización de las faltas de homicidio e imprudencia leve cometidas con vehículo a motor o ciclomotor, he de reconocer que en ambos casos la pena de privación del derecho a conducir se imponía de forma testimonial, y ello por varios motivos. El primero de ellos es que dichas infracciones únicamente se perseguían a instancia de parte y tan sólo en caso de denuncia del ofendido/perjudicado podía incoarse el procedimiento penal. El segundo motivo es que tanto en la falta de homicidio como en las lesiones causadas por imprudencia leve regía el perdón del ofendido por lo que en caso de acuerdo económico con la compañía aseguradora se procedía también a la renuncia de acciones penales y se dictaba auto de archivo. Es decir, únicamente en aquellos casos que se rebasaban ambos filtros y se celebrara Juicio Oral era posible que se realizara una petición de pena de privación del derecho a conducir. Por si dichos obstáculos no fueran pocos,

\footnotetext{
535 En relación a la justificación de la existencia de la pena de privación del derecho a conducir en sede de Juicio de Faltas, destacar la opinión de TRAPERO BARREALES, María.A., Los delitos..., op.cit., p.560.

536 Con relación al proyecto de Ley de Reforma del CP, vid. lo relativo a la supresión de los Juicios de Faltas: http://www.congreso.es/public oficiales/L10/CONG/BOCG/A/BOCG-10-A-66-1.PDF (último acceso: 14/04/2020).

537 El debate sobre la delimitación entre la imprudencia penal y la culpa extracontractual, ya fue puesto de relieve por VELÁZQUEZ VIOQUE, David, El juicio de faltas por imprudencia en la seguridad vial, Ed. Bosch, Sabadell (Barcelona), 2008, p.42.
} 
había que sumar el motivo más relevante de la escasa aplicación de la pena objeto de investigación en las faltas: únicamente se imponía con carácter facultativo por el Juzgador ${ }^{538}$. Esta circunstancia suponía que para la imposición de la pena de privación del derecho a conducir ésta debía fundamentarse debidamente ${ }^{539}$, a diferencia de lo que ocurría con su aplicación en sede de delitos donde siempre tenía carácter imperativo y sólo debía motivarse la extensión temporal.

Uno de los posibles factores que coadyuvaron a la desaparición del CP de las faltas de homicidio y lesiones por imprudencia leve causados con vehículo a motor o ciclomotor pudo ser la escasa actividad que en estos procedimientos tenía el Ministerio Fiscal ya que el peso del procedimiento lo llevaba la acusación particular. La pena de privación del derecho a conducir tenía una reducidísima aplicación en estos procedimientos ya que los herederos de la persona fallecida, en los casos de homicidio, así como los lesionados, cuando se alcanzaba un acuerdo indemnizatorio, mayoritariamente procedían a renunciar a la acción penal ${ }^{540}$. La renuncia suponía que el proceso penal quedaba archivado y no existía la posibilidad de celebrar Juicio Oral en el que se pudiera imponer la pena de privación del derecho a conducir, produciéndose lo que REQUEJO CONDE ha denominado el "proceso de privatización de los accidentes de tráfico"541.

La creación de la Fiscalía de Seguridad Vial ${ }^{542}$ tuvo un impacto escaso en la aplicación de la pena de privación del derecho a conducir en sede de faltas debido a que no se produjeron las reformas legislativas oportunas para que la dirección del proceso no la llevase la acusación particular en exclusiva, y dotar de preeminencia a la actuación del Ministerio Fiscal. Si realizamos un análisis de los motivos de la supresión de las faltas del art.621 CP en las que se aplicaba la pena de privación del derecho a conducir, valoro que el legislador no supo dotar de mecanismos legales para que la Fiscalía persiguiera de oficio dichas lesiones y homicidios causados por imprudencia leve. De haber existido mayores medios en la Fiscalía,

\footnotetext{
538 Vid. TAMARIT SUMALLA, Josep/ LUQUE REINA, Maㅡ Eulàlia, Automóviles, delitos y penas..., op.cit., p.130 y también TAMARIT SUMALLA, Josep," La pérdida definitiva del derecho de conducir o del derecho a la tenencia y porte de armas", en AA.VV. La adecuación... op.cit., p.125.

539 Referente a la obligación de fundamentar la pena de privación del derecho a conducir al ser potestativa y no ex lege, vid. la SAP de Valladolid, núm. 792/2002, Sección 2ª , de 31 de octubre de 2002, ponente IImo. Sr. Nicolás Cabezudo Rodríguez (TOL1.539.102).

540 Acerca del funcionamiento de los Juicios de Faltas por imprudencia cometida con vehículo a motor o ciclomotor vid. PALLíN IBÁÑEZ, Gabriela, El impacto..., op.cit., pp.168-169.

541 Vid. REQUEJO CONDE, Carmen, Delitos relativos..., op.cit., p.148.
} 
hubiese aumentado el número de sentencias condenatorias en las que se podría haber impuesto la pena de privación del derecho a conducir a título de falta.

En el ámbito de las faltas también considero que la pena que estudiamos pudo tener una mayor relevancia si, aprovechando la reforma de la LO 15/2007 de 30 de noviembre, se hubiese reformado el art.621 CP en el sentido de prever su aplicación siempre con carácter preceptivo. Ello podría haber contribuido a no trasladar la idea a los conductores que las faltas de lesiones y homicidio por imprudencia leve causadas con vehículo a motor o ciclomotor eran acciones de bagatela y no implicaban una pena importante. Esta era la percepción que podía transmitirse a los conductores que percibían que su acción únicamente recibiría en la sentencia condenatoria una simple multa, lo que era escasamente relevante para los fines de prevención general y especial. Si bien esta reforma legislativa podría haber coadyuvado a una mayor eficacia de la política criminal de seguridad vial, también era lógico que la imposición de la pena estudiada tuviese en los Juicios de Faltas un carácter facultativo. Este era un criterio coherente debido a que los hechos revestían un menor desvalor que aquellos castigados como delito, atendiendo a que la imprudencia que se cometió era de carácter leve, mientras que en los supuestos de imprudencia grave siempre se debía aplicar la pena objeto de estudio.

\subsection{La pérdida de vigencia del permiso o licencia (art.47.3 CP) y su relación con la pena de privación del derecho a conducir vehículos a motor y ciclomotores}

Uno de los elementos particulares de la pena de privación del derecho a conducir es la previsión contenida en el tercer párrafo del art. 47 CP según la cual cuando la pena de privación del derecho a conducir fuera impuesta por un periodo superior a dos años ello comportará la pérdida de vigencia del permiso o licencia que habilite para la conducción. Esta previsión, introducida por la LO 15/2007, plantea algunos problemas, tanto relativos a la naturaleza de la prohibición como de aplicación práctica, que se analizarán en este epígrafe.

El art. 47.3 CP establece un umbral temporal penológico de carácter objetivo que si se rebasa comportará la pérdida de la habilitación para poder conducir vehículos a

\footnotetext{
542 Vid. la referencia a dicho órgano efectuada por CERES MONTÉS, José Francisco, "La reforma del Código Penal en materia de seguridad vial por la LO 15/2007, desde la perspectiva de la
} 
motor y ciclomotores, no siendo necesario ningún otro requisito que el mero dato objetivo relativo a la duración de la pena impuesta ${ }^{543}$. La inclusión del apartado 3 del art.47 $\mathrm{CP}^{544}$, ha supuesto una modificación sustancial en la pena de privación del derecho a conducir vehículos a motor y ciclomotores al introducir una previsión penológica de mayor rigor que ha ampliado los efectos de esta pena ${ }^{545}$.

Los antecedentes del art.47.3 CP podemos situarlos en primer lugar en la Ley 3/1967, de 8 de abril de 1967 sobre modificación de determinados artículos del CP y de la LECrim y en concreto el art. 565 en el que se preveía la pérdida definitiva del permiso tras dos condenas temporales ${ }^{546}$. Además de esta Ley, ha tenido influencia el Decreto 3096/1973 de 14 de septiembre por el que se publica el CP, que contemplaba la posibilidad de privar definitivamente del permiso de conducir por repetición de condenas ${ }^{547}$. La actual regulación del art.47.3 CP también guarda similitudes con la tipificación legal existente hasta la entrada en vigor del CP de 1983 en la que en determinados supuestos se preveía la pérdida definitiva del permiso de conducir ${ }^{548}$.

La identificación de estos antecedentes no exime de valorar los motivos que pudieron influenciar al legislador para decidir su incorporación al CP. En primer lugar, podemos referirnos a la situación existente con anterioridad a la entrada en vigor de la LO 15/2007 que podemos denominar como de una cierta "alarma social vial" tras haber acaecido episodios de conductores infractores que provocaron un

ejecución", La Ley Penal, no 48, 2008, pp.42-62.

543 La pérdida definitiva del permiso o licencia en el ámbito penal ha tenido un devenir cambiante en el CP ya que en ocasiones se ha tipificado dicha consecuencia en el CP, en otras se ha erradicado y en la actualidad las consecuencias del art.47.3 implican su pérdida definitiva, aunque no a título de pena. Respecto de la pérdida definitiva del permiso o licencia, vid. MARTíN UCLES, FRANCISCO, Aspectos Jurídicos y Policiales de la Alcoholemia, Ed. Tirant Lo Blanch, Valencia, 2003, pp.52-53.

544 Art.47.3.CP: Cuando la pena impuesta lo fuere por un tiempo superior a dos años comportará la pérdida de vigencia del permiso o licencia que habilite para la conducción o la tenencia y porte, respectivamente.

545 En relación con la reforma operada vid. GONZÁLEZ CUSSAC, José Luis/VIDALES RODRÍGUEZ, Caty, en "Los nuevos delitos contra la seguridad vial", en AA.VV. Seguridad Vial..., op.cit., p.200. Ambos autores valoran de forma positiva la reforma realizada en el art. $47.3 \mathrm{CP}$ ya que para que se aplique dicho artículo nos hallaremos ante una infracción grave y además el penado estará durante más de dos años sin conducir lo que hace necesario que vuelva a ser examinado para acreditar que posee los conocimientos y habilidades necesarias para conducir un vehículo a motor o ciclomotor.

546 Vid. en: http://www.boe.es/buscar/doc.php?id=BOE-A-1967-5578 (último acceso: 13/11/2020).

547 Vid. en: https://www.boe.es/buscar/doc.php?id=BOE-A-1973-1715, y en concreto los Arts.340, bis a) y 565.1 y 6 CP de 1973, en vigor hasta la reforma operada por la LO 8/1983, de 25 de junio. (último acceso: 13/11/2020).

548 Relativo a la retirada definitiva del permiso, el comentario de LANDROVE DÍAZ, Gerardo, Las consecuencias..., op.cit., p.79. 
gran revuelo mediático ${ }^{549}$. Esta situación inspiró la nueva política criminal de la seguridad vial en España, ya que la sociedad peticionaba que se actuara como mayor contundencia desde el Derecho Penal en los temas relacionados con la seguridad vial ${ }^{550}$. Ello motivó que el legislador considerase que había que utilizar el Derecho Penal para transmitir a la sociedad el mensaje que se iba a actuar con dureza contra los "terroristas viarios" 551 , y el art.47.3 CP podía ser un instrumento "simbólico" 552 que era idóneo para dichos objetivos.

En segundo lugar, haremos referencia al que considero que fue el principal motivo de la entrada en vigor del art.47.3 CP: el hecho que el penado a quien se le aplique este precepto estará durante un lapso temporal muy prolongado sin poder conducir por lo que sus habilidades, aptitudes y pericia podrán verse disminuidas ${ }^{553}$. El legislador creyó que lo adecuado en dichos casos era decretar la pérdida de la vigencia del permiso o licencia y obligar al penado que quisiera volver a conducir a superar determinadas pruebas de conocimientos y aptitudes ${ }^{554}$. De esta forma el penado que ha estado durante más de dos años sin poder conducir estará obligado a volver a poner a prueba sus conocimientos y su pericia al volante ${ }^{555}$, garantizando una mayor seguridad al resto de usuarios de la vía ya que si quiere obtener de nuevo su permiso o licencia tendrá que realizar el curso de sensibilización y reeducación vial ${ }^{556}$. Incluso el Consejo General del Poder Judicial en su Informe al

\footnotetext{
549 Podemos señalar el caso "Farruquito" o el atropello de 30 personas en Oviedo en el 2002, citados en DE VICENTE MARTÍNEZ, Rosario, Derecho..., op.cit., p.53.

550 Con relación a la calificación de "huida insensata al Derecho Penal", vid. DE VICENTE MARTíNEZ, Rosario, Derecho..., op.cit., p.47.

551 Acerca del término "terroristas viarios", vid. la referencia de GARCÍA ALBERO, Ramón, "La nueva política criminal...". op.cit., p.2.

552 En torno al Derecho Penal simbólico vid. RODRÍGUEZ MESA, Ma José,"Las razones del derecho penal. Modelos de fundamentación y legitimación", Revista electrónica de ciencia penal y criminología, (RECPC), 9-10, (2007), p.6. Recurso electrónico disponible en: http://criminet.ugr.es/recpc/09/recpc09-10.pdf (último acceso: 02/11/2020).
}

553 Referente a la falta de pericia vid. DÍAZ SASTRE, CRISTINA, "Tratamiento jurídico-penal de las conductas atentatorias contra la seguridad vial”, Actualidad Jurídica Aranzadi. Año XVIII. № 792.

554 Vid. GONZÁLEZ CUSSAC, José Luis/VIDALES RODRíGUEZ, Caty, "Los nuevos delitos contra la seguridad vial", en AA.VV. Seguridad Vial..., op.cit., p.200.

555 Vid. la opinión de GONZÁLEZ CUSSAC, José Luis, " La reforma penal de los delitos contra la seguridad vial (Proyecto CP 2006)", en AA.VV. Derecho Penal y Seguridad Vial, DE VICENTE MARTíNEZ, Rosario (Dir.), Estudios de Derecho Judicial no 114, Ed. Centro de Documentación Consejo General del Poder Judicial, Madrid, 2007, p.309.

556 Sobre la justificación del art.47.3 vid. SANZ-DÍEZ DE ULZURRUN LLUCH, Marina, "Los nuevos delitos contra la seguridad vial contenidos en la LO 15/2007 de 30 de noviembre", Revista Cuatrimestral de las Facultades de Derecho y Ciencias Económicas y Empresariales, Icade ㄲo 74, mayo-agosto de 2008, p.336. 
Anteproyecto de la Reforma Penal operada por la LO 15/2007 de 30 de noviembre ${ }^{557}$, propuso aplicar los efectos del art.47.3 CP a supuestos que la pena de privación del derecho a conducir no superase los dos años, pero el penado mostrase una evidente peligrosidad para poder conducir ${ }^{558}$.

En tercer lugar, considero que también pudo tener influencia en la entrada en vigor del art.47.3 CP el hecho que el legislador quisiera determinar de forma objetiva cuando un conductor es en sí mismo un riesgo para la seguridad vial al haber protagonizado conductas especialmente lesivas o peligrosas, estableciendo el umbral en los dos años de condena a la pena de privación del derecho a conducir. El art.47.3 CP comparte dicho rasgo de objetivación del riesgo con lo preceptuado en el art.379 CP en relación con las tasas de alcohol y a los límites de velocidad penalmente relevantes, donde también se puede imponer la pena de privación del derecho a conducir. El art.47.3 CP funciona como una suerte de presunción iuris et de iure, ya que los conductores a los que se les aplique no podrán probar que son aptos para conducir, al no admitirse prueba en contra en la aplicación del art.47.3 CP. Al respecto autores como BERNAL MARTíN han señalado que los conductores a los que se les ha aplicado los efectos del art.47.3 CP pueden hallarse ante el ordenamiento penal en una doble situación ${ }^{559}$ : bien desconocen las normas que aprendieron al obtener el permiso o licencia o pese a conocerlas las ignoran, de manera voluntaria. Con estas premisas, además de la pena de privación del derecho a conducir, sí puede estar justificada la aplicación del art.47.3 CP como reproche penal a la actitud individual del conductor.

Pudo haber también motivado la previsión del art. 47.3 CP la voluntad del legislador de mejorar la coordinación de la legislación penal con la administrativa ${ }^{560}$ en lo relativo a las consecuencias administrativas derivadas de la pena de privación del

Recurso electrónico disponible en:

http://revistas.upcomillas.es/index.php/revistaicade/article/view/358/284 (último acceso: 02/11/2020).

557 Recurso electrónico disponible en:

http://www.poderjudicial.es/cgpi/es/Poder Judicial/Consejo General del Poder Judicial/Actividad d el CGPJ/Informes/Informe al anteproyecto de Ley Organica por el que se modifica la Ley $O$ rganica 101995 de 23 de noviembre del Codigo Penal (último acceso: 02/11/2020).

558 En este sentido vid. FERNÁNDEZ PANTOJA, Pilar, "Delitos contra la seguridad del tráfico: la pena de privación del derecho a conducir", en AA.VV. Delincuencia..., op.cit., p.89.

559 Vid. BERNAL MARTíN, LUIS FRANCISCO, "Artículo 47 del C. Penal", en: "Comentarios del art.384 del C Penal”, Actualizad Jurídica Aranzadi, n 755, 3 de julio de 2008.

560 Vid. LANZAROTE MARTíNEZ, Pablo, "Aspectos comunes a los delitos contra la Seguridad Vial", La dogmática penal sobre el asfalto: un enfoque práctico de los delitos contra la seguridad vial, AGÜERO RAMÓN-LLIN, Elena/HIDALGO DE MORILLO JIMÉNEZ, Agustín/ LANZAROTE MARTíNEZ, Pablo/ PRIETO GONZÁLEZ, Helena María, Ed. Comares, Granada, 2012, p.42. 
derecho a conducir cuando se pierde la vigencia del permiso o licencia. Es decir, cuando se decreta la pérdida de la autorización administrativa para conducir según lo previsto en el art. 47.3 CP, es la autoridad administrativa la que se encarga de su ejecución (desde la retirada del permiso o licencia, la realización del curso, etc.) ${ }^{561}$.

Otro motivo que pudo influir en la introducción del art.47.3 CP, fue la armonización con los efectos de la Ley 17/2005 de 19 de julio, conocida como del "carnet por puntos", que regulaba la pérdida de vigencia del permiso o licencia en el ámbito administrativo. Sin embargo, esta influencia es menos evidente pues los efectos del art.47.3 CP provocan la pérdida de vigencia desde el ámbito penal hacia el ámbito administrativo mientras que los efectos del "carnet por puntos" se desarrollan en el ámbito administrativo. En el único aspecto que el art.47.3 CP y la Ley 17/2005 de 19 de julio han tenido un cierto paralelismo es que ambas han configurado un nuevo grupo calificado por la doctrina como "delincuentes de riesgo" 562 , que han generado la comisión de delitos bien al conducir sin el permiso o licencia bien sin los puntos asignados.

Para finalizar podemos destacar que dicho precepto pudo recibir influencia de la legislación penal francesa en lo relativo a la pérdida de vigencia del permiso, ya que en el texto penal francés existe, igual que en nuestro sistema penal, tanto la suspensión del permiso, equiparable a nuestra pena de prohibición del derecho a conducir, como la anulación del permiso ${ }^{563}$. Esta consecuencia punitiva reflejada en la legislación penal francesa pudo influir en el redactado del art.47.3 CP, ya que, si bien el CP no se refiere a la anulación del permiso, sí regula la pérdida de vigencia, lo que las hace equiparables.

Una vez analizados los posibles antecedentes legislativos, así como los motivos o causas que pudieron llevar al legislador a la aprobación del art. 47.3 CP, estudiaremos el contenido de dicho artículo. En primer lugar, en cuanto al ámbito personal el art. 47.3 CP únicamente afectará a los conductores que con carácter

\footnotetext{
561 Con la articulación de dicho sistema se ha mejorado la ejecución de la pena de privación del derecho a conducir y se ha reducido la impunidad de muchos conductores que con anterioridad al año 2007 podían "burlar" el correcto cumplimiento de dicha pena como reconoció la FGE, en la Memoria anual del año 2008, p.688.

562 Vid. la referencia de FERNÁNDEZ PANTOJA, Pilar, "Delitos contra la seguridad del tráfico: la pena de privación del derecho a conducir", en AA.VV. Delincuencia..., op.cit., p .90.

563 En este sentido vid. CARDENAL MONTRAVETA, Sergi, "La protección penal de la seguridad vial", en AA.VV. Seguridad Vial y Derecho Penal. Análisis de la LO 15/2007, que modifica el Código Penal en materia de Seguridad Vial, MIR PUIG, Santiago y CORCOY BIDASOLO, Mirentxu (Dirs.) / CARDENAL MONTRAVETA, Sergi (Coord.), Ed. Tirant lo Blanch, Valencia, 2008, p.22.
} 
previo a la comisión del hecho delictivo sí poseían permiso o licencia, ya que a los conductores que carecían de ellos, sólo se les privará del derecho a conducir por tiempo superior a dos años y no podrá aplicarse el art.47.3 CP. Sin embargo, existe alguna resolución en la que también se ha aplicado el art. 47.3 a los conductores penados que no poseían permiso o licencia, acordándose la pérdida en el caso que lo obtuvieran durante el tiempo de la condena, cosa que formalmente es imposible ${ }^{564}$. En segundo lugar, es importante destacar que lo esencial del contenido del art.47.3 CP está ligado a una condena a la pena de privación del derecho a conducir por un plazo superior a dos años lo que comportará la pérdida definitiva del permiso o licencia y que el penado no podrá volver a conducir únicamente con el cumplimiento de dicha pena ${ }^{565}$, sino que debe someterse a las pruebas legalmente establecidas para volver a obtener la autorización que le habilite para conducir. La superación de estas pruebas le servirá para obtener un nuevo permiso o licencia y con ello se podrá acreditar que posee los conocimientos y habilidades suficientes para conducir sin ser un riesgo para la seguridad vial ${ }^{566}$. El contenido del art.47.3 CP podemos relacionarlo con lo que la doctrina ha denominado "diversificación de las consecuencias jurídicas" 567 , ya que las consecuencias de la pena de privación del derecho a conducir serán diferentes en función de la duración temporal que se imponga en la sentencia dictada, al establecerse un umbral de dos años para que el citado precepto se aplique. Aquellos conductores cuya pena de privación del derecho a conducir no supere dicho umbral no se verán afectados por el art.47.3 CP. Sin embargo, quienes lo rebasen verán cómo se produce un endurecimiento de las consecuencias jurídicas

\footnotetext{
564 En este sentido podemos destacar la SAP de Castellón, núm. 231/2016, Sección 2ª , de 11 de octubre de 2016, ponente IImo. Sr. Horacio Badenes Puentes (TOL5.934.981), que confirma la sentencia dictada en primera instancia por el Juzgado de lo Penal n 3 de Castellón.

565 Las consecuencias prácticas del art.47.3 tras la reforma operada por la LO 15/2007 han sido destacadas por DE VICENTE MARTÍNEZ, Rosario, en "Seguridad Vial y Derecho Penal. En especial el homicidio imprudente cometido con vehículo a motor", Abogacía, № 1, 2009, pp.101-130.

566 Comparto la referencia al respecto de MOLINA GIMENO, Francisco Javier, "Delitos contra la Seguridad Vial. Comentarios a la reforma del Código Penal operada por la LO 15/2007 de 30 de noviembre ", Revista El Ligall, II.lustre Col.legi d’Advocats de Granollers, no 41, Año 2008.

567 En este sentido vid. CORCOY BIDASOLO, Mirentxu, "Homicidio y lesiones en el ámbito viario. Problemática concursal entre los delitos contra la seguridad en el tráfico y los resultados lesivos a ellos imputables", en AA.VV. Seguridad Vial y Derecho Penal. Análisis de la LO 15/2007, que modifica el Código Penal en materia de Seguridad Vial, MIR PUIG, Santiago y CORCOY BIDASOLO, Mirentxu (Dirs.) / CARDENAL MONTRAVETA, Sergi (Coord.), Ed. Tirant lo Blanch, Valencia, 2008, p.80.En términos similares también se ha expresado ROBLEDO VILLAR, Antonio, La protección penal de la seguridad vial (configuración de los tipos delictivos tras la LO 15/2007, de 30 de noviembre, sobre modificación del C. Penal), Ed. Ilustre Col-legi d'Advocats de Lleida, 2008, p.71.
} 
de la pena de privación del derecho a conducir ${ }^{568}$, ya que el juez penal decretará la pérdida definitiva de vigencia del permiso o licencia con el dictado de una sentencia que tendrá efectos en la esfera administrativa ${ }^{569}$.

Una vez analizado el contenido del art. 47.3 CP, examinaremos los fines que pueden tener relación con el art.47.3 CP en su aplicación, tanto en el ámbito de los delitos contra la seguridad vial como en los delitos que protegen la vida e integridad física y psíquica de las personas. Las consecuencias del art.47.3 CP podemos relacionarlas con el "Estado de la prevención" 570 , ya que con la pérdida definitiva de la vigencia del permiso o licencia se busca controlar el riesgo potencial que para la sociedad supone el conductor penado con una pena superior a los dos años de privación del derecho a conducir. De esta forma se obliga al penado a volver a realizar todas las pruebas para la obtención de un nuevo permiso o licencia, excluyéndole además formalmente de la posibilidad de conducir vehículos a motor y ciclomotores, lo que incrementa las consecuencias jurídicas que acarrean las condenas por los delitos cometidos con un vehículo a motor o ciclomotor ${ }^{571}$.

Podemos destacar la relevancia del art.47.3 CP desde los fines de prevención general y especial que se asignan a la pena ${ }^{572}$. En cuanto al fin de prevención general es importante el efecto intimidatorio que puede tener el art.47.3 CP ya que implica unas consecuencias funestas para los conductores, por lo que sí puede tener unos fines asociados a la prevención general negativa ${ }^{573}$. A pesar de que ha pasado más de una década desde de entrada en vigor del art.47.3 CP el temor a las consecuencias de la pérdida definitiva del permiso o licencia considero que no está completamente implementado en la sociedad. En la generalidad de los conductores y ciudadanos es difícil que estén totalmente asumidas las consecuencias que puede

\footnotetext{
568 En relación con el agravamiento para la pena de privación del derecho a conducir que ha supuesto el art.47.3 estoy de acuerdo con lo expresado por PIPAÓN PULIDO Jorge Guillermo/ PEDREÑO NAVARRO, Lucía/ BAL FRANCÉS, Edmundo, Los delitos..., op.cit., p.126.

569 Respecto de la ejecución del art.47.3 en la vía administrativa, vid. NUÑO DE LA ROSA AMORES, José Antonio, "Aplicación práctica de la normativa sobre seguridad vial, con especial consideración de las reformas legales más recientes", en AA.VV. Prevención y control de la siniestralidad vial. Un análisis jurídico y criminológico, ORTS BERENGUER, Enrique (Coord.), Ed. Tirant lo Blanch, Valencia, 2011.p.115.

570 Vid. CUESTA PASTOR, Pablo.J, El delito..., op.cit., p.15.

571 Vid. RUSCA NADAL, Oriol, "Reforma del Código Penal: Seguridad Vial. Aspectos básicos de la LO 15/2007", Economist \& Jurist, Febrero 2008, Vol.16, núm. 117, p.28.

572 Vid. TRAPERO BARREALES, María.A., Los delitos..., op.cit., p.561.

573 En el mismo sentido se expresa CARBONELL MATEU, Juan Carlos, "La reforma del tratamiento penal de la seguridad vial", en AA.VV. Delincuencia... op.cit., p.387, y también "La Ley Orgánica de
} 
generar la imposición de una pena de privación del derecho a conducir por plazo superior a dos años. De entre los fines que puede tener el art.47.3 CP, la prevención general negativa es el menos visible ya que la mayoría de conductores desconoce que el umbral de los dos años supone la pérdida definitiva del permiso o licencia, motivado, en mi opinión, por la ausencia de un conocimiento general de dicho precepto penal ${ }^{574}$.

Con respecto a la prevención general positiva no estimo que tenga especial relevancia en los fines del art.47.3 CP ya que difícilmente a través del mismo se va a reforzar la confianza del resto de la sociedad en el Derecho ${ }^{575}$. En el ámbito de la seguridad vial es difícil que se produzca una toma de conciencia por parte de otros conductores $^{576}$, excepto en los casos que se tenga conocimiento directo a través de familiares, amigos, conocidos, etc., Son escasos los procedimientos judiciales con relevancia social y mediática en los que se publicitan las consecuencias del art.47.3 $\mathrm{CP}$ y se informa de la pérdida de la vigencia del permiso o licencia para el condenado ${ }^{577}$. Sin embargo, CARBONELL MATEU ${ }^{578}$ mantenía que la aplicación del art.47.3 CP era una medida alternativa a la pena de prisión para mantener la vigencia del Ordenamiento Jurídico y proteger el bien jurídico de la seguridad vial, siendo calificado incluso como "pena de pérdida del derecho a conducir", por lo que en mi opinión estaba otorgando unos fines de prevención general positiva a los efectos del art.47.3 CP.

El mismo autor también ha destacado la prevención especial como factor de rehabilitación y sensibilización, ya que el penado para volver a obtener el permiso o licencia tendrá que superar los controles que se establezcan en el ámbito administrativo ${ }^{579}$. El penado no sólo se verá privado del derecho a conducir, sino que además perderá la vigencia de dicho permiso, derivándose de esta forma unas consecuencias colaterales que añadirán un plus al elemento aflictivo de la pena de

Reforma del Código Penal en materia de seguridad vial: un comentario de urgencia", Reforma..., op.cit., p.181.

${ }^{574}$ En torno a la eficacia de la prevención general negativa, vid. LESCH, Heiko.H, La función..., op.cit., p 24.

575 Vid. MUÑOZ CONDE, Francisco/GARCÍA ARÁN, Mercedes, Derecho..., op.cit., p.51.

576 En relación con la eficacia de la prevención general positiva vid. LESCH, Heiko.H, La función..., op.cit., p 28.

577 En este sentido podemos citar como última gran sentencia "mediática" en el llamado "Caso Ortega Cano", en la que se ha aplicado el art.47.3, la SAP de Sevilla, núm. 624/2013, Sección 1ª̣, de 11 de diciembre de 2013, ponente Ilma.Sra. María Dolores Sánchez García (TOL4.037.201).

578 Vid. CARBONELL MATEU, Juan Carlos, "La reforma del tratamiento penal de la seguridad vial", en AA.VV. Delincuencia..., op.cit., p.387. 
privación del derecho a conducir. Dado que la aplicación del art.47.3 CP quedará reservada para aquellas conductas de mayor gravedad y frecuentemente asociadas a conductas reincidentes relacionadas con alcohol, drogas y exceso de velocidad, puede ser positiva para la prevención especial y que el penado tome conciencia de la gravedad de su acción.

Las consecuencias que se derivan de la aplicación del art.47.3 CP pueden ocasionar la "muerte civil" del penado580, al comportar la pérdida definitiva del permiso o licencia para conducir. Este hecho origina que en ocasiones se produzca la pérdida del puesto de trabajo y fuente de ingresos económicos del penado, y en estos casos sí podemos detectar una cierta finalidad de prevención especial negativa del art.47.3 CP al poder "eliminar" socialmente al infractor ${ }^{581}$. Debido a la gravedad de las consecuencias del art.47.3 CP su aplicación debería reservarse para los casos de conductores objetivamente peligrosos, y siempre guiada por el al principio de proporcionalidad ${ }^{582}$. Acerca de la adecuación del art.47.3 CP a dicho principio podemos citar el Informe de 27 de noviembre del 2006, del Consejo Fiscal sobre el anteproyecto de Ley Orgánica por el que se reforma la Ley Orgánica 10/1995, de 23 de noviembre del Código Penal. El Consejo Fiscal tenía una opinión crítica al considerar que la agravación y las consecuencias del art.47.3 CP podrían ser contrarias al principio de proporcionalidad al suponer un plus con relación a los apartados 1 y 2 . La justificación de la gravedad de la pena impuesta a criterio del Consejo Fiscal carecería de sentido ya que al tener un mayor tiempo de condena es también mayor el tiempo que el penado no puede ejercitar sus derechos.

Para finalizar el análisis de los fines relacionados con el art.47.3 CP invocaremos uno de los postulados enunciados por BECCARIA en relación con el fin de las penas: "El fin pues, no es otro que impedir al reo causar nuevos daños a sus ciudadanos y retraer a los demás de la comisión de otros iguales" ${ }^{253}$. Ello sirve para resumir el espíritu que ha guiado parte de la vigente política criminal de seguridad vial española desde el año 2007 así como también el objetivo y finalidad que motivó

\footnotetext{
579 Ibídem, p.387.

580 Acerca del concepto de "muerte civil" relacionado con las penas privativas de derechos vid. MUÑOZ CONDE, Francisco/GARCÍA ARÁN, Mercedes, Derecho..., op.cit., p.515.

581 Respecto a la prevención especial negativa y la eliminación del actor, vid. RíOS MARTíN, Julián Carlos/ SEGOVIA BERNABÉ, José Luis/ PASCUAL RODRÍGUEZ, Esther, Las penas..., op.cit., p. 26.

582 En relación con el principio de proporcionalidad, vid. la STC, núm. 62/1982, Sala Primera, de 15 de octubre de 1982, ponente Excmo. Sr. Rafael Gómez-Ferrer Morant (TOL79.035).

583 Vid. DE BECCARIA, Cesare, De los delitos..., op.cit., pp.45-46.
} 
la entrada en vigor del art.47.3 CP584, tanto en relación con fines de prevención especial como general.

\subsubsection{Discusión sobre la naturaleza penal o administrativa de la pérdida de vigencia del permiso o licencia}

A continuación, se analizará la naturaleza jurídica del art.47.3 CP con el objetivo de concretar si es una pena o una consecuencia administrativa derivada de la pena de privación del derecho a conducir, realizándose referencias a las posiciones doctrinales y a la jurisprudencia para finalizar con la toma de posición.

En primer lugar, podemos señalar que existen posiciones doctrinales favorables a considerar el art.47.3 CP como una pena. Entre los autores destacados cabe citar a CARBONELL MATEU ${ }^{585}$ quien, en relación con la naturaleza jurídica del redactado del art.47.3 en el Proyecto de Reforma del año 2006, lo calificaba como pena, descartando que pudiera ser calificada como medida de seguridad y consideró que era una medida alternativa a la pena de prisión para mantener la vigencia del Ordenamiento Jurídico y proteger el bien jurídico de la seguridad vial, calificándolo como "pena de pérdida del derecho a conducir"586. En el mismo sentido TRAPERO BARREALES ${ }^{587}$ afirma que si la pena de privación del derecho a conducir supera los dos años incluye un nuevo elemento en la pena que es la pérdida de la vigencia del permiso o licencia, ya que el art.47.3 CP forma parte de la pena principal, calificándolo como un "nuevo efecto de la pena de privación del derecho a conducir vehículos a motor o ciclomotores"588. Con esta definición se establece una relación directa del art.47.3 CP con la pena de privación del derecho a conducir al estimar que aquel artículo es un efecto directo de esta. También puede señalarse en este sentido la opinión de la FGE plasmada en la Circular 10/2011 de la FGE que

\footnotetext{
584 De esta opinión es MIRÓ LLINARES, Fernando para quien el art.47.3 CP es uno de los más claros ejemplos de la finalidad actual del moderno Derecho Penal de la Seguridad Vial. Vid. "El moderno derecho penal vial y la penalización de la conducción sin permiso", Indret, Revista para el análisis del Derecho, № 3, 2009, p.10. Recurso electrónico disponible en: http://www.indret.com/pdf/649.pdf (último acceso: 03/11/2020).

585 Vid. CARBONELL MATEU, Juan Carlos, "La reforma del tratamiento penal de la seguridad vial", en AA.VV. Delincuencia..., op.cit., p.387.

586 Ibídem, p.387.

587 Vid. TRAPERO BARREALES, María.A., Los delitos..., op.cit., p.572.

588 Ibídem.p.560.
} 
establece que la naturaleza jurídica del art.47.3 CP es asimilable a las penas accesorias $^{589}$.

Existe otra posición doctrinal en relación con la naturaleza jurídica del art.47.3 CP defendida por GONZÁLEZ CUSSAC y VIDALES RODRÍGUEZ que lo califican como equivalente a la pena de inhabilitación ${ }^{590}$, por lo que también tiene relación con las penas accesorias, ya que priva al penado de conducir, le imposibilita el poder obtener el permiso o licencia y se le cancela definitivamente la autorización para conducir al remitir testimonio de la sentencia penal a la autoridad administrativa.

Sin embargo, tras haber examinado las posiciones favorables a considerar el art.47.3 CP como pena, citaremos argumentos doctrinales y jurisprudenciales que defienden que no se puede calificar el art.47.3 CP como pena, sino como consecuencia administrativa. En este sentido SÁNCHEZ MORENO591 señala que no nos hallamos ante una pena sino ante una consecuencia administrativa de la pena de privación del derecho a conducir. En efecto, uno de los argumentos citados para no considerar la pérdida de vigencia del permiso del art.47.3 CP como pena es que la única persona que puede decretar la pérdida de vigencia es el Jefe de Tráfico de la provincia ${ }^{592}$, lo que excluye al Juez o Magistrado que dicta la sentencia condenatoria. Éste no podrá dejar sin efecto en el ámbito penal un documento expedido en el ámbito administrativo ya que no puede imponer como pena la privación definitiva del permiso o licencia que sería análogo a la pérdida definitiva que preceptúa el art.47.3 CP, al no existir en ningún tipo delictivo una pena privativa de derechos que conlleve la pérdida del permiso o licencia a perpetuidad ${ }^{593}$. En la misma línea REQUEJO CONDE594 define el art.47.3 CP como: "sanción administrativa, consecuencia de segundo grado, que da derecho a un procedimiento autónomo". Esta calificación del art. 47.3 CP como una sanción administrativa "de segundo grado" significa que deriva directamente de la pena de privación del

\footnotetext{
589 Circular 10/11, sobre criterios para la unidad de actuación especializada del Ministerio Fiscal en Materia de Seguridad Vial, p.71.

590 Vid. GONZÁLEZ CUSSAC, José Luis/VIDALES RODRÍGUEZ, Caty, "Los nuevos delitos contra la seguridad vial", en AA.VV. Seguridad Vial..., op.cit., p.200.

591 Vid. SÁNCHEZ MORENO, José, Conducción bajo la influencia de bebidas alcohólicas. Biblioteca básica de práctica procesal penal, Ed. Bosch, Barcelona, 2010, p.46.

592 Vid. Art.36.9 del RGCon: La competencia para declarar la pérdida de vigencia de las autorizaciones corresponde al Jefe de Tráfico de la provincia en cuyo territorio se haya detectado la presunta carencia de los requisitos exigidos, sin perjuicio de que pueda delegar esa competencia en los términos previstos en la Ley 30/1992, de 26 de noviembre.

593 Referente a la no consideración como pena, vid. SAP de Barcelona, núm. 99/2009, Sección 2ª , de 16 de febrero de 2009, ponente IIma.Sra. Mํㅡㄹ José Magaldi Paternostro (TOL1.582.845).
} 
derecho a conducir pero que genera un procedimiento administrativo autónomo diferente a un proceso penal y que será el Jefe Provincial de Tráfico quien decretará la pérdida del permiso o licencia.

Otro argumento para negar la naturaleza de pena del art.47.3 CP es el contenido de los arts.54 a $57 \mathrm{CP}$ que regulan las penas accesorias. Si analizamos dichas penas, en modo alguno el art.47.3 CP y sus consecuencias jurídicas puede ser calificado como una pena accesoria ya que la específica situación que se deriva de los delitos que acarrean la imposición de la pena de privación del derecho a conducir y el art.47.3 CP no encuentra encaje en la regulación de las penas accesorias, ni en su modalidad de penas accesorias propias ni de penas accesorias impropias ${ }^{595}$.

También por la jurisprudencia se ha descartado que el art.47.3 CP sea una pena accesoria y se ha optado por calificarlo como "consecuencia administrativa de la pena impuesta", que es la de privación del derecho a conducir vehículos a motor y ciclomotores ${ }^{596}$.

A pesar de la complejidad del tema, considero que, la pérdida de vigencia del permiso o licencia por aplicación del art.47.3 CP no puede ser calificada como pena y ello por diversos motivos. En primer lugar, el permiso o licencia sí se pueden perder definitivamente pero el derecho a conducir únicamente queda privado temporalmente pudiéndose de nuevo ejercer al transcurrir la pena y tras aprobar las pruebas establecidas. Es importante destacar dicha diferencia para mantener en dos ámbitos diferentes las consecuencias del art.47.3 CP y la pena de privación del derecho a conducir, ya que ésta nunca puede ser impuesta con carácter definitiva, sino que siempre ha de tener una limitación temporal como establece el art.33 CP. En segundo lugar, para que el art.47.3 CP tenga eficacia ha de existir un pronunciamiento jurisdiccional penal que desplegará sus consecuencias en el ámbito administrativo. Éste podría ser un argumento para calificar las

\footnotetext{
594 Vid. REQUEJO CONDE, Carmen, Delitos relativos..., op.cit., p.112.

595 Al respecto vid. CERVELLÓ DONDERIS, Vicenta, "Consecuencias jurídicas de las infracciones penales: las penas", en AA.VV. Esquemas de Teoría Jurídica del delito y de la pena, QUINTERO OLIVARES, Gonzalo et al. (Dir.) Tirant lo Blanch, Valencia, 2010, pp.219-220.

596 Vid. SAP de Tarragona, núm. 528/2010, Sección 2ª , de 18 de noviembre de 2010, ponente Ilma.Sra. María De Los Ángeles Barcenilla Visus (TOL2.060.382). Una prueba que el art. 47.3 CP es una consecuencia administrativa de la pena de privación del derecho a conducir es que en las sentencias en las que se aplica se acuerda remitir testimonio de la misma a la Jefatura Provincial de Tráfico correspondiente para sus efectos en el ámbito administrativo. Vid. SAP de Navarra, núm. 205/2019, Sección 1ạ, de 13 de septiembre de 2019, ponente llma. Sra. María Esther Erice Martínez (TOL7.568.572) y SAP de Barcelona, núm. 982/2019, Sección 22a ${ }^{\mathrm{a}}$, de 12 de diciembre de 2019, ponente Ilmo. Sr. Mariano David García Esteban (TOL7.811.798).
} 
consecuencias del art.47.3 como pena al ser una previsión regulada en el CP que ha de ser acordada por el juez penal, aunque ello no puede sustituir la ausencia de cobertura legal en el CP que califique a la pérdida de vigencia del permiso o licencia como pena. En tercer lugar, el hecho que el art.47.3 CP se encuentre insertado en el Libro I, Título III, Capítulo primero, no ha de generar obligatoriamente su calificación jurídica a título de pena. Su inclusión en dicho apartado del CP puede explicarse desde el convencimiento de considerar que el art.47.3 CP regula los efectos de una pena, que en nuestro caso es la pena de privación del derecho a conducir. Si nos ceñimos al principio de legalidad penal no hallamos en el CP la pérdida de vigencia del permiso o licencia como pena, y no cabe su clasificación ni como pena privativa de libertad, ni como pena privativa de derechos, ni como pena de multa ni como pena accesoria al no estar prevista en los arts.33 y $39 \mathrm{CP}$.

Considero discutible la línea doctrinal que considera los efectos del art.47.3 CP como equivalentes a la pena de inhabilitación, ya que el art.47.3 CP no puede ser considerado una pena en sentido estricto. Éste no puede enmarcarse en la inhabilitación absoluta ni tampoco como inhabilitación especial, y únicamente podría ser asimilable a la inhabilitación prevista en el art.45 CP en relación con "otro derecho", en el grupo del resto de inhabilitaciones ${ }^{597}$. Sí considero que ha de cuestionarse si las consecuencias jurídicas del art.47.3 CP pueden calificarse como una pena de inhabilitación especial para el derecho a conducir en el caso de los conductores profesionales que hayan cometido el delito por el que se aplica el art.47.3 CP en el ejercicio de su actividad profesional. Creo que sería de dudosa aplicabilidad bajo la invocación de la vulneración del principio de igualdad, así como de un posible non bis idem en relación con la doble punición, si bien de la lectura de determinadas posiciones doctrinales ${ }^{598}$ puede inferirse que legalmente podría existir cobertura a dicha posibilidad. En la aplicación del art.47.3 CP nos hallamos ante una pérdida definitiva del permiso o licencia como circunstancia añadida a no poder ejercer el derecho a conducir durante el tiempo de la condena mientras que en el art.45 CP en ningún momento se hace referencia a una pérdida definitiva de ningún derecho. Sí existe un reducto por el que podrían asimilarse las consecuencias del art.47.3 CP a la inhabilitación referida del art.45 $\mathrm{CP}^{599}$ en el sentido que únicamente se podría condenar a la inhabilitación de aquellos derechos tipificados en el CP,

597 En relación con la división en grupos de las penas privativas de derechos, vid. MOLINA BLÁZQUEZ Mํa Concepción, La aplicación..., op.cit., p.35.

598 Respecto a la división en grupos de las penas privativas de derechos, Ibídem, p.35.

599 Vid. MOLINA BLÁZQUEZ Mํㅡㄹ Concepción, La aplicación..., op.cit., p.36. 
como en nuestro caso es el derecho a conducir vehículos a motor y ciclomotores, pero es una interpretación muy forzada.

La naturaleza jurídica de la pérdida de vigencia del permiso o licencia ha de ser la de una consecuencia de naturaleza administrativa de la pena impuesta ${ }^{600}$. La pena de privación del derecho a conducir en ningún momento deja sin efecto la vigencia del permiso o licencia, sino que únicamente cuando ésta supere los dos años de duración implicará que se deje sin efecto el soporte documental del derecho que es el permiso o licencia y su vigencia ${ }^{601}$. Por ello, para determinar correctamente la naturaleza jurídica del art.47.3 CP sería recomendable que en ulteriores reformas del CP se definiera en el texto penal si es o no una pena, ya que el actual redactado hemos de calificarlo como "desafortunado"602.

\subsubsection{Cómputo del plazo de los dos años}

Una cuestión conflictiva es la relativa a cómo ha de computarse e interpretarse el requisito del plazo superior a los dos años de pena privación del derecho a conducir, en especial cuando recae sentencia por dos delitos que conllevan esta pena. La cuestión es importante porque para poder aplicar el art.47.3 CP, la pena de privación del derecho a conducir concretada en sentencia condenatoria firme ha de ser superior a dos años, es decir, ha de ser una pena impuesta tras la individualización realizada por el Juzgado o Tribunal603.

Al respecto, MOLINA GIMENO ${ }^{604}$ mantiene que ha de concretarse el cómputo temporal para cada delito y únicamente podríamos sostener la aplicación de la regla

\footnotetext{
600 En este aspecto comparto plenamente el criterio de MOLINA GIMENO, Francisco Javier, "Delitos contra la Seguridad Vial. Comentarios a la reforma del Código Penal operada por la LO 15/2007 de 30 de noviembre ", Revista El Ligall, II.lustre Col.legi d’Advocats de Granollers, № 41, Año 2008.

601 También es partidario de considerar el art.47.3 como una consecuencia administrativa, HIDALGO DE MORILLO JIMÉNEZ, Agustín "Aspectos comunes a los delitos contra la seguridad vial", La dogmática penal..., op.cit., p.10.

${ }^{602}$ Con relación a la crítica del redactado del art.47.3 del C. Penal y lo confuso de su redactado hemos de citar la SAP de Barcelona, núm.99/2009, Sección 2ª a de 16 de febrero de 2009, ponente Ilma.Sra. Mํㅡㄹ José Magaldi Paternostro. (TOL1.582.845).

603 En este sentido ya se expresaba GONZÁLEZ CUSSAC, José Luis, " La reforma penal de los delitos contra la seguridad vial (Proyecto CP 2006)", en AA.VV. Derecho Penal..., op.cit., p. 309, siendo éste el criterio que se ha seguido posteriormente tras la entrada en vigor de la LO 15/2007.

604 MOLINA GIMENO, Francisco Javier para quien únicamente cabe la excepción de la regla concursal del art.382. Vid. "Delitos contra la Seguridad Vial. Comentarios a la reforma del Código Penal operada por la LO 15/2007 de 30 de noviembre", Revista El Ligall, Il.lustre Col.legi d'Advocats de Granollers, ํo 41, Año 2008.
} 
concursal del art.382 CP cuando se produce un resultado lesivo constitutivo de delito. En los casos que proceda la aplicación del art.382 CP, una vez se imponga la pena de privación del derecho a conducir en concurso, la misma sí puede superar el umbral de los dos años de duración ${ }^{605}$. En este supuesto no cabrá un análisis por separado de los dos tipos penales que comportan la pena estudiada ni tampoco valorar si individualmente la pena de privación del derecho a conducir superaba los dos años en cada uno de ellos.

Las Fiscalías de Seguridad Vial se posicionan en el mismo sentido, al determinar que la suma de penas por distintos delitos no comportará la aplicación del art.47.3 $\mathrm{CP}$, con el argumento que tal previsión no aparece expresamente en el CP y no puede realizarse una interpretación extensiva contra el reo. De esta forma tampoco se beneficiaría a quienes hubiesen recibido penas de privación del derecho a conducir en diferentes procesos penales y que todas ellas computarán más de los dos años impuestos como límite en el art.47.3 CP, en detrimento de aquellos conductores que las hubieran recibido en un único proceso. Este criterio se plasmó en la Memoria de la FGE del año 2009, al determinar que no procede la suma de las distintas penas en una misma sentencia a los efectos del art.47.3 CP, sino que se deberá aplicar a cada una de las penas de manera individualizada606. La FGE ha seguido posteriormente la misma línea interpretativa en relación con el cómputo de las penas, ya que la Circular 10/2011 ha establecido que para la aplicación del art.47.3 CP ha de realizarse por cada una de las penas individualmente ${ }^{607}$.

El posicionamiento de la Fiscalía está fundamentado en la inexistencia en el CP de una previsión como la existente en el art.80.2. 2a $\mathrm{CP}$ para las penas privativas de libertad y que pudiera otorgar la posibilidad de sumar las diferentes penas de privación del derecho a conducir. Precisamente el redactado del art. 80.2. 2a $\mathrm{CP}$ puede utilizarse como argumento para sostener que el cómputo de los dos años de la pena de privación del derecho a conducir ha de realizarse de manera individual ya que cuando el legislador ha querido establecer la posibilidad que se puedan

\footnotetext{
605 En este sentido vid. la SAP de Madrid, núm. 683/2015, Sección 2a ponente IImo. Sr. Eduardo de Urbano Castrillo (TOL5.396.459); SAP de Zaragoza, núm. 141/2015, Sección 3ª , de 17 de junio de 2015, ponente Ilmo. Sr. Miguel Ángel López López del Hierro (TOL5.202.957) y SAP de Guipúzcoa, núm. 16/2015, Sección 1ª , de 26 de enero de 2015, ponente Ilma. Sra. María Josefa Barbarín Urquiaga (TOL4.806.366).

606 Memoria FGE, 2009, pp.780-781, en la que se recoge la conclusión no 16, sobre la interpretación del art.47.3 CP, y la totalidad de conclusiones, de las III Jornadas de fiscales delegados especialistas en seguridad vial celebradas en el mes de enero de 2009 en León.

607 Circular 10/11, sobre criterios para la unidad de actuación especializada del Ministerio Fiscal en Materia de Seguridad Vial, pp.72-73.
} 
sumar las penas privativas de libertad para poder valorar la suspensión de las mismas lo ha reflejado en el texto penal. En este sentido podemos destacar que el art. 80.2. 2a sí se refiere a: “...pena o penas impuestas o suma de las impuestas", por lo que estimo que deja abierta la posibilidad de que pueda existir una suma entre las penas privativas de libertad de los diferentes delitos. Sin embargo, a sensu contrario, como nada se indica en el CP al respecto en el art.47.3 CP el silencio del legislador ha de interpretarse de manera favorable al reo y no sumarse las penas de privación del derecho a conducir de diferentes delitos para su aplicación.

También la jurisprudencia se ha posicionado respecto de la interpretación del cómputo de los dos años determinando que se ha de valorar cada pena de manera individual y no la suma de las que se impongan en sentencia ${ }^{608}$. Este criterio es adecuado ya que el art.47.3 CP hace referencia a la "pena impuesta" por lo que no puede partirse de la pena en abstracto del delito sino de la que se imponga en sentencia condenatoria firme, máxime tras la aplicación de la regla del art.66 CP609.

Una consecuencia del art.47.3 CP a la que podemos hacer referencia es la relativa al cómputo del plazo de los dos años en las sentencias condenatorias que el acusado se conforma con la pena solicitada cuando se ejercita la acusación por un delito que comporta una pena de privación del derecho a conducir superior a los dos años. La opción que el penado acepte una sentencia condenatoria de conformidad es relevante ante el Juzgado de Guardia ya que con la reducción de un tercio de la pena solicitada por mor del art.801.2 de la LECrim, se puede evitar la aplicación del art.47.3 $\mathrm{CP}^{610}$. En el resto de casos en los que el penado acepte una sentencia de conformidad con la pena de privación del derecho a conducir y no se tramiten ante el Juzgado de Guardia también podrá evitarse la aplicación del art.47.3 pero pueden existir mayores dificultades ya que no podrá reducirse en un tercio la pena objeto de estudio. En todo caso, a través del trámite de una sentencia condenatoria de conformidad el penado puede llegar a obtener una pena cierta sin la necesidad de

\footnotetext{
608 Vid. la SAP de Girona, núm. 507/2008, Sección 3ạ , de 8 de agosto de 2008, ponente Ilmo. Sr. José Antonio Soria Casao (TOL1.384.137), SAP de Valencia, núm.67/2012, Sección 3â, de 31 de enero de 2012, ponente IImo. Sr Lamberto Juan Rodríguez Martínez (TOL2.532.773), SAP de Cantabria, núm.408/2014, Sección 3a , de 21 de octubre de 2014, ponente llma. Sra. María Almudena Congil Díez (TOL5.574.369) y SAP de Guipúzcoa, núm.32/2017, Sección 1ª̣, de 10 de febrero de 2017, ponente IImo. Sr. Jorge Juan Hoyos Moreno (TOL6.493.403).

609 En este sentido podemos citar con relación al Proyecto de CP de 2006 a GONZÁLEZ CUSSAC, José Luis, " La reforma penal de los delitos contra la seguridad vial (Proyecto CP 2006)", en AA.VV. Derecho Penal..., op.cit., p.309, siendo éste el criterio que se ha seguido posteriormente tras la entrada en vigor de la LO 15/2007.
} 
celebrar el Juicio Oral con la seguridad jurídica que sólo se aplicará el art.47.1 CP, retornándose al penado el permiso o licencia una vez cumplida la condena, actuando los dos años a los que se refiere el art.47.3 CP como un umbral psicológico 611 .

Tras lo expuesto y como conclusión he de señalar que es pacífico el criterio tanto doctrinal como jurisprudencial que para aplicar las consecuencias del art.47.3 CP en relación con el cómputo del plazo de los dos años hay que valorar la pena de privación del derecho a conducir de manera individualizada y no la suma de las diversas penas que se puedan imponer en una misma sentencia condenatoria.

\subsubsection{Efectos de la pérdida de vigencia del permiso o licencia}

En cuanto a los efectos relacionados con el art.47.3 CP, en primer lugar, haremos referencia a los permisos o licencia que se verán afectados tras decretarse la pérdida de vigencia de los mismos acordada en la sentencia penal. La aplicación del art.47.3 CP supondrá para el penado unas consecuencias que van más allá de la privación del derecho a conducir, así como la pérdida del permiso o licencia que le habilitaba para conducir el vehículo con el que cometió el delito. Estas consecuencias las encontramos detalladas en el art.40.3 del RGCon ${ }^{612}$, que regula los efectos administrativos de la declaración de la pérdida de vigencia del permiso 0 licencia cuando se aplica el art.47.3 CP. El art. 40.3 del RGCon determina que se verán afectadas todas las clases de permisos o licencias que posea el conductor penado al que se le haya impuesto una pena de privación del derecho a conducir superior a los dos años de duración.

Los efectos derivados del art.47.3 CP no serán igual de gravosos para todos los penados ya que los conductores profesionales sufrirán la pérdida de todos los

\footnotetext{
610 Vid. MOLINA GIMENO, Francisco Javier, "Delitos contra la Seguridad Vial. Comentarios a la reforma del Código Penal operada por la LO 15/2007 de 30 de noviembre ", Revista El Ligall, II.lustre Col.legi d'Advocats de Granollers, ㄲo 41, Año 2008.

611 Acerca de la conformidad penal del acusado ante el Juzgado de Guardia vid. VARONA GÓMEZ, Daniel, "La suspensión de la pena de prisión: razones de una historia de éxito", Revista Española de Investigación Criminológica, número 17, 2019, p. 27.

612 Art.40.3 del RGCon. La declaración de pérdida de vigencia por haber perdido el titular del permiso o de la licencia de conducción la totalidad del crédito de puntos, o por haber sido condenado a la pena de privación del derecho a conducir vehículos de motor y ciclomotores por tiempo superior a dos años, afectará a todas las clases del permiso o licencia de conducción de que sea titular, así como a cualquier otro certificado, autorización administrativa o documento cuyo otorgamiento
} 
permisos o licencias que posean. El plus punitivo que recae sobre los conductores profesionales o respecto los que posean más de un permiso o licencia es evidente, y puede quebrarse el principio de igualdad al resultar más perjudicado el conductor que posea un número más elevado de permisos o licencias para conducir. Los penados deberán realizar tanto el curso de reeducación vial como los respectivos exámenes de todos los permisos o licencias que poseían, por lo que además del factor tiempo ha de añadirse el factor económico613. Por este motivo, deberían articularse mecanismos para garantizar el principio de igualdad y el principio de proporcionalidad para evitar que quienes posean varios permisos o licencias resulten más perjudicados que los que únicamente poseen uno. Una posible solución sería que el conductor penado sólo perdiera el permiso relativo al vehículo con el que estaba conduciendo en el momento de cometer el delito y de esta forma ensamblar la comisión del delito con el medio utilizado.

En el estudio de los efectos que se derivan de la aplicación del art.47.3 CP, hemos de valorar si es posible que el penado al que se le imponga la pena de privación del derecho a conducir por tiempo superior a dos años puede obtener un nuevo permiso o licencia para poder conducir durante el tiempo de la condena o por el contrario le está prohibido.

Si nos ceñimos al texto del art.47 CP y lo relacionamos con el principio de legalidad penal, no existe prohibición ni expresa ni tácita que impida al penado poder volver a obtener el permiso o licencia aún en el caso que haya perdido su vigencia por aplicación del art.47.3 CP. El redactado del art.47.3 CP no establece interdicción alguna a que el penado que ha sido sancionado con la pérdida definitiva de su permiso o licencia no lo pueda obtener de nuevo durante el tiempo de la condena $^{614}$. El texto del art.47.3 CP no tipifica la prohibición expresa de obtención el permiso o licencia durante el tiempo de la condena, a diferencia de lo que preveía el Anteproyecto de reforma de CP de 2006. Éste, al incluir la prohibición de obtener el permiso en condenas superiores a dos años, estaba añadiendo una pena análoga a la inhabilitación ya que ni se podía conducir ni se podía obtener el permiso o

dependa de la vigencia de la clase o de las clases del permiso o licencia de conducción objeto del procedimiento.

613 Una vez aprobados los exámenes establecidos, los permisos que obtenga serán de la misma clase y antigüedad que el que poseía anteriormente, como establecía la DA $13^{\text {a }}$ de la LTSV y el actual art. 73 de la LTSV. Vid. TRAPERO BARREALES, María.A., Los delitos..., op.cit., p.574.

614 En este sentido se expresa CORCOY BIDASOLO, Mirentxu, "Homicidio y lesiones en el ámbito viario. Problemática concursal entre los delitos contra la seguridad en el tráfico y los resultados lesivos a ellos imputables", en AA.VV. Seguridad Vial..., op.cit., p.94. 
licencia ${ }^{615}$. GONZÁLEZ CUSSAC mantenía que en el Anteproyecto de Reforma del CP de 2006 existía una pena análoga a la inhabilitación ${ }^{616}$ ya que con la redacción del art.47 CP se equiparaba la pena de privación del derecho a conducir a la pena de inhabilitación. En relación con esta afirmación es cierto que tanto las consecuencias del art.47.3 en el anteproyecto de Reforma del CP de 2006 como la pena de inhabilitación compartían la característica de tener consecuencias diferentes y a la vez que dichas consecuencias no eran excluyentes, sino que se aplicaban de manera conjunta ${ }^{617}$.

TAMARIT SUMALLA ${ }^{618}$, destacó antes de la entrada en vigor de la LO 15/2007 de 30 de noviembre, una de las razones por las que el legislador no ha incorporado en el texto penal de 1995 la prohibición expresa de obtener el permiso durante el tiempo de la condena. Según el autor ello radica en el hecho que la pena que se imponga únicamente inhabilita al penado para ejercitar el derecho a conducir, pero no para obtener el permiso o licencia, aunque por otro lado dicha posibilidad resulte del todo inviable. En el mismo sentido QUERALT JIMÉNEZ ${ }^{619}$, señaló que el art.47.3 no impide desde el punto de vista formal del CP que los penados puedan obtener durante el tiempo de la condena la autorización para conducir vehículos a motor ya que el CP nada prohíbe al respecto. Existe una doble fundamentación basada en el CP para acreditar que formalmente no existe impedimento para obtener el permiso o licencia tras la aplicación del art.47.3 CP. El primer argumento es que ninguno de los tipos penales en los que se aplica la pena de privación del derecho a conducir prevé que no pueda hacerlo. El segundo sería que el art.47 CP en ninguno de sus tres apartados prohíbe que el penado pueda volver a obtener el permiso o licencia durante el tiempo de la condena.

\footnotetext{
615 Ibídem.p.80.

616 Vid. GONZÁLEZ CUSSAC, José Luis, “¿Es adecuada la intervención penal en materia de seguridad vial? Líneas básicas del anteproyecto de ley orgánica de reforma del código penal de 2006", en AA.VV. Seguridad del Tráfico: riesgos y respuestas, Academia Galega de Seguridad Pública, Xornadas n 8, Xunta de Galicia, Santiago de Compostela, 2007, p.52.

617 Referente a los efectos del art.47.3 CP y su equivalencia con las penas de inhabilitación vid. GONZÁLEZ CUSSAC, José Luis/VIDALES RODRÍGUEZ, Caty, "Los nuevos delitos contra la seguridad vial", en AA.VV. Seguridad Vial..., op.cit., p.200. En la redacción definitiva de la reforma operada en el 2007 se mantuvo la privación del derecho a conducir, mientras que el texto definitivo eliminó la prohibición de obtener el permiso o licencia durante el tiempo de la condena.

618 Vid. la opinión de TAMARIT SUMALLA, Josep respecto a la no imposibilidad de obtener el permiso durante el tiempo de la condena, "De las penas privativas de derechos", en AA.VV. Comentarios al nuevo..., QUINTERO OLIVARES, Gonzalo (Dir.), MORALES PRATS, Fermín (Coord.), op.cit., p. 380.

619 Vid. QUERALT JIMÉNEZ, Joan J., "El nuevo derecho penal vial: generalidades críticas", en AA.VV. Seguridad Vial y Derecho Penal. Análisis de la LO 15/2007, que modifica el Código Penal en
} 
Sin embargo, la legalidad administrativa impedirá al penado al que se le aplique el art.47.3 CP obtener la autorización para poder conducir durante el tiempo de la condena, puesto que lo único que podrían realizar sería clases prácticas en los centros de formación, pero sin poderse examinar, ya que quien conduce formalmente el vehículo es el profesor de autoescuela al carecer el alumno del permiso o licencia ${ }^{620}$. La respuesta a la cuestión de si el penado al que se le imponga el art. 47.3 CP puede obtener el permiso o licencia durante el cumplimiento de la pena de privación del derecho a conducir es negativa ${ }^{621}$, ya que tanto la LTSV como el RGCon determinan que únicamente puede obtener el permiso o licencia una vez cumplida la condena ${ }^{622}$.

Junto a la normativa administrativa, el art.794.2 de la LECrim especifica que la Jefatura de Tráfico no podrá expedir un nuevo permiso hasta la extinción de la condena, por lo que el penado al que se le impone el art.47.3 CP tendría dos posibilidades:

1) Intentar la obtención el permiso o licencia durante el periodo de cumplimiento de la condena, opción que es inviable ya que en la Jefatura de Tráfico se inscribe la pérdida de vigencia acordada en el procedimiento penal y no podrá obtener nuevo permiso o licencia hasta que no haya cumplido la pena.

2) Que tanto el examen para obtener el nuevo permiso o licencia, así como su expedición se efectúen tras finalizar el cumplimiento de la condena, siendo ésta la única alternativa legal para que los penados a los que se les aplica el art.47.3 CP puedan obtener un nuevo permiso o licencia. Deberán examinarse y obtener el permiso una vez que haya cumplido la condena, no pudiendo ni tan siquiera poder

materia de Seguridad Vial, MIR PUIG, Santiago y CORCOY BIDASOLO, Mirentxu (Dirs.) / CARDENAL MONTRAVETA, Sergi (Coord.), Ed. Tirant lo Blanch, Valencia, 2008, p.71.

620 En relación con la persona que formalmente conduce en las pruebas para obtener el correspondiente permiso vid. TAMARIT SUMALLA, Josep/ LUQUE REINA, Mª Eulàlia, Automóviles, delitos y penas..., op.cit., p.128 así como la LTSV, en su Anexo I, punto I, establece que: "En vehículos que circulen en función de aprendizaje de la conducción, tiene la consideración de conductor la persona que está a cargo de los mandos adicionales".

621 Vid. TRAPERO BARREALES, María.A., Los delitos..., op.cit., pp.574.

622 Vid. Art. 73 LTSV en: https://www.boe.es/buscar/act.php?id=BOE-A-2015-11722 (último acceso: 13/11/2020) y Art.38.4 del RGCon: El titular de una autorización para conducir que haya perdido su vigencia por haber sido condenado a la pena de privación del derecho a conducir vehículos de motor y ciclomotores por tiempo superior a dos años podrá obtener nuevamente un permiso o licencia de conducción de la misma clase de la que era titular y con la misma antigüedad, una vez cumplida la condena y previo cumplimiento de los requisitos exigidos en el texto articulado de la Ley sobre Tráfico, Circulación de Vehículos a Motor y Seguridad Vial. 
realizar el examen teórico durante el periodo de vigencia de la pena de privación del derecho a conducir impuesta.

La ausencia de una prohibición expresa en el CP para obtener el permiso y licencia podría haber sido zanjada simplemente añadiendo en el apartado 3 del art.47 la frase:"... así como la privación del derecho a obtenerlos durante el tiempo de la condena" ${ }^{23}$. En este sentido LTSV sí ha previsto expresamente algo que no prevé el CP y que sería necesario se implementara dicha prohibición por cuestiones de armonización entre la normativa penal y la administrativa. Por ello considero que debería establecerse en el CP la prohibición expresa de obtener el permiso o licencia durante el tiempo de condena en los casos que se aplique el art.47.3 CP, así como se le informase expresamente al penado de la prohibición.

\subsubsection{Toma de posición}

Para finalizar el apartado relativo al art.47.3 CP detallaremos los aspectos que sería necesario someter a debate con la finalidad de mejorar tanto la ejecución de la pena de privación del derecho a conducir como las consecuencias derivadas de aplicación del referido artículo. En primer lugar, para acreditar la importancia que ha adquirido el art.47.3 CP en la pena de privación del derecho a conducir, señalar que el número de sentencias condenatorias dictadas en las que se aplica se ha mantenido estable, incluso con una tendencia descendente en el periodo 2010-2016 en relación con el número total de sentencias condenatorias dictadas en los delitos tipificados en los arts.379, 380, 381 y 383 CP624. Sin embargo, en el año 2017 se produjo un ligero repunte de las sentencias en las que se impuso el art. 47.3 CP625, sufriendo de nuevo un pequeño descenso en los años 2018 y 2019, por lo que tendremos que esperar a los siguientes años para determinar si fue una tendencia 0 únicamente un incremento puntual en un ejercicio ${ }^{626}$. Estos datos podemos

\footnotetext{
623 Vid. GONZÁLEZ CUSSAC, José Luis, " La reforma penal de los delitos contra la seguridad vial (Proyecto CP 2006)", en AA.VV. Derecho Penal..., op.cit., pp.308-309.

624 Las sentencias condenatorias han oscilado en una horquilla entre las 2.060 y 3.500 en las que se ha aplicado cada año la pérdida de vigencia del permiso o licencia por aplicación del art.47.3 CP. Vid. la Memoria de la FGE del año 2013, p.405; año 2014; año 2015, p.483; año 2016, p. 527 y año 2017, p. 584, siendo el año 2016 en el que menos sentencias condenatorias han aplicado el art. 47.3 CP en el periodo 2010-2016.

625 En el año 2017 se acordó la pérdida de vigencia del permiso ex art. 47.3 CP en 2075 sentencias condenatorias. Vid. Memoria de la FGE del año 2018, p. 657.

626 En el año 2018 se acordó la pérdida de vigencia del permiso ex art. 47.3 CP en 1949 sentencias condenatorias. Vid. Memoria de la FGE del año 2019, p. 876 y el año 2019 se acordó la pérdida de
} 
relacionarlos con la posición de TRAPERO BARREALES ${ }^{627}$, que considera que la entrada en vigor del art.47.3 CP fue el aspecto penal más relevante de la reforma operada por la LO 15/2007 de 30 de noviembre, opinión que comparto.

En segundo lugar, cabe destacar las predicciones efectuadas en el año 2007 por FERNÁNDEZ PANTOJA ${ }^{628}$ sobre las consecuencias jurídicas de la entrada en vigor del art.47.3 CP en relación a que podría producirse un incremento de los delitos de conducción sin permiso o licencia, que hay que considerar plenamente acertadas trece años después. En la actualidad, muchos conductores que se han visto privados de manera definitiva del permiso o licencia han seguido conduciendo, y cuando han sido detectados por los agentes de la autoridad conduciendo durante el tiempo de condena han sido acusados por un nuevo delito contra la seguridad vial en la modalidad de quebrantamiento de condena.

En tercer lugar, es importante tener en cuenta la incidencia que tiene la privación del derecho a conducir y la aplicación del art.47.3 CP en los conductores profesionales, que se convierte en una especie de inhabilitación especial, tipificada en el art.39.b CP en lo relativo a la profesión u oficio, debido a que además de no poder conducir, el permiso que poseían pierde su vigencia ${ }^{629}$. En estos casos existe una triple punición derivada de un hecho delictivo; por un lado, la pena de privación del derecho a conducir; por otro la pérdida definitiva del permiso o licencia y en tercer lugar muchos de estos conductores profesionales perderán su puesto de trabajo y en definitiva el sustento económico de ellos y probablemente de su familia ${ }^{630}$. La aplicación del art.47.3 CP en estos supuestos puede ser contraria a los fines que pueda perseguir la pena de privación del derecho a conducir e incluso puede suponer más perjuicios que una pena privativa de libertad ${ }^{631}$. Por este motivo

vigencia del permiso ex art. 47.3 CP en 1922 sentencias condenatorias. Vid. Memoria de la FGE del año 2020, p. 913.

627 Vid. TRAPERO BARREALES, María.A., Los delitos..., op.cit., p.560.

628 Vid. FERNÁNDEZ PANTOJA, Pilar, "Delitos contra la seguridad del tráfico: la pena de privación del derecho a conducir", en AA.VV. Delincuencia..., op.cit., p.102.

629 Vid. CORCOY BIDASOLO, Mirentxu, "Homicidio y lesiones en el ámbito viario. Problemática concursal entre los delitos contra la seguridad en el tráfico y los resultados lesivos a ellos imputables", en AA.VV. Seguridad vial..., op.cit., p.80.

630 En relación con la pena de inhabilitación especial y a la privación del derecho a conducir, vid. MUÑOZ CONDE, Francisco/GARCÍA ARÁN, Mercedes, Derecho..., op.cit., pp.516-517, y también TRAPERO BARREALES, María.A., Los delitos...,op.cit., p.567, quien ha calificado las consecuencias del art.47.3 CP para los conductores profesionales como una la inhabilitación profesional de facto.

631 Vid. SANZ MULAS, Nieves, Alternativas..., op.cit., p.360. 
deberían articularse mecanismos para evitar las consecuencias del art.47.3 CP y no provocar mayores perjuicios que los buscados por los propios fines de la pena.

Otro aspecto del art.47.3 CP que merece una crítica es el automatismo con el que se aplican sus efectos ${ }^{632}$ ya que el juez penal lo ha de acordar ope legis como ha determinado la jurisprudencia633. Sería positivo eliminar la aplicación ex lege del art.47.3 CP y dotar de discrecionalidad a Jueces y Magistrados para valorar las circunstancias personales del penado, los hechos acaecidos e imponer el art.47.3 $\mathrm{CP}$ con carácter facultativo ${ }^{634}$. Soy partidario que en ulteriores reformas del CP se faculte al juez para no aplicar automáticamente la pérdida de vigencia del permiso o licencia, aunque se rebase el umbral de los dos años en la pena de privación del derecho a conducir635, insertando una cláusula excepcional cuando conste acreditado que el conductor infractor no reviste caracteres que le doten de una especial peligrosidad para la seguridad vial. A pesar de la reforma operada en el CP a través de la LO 5/2010 de 22 de junio, la LO 1/2015 de 30 de marzo y la LO 2/2019 de 1 de marzo no se ha modificado el art. 47.3 CP, y en este sentido me parece interesante la opinión de MIRÓ LLINARES ${ }^{636}$ y la de GARCÍA ALBERO ${ }^{637}$ quienes señalan que desde el año 2007 se ha ido reduciendo la capacidad de interpretación judicial, llevándonos a un automatismo que también impera en el art.47.3 CP. Esta pérdida de discrecionalidad judicial ${ }^{638}$, en el art.47.3 CP supone afirmar que todos los conductores que rebasen la pena de privación por el plazo de dos años carecen de facultades y pericia para hacerlo. Ante el automatismo del art.47.3 CP, a través de la individualización de la pena que permite el art.66 CP se puede llegar a imponer una pena de privación del derecho a conducir inferior a los dos años e indirectamente evitar los efectos del art.47.3 CP. Sin embargo, dicha

\footnotetext{
632 En este sentido también se expresa CUESTA PASTOR, Pablo.J, El delito..., op.cit., p.79.

${ }^{633}$ Acerca del carácter preceptivo del art.47.3 hemos de citar la SAP de Tarragona, núm. 422/2012, Sección $2^{a}$, de 20 de septiembre de 2012, ponente IIma. Sra. Maㅡ Concepción Montardit Chica (TOL2.671.082).

634 Una propuesta en términos similares fue realizada por la Comisión General de Codificación como destaca CARBONELL MATEU, Juan Carlos, "La Ley Orgánica de Reforma del Código Penal en materia de seguridad vial: un comentario de urgencia", Reforma..., op.cit., p.181.

635 La fórmula propuesta por la Comisión General de Codificación sería un medio adecuado, citada en TRAPERO BARREALES, María.A., Los delitos..., op.cit., p.574.

636 Vid. la crítica efectuada al automatismo por MIRÓ LLINARES, Fernando, "EI moderno...., op.cit., p.10.

637 En relación con la falta de capacidad de decisión de los Jueces y Magistrados en la nueva política criminal de seguridad es ilustrativa la frase: "Del juez penal al radar", expresada por de GARCíA ALBERO, Ramón, "La nueva política criminal...", op.cit., p.9.
} 
posibilidad no siempre será viable ya que cuando concurran circunstancias agravantes es fácil que el umbral de los dos años sea rebasado y deba aplicarse el art.47.3 CP.

Por ello, considero interesante que el CP recogiera la posibilidad, que, en supuestos excepcionales, se pueda acordar la suspensión de los efectos del art.47.3 CP cuando se prevea que sus consecuencias serán más negativas que los fines que se persigue con la pena de privación del derecho a conducir. Esta propuesta se podría articular a través de una suspensión condicional de la pérdida de vigencia del permiso o licencia con unos requisitos de obligado cumplimiento para el penado. En estos casos, sí se ejecutaría de manera efectiva la pena de privación del derecho a conducir, pero mantendría la vigencia del permiso o licencia una vez finalizado el cumplimiento de la misma. Sin embargo, si se produjera un quebrantamiento de condena, se revocaría la suspensión impuesta en relación a los efectos derivados del art.47.3 y se decretaría la pérdida de la vigencia del permiso o licencia. Sería un mecanismo similar a la suspensión condicional de la pena de prisión ex art.80 CP, con la diferencia que sí se cumpliría la pena de privación del derecho a conducir dejándose únicamente en suspenso la pérdida de vigencia del permiso o licencia. En todo caso, el penado debería realizar el curso de sensibilización y educación vial ya que tiene un componente de reeducación que puede coadyuvar a evitar tanto la reincidencia como el quebrantamiento de la pena impuesta, además de contribuir a fines de prevención especial positiva.

Llegados a este punto hemos de formular la siguiente pregunta: ¿Es necesario elevar el umbral de los dos años para la aplicación del art.47.3 CP? Si bien la justificación del plazo de los dos años se ciñe a criterios de inactividad del penado, falta de pericia y posible peligrosidad vial, considero oportuno plantear el debate en torno a la posibilidad de elevar el umbral de los dos años ya que no todos los penados que estén durante dicho periodo sin conducir ha de generar per se un riesgo objetivo para la seguridad vial. Las condenas a pena de privación del derecho a conducir superiores a dos años no son mayoritarias, y el art.47.3 CP se aplica principalmente a los conductores reincidentes, en los casos de gravedad, supuestos de conducción temeraria ${ }^{639}$ o de homicidio y lesiones por imprudencia

\footnotetext{
638 Hemos de ponerlo en contraposición a otros sistemas donde prima el dotar de autonomía a los jueces para poder determinar e individualizar la pena a imponer. Vid. TAMARIT SUMALLA, Josep M, "Sistema de sanciones...", op.cit., p.10.

639 Vid. la SAP de Tarragona, núm.422/2012, Sección 2a ${ }^{a}$, de 20 de septiembre de 2012, ponente IIma. Sra.Ma ${ }^{-}$Concepción Montardit Chica (TOL2.671.082) o la SAP de Burgos, núm.157/2012, Sección 1ạ, de 9 de abril de 2012, ponente Ilmo. Sr. Roger Redondo Argüelles (TOL2.509.401).
} 
grave cometidos con vehículo a motor o ciclomotor 640 . Sin embargo, la pena de privación del derecho a conducir en el art.379.2 CP, tipo penal de mayor aplicación en el que se impone la misma ${ }^{641}$, alcanza de uno a cuatro años por lo que se puede aplicar el art.47.3, máxime en los casos de reincidencia. Por este motivo, el art.47.3 CP no debería operar en la mitad de la pena máxima permitida por el tipo del art.379 CP, sino que debería operar en un tramo superior a la misma, es decir, en el umbral de los tres años.

Finalmente, una última cuestión importante del art. 47.3 es la relativa al posible quebrantamiento, en aquellos supuestos, que el sujeto ha cumplido la pena de privación del derecho a conducir y conduce sin haber obtenido un nuevo permiso. A ello me referiré más adelante en el epígrafe 4.1.3.

\footnotetext{
640 Vid. la SAP de Ourense, núm.167/2014, Sección 2ª ${ }^{\text {, }}$ de 21 de abril de 2014, ponente Ilma. Sra. Ana María del Carmen Blanco Arce (TOL4.477.356), SAP de Málaga, núm.137/2015, Sección 9ạ, de 16 de marzo de 2015, ponente Ilma. Sra. Lourdes García Ortiz (TOL5.005.184), SAP de Ciudad Real, núm.32/2016, Sección 1ạa, de 28 de marzo de 2016, ponente Ilma. Sra. María Pilar Astray Chacón (TOL5.715.376) y SAP de Guadalajara, núm.19/2017, Sección 1ª, de 22 de septiembre de 2017, ponente Ilma. Sra. María Elena Mayor Rodrigo (TOL6.378.913).

641 Vid. Memoria FGE del año 2018, p.659.
} 


\section{CAPÍTULO 4. CONDICIONES DE EJECUCIÓN DE LA PENA DE PRIVACIÓN DEL DERECHO A CONDUCIR}

Una vez analizada la regulación de la pena de privación del derecho a conducir, su contenido y aplicación en la parte especial del CP, examinaremos en el presente capítulo las condiciones de ejecución de la pena. El capítulo se endereza a analizar las singularidades en la fase de ejecución y los principales problemas que se derivan de su cumplimiento. En términos generales, la ejecución es "la piedra angular de todo el sistema" ${ }^{42}$, y en la pena de privación del derecho a conducir resulta de suma importancia el análisis de su régimen de ejecución.

En este capítulo determinaremos cómo se ha de cumplir la pena de privación del derecho a conducir de forma ordinaria, así como dos singularidades que existen en la misma. Para ello se analizará la ejecución ordinaria de la pena de privación del derecho a conducir, detallando los trámites procesales necesarios para su cumplimiento, así como los principales problemas existentes en cada uno de ellos. También se dedica un epígrafe a la obligatoriedad de realizar el curso de sensibilización y reeducación vial, ya que a pesar de ser un efecto administrativo de la condena tiene una relación directa con la misma, por lo que determinaremos sus condiciones de cumplimiento y los principales problemas derivados de su realización. Asimismo, en el mismo apartado se determinarán las consecuencias que en la esfera de la ejecución de la pena de privación del derecho a conducir origina el art.47.3 CP. Para finalizar el primer apartado del capítulo se estudiará la suspensión de la ejecución de la referida pena cuando se interpone bien una petición de indulto o bien un recurso de amparo ante el Tribunal Constitucional.

He considerado necesario examinar en este capítulo dos singularidades de cumplimiento en la ejecución ordinaria, y por ello se estudiará la posibilidad del cumplimiento fraccionado de la pena estudiada, así como el cumplimiento transnacional de la pena de privación del derecho a conducir, al ser una cuestión relevante debido a la movilidad de los conductores, especialmente en los países del espacio común europeo. Finalmente, el último apartado del presente capítulo se dedica a la posibilidad de que se produzca un quebrantamiento de la pena cuando esta no se cumpla según lo preceptuado en la sentencia y el penado decida volver a conducir durante el periodo que le ha sido privado el derecho.

\footnotetext{
642 Vid. MAGRO SERVET, Vicente, "¿Es posible fraccionar la ejecución de la pena de privación del permiso de conducir?”, Tráfico y Seguridad Vial, no115-116, 2008, pp.59-66.
} 


\subsection{La ejecución ordinaria de la pena de privación del derecho a conducir vehículos a motor y ciclomotores}

En este apartado se estudia la ejecución ordinaria de la pena de privación del derecho a conducir, se plantean cuestiones relacionadas con la inmediatez de su ejecución y se detallarán los trámites necesarios para que pueda ejecutarse la sentencia dictada, señalando las posibles disfunciones y proponiendo soluciones a las mismas. El primer aspecto a destacar de la ejecución ordinaria de la pena de privación del derecho a conducir es que, a pesar de ejecutarse en el ámbito penal, existen actuaciones administrativas que se realizan en la DGT. Por este motivo realizaremos referencias constantes a la conexión del Derecho Penal con el Derecho Administrativo para determinar el funcionamiento de la ejecución.

La ejecución ordinaria se inicia con la sentencia condenatoria que incluye la pena de privación del derecho a conducir. Una vez se decreta la firmeza de la sentencia se aplica el art.794 de la LECrim ${ }^{643}$, que establece su inmediata ejecución. La característica de inmediatez que rige la ejecución de la pena de privación del derecho a conducir viene refrendada por la Ley Rituaria, en la que se indica: “... Tan pronto como sea firme la sentencia...". La pena de privación del derecho a conducir, puede calificarse como de "ejecución inmediata"644, ya que una vez firme la sentencia dictada, con carácter general, ha de procederse a su ejecución puesto que el penado estará inhabilitado para el ejercicio del derecho desde ese mismo momento.

La ejecución ordinaria de la pena de privación del derecho a conducir puede materializarse a través de dos cauces procesales: bien como Diligencias UrgentesJuicio Rápido, bien mediante el procedimiento ordinario. Lo primero que queremos poner de manifiesto es que el inicio de la ejecución de la pena dependerá del tipo de juicio que se haya seguido.

\footnotetext{
${ }^{643}$ Art.794 LECrim: "Tan pronto como sea firme la sentencia, se procederá a su ejecución por el Juez o por la Audiencia que la hubiere dictado...".

${ }^{644}$ Respecto de la característica de ejecución inmediata de la pena, vid. MAGRO SERVET, Vicente: “¿Es posible fraccionar...?”, op.cit., pp.59-66. Del mismo modo, la ejecución inmediata de las penas privativas de derechos también ha sido destacada por ARMENTA DEU, Teresa, Lecciones..., op.cit., p.441.
} 
En relación con el procedimiento de Juicio Rápido, puede dictarse una sentencia condenatoria de conformidad en el Juzgado de Guardia que conlleve la imposición de la pena de privación del derecho a conducir. En tal caso, el mismo Juzgado de Guardia realiza los requerimientos al penado para que este entregue el permiso 0 licencia y se abstenga de conducir durante el tiempo de la condena, si bien el órgano judicial que ejecutará la pena será el Juzgado de lo Penal o bien un juzgado específico de ejecutorias penales, en caso que exista en el partido judicial. En este caso el inicio del cumplimiento de la pena de privación del derecho a conducir se producirá entre uno y dos meses antes que el Juzgado correspondiente dicte la incoación de la ejecutoria de dicha pena. No obstante, ello no afectará al cumplimiento de la pena objeto de estudio ya que la sentencia será firme desde el momento que se dicte en el Juzgado de Guardia y a partir de entonces el penado no podrá ejercer su derecho a conducir. Existe una segunda modalidad en relación con los Juicios Rápidos y es cuando no hay conformidad con la pena solicitada, y el Juicio se celebra en el Juzgado de lo Penal. Una vez la sentencia es firme, se dicta el decreto de incoación de ejecutoria y se realiza el trámite de la liquidación de condena de pena de privación del derecho a conducir. La segunda opción procesal es que la causa se tramite en un procedimiento ordinario, lo que sucederá cuando no sea posible su tramitación como Juicio Rápido, bien por tener que practicar diligencias esenciales para la averiguación del delito que precisan de una investigación más prolongada bien porque los hechos sean calificados como delito leve por imprudencia menos grave ${ }^{645}$. En estos casos, la instrucción de la causa la efectúa el juzgado correspondiente y la sentencia condenatoria la dicta bien el Juzgado de Instrucción, el Juzgado de lo Penal o la Audiencia Provincial, y la ejecución de la pena les corresponderá a ellos o bien un juzgado específico de ejecutorias penales, para el caso que exista en el partido judicial.

Aunque la ejecución de la pena analizada se caracteriza por la inmediatez, es posible un aplazamiento para iniciar el cumplimiento tanto en los casos de Juicio

\footnotetext{
645 La calificación como delito leve vendrá determinada por el art. 13.4 del CP. Existe otra modalidad procesal a través de la cual también se puede imponer la pena de privación del derecho a conducir. Es el procedimiento por aceptación de decreto, que permite convertir la propuesta sancionadora realizada por el Ministerio Fiscal en unas diligencias de investigación, previa conformidad del investigado, en sentencia firme. Este procedimiento entró en vigor con la Ley $41 / 2015$, de 5 de octubre de modificación de la LECrim para la agilización de la justicia penal y el fortalecimiento de las garantías procesales, y está regulado en los arts. 803 bis a) a 803 bis j). Sin embargo, este procedimiento, es absolutamente residual y a título de ejemplo podemos señalar que en los 2018 y 2019 se resolvieron respectivamente un total de 29 y 64 procedimientos de este tipo a nivel nacional en los Juzgados de Instrucción, pero en la estadística judicial no se indica si en alguno de ellos se impuso la pena de privación del derecho a conducir. Vid. la estadística en: http://www6.poderjudicial.es/PxWeb/pxweb/es/ (último acceso: 04/05/2020). Debido a la escasa utilización en la praxis judicial de este procedimiento, no se analizará en este trabajo.
} 
Rápido sin sentencia de conformidad ante el Juzgado de Guardia, como en los procedimientos ordinarios, ya que en ambos casos la sentencia que imponga la pena de privación del derecho a conducir la dictará bien el Juzgado de Instrucción, el Juzgado de lo Penal bien la Audiencia Provincial, por lo que la pena no dará inicio de forma inmediata como sucede en los casos que la sentencia es dictada por el Juzgado de Guardia en los cuales el penado empieza a cumplir la pena desde ese mismo instante como establece el art. 801.4 de la LECrim ${ }^{646}$. En este sentido DE LAMO RUBIO y CORDERO LOZANO ${ }^{647}$, consideran factible aplazar la fecha de inicio de cumplimiento de la pena, aun cuando puede resultar contraria a la inmediatez que caracteriza la ejecución de la pena que se analiza, cuando por razones justificadas pueda acreditarse por el penado que el inicio inmediato pueda perjudicar su situación laboral, personal o familiar ${ }^{648}$. En tales casos podría valorarse el aplazamiento del cumplimiento de la pena de privación del derecho a conducir y de esta forma evitar una afectación personal al penado que no está entre los fines de la pena ${ }^{649}$. La opción de conceder un aplazamiento para el inicio del cumplimiento de la pena es compatible con la LECrim, ya que si bien el art. 794.2 establece que la ejecución de la sentencia ha de ser inmediata nada obstaría a que la pena se ejecutara inmediatamente, pero estableciendo un día concreto en el que daría inicio el cumplimiento que funcionara, a efectos prácticos, a modo de

\footnotetext{
${ }^{646}$ Art.801.4. Dictada sentencia de conformidad y practicadas las actuaciones a que se refiere el apartado 2, el Juez de guardia acordará lo procedente sobre la puesta en libertad o el ingreso en prisión del condenado y realizará los requerimientos que de ella se deriven, remitiendo el Secretario judicial seguidamente las actuaciones junto con la sentencia redactada al Juzgado de lo Penal que corresponda, que continuará su ejecución.
}

647 Vid. DE LAMO RUBIO, Jaime, Penas y medidas..., op.cit., p.146, y CORDERO LOZANO, Carlos Ejecución..., op.cit., p.148.

648 Vid. AAP de Madrid, núm. 889/2012, Sección 30ạ, de 28 de diciembre de 2012, ponente llmo. Sr. Carlos Martín Meizoso (TOL5.363.507) y AAP de Vizcaya, núm. 90643/2018, Sección 6a , de 3 de diciembre de 2018, ponente IImo. Sr. José Ignacio Arévalo Lassa (TOL7.076.651), en los que se concede el aplazamiento para iniciar el cumplimiento de la pena de privación del derecho a conducir. Sin embargo, resoluciones como el AAP de Madrid, núm. 921/2012, Sección 1aㅡ, de 21 de diciembre de 2012, ponente Ilma. Sra. María Cruz Álvaro López (TOL3.626.934), a pesar de no negar la opción del aplazamiento la desestiman por las argumentos laborales esgrimidos por el penado, o el AAP de Burgos, núm. 580/2017, Sección 1aㅡ, de 22 de septiembre de 2017, ponente Ilmo. Sr. Francisco Manuel Marín Ibáñez (TOL6.381.299), que de nuevo sin negar la posibilidad del aplazamiento, desestima la petición al considerar que el inicio del cumplimiento de la pena privativa del derecho a conducir no va a generar graves perjuicios al penado, además de existir medios alternativos para desarrollar su actividad laboral. También hemos de citar el AAP de Burgos, núm. 157/2019, Sección 1aㅡ, de 26 de febrero de 2019, ponente Ilma. Sra. María Teresa Muñoz Quintana (TOL7.123.531), en el que se deniega la opción del aplazamiento por ser contraria al principio de legalidad ya que dicha opción no está prevista en el Código Penal.

649 También se posiciona favorablemente a dicha posibilidad, CERES MONTES, José Francisco, "La Reforma del Código Penal en materia de seguridad vial por la Ley Orgánica 15/2007, desde la perspectiva de su ejecución", La Ley Penal, no 48, 2008, pp.42-62 así como NUÑO DE LA ROSA AMORES, José Antonio, “Aplicación práctica...", op.cit., p.124. 
aplazamiento ${ }^{650}$. Si se concede el aplazamiento del inicio del cumplimiento de la pena, el penado puede organizar su vida laboral y personal, compatibilizando el cumplimiento de la pena privación del derecho a conducir con sus obligaciones preexistentes ${ }^{651}$ y ello con escasa afectación a los fines de prevención general que existen en la referida pena, ya que lo único que se concedería en estos casos sería una suspensión de facto de la ejecución, pero la pena se ejecutará de forma correcta posteriormente en la fecha acordada mediante resolución judicial.

El BCPP, para el caso que hubiese entrado en vigor, podría haber modificado la característica de la inmediatez que ha de regir la ejecución ordinaria de la pena de privación del derecho a conducir. El art.687 del BCPP regulaba específicamente la pena de privación del derecho a conducir, y preveía en su apartado 4, que, de forma excepcional, por causas justificadas y siempre que la pena no supere el umbral de los dos años, se podría demorar el inicio de su cumplimiento652. Con dicha previsión legal, la ejecución de la pena podría perder la característica de inmediatez, al establecerse en el texto procesal el aplazamiento del inicio de la pena de privación del derecho a conducir.

Atendiendo a la actual regulación en la tramitación del cumplimiento ordinario de la pena de privación del derecho a conducir, tras la liquidación de condena se informa por parte del Juzgado a la Jefatura Central de Tráfico para que deje sin efecto el permiso o licencia y no se pueda solicitar otro nuevo durante el tiempo de la condena como establece el art.794.2 de la LECrim ${ }^{653}$. Si bien la pena que se impone es la de privación del derecho y no del permiso, la FGE puso de manifiesto en la Memoria del año 2008, que en ocasiones los conductores penados acudían a la Jefatura Provincial a solicitar un duplicado del permiso que había sido retirado por el juez penal654.

Un supuesto que debemos incluir en la ejecución ordinaria de la pena de privación del derecho a conducir es cuando un penado que se encuentra cumpliendo una

\footnotetext{
650 Vid. RODRÍGUEZ LAINZ, José Luis, "Juzgado de Guardia y ejecución de sentencias de conformidad", Diario La Ley, no 7465, Sección Doctrina 10-09-2010, Año XXI, La Ley 5617/2010.

651 En torno a la opción del aplazamiento, vid. RODRÍGUEZ MORO, Luis, "La pena de privación del derecho a conducir vehículos a motor y ciclomotores", en AA.VV. Las penas..., op.cit., p.248.

652 Art.687.4: Excepcionalmente, el Tribunal podrá, a instancia del penado y previo informe del Ministerio Fiscal, aplazar por el tiempo indispensable y por causa justificada el inicio del cumplimiento de esta pena cuando su duración no sea superior a dos años.

653 Vid. DE URBANO CASTRILLO, Eduardo, “La privación...”, op.cit., p.9.

654 Esta situación fue puesta de manifiesto en la Memoria de la FGE del año 2008, p. 678, así como también ha sido destacada por CORDERO LOZANO, Carlos, Condenas..., op.cit., p.45.
} 
privación del derecho a conducir, es nuevamente condenado a la misma pena privativa de derechos. En este caso, podría plantearse la posibilidad de un cumplimiento simultáneo de ambas penas o bien por el contrario un cumplimiento individualizado. Entiendo que la única solución posible es el cumplimiento de las penas de forma individual y sucesiva a pesar de hallarnos ante penas idénticas y de la misma naturaleza, por lo que no cabrá aplicar el art.73 CP655.

\subsubsection{Trámites requeridos para la ejecución de la pena}

La ejecución ordinaria de la pena de privación del derecho a conducir requiere de una serie de pasos siendo los más destacados: la entrega del permiso o licencia, la advertencia de abstenerse de conducir, la liquidación de condena ${ }^{656}$ y remisión de la misma a la DGT, así como el control por parte de la Jefatura Central de Tráfico.

\section{a) Entrega del permiso o licencia}

Uno de los trámites que según establece la LECrim en el art.794.2 debe realizarse en los casos en los que se haya impuesto la pena de privación del derecho a conducir es que el penado efectúe la entrega del permiso o licencia, que es el documento administrativo que faculta para el ejercicio del derecho ${ }^{657}$. A través de esta acción se realiza un trámite de carácter simbólico ya que de lo que se priva con la pena es del derecho a conducir y no del permiso ${ }^{658}$. La retirada del permiso o

\footnotetext{
655 Un supuesto que desestima el posible cumplimiento simultáneo ha sido resuelto por el AAP de Madrid, núm.11/2013, Sección 6ª , de 11 de enero de 2013, ponente Ilmo. Sr.Pedro Javier Rodríguez González-Palacios. (TOL3.881.432). En el ámbito doctrinal GIRALT PADILLA, considera que cuando existan diversas condenas a la pena de privación del derecho a conducir lo habitual en el ámbito judicial es realizar una liquidación enlazada. Vid. GIRALT PADILLA, Cristina, "La acumulación de condenas tras la LO 1/2015 de reforma del Código Penal. Comentario a la STS 367/2015, de 11 de junio". Diario La Ley, no 8616, 1 de octubre de 2015.

656 Dichos trámites en la ejecución de la pena de privación del derecho a conducir han sido analizados en la SAP de Barcelona, núm. 417/2016, Sección 9ª , de 17 de mayo de 2016, ponente Ilma. Sra. María Inmaculada Vacas Márquez (TOL5.815.474).

657 Vid. AA.VV. "Delitos contra la seguridad vial: cuestiones comunes", GUTIÉRREZ RODRÍGUEZ, María (Coordinadora): GARCÍA DEL BLANCO, Victoria / MARTÍN LORENZO, María y SANZ-DÍEZ DE ULZURRUN LLUCH, Marina, Protección Penal de la Seguridad Vial, Ed. Tirant lo Blanch, Valencia, 2013, p.47.

658 Vid. CORDERO LOZANO, Carlos, Condenas..., op.cit., p.44 y RUIZ DE ERENCHUN ARTECHE, Eduardo, Sistema de Penas, Reglas de Determinación de la Pena y Suspensión de la Ejecución de la Pena, Ed. Aranzadi, Pamplona 2017, p. 48.
} 
licencia únicamente podrá realizarse en aquellos penados que sí lo poseían, y los que carezcan de ellos no llevarán a cabo el trámite simbólico de su entrega ${ }^{659}$.

Dada la tipología de los delitos en los que se prevé la aplicación de la pena de privación del derecho a conducir, especialmente en los delitos tipificados en los arts.379 y $383 \mathrm{CP}$, que pueden tramitarse como Diligencias Urgentes-Juicio Rápido, en numerosas ocasiones el permiso o licencia se entregará en el Juzgado de Guardia, si bien dicho Juzgado no será el encargado de la ejecutoria ni tampoco quien realice la liquidación definitiva de la pena ${ }^{660}$. En los supuestos tramitados como Juicio Rápido que conlleven la imposición de la pena de privación del derecho a conducir, una vez se dicta la sentencia condenatoria de conformidad en el Juzgado de Guardia, acto seguido se decreta su firmeza y se interviene el permiso o licencia, siempre que no conste ya intervenido por la autoridad policial ${ }^{661}$. En lo relativo a la ejecución inmediata de las sentencias condenatorias de conformidad en el Juzgado de Guardia el criterio de la Fiscalía es optar por la entrega inmediata del permiso ${ }^{662}$, en consonancia con el art.801.4 de la LECrim ${ }^{663}$, que determina que entre los requerimientos a practicar al penado se incluye el de entrega del permiso $o$ licencia. En el resto de procedimientos, es decir, aquellos que no sean Diligencias Urgentes- Juicio Rápido con sentencia de conformidad en el Juzgado de Guardia664, la entrega del permiso o licencia no se llevará a cabo hasta decretarse la firmeza de la sentencia condenatoria e incoación de la ejecutoria penal. En las dos vías a través de las que se puede imponer la pena de privación del derecho a conducir, las autoridades judiciales tras la entrega del permiso o licencia por el penado, han de

659 Acerca de la ejecución de la pena en aquellos que no poseen permiso o licencia, vid. CORDERO LOZANO, Carlos, Condenas..., op.cit., p.44 y RUIZ DE ERENCHUN ARTECHE, Eduardo, Sistema de Penas..., op.cit. p. 49.

660 En este sentido estimo que el Juzgado de Guardia es competente para realizar dicho trámite y comparto el criterio expresado por RODRÍGUEZ LAINZ, José Luis, "Juzgado de Guardia y ejecución de sentencias de conformidad”. Diario La Ley, no 7465, Sección Doctrina 10-09-2010, Año XXI, La Ley $5617 / 2010$.

${ }^{661}$ Este criterio también lo mantiene RODRíGUEZ LEÓN, Luis Carlos, Seguridad..., op.cit., p.50, así como DE URBANO CASTRILLO, Eduardo, "La privación...", op.cit., p.9 .

662 Vid. Vid. Circular 10/2011 "Sobre criterios para la unidad de actuación especializada del Ministerio Fiscal en materia de seguridad vial", apartado XI.3, pp.60-61.

663 Art.801.4. Dictada sentencia de conformidad y practicadas las actuaciones a que se refiere el apartado 2, el Juez de guardia acordará lo procedente sobre la puesta en libertad o el ingreso en prisión del condenado y realizará los requerimientos que de ella se deriven, remitiendo el Secretario judicial seguidamente las actuaciones junto con la sentencia redactada al Juzgado de lo Penal que corresponda, que continuará su ejecución.

664 En el ámbito de los delitos contra la seguridad vial que son en los que mayoritariamente se impone la pena de privación del derecho a conducir, los procedimientos más comunes son el procedimiento abreviado y el juicio rápido/diligencias urgentes. Vid. BARONA VILAR, Silvia, "Especialidades procedimentales", en AA.VV. Derecho Jurisdiccional III..., op.cit., p.611. 
cumplir lo establecido en el art.113.2 de la LTSV665 e informar en el plazo de 15 días naturales a la Jefatura de Tráfico, así como al Registro de Conductores de la resolución adoptada ${ }^{666}$.

En el trámite de entrega del permiso o licencia en el Juzgado de Guardia, puede darse una situación anómala en los casos que el penado se conforma con la acusación, se dicta sentencia condenatoria, se le requiere para que se abstenga de conducir y no puede entregar el permiso o licencia porque ni lo ha intervenido la Fuerza Policial ni el acusado ha acudido con él al Juzgado. En estos supuestos puede plantearse el debate sobre si la pena de privación del derecho a conducir ya habría dado inicio ante el Juzgado de Guardia y no existiría problema en diferir el trámite de la entrega del permiso hasta el momento que el Juzgado de lo Penal o bien un juzgado específico de ejecutorias penales, para el caso que exista en el partido judicial, incoe la ejecutoria y se requiera nuevamente al penado para su entrega ${ }^{667}$. Podemos destacar el criterio seguido por los Presidentes de las Secciones Penales de las Audiencias Provinciales de Catalunya que estiman que no es requisito imprescindible la entrega del documento físico, y en todo caso la pena se iniciaría desde el momento que el penado es requerido ${ }^{668}$. Sin embargo,

${ }^{665}$ Art. 113.2 LTSV. Las autoridades judiciales comunicarán al Registro de Conductores e Infractores del organismo autónomo Jefatura Central de Tráfico, en el plazo de los quince días naturales siguientes a su firmeza, las penas de privación del derecho a conducir vehículos a motor y ciclomotores que impongan por la comisión de delitos contra la seguridad vial.

666 Desde el mes de febrero de 2015 se ha instaurado el procedimiento de notificación telemática entre Juzgados y DGT con el fin de facilitar y agilizar esta comunicación. Vid.:

http://www.dgt.es/es/prensa/notas-de-prensa/2015/20150211-justicia-enviara-a-traficoautomaticamente-las-condenas-por-delitos-contra-la-seguridad-vial.shtml (último acceso: 13/12/2020).

Asimismo, por la Secretaría General de la Administración de Justicia, se dictó la Instrucción no $3 / 2015$ que hace referencia al procedimiento de notificación telemática entre los Juzgados y la DGT. También por el Ministerio del Interior se dictó la Instrucción 15/S-138 de 15 de septiembre de 2015, sobre el envío telemático de condenas penales, medidas cautelares y de seguridad en relación con la privación del derecho a conducir. Recurso electrónico disponible en: https://www.seguridadpublica.es/wp-content/uploads/2015/11/instruccon-DGT-telematicascondenas.pdf (último acceso: 03/11/2020).

667 Dicha situación ha sido analizada por RODRíGUEZ LAINZ, y estoy plenamente de acuerdo con las tres opciones propuestas para resolver dicha situación. En relación con las tres opciones vid. RODRÍGUEZ LAINZ, José Luis, "Juzgado de Guardia y ejecución de sentencias de conformidad", Diario La Ley, o 7465, Sección Doctrina 10-09-2010, Año XXI, La Ley 5617/2010.

668 Vid. el criterio de los Presidentes de las Secciones Penales de Audiencias Provinciales de Catalunya, AA.VV. Documents sobre execució penal. Centre d’Estudis Jurídics i Formació Especialitzada. Generalitat de Catalunya. Estudis i Formació de I'Administració de Justícia, Barcelona, 2011, 1a edición, p.41. Asimismo, podemos señalar que el criterio del requerimiento como inicio del cumplimiento de la pena de privación del derecho a conducir también lo encontramos en la SAP de Badajoz, núm. 232/2012, Sección 3a , de 10 de octubre de 2012, ponente IIma. Sra. María Isabel Bueno Trenado (TOL2.689.286) y en el AAP de Madrid, núm. 400/2018, Sección 29ą, de 8 de junio de 2018, ponente llma. Sra. María del Pilar Rasillo López (TOL6.756.758). En el mismo sentido 
AYO FERNÁNDEZ ${ }^{669}$ mantiene que para que la pena de privación del derecho a conducir tenga eficacia ha de exigirse la entrega física del documento, siendo ésta una posición minoritaria en la doctrina 670 .

Cuestión distinta es si los penados que posean permiso o licencia extranjeros han de realizar el trámite que hemos detallado, ya que pueden existir dos situaciones que han de resolverse en idéntico sentido. En primer lugar, los penados que posean permiso expedido en el extranjero pero que les habilita para conducir en España han de entregar físicamente el permiso, aunque la Magistratura ha considerado que dicho requisito no es imprescindible ${ }^{671}$. En segundo lugar, aquellos que posean permiso extranjero no válido para conducir en territorio español, entiendo que dicha ausencia de validez no afecta al trámite de la entrega del mismo y debe ser entregado y quedar unido a los autos, siendo retornado una vez cumpla la pena.

\section{b) Advertencia de abstenerse de conducir}

Una vez el penado ha entregado en el Juzgado el permiso o licencia, de forma instantánea se realiza el trámite de requerirle para que se abstenga de conducir durante el tiempo de duración de la condena ${ }^{672}$. Este requerimiento es uno de los trámites esenciales de la ejecución de la pena de privación del derecho a conducir, informando personalmente al penado que se ha de abstener de conducir vehículos a motor y ciclomotores durante el tiempo de duración de la condena, ya que si no

se posiciona la Circular 10/2011 "Sobre criterios para la unidad de actuación especializada del Ministerio Fiscal en materia de seguridad vial", apartado XI.3, p.59, así como NUÑO DE LA ROSA AMORES, José Antonio, "Aplicación práctica...", op.cit., p.123.

669 Vid. AYO FERNÁNDEZ, Manuel, Las penas..., op.cit., p.151.

670 Sin embargo, en el ámbito jurisprudencial existen resoluciones que sí determinan como relevante la entrega del permiso o licencia. Vid. AAP de León, núm. 318/2019, Sección $3^{a}$, de 21 de marzo de 2019, ponente Ilmo. Sr. Carlos Miguélez del Río (TOL7.191.363).

671 No consideran imprescindible la entrega del permiso en estos casos los Presidentes de las Secciones Penales de Audiencias Provinciales de Catalunya, AA.VV. Documents sobre execució penal, op.cit. p. 42. Hemos de señalar que el Código Penal de Portugal ha previsto en el artículo 69.5 que los conductores que posean un permiso extranjero no han de entregar físicamente el permiso, sino que únicamente quedará anotada la pena de privación del derecho a conducir en los registros correspondientes.

672 Respecto al carácter personalísimo del requerimiento, vid. DE URBANO CASTRILLO, Eduardo, "La privación...", op.cit.,p.9 y MAZA MARTIIN, José Manuel, "Penas privativas de derechos y accesorias en el nuevo Código Penal", en AA.VV. Penas y medidas de seguridad en el nuevo Código Penal, POZA CISNEROS, María (Dir.), Cuadernos de Derecho Judicial, Ed. Consejo General del Poder Judicial, Madrid, 1996, p.178. 
podría ser acusado por un delito de quebrantamiento del art.384 CP673. Aunque pueda parecer un trámite sencillo sin dificultades interpretativas, se han planteado problemas en lo relativo a cuando debe entenderse que el conductor ya ha sido requerido y no puede conducir674. En relación con este aspecto, estimo que el requerimiento en todo caso ha de realizarse de manera personal al conductor que ha de cumplir la pena y se deberá acreditar documentalmente a través de la firma del penado que el mismo es conocedor de la resolución judicial ${ }^{675}$.

A diferencia del trámite analizado en el apartado anterior donde los penados que no poseían permiso o licencia no debían realizar el trámite de entrega del permiso por carecer de él, el trámite de la advertencia de abstenerse de conducir sí debe dirigirse también a todos ellos. La advertencia se realiza tanto a los penados poseedores del permiso como a los que carecen de él, ya que la pena puede quebrantarse con independencia que se posea o no permiso o licencia ${ }^{676}$. Como dato relevante del trámite de advertencia de abstenerse de conducir en los penados que no posean el permiso o licencia, DE LAMO RUBIO y CORDERO LOZANO consideran que también se debe efectuar el requerimiento para que se abstengan de obtener el permiso durante el tiempo de la condena ${ }^{677}$. Al respecto podemos realizar al menos dos consideraciones. La primera es que estos penados en ningún caso podrán obtener el permiso de conducir durante el tiempo de duración de la condena de privación del derecho a conducir, ya que la anotación de la condena en la DGT lo impedirá. Esta imposibilidad de obtener el permiso o licencia entiendo que es una solución correcta y ajustada a los fines de la pena, ya que si lo pudieran obtener podríamos inferir que la pena sería más gravosa para los condenados que tenían permiso que para los que carecían de él, quebrándose sus fines. La segunda consideración es que al no existir en el catálogo de penas la prohibición de obtener el permiso de conducir, carece de sentido el que se les realice el requerimiento para que se abstengan de obtener el permiso, al no formar parte dicha opción del contenido de la pena. Por ello, este grupo de penados como en ningún caso podrá

\footnotetext{
${ }^{673}$ En relación con el trámite del requerimiento vid. DE LAMO RUBIO, Jaime, Penas y medidas..., op.cit., p.144 y CORDERO LOZANO, Carlos, Ejecución..., op.cit., p.147.

674 Relativo a las diferentes interpretaciones, vid. TRAPERO BARREALES, María.A., Los delitos..., op.cit., pp.418-419.

675 En este sentido podemos destacar el AAP de Salamanca, núm. 95/2017, Sección 1ä, de 13 de marzo de 2017, ponente IImo. Sr, José Antonio Vega Bravo (TOL6.084.204).

676 Vid. FERNÁNDEZ PANTOJA, Pilar, "Delitos contra la seguridad del tráfico: la pena de privación del derecho a conducir", en AA.VV. Delincuencia..., op.cit., p.82.

677 Vid. DE LAMO RUBIO, Jaime, Penas y medidas..., op.cit., p.144 yCORDERO LOZANO, Carlos, Condenas..., op.cit., p.44.
} 
obtener el permiso o licencia durante el tiempo de la condena, carece de sentido que además se les efectúe un requerimiento para que se abstengan de obtenerlo.

Sin embargo, existen resoluciones judiciales que sí han estimado necesario en el trámite de requerimiento al penado informarle de las consecuencias del art.47.3 CP, es decir, cuando ha perdido la vigencia del permiso o licencia por la imposición de una pena de privación del derecho a conducir por un plazo superior a dos años ${ }^{678}$. En estos supuestos considero que dicho requerimiento específico también es innecesario, ya que en modo alguno el sujeto podrá conducir por el mero transcurso del tiempo de la condena, puesto que, al haber perdido la vigencia de su permiso o licencia, no podrá conducir legalmente.

El requerimiento al penado de abstenerse de conducir se puede llevar a cabo a través de dos cauces procesales diferentes: ante el Juzgado de Guardia en el caso de Diligencias-Urgentes o ante el Juzgado de Instrucción, Juzgado de lo Penal o bien ante un Juzgado específico de ejecutorias penales, para el caso que exista en el partido judicial, o ante la Sala de la AP en el procedimiento ordinario. En el primer caso, cuando exista la conformidad del acusado con la pena solicitada, el requerimiento de abstenerse de conducir se realiza en el mismo Juzgado de Guardia. A pesar de que este aún no habrá incoado la ejecutoria para dar cumplimiento a la pena, el requerimiento que se efectúe al penado tiene plena validez en relación con su posible imputación por un delito de quebrantamiento de condena del art.384 CP. En el segundo supuesto, la advertencia de abstención de conducir la efectuará el Juzgado de Instrucción, el Juzgado de lo Penal, el Juzgado de Ejecutorias Penales o la Sala correspondiente de la AP, llevándose a cabo tras decretarse la firmeza de la sentencia, incoarse la ejecutoria y tras aprobarse la liquidación de condena de la pena de privación del derecho a conducir. La diferencia esencial con relación al requerimiento de abstenerse de conducir es que en los supuestos ante el Juzgado de Guardia se inicia el cumplimiento en ese mismo acto, mientras que en un procedimiento ordinario los trámites hasta que se realiza el requerimiento de abstenerse de conducir motivan que la sentencia tarde más tiempo en ejecutarse desde su firmeza.

\footnotetext{
678 Vid. AAP de A Coruña, núm. 725/2017, Sección 1a, de 8 de septiembre de 2017, ponente Ilma. Sra. María Teresa Cortizas González-Criado (TOL6.370.999).
} 


\section{c) Práctica de liquidación y comunicación a la Dirección General de Tráfico}

Tras la entrega del permiso o licencia y el requerimiento al penado para no conducir durante el tiempo de la condena, el siguiente trámite es el de la práctica de liquidación de la condena y la comunicación de la misma a la DGT679. La liquidación de condena será esencial para determinar tanto la fecha de inicio del cumplimiento como la finalización de la pena de privación del derecho a conducir ${ }^{680}$, y marcará el periodo en que el penado puede incurrir en un posible delito de quebrantamiento de condena del art.384 CP.

Para mantener la metodología utilizada en los epígrafes precedentes, en el análisis de la liquidación de condena y mandamiento a la DGT, diferenciaremos según la pena de privación del derecho a conducir se haya impuesto en Diligencias Urgentes-Juicio Rápido con sentencia condenatoria de conformidad en el Juzgado de Guardia o bien en un procedimiento ordinario o Juicio Rápido que se celebre en el Juzgado de lo Penal. En estos dos casos, la práctica de la liquidación de condena se realiza después de decretarse la firmeza de la sentencia condenatoria, y tras la apertura de la ejecutoria. Una vez aprobada la liquidación de condena se informará a la DGT del periodo en el que el penado no podrá conducir. Por su parte, en los procedimientos tramitados como Juicio Rápido-Diligencias Urgentes que finalizan con una sentencia condenatoria de conformidad en el Juzgado de Guardia, la liquidación de condena se realiza posteriormente una vez las actuaciones lleguen al Juzgado de lo Penal o bien al juzgado específico de ejecutorias penales, aunque se remite por el Juzgado de Guardia una primera comunicación a la DGT con el contenido de la sentencia condenatoria que incluye la pena de privación del derecho a conducir.

A continuación, analizaremos el trámite de la liquidación de condena y la comunicación a la DGT, haciendo referencia a los distintos tipos de conductores y a cómo les afecta la realización de dicho trámite. El trámite de liquidación de condena debe llevarse a cabo en todos los supuestos de condena y por lo tanto también en

\footnotetext{
679 En lo relativo al trámite de la liquidación coincido con CERES MONTES, en que ha de ser ulterior al requerimiento efectuado al penado para que se abstenga de conducir. Vid. "La reforma del Código Penal...", op.cit., pp.42-62. En torno a la práctica de la liquidación y el requerimiento véase también AGUDO FERNÁNDEZ, Enrique/ JAÉN VALLEJO, Manuel/ PERRINO PÉREZ, Ángel Luis, Penas..., op.cit., p.148.

680 El permiso o licencia del penado restará en la Oficina Judicial hasta la finalización de la condena en que se retornará de nuevo al penado. Vid. DE LAMO RUBIO, Jaime, Penas y medidas..., op.cit., p. 145 y CORDERO LOZANO, Carlos, Condenas..., op.cit., p.147.
} 
relación con aquellos penados que no posean el permiso o licencia por mor de estar cumpliendo condena privativa del mismo derecho y estar unido en otra ejecutoria, los penados que tengan permiso o licencia expedido por autoridad extranjera válido para conducir en España, aquellos que lo posean tras ser emitido por autoridad no reconocida en España así como aquellos que nunca han tenido permiso o licencia. En todos los supuestos, los penados además de no poder conducir vehículos a motor y ciclomotores tampoco podrán obtener un nuevo permiso o licencia ya que tras la liquidación de condena y la comunicación a la DGT dicha posibilidad la tendrán vedada ${ }^{681}$. En relación con lo expuesto me parece interesante la opinión de VALLESPÍN PÉREZ que mantiene que para el correcto control de la pena de privación del derecho a conducir es esencial la remisión de la información de la condena a la DGT para que se lleve a cabo la vigilancia de la expedición de posibles permisos ${ }^{682}$, y esta circunstancia puede afectar especialmente a aquellos conductores extranjeros que quieran regularizar su permiso en territorio español.

Las actuaciones a realizar para alcanzar la liquidación definitiva de la condena de privación del derecho a conducir son las siguientes. Con carácter previo a que se apruebe la liquidación definitiva, se deberá dar traslado de la misma tanto al penado, al Ministerio Fiscal y al resto de partes del procedimiento para realizar alegaciones respecto a la fecha de inicio y finalización, así como indicar los errores que puedan existir en la liquidación provisional683. Asimismo, en esta fase es cuando el penado puede instar el posible aplazamiento del inicio del cumplimiento de la pena y solicitar el cumplimiento fraccionado de la misma. En el trámite de la liquidación podemos señalar que el dies a quo no se inicia en el momento que la sentencia que priva del derecho ha sido declarada firme, sino que empieza a computar desde el momento que el penado ha sido requerido personalmente y advertido de las consecuencias del no cumplimiento de la pena ${ }^{684}$.

\footnotetext{
681 Respecto al trámite de liquidación de condena y remisión de mandamiento de tráfico, vid. DE LAMO RUBIO, Jaime, Penas y medidas..., op.cit., pp.144-145 y CORDERO LOZANO, Carlos, Ejecución..., .op.cit., p.148.

682 Vid. VALLESPÍN PÉREZ, David, Aspectos procesales..., op.cit., p.85.

683 En relación con el trámite de la liquidación de condena, vid. CORDERO LOZANO, Carlos, Condenas..., op.cit., p.44. El trámite de liquidación de la condena de privación del derecho a conducir es esencial en el procedimiento, así como el traslado de la misma a la defensa del penado en aras a poder efectuar alegaciones como ha destacado el AAP de Navarra, núm. 90/2017, Sección 2aㅡ, de 20 de marzo de 2017, ponente Ilmo. Sr. José Francisco Cobo Sáenz (TOL6.156.838).

684 Vid. en este sentido AAP de Cantabria, núm. 524/2015, Sección 3a , de 21 de diciembre de 2015, ponente Ilmo. Sr. Agustín Alonso Roca (TOL5.658.875) y AAP de Salamanca, núm. 95/2017, Sección 1a , de 13 de marzo de 2017, ponente llmo. Sr, José Antonio Vega Bravo (TOL6.084.204).
} 
Uno de los problemas que se suscitan en el trámite de la liquidación de condena es el relativo a la valoración de los periodos que el penado ha estado privado del derecho a conducir en la instrucción de la causa y que han de ser computados en la liquidación definitiva. El penado ha podido sufrir la privación del derecho a conducir como medida cautelar policial, ex art. $770.6^{\circ}$ de la LECrim o judicial ex art. 529 bis y 764.4 de la LECrim, y ambos supuestos han de valorarse por imperativo del art.58.4 $\mathrm{CP}$ que establece el abono de las privaciones de derechos sufridas de forma cautelar. En los dos casos HIDALGO DE MORILLO 685 estima que han de ser abonados en la liquidación de condena, en términos similares a lo que se realiza con el abono de la prisión provisional. En el mismo sentido se posiciona FERNÁNDEZ PANTOJA ${ }^{686}$ en relación con el periodo de privación por medida cautelar judicial en base a lo previsto en los arts.58.4 y 59 CP y MARTíNEZ PARDO $^{687}$ que mantiene que el abono del periodo en que ha estado vigente la medida cautelar ha de ser imperativo en base al tenor literal del art.58.4 CP. Comparto las anteriores posiciones doctrinales ya que cuando el penado ha sufrido la privación cautelar de su derecho a conducir bien en el ámbito policial o judicial, ulteriormente se ha de abonar en la liquidación definitiva de la condena, siempre que la medida cautelar esté acreditada documentalmente.

En relación con el abono a practicar en la liquidación de la pena de privación del derecho a conducir, VALLESPÍN PÉREZ688 y MORENO CATENA689 incluso mantienen que se debe abonar el periodo en el que el penado no ha podido utilizar el permiso o licencia al hallarse en situación de prisión provisional en la misma causa por la que ha sido finalmente condenado. Acerca de esta posibilidad considero que únicamente procederá el abono de la misma si además de la prisión provisional se ha acordado por resolución judicial que el penado tampoco podrá ejercer su derecho a conducir de manera cautelar, siendo necesario que expresamente por la autoridad judicial se prive del ejercicio de dicho derecho. El cumplimiento simultáneo de dos medidas cautelares puede suceder en aquellos supuestos que se imputan delitos de homicidio, lesiones graves o incluso en

\footnotetext{
685 Vid. HIDALGO DE MORILLO JIMÉNEZ, Agustín, "Aspectos comunes a los delitos contra la seguridad vial", La dogmática penal..., op.cit., p.46.

686 Acerca del abono del tiempo de privación sufrido por la medida cautelar, vid. FERNÁNDEZ PANTOJA, Pilar, "Delitos contra la seguridad del tráfico: la pena de privación del derecho a conducir", en AA.VV. Delincuencia..., op.cit., p.82.

687 Vid. MARTÍNEZ PARDO, Vicente José, La ejecución..., op.cit., pp.61-62.

688 Vid. VALLESPÍN PÉREZ, David, Aspectos procesales..., op.cit., p.86.

689 Vid. MORENO CATENA, Víctor, "La ejecución", en MORENO CATENA, Víctor/CORTÉS DOMÍNGUEZ, Valentín, Derecho..., op.cit., p.691.
} 
supuestos de quebrantamiento de condena o medida cautelar de privación del derecho a conducir o delito de abandono del lugar del accidente. Estas situaciones son minoría y en concreto han sido calificadas de "residuales" ya que como señaló la Fiscalía de Seguridad Vial, la proyección del año 2014 era de 54 supuestos en los que se había solicitado la prisión provisional690. En este sentido hemos de señalar que entre los años 2015 y 2019 las personas en situación de prisión preventiva por delitos contra la seguridad vial han oscilado entre las dos y las diez ${ }^{691}$.

La jurisprudencia, de forma mayoritaria, estima como periodo a abonar en la liquidación definitiva de la pena de privación del derecho a conducir el periodo de intervención policial y judicial del permiso o licencia aún en el caso que no exista resolución judicial expresa que la acordara ${ }^{692}$, criterio que comparto ya que el penado en ese lapso temporal habrá estado privado cautelarmente de poder conducir y carecería de sentido no abonarle dicho periodo, ya que de lo contrario se le estaría obligando a cumplir doblemente la pena.

\section{d) Control por parte de la Jefatura Central de Tráfico}

Tras realizarse la liquidación definitiva de la condena y concretar los periodos de inicio y finalización de la pena de privación del derecho a conducir, para garantizar el efectivo cumplimiento de la pena, por parte del juzgado se informa a la Jefatura

\footnotetext{
690 Vid. la nota de prensa del Fiscal Coordinador de Sala de Seguridad Vial de 1/08/2014. Recurso electrónico disponible en:

https://www.fiscal.es/documents/20142/159294/INFORME+DE+SEGURIDAD+VIAL.pdf/08a5c9bdbba4-be9b-ce4d-494dcb3fc2a8 (último acceso: 03/11/2020).

691 En relación con las personas en situación de prisión preventiva vid. Memoria FGE año 2016, p. 526, Memoria FGE año 2017, p.583 y Memoria FGE año 2020, p. 912.

692 En este sentido podemos citar los interesantísimos AAP de Tarragona, núm. 318/2012, Sección $2^{2}$, de 5 de julio de 2012, ponente IIma. Sra. Mํㅡㄹ Concepción Montardit Chica (TOL3.591.641), AAP de Tarragona, núm. 54/2013, Sección 2a a de 24 de enero de 2013, ponente llmo. Sr. José Manuel Sánchez Siscart (TOL3.881.747); AAP de Asturias, núm. 476/2012, Sección 3ạa , de 15 de junio de 2012, ponente IImo. Sr. Javier Gustavo Fernández Teruelo (TOL3.642.952); AAP de Barcelona, núm. 470/2017, Sección 9â, de 3 de julio de 2017, ponente Ilmo. Sr. Ignacio de Ramón Forns (TOL6.400.984) y AAP de Zaragoza, núm. 167/2019, Sección 1ª de 13 de marzo de 2019, ponente Ilmo. Sr. Juan Alberto Belloch Julbe (TOL7.195.357). También podemos destacar la Sentencia del Juzgado de lo Penal no 7 de Alicante, núm. 44/2016 de 1 de marzo de 2016, Magistrado Ilmo. Sr. Leopoldo David Macia Llobregat (TOL5.666.675).

Asimismo, podemos destacar también el AAP de Cantabria, núm. 524/2015, Sección 3a , de 21 de diciembre de 2015, ponente IImo. Sr. Agustín Alonso Roca (TOL5.658.875), en el que se deniega el abono solicitado por el penado en la liquidación de condena, ya que el permiso de conducir nunca estuvo cautelarmente intervenido ni por la policía ni por el Juzgado.
} 
Central de Tráfico693. En dicha comunicación se determinará el periodo que el penado ha de cumplir de condena y estará privado de su derecho a conducir, para de esta forma obtenerse el control administrativo del cumplimiento de la pena en todo el territorio nacional al anotarse en las bases de datos de todos los cuerpos policiales: locales, autonómicos y estatales. Una vez recibida la comunicación judicial por la Jefatura Central de Tráfico, existe una triple finalidad en el ámbito administrativo relacionada con el control del cumplimiento de la pena. En primer lugar las Jefaturas Provinciales de Tráfico podrán tener la certeza de la existencia de una pena y por lo tanto no expedirán a los penados un nuevo permiso o licencia hasta que haya sido efectivamente cumplida. En segundo lugar, al controlarse administrativamente los periodos de cumplimiento de la condena sirve para detectar los posibles quebrantamientos de condena que pueda efectuar el penado. Existe en mi opinión una tercera finalidad en el control administrativo de la pena relacionada con los penados que han delinquido y no poseen permiso o licencia, que no podrán obtenerlos durante el tiempo de cumplimiento de la misma.

En relación con el control por parte de la Jefatura Central de Tráfico de las condenas que incorporan la pena de privación del derecho a conducir, con anterioridad al año 2015 podría existir un resquicio para eludir el control y la coordinación penal-administrativa. Eran los supuestos de Juicio Rápido en los que se dictaba una sentencia condenatoria de conformidad en el Juzgado de Guardia en que se imponía la pena de privación del derecho a conducir, pero era el Juzgado de lo Penal o bien un juzgado específico de ejecutorias penales para el caso que existiera en el partido judicial, quien ejecutaba la sentencia dictada y posteriormente realizaba la liquidación de condena de la pena de privación del derecho a conducir. Debido a que podía transcurrir un lapso temporal entre la sentencia condenatoria de conformidad y la recepción de la información en la Jefatura Provincial de Tráfico, el penado podría llegar a solicitar un duplicado del permiso que se había intervenido judicialmente. Sin embargo, en la actualidad tras la firma del protocolo de fecha 10 de febrero de 2015 para la remisión telemática de penas, medidas de seguridad y medidas cautelares en materia de seguridad vial de la Administración de Justicia a la DGT, existe una coordinación telemática entre los Juzgados y la Jefatura de Tráfico, registrándose de forma instantánea las sentencias condenatorias que incluyan la pena de privación del derecho a conducir. Asimismo, con la finalidad de profundizar en la coordinación entre ambas administraciones se dictó la Instrucción

\footnotetext{
693 Relativo a la Jefatura Central de Tráfico: http://www.dgt.es/es/la-dgt/quienes-somos/estructuraorganica/ (último acceso: 03/11/2020).
} 
15/ S-138, de 15 de septiembre de 2015 de la DGT, que desarrolló la forma de ejecutar el citado protocolo694.

En la ejecución de la pena estudiada también tiene relevancia la intervención de la DGT a través del Registro de Conductores e Infractores, regulado en el Reglamento General de Conductores, aprobado por RD 818/2009 de 8 de mayo por el que se aprueba el RGCon ${ }^{695}$. En el art. art.77.i) del citado texto legal se detalla el contenido del Registro de Conductores e Infractores en el que se han de anotar las condenas en sede penal relacionadas con la privación del derecho a conducir, siendo un mecanismo ágil e informatizado que permite controlar administrativamente las penas de privación del derecho a conducir696. Además del control por el juez penal, con la inscripción de la condena a la pena de privación del derecho a conducir en los Registros dependientes de la DGT se ha considerado por parte de la doctrina ${ }^{697}$, que existe un control administrativo de la pena impuesta. La coordinación entre el ámbito penal y administrativo a través de la DGT ha sido uno de los factores que ha coadyuvado a mejorar la lucha contra los delitos contra la seguridad vial ${ }^{698}$, siendo relevantes los proyectos y protocolos instaurados especialmente desde el año 2007.

Para finalizar el análisis referente a la ejecución ordinaria de la pena de privación del derecho a conducir debemos señalar las posibilidades que ofrece la misma en sede de ejecución y que han sido poco exploradas. El cumplimiento de la misma se sigue caracterizando por la rigidez y el automatismo, lo que implica que opciones como el aplazamiento del inicio de su cumplimiento o la suspensión de la ejecución sean residuales. En este sentido comparto lo manifestado hace años por TAMARIT SUMALLA relativo a que la pena de privación del derecho a conducir "debería prever expresamente una pluralidad de formas de cumplimiento"699, así como por las propuestas doctrinales realizadas en relación con la flexibilización de la

\section{Vid. la Instrucción en: http://siprojefes.com/wp-content/uploads/2017/02/ins 15s138-DGT.pdf (último acceso: 03/11/2020). \\ 695 Recurso electrónico disponible en: https://www.boe.es/boe/dias/2009/06/08/pdfs/BOE-A-2009- 9481.pdf (último acceso: 13/11/2020).}

696 Art.77.Datos que han de figurar en el Registro. En el Registro de conductores e infractores figurarán los siguientes datos. i) Condenas judiciales que afecten a la autorización administrativa para conducir y las sanciones administrativas que sean firmes impuestas por infracciones graves y muy graves.

697 Vid. MAGRO SERVET, Vicente, “¿Es posible fraccionar...?”, op.cit., pp.59-66.

698 Vid. los proyectos llevados a cabo en la Memoria de la FGE del año 2008, pp.677-678. Asimismo, desde el año 2015 y como muestra de la coordinación penal y administrativa, existe el protocolo de remisión telemática de sentencias condenatorias por parte de los Juzgados a la DGT.

699 Vid. TAMARIT SUMALLA, Josep/ LUQUE REINA, Maㅡ Eulàlia, Automóviles, delitos y penas..., op.cit., p.164. 
ejecución de la pena de privación del derecho a conducir ${ }^{700}$. Precisamente en el BCPP, por primera vez se reconocían dos opciones distintas de poder cumplir la pena objeto de análisis como son el aplazamiento para iniciar su cumplimiento, así como el fraccionamiento de la misma. Con dicha previsión legal en mi opinión se recogían las sensibilidades expresadas en la doctrina y jurisprudencia minoritaria durante la última década y podrían ser útiles para una mejor ejecución de la pena de privación del derecho a conducir en el caso que dicho Proyecto fuese aprobado.

\subsubsection{Efectos administrativos vinculados a la ejecución. La obligatoriedad de realizar el curso de sensibilización y reeducación vial}

Los efectos de la aplicación de la pena de privación del derecho a conducir no se circunscriben al ámbito penal, sino que existe un efecto administrativo derivado de esta pena que es la obligatoriedad de realizar el curso de sensibilización y reeducación vial. A pesar de que el curso está regulado por la normativa administrativa, afecta a los delitos que conllevan la pena de privación del derecho a conducir y es debido a que las condenas de privación del derecho a conducir no acarrean la pérdida de puntos en el permiso de conducir, aunque sí es obligatorio que para poder volver a conducir se realice dicho curso.

La pena de privación del derecho a conducir, es junto a los casos de pérdida de todos los puntos o de casos de pérdida parcial, uno los tres supuestos establecidos legalmente para realización el curso de sensibilización y reeducación vial ${ }^{701}$, derivando su obligatoriedad del RDL 6/2015 de 30 de octubre por el que se aprueba el texto refundido de la LTSV, que ha derogado la DA $13^{\text {a }}$ de la LTSV y la Ley 17/2005 de 19 de julio ${ }^{702}$. Tanto en los casos que se impone una pena de privación del derecho a conducir superior a los dos años como en los que la pena sea inferior y el permiso o licencia sigan vigentes, siempre se tendrá que llevar a cabo por el penado el curso de sensibilización y reeducación vial. Se han puesto de manifiesto en este trabajo las conexiones existentes entre el ámbito penal y el administrativo en los aspectos relacionados con la pena de privación del derecho a conducir y la

\footnotetext{
700 Vid. Grupo de Estudios de Política Criminal, Una propuesta..., op.cit., pp.37-38.

701 Vid. TORRES FERNÁNDEZ, Ma Elena, "Reflexiones sobre algunos efectos administrativos del llamado "carnet por puntos" en las consecuencias penales de los delitos contra la seguridad en el tráfico", en AA.VV. Delincuencia..., op.cit., p.102.

702 Una diferencia entre aquellos penados que han de realizar el curso derivado de una condena a la pena de privación del derecho a conducir inferior a dos años y aquellos conductores que han perdido la vigencia del permiso por haber agotado todos sus puntos, es que aquellos no estarán obligados a realizar ningún examen, sino que únicamente han de realizar el curso establecido.
} 
realización del curso de sensibilización y reeducación vial es otra prueba de como la pena privación del derecho a conducir acude al ámbito administrativo para determinar todas las consecuencias que se derivan de la misma ${ }^{703}$.

La regulación y contenido del curso de sensibilización y reeducación vial se detalla en la Orden INT/2596/2005 de 28 de julio por la que se regulan los cursos de sensibilización y reeducación vial para los titulares de un permiso o licencia de conducción. En el artículo tercero de la citada orden se determina que la realización y aprovechamiento del curso permitirá volver a conducir a los penados que hayan sido condenados a la pena de privación del derecho a conducir ${ }^{704}$.

Respecto a la realización del referido curso hemos de diferenciar a los conductores sancionados con una pena de privación del derecho a conducir inferior a dos años de aquellos que reciben una pena de mayor duración. En el primer supuesto puede realizarse el curso durante el cumplimiento de la condena y de esta forma una vez finalizada la misma podría volver a conducir sin más trámites que realizar ${ }^{705}$. Sin embargo, cuando la pena de privación del derecho a conducir se ha impuesto por un periodo superior a los dos años la aplicación del art.47.3 CP comporta un tratamiento diferenciado. Es interesante analizar cuando se aplique el art.47.3 CP en qué momento se debía realizar tanto el curso de sensibilización y reeducación vial como las pruebas para la obtención del nuevo permiso, ya que podemos hallarnos ante dos opciones: realizarlo antes o después de haber cumplido la pena de privación del derecho a conducir. Si bien de la hoy derogada DA $13^{\text {a }}$ de la

\footnotetext{
703 Vid. TRAPERO BARREALES, María.A., Los delitos..., op.cit., p.571 y GONZÁLEZ COLLANTES, Tàlia, "Seguridad vial, reformas penales y reeducación", en AA.VV. Prevención y control de la siniestralidad vial. Un análisis jurídico y criminológico, ORTS BERENGUER, Enrique (Coord.), Ed. Tirant lo Blanch, Valencia, 2011, pp.212-213.

704 Artículo Tercero Orden INT/2596/2005 de 28 de julio. Tipos de cursos.- Los cursos podrán ser de dos tipos: a) De recuperación parcial de puntos. La realización y superación con aprovechamiento de este curso permitirá al titular de la autorización para conducir la recuperación de un máximo de cuatro puntos, sin que en ningún caso se puedan recuperar más puntos de los que se hubieran perdido. b) De recuperación del permiso o la licencia de conducción. La realización y superación con aprovechamiento de este curso, y la posterior superación de la prueba de control de conocimientos a que se refiere el apartado décimo de la presente Orden, permitirán la recuperación de un permiso o de una licencia de conducción de la misma clase de la que se fuera titular. Asimismo, su realización y superación con aprovechamiento, permitirá al titular de un permiso o de una licencia de conducción que haya sido condenado por sentencia firme por la comisión de un delito castigado con la privación del derecho a conducir un vehículo a motor o un ciclomotor, volver a ejercer la actividad de la conducción.

705 La Memoria de la FGE del año 2008, p.682, reconoce la posibilidad de realizar los cursos durante el cumplimiento de la condena de privación del derecho a conducir.
} 
LTSV706 así como del vigente art. 73.1 de la LTSV puede inferirse que los penados únicamente podrán realizar el curso una vez cumplida la pena ${ }^{707}$, la DGT emitió el 16/04/2009 la Instrucción nº 09/S-108, sobre "Pérdida de vigencia del artículo 47 del Código Penal", que en su apartado E), en lo relativo al momento para realizar el curso de sensibilización y reeducación vial indicaba que:"... El curso podrá realizarse en cualquier momento posterior a la firmeza de la sentencia y podrá hacerse incluso durante el tiempo de cumplimiento de la pena impuesta en aquélla...". Con esta Instrucción, la propia DGT faculta que se pueda realizar el referido curso durante el periodo de cumplimiento de la pena, opción que no comparto al ser contraria al fundamento del art. 47.3 CP.

Tras lo expuesto podemos concluir que la realización del curso de sensibilización y reeducación vial, tanto en los casos que la condena de privación del derecho a conducir sea inferior o superior a los dos años, puede llevarse a cabo durante el periodo de cumplimiento de la misma, y en todo caso se tendrá que haber realizado antes que el penado quiera ejercer de nuevo su derecho a conducir.

En lo que respecta al contenido del curso de sensibilización y reeducación vial, el mismo está regulado en la Orden INT/2596/2005, de 28 de julio, por la que se regulan los cursos de sensibilización y reeducación vial para los titulares de un permiso o licencia de conducción ${ }^{708}$. En dichos cursos a los penados que lo realicen se les imparten materias relacionadas con el delito cometido tales como la influencia del alcohol, las drogas o la velocidad como factores de riesgo o la importancia del cumplimiento de las normas de tráfico. Cabe señalar que los penados a la privación del derecho a conducir inferior a dos años están obligados a hacer el curso, pero únicamente será necesario que se lleve a cabo un aprovechamiento del mismo sin necesidad de realizar examen. En este sentido TORRES FERNÁNDEZ709, mantenía que los penados a la privación del derecho a conducir inferior a dos años no han de

\footnotetext{
706 DA 13a LTSV: Obtención del permiso o licencia de conducción cuando su titular haya sido condenado por sentencia penal con la privación del derecho a conducir. 1. El titular de una autorización administrativa para conducir que haya perdido su vigencia de acuerdo con lo previsto en el artículo 47 del Código Penal al haber sido condenado por sentencia firme a la pena de privación del derecho a conducir vehículos a motor y ciclomotores por tiempo superior a dos años, podrá obtener, una vez cumplida la condena, una autorización administrativa de la misma clase y con la misma antigüedad, de acuerdo con el procedimiento establecido en el artículo 63.7 para la pérdida de vigencia de la autorización por la pérdida total de los puntos asignados.

707 Vid. MAGRO SERVET, Vicente, Análisis..., op.cit., p.81.

708 Vid. el contenido íntegro de la Orden, así como la totalidad de materias que se imparten en los cursos en: http://www.boe.es/diario boe/txt.php?id=BOE-A-2005-13723 (último acceso: 13/11/2020).
} 
hacer el examen que sí se exige en los casos que se aplicaba el párrafo primero de la DA $13^{\text {a }}$ de la LTSV, actualmente art.73.1 de la LTSV, en el que se regulaban los supuestos de aquellos penados que por mor del art.47.3 CP perdían la vigencia de su permiso.

Una cuestión que resulta de sumo interés es si la realización del curso de reeducación y sensibilización vial es obligatoria o si el penado puede oponerse a llevar cabo el curso. La respuesta es que la realización del curso es obligatoria desde la perspectiva administrativa aun cuando desde el punto de vista penal tal obligatoriedad no aparezca recogida en la sentencia por la que se le priva del derecho a conducir, ya que la no realización comportará la imposición de multas administrativas. El penado una vez haya transcurrido el plazo por el que ha sido impuesta la pena de privación del derecho a conducir, podrá ejercer de nuevo su derecho a conducir, ya que el Juzgado o Tribunal le retornará el permiso o licencia informándole del cumplimiento de la pena, no controlando si ha realizado o no el curso ${ }^{710}$. Sin embargo, deberá cumplirse la obligación administrativa de realizar el curso de reeducación y sensibilización vial ya que de lo contrario podrá ser sancionado administrativamente.

Una de las disfunciones relacionadas con la obligación de realizar el curso de sensibilización y reeducación vial es que los penados en numerosas ocasiones o bien no llegan a recibir el requerimiento por parte de la Jefatura de Tráfico para llevar a cabo el mismo, o bien la reciben una vez cumplida ya la pena, retornado el permiso por el Juzgado y cuando llevan ya un tiempo ejerciendo de nuevo su derecho a conducir ${ }^{711}$. En estos supuestos la función del curso quedará desvirtuada ya que el penado volverá a conducir por el mero transcurso del tiempo y sin haber obtenido toda la información que se proporciona en el curso. Por ello, sería interesante que los Juzgados o Tribunales no retornaran el permiso de conducir en aquellos casos con una pena inferior a los dos años hasta que no se acreditara que

\footnotetext{
709 Vid. TORRES FERNÁNDEZ, Ma Elena, "Reflexiones sobre algunos efectos administrativos del llamado "carnet por puntos" en las consecuencias penales de los delitos contra la seguridad en el tráfico", en AA.VV. Delincuencia..., op.cit., pp.111-113.

710 Acerca a la ausencia de control penal de los cursos de sensibilización y reeducación vial, vid. CORDERO LOZANO, Carlos, Ejecución..., op.cit., p.152.

711 Hemos de señalar que la sanción administrativa por conducir una vez cumplida la pena sin haber realizado el curso de sensibilización y reeducación vial es de $200 €$ según establece el art. 76 II) de la LTSV, por lo que considero que tiene muy pocos efectos disuasorios, por lo que determinados penados pueden optar por no hacerlo y conducir.
} 
el penado ha realizado el curso de sensibilización y reeducación vial ${ }^{712}$. Sin embargo, esta posibilidad hoy día es imposible y al no existir previsión alguna en la normativa penal en relación al referido curso sería necesaria una reforma legislativa.

La conclusión más importante de la influencia del referido curso en la pena que analizamos, es que carece de relevancia penal al no formar parte del contenido de la sentencia dictada ${ }^{713}$. A pesar de ser una condición de ejecución para que los penados puedan volver a conducir una vez cumplida la condena, su obligatoriedad viene impuesta por una norma extrapenal, en este caso administrativa. Por ello considero que cuando el penado conduzca tras haber cumplido la pena de privación del derecho a conducir, pero sin haber realizado el curso, no podrá ser acusado por un delito de quebrantamiento de condena y su acción únicamente podrá ser sancionada en la vía administrativa ${ }^{714}$ al amparo del art.73.1 de la LTSV, en relación con el art. 76 II) del mismo texto legal.

\subsubsection{Supuesto de concurrencia de la privación del derecho a conducir con la previsión del art.47.3 CP}

En el último epígrafe del capítulo dedicado a las condiciones de ejecución se examinará la ejecución de la pena de privación del derecho a conducir en relación con el art.47.3 CP. El efecto del art.47.3 CP en la condena de privación del derecho a conducir vehículos a motor y ciclomotores podemos calificarlo como ipso iure 715 ya que la pérdida de vigencia del permiso o licencia opera de manera automática en el caso que la pena de privación supere el umbral establecido de los dos años. Uno de los aspectos destacables de la ejecución del art.47.3 CP es que la pérdida de vigencia del permiso o licencia se produce desde el mismo momento en el que se decreta la firmeza de la sentencia ${ }^{716}$, ya que no tendría sentido que sus efectos se

\footnotetext{
712 En este sentido vid. MAGRO SERVET, Vicente, Análisis..., op.cit., p.81, quien señala que el permiso de conducir no se debería retornar hasta que no se haya acreditado la realización del curso por parte del penado.

${ }^{713}$ Vid. SAP de Murcia, núm. 387/2017, Sección 3a , de 22 de septiembre de 2017, ponente llmo. Sr. Álvaro Castaño Penalva (TOL6.397.049), en la que se determina que el referido curso no aparece en el listado de penas del CP.

714 En el mismo sentido se ha expresado PRIETO GONZÁLEZ, Helena María, " El delito de conducción sin permiso en la reforma de los delitos contra "la seguridad vial", en AA.VV. Seguridad Vial..., op.cit., pp. 264-265.

715 En relación con el art.47.3 vid. VÁZQUEZ IRUZUBIETA, Carlos, Comentario al Código Penal: actualizado por LO 5/2010, de 22 de junio, Ed. La Ley, Madrid, 2010, p.198.
}

716 Vid. NUÑO DE LA ROSA AMORES, José Antonio, “Aplicación práctica...”, op.cit., p.115. 
produjeran una vez cumplida la pena, pues la finalidad del precepto es evitar que el penado pueda seguir conduciendo.

Uno de los problemas que se plantean en este ámbito es el relativo a la concurrencia de lo previsto en el art.47.3 y la modalidad delictiva del art.384.2 CP en relación con la conducción sin permiso tras haber sido privado definitivamente por decisión judicial. En concreto, el problema se plantea en determinar cuándo nos hallamos ante una privación definitiva del permiso, habida cuenta de la falta de taxatividad del tipo penal que puede permitir diferentes interpretaciones, lo que es sumamente difícil, como ha señalado TRAPERO BARREALES ${ }^{717}$. Es importante matizar cuando nos hallamos ante una privación definitiva del permiso y cuando nos hallamos ante una pérdida de vigencia que deriva del art.47.3 CP, al ser dos términos que, aunque similares, sus consecuencias son diferentes. Considero que el art.384 CP apartado segundo no se refiere al art.47.3 CP, sino que refiere a una sentencia condenatoria firme como estableció ab initio la Fiscalía de Seguridad Vial $^{718}$. Si se realizara otra interpretación, el legislador habría previsto dicha opción en el tipo penal y entenderlo de manera diferente podría ser contrario al principio de legalidad penal.

Por otro lado, hemos de plantearnos qué sucede si las consecuencias del art.47.3 CP no aparecen reflejadas en la sentencia que impone una pena de privación del derecho a conducir superior a los dos años, por lo que hemos de determinar cómo se ha de resolver. Los efectos del art.47.3 CP acordando la pérdida de vigencia del permiso o licencia al estar previstos en el CP, obligan a un procedimiento jurisdiccional en la sentencia dictada y únicamente los puede adoptar el juez penal para su posterior eficacia en la esfera administrativa. Es por ello que, en todo caso, debe existir el reflejo documental en la jurisdicción penal de la pérdida de vigencia del permiso o licencia ex art.47.3 CP, ya que la autoridad administrativa no podrá acordarla y ello en base a la interpretación analógica que podemos realizar del criterio que se sigue con las penas accesorias ${ }^{719}$.

A pesar del carácter imperativo del art.47.3 CP puede suceder que la sentencia imponga la pena de privación del derecho a conducir por tiempo superior a dos años, pero no recoja los efectos del art.47.3 CP. Si ello acontece, los efectos serán idénticos a los que se deriven de la inclusión de los efectos del art.47.3 CP en la

\footnotetext{
717 Vid. TRAPERO BARREALES, María.A., Los delitos..., op.cit., p.407.

718 Vid. Memoria de la FGE, año 2009, p.780.

719 Referente a las penas accesorias, vid. arts.54 y 56 CP.
} 
sentencia dictada ya que en ambos en fase de ejecución de la misma se deberá remitir comunicación a la Jefatura Provincial de Tráfico ${ }^{720}$. Cuando no consten en la sentencia los efectos del art.47.3 CP, la Circular 10/11 de la FGE ${ }^{721}$ ha establecido que la Jefatura Provincial de Tráfico como autoridad administrativa, no podrá decretar de oficio la pérdida de vigencia del permiso o licencia ya que no habrá sido acordada en sentencia y carecería de competencia para hacerlo. Sin embargo, MOLINA GIMENO y ROBLEDO VILLAR ${ }^{722}$ estiman que la pérdida de vigencia del permiso o licencia ha de operar ope legis aunque no se contemple en el fallo judicial. En el mismo sentido se expresaba el Ministerio del Interior ${ }^{723}$, que consideraba que dicha consecuencia operaba de forma automática, aunque no se hiciera referencia alguna en la sentencia dictada. Estos argumentos considero que no son válidos, ya que la autoridad administrativa no podrá ir más allá del contenido de la sentencia dictada. De aceptarse lo contrario estaríamos otorgando facultades a la autoridad administrativa que le corresponden al juez penal y que no puede aplicarlas ni tan siquiera manera indirecta, ya que en la sentencia dictada ha de constar expresamente que se decreta la pérdida de vigencia del permiso o licencia.

En todo caso debe tenerse en cuenta que existen mecanismos que puede utilizar la autoridad administrativa para subsanar la omisión que se ha producido en la sentencia. Una de las vías es informar al Tribunal sentenciador de la omisión en la sentencia dictada para aclarar o complementar la misma. La Jefatura Provincial de Tráfico sí tendría legitimación para instar la aclaración de la sentencia dictada, ya que dicho organismo es quien ha de aplicar los efectos del art.47.3 CP. La segunda vía que puede activarse es que, dentro del procedimiento penal, se dicte un auto aclaratorio donde especifique que se ha producido la pérdida de vigencia del permiso o licencia ${ }^{724}$, opción que incluso se podría acordar de oficio por el órgano judicial. Además, el Ministerio Fiscal o la acusación particular, también podrían alertar de la omisión acaecida a través de las diferentes opciones existentes. Podría

\footnotetext{
720 En este sentido coincido con la opinión de MOLINA GIMENO, Francisco Javier, "Delitos contra la Seguridad Vial. Comentarios a la reforma del Código Penal operada por la LO 15/2007 de 30 de noviembre “, Revista El Ligall, II·lustre Col-legi d’Advocats de Granollers, № 41, Año 2008.

721 Vid. al respecto el criterio de la FGE, en la circular 10/2011, p.72.

722 Vid. MOLINA GIMENO, Francisco Javier, "Delitos contra la Seguridad Vial. Comentarios a la reforma del Código Penal operada por la LO 15/2007 de 30 de noviembre ", Revista El Ligall, II-Iustre Col-legi d'Advocats de Granollers, no 41, Año 2008, y también ROBLEDO VILLAR, Antonio, La protección penal de la seguridad vial (configuración de los tipos delictivos tras la LO 15/2007, de 30 de noviembre, sobre modificación del C.Penal), Ed. Ilustre Col-legi d'Advocats de Lleida, 2008, p.70.

723 Vid. la Instrucción 09/ S- 1098 de la Dirección General de Tráfico, relativa a la pérdida de vigencia del permiso o licencia por aplicación del art.47 CP.

724 Comparto lo expresado por LANZAROTE MARTíNEZ, Pablo, "Aspectos comunes a los delitos contra la seguridad vial", La dogmática penal..., op.cit., p.42.
} 
instarse una aclaración y/o complementación de la sentencia ante el mismo Juzgado o Tribunal que ha dictado la misma para incluir en el fallo de la misma las consecuencias del art.47.3 CP. Otra posibilidad sería interponer un Recurso de Apelación contra la sentencia dictada, para el caso que no fuera firme, y solicitar la inclusión de los efectos que prevé ex lege el art.47.3 CP725.

También destacaremos las opciones dentro del proceso penal en los casos que la sentencia hubiese devenido firme y no se incluyeran en la misma los efectos del art.47.3 CP. Para solucionar dicha omisión, en sede de ejecución aún existirían cuando menos dos posibilidades para subsanar dicha circunstancia. La primera sería instar un recurso de revisión de sentencia firme bien por parte del Ministerio Fiscal bien por parte de la acusación particular, para complementar la sentencia con los efectos del art.47.3 CP. La segunda opción sería presentar un escrito en el trámite de la ejecución penal indicando el error producido en la sentencia dictada, y solicitando a la vez la complementación de la misma. En estos casos, y cuando no se haya dictado auto aclaratorio la jurisprudencia ha determinado que la pérdida de vigencia se activará ope legis se contemple o no en el fallo de la sentencia ${ }^{726}$, subsanándose por la vía de su incorporación en la ejecutoria ${ }^{727}$.

En el sentido contrario, es posible que el juzgador incluya en la sentencia los efectos del art. 47.3 CP cuando el Ministerio Fiscal o la acusación particular en sus escritos de conclusiones provisionales y definitivas no hubieran peticionado que se aplicara el art.47.3 CP y en la sentencia dictada por imperativo del art.47.3 el Juez o Magistrado la impusiera. Si el conductor penado quisiera invocar una posible vulneración de su derecho de defensa o la vulneración del principio de seguridad jurídica, tendría unas posibilidades mínimas que sus alegaciones prosperasen al

\footnotetext{
725 Esta opción ya fue aplicada en otros tipos delictivos como el del art.379 CP, en un supuesto en el que no se imponía la pena obligatoria de TBC, y a través del Recurso de Apelación interpuesto por la Fiscalía se complementó posteriormente la sentencia dictada. Vid. SAP de Madrid, núm.709/2009, Sección 16a , de 11 de noviembre de 2009, ponente Ilmo.Sr. Miguel Hidalgo Abia (TOL1.771.189). Asimismo, también se presentó recurso de Apelación por la Fiscalía contra una sentencia del Juzgado de lo Penal en la que no se reflejaban los efectos del art. 47.3, siendo la pena de privación del derecho a conducir superior a tres años. En este caso, la Audiencia Provincial resolvió que no era necesario que constaran expresamente los efectos del art. 47.3, al ser de aplicación imperativa. Vid. SAP de Guipúzcoa, núm.252/2015, Sección 1ạ, de 18 de diciembre de 2015, ponente Ilma. Sra. María Josefa Barbarin Urquiaga (TOL5.674.471).

726 Vid. la SAP de Tarragona, núm. 528/2010, Sección 2ª , de 18 de noviembre de 2010, ponente Ilma. Sra.María De Los Ángeles Barcenilla Visus (TOL2.060.382).

727 Vid. la SAP de Tenerife, núm. 710/2008, Sección 2ª , de 10 de octubre de 2008, ponente llmo. Sr. Joaquín Luis Astor Landete. (JUR 2009/52342).
} 
hallarnos ante una consecuencia ex lege, que el juez tendrá que acordar cuando la pena de privación del derecho a conducir sea superior a dos años ${ }^{728}$.

Por todo lo expuesto podemos concluir que cuando la pena de privación del derecho a conducir rebase el umbral de los dos años de duración y no se recojan en la sentencia dictada los efectos del art.47.3 CP, existen mecanismos tanto intraprocesales como extraprocesales para que se acuerde la pérdida de vigencia del permiso o licencia. De lo contrario, el penado podría seguir conduciendo una vez cumplida la pena de privación del derecho a conducir, lo que es incompatible con el espíritu de la política criminal que motivó la entrada en vigor del art.47.3 CP.

A continuación, se analizan las incidencias relacionadas con los quebrantamientos que pueden cometer los penados que han sido privados del derecho a conducir que han visto como se ha decretado la pérdida de vigencia del permiso o licencia al rebasar el umbral de los dos años, ex art.47.3 CP.

En primer lugar, hemos de valorar si el penado carente de permiso o licencia por aplicación del art.47.3 CP que vuelve a conducir durante el periodo de privación puede cometer el delito del art.384, apartado segundo ${ }^{729}$. Una idea a destacar referente a la ejecución de la pena de privación del derecho a conducir con relación al art.47.3 CP, es que tras su entrada en vigor había que concretar su relación con el art.384, apartado segundo, y al adverbio "definitivamente", para poder determinar si el tipo del art.384 únicamente era aplicable tras la sentencia condenatoria con los efectos del art.47.3. Las dudas interpretativas respecto del art.384 se trasladaron a la Fiscalía, tal como se recogió en la Memoria de la Fiscalía Superior de Andalucía $^{730}$ del año 2011, y ha sido la FGE quien ha concretado cómo ha de interpretarse. Se ha fijado como criterio que cuando el artículo hace referencia al término "definitivamente" no se refiere en exclusiva al art.47.3 sino que hay que entender que se refiere a la sentencia que deja finalizado de manera definitiva el proceso penal ${ }^{731}$, por lo que lo penados a los que se les aplica el art. 47.3 CP que

\footnotetext{
728 Al respecto del art.47.3 señalar el comentario VÁZQUEZ IRUZUBIETA, Carlos: Comentario..., op.cit., p.198 y DE VICENTE MARTÍNEZ, Rosario, Siniestralidad vial..., op.cit., pp.90-91.

729 Vid. la Circular 10/2011 de la FGE, p.49.

730 Vid. Memoria de la Fiscalía Superior de la Comunidad Autónoma de Andalucía del año 2011, p.193.

Recurso electrónico disponible en: http://www.juntadeandalucia.es/justicia/portal/adriano/.content/recursosexternos/Memoria2012FSSA. pdf (último acceso: 03/11/2020).

731 Vid. el criterio que ha instaurado la Circular 10/2011 de la FGE, sobre criterios para unidad de actuación especializada del Ministerio Fiscal en materia de Seguridad Vial, p.58.
} 
conduzcan durante el tiempo de privación del derecho a conducir podrán ser acusados por el art.384 apartado segundo CP.

En segundo lugar, un supuesto que puede plantearse es el del penado que haya cumplido la pena objeto del estudio y vuelva a conducir sin haber recuperado la vigencia del permiso o licencia que se le privó por mor del art.47.3 CP y conforme a lo preceptuado en el art. 73.1 de la LTSV, debido a que no ha realizado las pruebas establecidas a tal efecto. Ante dicha situación deberá determinarse si nos hallamos ante un quebrantamiento de condena o bien ante hechos sin relevancia penal, por lo que estudiaremos las posturas doctrinales, resoluciones jurisprudenciales y el criterio que se mantiene por la FGE, para finalizar con la toma de posición.

Para resolver esta situación hemos de acudir al redactado del art.384 apartado segundo y comprobar si puede implementarse la conducta en el contenido punitivo del citado precepto. El primer dato relevante en esta conducta es que el penado habrá cumplido la pena de privación del derecho a conducir por lo que no se puede quebrantar. Además, el penado originariamente sí ha poseído el permiso por lo que su conducta no podría incardinarse en la conducta típica del art.384 que requiere que nunca haya poseído permiso o licencia ${ }^{732}$. A todo ello hemos de añadir que el Juzgado, cuando al penado al que se le aplica el art.47.3 CP cumple la pena de privación del derecho a conducir, no le realiza la advertencia ni requerimiento expreso que se abstenga de conducir hasta obtener de nuevo el permiso o licencia, por lo que no quebrantará ningún mandato judicial expreso.

Ante las dudas interpretativas que pueden generarse en supuestos de hecho en que el penado ex art.47.3 haya perdido la vigencia de su permiso y vuelva a conducir, cumplida la pena, pero sin obtener una nueva autorización, autores como SÁNCHEZ MORENO ${ }^{733}$ y BOLDÓ PRATS ${ }^{734}$ se han posicionado a favor de la atipicidad y la remisión de dicha conducta al Derecho Administrativo sancionador. Esta posición favorable a la atipicidad encuentra apoyo en la Instrucción nº 09/S108, sobre "Pérdida de vigencia del artículo 47 del Código Penal" de la DGT de fecha 16/04/2009. La Instrucción establece que la conducta de conducir una vez cumplida la pena y sin recuperar la vigencia del permiso es una sanción

\footnotetext{
732 En el mismo sentido y contrario a la imputación por el 384 vid. MIRÓ LLINARES, Fernando, "EI moderno...", op.cit., p.42.

733 Vid. SÁNCHEZ MORENO, José, Conducción..., op.cit., p.46.

734 Vid. BOLDÓ PRATS, Gabriela, "La Disposición Adicional decimotercera y el delito contra la seguridad vial, en concreto: el tipo penal del art.384". Revista de Derecho vLex, № 123, Julio 2014.
} 
administrativa muy grave del art. 65.5.j) de la LTSV735, que estaba en vigor en el momento en que se dictó la misma y actualmente se corresponde con el art. 77 letra $\mathrm{k}$ de la LTSV.

Sin embargo, existen también opiniones favorables a la punición de la conducción de los penados que han perdido la vigencia de su permiso por mor del art.47.3 y que conducen tras haber cumplido la pena. REQUEJO CONDE736 y BERNAL MARTíN ${ }^{737}$ son partidarios que estas conductas se puedan imputar por la vía del art.384 apartado primero, que hace referencia a la conducción tras la pérdida de todos los puntos, al considerar que si se pierde la vigencia del permiso también se pierden los puntos. Esta posición encuentra un cierto respaldo en el criterio expresado en la Circular 10/2011 de la FGE que determina que la pérdida de vigencia del permiso por pérdida de puntos y la pérdida de vigencia del permiso a causa del art.47.3 CP cuando se impone una pena de privación del derecho a conducir superior a dos años tienen una naturaleza similar ${ }^{738}$.

Otra posición favorable a la punición de la conducta de conducir tras haber perdido el permiso por mor del art.47.3 CP sin haber recuperado su vigencia, mantiene que puede incardinarse dicha acción en el art.468 CP que tipifica el quebrantamiento de condena genérico. Es la línea que mantiene la $\mathrm{FGE}^{739}$, con el argumento de considerar que la pérdida de vigencia es una consecuencia directa de la pena de privación del derecho a conducir, formando parte del fallo de la sentencia condenatoria. El criterio de la FGE en la Circular 10/2011 al calificar la conducta descrita como quebrantamiento de condena del art.468 $\mathrm{CP}^{740}$, viene matizado con el requisito que el penado debe ser expresamente advertido una vez cumplida la pena de privación del derecho a conducir. Por lo tanto, todo aquel que conduzca sin haber recuperado la vigencia del permiso o licencia según lo preceptuado en el art.73 de la LTSV, podría ser acusado por un delito del art.468 CP. Este argumento es muy forzado ya que mantiene que la pena de privación del derecho a conducir puede estar incursa en el último inciso del art.39.b CP, teniendo la misma la naturaleza de pena accesoria ya que así aparece reflejada en el art.47 CP. Además,

\footnotetext{
735 Art.65.5. Son infracciones muy graves, cuando no sean constitutivas de delito, las siguientes conductas. k): Conducir un vehículo careciendo de la autorización administrativa correspondiente.

736 Vid. REQUEJO CONDE, Carmen, Delitos relativos..., op.cit., p.126.

737 Vid. BERNAL MARTíN, LUIS FRANCISCO, "Comentario del artículo 384 del C. Penal”, Actualidad jurídica Aranzadi, no 7552008.

738 Vid. Circular FGE 10/2011, p.50.

739 Vid. Circular FGE 10/2011, p.50, así como la Memoria de la FGE del año 2012, p.881.

740 Vid. Circular FGE 10/2011, p.113, conclusión decimosegunda.
} 
iría contra la exposición de motivos de la LO 15/2007 de 30 de noviembre que en el párrafo cuarto indicaba que el art.384 CP nacía con la voluntad de reunir en un solo precepto todas las situaciones de quebrantamiento en relación con la seguridad vial.

Por su parte, debemos destacar que hay jurisprudencia que se ha posicionado a favor de la atipicidad de dicha conducta ${ }^{741}$ con el argumento que la pena no puede quebrantarse una vez que ya ha sido cumplida. Sin embargo, también existe una línea jurisprudencial que mantiene que estas conductas podrían ser incardinadas en el art. 384, segundo párrafo del $\mathrm{CP}$, ya que en virtud del principio de especialidad éste sería de aplicación preferente a la aplicación de art. $468 \mathrm{CP}^{742}$.

En los delitos que acarrean la pena de privación del derecho a conducir se apercibe al penado de la no posibilidad de conducir durante el tiempo de la condena, y en los casos que la pena sea superior a los dos años también se informa expresamente acerca de la pérdida definitiva del permiso o licencia ${ }^{743}$. Sin embargo, la parte dispositiva de la sentencia no recoge que no pueda volver a conducir hasta que se recobre de nuevo la vigencia del permiso o licencia. Como se ha expuesto, existirán amplias dificultades para proceder tanto por un delito del art.468 como por un delito del art.384 apartado segundo, por lo que debería concretarse por el legislador si dicha conducta es relevante penalmente o por el contrario únicamente es merecedora de sanción en la vía administrativa al amparo de lo establecido en el art.77.k de la LTSV744. Si se estimara que dicha conducta ha de tener relevancia penal, sería recomendable la reforma del art.384 CP en el sentido de incluir que además de los casos de pérdida de puntos se añada: "...y en los casos de pérdida de vigencia por aplicación del art.47.3”.

\footnotetext{
741 Vid. SAP de Barcelona, núm. 99/2009, Sección 2ª , de 16 de febrero de 2009, ponente Ilma.Sra. María José Magaldi Paternostro (TOL1.582.845).

742 Vid. SAP de Murcia, núm. 387/2017, Sección 3ạ, de 22 de septiembre de 2017, ponente llmo. Sr. Álvaro Castaño Penalva (TOL6.397.049).

743 Vid. SAP de La Coruña, núm. 259/2012, Sección 1ạ, de 16 de mayo de 2012, ponente llmo.Sr. José María Sánchez Jiménez (TOL2.576.616).

744 Art.77 LTSV. Son infracciones muy graves, cuando no sean constitutivas de delito, las conductas tipificadas en esta ley referidas a. k) Conducir un vehículo careciendo del permiso o licencia de conducción correspondiente.
} 


\subsubsection{La suspensión de la ejecución de la pena de privación del derecho a conducir vehículos a motor y ciclomotores por interposición de recurso de amparo y petición de indulto}

Para finalizar el apartado relativo a la ejecución ordinaria de la pena de privación del derecho a conducir, analizaremos la opción que la ejecución de dicha pena se suspenda por la interposición bien de recurso de amparo ante el Tribunal Constitucional bien por petición de indulto ante el Ministerio de Justicia. Se examinarán dos posibilidades de cumplir la pena de privación del derecho a conducir que se caracterizan por no adecuarse al principio de la inmediatez en su ejecución, ya que suspenden el inicio de la misma por dos motivos distintos hasta que no se resuelvan dos peticiones que el penado puede peticionar de manera simultánea o bien de forma sucesiva. Como hemos visto anteriormente, el cumplimiento ordinario de la pena de privación del derecho a conducir da inicio tras la firmeza de la sentencia dictada, bien sea por el trámite de Juicio Rápido con sentencia de conformidad ante el Juzgado de Guardia o por los trámites ordinarios, ante el Juzgado de Instrucción, ante el Juzgado de lo Penal, ante un juzgado específico de ejecutorias penales, para el caso que exista en el partido judicial, o ante la Audiencia Provincial, y en los supuestos que detallaremos en este epígrafe, la inmediatez no se cumplirá.

\section{a) Supuestos de suspensión por interposición de recurso de amparo}

El primer supuesto relacionado con la suspensión de la ejecución de la pena de privación del derecho a conducir es cuando se interpone recurso de amparo ante el TC tras haberse declarado la firmeza de una sentencia condenatoria. Debido a las características de la pena de privación del derecho a conducir, que se rige por la ejecución inmediata y por no poder ser sustituida ni suspendida, a través del recurso de amparo ante el TC el penado utiliza uno de los escasos reductos procesales a través de los cuales puede obtener la suspensión de la ejecución de la misma. Con la interposición del recurso de amparo, la ejecución de la pena de privación del derecho a conducir puede quedar en suspenso hasta la resolución del mismo ${ }^{745}$, ya que, si el TC lo acuerda, el penado podrá ejercer su derecho a conducir mientras dure la tramitación de dicho recurso.

\footnotetext{
745 Vid. FERNÁNDEZ PANTOJA, Pilar, "Delitos contra la seguridad del tráfico: la pena de privación del derecho a conducir", en AA.VV. Delincuencia..., op.cit., pp.83-84.
} 
Analizaremos las posibilidades existentes con relación al recurso de amparo cuando la pena impuesta es la privación del derecho a conducir, y detallaremos los criterios constitucionales para denegar o conceder la suspensión de su ejecución. La petición de suspensión de ejecución de la pena de privación del derecho a conducir se realiza ante el TC, siendo éste quien tiene la facultad de conceder o denegar la misma $^{746}$, y el Juzgado o Tribunal que ejecuta la sentencia estará subordinado a la decisión que adopte el $\mathrm{TC}^{747}$. Hemos de señalar que la jurisprudencia en supuestos en los que se ha peticionado la suspensión de la ejecución de la pena ante el Tribunal de ejecución ha resuelto que éste no es competente, sino que únicamente lo es el $\mathrm{TC}^{748}$.

La suspensión de la ejecución de la pena de privación del derecho a conducir por interposición de recurso de amparo tiene el fundamento jurídico en el art.56 de la Ley Orgánica del Tribunal Constitucional (en adelante LOTC), que fija los criterios para la resolución de supuestos como los aquí planteados ${ }^{749}$. Si bien la interposición de recurso de amparo contra una sentencia que imponga la pena de privación de derecho a conducir, con carácter general no suspenderá su ejecución, existen excepciones al amparo del art.56.2 de la LOTC que lo permiten ${ }^{750}$. En los recursos de amparo que se efectúan peticiones relacionadas con la pena de privación del derecho a conducir solicitando la suspensión de la ejecución, el TC puede optar por tres soluciones: bien deniega la suspensión de la ejecución de la pena, bien concede la suspensión solicitada, o bien, en tercer lugar, suspende la pena de privación del derecho a conducir pero no la de la pena acumulativa de prisión, multa o la pena de TBC por lo que nos hallaríamos ante una suspensión parcial de la ejecución.

\footnotetext{
746 Vid. CORDERO LOZANO, Carlos, Ejecución..., op.cit., p.48.

747 Relativo a la facultad de suspender la ejecución de la pena, vid. CERES MONTÉS, José Francisco, "La reforma del Código Penal...", op.cit., pp.42-62, y en el ámbito jurisprudencial: el AAP de Cáceres, núm. 261/2005, Sección 2a , de 13 de diciembre de 2005, ponente IImo. Sr. Pedro V. Cano Maíllo Rey. (JUR 2006/32471).

748 Vid. AAP de Valladolid, núm.143/2017, Sección 2ª , de 9 de marzo de 2017, ponente Ilmo. Sr. Feliciano Trebolle Fernández (TOL6.068.035), recogiendo el acuerdo por unanimidad del pleno no jurisdiccional de las dos Secciones de la Audiencia Provincial de Valladolid de fecha 30/10/2014.
}

${ }^{749}$ Art.56 LOTC: 1. La interposición del recurso de amparo no suspenderá los efectos del acto o sentencia impugnados.

750 Art.56.2 LOTC: Ello no obstante, cuando la ejecución del acto o sentencia impugnados produzca un perjuicio al recurrente que pudiera hacer perder al amparo su finalidad, la Sala, o la Sección en el supuesto del artículo 52.2, de oficio o a instancia del recurrente, podrá disponer la suspensión, total o parcial, de sus efectos, siempre y cuando la suspensión no ocasione perturbación grave a un interés constitucionalmente protegido, ni a los derechos fundamentales o libertades de otra persona. 
El TC ha concedido en numerosas ocasiones la suspensión de la ejecución de la pena de privación del derecho a conducir por interposición del recurso de amparo, siendo dos criterios seguidos por el TC desde la década de los años ochenta, el de no contravenir con la suspensión de la ejecución los intereses generales, así como que, para el caso de ser concedido el amparo, el mismo carecería de sentido en penas de corta duración que ya estarían cumplidas ${ }^{751}$. Otra regla utilizada por el TC para conceder la suspensión de la ejecución de la pena de privación del derecho a conducir es la afectación a la actividad laboral en los casos que el vehículo es indispensable, así como la naturaleza de los hechos que han originado la condena en relación con la extensión de la pena y que la misma se imponga a raíz de un control preventivo de alcoholemia ${ }^{752}$. Además, se ha valorado para conceder la suspensión de la ejecución el riesgo de eludir la acción de la justicia, la posible desprotección de las víctimas, así como la posible trascendencia social que haya podido tener el delito que ha dado origen a la pena de privación del derecho a conducir $^{753}$. Es importante destacar un criterio utilizado por el TC para conceder la suspensión de la ejecución de la pena, y es que no se produzca la vulneración de derechos fundamentales ni libertades públicas de un tercero ${ }^{754}$.

Por otra parte, encontramos los siguientes criterios utilizados por el TC para su denegación. Uno de ellos ha sido la falta de acreditación de los perjuicios irreparables que en el penado puede causar la ejecución de la pena estudiada ${ }^{755}$. Este requisito lo considero acertado ya que, para suspender la ejecución de la pena de privación del derecho a conducir, ha de acreditarse indiciaria y documentalmente la perturbación que se puede causar al penado, pues de lo contrario la pena dejaría de tener sentido. Si esto se produjera se podría desvirtuar el sentido de la pena al poder interpretar la petición de suspensión de ejecución de la pena de privación del derecho a conducir como una mera maniobra dilatoria para retrasar su cumplimiento. EI TC para denegar la suspensión de la ejecución también ha

\footnotetext{
751 Con relación a estos criterios vid. el ATC, núm. 172/1985, Sala Segunda, Sección 3ạa de 6 de marzo de 1985 (RTC 1985/172 AUTO).

752 Respecto a los requisitos para la concesión vid. el ATC, núm. 282/2008, Sala Segunda, de 22 de septiembre de 2008 (JUR 2008/350169) y ATC, núm. 361/2003, Sala Primera, de 10 de noviembre de 2003 (RTC 2003/361 AUTO) y ATC, núm. 241/2005, Sala Primera, de 06 de junio de 2005 (RTC 2005/241 AUTO).

753 Vid. en relación con estos criterios el ATC, núm. 291/2004, Sala Segunda, de 19 de julio de 2004 (JUR 2004/242785).

754 Vid. el ATC, núm. 136/1996, Sala Segunda, de 27 de mayo de 1996 (RTC 1996/136 AUTO).

755 Acerca de la falta de acreditación de los perjuicios como criterio para denegar la suspensión de la ejecución de la pena de privación del derecho a conducir podemos citar el ATC, núm. 324/2006, Sala Primera, de 25 de septiembre de 2006 (JUR 2006/256533) y ATC, núm. 185/2014, Sala Segunda, de 8 de julio de 2014 (TOL4.519.858).
} 
ponderado la perturbación que la misma ocasiona a los intereses generales y el perjuicio inherente que le puede suponer al penado ${ }^{756}$. Este criterio es de difícil objetivación ante la complejidad de sopesar intereses generales y particulares, por lo que deberemos acudir a la casuística para determinar los motivos de estimación o no de la petición de suspensión de la ejecución de la pena de privación del derecho a conducir durante el proceso de tramitación del recurso de amparo.

Existe la posibilidad que se suspenda la ejecución de la pena de privación del derecho a conducir y sin embargo no se acuerde la suspensión de las penas que se imponen con la misma como podría ser la prisión, los TBC o la pena de multa. Esta opción podría calificarse como una tercera vía, y acredita la importancia que tiene la pena privativa del derecho a conducir que una vez se inicia su cumplimiento los perjuicios para el penado pueden ser irreparables. Por ello, es acertado el criterio seguido por el TC en algunas resoluciones de suspender la ejecución de la privación del derecho a conducir y sin embargo ordenar la ejecución de la pena acumulativa que se impone con la misma ${ }^{757}$. El motivo es que la privación de derechos, para el caso que el recurso de amparo resultase estimado, sería de muy difícil reparación, lo que no sucede en la pena de multa al poder retornar el dinero que el penado ha satisfecho por ese concepto.

Considero adecuada la posibilidad de decretar la suspensión de la ejecución de la pena de privación del derecho a conducir durante el proceso del recurso de amparo $^{758}$, ya que si éste fuera estimado la pena se habrá cumplido por lo que el sentido de la resolución constitucional habrá decaído y no tendrá sentido. Si esto sucediera, la forma de reparar los perjuicios al penado que se le ha concedido el amparo sería difícil, pues una indemnización económica nunca resarcirá la pena de privación del derecho a conducir que se ha ejecutado. Sin embargo, para la concesión de la suspensión de la ejecución en estos casos es necesario ponderar las circunstancias concurrentes y no soy partidario que la suspensión de la ejecución de la pena de privación del derecho a conducir se conceda en todos los

\footnotetext{
756 En relación con este criterio vid. ATC, núm. 128/2006, Sala Primera, de 3 de abril de 2006 (RTC 2006/128 AUTO) y ATC 258/2004 de 12 de julio de 2004, Sala Primera (JUR 2004/242773).

757 Sirva como ejemplo de esta tercera opción el ATC, núm. 241/2005, Sala Primera, de 6 de junio de 2005 (RTC 2005/241 AUTO) y ATC, núm. 196/2006, Sala Segunda, de 19 de junio de 2006 (RTC 2006/196 AUTO), en los que se suspende la ejecución de la pena de privación del derecho a conducir y se deniega la suspensión de la pena de multa.

758 Vid. ÁlVARO LÓPEZ, Mari Cruz/ PERDICES LÓPEZ, Araceli, Delitos de Tráfico. Criterios y respuestas de los Tribunales Penales en Seguridad Vial, Ed. Lex Nova, Valladolid, 2010, p.706.
} 
casos, criterio que también ha mantenido el $\mathrm{TC}^{759}$. Si se generalizase la suspensión de la ejecución nos hallaríamos ante una mera artimaña legal utilizada con la única finalidad de demorar el inicio del cumplimiento de la pena impuesta, desvirtuándose la finalidad del recurso de amparo. En este sentido, comparto lo expuesto por CERES MONTES ${ }^{760}$ de considerar que la suspensión de la ejecución ha de tener carácter restrictivo ya que de lo contrario se pondría en entredicho la capacidad de los Juzgados y Tribunales para ejecutar sus propias resoluciones, reconocida al Poder Judicial en el art.117.1 de la CE, así como también debe ponderarse con lo establecido en el art.18 de la LOPJ.

Como conclusión sobre esta modalidad de ejecución de la pena, destacar que sí es viable tal como se ha acreditado con la jurisprudencia invocada, pero está caracterizada por su carácter restrictivo, así como por la acreditación que la no suspensión de la ejecución de la pena pueda causar perjuicios irreparables al penado.

\section{b) Supuestos de suspensión por petición de indulto}

La segunda posibilidad de suspender la ejecución de la pena de privación del derecho a conducir es a través de la petición de indulto ante el Ministerio de Justicia, que es uno de los medios más utilizados para evitar que la pena se ejecute de forma inmediata ${ }^{761}$ y quede en suspenso mientras se resuelve el mismo ${ }^{762}$. Ésta puede interponerse de forma simultánea al recurso de amparo con solicitud de suspensión de la ejecución, ya que son dos mecanismos legales que pueden ejercerse de forma simultánea y no son excluyentes. Por ello es necesario analizar las diferentes posibilidades existentes en relación con la solicitud de indulto, centrándonos en el supuesto que la pena impuesta sea la privación del derecho a conducir, determinando las diferentes posiciones de las Audiencias Provinciales para dejar en suspenso su ejecución.

\footnotetext{
759 Vid. FERNÁNDEZ PANTOJA, Pilar, "Delitos contra la seguridad del tráfico: la pena de privación del derecho a conducir", en AA.VV. Delincuencia..., op.cit., p.83.

760 Vid. CERES MONTES, José Francisco, "La reforma del Código Penal...", op.cit., pp.42-62.

761 Vid. CORDERO LOZANO, Carlos, Ejecución..., op.cit., p.43.

762 Referente a la posibilidad de suspender la ejecución de la pena por interposición de indulto, vid. VALEIJE ÁLVAREZ, Inmaculada," El sistema de penas en los delitos contra la seguridad vial", en AA.VV. Prevención y control..., op.cit., p.480 y FERRER GUTIÉRREZ, Antonio, Manual práctico sobre ejecución penal y derecho penitenciario, Ed. Tirant Lo Blanch, Valencia, 2011, p. 56-57.
} 
La solicitud de indulto, ejercitada al amparo de la ley que regula el derecho de gracia, Ley de 18 de junio de 1870 de Reglas para el ejercicio de la Gracia de indulto, puede ser una petición de indulto total o bien de indulto parcial en función de si se peticiona de la totalidad de las penas o alguna de ellas. Si se opta por una petición total incluirá la pena de prisión, multa, TBC o inhabilitación profesional además de la pena de privación del derecho a conducir, ya que ésta siempre se impone de forma acumulativa con alguna de las anteriores. Si se opta por interponer una petición de indulto parcial puede solicitarse un indulto de la pena de privación del derecho a conducir, con el argumento de los perjuicios que pueda originar el cumplimiento de dicha pena en su esfera personal, laboral, económica, social, etc., y proseguirse la ejecución por el resto de penas que se han impuesto en la sentencia.

El debate jurídico relativo a la posibilidad de suspender la ejecución de la pena de privación del derecho a conducir hemos de centrarlo en el art. 32 de la Ley de Reglas para el ejercicio de la Gracia de indulto de 18 de junio de 1870, que determina que la presentación de petición de indulto no suspende la ejecución de la sentencia dictada ${ }^{763}$. Este precepto debemos valorarlo de forma conjunta con la regulación del indulto según lo establecido en el art.4.4 $\mathrm{CP}^{764}$ que faculta al Juez o Tribunal para suspender la ejecución de la pena. Por ello en esta modalidad de ejecución, tendrá relevancia la facultad del juez penal para conceder o no la suspensión de la ejecución de la pena, decidiendo en base al art. 4.4 CP.

Si realizamos una comparativa con la modalidad de suspensión de la ejecución de la pena por interposición de recurso de amparo, existe una diferencia fundamental con los supuestos que se interpone la petición de indulto. Ésta radica que en los casos de petición de indulto quien decide si se concede o no la suspensión de la ejecución es el Juzgado o Tribunal encargado de la ejecución de la pena, mientras que en aquéllos quien decidía al respecto era el TC. El fundamento de esta diferencia es que en el indulto existe una previsión normativa en el art.4.4 CP que recoge la posibilidad de suspender la ejecución de la pena por la interposición de indulto, determinando la competencia para resolver al Juez o Tribunal. Respecto el

\footnotetext{
763 Art.32 de la Ley de Reglas para el ejercicio de la Gracia de indulto: La solicitud o propuesta de indulto no suspenderá el cumplimiento de la sentencia ejecutoria, salvo el caso en que la pena impuesta fuese la de muerte, la cual no se ejecutará hasta que el Gobierno haya acusado el recibo de la solicitud o propuesta al Tribunal sentenciador.

${ }^{764}$ Art.4.4 CP: Si mediara petición de indulto, y el Juez o Tribunal hubiere apreciado en resolución fundada que por el cumplimiento de la pena puede resultar vulnerado el derecho a un proceso sin dilaciones indebidas, suspenderá la ejecución de la misma en tanto no se resuelva sobre la petición formulada.
} 
contenido del art.4.4 CP y el ámbito al que puede aplicarse el derecho de gracia, este no se refiere únicamente a la pena de prisión, sino que puede ser aplicable en cualquiera de las penas previstas en el $\mathrm{CP}^{765}$. Del contenido del art.4.4 CP y la Ley de Reglas para el ejercicio de la Gracia de indulto de 18 de junio de 1870, se desprende que nada obsta que pueda aplicarse la suspensión de la ejecución de la pena por interposición de indulto a la pena de privación del derecho a conducir ${ }^{766}$.

La interposición de petición de indulto con petición de suspensión de ejecución de la pena de privación del derecho a conducir es desde hace unos años una alternativa para intentar que la pena no se ejecute en penados que son conductores profesionales o necesitan el vehículo para desarrollar su actividad laboral. Relacionado con este particular la $\mathrm{FGE}^{767}$ en su Memoria del año 2005, dejó constancia que numerosos Fiscales apoyaban en los procedimientos de indulto el dejar sin efecto total o parcialmente con determinadas condiciones la pena de privación del derecho a conducir ${ }^{768}$. La preocupación mostrada por la Fiscalía en los procedimientos de indulto en los que aparece esta pena fue destacada de nuevo en el año 2007 en la Memoria de la FGE769. En ella se reconoció que, ante la ausencia de mecanismos para suspender o sustituir la pena de privación del derecho a conducir, la Fiscalía de Valladolid optaba por apoyar en casos concretos y con determinadas condiciones indultos parciales con la finalidad de no aplicar la pena de privación del derecho a conducir. Esta opción planteada en la Fiscalía es adecuada mientras no se produzca un cambio legislativo que posibilite bien la suspensión, bien la sustitución de la pena de privación del derecho a conducir o se regule la posibilidad del cumplimiento fraccionado de la pena privativa del derecho a conducir.

A continuación, señalaremos los criterios que han aplicado las diferentes Audiencias Provinciales para conceder la suspensión de la ejecución de la pena de privación del derecho a conducir cuando se ha interpuesto la petición de indulto. Uno de los criterios esgrimidos es el relacionado con el hecho que si la petición de indulto

\footnotetext{
765 Acerca del ámbito de aplicación del indulto, vid. MAGRO SERVET, Vicente/ SOLAZ SOLAZ, Esteban, Manual práctico sobre la ejecución penal. Las medidas alternativas a la prisión: suspensión, sustitución y expulsión, Ed. La Ley. Madrid, 2008, 1ae edición, p.110.

766 Esta posibilidad ha sido señalada por CABALLERO GEA, José-Alfredo, Delitos contra la seguridad vial. Código Penal y Derecho Procesal Penal, Ed. Dykinson, Madrid, 2008, p.326.

767 Vid. Memoria FGE del año 2005, p.603.

${ }^{768}$ Vid. DE VICENTE MARTÍNEZ, Rosario, Derecho..., op.cit., p.297.

769 Vid. Memoria FGE del año 2007, p.535, y la referencia a la misma en TRAPERO BARREALES, María.A., Los delitos..., op.cit., p.570.
} 
resultare estimada y no se hubiese procedido a la suspensión de la ejecución de la pena privativa de derechos la finalidad del indulto quedaría vacía de contenido ${ }^{770}$. También se ha valorado para conceder la suspensión de la ejecución mientras se tramita el indulto las circunstancias laborales del penado, la necesidad de utilizar el vehículo a motor para poder trabajar, así como el hecho que se haya satisfecho la pena de multa que acompaña en muchas ocasiones a la pena de privación del derecho a conducir ${ }^{771}$. Otros datos periféricos que pueden coadyuvar a que el Juez o Tribunal acuerde la suspensión de la ejecución de la pena por la tramitación de indulto pueden ser la ausencia de antecedentes penales y la inexistencia de lesiones en terceros ${ }^{772}$.

En la suspensión de la ejecución de la pena por interposición de indulto, incluso en los casos que se dicta una sentencia condenatoria de conformidad y se impone la pena de privación del derecho a conducir, es posible que la misma se suspenda durante la tramitación del derecho de gracia ${ }^{773}$. Ello parece apuntar a que uno de los criterios valorados de forma positiva por los Tribunales para la suspensión de la ejecución es la actitud de reconocimiento de hechos y arrepentimiento mostrada por el penado en sede judicial. Por último, indicar que cuando el penado necesite hacer uso del derecho a conducir por motivos salud, tras ponderar el resto de circunstancias concurrentes, sí se ha procedido a dejar en suspenso la pena mientras se tramita el indulto ${ }^{774}$. En casos tan excepcionales como pueden ser los relacionados con los motivos de salud del penado e incluso un familiar directo sí puede ser adecuada a los propios fines de la pena, la concesión de la suspensión de la ejecución durante la tramitación del indulto siempre que la misma no supere el umbral de los dos años establecido en el art.47.3 CP.

\footnotetext{
770 Vid. AAP de Madrid, núm.331/2003, Sección 23ä, de 30 de abril de 2003, ponente Ilmo.Sr. Rafael Mozo Muelas (JUR 2005/248150); AAP de Madrid, núm.796/2012, Sección 15ª , de 21 de noviembre de 2012, ponente IIma. Sra. Ana Victoria Revuelta Iglesias (TOL3.560.874) y AAP de Valladolid, núm. 268/2017, Sección 4ạ̄, de 1 de junio de 2017, ponente Ilma. Sra. María Teresa González Cuartero (TOL6.218.402).

771 Vid. AAP de Guipúzcoa, Sección 2a ${ }^{a}$, de 10 de diciembre de 2004, ponente Ilma.Sra. Ana Maite Loyola Iriondo (JUR 2005/56916) y AAP de Asturias, núm. 34/2019, Sección $2^{a}$, de 22 de enero de 2019, ponente Ilma. Sra. María Covadonga Vázquez Llorens (TOL7.131.920).

772 Vid. AAP de Madrid, Sección 1a, de 3 de diciembre de 2012, ponente IImo.Sr. Eduardo de Porres Ortiz de Urbina (JUR 2013/5365).

773 Vid. AAP de Madrid, núm. 595/2007, Sección 16ª , de 27 de septiembre de 2007, ponente llmo. Sr. Miguel Hidalgo Abia (JUR 2007/325219) y AAP de León, núm. 1238/2017, Sección 3ª , de 16 de noviembre de 2017, ponente Ilmo. Sr. Miguel Ángel Amez Martínez (TOL6.472.891).

774 Vid. AAP de Madrid, Sección 17ª , de 25 de enero de 2006, ponente IImo. Sr. Fernando F. Orteu Cebrián (JUR 2006/100336).
} 
Como hemos señalado anteriormente, no existe en la jurisprudencia un criterio objetivo para determinar la suspensión de la ejecución de la pena durante la tramitación del indulto. Sin embargo, se han realizado acuerdos de Magistrados de las Secciones Penales de Audiencias Provinciales en los que se ha establecido el plazo de hasta tres años para otras penas como son las penas privativas de libertad ${ }^{775}$. La opción de fijar en las Audiencias Provinciales criterios similares para la pena de privación del derecho a conducir en el umbral de dos años sería un criterio que dotaría de seguridad jurídica a los penados que presentaran la petición de indulto y la vez solicitaran la suspensión de la ejecución de la pena de privación del derecho a conducir, al ser el umbral establecido en el art.47.3 CP para decretar la pérdida de la vigencia del permiso.

En cuanto al plazo máximo de suspensión de la ejecución de la pena de privación del derecho a conducir por tramitación de indulto, la jurisprudencia, en los casos que lo ha concedido, ha determinado que esta pena no se ejecutará mientras se tramita el derecho de gracia con el plazo máximo de un año desde que se solicitó, ya que éste es límite temporal que dispone el Gobierno para resolverlo al amparo del artículo 6 del Real Decreto 1879/1994 de 16 de septiembre, por el que se aprueban determinadas normas procedimentales en materia de Justicia e Interior ${ }^{776}$.

En lo que atañe a los criterios utilizados por las diferentes Audiencias Provinciales para denegar la concesión de la suspensión de la ejecución en los casos que se interpone una petición de indulto, cabe señalar que uno de los más novedosos es el relativo a la posibilidad de prescripción de las penas, mientras se tramita la petición de indulto al entenderse que el plazo prescriptivo no se interrumpe en dichos procedimientos ${ }^{777}$. Este criterio puede ser interesante para garantizar el cumplimiento de la pena, debido a que puede suceder que una tramitación de indulto que se dilate de manera excesiva deje sin efecto el cumplimiento de la misma al concurrir la prescripción en sede de ejecución. Otra línea jurisprudencial

\footnotetext{
775 Vid. Acuerdos adoptados por los Magistrados de las Secciones Penales de la Audiencia Provincial de Barcelona, que han citados en el AAP Barcelona, núm. 685/2018, Sección 3ª , de 3 de septiembre de 2018, ponente IImo.Sr. Fernando Jerónimo Valle Esque (TOL6.925.737). También Acuerdos adoptados por los Magistrados de las Secciones Penales de la Audiencia Provincial de Valencia en la Junta para la unificación de criterios celebrada el día 17 de junio de 2011. Recurso electrónico disponible en: https://www.cograsova.es/adjuntosmail/2011/20110711/uca.pdf (último acceso: 03/11/2020).

776 Vid. AAP de Barcelona, núm. 743/2016, Sección 2ª , de 7 de noviembre de 2016, ponente IIma. Sra. María José Magaldi Paternostro (TOL5.969.031) y el anteriormente citado AAP Barcelona, núm. 685/2018, Sección 3a , de 3 de septiembre de 2018, ponente llmo.Sr. Fernando Jerónimo Valle Esque (TOL6.925.737).
} 
para denegar la suspensión de la ejecución sostiene que el principio general ha de ser el de ejecutar las penas y la excepción ha de ser la suspensión de su ejecución ${ }^{778}$. Asimismo, la jurisprudencia es proclive a denegar la solicitud en los casos de conductores a los que se les aplique la agravante de reincidencia, así como aquellos supuestos de penas de privación de conducir elevadas, como pudieran ser aquellas superiores a dos años ${ }^{779}$. Incluso podemos destacar que el hecho que el penado sea conductor profesional ${ }^{780}$, o titular de una licencia de taxi $^{781}$, y dependa económicamente de su derecho a conducir, no comporta que se suspenda la ejecución de la pena de privación del derecho por la interposición de indulto

Una línea jurisprudencial, que no compartimos, mantiene la imposibilidad de suspender la ejecución de la pena de privación del derecho a conducir por interposición de petición de indulto, ya que únicamente limita esta posibilidad a las penas privativas de libertad, ya que únicamente son éstas las que pueden suspenderse al amparo del art. $80 \mathrm{CP}^{782}$. Discrepamos de dicha argumentación, ya que hemos podido constatar en el trabajo que no existe óbice alguno en suspender la ejecución de la pena de privación del derecho a conducir cuando se peticiona el indulto existiendo numerosas resoluciones al respecto, y ello ha de valorarse independientemente de los criterios que establece el art.80 CP para la suspensión de las penas privativas de libertad. Asimismo, también existen resoluciones que han utilizado como criterio para denegar la suspensión de la ejecución el hecho que la pena de privación del derecho a conducir afecta a un derecho muy concreto, que es el de conducir vehículos a motor y ciclomotores, y que además no es un derecho

777 Vid. AAP de La Coruña, Sección 2ª , de 22 de octubre de 2012, ponente Ilmo.Sr. Salvador Pedro Sanz Crego (JUR 2012/399709).

778 Vid. AAP de Madrid, Sección 23a a de 6 de febrero de 2013, ponente Ilmo. Sr. Jesús Eduardo Gutiérrez Gómez (JUR 2013/92474); AAP de Madrid, núm. 533/2013, Sección 15ạ, de 6 de junio de 2013, ponente Ilma. Sra. María del Pilar de Prada Bengoa (TOL4.581.225) y AAP de Barcelona, núm. 377/2017, Sección 2aa de 17 de mayo de 2017, ponente Ilma. Sra. María Carmen Hita Martiz (TOL6.238.950).

779 En relación con los criterios de reincidencia y de una penalidad elevada, vid. AAP de Tarragona, núm. 498/2012, Sección 2ạa de 26 de julio de 2012, ponente Ilmo.Sr. José Manuel Sánchez Siscart (TOL3.654.421) y AAP de Pontevedra, núm. 241/2017, Sección 4ª , de 28 de marzo de 2017, ponente Ilma.Sra. María Cristina Navares Villar (TOL.6.084.192).

780 Vid. AAP de Zaragoza, núm. 3106/2019, Sección 1aㅡ, de 19 de febrero de 2019, ponente llmo. Sr. Alfredo José Lajusticia Pérez (TOL7.121.270).

781 Vid. AAP de Madrid, núm. 375/2018, Sección 29ạ , de 4 de junio de 2018, ponente Ilma. Sra. María Luz García Monteys (TOL6.756.742).

782 Vid. AAP de Barcelona, núm. recurso 280/2018, Sección 8ạ, de 2 de mayo de 2018, ponente llmo. Sr. Jesús Navarro Morales (TOL6.776.648). 
fundamental como pudiera ser la libertad, para denegar la suspensión de la ejecución ${ }^{783}$.

Entre la doctrina hallamos también posiciones favorables y contrarias a la posibilidad de suspensión de la ejecución. Así, por ejemplo, CERES MONTES ${ }^{784}$ ha señalado que en los casos que la pena de privación del derecho a conducir fuera superior a un año de duración, no procedería la suspensión de la ejecución de la misma por interposición de indulto. No considero, sin embargo, que el umbral de un año sea adecuado como criterio objetivo para denegar la suspensión, ya que es el periodo mínimo de duración de la pena de privación del derecho a conducir en determinados delitos, como los de los arts.142.1, 152.1, 379, 380 o 383 CP. Por el contrario, elementos objetivos como la ausencia de antecedentes penales, la inexistencia de lesionados o el pago de la multa pueden ser datos objetivos que pueden utilizarse por el Juez o Tribunal para conceder o denegar la suspensión de la ejecución.

Como posición favorable a la concesión de la suspensión de la ejecución de la pena de privación del derecho a conducir por interposición de indulto, MAGRO SERVET/SOLAZ SOLAZ utilizan el argumento que de no concederse la suspensión de la ejecución la finalidad que persigue el indulto sería ilusoria, pues una vez cumplida la pena de privación del derecho a conducir si el ulterior indulto fuese concedido estaría vacío de contenido ${ }^{785}$.

A modo de conclusión destacaremos como acertada la argumentación que se ha señalado desde la jurisprudencia, según la cual la interposición del indulto no puede convertirse en un subterfugio procesal para dilatar el inicio del cumplimiento de la pena $^{786}$. En numerosas ocasiones, ante la dificultad de obtener un aplazamiento del cumplimiento de la pena o su fraccionamiento, se utiliza el indulto para evitar el inicio del cumplimiento de la pena. Por ello, comparto el criterio expresado por VALEIJE ÁLVAREZ ${ }^{787}$ que el mecanismo de suspensión de la ejecución de la pena

\footnotetext{
783 Vid. AAP de Cáceres, núm. 832/2016, Sección 2ª , de 16 de diciembre de 2016, ponente Ilmo. Sr. Valentín Pérez Aparicio (TOL5.987.506).

${ }^{784}$ En torno a la negativa a conceder la suspensión en condenas superiores a un año vid. CERES MONTES, José Francisco, "La reforma del Código Penal...", op.cit., pp.42-62.

785 Vid. MAGRO SERVET, Vicente/ SOLAZ SOLAZ, Esteban, Manual práctico..., op.cit., p.113.

786 Vid. AAP de Tarragona, núm. 498/2012, Sección 2ª , de 26 de julio de 2012, ponente Ilmo.Sr. José Manuel Sánchez Siscart, (TOL3.654.421).

787 Vid. VALEIJE ÁLVAREZ, Inmaculada," El sistema de penas en los delitos contra la seguridad vial", en AA.VV. Prevención y control..., op.cit., p.481.
} 
por interposición del indulto ha de tener la consideración de excepcional, ya que de lo contrario se iría contra la finalidad de ejecución de las penas impuestas en sentencia firme.

\subsection{Singularidades en la ejecución ordinaria}

Tras analizar la ejecución ordinaria de la pena de privación del derecho a conducir, estudiaremos dos singularidades que existen en la misma. En primer lugar, se examinará el cumplimiento fraccionado de la pena de privación del derecho a conducir, detallando las posiciones doctrinales y jurisprudenciales contrarias y favorables a la misma. En segundo lugar, analizaremos el cumplimiento transnacional de la pena de privación del derecho a conducir, con el objetivo de determinar las diversas vicisitudes que se producen en las condenas que pueden tener repercusiones de carácter extra nacional.

\subsubsection{El cumplimiento fraccionado de la pena de privación del derecho a conducir vehículos a motor y ciclomotores}

Una de las cuestiones que se plantean en relación con la ejecución de la pena objeto de estudio es la posibilidad del cumplimiento fraccionado. Para el análisis de esta cuestión, se partirá del marco legal vigente realizando un estudio de los artículos de la CE, LOPJ, CP y de la LECrim, que pueden tener incidencia en esta modalidad de ejecución. En segundo lugar, haremos referencia a las reformas que se han aprobado en la normativa penal y administrativa que han podido incidir en la posibilidad de cumplir fraccionadamente la pena de privación del derecho a conducir, así como destacaremos las propuestas de reforma que han abordado esta modalidad de cumplimiento. En tercer lugar, se estudiarán las posturas doctrinales y jurisprudenciales favorables y contrarias al cumplimiento fraccionado. En este apartado también se examinará la forma de llevar a cabo el cumplimiento fraccionado de la pena de privación del derecho a conducir, así como la referencia a dicha opción en el BCPP, que expresamente regulaba dicha posibilidad. Por último, una vez definido el marco legal y las posiciones doctrinales y jurisprudenciales con relación al cumplimiento fraccionado, concretaremos la toma de posición.

La modalidad de ejecución que se analiza en este epígrafe pone de manifiesto que la pena de privación del derecho a conducir tiene aspectos que no han sido resueltos normativamente por el legislador y que deberían poderse adecuar a la 
realidad social del siglo XXI. En este sentido considero interesante la posibilidad de cumplir de forma fraccionada la pena estudiada ya que en la actualidad son numerosos los casos en que el derecho a conducir constituye el medio a través del que desarrollan su actividad laboral los penados y posiblemente el cumplimiento adaptado a las circunstancias del penado evitaría efectos muchos más perjudiciales que los propios de la privación de desplazarse con vehículo o ciclomotor. Además, en modo alguno la pena de privación del derecho a conducir se vería afectada en ninguno de sus fines si se cumple de forma fraccionada, ya que se acabará cumpliendo y se habrá permitido que se compatibilice con la actividad laboral del penado.

Debido a la ausencia de previsión legal en el CP788 tanto de la suspensión de la ejecución como del cumplimiento fraccionado de la pena de privación del derecho a conducir, que sí existe en otras penas como la pena de prisión o la pena de multa, ha sido la jurisprudencia la que ha determinado caso a caso si es o no procedente cumplir de manera fraccionada la misma. Ante la carencia de un criterio taxativo tanto en el CP como en la LECrim han sido las resoluciones de las Audiencias Provinciales las que han perfilado los requisitos para su concesión o denegación.

Aun cuando el cumplimiento fraccionado de la pena de privación del derecho a conducir no está expresamente prohibido en el CP, ha sido concedido de forma restrictiva por los diferentes Juzgados y Audiencias Provinciales únicamente cuando concurren determinados requisitos, no existiendo un criterio unánime en nuestros tribunales como ha señalado CORDERO LOZANO ${ }^{789}$. La FGE se ha hecho eco de esta cuestión en las diversas Memorias anuales publicadas. Así, en el año 2007 la FGE puso de relieve las posturas divergentes en las diferentes Audiencias Provinciales, e incluso entre diferentes secciones de una misma Audiencia referente a este tema ${ }^{790}$. Si bien de forma minoritaria alguna Fiscalía autonómica se había mostrado favorable a su concesión, en general, el criterio ha sido contrario al cumplimiento fraccionado de la pena de privación del derecho a conducir ${ }^{791}$. La Memoria de la FGE del año 2012 reflejaba que la Fiscalía invocaba el principio de

\footnotetext{
788 En relación con la no previsión legal del fraccionamiento vid. CERES MONTES, José Francisco, “La reforma del Código Penal...", op.cit., pp.42-62.

789 Vid. CORDERO LOZANO, Carlos, Ejecución..., op.cit., p.148.

790 Vid. la Memoria de la FGE, año 2007, pp.535-536, donde se pone de manifiesto la disparidad de criterios entre las diversas Audiencias Provinciales.

791 Vid. la referencia a la Reunión de Fiscales Coordinadores de Seguridad Vial, RODRíGUEZ LEÓN, Luis Carlos, Seguridad Vial..., op.cit., p.55.
} 
legalidad para denegar el cumplimiento fraccionado ${ }^{792}$, así como la Memoria de la FGE del año 2013 que hace referencia a su ausencia de previsión en el CP793 o la Memoria de la FGE del año 2017, en la que se invocan como criterios para la denegación del fraccionamiento del cumplimiento, la ausencia de aflictividad y pérdida del contenido disuasorio para dicha modalidad de cumplimiento de la pena ${ }^{794}$. Sin embargo, merecen una mención destacada la Fiscalía del País Vasco $^{795}$ y la de Valladolid ${ }^{796}$, que se han mostrado favorables a conceder el fraccionamiento de la pena de privación del derecho a conducir, como medida excepcional, de forma motivada y siempre que se cumplan una serie de requisitos. En todo caso, de lo expuesto se aprecia que la falta de unanimidad en la Fiscalía y la ausencia de un criterio en el $\mathrm{CP}$, pone de relieve que nuestro sistema de ejecución penal no ha desplegado suficientemente la fase de ejecución de la pena de privación del derecho a conducir ${ }^{797}$.

El cumplimiento fraccionado de la pena de privación del derecho a conducir ha sido objeto de propuestas de reforma legislativa, lo que acredita que es tributario de una regulación de la que carece hoy día. La propia FGE propuso en el año 2005 reformar el CP en este aspecto ${ }^{798}$, con el fin de posibilitar dejar en suspenso la misma siempre que se cumplieran dos requisitos: causar perjuicios irreparables al penado y la ausencia de daños personales o materiales. Esta posibilidad pudo servir como base para una previsión legal del cumplimiento fraccionado de la pena de privación del derecho a conducir, pero nada se introdujo al respecto en la reforma operada por la LO 15/2007 de 30 de noviembre, última gran reforma de los delitos contra la seguridad vial. Con ello, se perdió una oportunidad para clarificar la posibilidad del cumplimiento fraccionado de la pena de privación del derecho a conducir.

\footnotetext{
792 Relativo a dicho aspecto, vid. p.1253, apartado g), en el que se analiza específicamente el cumplimiento fraccionado de la pena de privación del derecho a conducir.

793 Vid. la Memoria de la FGE, año 2014, p.735.

794 Vid. la Memoria de la FGE, año 2017, p.567.

795 Entre otros requisitos que se exigen: $1^{\circ}$ que exista una necesidad justificada, $2^{\circ}$ que el penado no sea reincidente; 3 . que no suponga la prolongación del cumplimiento más allá del doble de la pena $y, 4 .{ }^{\circ}$ que la entrega se haga al menos durante dos meses consecutivos.

796 Vid. al respecto el criterio existente en la Fiscalía de Valladolid que se mostraba partidaria del fraccionamiento de la pena de privación del derecho a conducir, como señala RODRíGUEZ LEÓN, Luis Carlos, Seguridad Vial..., op.cit., p.55.

797 Vid. TAMARIT SUMALLA, Josep/ LUQUE REINA, Ma Eulàlia, Automóviles, delitos y penas..., op.cit., p.133.

798 Vid. al respecto la Memoria de la FGE, año 2005, p.603.
} 
En el mismo sentido que la FGE, en el año 2005 el Grupo de Estudios de Política Criminal ${ }^{799}$ se planteó la necesidad de mejorar la ejecución de pena de privación del derecho a conducir a través del cumplimiento fraccionado como mecanismo para corregir las desigualdades objetivas que generaba su cumplimiento en función de las circunstancias personales del penado.

Cabe señalar que las propuestas para introducir el cumplimiento fraccionado en la ejecución penal, derivan en parte de la influencia que en dicha modalidad ha tenido la regulación administrativa. Uno de los argumentos utilizados hasta hace escasos años para solicitar el cumplimiento fraccionado de la pena estaba relacionado con la posibilidad existente en el Derecho Administrativo sancionador de cumplir la sanción de privación del derecho a conducir de manera fraccionada ${ }^{800}$. Esta opción contemplada en el antiguo art.67 de la LTSV, exigía periodos de cumplimiento no inferiores a quince días ${ }^{801}$ y facultaba al sancionado para proponer el mes de inicio del cumplimiento para interferir lo menos posible en la situación laboral y personal del conductor infractor. La posibilidad de invocar dicho criterio en la jurisdicción penal quedó vedada tras la entrada en vigor de la Ley 18/2009 de 23 de noviembre que modifica el texto articulado de la LTSV en materia sancionadora ya que derogó el cumplimiento fraccionado de la privación del derecho a conducir en la esfera administrativa ${ }^{802}$. Por ello tal argumento ha quedado también excluido de la vía penal para la concesión del cumplimiento fraccionado, ya que ni tan siquiera existe dicha posibilidad actualmente en el Derecho Administrativo.

Otro de los argumentos empleados para solicitar el cumplimiento fraccionado consistía, junto a invocar la práctica administrativa, en aludir al resto de

\footnotetext{
799 Vid. Grupo de Estudios de Política Criminal, Una propuesta..., op.cit., p.38.

800 Esta posibilidad que preveía la norma administrativa era aplicable únicamente a las sanciones administrativas, pero se alegaba como criterio orientativo para sustentar la petición de fraccionamiento en la vía penal. Vid. CERES MONTES, José Francisco, "La reforma del Código Penal...", op.cit., pp.42-62.

801 Art. 67 LTSV: 1. Las infracciones leves serán sancionadas con multa de hasta 90 euros; las graves, con multa de 91 a 300 euros, y las muy graves, de 301 a 600 euros. En el caso de infracciones graves, podrá imponerse, además, la sanción de suspensión del permiso o licencia de conducción por el tiempo mínimo de un mes y máximo de hasta tres meses, y en el supuesto de infracciones muy graves se impondrá, en todo caso, la sanción de suspensión por el tiempo mínimo de un mes y máximo de tres meses, todo ello sin perjuicio de las excepciones que se establecen en este artículo. El cumplimiento de la sanción de suspensión de la autorización para conducir podrá realizarse fraccionadamente, a petición del interesado, en periodos que en ningún caso serán inferiores a 15 días naturales. Se podrá establecer un fraccionamiento inferior al antes indicado en el caso de los conductores profesionales, siempre que éstos lo soliciten y el cumplimiento íntegro de la sanción se realice en el plazo de doce meses desde la fecha de la resolución de la suspensión.

802 Referente a la modificación operada por la Ley 18/2009 vid. TRAPERO BARREALES, María.A., Los delitos..., op.cit., p.570.
} 
circunstancias periféricas del penado: ser conductor profesional, necesidad del vehículo para trabajar, etc. ${ }^{803}$. De esta forma se debía llevar a cabo una valoración conjunta y en el caso que además se causaran perjuicios económicos graves, no sólo para el penado sino para la economía familiar, se optaba por conceder el fraccionamiento. Sin embargo, existían posiciones jurisprudenciales contrarias a aplicar dicha opción en la vía penal por cuanto, se decía, que los delitos que llevaban aparejada la pena de privación del derecho a conducir no eran en ningún caso normas penales en blanco por lo que el juez penal debía aplicar el CP y no era procedente aplicar analógicamente la norma administrativa ${ }^{804}$.

A pesar, pues, del escaso margen para la aplicación del cumplimiento fraccionado, nos proponemos analizar, a continuación, las posibilidades que esta modalidad de cumplimiento pueda ser una realidad atendiendo al marco legal vigente.

\section{a) Marco legal}

El primer ámbito para definir el marco legal en el que puede fundamentarse la opción del cumplimiento fraccionado de la pena de privación del derecho a conducir es el de la propia CE. La obligación de cumplir las sentencias firmes contenida en el art.118 de la $\mathrm{CE}^{805}$ no debería impedir, a mi entender, la previsión legal de cumplimiento fraccionado de la pena.

Asimismo, el art.25.2 de la $\mathrm{CE}^{806}$ que fija como fin primordial para las penas privativas de libertad y las medidas de seguridad la reeducación y reinserción social, puede inspirar también una modalidad de ejecución de la privación del derecho a conducir que facilite la adecuada socialización del individuo.

\footnotetext{
803 Vid. AAP de Madrid, núm. 56/2004, Sección 2ª , de 6 de febrero de 2004, ponente Ilma.Sra. Susana García Polo (TOL2.553.218).

804 En este sentido se expresa el AAP de Lleida, Sección 1ạ, de 10 de marzo de 2004, ponente Ilmo. Sr. Francisco Segura Sancho (EDJ 2004/13930).

805 Art.118 CE: Es obligado cumplir las sentencias y demás resoluciones firmes de los Jueces y Tribunales, así como prestar la colaboración requerida por éstos en el curso del proceso y en la ejecución de lo resuelto.

${ }^{806}$ Art.25.2 CE: Las penas privativas de libertad y las medidas de seguridad estarán orientadas hacia la reeducación y reinserción social y no podrán consistir en trabajos forzados. El condenado a pena de prisión que estuviere cumpliendo la misma gozará de los derechos fundamentales de este Capítulo, a excepción de los que se vean expresamente limitados por el contenido del fallo condenatorio, el sentido de la pena y la ley penitenciaria. En todo caso, tendrá derecho a un trabajo
} 
El contenido del art.25.2 de la CE, puede tener una especial incidencia en los casos de conductores profesionales o de penados que su trabajo esté unido a la utilización de un vehículo a motor o ciclomotor. También el principio de humanidad y el principio de proporcionalidad ${ }^{807}$ pueden justificar esta modalidad de cumplimiento de la pena de privación del derecho a conducir en estos supuestos, ya que, de negarse la posibilidad de poder fraccionar la pena de privación y combinar el cumplimiento efectivo de la misma con su actividad laboral, pueden soportar el efecto añadido de una situación de desempleo. Esta consecuencia tiene un difícil encaje con el espíritu de la ejecución penal en nuestro sistema e incluso podría ser contraria a los principios de resocialización y reeducación que están relacionados con el contenido del art.25.2 de la CE.

También son relevantes para determinar la concesión el cumplimiento fraccionado de la pena de privación del derecho a conducir los fines de la pena, y analizar dicha opción desde la prevención general y la prevención especial. Situándonos en la prevención general ${ }^{808}$, el cumplimiento fraccionado de la pena de estudiada no sería contrario a dicho fin, siempre que se aplique de forma excepcional y con determinadas condiciones, ya que no afectará al efecto de intimidación que pueda tener en la ciudadanía, pues la pena se cumple, aunque se ejecute de manera diferente. Desde la perspectiva de la prevención especial, podemos entender que la función de corrección y la intimidación que pueda tener la pena no se eliminarán por el hecho que se cumpla de forma fraccionada, ya que ésta se ejecutará en sus propios términos, el delito cometido tendrá su respuesta y así será percibido por el penado. Como ha señalado MUÑOZ $\mathrm{CONDE}^{809}$, en la ejecutoria penal predomina la prevención especial, y en ese ámbito se puede llevar a cabo el cumplimiento fraccionado de la pena de privación del derecho a conducir. De ejecutarse la pena fraccionadamente se podría conseguir tanto la reeducación como la socialización del penado, ya que se lograría evitar quebrantamientos y el rechazo del penado hacia el sistema penal, lo cual no significa impunidad ya que la pena se cumplirá de forma efectiva.

remunerado y a los beneficios correspondientes de la Seguridad Social, así como al acceso a la cultura y al desarrollo integral de su personalidad.

807 Acerca de ambos principios, vid. MUÑOZ CONDE, Francisco/GARCíA ARÁN, Mercedes, Derecho..., op.cit., pp.84-85.

${ }^{808}$ En relación con la prevención general según las teorías relativas, Ibidem, p.48.

809 Relativo a la prevención especial en la fase de ejecución penal, vid. MUÑOZ CONDE, Francisco/GARCÍA ARÁN, Mercedes, Derecho..., op.cit., p.50. 
Uno de los argumentos constitucionales aplicables al fraccionamiento es el contenido del art.24 de la CE, que establece que las sentencias se han de ejecutar en sus propios términos. Del art. 24 de la $C^{810}$ no se infiere una incompatibilidad con el cumplimiento fraccionado de la pena de privación del derecho a conducir ya que el derecho a la tutela judicial efectiva se respetaría sin cercenar su contenido constitucional. Relacionado con el contenido del art.24 de la CE, el cumplimiento fraccionado tampoco sería contrario al art.18.2 de la LOPJ811, ya que la sentencia se cumplirá en sus propios términos. Si bien la pena no se cumplirá de manera continuada, el periodo total impuesto en sentencia condenatoria firme será finalmente cumplido, aunque posiciones jurisprudenciales contrarias al fraccionamiento han realizado una interpretación taxativa de los artículos citados ${ }^{812}$.

En segundo lugar, analizaremos los diversos artículos del CP que pueden tener relación con la opción de cumplir fraccionadamente la pena que estudiamos, partiendo de la base que el CP no prevé de forma expresa la posibilidad. La posibilidad tanto de acordar o prohibir de forma explícita esta opción en el CP sería factible con una reforma del texto penal. Sin embargo, para estudiar el marco legal del cumplimiento fraccionado de la pena de privación del derecho a conducir en el $\mathrm{CP}$ hemos de ceñirnos a su contenido actual.

El art.3.2 CP813 regula la ejecución de la pena y el contenido de su redactado puede ser compatible con un cumplimiento fraccionado de la pena de privación del derecho a conducir, así como esta forma de cumplir la pena no quebraría el principio de legalidad penal en la ejecución ${ }^{814}$. El cumplimiento fraccionado de la pena de privación del derecho a conducir tiene que respetar el principio de legalidad

\footnotetext{
810 Podemos citar la STC núm. 67/1984 Sala Primera de 7 de junio de 1984, ponente Excmo. Sr. Rafael Gómez-Ferrer Morant (TOL79.357), STC núm. 148/1989, Sala Primera de 21 de septiembre de 1989, ponente Excmo. Sr. Carlos de la Vega Benayas (TOL81.596), STC núm. 152/1990, Sala Primera, de 4 de octubre de 1990, ponente Excmo.Sr. Fernando García-Mon y González-Regueral (TOL81.831).

${ }^{11}$ Art.18.2 LOPJ: Las sentencias se ejecutarán en sus propios términos.

812 Vid. el AAP de Lleida, Sección 1ㄹa , de 10 de marzo de 2004, ponente Ilmo. Sr. Francisco Segura Sancho (EDJ 2004/13930).

813 Art.3.2 CP: Tampoco podrá ejecutarse pena ni medida de seguridad en otra forma que la prescrita por la Ley y reglamentos que la desarrollan, ni con otras circunstancias o accidentes que los expresados en su texto. La ejecución de la pena o de la medida de seguridad se realizará bajo el control de los Jueces y Tribunales competentes.

${ }^{814}$ En relación con el principio de legalidad penal el TS ha reconocido que se extiende no sólo a las sanciones que se imponen, sino que también a la forma en que se han de cumplir, por lo que remite a la ejecución penal, y en nuestro caso a la ejecución de la pena de privación del derecho a conducir. Vid. STS, núm. 1468/1997, Sala Segunda, de 1 de diciembre de 1997, ponente Excmo. Sr. José Manuel Martínez-Pereda Rodríguez (TOL407.780).
} 
penal de la ejecución previsto en el art. 3.2 CP, que implica que el cumplimiento sea de total "sumisión a lo establecido en las leyes"815. Por ello, esta forma de cumplimiento no es contraria al principio de legalidad, al no regular el CP en ningún precepto que la misma se deba cumplir de manera continuada o no fraccionada, 0 cuanto menos no prohíbe que se pueda cumplir fraccionadamente ${ }^{816}$. Para compatibilizar el principio de legalidad penal con la posibilidad de instaurar en una resolución judicial un cumplimiento de la pena no previsto, pero tampoco prohibido en el CP, podemos examinar la situación de otras penas y verificar si el cumplimiento fraccionado de la pena de privación del derecho a conducir tiene encaje en nuestro sistema penal o bien ha de estimarse contrario a derecho.

Uno de los argumentos de mayor peso para regular una modalidad de cumplimiento fraccionado de la pena de privación del derecho a conducir es que otras penas previstas en el CP sí tienen reconocida esta opción. Así, tanto la multa como la localización permanente disponen de previsión legal en el CP bien para acordar su suspensión o su cumplimiento fraccionado. En cuanto a las penas privativas de libertad, el CP es explícito con la pena de localización permanente y su cumplimiento fraccionado ya que dedica el art. 37.2 a dicha posibilidad estableciendo que se puede cumplir durante los sábados y domingos o de forma no continuada $^{817}$. En el mismo sentido, para la pena de multa el art. 50.6 CP dispone que ésta se podrá pagar de una vez o en plazos ${ }^{818}$. A través de dicha analogía ${ }^{819}$, se puede acordar el fraccionamiento de la pena objeto de estudio y puede ser beneficioso para el reo en aras a compatibilizar la ejecución de la pena con su vida laboral.

Una vez examinada la posibilidad de cumplir fraccionadamente la pena de privación del derecho a conducir, según los preceptos del CP que tienen relación con dicha

815 En relación con el principio de legalidad de la ejecución vid. MUÑOZ CONDE, Francisco/GARCíA ARÁN, Mercedes, Derecho..., op.cit., p.111.

${ }^{816}$ En este sentido destacar que la jurisprudencia ha señalado que no puede vulnerarse el principio de legalidad al acordar algo que la ley no prohíbe. Vid. AAP de Toledo, núm. 63/2007, Sección 1ª̂, 4 de junio de 2007, ponente Ilma. Sra.Gema Adoración Ocáriz Azaustre, (JUR 2007/302493).

817 Art.37.2 CP: Si el reo lo solicitare y las circunstancias lo aconsejaren, oído el ministerio fiscal, el juez o tribunal sentenciador podrá acordar que la condena se cumpla durante los sábados y domingos o de forma no continuada.

${ }^{818}$ Art.50.6 CP: El tribunal, por causa justificada, podrá autorizar el pago de la multa dentro de un plazo que no exceda de dos años desde la firmeza de la sentencia, bien de una vez o en los plazos que se determinen. En este caso, el impago de dos de ellos determinará el vencimiento de los restantes.

${ }^{819}$ Con relación a la analogía in bonam partem vid. MUÑOZ CONDE, Francisco/GARCÍA ARÁN, Mercedes, Derecho..., op.cit., pp.122-123. 
opción, analizaremos los preceptos de la LECrim que pueden utilizarse para denegar o conceder dicha modalidad de ejecución. En primer lugar, la ejecución de la pena de privación del derecho a conducir está regulada en el art.794.2 de la LECrim ${ }^{820}$, determinándose la forma en que ha de llevarse a cabo la misma según lo preceptuado en el art. 990 del mismo texto legal. En este sentido, el art.794.2 de la LECrim establece "la inmediata retirada" del permiso o licencia ${ }^{821}$. El tenor literal del artículo parece ser que veda la posibilidad de fraccionar la pena de privación del derecho a conducir ya que la retirada del permiso o licencia supondrá el inicio del cumplimiento y se realizan ipso facto los apercibimientos al penado con relación al posible quebrantamiento de condena. Sin embargo, es posible también interpretar que cuando el precepto se refiere a "la inmediata retirada" del permiso o licencia, alude a los supuestos de los Juicios Rápidos en los que se dicta una sentencia condenatoria de conformidad en el Juzgado de Guardia, y no para el resto de casos. En los procedimientos que no se tramiten como Diligencias Urgentes-Juicio Rápido con sentencia de conformidad, el penado una vez se dicte sentencia condenatoria tiene diversos mecanismos para evitar que el inicio del cumplimiento de la pena que hemos estudiado sea inmediato: solicitar el indulto, la petición de fraccionamiento de la pena o la petición de aplazar el inicio de la ejecución.

Por su parte, el art. 990 de la LECrim determina la forma en que se ha de llevar a cabo la ejecución de las penas ${ }^{822}$. Sin embargo, el CP no determina un plazo para ejecutar la pena de privación del derecho a conducir por lo que no podrá ser utilizado como argumento para denegar el cumplimiento fraccionado, ya que incluso su apartado segundo únicamente hace referencia al ingreso en el centro penitenciario sin dilaciones indebidas, pero no a la ejecución de una pena privativa de derechos como es la analizada.

También en el ámbito de la LECrim es interesante el art.198, ya que de la lectura del mismo no se deduce que sea contrario a un cumplimiento fraccionado de la

\footnotetext{
820 Art. 794.2 $2^{-}$LECrim. En los casos en que se haya impuesto la pena de privación del derecho a conducir vehículos a motor y ciclomotores, el Secretario judicial procederá a la inmediata retirada del permiso y licencia habilitante, si tal medida no estuviera ya acordada, dejando unido el documento a los autos y remitirá mandamiento a la Jefatura Central de Tráfico para que lo deje sin efecto y no expida otro nuevo hasta la extinción de la condena.

821 Éste es uno de los argumentos utilizados por MAGRO SERVET para denegar la posibilidad del cumplimiento fraccionado, MAGRO SERVET, Vicente “¿Es posible fraccionar...?”, op.cit., pp.59-66.

822 Art. 990 LECrim: Las penas se ejecutarán en la forma y tiempo prescritos en el Código penal y en los reglamentos. Corresponde al Juez o Tribunal a quien el presente Código impone el deber de hacer ejecutar la sentencia adoptar sin dilación las medidas necesarias para que el condenado ingrese en el establecimiento penal destinado al efecto, a cuyo fin requerirá el auxilio de las Autoridades administrativas, que deberán prestárselo sin excusa ni pretexto alguno.
} 
pena de privación del derecho a conducir, así como que ésta forma de cumplimiento sea contraria a un procedimiento con dilaciones indebidas ${ }^{823}$. La LECrim, igual que el CP, no establece un plazo para el cumplimiento fraccionado por lo que las resoluciones que acuerden dicha modalidad únicamente establecerán que se deberá iniciar sin dilaciones, pero sin un plazo predeterminado. Por ello, siempre que se establezca un periodo y calendario de cumplimiento por parte del penado, no se estaría vulnerando el cumplimiento de la pena sin dilaciones indebidas.

Sin embargo, sí parece ofrecer argumentos a favor del cumplimiento fraccionado el art.202 de la LECrim, en concreto el segundo apartado, por cuanto dispone que podrán suspenderse los términos judiciales si hubiera justa causa y probada ${ }^{824}$, lo que permitiría la opción del cumplimiento fraccionado de la pena de privación del derecho a conducir, siempre y cuando concurran los requisitos personales del penado que hagan necesaria dicha medida.

Tras estudiar el marco legal en el que puede sustentarse el cumplimiento fraccionado de la pena de privación del derecho a conducir, nos referiremos a continuación a la posición de la doctrina y la jurisprudencia sobre esta cuestión.

\section{b) Posiciones doctrinales}

Después de analizar el marco legal que puede afectar al cumplimiento fraccionado de la privación del derecho a conducir, valoraremos esta modalidad desde el punto de vista doctrinal, con las posiciones tanto a favor como en contra para definir la situación actual de la cuestión. En la doctrina existen posiciones discrepantes, siendo la mayoritaria la que mantiene que la pena de privación del derecho a conducir debe cumplirse de forma continuada. En este sentido, MAGRO SERVET 825 se opone al fraccionamiento con el argumento de la eternización del cumplimiento de la pena impuesta lo que significaría que su ejecución se prolongara de forma desmesurada, realizando una comparativa con la pena de multa en la que sí se

823 Art.198 LECrim: Cuando no se fije término, se entenderá que han de dictarse y practicarse sin dilación.

824 Art.202 LECrim: Serán improrrogables los términos judiciales cuando la Ley no disponga expresamente lo contrario. Pero podrán suspenderse o abrirse de nuevo, si fuere posible sin retroceder el juicio del estado en que se halle cuando hubiere causa justa y probada. Se reputará causa justa la que hubiere hecho imposible dictar la resolución o practicar la diligencia judicial, independientemente de la voluntad de quienes hubiesen debido hacerlo.

825 Vid. MAGRO SERVET, Vicente: “¿Es posible fraccionar...?”, op.cit., pp.59-66. 
establece el fraccionamiento y en ocasiones su cumplimiento se dilata de forma excesiva en el tiempo.

En la misma línea se han invocado como razonamientos para denegar la posibilidad del cumplimiento fraccionado, la ausencia de previsión legal o la posibilidad que el cumplimiento fraccionado constituya una vulneración del principio de legalidad penal ${ }^{826}$. Ante el hecho que el CP no regula el cumplimiento fraccionado se ha calificado dicha posibilidad por parte de la doctrina como de "ausencia de opción"827, destacando que en el CP no existe ningún artículo que pueda facilitar un encaje legal al cumplimiento fraccionado de la pena de privación del derecho a conducirr28. En relación con este argumento doctrinal, más bien se puede calificar la situación como un vacío legislativo, que ha sido completado al resolverse de manera individual por la jurisprudencia de las diferentes Audiencias Provinciales las peticiones de cumplir la pena fraccionadamente. En ningún caso nos hallamos ni ante una prohibición tácita ni expresa, ni tampoco ha de interpretarse el silencio que mantiene el CP en relación con la posibilidad de fraccionamiento como una negación ya que sería una interpretación contraria al reo sobre una prohibición inexistente.

También se ha utilizado como motivo para denegar el cumplimiento fraccionado la comparativa de la pena de privación del derecho a conducir impuesta en sentencia firme con la medida cautelar de intervención judicial del permiso o licencia regulada en el art.764.4 de la LECrim ${ }^{829}$. Esta comparativa ha sido invocada por CERES MONTES ${ }^{830}$, para denegar el cumplimiento fraccionado ya que en sede de medida cautelar no se permite el cumplimiento fraccionado, sino que su cumplimiento tiene que ser continuado.

826 En este sentido se manifiesta CERES MONTES, José Francisco, "La reforma del Código Penal...", op.cit., pp.42-62.

827 Siendo ésta la opinión de CABALLERO GEA, José-Alfredo, Delitos..., op.cit., p.296.

828 Éste ha sido también uno de los argumentos expresados por GUTIÉRREZ RODRíGUEZ, María, "Excesos de velocidad e intoxicaciones punibles", AA.VV. Protección Penal..., op.cit., p.128.

${ }^{229}$ Art. 764.4 LECrim: Se podrá acordar la intervención inmediata del vehículo y la retención del permiso de circulación del mismo, por el tiempo indispensable, cuando fuere necesario practicar alguna investigación en aquél o para asegurar las responsabilidades pecuniarias, en tanto no conste acreditada la solvencia del investigado o encausado o del tercero responsable civil. También podrá acordarse la intervención del permiso de conducción requiriendo al investigado o encausado para que se abstenga de conducir vehículos de motor, en tanto subsista la medida, con la prevención de lo dispuesto en el artículo $556 \mathrm{del}$ Código Penal. Las medidas anteriores, una vez adoptadas, llevarán consigo la retirada de los documentos respectivos y su comunicación a los organismos administrativos correspondientes.

830 Vid. al respecto la comparativa realizada por CERES MONTES, José Francisco, "La reforma del Código Penal...", op.cit., pp.42-62. 
Otro argumento doctrinal para negar la posibilidad del cumplimiento fraccionado es el relacionado con la hipotética dificultad para controlar la ejecución de la pena de privación del derecho a conducir ${ }^{831}$ así como con los problemas de índole logística y organizativa que se generarían. Ciertamente se trata de un problema innegable, pues a las dificultades existentes para controlar la ejecución de la pena debería sumarse los supuestos de cumplimiento fraccionado. Sin embargo, debe ponerse también en valor las posibilidades que hoy en día pueden abrirse mediante los medios tecnológicos existentes, como por ejemplo la conexión entre las bases de datos de los Juzgados y Tribunales y la DGT. De esta forma pueden reducirse los posibles reductos de impunidad que pudieran alegarse, y la dificultad que puede existir en su control es similar a la de un cumplimiento continuado. La respuesta es sencilla: el penado que quiera conducir estando ejecutoriamente condenado a la pena de privación del derecho a conducir, lo hará igual bien se le imponga el cumplimiento fraccionado de la pena o bien sea de forma continuada. Lo relevante es la voluntad del legislador así como de todos los operadores jurídicos que intervienen en la ejecución penal para que se pueda cumplir la ejecución, en la modalidad que sea, y con absolutas garantías, como puede ser la comunicación entre Juzgados, DGT y Policía del calendario del cumplimiento fraccionado al objeto de saber en todo momento en qué periodos no podrá conducir el penado así como que éste lleve consigo siempre que conduzca en los periodos autorizados el auto judicial que apruebe dicha forma de cumplimiento.

Como hemos señalado anteriormente, en el CP sí existe la previsión legal para que la pena de multa se pueda cumplir de forma fraccionada. Desde la doctrina se ha mantenido que no es posible equiparar el mecanismo de fraccionamiento existente en la pena de multa con el de la pena de privación del derecho a conducir, ya que los principios inspiradores de su cumplimiento son divergentes ${ }^{832}$. Un argumento favorable al fraccionamiento es que en la pena de multa rige el tratamiento desigual para casos desiguales ${ }^{833}$. Si trasladamos por analogía dicho principio al fraccionamiento de la pena de privación del derecho a conducir podríamos sostener que es posible en relación con las circunstancias personales del penado que no cumpla la pena de forma continuada y ello en base a las desigualdades que puede

\footnotetext{
831 Ibídem, op.cit., pp.42-62 y también VALEIJE ÁLVAREZ, Inmaculada, "El sistema de penas en los delitos contra la seguridad vial", en AA.VV. Prevención y control..., op.cit., p.484.

832 En este sentido vid. MAGRO SERVET, quien es contrario a equiparar la forma de cumplir ambas penas, “¿Es posible fraccionar...?”, op.cit., pp.59-66.

833 En relación con las características de la pena de multa vid. MUNOZ CONDE, FRANCISCO/GARCÍA ARÁN, Mercedes, Derecho..., op.cit., p.523.
} 
presentar su ejecución en relación con la generalidad de penados. En relación con el principio de igualdad en la pena de privación del derecho a conducir, RODRÍGUEZ MORO ${ }^{834}$ es favorable al cumplimiento fraccionado de la pena de privación del derecho a conducir. Para este autor, el cumplimiento fraccionado es un mecanismo idóneo para mitigar las diferencias que se producen en la ejecución de la pena estudiada ya que los penados que requieren el vehículo diariamente para su actividad laboral sufrirán mayores agravios que en aquellos que no lo precisan. Esta circunstancia hemos de relacionarla con el contenido aflictivo de la pena y su mayor grado en aquel penado cuyo cumplimiento continuado le sea de difícil ejecución, por lo que a través del fraccionamiento se puede conseguir que la aflictividad sea similar en todos los penados, y evitar situaciones de quebrantamiento e incumplimientos de la pena ${ }^{835}$. También se ha destacado la ausencia de prohibición del cumplimiento fraccionado, así como razones familiares relacionadas con la evitación de perjuicios a la economía del núcleo familiar, como posición doctrinal favorable a esta modalidad de cumplimiento ${ }^{836}$. CORDERO LOZANO se muestra favorable a esta forma de ejecutar la pena y ha propuesto una serie de criterios que deberían cumplirse cuando se acuerde el fraccionamiento de la pena de privación del derecho a conducir, entre ellos, que se establezcan periodos mínimos de cumplimiento de siete días o que el plazo máximo de cumplimiento fraccionado no pueda exceder del doble del periodo de la condena ${ }^{837}$.

\section{c) Criterios jurisprudenciales}

Las resoluciones en las que se ha abordado esta cuestión provienen primordialmente de las Audiencias Provinciales lo que ha contribuido a la inexistencia de un criterio taxativo en relación con el cumplimiento fraccionado de la pena de privación del derecho a conducir al existir posiciones divergentes ${ }^{838}$, predominando la contraria al cumplimiento fraccionado.

\footnotetext{
${ }^{834}$ Vid. RODRÍGUEZ MORO, Luis, "La pena de privación del derecho a conducir vehículos a motor y ciclomotores", en AA.VV. Las penas..., op.cit., p.248.

835 En este sentido destaca la posición doctrinal favorable al cumplimiento fraccionado de la pena de privación del derecho a conducir de TAMARIT SUMALLA, Josep, "La pérdida definitiva del derecho de conducir o del derecho a la tenencia y porte de armas", en AA.VV. La adecuación..., op.cit., p. 126.

836 Vid. DE URBANO CASTRILLO, Eduardo, "La privación...", op.cit., p.9.

${ }^{837}$ En relación con los nueve requisitos exigidos, vid. CORDERO LOZANO, Carlos, Ejecución..., op.cit., p.151.

838 Vid. CORDERO LOZANO, Carlos, Condenas..., op.cit., p.45.
} 
Examinaremos en primer lugar los argumentos que sostienen la negativa a conceder el cumplimiento fraccionado de la pena de privación del derecho a conducir, destacando que determinadas Audiencias Provinciales incluso han adoptado acuerdos que fijan como criterio denegar la posibilidad del cumplimiento fraccionado de la pena de privación del derecho a conducir839. Un argumento utilizado para denegar el fraccionamiento de la misma está relacionado con evitar los posibles abusos que podría originar esta forma de cumplimiento, que llevada al extremo podría dar lugar a que fuera el propio penado quien decidiera cómo ejecutar la pena ${ }^{840}$. En torno a este criterio, señalar que en la actualidad existen mecanismos para poder cumplir la pena de forma fraccionada con totales garantías, ya que existe una comunicación telemática entre Juzgados y DGT en lo relativo al cumplimiento de las penas de privación del derecho a conducir y a dicha información pueden acceder todas las Fuerzas y Cuerpos de Seguridad del Estado.

Otro argumento jurisprudencial contrario al fraccionamiento está relacionado con la inexistencia de esta posibilidad en el $\mathrm{CP}^{841}$. Dicha línea jurisprudencial mantiene que cumplir la pena de forma fraccionada sería contrario a la voluntas legislatoris dado que no es posible conceder algo que no está previsto en el $\mathrm{CP}^{842}$. Esta posición sostiene que si el legislador hubiese querido que la pena de privación del derecho a conducir se cumpliera de manera fraccionada lo hubiera previsto, y como nada existe al respecto nada puede acordarse en sentido contrario ${ }^{843}$. Entre los

839 En este sentido podemos citar el Acuerdo de la Junta Sectorial de Magistrados de Secciones Penales de la Audiencia Provincial de Valladolid, de fecha 28 de enero de 2013, así como el Acuerdo de 18-6-2009 de las Secciones penales de la Audiencia Provincial de Madrid, para Unificación de Criterios, se aprobó por mayoría que no es posible el cumplimiento fraccionado.

840 Vid. AAP de Granada, núm. 348/2012, Sección 2a Ramos Almenara. (TOL3.592.149); AAP de Ciudad Real, núm. 476/2016, Sección 1ạ, de 16 de diciembre de 2016, ponente Ilma. Sra. María Pilar Astray Chacón, (TOL5.987.575); AAP de Vizcaya, núm. 90189/2018, Sección 2a ${ }^{\mathrm{a}}$, de 3 de mayo de 2018, ponente Ilmo. Sr. Manuel Ayo Fernández, (TOL6.683.230) y AAP de Girona, núm. 424/2020, Sección 4aa , de 14 de septiembre de 2020, ponente Ilmo. Sr. Daniel Varona Gómez, (TOL8.194.418).

841 En este sentido se ha expresado el AAP de Cádiz, núm. 484/2011, Sección 8ª , de 27 de diciembre de 2011, ponente Ilmo. Sr. Ignacio Rodríguez Bermúdez de Castro (TOL3.641.742), el AAP de Cantabria, núm. 357/2015, Sección 3a ${ }^{a}$, de 26 de agosto de 2015, ponente Ilma. Sra. Paz Mercedes Aldecoa Álvarez-Santullano (TOL5.562.610), el AAP de Barcelona, núm. 530/2017, Sección 9âa, de 27 de julio de 2017, ponente IImo. Sr. Ignacio de Ramón Fors (TOL6.400.952) y el AAP de Córdoba, núm. 274/2020, Sección 3a ${ }^{a}$, de 15 de mayo de 2020, ponente IImo. Sr. Félix Degayón Rojo (TOL8.004.802).

842 Vid. AAP de Sevilla, núm. 464/2012, Sección 3a Gonzaga de Oro-Pulido Sanz (TOL3.640.627), en el que se explicita respecto del fraccionamiento que: "no existe vacío legislativo sino ausencia de opción".

843 Vid. AAP de Madrid, núm. 887/2008, Sección 23ä, de 15 de octubre de 2008, ponente llmo.Sr. Rafael Mozo Muelas. (JUR 2009/79682); AAP de Asturias, núm. 837/2018, Sección 3ª , de 20 de diciembre de 2018, ponente IImo.Sr. Francisco Javier Rodríguez Santolcides (TOL7.122.775) y AAP de Zaragoza, núm. 170/2020, Sección 6ª , de 12 de mayo de 2020, ponente Ilma.Sra. María del 
argumentos jurisprudenciales utilizados para denegar el cumplimiento fraccionado destacaremos que dicha concesión podría implicar su generalización y debería aplicarse en todos los supuestos ${ }^{844}$. Este criterio lo considero correcto ya que el cumplimiento fraccionado de la pena de privación del derecho a conducir únicamente debe ser otorgado en casos excepcionales y con determinados requisitos por lo que en modo alguno podemos hablar de una generalización. De hecho, las resoluciones que han acordado el cumplimiento fraccionado siempre han hecho referencia a que debe ser una medida con carácter excepcional y han de concurrir determinadas condiciones.

Las peticiones de cumplimiento fraccionado, en numerosas ocasiones están relacionadas con la necesidad de conducir para seguir realizando la actividad laboral, invocando el derecho al trabajo. Al respecto, la jurisprudencia ha determinado que el cumplimiento continuado de la pena de privación del derecho a conducir, aún en el caso de conductores profesionales, no es incompatible con el derecho al trabajo, que no es un derecho fundamental, sino un principio rector de la política económica y social ${ }^{845}$. En relación con el derecho al trabajo, la jurisprudencia exige razones especiales que justifiquen la petición de fraccionamiento ya que per se este derecho no puede actuar como un automatismo de concesión del fraccionamiento de la pena ${ }^{846}$, ya que ha de ponderarse los derechos a proteger y los fines de la pena ${ }^{847}$. El derecho al trabajo del penado, la situación económica familiar y la quiebra económica que puede provocar el cumplimiento continuado, han de ponderarse con la aflictividad de la pena, su sentido retributivo y razones de prevención general y especial, lo que significará que siempre tendrán que resolverse de manera individualizada. Otra de las peticiones de cumplimiento fraccionado relacionadas con la actividad laboral que ha sido rechazada por la jurisprudencia, es la de cumplir la pena de privación del derecho a conducir incluso por horas siendo calificada como "contraria a derecho y de

Milagro Rubio Gil (TOL7.992.220).

844 Vid. AAP de Cádiz, núm. 484/2011, Sección 8a , de 27 de diciembre de 2011, ponente Ilmo. Sr. Ignacio Rodríguez Bermúdez de Castro (TOL3.641.742).

845 Dicho criterio es utilizado en el AAP de Zaragoza, núm. 380/2008, Sección 1르, de 21 de abril de 2008, ponente Ilmo.Sr. Antonio Eloy López Millán. (JUR 2008/215624).

${ }^{846}$ Acerca de la denegación del fraccionamiento a pesar de alegar el derecho al trabajo, vid. AAP de Vizcaya núm. 7/2011, Sección 2ª , de 11 de enero de 2011, ponente Ilmo.Sr. Manuel Ayo Fernández. (JUR 2011/305945).

847 Vid. AAP de Madrid, núm. 938/2015, Sección 16a , de 30 de octubre de 2015, ponente Ilmo. Sr. Miguel Hidalgo Abia (TOL5.598.500), en el que se deniega la concesión del cumplimiento fraccionado a un conductor profesional debido a que el mismo había cometido varios delitos relacionados con la seguridad vial. 
imposible aplicación"848, descartándose la misma al peticionarse plazos inferiores a los días o meses que son los que establece el CP.

En el ámbito territorial de Catalunya, en las Jornadas de trabajo sobre Ejecución Penal del año 2009, se acordó por unanimidad de los participantes que no existe posibilidad de fraccionar la pena de privación del derecho a conducir vehículos a motor y ciclomotores ${ }^{849}$, manteniendo el criterio seguido por las diferentes Audiencias Provinciales de Catalunya en las dos últimas décadas que se han caracterizado por denegar el cumplimiento fraccionado 850 .

Tras citar los criterios jurisprudenciales utilizados para denegar el cumplimiento fraccionado de la pena de privación del derecho a conducir, señalaremos los argumentos utilizados cuando se ha concedido. Mayoritariamente ha sido en casos de conductores profesionales o que dependían laboralmente de la utilización del derecho a conducir, a los que además se les ha impuesto unas condiciones estrictas de cumplimiento. Prueba de ello es una de las resoluciones más interesantes en relación con el fraccionamiento de la privación del derecho a conducir ${ }^{851}$, en la que el penado era un conductor profesional y se concede el fraccionamiento articulando un sistema de cumplimiento en fines de semana y vacaciones, que no interfieran su actividad laboral. La misma resolución incorpora una idea que refuerza la opción del cumplimiento fraccionado y es que la pena impuesta no ha de resultar más gravosa de lo previsto por el legislador, circunstancia que sí concurría en el supuesto analizado ya que la situación laboral del penado dependía directamente de poder ejercer su derecho a conducir.

En idéntico sentido se han utilizado como pautas para conceder el cumplimiento fraccionado de la pena analizada, la posibilidad de la pérdida del puesto de trabajo y las consecuencias directas en la esfera familiar852. Relacionado con el ámbito

\footnotetext{
848 Vid. AAP de Madrid núm. 355/ 2010, Sección 17ạ, de 29 de marzo de 2010, ponente llmo.Sr. Ramiro José Ventura Faci. (TOL2.084.748)

${ }^{849}$ En relación con la pena de privación del derecho a conducir vid. las conclusiones en AA.VV. Documents sobre execució penal, op.cit. p. 41.

850 Vid. AAP de Lleida, Sección 1a 10 de marzo de 2004, ponente Ilmo.Sr. Francisco Segura Sancho (EDJ 2004/13930); AAP de Girona, núm. 61/2011, Sección 3ª , de 9 de febrero de 2011, ponente Ilmo. Sr. Ildefonso Carol Grau (TOL3.575.148); AAP de Barcelona núm.116/2011, Sección 5ª , de 16 de febrero de 2011, ponente IImo.Sr. Sergi Cardenal Montraveta (TOL3.717.244) y AAP de Tarragona núm. 540/2010, Sección 2ª , de 18 de noviembre de 2010, ponente Ilma. Sra. Samantha Romero Adán (TOL3.716.473).

851 Vid. AAP de Castellón, núm. 344/2001, Sección 3ª̣, de 12 de diciembre de 2001, ponente Ilma.Sra. María Filomena Ibáñez Solaz (TOL2.670.005).

852 Vid. AAP de Castellón, núm. 142/2009, Sección 2ª , de 4 de mayo de 2009, ponente llma.Sra.
} 
laboral es interesante el criterio expuesto en alguna resolución ${ }^{853}$ que concede la petición de fraccionamiento, analizando el art.3 CP y el argumento de evitar lo que la propia resolución denomina como "la pena laboral". Cuando se relacione la petición de fraccionamiento con la posibilidad de perder el puesto de trabajo, debe acreditarse documentalmente dicha circunstancia, y ponderar el art. $47 \mathrm{CP}$ con uno de los valores fundamentales de nuestra Carta Magna en forma de principio rector de la política económica y social como es el derecho al Trabajo ${ }^{854}$. También en el caso de conductores profesionales existen resoluciones que al amparo del principio general del derecho de la equidad han concedido el cumplimiento fraccionado de la pena de privación del derecho a conducir ${ }^{855}$.

Existen casos anteriores a la entrada en vigor de la Ley 18/2009 de 23 de noviembre por la que se modifica el texto articulado de la LTSV en materia sancionadora, que atendiendo a la opción existente en el procedimiento administrativo de cumplir la sanción de privación de conducir de forma fraccionada se dictaron resoluciones penales que concedieron dicha opción ${ }^{856}$. Los argumentos vertidos en esta línea jurisprudencial eran coherentes, ya que en sede de ejecución hay que modular el cumplimiento de la pena con las circunstancias personales del penado, pues de lo contrario los conductores profesionales o que necesariamente necesiten hacer uso del derecho a conducir se verían abocados a una nueva pena o condena: la de ser excluidos del mercado laboral857. Esta misma línea la han seguido otras resoluciones ${ }^{858}$ con el argumento que, si se denegara el fraccionamiento por los Tribunales, se impondría al penado un perjuicio económico que no está previsto ni en el contenido de la pena ni en los fines que inspiran a la misma. En relación con los criterios señalados destacar que los mismos son

María Luisa Cuerda Arnau. (TOL1.579.489) y AAP de Huelva, núm. 142/2017, Sección 1a, de 6 de abril de 2017, ponente Ilmo. Sr. Antonio Germán Pontón Práxedes (TOL6.223.227).

853 Vid. AAP de Madrid, núm. 272/2009 Sección 16ª , de 2 de abril de 2009, ponente Ilma.Sra. Rosa Esperanza Rebollo Hidalgo. (TOL2.253.101).

854 Vid. AAP de Guipúzcoa, núm. 834/2018 Sección 1ạ, de 26 de diciembre de 2018, ponente Ilma.Sra. María Josefa Barbarín Urquiaga. (TOL7.068.118).

855 Vid. AAP de Zaragoza, núm. 485/2019 Sección 6ª , de 30 de octubre de 2019, ponente llmo.Sr. Francisco José Picazo Blasco. (TOL7.558.560).

${ }^{856}$ En estos supuestos se argumentaba sobre la base de combinar el cumplimiento de la pena con la actividad laboral del penado, siempre con el límite de no causar perjuicios irreparables de índole económica y familiar al reo en conductores profesionales, vid. el AAP de Madrid, núm. 486/2004, Sección 2a , de 10 de diciembre de 2004, ponente Ilmo.Sr. José Luis Sánchez Trujillano (TOL744.516).

857 Vid. AAP de Madrid, núm. 56/2004, Sección 2ª , de 6 de febrero de 2004, ponente Ilma.Sra. Susana García Polo (TOL2.553.218).

858 Vid. AAP de Toledo, núm. 63/2007, Sección 1a, 4 de junio de 2007, ponente Ilma.Sra. Gema Adoración Ocáriz Azaustre. (JUR 2007/302493). 
acertados, ya que de esta forma se puede compatibilizar la pena con la actividad laboral del penado y evitar que se vea abocado a una especie de "muerte civip"859.

Si analizamos los parámetros para acordar el cumplimiento fraccionado de la pena de privación del derecho a conducir, destacaremos la línea jurisprudencial de la Audiencia Provincial de Castellón, que históricamente ha sido proclive a esta opción al determinar que excepcionalmente sí cabe conceder dicha modalidad de cumplimiento. La referida Audiencia Provincial unificó criterios concluyendo que como norma general no se puede conceder el cumplimiento fraccionado ya que la pena se ha de cumplir de forma continuada, aunque en casos excepcionales sí cabe la opción del fraccionamiento ${ }^{860}$.

En sentido contrario a lo expresado por autores y jurisprudencia, en el sentido de excluir la aplicación del fraccionamiento por su falta de previsión legal, algunas resoluciones aluden precisamente al hecho que la no previsión legal de dicha posibilidad en el CP no puede impedir el cumplimiento fraccionado de la pena ${ }^{861}$. También se ha utilizado como criterio para conceder el cumplimiento fraccionado la ponderación del fin y sentido de la pena de privación del derecho a conducir y los efectos que el cumplimiento continuado de la misma podría tener en el penado ${ }^{862}$. El cumplimiento de la pena de forma continuada no puede generar unas consecuencias mayores que las que el propio legislador previó a la hora de su entrada en vigor en el CP863. De generarse consecuencias no deseadas, ha de procurarse que el penado cumpla la pena y a la vez que no sufra perjuicios irreparables, siendo el cumplimiento fraccionado un mecanismo idóneo para ello.

859 En relación con el concepto de "muerte civil", si bien no puede equipararse al expuesto por LANDROVE DÍAZ, Gerardo, Las consecuencias..., op.cit., p. 73, el penado sí se verá privado de un número importante de derechos y actividades que no podrá realizar en la sociedad.

860 Vid. la Jornada Sobre Unificación de Criterios en la Audiencia Provincial de Castellón, de fecha 6 de mayo de 2011, en el que se establece que excepcionalmente sí es posible conceder el cumplimiento fraccionado de la pena de privación del derecho a conducir.

861 En este sentido vid. AAP. de Guipúzcoa, núm. 59/2008, Sección 1ạ , de 18 de marzo de 2008, Recurso 1038/2008, ponente IImo. Sr. Augusto Maeso Ventureira. (JUR 2008/ 172556) y AAP de Madrid, núm. 685/2012, Sección 17ª , de 17 de mayo de 2012, ponente Ilmo. Sr. Ramiro José Ventura Faci (TOL3.563.687).

862 Vid. AAP de Vizcaya, núm. 658/2005, Sección 1ạ, de 29 de septiembre de 2005, ponente Ilma.Sra. Miren Nekane Sanmiguel Bergaretxe. (JUR 2006/7228) y AAP de Guipúzcoa, núm. 745/2018, Sección 1ㄹa de 23 de noviembre de 2018, ponente Ilmo. Sr. Augusto Maeso Ventureira. (TOL.7.072.593).

${ }^{863}$ Vid. AAP de Vizcaya, núm. 158/2003, Sección 6ª , de 11 de marzo de 2003, ponente llma.Sra. Mª José Martínez Sáinz. (JUR 2003/238381). 
El criterio de utilizar analógicamente lo establecido para la pena de multa es una norma interpretativa invocada por Tribunales que han acordado el cumplimiento fraccionado 864 , ya que la posibilidad de fraccionar la pena de multa impuesta ex art.50.6 CP está vinculada a evitar perjuicios económicos al penado ${ }^{865}$. Es adecuado sostener dicha opción bajo el prisma que tanto la pena de multa como incluso el antiguo arresto de fin de semana, eran penas que sí podían ejecutarse por el penado de forma fraccionada, por lo que con mayor motivo podría ejecutarse del mismo modo una pena privativa de derechos, ya que todas ellas están regidas por el principio de personalidad de las penas.

Para determinar los penados que pueden ser beneficiarios del cumplimiento fraccionado, existen criterios jurisprudenciales que cuestionan que las únicas personas que se beneficien de esta modalidad de cumplimiento sean los conductores profesionales. Se indica que a este colectivo se le debería exigir un plus y deberían cumplir la pena de manera continuada bajo el argumento de la prevención especial del penado ${ }^{866}$, al no haber extremado las precauciones para evitar un delito que conlleva una pena que pueda privarles de su medio de vida y trabajo. Es obvio que los conductores profesionales son más conocedores de la normativa vial, de los límites de velocidad, límites de alcohol, etc., pero ello no debe ser óbice para que sean excluidos de cumplir fraccionadamente la pena de privación ya que se quebraría el principio de igualdad reconocido en el art.14 de la $\mathrm{CE}^{867}$. El colectivo de conductores profesionales puede ser en el que más se aplique el cumplimiento fraccionado, ya que además de la pena de privación del derecho a conducir, de facto estarán inhabilitados para su profesión u oficio, y estarán cumpliendo una pena que no está recogida en la sentencia. Por ello, cumplir la pena de forma fraccionada es una forma de asegurar su correcta ejecución y a la vez que no afecte a la profesión u oficio de los penados. Sin embargo, la invocación del principio de igualdad puede interpretarse en sentido inverso ya que de concederse el fraccionamiento únicamente a los conductores profesionales quienes resultarían agraviados serían aquellos que no lo son.

\footnotetext{
${ }^{864}$ En relación con el fraccionamiento por analogía que está previsto para otras penas, vid. AAP de Castellón, núm. 344/2001, Sección 3åa , de 12 de diciembre de 2001, ponente Ilma.Sra. María Filomena lbáñez Solaz (TOL2.670.005).

865 Vid. AAP de Madrid, núm. 877/2011, Sección 17ª̣ , de 14 de septiembre de 2011, ponente Ilmo.Sr. Carlos Águeda Holgueras (TOL3.639.336).

866 Vid. AAP de Madrid, núm.11/2009, Sección 2ª , de 13 de enero de 2009, Rec: 346/2008, ponente Ilmo.Sr. Mario Pestana Pérez. (JUR 2009/113209).

867 Respecto a la compatibilidad del cumplimiento fraccionado y el principio de igualdad, vid. AAP de Castellón, núm. 142/2009 Sección 2ª , de 4 de mayo de 2009, ponente llma.Sra. María Luisa Cuerda Arnau. (TOL1.579.489).
} 


\section{d) Modalidades de cumplimiento fraccionado}

Tras haber fijado el marco legal, las posiciones doctrinales y los criterios jurisprudenciales que han analizado el cumplimiento fraccionado de la pena de privación del derecho a conducir, detallaremos cómo se ha llevado a cabo en los casos que se ha acordado. La forma de ejecutar el cumplimiento fraccionado ha sido tratada en algunas resoluciones jurisprudenciales en las que los tribunales han concretado cómo compatibilizar el cumplimiento de la pena con el control de la ejecución. Para ello, es necesario que el penado aporte en su petición toda la documentación relativa a su calendario laboral para de esta forma, proponer un plan o calendario de ejecución que determine los periodos de fraccionamiento de la pena ${ }^{868}$, y la forma de ejecutarlo.

Una de las modalidades más interesantes de cumplimiento fraccionado que se observa en algunas resoluciones jurisprudenciales es la de ejecutar la pena en fines de semana, días festivos y periodos vacacionales en los que el penado no desarrolle la actividad laboral para que la que requiere el uso de un vehículo a motor o ciclomotor ${ }^{869}$. Otra forma de cumplimiento fraccionado que se observa en algunas sentencias es la que impone plazos de cumplimiento superiores a los dos meses de tal forma que la pena se cumpla totalmente en un periodo que no supere el doble del inicialmente previsto en sentencia ${ }^{870}$. Así, por ejemplo, en una pena de un año de privación del derecho a conducir, la ejecución de modo fraccionado implicaría que debería ejecutarse en el periodo máximo de dos años.

Para acreditar el correcto cumplimiento de la pena, cuando esta se ejecuta en modalidad fraccionada, el penado debería llevar siempre consigo la resolución judicial en que se acuerde el cumplimiento fraccionado donde conste el plan de ejecución acordado, de forma que pueda comprobarse que el día que está conduciendo estaba autorizado a ello ${ }^{871}$. De esta forma, tanto él como las Fuerzas y

\footnotetext{
${ }^{868}$ Así lo recogen resoluciones como el AAP de Castellón, núm.142/2009, Sección 2ª̄, de 4 de mayo de 2009, ponente Ilma.Sra. María Luisa Cuerda Arnau. (TOL1.579.489).

869 Vid. AAP de Castellón, núm. 344/2001, Sección 3ª , de 12 de diciembre de 2001, ponente Ilma.Sra. María Filomena Ibáñez Solaz (TOL2.670.005).

870 Vid. AAP de Vizcaya, núm. 411/2011, Sección 2a ${ }^{a}$, de 31 de mayo de 2011, ponente llmo.Sr. Manuel Ayo Fernández. (TOL3.632.636) y AAP de Guipúzcoa, núm. 722/2018, Sección 1ª , de 16 de noviembre de 2018, ponente Ilma.Sra. María Josefa Barbarín Urquiaga. (TOL7.072.577).

871 Respecto de las posibles formas de cumplimiento fraccionado, podemos citar: AAP de Castellón, núm. 344/2001, Sección 3ạ , de 12 de diciembre de 2001, ponente Ilma. Sra. María Filomena Ibáñez
} 
Cuerpos de Seguridad podrían comprobar en todo momento los periodos que debe estar cumpliendo la pena y los periodos que puede hacer uso del derecho a conducir, constando también dicho documento tanto en la DGT como en las Jefaturas Provinciales. Ello no ha de suponer un obstáculo en la coordinación entre los Juzgados del orden penal y las autoridades de la Dirección General de Tráfico, al existir mecanismos informatizados entre ambos. La opción de cumplir la pena de forma fraccionada supondría una mayor labor de planificación de la fase de ejecución por cuanto debería adaptarse a las circunstancias personales y laborales del penado, pero no atenta ni contra el CP ni contra la LECrim, e incluso podría favorecer que el penado cumpla la pena y no incurra en posibles quebrantamientos.

\section{e) Toma de posición}

Si bien la doctrina y jurisprudencia mayoritaria no son proclives a esta forma de cumplir la pena estudiada, considero que existen argumentos de peso para defender la viabilidad de la propuesta.

Que el legislador no recogiera expresamente en el CP la opción de cumplimiento fraccionado, como sí realizó con la pena de multa en el art.50.6 CP, no puede determinar872 la imposibilidad de cumplimiento fraccionado, ya que estimo que no puede equipararse la ausencia de regulación en el CP con un mandato de prohibición, a pesar de que numerosas resoluciones jurisprudenciales así lo han establecido ${ }^{873}$. Sin embargo, numerosas resoluciones han concedido el cumplimiento fraccionado, y de estar prohibida dicha opción ningún Juzgado la habría acordado. Por ello, no hay que denominar al cumplimiento fraccionado de la pena de privación del derecho a conducir como una modalidad de ejecución penal prohibida, sino que se trata de una ausencia de previsión legal en el CP.

Otro criterio relacionado con la negativa a conceder el cumplimiento fraccionado de es que la pena que hemos analizado se ha de ejecutar de manera continuada y con

Solaz (TOL2.670.005); AAP de Castellón, núm.142/2009, Sección 2ª , de 4 de mayo de 2009, ponente Ilma.Sra. Luisa Cuerda Arnau. (TOL1.579.489) o el AAP de Madrid, núm. 931/2012, Sección 16르, de 5 de diciembre de 20012, ponente Ilma. Sra. Rosa Brobia Varona (TOL3.556.125).

872 Vid. MAGRO SERVET, Vicente, quien bajo este criterio no es partidario de poder fraccionar la pena de privación, “¿Es posible fraccionar...”?, op.cit., pp.59-66.

${ }^{873}$ A título ilustrativo vid. el AAP de Barcelona, núm. 553/2007, Sección 7ª , de 12 de septiembre de 2007, ponente llma.Sra. Ana Rodríguez Santamaría (JUR 2007/330401) o el AAP de Zaragoza, núm. 499/2009, Sección 3aa, de 3 de julio de 2009, ponente Ilmo.Sr. Mauricio Manuel Murillo García-Atance (JUR 2009/ 329385). 
carácter inmediato. En mi opinión, del redactado del art.47 CP no se infiere que el cumplimiento de la pena de privación del derecho a conducir deba llevarse a cabo de manera continuada y tampoco puede determinarse que su fundamento jurídico sea contrario al cumplimiento fraccionado como sostiene MAGRO SERVET ${ }^{874}$. EI principio de la ejecución inmediata de la pena al amparo de lo tipificado en el art.794 de la LECrim, debe ser matizado al no existir impedimento para que se pueda demorar el inicio del cumplimiento, así como también solicitar el fraccionamiento, posibilidades que valoro como factibles.

En cuanto a la aplicación del cumplimiento fraccionado de la pena de privación del derecho a conducir he de posicionarme a favor que dicha modalidad de cumplimiento sea excepcional y no generalizada, para así mantener los efectos intimidatorios y el contenido aflictivo de la pena. La mayoría de resoluciones denegatorias del cumplimiento fraccionado, hacen referencia a que, de concederse, se dejaría sin sentido la pena, se desnaturalizarían los fines de la misma, y podrían decaer los efectos de prevención general y especial. Sin embargo, considero que tales argumentos no pueden aplicarse de forma generalizada para denegar el cumplimiento fraccionado, sino que el mismo, además de acordarse de forma extraordinaria, deberían requerir la previa valoración de unos requisitos para el penado y, en especial, la posible causación de perjuicios irreparables, yendo incluso contra la finalidad de la pena. En este sentido, considero que el cumplimiento fraccionado de la pena de privación del derecho a conducir no puede ser calificado como de una pena a la carta, dado que el penado lo que propone es una forma de cumplir la pena que pueda compaginarla con su horario laboral, pero quien finalmente decidirá la forma en que la pena se tendrá que ejecutar será el Juzgado - Tribunal tras ponderar las circunstancias del penado875. El cumplimiento fraccionado no desnaturalizaría la pena ni le restaría su contenido aflictivo, e incluso el penado podría encontrar un mayor sentido a la pena impuesta, evitando incurrir en posibles quebrantamientos ${ }^{876}$.

En lo relativo al ámbito subjetivo al que se debería poder extender la modalidad de cumplimiento fraccionado, estimo que éste no ha de estar vedado únicamente a los conductores profesionales, sino que ha de prevalecer el conjunto de datos periféricos que puedan justificar con carácter excepcional su concesión. Existen

\footnotetext{
874 Vid. MAGRO SERVET, Vicente, “¿Es posible fraccionar...?”, op.cit., pp.59-66.

875 Por el contrario, apunta a la posibilidad de que el cumplimiento fraccionado produzca quebranto en el sistema de ejecución penal español CABALLERO GEA, José-Alfredo, Delitos..., op.cit., p.493.
} 
penados que, aun no siendo conductores profesionales, necesitan compatibilizar su actividad laboral con el ejercicio del derecho a conducir y en estos casos puede valorarse como adecuada la concesión del cumplimiento fraccionado de la pena. En todo caso y dado el carácter excepcional con el que se propone en estas páginas la implantación de esta modalidad de cumplimiento, considero que el cumplimiento fraccionado de la pena, en cuanto medida facultativa que podría adoptarse atendiendo a circunstancias del penado, debería ser susceptible de poder ser revocada. Ello podría plantearse en dos supuestos distintos: en primer lugar, cuando variaran las circunstancias personales o laborales que en su momento se hubieran tomado en consideración para solicitar el cumplimiento fraccionado, y, en segundo lugar, cuando el penado realizara alguna conducta que atentara contra la seguridad vial o contra la integridad corporal o la vida de las personas, tales como un posible quebrantamiento de condena, conducción bajo la influencia del alcohol y drogas, conducción temeraria, etc. La posibilidad que se pudiera revocar la concesión del cumplimiento fraccionado de la pena de privación del derecho a conducir sería un mecanismo análogo a los establecidos en el CP para la suspensión de las penas privativas de libertad ex art.80 y siguientes. Si el conductor cometiera un delito relacionado con el tráfico viario en el periodo de condena, se revocaría la concesión del cumplimiento fraccionado y se cumpliría la pena de privación del derecho a conducir de manera continuada ${ }^{877}$.

En último lugar resulta destacable la referencia al cumplimiento fraccionado de la pena de privación del derecho a conducir en el BCPP, en el art.687, apartados 4 y 5, como argumento que respalda la posición favorable a esta forma singular de cumplimiento ${ }^{878}$. El BCPP recogió el sentir minoritario de aquellos juzgados y tribunales que en las dos últimas décadas han concedido la opción de cumplir la pena de privación del derecho a conducir de forma fraccionada tras las solicitudes de los penados a los que el cumplimiento continuado les generaría consecuencias irreparables. EI BCPP gravitaba en sentido contrario de la tendencia mayoritaria de

${ }^{876}$ En este sentido disiento del criterio expresado por CABALLERO GEA, José-Alfredo, Delitos..., op.cit., p.296.

877 La posibilidad de revocar el fraccionamiento en caso de quebrantamiento ya ha sido citada por CORDERO LOZANO, Carlos, Ejecución..., op.cit., p.151.

878 Artículo 687. 4.- Excepcionalmente, el Tribunal podrá, a instancia del penado y previo informe del Ministerio Fiscal, aplazar por el tiempo indispensable y por causa justificada el inicio del cumplimiento de esta pena cuando su duración no sea superior a dos años. El plazo de prescripción de la pena permanecerá en suspenso durante el tiempo por el que se hubiera concedido el aplazamiento en la ejecución. 5.- En los mismos casos se podrá autorizar su cumplimiento fraccionado en supuestos excepcionales cuando hubiese causa justa y sin que la fecha de extinción definitiva pueda extenderse más allá del doble de la duración total de la pena. El auto accediendo o denegando tal cumplimiento fraccionado será susceptible de recurso de apelación. 
las distintas Audiencias Provinciales, optando por flexibilizar el cumplimiento de la pena de privación del derecho a conducir además de introducir un redactado favorable al fraccionamiento de la misma, ya que fijaba unos parámetros objetivos para que dicha modalidad de cumplimiento pudiera ser acordada. A pesar de establecer criterios restrictivos para la concesión del cumplimiento fraccionado de la pena privativa del derecho a conducir, como que la misma no tenga una duración superior a los dos años, que sea un supuesto excepcional, que concurra justa causa y que la fecha de extinción definitiva de la pena no supere el doble de la duración de la misma, el BCPP podría haber cambiado el funcionamiento de la ejecución penal de la pena que estudiamos y generar un incremento de las peticiones de cumplimiento fraccionado. Por ello, para el caso de aprobarse los criterios establecidos en el BCPP, aventuramos que de no dotar de mayores medios humanos, técnicos y económicos a los Juzgados que gestionan las ejecutorias penales, se producirían situaciones de demora excesiva en el cumplimiento de la pena.

El BCPP fue coherente con el redactado actual del art.47.3 CP que establece el umbral de los dos años para decretar la pérdida de la vigencia del permiso o licencia. No tiene sentido que los penados que superen la pena de privación del derecho a conducir por plazo de dos años soliciten ni la suspensión del inicio de la pena ni tampoco el fraccionamiento, al haber perdido ex lege la vigencia del permiso o licencia. En la reforma proyectada el juzgador seguiría manteniendo un elevado nivel de discrecionalidad a la hora de valorar las circunstancias personales del penado y los datos periféricos que rodean al hecho delictivo, alejando la regulación de automatismos y permitiendo la valoración del juez. Finalmente cabe señalar que el texto del borrador remitía a conceptos indeterminados tales como "excepcional" y "justa causa", y que podían llevar a resoluciones diversas por las Audiencias Provinciales ${ }^{879}$.

Por todo lo expuesto, y atendiendo a las resoluciones favorables a la opción del cumplimiento fraccionado, así como las posiciones doctrinales proclives a dicha opción, considero que se trata de una modalidad de cumplimiento que debería ser implementada. En determinadas circunstancias y con ciertos requisitos es factible que se pueda cumplir la pena de privación del derecho a conducir de forma fraccionada, como de hecho recogía el BCPP, lo que reafirma las posiciones favorables a la concesión de dicha opción de cumplimiento.

\footnotetext{
879 En relación con la posibilidad del cumplimiento fraccionado en el nuevo Código Procesal Penal, vid. MAGRO SERVET, Vicente, "Medidas que afectan...", op.cit., pp.7-10.
} 


\subsubsection{El cumplimiento transnacional de la pena de privación del derecho a conducir vehículos a motor y ciclomotores}

En el ámbito de las singularidades de la ejecución ordinaria de la pena de privación del derecho a conducir se analizará el cumplimiento transnacional de la misma, centrándonos en el espacio de la Unión Europea. La finalidad del epígrafe es determinar si la pena de privación del derecho a conducir impuesta por tribunales españoles resulta de obligado cumplimiento más allá de nuestras fronteras, los mecanismos existentes para garantizar su cumplimiento, así como las propuestas de mejora que estimo necesarias. Asimismo, se examinará la eficacia que puedan tener en el territorio español las resoluciones de tribunales extranjeros que priven del derecho a conducir.

La situación europea en materia de delincuencia vial y en concreto la pena de privación del derecho a conducir es peculiar, ya que como señaló la Memoria de la FGE del año 2012, es la única de las penas que se imponen en los delitos relacionados con la seguridad vial que no es directamente ejecutable en un estado diferente al que se ha cometido la infracción ${ }^{880}$. Podemos citar en relación con las distintas sanciones relacionadas con los delitos contra la seguridad vial: la Decisión Marco 2005/214/JAI, del Consejo de 24 de febrero de 2005 en relación con las penas pecuniarias; Decisión Marco 2008/909/JAI, del Consejo de 27 de noviembre de 2008, relativa a las penas y otras medidas privativas de libertad ; Decisión Marco 2006/783/JAl, del Consejo de 6 de octubre de 2006 relativa al decomiso y la Decisión Marco 2008/947/JAI del Consejo de 27 de noviembre de 2008, relativa al reconocimiento mutuo de sentencias así como a la libertad vigilada ${ }^{881}$. Ninguna de las diferentes Decisiones Marco citadas, permite insertar en su contenido una pena privativa de derechos como la privación del derecho a conducir, que es en mi opinión, la que tiene una mayor relación con el delito cometido tanto en los delitos contra la seguridad vial como en los delitos contra la vida e integridad física o psíquica de las personas cometidos con vehículo a motor o ciclomotor ${ }^{882}$.

\footnotetext{
880 Vid. Memoria de la FGE año 2012, p.903, nota pie de p. 153.

881 Las cuatro decisiones Marco citadas han sido incorporadas al derecho español a través de la Ley 23/2014, de 20 de noviembre, de reconocimiento mutuo de resoluciones penales en la Unión Europea, como consta en la disposición final tercera.

${ }^{882}$ Acerca de esta situación vid. lo manifestado por MUÑOZ GARRIDO, Rubén, "La privación del derecho a conducir y la pérdida de vigencia del permiso de conducción en el ámbito de la Unión Europea", Diario La Ley, ํo 8045, 18 marzo, 2013.
} 
Debido a la alta movilidad de los ciudadanos son frecuentes los supuestos en que la pena de privación del derecho a conducir puede afectar a ciudadanos extranjeros, así como a españoles que circulen por el espacio comunitario ${ }^{883}$. En el año 2004, el Libro Verde presentado por la Comisión Europea sobre la aproximación, el reconocimiento mutuo y la ejecución de penas en la Unión Europea reconoció el interés de esta visión transnacional del cumplimiento de esta pena ${ }^{884}$. Es importante determinar el alcance territorial que puede tener la pena objeto de estudio, ya que inicialmente sólo es de aplicación en el territorio español, y una vez el conductor penado rebase las fronteras españolas hemos de preguntarnos si existen mecanismos para que se cumpla y sea eficaz en el ámbito comunitario.

La doctrina ha señalado que la pena de privación del derecho a conducir tiene un cumplimiento complejo en un estado diferente al que la había impuesto, es decir, su cumplimiento supranacional o transnacional sería de difícil ejecución ${ }^{885}$. La delincuencia vial y su control transfronterizo es una cuestión que, a pesar de los diferentes intentos realizados tanto a nivel nacional como comunitario, sigue sin estar correctamente resuelta en la actualidad ${ }^{886}$. Sin embargo, tanto a nivel nacional como europeo se han realizado algunos intentos para analizar y abordar dicha problemática. Así, por ejemplo, la FGE en la Memoria del año 2009 puso énfasis en los delitos contra la seguridad vial cometidos por ciudadanos extranjeros que no tienen la residencia habitual en España ${ }^{887}$ de modo que las penas de privación del derecho a conducir impuestas a estos conductores no se cumplen, debido a que los penados seguían conduciendo con normalidad en su país de residencia ${ }^{888}$.

\footnotetext{
${ }^{883}$ La problemática de la delincuencia transfronteriza ya fue puesta de relieve en la Memoria FGE del año 2008, p.678 y sigue vigente en la actualidad, como refleja la Memoria FGE del año 2020, p. 894.

884 Vid. Libro Verde COM (2004) 334, abril de 2004. Recurso electrónico disponible en: http://eurlex.europa.eu/legal-content/ES/TXT/?uri=CELEX:52004DC0334 (último acceso: 03/11/2020).

885 Vid. FERNÁNDEZ PANTOJA, Pilar, "Delitos contra la seguridad del tráfico: la pena de privación del derecho a conducir", en AA.VV. Delincuencia..., op.cit., pp.84-85.

${ }^{886}$ Así lo puso de manifiesto la Fiscalía de Badajoz en septiembre de 2014 cuando alertó de la dificultad de perseguir la delincuencia transnacional relacionada con la privación del derecho a conducir. Recurso electrónico disponible en: http://www.hoy.es/badajoz/201409/16/conductorescarne-retirado-intentan-20140916220204.html (último acceso: 03/11/2020). El problema sigue estando presente como se destaca en la Memoria de la FGE del año 2017. Vid. Memoria FGE año 2017, p. 555-556.

887 Vid. Memoria de la FGE del año 2009, p.805.

888 Los problemas históricos de la delincuencia vial transfronteriza como pueden ser la ausencia de una normativa penal armonizada a nivel europeo o el hecho de ser considerada una delincuencia "de segunda", han sido puestos de relieve por la Fiscalía de Seguridad Vial a lo largo de los últimos años y con cuya postura estoy absolutamente de acuerdo. vid. la Memoria de la FGE del año 2009, p.807.
} 
En aras de buscar soluciones a dicha problemática, son interesantes las acciones emprendidas en la provincia de Guipúzcoa y la localidad francesa limítrofe de Bayona, en el sentido que los Juzgados de lo Penal de Guipúzcoa informaran a la Fiscalía de Bayona de las condenas de privación del derecho a conducir impuestas a ciudadanos franceses en España. En las zonas limítrofes de Francia y Portugal, es donde con mayor asiduidad podemos encontrarnos con supuestos de delincuencia transnacional e incluso con situaciones que ponen de relieve las lagunas legales existentes en la materia. A título ilustrativo podemos citar el ejemplo de un ciudadano que poseía permiso de conducir en Francia y España, estando el español carente de puntos y el francés en vigor y que le habilitaba para conducir, y que resultó absuelto por la imputación de un delito del art.384 $\mathrm{CP}^{889}$. Esta propuesta, que tiene el fin de evitar que se solicite por los ciudadanos franceses un duplicado del permiso de conducir que le ha sido retirado en España, siempre dejará reductos para que pueda obtenerse un duplicado del permiso o licencia, siendo más una firma de buenas intenciones que un verdadero instrumento jurídico para asegurar el correcto cumplimiento de la ejecución de la pena de privación del derecho a conducir.

Con el objetivo de concretar el marco legal en el que debemos situar el cumplimiento transnacional de la pena de privación del derecho a conducir analizaremos por orden cronológico la diferente normativa a nivel comunitario relacionada con dicha opción de cumplimiento. La primera norma europea es el Convenio Europeo del Consejo de Europa sobre los efectos internacionales de la privación del derecho a conducir vehículos a motor de 1976. Este convenio, con origen en la ciudad de Bruselas hace más de 40 años, ha tenido como principal dificultad el escaso número de países que han firmado y se han adherido el mismo, no formando parte de él España ${ }^{890}$. En los objetivos del convenio subyace la intención que se aplique la privación del derecho a conducir tanto en el país de residencia del conductor como en el país que ha cometido la infracción para el caso que sea distinto, y de esta forma la pena no quede sin ejecutar, con independencia

\footnotetext{
889 Vid. la noticia en: http://www.europapress.es/navarra/noticia-absuelto-conductor-circulaba-puntoscarne-porque-tambien-tenia-permiso-frances-valido-20110113172410.html (último acceso: $03 / 11 / 2020)$.

890 En relación con su escasa aplicación y el número de país que han ratificado el citado convenio, vid. MUÑOZ GARRIDO, Rubén, "La privación del derecho a conducir y la pérdida de vigencia del permiso de conducción en el ámbito de la Unión Europea", Tráfico y Seguridad Vial, no 173, 2013, pp.61-74.
} 
de la nacionalidad del conductor y el lugar de comisión de la acción. En cuanto a las infracciones que se recogen en el Convenio de 1976, son amplias, ya que prácticamente incluye todas las infracciones que recoge el CP como susceptibles de imponer la privación del derecho a conducir ${ }^{891}$, por lo que sí hubiese podido suponer un buen mecanismo para luchar contra la delincuencia vial transfronteriza.

A pesar de la existencia del anterior Convenio, y probablemente debido a su escasa utilización, se decidió aprobar un nuevo texto en el marco del Consejo de la Unión Europea, el Convenio de 17 de junio de 1998, sobre las decisiones de privación del derecho a conducir892. El espíritu que guio la redacción de dicho Convenio, igual que el de 1976 antes citado, fue el de evitar que aquellos conductores que habían sido penados con la privación del derecho a conducir en un país distinto del que residen, consigan la impunidad y dejen de cumplir la pena por el hecho de volver a su país y abandonar los límites territoriales del estado que les ha impuesto la pena ${ }^{893}$. Sin embargo, el Convenio de 1998, jamás entró en vigor ya que sólo fue ratificado por siete Estados miembros, por lo que nunca pudo ser aplicado por las autoridades judiciales españoles. El Convenio de 17 de junio de 1998 recoge en su Anexo un listado de infracciones que son todas las que actualmente el CP tipifica como delito que pueda comportar la pena de privación del derecho a conducir, por lo que sería un buen instrumento para combatir la delincuencia vial transfronteriza y asegurar el cumplimiento transnacional de la pena. A nivel de la Unión Europea, la Comisión se refirió a la nula utilización del referido Convenio en el Libro Verde sobre la aproximación, el reconocimiento mutuo y la ejecución de penas en la Unión Europea del año 2004, se indicaba que sólo preveía: “... un mecanismo de reconocimiento relativamente débir'894. Ello motivó que el Reglamento (UE) 2016/95 del Parlamento Europeo y del Consejo de 20 de enero de 2016, por el que se

\footnotetext{
891 Vid. la referencia a las infracciones que se recogen realizada por PALOMO DEL ARCO, Andrés, "Reconocimiento y ejecución de sentencias penales dictadas en otro estado europeo", Revista jurídica de Castilla y León, núm.21, Mayo, 2010, pp.135-136.

892 Establecido en el Acto 98/C, 216/01 del Consejo. Vid. el contenido del Convenio en: http://eurlex.europa.eu/legal-content/ES/TXT/?uri=CELEX:41998A0710\%2801\%29 (último acceso: 03/11/2020).

893 Los objetivos de este convenio han sido destacados por BUJOSA VADELL, Lorenzo, "Reconocimiento y ejecución de sentencias penales extranjeras", Diario La Ley, Sección Doctrina, 2001. Ref. D-167, Tomo 5, Ed. La Ley, La Ley 1390/2002 así como por TAMARIT SUMALLA, Josep, "La prohibición de conducir y otras sanciones penales relacionadas con los vehículos", en AA.VV. Las sanciones..., op.cit., p. 303.

$894 \mathrm{Vid}$. la referencia en el Libro Verde sobre la aproximación, el reconocimiento mutuo y la ejecución de penas en la Unión Europea del año 2004, p.49.
} 
derogan determinados actos en el ámbito de la cooperación policial y judicial en materia penal, derogara expresamente el referido Convenio ${ }^{895}$ de 1998.

Otra muestra de la preocupación de las instituciones comunitarias por las penas privativas de derechos impuestas en el contexto penal de la Unión Europea es la Comunicación de la Comisión de 21 de febrero de 2006 al Consejo y al Parlamento Europeo sobre penas privativas de derechos impuestas por condenas penales en la Unión Europea ${ }^{896}$, en la que se hace referencia a la pena de privación del derecho a conducir. En ella se destaca la falta de eficacia de las penas privativas de derechos en el espacio europeo, siendo uno de los objetivos el de la progresiva armonización de las normativas nacionales, así como el de crear un espacio común europeo donde se reconozca la eficacia de dichas penas a nivel comunitario.

Por ello, considero que para controlar a nivel comunitario la pena de privación del derecho a conducir sería necesario aprobar una normativa similar al Convenio del Consejo de la Unión Europea de 1998 y ello con el fin de evitar que los conductores europeos a quienes se les haya impuesto la pena de privación del derecho a conducir puedan manejar un vehículo a motor únicamente rebasando las fronteras del estado donde han sido condenados ${ }^{897}$.

Además, también señalar que la revocación o suspensión del permiso de conducir, a nivel europeo se incluye tanto en el sistema de las sanciones penales, como en el ámbito de las sanciones administrativas ${ }^{898}$, lo que indudablemente podría generar problemas para su posterior ejecución de forma armonizada.

La importancia que tiene la delincuencia vial transfronteriza a nivel europeo también se ha reflejado en la Resolución del Parlamento Europeo de 27 de septiembre de

\footnotetext{
895 Vid. el contenido del Reglamento en: https://eur-lex.europa.eu/legalcontent/ES/TXT/?uri=CELEX\%3A32016R0095 (último acceso: 03/11/2020).

896 Vid. el contenido de la Comunicación en:

http://eurlex.europa.eu/LexUriServ/LexUriServ.do?uri=COM:2006:0073:FIN:ES:HTML (último acceso: 03/11/2020).

897 Un ejemplo de ello es la sentencia del Tribunal de Justicia de la Unión Europea, Sala $5^{\underline{a}}$, de 14 de mayo de 2020, núm. de recurso C-615/18 (TOL7.917.465), relativa al caso de un conductor profesional polaco que fue condenado a la pena de privación del derecho a conducir en Alemania y que analiza la posible vulneración del derecho a la información en los procesos penales cuando se imponen sanciones penales por un estado a un nacional de otro estado.
}

Vid. el contenido de la sentencia en:

https://eur-lex.europa.eu/legal-content/ES/TXT/?qid=1590318166279\&uri=CELEX:62018CJ0615 (último acceso: 24/05/2020). 
2011 sobre la seguridad vial europea 2011-2020. En ella, se incluye la recomendación número 46 relacionada con el intercambio transfronterizo de información relacionada con la seguridad vial899, lo que acredita la situación de mínimos en la que se hallaba hace nueve años el derecho comunitario en la materia.

También en el año 2011 se aprobó la Directiva 2011/82/UE del Parlamento Europeo y el Consejo de 25 de octubre por la que se facilita el intercambio transfronterizo de información sobre infracciones de tráfico en materia de seguridad vial ${ }^{900}$, como texto de referencia del proyecto europeo de cumplimiento transfronterizo en materia de seguridad vial. La citada directiva seguía la estela de los dos textos citados anteriormente, al preconizar como objetivo la persecución transfronteriza de los infractores viales y la eficacia de las sanciones que se imponen a los mismos, como puede ser la pena de privación del derecho a conducir. Respecto la aplicación que ha tenido la directiva 2011/82/UE del Parlamento Europeo y el Consejo de 25 de octubre, podemos destacar que fue anulada en fecha 6 de mayo de 2014 tras la sentencia dictada por el Tribunal de Justicia de la Unión Europea ${ }^{901}$ debido a que estaba basada en el art. 87, apartado 2 del Tratado de Funcionamiento de la Unión Europea que hace referencia a la cooperación policial, en lugar de la seguridad en los transportes, que está regulada en el art. 91, apartado 1, letra c) de citado Tratado ya que éste era el objetivo principal de dicha directiva. Ello originó que en fecha 11 de marzo de 2015 se aprobara la Directiva 2015/413 del Parlamento Europeo y del Consejo de 11 de marzo de 2015 por la que se facilita el intercambio transfronterizo de información sobre infracciones de tráfico en materia de seguridad vial que sustituye a la anulada902. La Directiva 2015/413 ha sido transpuesta a través del RDL 6/2015, de 30 de octubre, por el que se aprueba el texto refundido de la LTSV, dedicándose a la misma los arts. 97 al 102.

\footnotetext{
898 Vid. LAURELL, H, "Hacia unas carreteras sin alcohol en Europa”, op.cit., p.44.

$899 \mathrm{Vid}$. la resolución en:

http://eur-lex.europa.eu/LexUriServ/LexUriServ.do?uri=OJ:C:2013:056E:0054:0067:ES:PDF (último acceso: 05/11/2020).

900 Vid. el contenido de la Directiva en: https://www.boe.es/doue/2011/288/L00001-00015.pdf (último acceso: 13/11/2020).

901 Vid. Sentencia de la Gran Sala del Tribunal de Justicia de la Unión Europea, de 6 de mayo de 2014, núm. de recurso C-43/12 (TOL4.219.330).

902 Vid. la directiva en: http://www.boe.es/doue/2015/068/L00009-00025.pdf (último acceso: 13/11/2020).
} 
En relación con las infracciones a las que puede aplicarse la Directiva 2015/413, podemos señalar que de la misma quedarían fuera delitos que en el CP están regulados como podrían ser los delitos de conducción temeraria, el delito de abandono del lugar del accidente o el delito de negativa a someterse a las pruebas de alcohol o drogas establecidas legalmente y que conllevan, la pena de privación del derecho a conducir. El motivo es que tanto las infracciones tipificadas en la directiva en el apartado 2 c) que hace referencia a la no detención ante un semáforo en rojo así como la regulada en el apartado $2 \mathrm{~g}$ ) que se refiere a la circulación por un carril prohibido, por sí mismas, y de no existir más datos periféricos que evidencien un peligro concreto, no han de ser consideradas per se constitutivas de un delito de conducción temeraria de los tipificados en los arts.380 o 381 CP. Asimismo, en relación al delito de negativa a someterse a las pruebas de alcohol o sangre del art. 383 CP, no existe en la Directiva 2015/413 del Parlamento Europeo y el Consejo de 11 de marzo de 2015 ninguna de las ocho infracciones que se detallan en el art. 2 que se correspondan con dicha conducta. En el mismo sentido, tampoco aparece en el listado de infracciones del art. 2 de la Directiva 2015/413 ninguna infracción que pueda incardinarse en la conducta del delito del art. 382 bis $\mathrm{CP}$, que entró en vigor con la LO 2/2019 de 1 de marzo, denominado como delito de abandono del lugar del accidente.

Sin embargo, en la referida directiva sí considero que las infracciones que se regulan pueden equipararse a los delitos tipificados en el art.379 CP en lo relativo a la conducción bajo la influencia de alcohol o drogas, así como en los delitos relacionados con la velocidad, en los que se puede imponer la pena objeto de estudio. Por último, respecto a los delitos tipificados en los arts.142 y 152 CP de lesiones y homicidio por imprudencia que también pueden acarrear la pena de privación del derecho a conducir, estimo que algunas de las acciones que constituyen dichas infracciones penales pueden incluirse directamente en el listado de conductas del art.2 de la Directiva 2015/413/UE del Parlamento Europeo y el Consejo de 11 de marzo de 2015, pero no se incorporan todas.

Una de las incoherencias que pueden realizarse a la citada directiva es que otorga una gran relevancia a aspectos relacionados con el vehículo infractor cuando en el ámbito de la delincuencia lo que ha de tener una mayor preeminencia es las infracciones que realice el conductor, que es quien al final será el penado. Además, con relación a la pena de privación del derecho a conducir, se puede realizar una crítica negativa al contenido de la directiva ya que como ha señalado REQUEJO 
CONDE $^{903}$, no se establece un reconocimiento mutuo de la pena de privación del derecho a conducir, motivo por el que muchos aspectos pueden quedar sin eficacia práctica en los casos de delincuencia vial transfronteriza ${ }^{904}$.

Nos planteamos, llegados a este punto, si puede tener alguna relevancia a nivel transnacional la pérdida definitiva del permiso o licencia en el marco de la Unión Europea, así como en el de terceros países, cuando se aplique el art.47.3 CP. A día de hoy, carecemos de un sistema en el que se garantice que aquellos penados con la pérdida de vigencia del permiso en un país de la UE o de un tercero no puedan conducir en otro diferente, debido a la ausencia de mecanismos que interrelacionen los sistemas de ejecuciones penales a nivel europeo. La eficacia del art.47.3 CP que supone la pérdida de vigencia del permiso o licencia más allá de las fronteras del territorio español, quedará al albur del Estado en el que el penado vuelva a conducir en relación con el reconocimiento de las resoluciones penales dictadas por Tribunales españoles ${ }^{905}$. Además, no existirán excesivas dificultades para que el conductor al que se le ha aplicado el art.47.3 CP pueda conseguir un duplicado de su permiso o licencia cuya pérdida ha decretado un tribunal penal español, por lo que se debe profundizar y mejorar los mecanismos de cooperación tanto a nivel comunitario como con terceros países a través de los convenios bilaterales.

Cuestión distinta es la relativa a la cobertura legal que la LECrim establece para conductores extranjeros con permiso expedido en país extranjero habilitados para conducir en España que puedan estar implicados en delitos relacionados con la seguridad vial o contra la vida o integridad física o psíquica de las personas cometidos en España, y que podemos referenciarla en el art.794.2 de la LECrim ${ }^{906}$. En estos casos, si el conductor extranjero comete en España un delito que comporta la pena de privación del derecho a conducir, la ejecución de la misma no será diferente a la de un ciudadano español con permiso expedido por las

\footnotetext{
903 Vid. REQUEJO CONDE, Carmen, El delito..., op.cit., p.122.

904 Respecto de la posibilidad de la incorporación de la directiva al ordenamiento jurídico español la modificación que se llevó a cabo en la LTSV a través de la Ley 6/2014 de 7 de abril de 2014 ya previó en la disposición adicional segunda que través de la redacción de la nueva LTSV, ésta pudiera incorporar el texto comunitario como finalmente sucedió en el año 2015. Recurso electrónico disponible en: http://www.boe.es/boe/dias/2014/04/08/pdfs/BOE-A-2014-3715.pdf (último acceso: 13/11/2020).

905 Con relación al cumplimiento transfronterizo de la pérdida de vigencia, coincido con la opinión de MUÑOZ GARRIDO, Rubén, en: "La privación del derecho a conducir y la pérdida de vigencia del permiso de conducción en el ámbito de la Unión Europea", Diario La Ley, ㄲo 8045, 18 marzo, 2013.

906 Vid. la Memoria de la FGE del año 2012, p.887.
} 
autoridades españolas ${ }^{907}$. Según el tenor literal del art. 794.2 de la LECrim, este puede ser aplicable tanto a conductores españoles, así como a conductores extranjeros, ya que los Juzgados y Tribunales no podrán ir más allá de lo que dice la ley procesal, y ésta no hace diferencias por criterio de nacionalidad. Por este motivo se le intervendrá el permiso; se le realizará el preceptivo requerimiento para que se abstenga de conducir, se inscribirá la sentencia condenatoria en el Registro Central de Penados y Rebeldes y se remitirá la sentencia a la Jefatura de Tráfico al amparo del principio de soberanía ya que es en España donde ha cometido el delito y se le ha impuesto la pena. Sin embargo, el problema aparecerá en la fase de ejecución de la pena impuesta, ya que los jueces nacionales no podrán controlar si el penado conduce y quebranta la condena más allá de nuestras fronteras.

Uno de los mecanismos previstos en la LECrim para hacer eficaz el cumplimiento transnacional de la pena de privación del derecho a conducir es la intervención cautelar del permiso. Esta posibilidad, regulada en el art.764.4 de la LECrim, se puede acordar en aquellos conductores que no posean permiso de conducir español y el permiso expedido en un tercer país podrá quedar intervenido hasta la celebración del Juicio Oral. A través de la medida cautelar se consigue que el conductor extranjero no pueda conducir en territorio nacional hasta que la misma cese y de manera simultánea podría informarse a sus autoridades nacionales de la intervención de su permiso de conducir. Si el conductor que posee permiso extranjero y reside fuera de España resulta condenado, no existiría problema alguno en que el mismo deba entregar su permiso a los Tribunales españoles tal como establece el art. 794.2 de la LECrim, ya que el delito se habrá cometido en España y habrá sido juzgado por los tribunales españoles ${ }^{908}$. Sin embargo, a pesar de que el penado pueda entregar su permiso, existirá de nuevo el mismo problema, ya que la eficacia de la pena de privación del derecho a conducir quedará reducida a la mínima expresión en el momento que rebase nuestras fronteras.

Asimismo, existen otros supuestos relacionados con el cumplimiento transnacional de la pena de privación del derecho a conducir que entiendo no están resueltos y por este motivo gozan de impunidad. Uno de ellos es cuando se impone una pena

907 En relación con estos supuestos, existe un auto judicial que ha resuelto que el conductor extranjero que delinque en España ha de entregar el permiso de conducir, aunque éste sea extranjero, y no se le puede retornar hasta que cumpla la pena de privación del derecho a conducir a la que ha sido condenado. Vid. AAP de Barcelona, núm. 83/2016, Sección 7ạ, de 29 de enero de 2016, ponente IImo. Sr. Luis Fernando Martínez Zapater (TOL5.967.679). Sin embargo, hemos constatado con diversas consultas con Letrados de la Administración de Justicia que no existe un criterio uniforme en la praxis diaria: algunos Juzgados intervienen el permiso y otros no.

908 Vid. Memoria FGE año 2012, p.887. 
de privación del derecho a conducir inferior a dos años en España, por lo que se no se decreta la pérdida de vigencia del permiso o licencia. El ciudadano español que se encuentre en este supuesto podrá conducir sin ningún problema por el resto de estados europeos, ya que la pena únicamente afectará al territorio español, y además seguirá manteniendo la vigencia de su permiso. A sensu contrario, en los casos que se produzca una condena a la privación del derecho a conducir o la retirada de un permiso de conducir por tribunal europeo o tribunal de un estado miembro, no afectará la posible responsabilidad penal que ese mismo conductor pueda tener en territorio español, ya que la misma no será ejecutable en España909. En este caso, el penado, al no haber sido privado de conducir por ningún Juzgado o Tribunal español, no habrá quebrantado ni pena ni medida cautelar impuesta de acuerdo con el CP español, por lo que dicha conducta carecerá de relevancia penal y no podrá ser acusado por la comisión de un delito del art.384 del C.P910. Sin embargo, nada obstará que dicho conductor pueda ser procesado por los hechos delictivos que sí haya podido cometer en España como pudieran ser: conducción bajo la influencia del alcohol o drogas, negativa a someterse a las pruebas $u$ homicidio o lesiones por imprudencia.

A la vista de las consideraciones realizadas podemos señalar que la situación de la delincuencia en materia de seguridad vial en Europa, puede denotar que las autoridades comunitarias no la consideran como una prioridad ${ }^{911}$. Si bien en el año 2014 entraron en vigor dos leyes relacionadas con las resoluciones penales en la Unión Europea ${ }^{912}$, ninguna de ellas ha previsto mecanismos para un efectivo cumplimiento transnacional de la pena de privación del derecho a conducir. Debido a esta circunstancia no serán aplicables en terceros estados con carácter general las penas de privación del derecho a conducir impuestas por otros, siendo la lucha contra la delincuencia vial transfronteriza uno de campos en los que más trabajo hay que realizar para que la misma devenga una realidad ${ }^{913}$. Es esencial que la pena analizada pueda tener eficacia a nivel europeo ya que lo contrario, en

\footnotetext{
909 Vid. REQUEJO CONDE, Carmen, El delito..., op.cit., pp.119-120 y también MIRÓ LLINARES, Fernando, "El moderno..."; op.cit., p.42.

910 En este sentido estoy de acuerdo con lo expresado por TRAPERO BARREALES, María.A., Los delitos..., op.cit., p.416.

911 Vid. REQUEJO CONDE, Carmen, El delito...op.cit., p.121 y también la Memoria de la FGE del año 2012, p.901.

912 Vid. Ley Orgánica $7 / 2014$, de 12 de noviembre, sobre intercambio de información de antecedentes penales y consideración de resoluciones judiciales penales en la Unión Europea y la Ley 23/2014, de 20 de noviembre, de reconocimiento mutuo de resoluciones penales en la Unión Europea.

913 Referente a la situación actual de la delincuencia vial transfronteriza, vid. Memoria FGE año 2012, pp.900-903.
} 
supuestos de delincuencia transfronteriza no tendrá eficacia disuasoria ni preventiva ni retributiva para mejorar la seguridad vial. Para que se puedan conseguir dichos objetivos, es necesario que las penas se cumplan en todo el espacio europeo, y generar la conciencia que, si delinque con un vehículo a motor o ciclomotor en Europa, la pena se cumplirá en todo el espacio europeo con independencia del país de emisión del permiso o licencia del conductor.

Para ello resulta indispensable mejorar los mecanismos de cooperación y reconocimiento mutuo de la pena de privación del derecho a conducir que garanticen su ejecución en el ámbito comunitario ${ }^{914}$ y desplegar una normativa en materia de seguridad vial común a todos los países europeos. En consecuencia, es necesario plantear diversas opciones que podrían coadyuvar al control transfronterizo de la pena de privación del derecho a conducir a nivel europeo y que la misma pueda ser aplicable no sólo en territorio español sino en todo el espacio europeo. En este sentido considero acertadas propuestas como la de iniciar una progresiva armonización entre países limítrofes como Portugal/España/Francia ${ }^{915}$ ya que en estos Estados es frecuente que los conductores atraviesen las fronteras próximas y puedan cometer infracciones relacionadas con la seguridad vial por las que se impongan penas de privación del derecho a conducir. Por ello puede ser más sencillo el control a través de convenios bilaterales o trilaterales que articular mecanismos en los que intervengan todos los estados de la Unión Europea, ya que podrían establecerse mecanismos de reconocimiento mutuo de las sentencias que incluyan la pena estudiada, que sean ágiles aprovechando los medios informáticos y que fueran de aplicación efectiva en el ámbito de éstos tres países. Una segunda opción que podría implementarse para combatir la delincuencia vial transnacional sería aplicar el principio de justicia universal de la jurisdicción española regulada en el art. 23. $2^{\circ}$ de la LOPJ, aunque tiene el hándicap que para poderse ejecutar son necesarios los tres requisitos que se establecen en el art. $23.2^{\circ}$ de la LOPJ y no es sencillo que se puedan dar a la vez ${ }^{916}$. Además, esta posibilidad puede resultar

\footnotetext{
914 Al respecto podemos citar la comparecencia efectuada el pasado 11 de marzo de 2015 por el Fiscal de Sala Coordinador de Seguridad Vial, Ilmo.Sr. Bartolomé Vargas Cabrera, en el Congreso de los Diputados, en la Comisión de Seguridad Vial y Movilidad Sostenible en la que expresamente manifestó que: "Realmente, los recursos para combatir la delincuencia europea de seguridad vial son muy escasos". Vid. Diario de Sesiones del Congreso de los Diputados, año 2015, Núm.766. Recurso electrónico disponible en: http://www.congreso.es/public oficiales/L10/CONG/DS/CO/DSCD-10-CO766.PDF (último acceso: 14/04/2020).

915 Vid. MUÑOZ GARRIDO, Rubén, "La privación del derecho a conducir y la pérdida de vigencia del permiso de conducción en el ámbito de la Unión Europea", Diario La Ley, № 8045, 18 marzo 2013.

916 Art. 23.2 LOPJ: También conocerá la jurisdicción española de los delitos que hayan sido cometidos fuera del territorio nacional, siempre que los criminalmente responsables fueren españoles o extranjeros que hubieran adquirido la nacionalidad española con posterioridad a la comisión del
} 
costosa desde el punto de vista procesal y nada ágil, ya que requiere una gran coordinación con el resto de estados miembros de la UE.

La directiva 2015/413 del Parlamento Europeo y del Consejo de 11 de marzo de 2015, por la que se facilita el intercambio transfronterizo de información sobre infracciones de tráfico en materia de seguridad vial, podría emplearse para que la pena de privación del derecho a conducir que se aplique a ciudadanos comunitarios en España o a españoles en el resto del espacio europeo no resulte ilusoria. Del mismo modo que la citada directiva ha utilizado como criterio la matriculación de los vehículos en otros países para intercambiar información y que las sanciones no queden impunes, podrían establecerse mecanismos similares para establecer la posibilidad que se pueda aplicar la pena de privación del derecho a conducir en todo el espacio europeo, pudiéndose utilizar las aplicaciones informáticas que se aplican en la citada directiva para los condenados a dicha pena.

Con el fin de evitar que los penados extranjeros cuando abandonan España no cumplan la pena de privación del derecho a conducir en su país de nacionalidad, debería poder informarse a las autoridades judiciales y de Tráfico de dicho país que a un nacional se le ha impuesto una pena de privación del derecho a conducir en un estado miembro de la UE. A través de la cooperación de diferentes países podría conseguirse que los penados a los que se les ha impuesto la pena de privación del derecho a conducir la deban cumplir tanto en el país en el que se ha cometido como en el país del que son nacionales y evitar de esta forma la impunidad en la conducción cuando rebasen una frontera.

Puesto que, en España, como hemos indicado anteriormente, la LECrim no distingue entre la nacionalidad a la hora de entregar el correspondiente permiso o licencia de conducir para dar inicio al cumplimiento de la pena de privación del derecho a conducir, considero que podría implementarse en España la medida que se lleva a cabo en Alemania. Ésta consiste en que cuando el penado tenga una autorización para conducir extranjera sólo se anota la condena, no siendo necesaria la entrega del permiso o licencia ${ }^{917}$. Si ello lo aplicáramos a nuestro sistema penal,

hecho y concurrieren los siguientes requisitos: a) Que el hecho sea punible en el lugar de ejecución, salvo que, en virtud de un Tratado internacional o de un acto normativo de una Organización internacional de la que España sea parte, no resulte necesario dicho requisito, sin perjuicio de lo dispuesto en los apartados siguientes. b) Que el agraviado o el Ministerio Fiscal interpongan querella ante los Tribunales españoles. c) Que el delincuente no haya sido absuelto, indultado o penado en el extranjero, o, en este último caso, no haya cumplido la condena. Si sólo la hubiere cumplido en parte, se le tendrá en cuenta para rebajarle proporcionalmente la que le corresponda.

917 En este sentido vid. CHOCLÁN MONTALVO, José Antonio, "Las penas privativas...", op.cit., p.159 así como el art. 44.3 del Código Penal alemán. 
los Tribunales españoles únicamente deberían ordenar la retirada física del permiso de conducir a los penados cuyo permiso haya sido emitido por la DGT y en relación al resto de conductores no, ya que las autoridades españolas no son emisoras de permisos extranjeros, anotando únicamente la prohibición de conducir en España.

Para alcanzar el objetivo del reconocimiento mutuo de la pena de privación del derecho a conducir sería necesario que se armonizaran a nivel europeo las legislaciones de los diferentes países miembros, y para ello considero interesante que la pena objeto de estudio se incorpore en una normativa como la Ley 23/2014 de 20 de noviembre de reconocimiento mutuo de resoluciones penales de la Unión Europea $^{918}$, que regula todos los mecanismos de reconocimiento mutuo a nivel de la Unión Europea, por lo que para una aplicación transnacional de la pena de privación del derecho a conducir este texto legal ha de ser obligatoriamente el punto de partida.

Sí que podemos destacar que en el ámbito de la Ley 23/2014 de 20 de noviembre se hace referencia en su Título $\mathrm{V}$, a las resoluciones sobre medidas alternativas a la prisión provisional, y en el artículo 110.1.h), se hace referencia a la obligación de no conducir vehículos a motor como medida cautelar. Ello puede ser un primer paso y la base para la posible ejecución en el territorio comunitario de la pena de privación del derecho a conducir, ya que en la actualidad únicamente podemos destacar que existe dicha posibilidad en sede de medida cautelar y siempre como una alternativa a la prisión provisional. Hoy en día si en un procedimiento penal un juzgado acordase como medida cautelar alternativa a la prisión provisional, entre otras, la obligación de no conducir vehículos a motor, al amparo del art. 2 de la Ley 23/2014 valoro que no existiría ningún óbice en emitir un instrumento de reconocimiento mutuo en el país de procedencia del ciudadano comunitario que ha cometido la infracción relacionada con la seguridad vial en España ${ }^{919}$, ello siempre que en el estado que ha de ejecutar la misma haya incorporado a su derecho interno la normativa comunitaria. Además, para alcanzar objetivo del cumplimiento efectivo de la pena de privación del derecho a conducir en todo el territorio comunitario puede utilizarse un mecanismo existente desde hace más de un lustro y que puede coadyuvar a conseguirlo. Es el Sistema Europeo de Información de Antecedentes

\footnotetext{
918 En relación con la génesis de esta ley vid. RODRíGUEZ-MEDEL NIETO, Carmen/ SEBASTIÁN MONTESINOS, Ángeles, Manual práctico de reconocimiento mutuo penal en la Unión Europea, Ed. Tirant lo Blanch, Valencia 2015, p.19.

919 Acerca de los requisitos para la emisión de un instrumento de reconocimiento mutuo vid. RODRíGUEZ-MEDEL NIETO, Carmen/ SEBASTIÁN MONTESINOS, Ángeles, Manual práctico..., op.cit., p.26.
} 
Penales (ECRIS), a través del cual se puede intercambiar información entre los estados miembros de la Unión Europea de los antecedentes penales en los mismos $^{920}$ y que persigue uno de los fines comunitarios, como es la creación de un espacio común de libertad y justicia, lo que demuestra que puede establecerse un mecanismo para el control de las condenas más allá de las fronteras del país en el que se ha cometido el delito.

Por ello, es necesario que, en el ámbito europeo, sobre la base del principio de mutuo reconocimiento, se implementen mecanismos para conseguir que el cumplimiento de una pena privativa de derechos, como la privación del derecho a conducir, no tenga únicamente eficacia en el territorio del Estado que la impone, sino que tenga un alcance comunitario, cosa que no sucede en la actualidad ${ }^{921}$. En este sentido, sería necesario establecer un reconocimiento europeo de la pena de privación del derecho a conducir ya que precisamente la Comunicación de la Comisión de 21 de febrero de 2006 al Consejo y al Parlamento Europeo sobre penas privativas de derechos impuestas por condenas penales en la Unión Europea, en su conclusión (33), ya determinaba hace más de una década que la pena de privación del derecho a conducir era una de las penas idóneas para el reconocimiento mutuo en los estados miembros. Como hemos señalado en este epígrafe, actualmente existen mecanismos, tanto en el ámbito administrativo como en el ámbito penal, que pueden servir de base para instaurar un sistema de cumplimiento eficaz de la ejecución de la pena de privación del derecho a conducir a nivel comunitario, motivo por lo que considero que es posible que, en los próximos años, se pueda subsanar este déficit de nuestro sistema de ejecución penal.

\subsection{Control de la ejecución y quebrantamiento de la pena}

El último apartado del capítulo está dedicado al control de la ejecución de la pena de privación del derecho a conducir y haremos especial referencia a las situaciones de quebrantamiento, cómo ha de interpretarse y las consecuencias que derivan del mismo.

\footnotetext{
920 En torno al sistema ECRIS y su funcionamiento vid. AGUDO FERNÁNDEZ, Enrique/ JAÉN VALLEJO, Manuel/ PERRINO PÉREZ, Ángel Luis, Penas..., op.cit., p.219-222.

921 En este sentido, podemos destacar las Conclusiones del Consejo de la Unión Europea sobre la seguridad vial en refrendo de la declaración de La Valeta de marzo de 2017, en las que se destaca que los Estados miembros peticionan a la Comisión la creación de mecanismos jurídicos para alcanzar el reconocimiento mutuo de las privaciones del derecho a conducir de conductores no residentes. Vid. las conclusiones en: http://data.consilium.europa.eu/doc/document/ST-8666-2017INIT/es/pdf (último acceso: 05/11/2020).
} 
En el ámbito de las condiciones de ejecución de la pena de privación del derecho a conducir puede suceder que la pena se quebrante, lo que supondrá la imputación de un nuevo delito al penado tipificado en el art.384 CP. En este artículo, se tipifican tres conductas relacionadas con la conducción de vehículos a motor y ciclomotores, así como con el permiso o licencia: la conducción sin licencia por pérdida de puntos, la conducción tras la privación judicial del permiso o licencia y la conducción sin haber obtenido nunca el permiso o licencia. Las tres conductas forman un delito unitario de quebrantamiento específico en la esfera de la seguridad vial, incluyéndose todas las conductas que por un mandato expreso impiden que un conductor pueda utilizar un vehículo a motor o ciclomotor. Nos centraremos únicamente en el párrafo segundo, inciso segundo del art.384 CP que tipifica como delito la conducción de un vehículo a motor o ciclomotor tras haber sido privado cautelar o definitivamente del permiso o licencia por decisión judicial922, ya que es el que tiene relación con la pena objeto de estudio.

El procedimiento para ejecutar la pena de privación del derecho a conducir comienza en el trámite formal en el que el penado ha de entregar el permiso o licencia ante el Juzgado o Tribunal. Son frecuentes los casos que los conductores a pesar de la pena impuesta siguen conduciendo, aunque no pueden ejercitar su derecho a conducir por expreso mandato de una sentencia penal. La impunidad de estas situaciones deriva de la dificultad para controlar a todos los conductores a los que se les ha impuesto la pena de privación del derecho a conducir. Es importante destacar que los conductores no suelen ser descubiertos sino es por azar en un control policial o cuando se ven involucrados en un accidente, lo que provoca la intervención policia|923. Los problemas relacionados con el cumplimiento de la pena de privación del derecho a conducir han sido destacados por la doctrina ${ }^{924}$ al poner de manifiesto la dificultad que existe para detectar los posibles quebrantamientos ya que para su correcto cumplimiento es imprescindible la actitud colaborativa del penado.

922 Art.384.Apartado Segundo CP: La misma pena se impondrá al que realizare la conducción tras haber sido privado cautelar o definitivamente del permiso o licencia por decisión judicial.

923 Vid. TAMARIT SUMALLA, Josep/ LUQUE REINA, Ma Eulàlia, Automóviles, delitos y penas..., op.cit., p.149. Es interesante lo expresado por SERRANO MAILLO y REALPE QUINTERO en relación a que siguen existiendo hechos delictivos que no llegan a ser descubiertos y por lo tanto nunca reciben sanción penal. Vid. SERRANO MAÍLLO, Alfonso/REALPE QUINTERO, María Fernanda, Criminología del delincuente vial. La generalidad de la desviación en la conducción de vehículos a motor, Ed. Edisofer, Madrid, 2015, p.54.

924 Vid. MATUS ACUÑA, Jean Pierre, "Penas privativas de derechos", en AA.VV. Penas alternativas...op.cit., p.133 y TAMARIT SUMALLA, Josep, "La prohibición de conducir y otras sanciones penales relacionadas con los vehículos", en AA.VV. Las sanciones..., op.cit., p. 330. 
Uno de los motivos por los que se reforzó en el año 2007 el CP el delito de quebrantamiento relacionado con la privación del derecho a conducir, fue la percepción existente de una cierta laxitud en la respuesta punitiva al incumplimiento de dicha pena, que únicamente acarreaba la pena de multa en aplicación de lo previsto en el art.468 $\mathrm{CP}^{925}$. El tipo penal del art.384 CP regula de forma específica el quebrantamiento de condena o medida cautelar relacionados con la pena de privación del derecho a conducir, y con la reforma de 2007 el quebrantamiento pasa a configurarse como un tipo autónomo mejorando con ello, tanto su ubicación en el $\mathrm{CP}$, junto al resto de delitos contra la seguridad vial, como la respuesta punitiva al incrementarse la misma, así como la configuración del tipo delictivo ${ }^{926}$. La opción del legislador no sólo de sancionar en la vía penal, sino además de reforzar la penalidad de los posibles quebrantamientos, considero que fue acertada, ya que en la vía administrativa únicamente tendrían una sanción económica.

Uno de los mecanismos que tiene el Estado es sancionar penalmente el incumplimiento de las propias resoluciones penales, como en nuestro caso la pena de privación del derecho a conducir, para de esta forma proteger tanto bienes jurídicos colectivos como individuales. En este sentido la actual configuración del art. $384 \mathrm{CP}$ es una prueba de cómo se puede reforzar la eficacia preventiva de la norma penal, ya que la ciudadanía puede percibir una mayor disuasión a través de una sanción penal que no a través de una sanción administrativa.

Un aspecto destacable de los posibles quebrantamientos es que aun cuando el redactado del art.384 CP hace referencia a la privación del permiso o licencia, la referencia debe entenderse que alcanza a la privación del derecho a conducir. Hemos de referirnos al quebrantamiento de la pena de privación del derecho a conducir de manera indistinta a la privación del permiso o licencia, ya que las consecuencias son idénticas, estando regulado el cumplimiento de la pena de privación del derecho a conducir en el art.47 CP927.

\footnotetext{
${ }^{925}$ En este sentido estoy plenamente de acuerdo con lo expresado en la Circular 10/2011 de la FGE, en lo relativo a los deficientes efectos de prevención general negativa que conllevaba la aplicación del art.468 CP, p.58.

926 Vid. MOLINA GIMENO, Francisco Javier, "Delitos contra la Seguridad Vial. Comentarios a la reforma del Código Penal operada por la LO 15/2007 de 30 de noviembre ", Revista El Ligall, II.lustre Col.legi d'Advocats de Granollers, № 41, Año 2008.

927 Art. 47 CP: La imposición de la pena de privación del derecho a conducir vehículos a motor y ciclomotores inhabilitará al penado para el ejercicio de ambos derechos durante el tiempo fijado en la sentencia.
} 
El control que se efectúe del cumplimiento de la pena de privación del derecho a conducir es más adecuado a través del art.384 CP, ya que antes de la reforma operada en el año 2007 por parte del poder judicial se realizaba una interpretación extensiva de los arts.468 y 556 para incluir los quebrantamientos relacionados con la pena de privación del derecho a conducir ${ }^{928}$. Esta circunstancia ha sido destacada por GARCíA DEL BLANCO ${ }^{929}$, al indicar que las opciones penales existentes antes de la entrada en vigor del actual art.384 CP no eran la mejor herramienta desde el punto de vista de técnica jurídica para combatir el control judicial de la ejecución de la privación del derecho a conducir.

En la actualidad, en los supuestos en que se quebranta la privación del derecho a conducir bien como pena bien como medida cautelar hay que determinar el tipo delictivo por el que ha de imputarse a los conductores, ya que en el CP existen dos preceptos relacionados con los quebrantamientos de resoluciones judiciales: el art.468 y el art.384 CP. Tras la entrada en vigor del art.384 CP la doctrina planteó un debate en torno al precepto penal aplicable a los supuestos de quebrantamiento de privación del derecho a conducir ${ }^{930}$, que en la actualidad ha de considerarse superado. El motivo por el que ha de considerarse resuelta dicha problemática, es que el art.384 CP es un precepto especial a aplicar en los quebrantamientos relacionados con la privación del derecho a conducir, en detrimento del art.468 CP que tipifica los quebrantamientos genéricos ${ }^{931}$. Un argumento que puede fundamentar la aplicación del art.384 en detrimento del art.468 CP, lo hallamos en

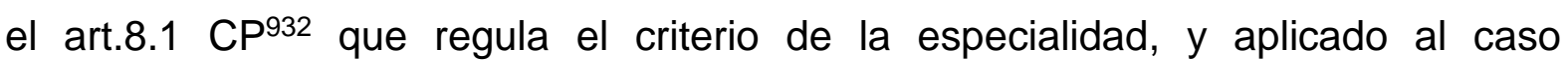
analizado, implica que ha de prevalecer el art.384 $\mathrm{CP}^{933}$.

928 Vid. GANZENMÜLLER ROIG, Carlos/ DE LAMO RUBIO, Jaime/ ROBLEDO VILLAR, Antonio, ESCUDERO MORATALLA, José Francisco y FRIGOLA VALLINA, Joaquín, Delitos..., op.cit., p.46. in fine.

929 Vid. GARCÍA DEL BLANCO, Victoria, "El nuevo artículo 384 del Código Penal: quebrantamientos, desobediencias y conductas afines", en AA.VV. Protección Penal..., op.cit., pp.436-438.

930 Vid. LANZAROTE MARTÍNEZ, Pablo, "El quebrantamiento de la privación del derecho a conducir vehículos a motor o ciclomotores después de la reforma del CP por la LO 15/2007”, Sepin, Tráfico, Circulación y Seguridad Vial, Marzo-Abril-2009, № 23, pp.13-14.

931 Acerca de aplicar el criterio de la especialidad del art.384 CP, vid. RUSCA NADAL, Oriol, "Reforma...", op.cit., p.27; MIRÓ LLINARES, Fernando, "El moderno...", op.cit., p.41, y también NUÑO DE LA ROSA AMORES, José Antonio, "Aplicación práctica...", op.cit., p.111.

932 Art. 8 CP: Los hechos susceptibles de ser calificados con arreglo a dos o más preceptos de este Código, y no comprendidos en los artículos 73 a 77, se castigarán observando las siguientes reglas: 1‥ El precepto especial se aplicará con preferencia al general.

933 Vid. LANZAROTE MARTÍNEZ, Pablo, "Algunas cuestiones discutidas en el delito de conducción punible del art.384 del Código Penal”, La dogmática penal..., op.cit., p.213. 
Además del criterio de la especialidad, otro es el de la gravedad de la pena establecida en ambos artículos, circunstancia que podemos relacionar con el criterio de la alternatividad. El art.384 acarrea la imposición de la pena de prisión mientras que el art.468 conllevaría únicamente la pena de multa por lo que al amparo del art.8.4 $\mathrm{CP}^{934}$ será preferente el art.384 $\mathrm{CP}^{935}$. La similitud entre el delito del art.468 CP y el art.484 apartado segundo también fue analizada por la Circular 10/2011 de la FGE ${ }^{936}$. No comparto la definición que se realiza en la citada Circular de ambos tipos penales, ya que parece inferirse que el tipo del art.384 apartado segundo deriva del art.468 con la única diferencia de un incremento punitivo, cuando precisamente su ubicación en el marco de los delitos contra la seguridad vial le hace tener personalidad propia, siendo específico para los delitos contra la seguridad vial.

La deficiente redacción del tipo penal del art.384 y su posible conflicto con el art.468 ha tenido su repercusión en la jurisprudencia, habiéndose detectado diferentes interpretaciones jurisprudenciales acerca del tipo penal aplicable ${ }^{937}$, lo que evidencia que el contenido del art.384 no ha sido interpretado de forma clara y unánime.

Con la actual regulación del delito de quebrantamiento, en lo que afecta a la pena estudiada, el legislador ha buscado una cierta eficacia disuasoria hacia los conductores penados con la finalidad que respeten la sentencia o medida cautelar que incluya la privación del derecho a conducir. A ello responde la incorporación de la pena de prisión en el catálogo de penas que con carácter alternativo se pueden imponer en el delito del art.384 CP, y que no aparecía en el art.468 CP938. Es cierto que la pena de prisión es de corta duración, pero es un mensaje del legislador para dotar de eficacia al cumplimiento de la pena de privación del derecho a conducir, al

\footnotetext{
934 Artículo 8. 4a . CP: En defecto de los criterios anteriores, el precepto penal más grave excluirá los que castiguen el hecho con pena menor.

935 Dicho criterio también es mantenido por LANZAROTE MARTíNEZ, Pablo, "Algunas cuestiones discutidas en el delito de conducción punible del art.384 del Código Penal", La dogmática penal..., op.cit., p.213.

936 Vid. Circular 10/2011 de la FGE sobre criterios para la unidad de actuación especializada del Ministerio Fiscal en materia de seguridad vial, pp.48-49.

937 En relación con las diferentes resoluciones de las Audiencias Provinciales respecto a la aplicación del art.468 o 384.2 CP, vid. LANZAROTE MARTíNEZ, Pablo, "Algunas cuestiones discutidas en el delito de conducción punible del art.384 del Código Penal"; La dogmática penal..., op.cit., pp.216217.

938 Vid. TAMARIT SUMALLA, Josep $M^{a}$, "De los delitos contra la seguridad vial", en AA.VV. Comentarios a la Parte Especial del Derecho Penal, QUINTERO OLIVARES, Gonzalo (Dir.), MORALES PRATS, Fermín (Coord.), Ed. Thomson-Aranzadi, Cizur Menor (Navarra), 2011, p.1586.
} 
revestirla de una mayor gravedad que al resto de quebrantamientos como señala MIRÓ LLINARES ${ }^{939}$. La situación anterior a la reforma del art.384 CP, favorecía el incumplimiento de las sentencias que condenaban a la pena de privación del derecho a conducir, y en mi opinión era por los escasos efectos de prevención general y especial que tenía el art.468 CP. Esta situación podía llegar a ser especialmente relevante en aquellos penados para los que la utilización del vehículo y el ejercicio de su derecho a conducir eran necesarios debido a su actividad laboral y que reiteradamente incumplían la sentencia dictada, como ha manifestado TRAPERO BARREALES ${ }^{940}$.

El art.384 CP está redactado en consonancia con la política criminal de seguridad vial de los últimos tres lustros ya que equipara la respuesta punitiva del quebrantamiento de una resolución administrativa y el de una resolución judicial ${ }^{941}$. De este modo el legislador ha situado al mismo nivel el Derecho Administrativo sancionador con el Derecho Penal, lo que acredita la administrativización que está sufriendo el Derecho Penal, en el sentido de destacar la homologación punitiva del quebrantamiento de resoluciones administrativas y judiciales ${ }^{942}$. Estimo que el quebrantamiento de resoluciones judiciales debería tener una respuesta punitiva de mayor entidad que la conducción sin puntos, en la que se incumple una resolución administrativa. El desvalor de incumplir una resolución judicial penal de una pena privativa de derechos ha de merecer mayor reproche que el de una resolución administrativa, ya que lo contrario significa que podrían equipararse resoluciones judiciales penales con resoluciones administrativas.

La entrada en vigor del art.384 CP también generó un debate relacionado con la expresión "decisión judicial" que se detalla en el tipo penal, y que viene motivada por la no distinción entre juzgados de la jurisdicción penal o contenciosoadministrativa. Como hemos señalado en el apartado de naturaleza de la pena, en el Derecho Administrativo ha desaparecido la suspensión temporal del derecho a conducir, pero puede decretarse su suspensión cautelar e incluso la pérdida de vigencia del mismo, por lo que podría interpretarse que dichas conductas se pueden incardinar en el art.384, cuando son confirmadas por los tribunales contenciosoadministrativos. También relacionado con la redacción del tipo del art.384 en lo

\footnotetext{
939 Vid. MIRÓ LLINARES, Fernando, “El moderno...”, op. cit., pp.41-42.

940 Vid. TRAPERO BARREALES, María.A., Los delitos..., op.cit., p.468.

941 Al respecto, vid. GONZÁLEZ CUSSAC, José Luis/VIDALES RODRÍGUEZ, Caty, "Los nuevos delitos contra la seguridad vial", en AA.VV. Seguridad Vial..., op.cit., p.219.
} 
relativo a la pena de privación del derecho a conducir, hubiese sido más adecuado utilizar la fórmula de "privado por sentencia firme" en detrimento del actual redactado del tipo que se refiere a la expresión: "privado definitivamente"943. La justificación podemos encontrarla en el redactado art.33 $\mathrm{CP}$, ya que de su lectura podemos determinar que no existe una pena de privación del derecho a conducir vitalicia que es la interpretación que podría inferirse de la expresión "privado definitivamente", por lo que no debería existir duda alguna que la descripción del tipo hace referencia a una sentencia firme. Para una mayor claridad, podría realizarse una modificación del tipo, como ya propuso en su momento en la Memoria de la FGE del año 2009 la Fiscalía de Seguridad Vial ${ }^{944}$.

Como conclusión valorativa del art.384.2 inciso segundo del CP, entiendo positiva la reforma operada en el año 2007 para el cumplimiento de la ejecución de la pena de privación del derecho a conducir y el control de la privación del derecho a conducir acordada en sede de medida cautelar. Tanto su ubicación en los delitos contra la seguridad vial como la mayor punición que comporta el actual tipo han de redundar en un cumplimiento más eficaz de la pena de privación del derecho a conducir.

\footnotetext{
942 Vid. TAMARIT SUMALLA, Josep Ma, "De los delitos contra la seguridad Vial", en AA.VV. Comentarios..., op.cit., p.1586.

943 Vid. la crítica efectuada a la técnica legislativa por LANZAROTE MARTínEZ, Pablo, "EI quebrantamiento...", op.cit., p.15

944 Vid. Memoria de la FGE del año 2009, p.780.
} 


\section{CAPÍTULO 5. APLICACIÓN ACUMULATIVA DE LA PENA DE PRIVACIÓN DEL DERECHO A CONDUCIR CON OTRAS SANCIONES PENALES}

La pena de privación del derecho a conducir, concurre siempre con otras sanciones penales ya que nunca se aplica sola. Se puede imponer de forma conjunta con otras penas, consecuencias accesorias y medidas de seguridad, por lo que se examinará cómo puede afectar esta concurrencia de sanciones en el régimen de ejecución. En el Derecho Penal español la pena de privación del derecho a conducir se prevé en los delitos contra la seguridad vial, así como en los delitos de homicidio y lesiones imprudentes cometidos con vehículo a motor o ciclomotor, y en estos casos siempre concurrirá con otras penas principales de manera acumulativa ${ }^{945}$. Por todo ello, el objetivo del capítulo es determinar los supuestos en los que puede producirse esta aplicación acumulativa y definir los efectos de la ejecución conjunta de la pena de privación del derecho a conducir con el resto de sanciones penales.

Se considera en primer lugar la imposición de la pena de privación del derecho a conducir con las penas de prisión, multa y de TBC, que se produce en los delitos contra la seguridad vial y los delitos contra la vida e integridad física o psíquica de las personas. También estudiamos la aplicación conjunta con la pena de inhabilitación profesional del conductor cuando el delito cometido se ha llevado a cabo en el ejercicio de la actividad profesional en la que se utiliza un vehículo a motor o ciclomotor. El estudio de la imposición conjunta de ambas penas es interesante desde el punto de vista de la posible duplicidad de penas que se acuerdan respecto a un mismo hecho delictivo y la incidencia que pueda tener el principio de proporcionalidad. En el segundo apartado del capítulo se examina la aplicación acumulativa de la pena de privación del derecho a conducir con la medida de seguridad, detallando el funcionamiento conjunto de pena y medida de seguridad tanto las privativas de libertad como las no privativas de libertad. El último aspecto que se aborda en el capítulo es la concurrencia de la pena analizada con la consecuencia accesoria del decomiso del vehículo a motor o ciclomotor, ya que tras la entrada en vigor de la LO 5/2010 de 22 de junio se ha producido un mayor uso del decomiso en los delitos que conllevan la pena de privación del derecho a conducir.

\footnotetext{
945 Puede calificarse la pena de privación del derecho a conducir como una pena compuesta, ya que en los tipos penales en los que se aplica, siempre se impondrá de forma conjunta con otra pena. Ello ha sido destacado por DE LAMO RUBIO, Jaime, Penas y medidas..., op.cit., p. 46.
} 


\subsection{Aplicación acumulativa de la pena de privación del derecho a conducir con otras penas}

En este primer apartado del capítulo se analiza la pena de privación del derecho a conducir cuando se impone con las penas de prisión, multa, TBC e inhabilitación profesional ${ }^{946}$. Aun cuando es posible plantearse también la posibilidad de aplicación acumulativa de la pena de privación del derecho a conducir con la de localización permanente, constatamos que no existe ningún tipo delictivo que imponga ambas penas de forma directa por lo que se ha decidido no dedicarle un epígrafe. En este sentido, la concurrencia de ambas penas únicamente se produce cuando la localización permanente sea la forma de cumplir la responsabilidad personalidad subsidiaria por impago de multa (art. $53 \mathrm{CP}$ ) o bien cuando se aplique a través de la vía de la sustitución directa del art.71.2 CP947.

Me referiré, en primer lugar, a la aplicación conjunta de la pena de privación del derecho a conducir con la pena de prisión, multa y TBC debido a que son las que se aplican más frecuentemente ya que son las tres penas alternativas que se prevén en el art.379 CP, si bien pueden encontrarse presentes también en los arts.142, 152, 380, 381, 382 bis y 383 CP. En relación con esta materia hemos de hacer referencia a la entrada en vigor de la LO 15/2007 de 30 de noviembre de reforma del CP, ya que ésta introdujo en el redactado del art.379 CP la imposición conjunta de la pena multa y la pena de TBC con la pena de privación del derecho a conducir. Esta circunstancia, unida al incremento de sentencias condenatorias en aplicación del art.379 CP por conducción etílica, generó en su momento una situación de colapso en el sistema de medidas penales alternativas ${ }^{948}$. La reforma operada por la LO 5/2010 de 22 de junio, vino a mitigar esta situación al introducir la alternatividad en la pena a imponer en el art.379 CP, pudiéndose optar por la pena de prisión,

\footnotetext{
946 La pena de privación del derecho a conducir vehículos a motor y ciclomotores en los delitos que prevén su aplicación tiene la consideración de pena principal y siempre acompaña a diferentes penas bien sea la prisión, multa o TBC, acumulándose. Vid. VALEIJE ÁLVAREZ, Inmaculada," EI sistema de penas en los delitos contra la seguridad vial", en AA.VV. Prevención y control..., op.cit., p.477.

947 En relación con las vías a través de las cuales se puede imponer la localización permanente vid. TORRES ROSELL, Núria, "Trabajos en beneficio de la comunidad y localización permanente", en AA.VV. Comentario a la reforma penal de 2015, QUINTERO OLIVARES, Gonzalo (Dir.), Ed.Thomson Reuters- Aranzadi, Cizur Menor (Navarra), 2015, p.112 y BRANDARIZ GARCÍA, José Ángel, "Las penas de trabajos en beneficio de la comunidad y localización permanente (arts.40, 48 y 35)", en AA.VV. Comentarios a la Reforma del Código Penal de 2015, GONZÁLEZ CUSSAC, José.L (Dir.), MATALLíN EVANGELIO, Ángela/ GÓRRIZ ROYO, Elena (Coords.), Ed. Tirant Lo Blanch, Valencia, 2015, p.254.

948 En relación con este particular, vid. la Memoria FGE del año 2011, pp.1153-1154, apartado 7.8, relativo al Fiscal de Sala Delegado en materia de Vigilancia Penitenciaria.
} 
multa o pena de TBC junto a la pena de privación del derecho a conducir ${ }^{949}$. La reforma de 2010 ha permitido que los Juzgados y Tribunales puedan acordar la pena más adecuada a las circunstancias del hecho y a las circunstancias del penado ${ }^{950}$ aplicando, en todo caso, la pena de privación del derecho a conducir que será impuesta en todos los casos en los que se dicte condena al amparo del art. $379 \mathrm{CP}$.

En relación precisamente con el art.379 CP puede señalarse que este es el único artículo en el que aparece la expresión "en cualquier caso", a diferencia de los delitos tipificados en los arts. 142.1, 152.1, 380, 381, 382 bis y $383 \mathrm{CP}$ en los que también se prevé la aplicación de la pena de privación del derecho a conducir con carácter imperativo, si bien en tales casos el legislador expresa la acumulación de penas meramente mediante la conjunción copulativa " $y$ ", con lo que la pena de privación del derecho a conducir también se aplica siempre en todo caso ${ }^{951}$.

\subsubsection{Concurrencia con la pena de prisión}

En aquellos supuestos en los que al sujeto se le priva de libertad en aplicación de la pena de prisión, de entrada, parece que no deba tener sentido imponer de forma conjunta la pena de privación del derecho a conducir ya que al estar recluido no podrá ejercer dicho derecho. Sin embargo, en algunos casos, bien sea porque el penado cumple en medio abierto o bien porque se le suspende la pena de prisión, sí existe la posibilidad que pueda conducir un vehículo a motor o ciclomotor. Por ello, consideramos adecuado analizar la concurrencia de la pena de privación del derecho a conducir con la pena de prisión detectando los problemas que se plantean en su ejecución, además de realizar propuestas relacionadas con la imposición conjunta de ambas penas.

949 Referente al actual sistema de alternatividad de penas en el art.379 CP vid. MARTíNEZ ZAPATER, Luis Fernando, "Los delitos contra la seguridad vial, arts.379, 381, 384, 385 bis y 385 ter", en AA.VV. La reforma Penal de 2010: Análisis y comentarios, QUINTERO OLIVARES, Gonzalo (Dir.), Thomson Reuters- Aranzadi, Cizur Menor (Navarra), 2010, p.320, y MONTANER FERNÁNDEZ, Raquel "Delitos contra la seguridad vial", en AA.VV. El nuevo Código Penal: Comentarios a la Reforma, SILVA SÁNCHEZ, Jesús-María (Dir.), PASTOR MUÑOZ, Nuria (Coord.), Ed. La Ley, Las Rozas (Madrid), 2012, p.578.

950 Vid. VALLESPÍN PÉREZ, David, Aspectos procesales..., op.cit., p. 19.

951 En relación con la naturaleza acumulativa de la pena de privación del derecho a conducir, vid. GANZENMÜLLER ROIG, Carlos/ DE LAMO RUBIO, Jaime/ ROBLEDO VILLAR, Antonio, ESCUDERO MORATALLA, José Francisco y FRIGOLA VALLINA, Joaquín; Delitos..., op.cit., pp.156-157. 


\section{a) Marco normativo y ámbito de aplicación.}

Los delitos en los que concurre la pena de prisión con la pena de privación del derecho a conducir, son los delitos contra la vida e integridad física y psíquica de las personas, así como de los delitos contra la seguridad vial. Nos referiremos en primer lugar a los tipos delictivos relacionados con la vida e integridad física y psíquica de las personas, cuando las acciones se realizan con un vehículo a motor o ciclomotor. El art.142.1 CP, tipifica el delito de homicidio por imprudencia grave cometido con vehículo a motor o ciclomotor y conlleva una pena de prisión de uno a cuatro años, así como una pena de privación del derecho a conducir de uno a seis años. La imposición conjunta de ambas penas en el tipo del art.142.1 CP tiene como característica que las dos son principales y no existe la opción de una pena alternativa a la pena de prisión de forma originaria. En relación con este tipo delictivo en el año 2013 se impusieron 196 sentencias condenatorias, habiéndose producido el efectivo ingreso en prisión de al menos 98 de estos conductores a los que también se les impuso la preceptiva pena de privación del derecho a conducir $^{952}$. De modo similar, en 2014 fueron 191 sentencias condenatorias, si bien no se dispone de información al respecto relativa a los años siguientes puesto que no se especifica si el homicidio imprudente fue cometido mediante vehículo a motor o ciclomotor. Sin embargo, desde el mes de mayo de 2019 se ha iniciado por parte del Ministerio del Interior un registro semanal de las personas condenadas que cumplen pena de prisión por el delito de homicidio imprudente cometido con vehículo a motor y en fecha 31 de diciembre de 2019, eran 26 las personas que se encontraban cumpliendo pena de prisión en cárceles dependientes de la Administración General del Estado ${ }^{953}$.

En el ámbito del art. 142 tenemos que hacer referencia al art. 142 bis CP, introducido mediante la LO 2/2019 de 1 de marzo de reforma del Código Penal, en el que se establece la posibilidad de imponer la pena superior en un grado o incluso en dos grados si concurren determinadas circunstancias, lo que afectará a las dos penas que se imponen de forma conjunta y acumulativa en el delito del art.142.1 $\mathrm{CP}$ : la pena de prisión y la privación del derecho a conducir de modo que esta última puede alcanzar los trece años y medio de duración. Cabe destacar que la pena de privación del derecho a conducir se prevé en el homicidio imprudente

\footnotetext{
952 Vid. la estadística en: www.fiscal.es, nota de prensa de 01/08/2014 del Fiscal de Sala Coordinador de Seguridad Vial.
} 
cometido con vehículo a motor o ciclomotor, pero no en el homicidio doloso cometido también con vehículo a motor o ciclomotor, en cuyo caso únicamente se puede imponer la pena de prisión ${ }^{954}$.

El otro tipo delictivo relativo a la vida e integridad física y psíquica de las personas en el que concurre la pena de prisión con la pena de privación del derecho a conducir es el del art.152.1 CP, que regula las lesiones por imprudencia grave causadas con vehículo a motor o ciclomotor. Se establece una pena de prisión de tres meses a tres años en función de la gravedad de las lesiones y una pena de privación del derecho a conducir de uno a cuatro años ${ }^{955}$. A diferencia de lo que sucede en el art.142.1 CP, en la pena de prisión del art.152.1.1 CP sí existe opción alternativa, ya que se puede imponer la pena de prisión o alternativamente la pena de multa junto con la pena de privación del derecho a conducir y ambas son penas principales. Es importante tener en cuenta que si la calificación de los hechos fuera la de un delito de lesiones dolosas cometidas con vehículo a motor o ciclomotor podría plantearse la condena por la vía del art. $148.1 \mathrm{CP}$, por considerar el vehículo como instrumento peligroso pero en tal caso se establece únicamente la pena de prisión, pero no la pena de privación del derecho a conducir ${ }^{956}$, en términos similares a los que hemos observado en el homicidio doloso cometido utilizando un vehículo a motor o ciclomotor.

Tras revisar los delitos contra la vida y la integridad de las personas, nos referiremos en segundo lugar a, los delitos contra la seguridad vial que contemplan una pena de prisión junto a la pena de privación del derecho a conducir. Se trata de los de los arts. 379, 380, 381, 382, 382 bis y 383 CP. En el art. 379 CP si se impone

953 Vid. la estadística en el informe "Seguridad Vial y su incidencia en el ámbito penitenciario", elaborado por el Ministerio del Interior, pp.9-10.

954 Vid. STS, núm. 427/2007, Sala Segunda, de 8 de mayo de 2007, ponente Excmo. Sr. Luis Román Puerta. (TOL1.079.766); STS, núm. 224/2013 Sala Segunda, de 1 de marzo de 2013, ponente Excmo. Sr. Francisco Monterde Ferrer (TOL3.408.174), en la que se ratifica la condena por tentativa de homicidio cometida con un vehículo por un taxista, imponiéndose pena de prisión, pero no pena de privación del derecho a conducir; STS, núm. 717/2014, Sala Segunda, de 29 de enero de 2015, ponente Excmo. Sr. Andrés Martínez Arrieta. (TOL4.776.636); STSJ de la Comunidad Valenciana, núm. 20/2017, Sala de lo Civil y Penal, Sección 1ạ, de 28 de junio de 2017, Ilmo. Sr. José Francisco Ceres Montes (TOL6.563.841), relativa a un caso de asesinato cometido con vehículo a motor y SAP de Tarragona, núm. 543/2018, Sección 2ª , de 27 de noviembre de 2018, ponente IImo.Sr. Antonio Fernández Mata (TOL7.014.255).

955 Vid. TAMARIT SUMALLA, Josep $\mathrm{M}^{\mathrm{a}}$, "De las lesiones", en AA.VV. Comentarios a la Parte Especial del Derecho Penal, QUINTERO OLIVARES, Gonzalo (Dir.), MORALES PRATS, Fermín (Coord.), Ed. Thomson-Aranzadi, Cizur Menor (Navarra), 2011, pp.121-123.

956 Vid. STS, núm. 423/2012 Sala Segunda, de 22 de mayo de 2012, ponente Excmo. Sr. Alberto Gumersindo Jorge Barreiro (TOL2.557.838), en la que se impone la pena de prisión de tres años, pero no se impone la pena de privación del derecho a conducir al no existir previsión legal al efecto. 
la pena de prisión con la privación del derecho a conducir será por mor de haber elegido el juzgador aquélla entre la pena de multa y la pena de TBC. La reforma operada por la LO 5/2010 de 22 de junio estableció un régimen de alternatividad en el art.379 al introducir la conjunción "o" entre las penas de prisión, multa o TBC, por lo que la posibilidad de aplicar la pena de prisión con la pena de privación del derecho a conducir puede haberse reducido a efectos prácticos. El régimen de alternatividad del art.379 CP introducido en 2010 ha podido generar determinadas consecuencias, siendo una de ellas el incremento de las penas de multa en su imposición conjunta con la pena de privación del derecho a conducir ${ }^{957}$ y el detrimento, correlativo, de las penas de prisión. En este sentido, la reforma operada al art.379 CP contribuyó al descenso en la población penitenciaria958 que se constató en el año 2011, y al que hizo referencia VALEIJE ÁLVAREZ ${ }^{959}$. En términos similares GÓMEZ PAVÓN ${ }^{960}$ ha manifestado que con la actual penalidad del art.379 CP se ha favorecido al penado, ya que por parte del Juzgado se tiene mayor discrecionalidad para evitar imponer la pena de prisión, al tener ahora tres opciones penales alternativas, lo que podrá favorecer que la pena de prisión se aplique con criterios restrictivos. Además, la duración de la pena de prisión en el tipo del art.379 CP es muy corta, ya que alcanza desde los tres a los seis meses, lo que puede poner en entredicho su eficacia preventiva ${ }^{961}$.

\footnotetext{
957 En este sentido, la reforma sigue la idea ya apuntada por TAMARIT SUMALLA, Josep, "La prohibición de conducir y otras sanciones penales relacionadas con los vehículos", en AA.VV. Las sanciones..., op.cit., p. 326. En relación al incremento de la pena de multa, vid. Memoria de la FGE, año 2014, p. 432, destacando que en el año 2013 se impusieron 36.000 condenas con pena de multa en delitos contra la seguridad vial, en el año 2014 el número fue de 54.000, vid. Memoria de la FGE año 2015, p.483 y en el año 2015 y 2016, fueron alrededor de 50.000, vid. Memoria de la FGE año 2016, p.527 y del año 2017 p.583. En el año 2017 el número fue de alrededor de 53.000, vid. Memoria de la FGE año 2018 p.665 y en el año 2018 de aproximadamente 60.000, vid. Memoria de la FGE año 2019 p. 876, destacándose la triple alternatividad de los artículos 379 y 384 CP. Sin embargo, en el año 2019 se ha producido un descenso en la imposición de la pena de multa, siendo el número aproximado de 55.000 penas de multa. Vid. Memoria de la FGE año 2020 p. 913.
}

958 Respecto al descenso de la población penitenciaria, vid. la nota de prensa de la Fiscalía de Seguridad Vial de septiembre de 2012 en:

https://www.fiscal.es/documents/20142/159534/DOSSIER DE PRENSA FSV SEPTIEMBRE 2012. pdf/078d3bde-f1ae-3a0b-0f29-751b5542894d (último acceso: 05/11/2020).

959 Relativo a la pena privativa de libertad en los delitos contra la seguridad vial, vid. VALEIJE ÁLVAREZ, Inmaculada," El sistema de penas en los delitos contra la seguridad vial", en AA.VV. Prevención y control..., op.cit., p.461.

960 En torno a la reforma de la LO 5/2010 en el art.379 y su influencia en la pena de prisión, vid. GÓMEZ PAVÓN, Pilar, "La reforma de los delitos contra la seguridad del tráfico (arts.379, 381, 385 bis y 385 ter)", en AA.VV. Comentarios a la Reforma Penal de 2010, ÁLVAREZ GARCíA, Francisco.J/ GONZÁLEZ CUSSAC, José.L (Dirs.), Ed. Tirant lo Blanch, Valencia, 2010, p.431.

961 En relación con los escasos efectos positivos respecto del penado de las penas privativas de libertad de corta duración, vid. GUTIÉRREZ RODRÍGUEZ, María, "Excesos de velocidad e intoxicaciones punibles, en AA.VV. Protección Penal..., op.cit., p.125. 
La modificación operada al art.379 CP en lo relativo a las penas aplicables está en consonancia con lo que proponía la Instrucción 3/2006 de la FGE que sugería una menor aplicación de la pena de prisión en los delitos relacionados con la circulación de vehículos a motor ${ }^{962}$. El criterio que ha seguido la Fiscalía de Seguridad Vial es el peticionar la imposición de la pena de prisión únicamente en aquellos casos de gravedad, siendo calificada incluso como el "último recurso" dentro del catálogo de penas que se pueden instar963. En la misma línea, la Instrucción no 1/2011 de la Fiscalía Provincial de Madrid"664 "sobre algunas cuestiones en materia de seguridad vial', establece que la pena de prisión ha de solicitarse en los supuestos de mayor gravedad. Igualmente podemos citar el criterio seguido por la Fiscalía de la Comunidad Foral de Navarra en relación con la posibilidad de optar por la pena de prisión en detrimento de las alternativas en el art.379 CP, al establecer que se ha de imponer en los supuestos de reincidencia, señalando como parámetro el haber cometido el delito más de dos veces en los últimos tres años ${ }^{965}$. En la misma línea TAMARIT SUMALLA ${ }^{966}$ es partidario que, en los delitos relacionados con la seguridad vial, así como en aquellos delitos contra la vida e integridad física y psíquica de las personas, la pena de prisión únicamente sea aplicada en aquellos casos que denoten una mayor gravedad o un mayor desprecio hacia la normativa de tráfico. También en relación a la posibilidad de aplicar bien la prisión, la pena de TBC o pena de multa, con la pena de privación del derecho a conducir me parece interesante lo expresado por MORILLAS CUEVA, que mantiene que la pena de prisión debe estar reservada para los casos de mayor gravedad o reincidencia delictiva $^{967}$. En la misma línea doctrinal, también es destacable el posicionamiento

962 Vid. la Instrucción de 3 de junio de 2006, sobre criterios de actuación del Ministerio Fiscal para una efectiva persecución de los ilícitos penales relacionados con la circulación de vehículos a motor, p.18.

963 Referente a la utilización de la pena de prisión como último recurso, vid. la nota de prensa de 26/09/2012 de la Fiscalía de Seguridad Vial, disponible en:

https://www.fiscal.es/documents/20142/159534/DOSSIER DE PRENSA FSV SEPTIEMBRE 2012. pdf/078d3bde-f1ae-3a0b-0f29-751b5542894d (último acceso: 05/11/2020).

964 Vid. la Instrucción no 1/2011 de la Fiscalía Provincial de Madrid, "Sobre algunas cuestiones en material de seguridad vial", p.6.

Recurso electrónico disponible en: http://www.apifiscales.es/secciones-territoriales/madrid/ (último acceso: 05/11/2020).

965 Referente al criterio de la aplicación de la pena de prisión, vid. la Memoria del año 2013 (ejercicio 2012) de la Fiscalía de la Comunidad Foral de Navarra, p.100.

966 Vid. TAMARIT SUMALLA, Josep/ LUQUE REINA, Ma Eulàlia, Automóviles, delitos y penas..., op.cit., p.163, y TAMARIT SUMALLA, Josep, "La prohibición de conducir y otras sanciones penales relacionadas con los vehículos", en AA.VV. Las sanciones..., op.cit., p.326.

967 En relación con la pena de prisión y el hecho que debe estar reservada para los casos más graves, MORILLAS CUEVA ha manifestado que esta pena ha de ser "la ultima ratio de la ultima ratio 
de MIRÓ LLINARES/BAUTISTA ORTUÑO en el sentido de ser favorables a la menor utilización de la pena privativa de libertad en los delitos contra la seguridad vial y acordar otras sanciones alternativas ${ }^{968}$.

Asimismo, existen otros tres tipos delictivos que aplican la pena de prisión como pena principal con la pena de privación del derecho a conducir, y en los que no existe opción de una pena alternativa a la privativa de libertad. El primero es el art.380 CP que regula la conducción temeraria y que prevé una pena de prisión de seis meses a dos años y privación del derecho a conducir de uno hasta seis años $^{969}$. El segundo tipo delictivo es el delito del art. 382 bis CP, que entró en vigor con la LO 2/2019 de 1 de marzo, denominado como delito de abandono del lugar del accidente, y en el que se prevén penas de prisión de tres meses a cuatro años y de privación del derecho a conducir de seis meses a cuatro años, ello dependiendo si los hechos que originan el accidente son fortuitos o imprudentes. El tercero es el art. $383 \mathrm{CP}$ que tipifica como delito las conductas de negativa a someterse a las pruebas legalmente establecidas para control de alcohol o drogas. En este caso, la pena de prisión será de seis meses a un año y la privación del derecho a conducir de uno hasta cuatro años. Tras la reforma operada por la LO 15/2007 de 30 de noviembre se produjo un incremento punitivo en el art. 383, siendo las penas más elevadas que las previstas en el propio art.379 $\mathrm{CP}^{970}$, lo que merece ser objeto de crítica.

Por último, el art. 381 CP obligatoriamente implica una triple condena: prisión, multa y pena de privación del derecho a conducir. En relación con el artículo 381 hemos de señalar que tras la reforma operada por la LO 2/2019 de 1 de marzo de reforma del Código Penal, cuando se ocasione además un resultado lesivo se impondrá la pena de privación del derecho a conducir en su mitad superior, lo que deviene en mi

del Derecho Penal". Vid. " La función de la pena en el Estado Social y Democrático de Derecho", Revista Internacional de Doctrina y Jurisprudencia, Vol.4, Diciembre de 2013, pp.20-21.

Recurso electrónico disponible en:

http://www.ual.es/revistas/RevistalnternacionaldeDoctrinayJurisprudencia/pdfs/201312/articulos discurso-investidura.pdf (último acceso: 05/11/2020).

968 Vid. BAUTISTA ORTUÑO, Rebeca/ MIRÓ LLINARES, Fernando, “¿Por qué algunos siempre incumplen?...", op.cit., p.32.

969 Acerca de la penalidad del art.380 CP, vid. TOLEDO CASTILLO, Francisco/ CAMPÓN DOMÍNGUEZ, José Andrés/ MARTíN UCLÉS, Francisco, Manual..., op.cit., pp.316-317.

970 En torno a dicha circunstancia vid. TRABADO ÁLVAREZ, Concepción, "Non bis in ídem por la condena contra la seguridad del tráfico, alcoholemia y de negativa a someterse a las pruebas de alcoholemia". Diario La Ley, oㅜ 7681, 26 de julio de 2011, año XXXII, Ref.D-315. 
opinión en la máxima expresión punitiva en los delitos relacionados con la seguridad vial $^{971}$.

Tras haber determinado el ámbito de aplicación conjunta de la pena de prisión y la pena de privación del derecho a conducir, en los casos que exista una penalidad alternativa a la pena de prisión la petición de condena a esta pena ha de realizarse de forma expresa, ya que de lo contrario el Juzgador no podrá aplicarla. EI TC así lo ha determinado en los casos que existe la posibilidad alternativa de imponer la pena de prisión u otras penas como en el art.379.2 $\mathrm{CP}^{972}$. En los delitos que conllevan la pena de privación del derecho a conducir y que se puede imponer la pena de prisión, esta no debería constituir la primera opción para el juzgador, sino que debería optarse, siempre que ello sea posible, por otro tipo de medidas penales alternativas a la prisión habida cuenta de la frecuencia con la que se acude a la pena de prisión en nuestro sistema penal ${ }^{973}$.

Una particularidad de los arts.379 y 383 CP es que en ambos puede aplicarse la cláusula del art.385 ter $\mathrm{CP}^{974}$, que permite rebajar en un grado la pena de prisión atendiendo a las circunstancias periféricas del delito cometido, mientras que la pena de privación del derecho a conducir no se verá afectada por el art.385 ter. Cuando se imponga conjuntamente la pena de prisión con la pena de privación del derecho a conducir y proceda aplicar el art.385 ter CP, la doctrina y la jurisprudencia han determinado los criterios para que prospere la reducción en un grado de la pena impuesta. Desde la doctrina ${ }^{975}$ se ha señalado que en los supuestos donde no ha existido una situación de riesgo concreto y el peligro para la seguridad del tráfico haya sido mínimo, se podrá aplicar los efectos del art.385 ter CP. En diversas

\footnotetext{
971 En relación con la gravedad de las penas a imponer en el delito del art.381 CP vid. VALEIJE ÁLVAREZ, Inmaculada,"El sistema de penas en los delitos contra la seguridad vial", en AA.VV. Prevención y control..., op.cit., p.462.

972 Vid. STC, núm. 155/2009, dictada por el Pleno del Tribunal Constitucional, de 25 de junio de 2009, ponente Excmo. Sr. Vicente Conde Martín de Hijas (TOL1.568.033).

973 En este sentido me parece acertada la posición crítica con la utilización de la pena de prisión en los delitos contra la seguridad vial que ha mostrado CARBONELL MATEU, Juan Carlos, "La Ley Orgánica de Reforma del Código Penal en materia de seguridad vial: un comentario de urgencia", Reforma..., op.cit., p.181 También podemos señalar la referencia del Fiscal delegado de Vigilancia Penitenciaria en la Memoria de la FGE del año 2012, pp.1001-1002.

974 En los delitos previstos en los artículos 379, 383, 384 y 385, el Juez o Tribunal, razonándolo en sentencia, podrá rebajar en un grado la pena de prisión en atención a la menor entidad del riesgo causado y a las demás circunstancias del hecho.

975 Vid. GÓMEZ PAVÓN, Pilar, "La reforma de los delitos contra la seguridad del tráfico (arts.379, 381, 385 bis y 385 ter)", en AA.VV. Comentarios..., op.cit., pp.436-438; VALEIJE ÁLVAREZ, Inmaculada,"El sistema de penas en los delitos contra la seguridad vial", en AA.VV. Prevención y control..., op.cit., p.463 y MONTANER FERNÁNDEZ, Raquel, "Delitos..." op.cit., p.581.
} 
resoluciones jurisprudenciales se han utilizado como parámetros para la aplicación del art. 385 ter CP, la inexistencia de antecedentes penales, y un resultado positivo en la prueba de alcoholemia en un control rutinario ${ }^{976}$. Como criterios denegatorios podemos destacar: una tasa de alcohol alta ${ }^{977}$, la reincidencia y los síntomas evidentes de intoxicación etílica ${ }^{978}$, una conducción irregular o anómala ${ }^{979}$, darse a la fuga en un vehículo ocupado por terceros ${ }^{980}$ o la existencia de condenas anteriores en las que se le impusieron la pena de multa y la pena de TBC ${ }^{981}$, ha significado la inaplicación del art.385 ter atendiendo al nulo efecto disuasorio de las penas anteriores.

La Fiscalía no ha emitido un criterio claro al respecto, y así, la Fiscalía Provincial de Madrid consideró que se podría aplicar en los supuestos que se impute por el art.383 cuando el acusado no presente sintomatología clara de estar embriagado ${ }^{982}$. En mi opinión el uso del art.385 ter, no puede circunscribirse únicamente a dicho supuesto, sino que podrá ser aplicado de manera mucho más amplia tal como se analizará en el capítulo de propuestas alternativas. En este sentido considero que tras la reforma operada por la LO 2/2019 de 1 de marzo, se debería haber modificado el artículo 385 ter CP, e incluir el delito de abandono del lugar del accidente del art. 382 bis entre los que se podía aplicar, ya que éste sólo prevé la pena de prisión junto a la pena de privación del derecho a conducir como pena principal, lo que en determinados casos puede suponer el efectivo ingreso en prisión de la persona condenada.

\footnotetext{
976 Vid. Sentencia del Juzgado de lo Penal no 1 de Córdoba, núm.76/2011, Sección 2ª , de 24/2/2011, Magistrada: Ilma.Sra. Ascensión Miranda Castañón (TOL2.057.442).

977 Vid. SAP de La Coruña, núm.484/2011, Sección 2a ${ }^{a}$, de 30 de diciembre de 2011, ponente llmo.Sr. Agustín Jesús Pérez-Cruz Martín (TOL2.406.204); SAP de Barcelona, núm. 778/2013, Sección 5ª̆, de 30 de septiembre de 2013, ponente Ilma. Sra. Elena Guindulain Oliveras (TOL4.016.566).
}

978 Vid. SAP de Barcelona, núm. 247/2011, Sección 22ª , de 13 de abril de 2011, ponente IImo. Sr. Francisco Abellanet Guillot (TOL2.129.283); SAP de Madrid, núm.158/2011, Sección 32āe de 26 de abril de 2011, ponente Ilma. Sra. Josefina Molina Marín (TOL2.152.409) y SAP de Albacete, núm. 384/2017, Sección 2ª , de 28 de septiembre de 2017, ponente IImo. Sr. Manuel Mateos Rodríguez (TOL6.420.927).

979 Vid. SAP de La Coruña, núm.132/2017 Sección 2a , de 17 de marzo de 2017, ponente Ilma. Sra. Ma del Carmen Taboada Caseiro. (TOL6.100.564).

980 Vid. SAP de Barcelona, núm. 697/2015 Sección 6a , de 27 de julio de 2015, ponente IImo. Sr. Pablo Llarena Conde. (TOL5.579.261).

981 Vid. SAP de La Coruña, núm. 351/2013 Sección 2ª , de 28 de mayo de 2013, ponente IIma. Sra.Mª Dolores Fernández Galiño. (TOL3.874.055).

982 Vid. la Instrucción $n^{\circ} 1 / 2011$, "Sobre algunas cuestiones en material de seguridad vial" de la Audiencia Provincial de Madrid, pp.6-7.

Recurso electrónico disponible en: http://www.apifiscales.es/secciones-territoriales/madrid/ (último acceso: 05/11/2020). 


\section{b) Cuestiones de ejecución}

Los aspectos que analizamos en este epígrafe están relacionados con las cuestiones de ejecución cuando se imponen de forma conjunta la pena de prisión y la pena de privación del derecho a conducir. Hacemos referencia a cómo han de ejecutarse las sentencias en las que se aplican de forma conjunta una pena privativa de libertad y la pena de privación del derecho a conducir. También estudiamos la posibilidad que la pena de prisión, cuando concurre con la pena de privación del derecho a conducir, no se cumpla de forma efectiva, bien por la suspensión de aquella o bien por la sustitución cuando la pena de prisión tiene una duración inferior a tres meses. A continuación, se realizan propuestas de mejora que podrían implementarse en los supuestos en los que se aplican de forma acumulativa ambas penas.

En primer lugar, la revisión del número de penados que están en prisión por delitos relacionados contra la seguridad vial, nos puede dar una orientación acerca de la aplicación conjunta de la pena de prisión y la pena de privación del derecho a conducir en estos delitos ${ }^{983}$. Antes de la entrada en vigor de la reforma del CP operada por la LO 5/2010 de 22 de junio, la Memoria de la FGE del año 2009 constató que en enero de 2009 eran 395 los internos que estaban cumpliendo pena efectiva de prisión exclusivamente por un delito contra la seguridad vial, siendo casi un $90 \%$ condenados por conducción temeraria con producción de muerte o lesiones graves ${ }^{984}$. En todos estos supuestos se aplicó de forma acumulativa la pena de prisión con la pena de privación del derecho a conducir, ya que, en todos los tipos de conducción de temeraria, homicidio y lesiones aparecen de forma conjunta ambas penas. En los años 2010-2011 se incrementó el número de penados en prisión por los delitos de los arts. 379, 380 y $383 \mathrm{CP}$, ya que en el mes de diciembre del año 2011 el número de internos en prisión se aproximaba a los 500 , y en todos los casos cometieron delitos en los que se aplica de forma conjunta

\footnotetext{
983 En relación con las cifras de penados que cumplen pena de prisión y además han sido condenados por delitos en los que se prevé la aplicación de la pena de privación del derecho a conducir, existen unos datos que no se han podido obtener. Son los de aquellos penados que cumplen pena de prisión por los delitos de los arts.142 y 152 CP, delitos de homicidio y lesiones por imprudencia causadas con vehículo a motor y ciclomotor.
}

984 Vid. Memoria de la FGE del año 2009, p.824. 
la pena de prisión y la pena de privación del derecho a conducir ${ }^{985}$. Los datos a diciembre de 2012, nuevamente constataron un aumento de los penados que cumplían pena efectiva de prisión por los delitos relacionados contra la seguridad vial, siendo 613, en los que se puede imponer de forma conjunta la pena de privación del derecho a conducir con la pena de prisión ${ }^{986}$. Para finalizar señalaremos que los últimos datos de 2014, indican que el número de internos en prisión cumpliendo pena efectiva por delitos relacionados con la seguridad vial en los que se aplica la pena estudiada asciende a $495^{987}$, lo que supone un descenso respecto al año 2012, acercándonos de nuevo a las cifras del año 2011. En el mes de julio de 2020 se publicó por parte del Ministerio del Interior un informe que determinó, que a fecha 31 de julio de 2019, eran 498 las personas que cumplían pena de prisión como delito principal, por un delito contra la seguridad vial en el que se impone la pena de privación del derecho a conducir ${ }^{988}$.

En segundo lugar, hemos de señalar que existe la posibilidad que determinados penados a los que se les impone la pena de prisión junto con la pena de privación del derecho a conducir tengan que cumplir aquella de forma efectiva. En estos casos, el cumplimiento de las dos penas principales se ha de realizar de forma simultánea sin esperar a que el penado obtenga la libertad definitiva para iniciar el cumplimiento de la privación del derecho a conducir ${ }^{989}$. En este sentido, como ha

985 Datos obtenidos de la nota de prensa de la Fiscalía de Seguridad Vial de 26 de septiembre de 2012, y en cuyo número se ha computado los delitos de los arts.379, 380, y 383. Recurso electrónico disponible en:

https://www.fiscal.es/documents/20142/159534/DOSSIER DE PRENSA FSV SEPTIEMBRE 2012. pdf/078d3bde-f1ae-3a0b-0f29-751b5542894d (último acceso: 05/11/2020).

986 Vid. la Memoria de la FGE del año 2013, pp.403-404, pudiendo determinar que el número de penados que cumplen pena de prisión es de 613.

987 Vid. al respecto la nota de prensa del Fiscal de Sala Coordinador de Seguridad Vial de 01/08/2014, en la que se establece que a fecha 15/07/2014 los internos cumpliendo pena de prisión por delitos contra la seguridad vial en los que se prevé la aplicación de la pena de privación del derecho a conducir era de 495, para cuyo cálculo se ha computado los delitos de los arts.379, 380,381 , y 383. Vid. la nota de prensa del Fiscal de Seguridad vial en:

https://www.fiscal.es/documents/20142/159294/INFORME+DE+SEGURIDAD+VIAL.pdf/08a5c9bdbba4-be9b-ce4d-494dcb3fc2a8 (último acceso: 05/11/2020).

También puede consultarse la referencia en:

http://politica.elpais.com/politica/2014/07/31/actualidad/1406807928 917009.html (último acceso: 05/11/2020).

988 Vid. la estadística en el informe "Seguridad Vial y su incidencia en el ámbito penitenciario", elaborado por el Ministerio del Interior sobre cárceles dependientes de la Administración General del Estado, p.17.

989 Del mismo modo también se deberá cumplir de forma conjunta la medida de seguridad de internamiento en centro médico y la medida de seguridad de privación del derecho a conducir. Vid. 
señalado POZUELO PÉREZ990, existe la posibilidad que el penado a pena de prisión pueda obtener permisos bien ordinarios, bien extraordinarios, beneficios penitenciarios, cumplir la pena en medio abierto, etc., por lo que en dichos lapsos temporales sí podría hacer uso del derecho a conducir vehículos a motor o ciclomotores, por lo que en aras a un correcto cumplimiento de la pena de privación del derecho a conducir, estimo que la solución es el cumplimiento simultáneo de ambas.

En tercer lugar, en lo relativo a la aplicación acumulativa de la pena de prisión y la pena de privación del derecho a conducir es importante señalar que la duración prevista para la pena de prisión comporta que pueda no llegar a ejecutarse, lo que sucedería si se procediera a la suspensión de la ejecución de la pena de prisión establecida en el art.80 $\mathrm{CP}^{991}$ o bien su sustitución directa ex art.71.2 $\mathrm{CP}^{992}$, que tras la entrada en vigor de la LO 1/2015 de 30 de marzo de reforma del CP es la única posibilidad que existe de sustituir dicha pena privativa de libertad.

A) En primer lugar, en cuanto a la suspensión de la pena de prisión993 ésta es de concesión facultativa del Juez o Tribunal, que discrecionalmente y de forma motivada la concederá o denegará, siempre desde la perspectiva de la prevención general y especial, que en los delitos relacionados con la seguridad vial tienen importancia al ser numerosos los delincuentes primarios y ocasionales ${ }^{994}$.

En los supuestos de suspensión de la pena de prisión que ha sido impuesta con la pena de privación del derecho a conducir, dado que con el delito cometido se ha puesto en riesgo el tráfico viario, sería positivo para la reinserción del penado que

SAP de Cuenca, núm. 55/2005, Sección 1aㅡ, de 25 de mayo de 2005, ponente Ilmo. Sr. Ernesto Casado Delgado, (TOL666.276).

990 Vid. POZUELO PÉREZ, Laura., Las penas..., op.cit., pp.28-29.

991 Sobre la posibilidad de suspender o sustituir la pena de prisión en el art.379 CP, vid. GUTIÉRREZ RODRÍGUEZ, María, "Excesos de velocidad e intoxicaciones punibles", en AA.VV. Protección Penal..., op.cit., pp.125-126.

992 Art.71.2 CP: No obstante, cuando por aplicación de las reglas anteriores proceda imponer una pena de prisión inferior a tres meses, ésta será en todo caso sustituida por multa, trabajos en beneficio de la comunidad, o localización permanente, aunque la ley no prevea estas penas para el delito de que se trate, sustituyéndose cada día de prisión por dos cuotas de multa o por una jornada de trabajo o por un día de localización permanente.

993 Acerca de la suspensión de la ejecución de la pena de prisión, vid. la STC, núm. 110/2003, Sala Primera, de 16 de junio de 2003, ponente Excmo. Sr. Jorge Rodríguez-Zapata Pérez (TOL285.440).

994 En relación con la suspensión de la pena de prisión ha de señalarse que ésta es factible que se produzca en los delitos relacionados con la seguridad vial, al ser una tipología delictiva que, en general, no es de gravedad. En este sentido vid. VARONA GÓMEZ, Daniel, "La suspensión...", op.cit., p. 17. 
se impusiera como regla de conducta la realización de programas de educación vial (art.83 CP) y así potenciar los efectos de la prevención especial de la pena de prisión y de la pena de privación del derecho a conducir ${ }^{995}$. El programa formativo en materia de educación vial, además de evitar que el penado ingrese en prisión, tiene objetivos de carácter formativo y educativo. En dicho programa, el penado recibirá formación de diversa índole: jurídica, criminológica, psicosocial, sanitaria y educación vial, por lo que no se ceñirá a un único aspecto, sino que el penado obtendrá información de diversas disciplinas relacionadas con la seguridad vial996.

La aplicación conjunta de los programas formativos en seguridad vial como regla de conducta para suspender la pena de prisión con la pena de privación del derecho a conducir pueden fomentar unos fines de prevención especial positiva. A través del programa formativo se intenta que el conductor penado mejore su conducción, respetando las reglas viarias y así reducir el riesgo de reiteración delictiva997. En este sentido podemos destacar que la imposición de estos programas formativos de educación vial ha tenido una singular acogida en la Audiencia Provincial de Alicante ${ }^{998}$, especialmente con los delitos del art.379 CP. La posibilidad de acordar la regla de conducta del art.83.1.6 CP y obligar al penado a realizar programas formativos en materia de seguridad como requisito para suspender la pena privativa de libertad vial no es algo novedoso, ya que la FGE lo propuso en la Instrucción no 3/2006 como una herramienta del sistema penal para erradicar la siniestralidad vial999. En el mismo sentido se han expresado AGÜERO RAMÓN-LLIN y RODRÍGUEZ LEÓN ${ }^{1000}$, en torno a la posibilidad de imponer la realización de un

995 Al respecto vid. MAGRO SERVET, Vicente, "El Real Decreto 1849/2009, de 4 de diciembre y la introducción de la reeducación en la seguridad vial para cumplir la pena de trabajos en beneficio de la comunidad", Tráfico y Seguridad Vial, no 134, 2010, pp.5-14.

996 En relación con el contenido de los programas formativos, vid. HILTERMAN, Ed/ MANCHO FORA, Roger: Evaluación de Programas Formativos de Seguridad Vial y la reincidencia posterior. Generalitat de Catalunya, Departament de Justícia, Centre d’Estudis Jurídics i Formació Especialitzada. Barcelona.2012, p. 19.

997 Referente a la finalidad del programa formativo, vid. HILTERMAN, Ed/ TRASOVARES NAVARRETE, Mavi, ¿Cómo conducimos...? op.cit., p.16. También con relación a la reincidencia delictiva, vid. MAGRO SERVET, Vicente,"El Real Decreto 1849/2009...", op.cit., pp.5-14.

998 Vid. la referencia al contenido del Plan Formativo en Seguridad Vial relacionado con el art.83.1.5 CP realizada por GONZÁLEZ COLLANTES, Tàlia, "Seguridad vial..." op.cit., pp.217-218.

999 Vid. Instrucción de 3 de junio de 2006, sobre criterios de actuación del Ministerio Fiscal para una efectiva persecución de los ilícitos penales relacionados con la circulación de vehículos a motor, p.18.

1000 Vid. RODRíGUEZ LEÓN, Luis Carlos, Seguridad..., op.cit., p.49 y AGÜERO RAMÓN-LLíN, Elena, "Los delitos de conducción etílica y de conducción bajo la influencia de bebidas alcohólicas", La dogmática penal sobre el asfalto: un enfoque práctico de los delitos contra la seguridad vial, AGÜERO RAMÓN-LLIN, Elena/HIDALGO DE MORILLO JIMÉNEZ, Agustín/ LANZAROTE MARTíNEZ, Pablo/ PRIETO GONZÁLEZ, Helena María, Ed. Comares, Granada, 2012, p. 91. 
programa de formación vial como requisito para que se pueda suspender la ejecución de la pena de prisión, del mismo modo que sucede con aquellos penados que resultan condenados por delitos de violencia de género ${ }^{1001}$. Sin embargo, los resultados de la evaluación del programa formativo que se impone como regla de conducta, han resaltado que no ha servido para que los penados mejoren de manera ostensible su forma de conducir, por lo que este estudio es crítico con su utilización $^{1002}$. Además, los autores han recomendado que los programas formativos de educación vial se adapten al tipo de penado y no se faciliten los mismos contenidos a todos los penados ${ }^{1003}$, con el fin que se acomoden a cada perfil delictivo.

Nos planteamos a continuación si tiene sentido aplicar la regla de conducta relativa a la formación en seguridad vial del art. 83.1.6 en sede de suspensión cuando la propia aplicación de la pena de privación del derecho a conducir ya implica la obligación de realizar el curso de sensibilización y reeducación vial como establece el art.73 de la LTSV. Aunque es cierto que el contenido de ambos cursos puede ser muy similar, considero que sí es posible que se pueda realizar tanto el programa formativo asociado a la regla de conducta impuesta como el curso de sensibilización y reeducación vial, al tener ambos un fundamento diferente ${ }^{1004}$. La regla de conducta se impone en los supuestos que el penado solicita la suspensión de la pena de prisión para evitar su cumplimiento efectivo, mientras que el fundamento del curso de sensibilización y reeducación vial es diferente, al no tener su origen en el CP sino en la LTSV y además se ha de realizar tanto en los casos de condenas por delitos en los que se imponga pena de prisión, multa o pena de TBC.

Además de la participación en un programa formativo, el art. 83 CP contempla otras reglas de conducta vinculadas a la delincuencia vial y que, por lo tanto, pueden ser aplicadas junto a una pena de privación del derecho a conducir. Así, por ejemplo, podemos hacer referencia a la regla contenida en el art.83.1.7 CP, que establece la

\footnotetext{
1001 Acerca de la comparativa con los delitos de violencia de género, vid. TAMARIT SUMALLA, Josep/ LUQUE REINA, Mํㅡㄹ Eulàlia, Automóviles, delitos y penas..., op.cit., p.163.

1002 Vid. la referencia en HILTERMAN, Ed/ TRASOVARES NAVARRETE, Mavi, ¿Cómo conducimos después de un programa formativo de seguridad vial? Generalitat de Catalunya, Departament de Justícia, Centre d’Estudis Jurídics i Formació Especialitzada. Barcelona.2010, p.77.

1003 Vid. HILTERMAN, Ed/ MANCHO FORA, Roger, Evaluación de Programas... op.cit., p.113.

1004 En relación con la obligatoriedad de realizar los dos cursos de reeducación vial, vid. MAGRO SERVET, Vicente, Análisis...op.cit., p.81.
} 
participación en programas de deshabituación bien sea de alcohol o drogas tóxicas o sustancias estupefacientes ${ }^{1005}$.

Asimismo, hemos de destacar la regla de conducta del art. 83.1.8 $\mathrm{CP}^{1006}$ relativa al llamado sistema alcolock que es una novedad introducida por la LO 1/2015 de 30 de marzo de reforma del CP. El dispositivo, instalado en el vehículo del penado tiene como objetivo que éste realice un autocontrol de alcoholemia, y, para el caso de rebasar las tasas establecidas, impide el arranque del vehículo ${ }^{1007}$. En relación con la previsión del dispositivo alcolock, merecen la crítica cinco aspectos importantes, siendo el primero de ellos el hecho que en el texto penal no está resuelto cuando ha de iniciarse el cumplimiento de la regla de conducta, si a la vez que la pena de privación del derecho a conducir o una vez ésta se haya cumplido ${ }^{1008}$. En segundo lugar, considero que el redactado del art.83.1.8 CP es erróneo al hacer referencia a que se podrá imponer "cuando el sujeto haya sido condenado por un delito contra la seguridad vial". El mismo debería ceñirse únicamente a los penados por un delito contra la seguridad vial, en su modalidad del art.379.2 CP por conducción bien bajo la influencia del alcohol o bien por conducción con tasas superiores a 0’60 mg/l aire espirado. Carece de sentido que dicha regla de conducta se pueda imponer a un penado por un tipo delictivo como los del art. 380, 381, 382 bis o $383 \mathrm{CP}$, que siempre suponen la pena de privación del derecho a conducir y en los que puede dictarse una sentencia condenatoria que no esté relacionada con el consumo de alcohol. Sin embargo, en aquellos casos en los que se haya cometido alguno de los delitos antes citados, así como cuando se hayan cometido delitos de homicidio o lesiones por imprudencia de los arts. $142.1 \mathrm{y}$ 152.1 CP siendo la causa el consumo de alcohol sí estimo adecuada la imposición

1005 Art.83.1. 7ạ. CP: Participar en programas de deshabituación al consumo de alcohol, drogas tóxicas o sustancias estupefacientes, o de tratamiento de otros comportamientos adictivos.

1006 Art.83.1.8 ${ }^{\text {a }}$ CP: Prohibición de conducir vehículos de motor que no dispongan de dispositivos tecnológicos que condicionen su encendido o funcionamiento a la comprobación previa de las condiciones físicas del conductor, cuando el sujeto haya sido condenado por un delito contra la seguridad vial y la medida resulte necesaria para prevenir la posible comisión de nuevos delitos.

1007 Respecto al funcionamiento del alcolock, vid. Tráfico y Seguridad Vial, Dirección General de Tráfico, Septiembre-Octubre de 2008.

Recurso electrónico disponible en: http://www.dgt.es/revista/archivo/pdf/num192-2008-alcolock.pdf (último acceso: 05/11/2020).

1008 En relación con esta regla de conducta DAUNIS RODRíGUEZ se ha mostrado crítico con la misma ya que considera que es "innecesaria" y "excesiva" cuando el penado al que se le impone, a su vez ya ha cumplido la pena de privación del derecho a conducir. Vid. DAUNIS RODRÍGUEZ, Alberto., Ejecución de penas en España. La reinserción social en retirada, Ed. Comares, Granada, 2016, p.254. Los problemas de coordinación entre la regla de conducta y la pena de privación del derecho a conducir también han sido destacados por TRAPERO BARREALES, María A, El nuevo 
del alcolock puesto que existirá una vinculación entre el alcohol como causa del delito cometido y la finalidad que persigue el dispositivo alcolock ${ }^{1009}$. La tercera crítica es que esta regla de conducta puede resultar ineficaz y quedar vacía de contenido para prevenir futuros delitos dada la dificultad técnica para comprobar la identidad del sujeto que ha de soplar en el dispositivo alcolock y acreditar que realmente sea la persona a la que se le ha impuesto dicha regla ${ }^{1010}$. En cuarto lugar, habrá que determinar quién asume el coste económico de la instalación de dichos dispositivos en los vehículos, ya que puede ser bien el penado o bien la administración de justicia como sucede con los brazaletes electrónicos que se aplican mayoritariamente en los delitos de violencia de género ${ }^{1011}$. En último lugar, hemos de hacer referencia al "olvido" del legislador ya que en el redactado del art. 83.1.8 CP únicamente hace referencia a los vehículos a motor y sin embargo nada se indica respecto de los ciclomotores. Como dato estadístico podemos señalar que es una regla de conducta que tiene una escasa aplicación, ya que en el año 2018 se produjeron únicamente siete peticiones para llevar a cabo la ejecución del alcolock $^{1012}$, aunque sí que supone un incremento respecto el año anterior en el que fueron tres las peticiones ${ }^{1013}$.

Otro aspecto destacable de la pena de prisión, aunque estrictamente no se produce una aplicación acumulativa entre ésta y la pena de privación del derecho a conducir, es que aquella se puede imponer a los penados que cometan el delito previsto en el art.384 CP, esto es, aquellos que no posean el permiso o licencia. En estos casos, puede plantearse si cabe imponer como regla de conducta, en caso de suspenderse

modelo de suspensión de la ejecución de las penas privativas de libertad, Ed. Dykinson, Madrid, 2017, pp. 241-246.

1009 La finalidad de esta regla de conducta está dirigida a que el penado no pueda cometer un nuevo delito conduciendo un vehículo a motor o ciclomotor. En este sentido vid. VARONA GÓMEZ, Daniel, "Fundamentación y aplicación práctica de la suspensión de la pena de prisión"; en AA.VV. La ejecución de las penas, Cuadernos penales José María Lidón, número 15, Ed. Universidad de Deusto, Bilbao, 2019, p. 238.

1010 Acerca de la finalidad de reinserción social del "alcolock" en los penados, vid. el artículo de opinión de SANZ FERNÁNDEZ-VEGA, Mario, Tráfico y Seguridad Vial, Dirección General de Tráfico, Marzo/Abril de 2014.

Recurso electrónico disponible en: http://revista.dgt.es/es/opinion/articulos/2014/04ABRIL/04.01.Fiscal-reincidentes.shtm|\#.U6iUUdiKDIU (último acceso: 05/11/2020).

1011 El dispositivo tiene un coste de $3500 €$ y aproximadamente $1000 €$ anuales en concepto de mantenimiento. En relación con este particular y la problemática existente en Bélgica respecto el alcolock y su eficacia vid. http://www.diariosur.es/v/20130923/sociedad/bebes-arrancas20130923.html (último acceso: 05/11/2020).

1012 Vid. Memoria FGE del año 2019, pp.875-876. Sobre la escasa imposición de la reglas de conducta en los casos de suspensión de le ejecución de la pena de prisión vid. VARONA GÓMEZ, Daniel, "La suspensión...", op.cit., p. 25.

1013 Vid. Memoria FGE del año 2018, p. 664. 
la pena de prisión, que el penado deba obtener el permiso o licencia durante el plazo de suspensión ${ }^{1014}$. Esta opción hoy día no está prevista en el listado de reglas de conducta, aunque considero que podría tener cabida sin necesidad de una reforma del CP a través del art. 83.1. 9a , que genéricamente se refiere a los "demás deberes"1015, por lo que sí podría incluirse la obligación de obtener el permiso o licencia. Para que esta propuesta pudiera ser viable deberían solucionarse dos cuestiones: quién debe abonar el coste económico de obtener el permiso o licencia y qué sucede si el penado a pesar de presentarse a las pruebas correspondientes no obtiene el permiso al suspender las pruebas establecidas. Con relación a la primera cuestión, el tema económico no debería ser un obstáculo para poder acceder a la obtención del permiso y podrían establecerse mecanismos para facilitar el pago fraccionado para la obtención del permiso ${ }^{1016}$. Ello, en modo alguno supondría que aquellos que han delinquido estén en mejores condiciones para obtener el permiso que quienes que no han cometido delito alguno, ya que precisamente a través de la regla de conducta de obligación de obtener el permiso además de favorecer que los penados conozcan la normativa viaria se podría evitar que incurrieran en un nuevo delito de conducción sin permiso o licencia. En la segunda dificultad descrita, la no superación de los exámenes no debería ser constitutiva de la revocación de la suspensión e ingreso en prisión, siempre estableciendo unos plazos para una nueva convocatoria ya que habrá de valorarse el esfuerzo del penado por obtener la autorización que le permita conducir. En estos supuestos, sí puede inferirse que el penado, para eludir un cumplimiento efectivo de la pena de prisión, procederá a obtener el permiso o licencia que le habilite para poder conducir, e intentará esforzarse en el estudio teórico-práctico de la normativa de seguridad vial que le evite el ingreso en un centro penitenciario.

\footnotetext{
1014 Vid. MONTERO HERNANZ, Tomás, "La reforma penal en materia de seguridad vial desde una óptica penitenciaria", Tráfico y Seguridad Vial, № 143, 2010, pp.15-26.

1015 Art.83.1.9. a CP: Cumplir los demás deberes que el juez o tribunal estime convenientes para la rehabilitación social del penado, previa conformidad de éste, siempre que no atenten contra su dignidad como persona.

1016 El problema económico fue uno de los que se han detectaron en la "Campaña de universalización de educación vial en los Centros Penitenciarios", a través de cual se permite la obtención del permiso de conducir a los penados internos que cumplen pena de prisión en establecimientos penitenciarios. Recurso electrónico disponible en: http://www.dgt.es/es/prensa/notas-de-prensa/2019/IIPP-y-la-DGT-nueva-campana-formativa-deseguridad-vial-en-carceles.shtml (último acceso: 05/11/2020). En el mismo sentido se ha expresado MONTERO HERNANZ, Tomás, "Reflexiones sobre la política criminal en España (A propósito de la completa entrada en vigor de la LO 15/2007)", Diario La Ley, no 7065, 26 de noviembre de 2008, año XXIX, Ref.D-340, quien propone una política de becas y ayudas para que personas sin recursos que han resultado condenadas pueden obtener el permiso o licencia para conducir.
} 
B) En relación a la posibilidad de sustitución de la pena de prisión cuando esta se impone conjuntamente con la pena de privación del derecho a conducir, hemos de indicar que ello sucederá únicamente cuando la pena de prisión es inferior a tres meses de duración, en cuyo caso se deberá aplicar de forma obligatoria el art.71.2 CP y sustituir aquella por la pena de multa, pena de TBC o pena de localización permanente.

C) En último lugar, para mejorar exclusivamente la aplicación conjunta de la pena de prisión con la pena de privación del derecho a conducir sería partidario que se acordara la obligación de acudir a los citados programas formativos en materia de seguridad vial como requisito de suspensión de la pena de prisión ${ }^{1017}$. De lo contrario, puede transmitirse a la sociedad la idea que la pena de prisión en los supuestos que se impone con la privación del derecho a conducir, tiene nulos efectos intimidatorios, al no cumplirse de forma efectiva, por lo que los fines de prevención general y especial pueden quedar diluidos.

Tras el análisis de la imposición conjunta de la pena de privación del derecho a conducir con la pena de prisión, estimo acertada la tendencia seguida en los últimos años por el legislador de introducir en determinados tipos penales la fórmula de la alternatividad y así reducir el recurso a la pena de prisión. Esta pena debe reservarse para aquellos supuestos de gravedad, reincidencia delictiva o desprecio a la normativa de tráfico, ya que existiendo otras penas como las que se analizan en este capítulo la prisión debe utilizarse en aquellos supuestos indispensables ${ }^{1018}$. Además, en el caso de reducir el uso de la pena de prisión de forma conjunta con la pena de privación del derecho a conducir, el delincuente recibiría una sanción con alto contenido aflictivo, como es la pena que analizamos en el trabajo, y que tiene fines preventivos tanto generales como especiales y evitará que se aplique una pena tan gravosa como la privativa de libertad. Es por todo ello por lo que sería adecuado que en determinados tipos penales se previera la imposición de la pena de privación del derecho a conducir en tanto que pena principal, junto a la pena de multa o la pena de TBC y de esta forma reducir el uso de la pena de prisión, como sucede actualmente en los tipos del art. 383 y 382 bis $\mathrm{CP}$, en los que únicamente se prevé esta pena sin otras alternativas. Esta reducción del uso de la pena de prisión en el ámbito de la delincuencia vial iría en consonancia en lo que ya mantenía hace

1017 En este sentido se manifiesta VALEIJE ÁLVAREZ, Inmaculada,"El sistema de penas en los delitos contra la seguridad vial", en AA.VV. Prevención y control..., op.cit., p.463.

1018 En relación con los posibles parámetros para aplicar la pena de prisión, vid. GÓMEZ PAVÓN, Pilar, "La reforma de los delitos contra la seguridad del tráfico (arts.379, 381, 385 bis y 385 ter)", en AA.VV. Comentarios..., op.cit., p.431. 
más de una década QUINTERO OLIVARES ${ }^{1019}$ y el ámbito de la seguridad vial puede ser idóneo para ello.

\subsubsection{Concurrencia con la pena de multa}

El objetivo del epígrafe es analizar la aplicación conjunta de la pena de multa con la pena de privación del derecho a conducir, determinar los supuestos delictivos en los que procede su imposición de forma acumulativa y plantear los problemas que pueden darse.

Los tipos penales que establecen la posibilidad de aplicación conjunta de la pena de privación del derecho a conducir y la pena de multa están relacionados con los delitos contra la seguridad vial y son los delitos de los arts. 379 y $381 \mathrm{CP}$, así como también con los delitos contra la vida e integridad física y psíquica de las personas, en los delitos de los arts. 142.2, 152.1.1 y 152.2 CP. Además, esta concurrencia será también posible cuando la multa no actúe como pena principal sino como pena sustitutiva.

El primer tipo delictivo en el que se puede imponer de forma acumulativa la pena de multa con la pena de privación del derecho a conducir es el del art.379 CP, aplicándose aquella de forma alternativa a la pena de prisión y a la pena de TBC. La importancia que tiene la pena de multa en su imposición con la pena de privación del derecho a conducir en el art.379 CP, se acredita con el hecho que por determinadas Fiscalías ${ }^{1020}$ se considera que ha de ser la pena preferente en detrimento de la prisión o la pena de TBC. También existen en la doctrina posiciones favorables a imponer la pena de multa como pena prioritaria en los delitos contra la seguridad vial en general y ello para evitar la imposición de penas privativas de libertad ${ }^{1021}$. El segundo tipo de los delitos contra la seguridad vial en el que se imponen conjuntamente la pena de multa y la pena de privación del derecho a conducir, es el art.381 CP en el que siempre concurren como penas principales y acumulativas con la pena de prisión.

\footnotetext{
1019 Vid. QUINTERO OLIVARES, Gonzalo, “La progresiva renuncia...”, op.cit., p.128.

1020 Vid. la Memoria del año 2013 (ejercicio 2012) de la Fiscalía de la Comunidad Foral de Navarra, p.99.

1021 Vid. TOLEDO CASTILLO, Francisco/ CAMPÓN DOMÍNGUEZ, José Andrés/ MARTíN UCLÉS, Francisco, Manual..., op.cit., pp.290-291.
} 
La imposición conjunta de la pena de multa con la privación del derecho a conducir se amplió a tres tipos delictivos tras la entrada en vigor de la LO 1/2015 de 30 marzo de reforma del CP. En primer lugar, en el delito de homicidio por imprudencia menos grave del art.142.2 $\mathrm{CP}^{1022}$ la pena de multa es pena principal única y se podrá imponer de forma facultativa la pena de privación del derecho a conducir, por lo que su esquema es similar al existente en la antigua falta de homicidio por imprudencia leve. En segundo lugar, en el delito de lesiones por imprudencia grave del art.152.1.1 CP se puede optar de manera alternativa como pena principal por la prisión o la multa ${ }^{1023}$, y en todo caso se impondrá la pena de privación del derecho a conducir. En tercer lugar, en el delito de lesiones por imprudencia menos grave del art.152.2 $\mathrm{CP}^{1024}$, que sigue el mismo esquema que el citado delito de homicidio por imprudencia menos grave, se impone la pena de multa de tres a doce meses. En relación con este último tipo delictivo es importante destacar que tras la entrada en vigor de la LO 2/2019 de 1 de marzo, ha visto ampliada su aplicación ya que ahora incluye las lesiones del art. 147.1 $\mathrm{CP}^{1025}$. Esta circunstancia puede hacer que se incremente el número de condenas que incluyan la pena de privación del derecho a conducir, aun cuando su imposición será en todo caso facultativa.

Tras la LO 2/2019 de 1 de marzo de reforma del Código Penal, el art. 152 bis CP, al que ya nos hemos referido anteriormente, establece la posibilidad de imponer la pena superior en un grado 0 incluso en dos si concurren determinadas circunstancias. Dado que en el art. 152.1.1 CP se puede imponer la pena de multa de forma alternativa a la pena de prisión, junto a la pena de privación del derecho a conducir, ambas podrán ser incrementadas de forma importante.

La aplicación acumulativa de la pena de multa con la pena de privación del derecho a conducir también concurre en los casos en los que proceda la sustitución directa de la pena de prisión ex art.71.2 CP, y la pena original de prisión puede ser

\footnotetext{
1022 Art.142.2 CP: El que por imprudencia menos grave causare la muerte de otro, será castigado con la pena de multa de tres meses a dieciocho meses.

1023 Art.152.1.1 CP: El que por imprudencia grave causare alguna de las lesiones previstas en los artículos anteriores será castigado, en atención al riesgo creado y el resultado producido: 1o Con la pena de prisión de tres a seis meses o multa de seis a dieciocho meses, si se tratare de las lesiones del apartado 1 del artículo 147.

1024 Art.152.2 CP: El que por imprudencia menos grave causare alguna de las lesiones a que se refieren los artículos 149 y 150 será castigado con una pena de multa de tres meses a doce meses.

1025 Vid. MAGRO SERVET, Vicente, “¿Cómo se van a tramitar ahora...?.", Diario La Ley no 9370, Sección Doctrina, 5 de marzo de 2019.
} 
sustituida por pena de multa ${ }^{1026}$, a razón de un día de prisión por dos cuotas de multas $^{1027}$. Asimismo, a tenor de lo dispuesto en el art.84 CP, es posible que la multa se aplique como prestación en caso de suspensión de la pena de prisión.

Una de las cuestiones problemáticas inherentes a la pena de multa es la determinación de la cuota diaria y la necesaria investigación previa sobre la capacidad económica del penado. En el ámbito de los delitos contra la seguridad vial se había propuesto como indicador de tal capacidad económica la propiedad del vehículo con el que se hubiera cometido el delito ${ }^{1028}$. Sin embargo, este criterio debe ser matizado, ya que es posible que el vehículo propiedad del penado tenga un valor escaso y no servirá para acreditar una situación de cierta solvencia económica. Es por ello que el factor de la propiedad del vehículo no puede ser el único que se utilice para determinar la pena de multa y en la declaración judicial se podrá interrogar al conductor investigado acerca de sus condiciones económicofinancieras para perfilar su capacidad económica ex art.50.5 CP ${ }^{1029}$. Así, con el objetivo de definir correctamente los elementos indiciarios en relación con la capacidad patrimonial del penado la FGE exigió una mayor actividad de la Policía en el momento de redacción del atestado ${ }^{1030}$. En los procedimientos relacionados con los delitos contra la seguridad vial tramitados como Juicio Rápido-Diligencias Urgentes en los que se peticiona la pena de multa y la pena de privación del derecho a conducir, siguen vigentes los problemas señalados antaño por MANZANARES SAMANIEGO ${ }^{1031}$ para determinar la real capacidad económica del investigado y fijar la cuantía diaria de la pena de multa ${ }^{1032}$. Precisamente la cuantificación de la pena de multa en función de las circunstancias personales del

1026 En relación con la viabilidad de dicha opción, vid. MAGRO SERVET, Vicente/ SOLAZ SOLAZ, Esteban, Manual práctico..., op.cit., p.119.

1027 Relativo a la función de la pena de multa como pena sustitutiva, GRACIA MARTíN, Luis, "La pena de multa", en AA.VV. Lecciones de consecuencias jurídicas del delito: el sistema de penas, de medidas de seguridad, de consecuencias accesorias y de responsabilidad civil derivada del delito, GRACIA MARTíN, Luis (Coord.)/ BOLDOVA PASAMAR, Miguel ÁngeL/ ALASTUEY DOBÓN, M.Carmen, Ed. Tirant lo Blanch, Valencia, 2012, 4ª edición, p.90.

1028 En relación con los criterios para la determinación de la pena de multa vid. RíOS MARTíN, Julián Carlos/ SEGOVIA BERNABÉ, José Luis/ PASCUAL RODRÍGUEZ, Esther, Las penas..., op.cit., p.61.

1029 En referencia al criterio para determinar la cuota de multa, estimo acertado lo expuesto por el Grupo de Estudios de Política Criminal, Una propuesta..., op.cit., pp.46-47. Vid. también con relación al art.50.5 los criterios jurisprudenciales citados por CABALLERO GEA, José-Alfredo, Delitos..., op.cit., pp.299-302.

1030 Vid. Memoria de la FGE, año 2008, p.702.

1031 Referente a la determinación de la pena de multa y el contenido del art.50.5 CP, vid. MANZANARES SAMANIEGO, José Luis, "La pena de multa", Diario La Ley, Sección Doctrina 1996, Ref. D-30, tomo 2, Ed. La Ley, La Ley 12162/2001.

1032 Esta problemática ha sido destacada en la Memoria de la FGE del año 2012, p.1254. 
penado, de su capacidad económica y de la gravedad del hecho es una de las ventajas de esta pena que han sido resaltadas por la doctrina ${ }^{1033}$. A diferencia de la pena de privación del derecho a conducir, en la que no influyen las circunstancias personales del penado para su determinación, la pena de multa tiene una relación directa con la capacidad económica y circunstancias personales del autor del hecho delictivo ${ }^{1034}$, como ha señalado ROCA AGAPITO ${ }^{1035}$. En los delitos contra la seguridad vial la pena de multa sí ha merecido una especial atención por parte de la FGE en la Instrucción 3/2006, al fijar los parámetros para su imposición ${ }^{1036}$, y concretar que para que dicha pena tenga una verdadera eficacia se debería evitar que la misma sea impuesta en sus umbrales mínimos, excepto los casos que estén acreditados. Con carácter general la FGE promulgó la Circular 2/2004 sobre aplicación de la reforma del CP operada por LO 15/2003 de 25 de noviembre, en la que también se detallaban los parámetros para imponer la pena de multa ${ }^{1037}$.

A continuación, nos referiremos a los problemas que pueden plantear la aplicación conjunta de la pena de multa y la pena de privación del derecho a conducir. El primero de ellos se plantea en ocasión del impago de la multa a pesar de poderla abonar de forma fraccionada ${ }^{1038}$, lo que comportará la responsabilidad personal subsidiaria del art.53.1 CP y la pena de multa se transformará en una pena privativa de libertad de corta duración, agravándose las consecuencias iniciales derivadas del delito ${ }^{1039}$. En la responsabilidad personal subsidiaria del art.53.1 CP existe una novedad introducida por la LO 1/2015 de 30 de marzo de reforma del CP y es que

\footnotetext{
1033 En relación con las ventajas de la pena de multa, vid. ROCA AGAPITO, Luis, La responsabilidad personal subsidiaria por impago de la pena de multa, Ed. Lex Nova, Valladolid, 2003, 1 a edición, p.77 y también REVILLA REVILLA, Eusebio "La pena de multa", Diario la Ley, Sección Doctrina, 1997, Ref. D-220, tomo 4, Ed. La Ley, relativo a la individualización de la multa.

1034 Referente a este aspecto, destacar la sentencia por un delito del art.379.1 CP por exceso de velocidad al ex futbolista internacional alemán Michael Ballack, al que se le impuso una pena de multa de $6750 €$ y privación del derecho a conducir durante un año y seis meses.

Vid. la sentencia en: http://servicios.hoy.es/datos/documentos/sentencia-condena-ballck-2.pdf (último acceso: 05/11/2020).

1035 Esta característica la relaciona con el principio de igualdad de sacrificio, ROCA AGAPITO, Luis, El sistema..., op.cit., p.274.

1036 Vid. la Instrucción 3/2006 de la FGE, sobre criterios de actuación del Ministerio Fiscal para una efectiva persecución de los ilícitos penales relacionados con la circulación de vehículos a motor, pp.17-18.

1037 Vid. la Circular 2/2004 de la FGE, pp.43-47.

1038 Las carencias de la pena de multa en los delitos relacionados con la seguridad vial han sido puestas de manifiesto por TAMARIT SUMALLA, Josep, "La prohibición de conducir y otras sanciones penales relacionadas con los vehículos", en AA.VV. Las sanciones..., op.cit., p. 326.

1039 En relación con los inconvenientes de la pena de multa relacionados con el impago de la misma, Vid. ROCA AGAPITO, Luis, La responsabilidad..., op.cit., p.83.
} 
aquella se podrá cumplir con localización permanente en los delitos leves ${ }^{1040}$, lo que se constata únicamente en el caso de delitos de homicidio y lesiones por imprudencia menos grave ex art. 142.2 y 152.2 CP.

Para aquellos supuestos en que el penado no satisfaga la multa impuesta en un delito en el que se ha utilizado un vehículo a motor o ciclomotor, alguna resolución jurisprudencial ha propuesto la posibilidad del embargo del vehículo para garantizar el pago de la multa ${ }^{1041}$. Esta opción, que no debe confundirse con un decomiso del vehículo, podría contribuir a dotar de mayor eficacia a la pena de multa, ya que los penados podrán percibir que en caso de no satisfacer la misma podrán perder el vehículo de su propiedad.

El segundo aspecto problemático es que sus cuotas pueden ser abonadas por un tercero, por lo que el contenido aflictivo y de prevención especial que pueda tener en los delitos relacionados con el tráfico viario puede ser muy bajo ${ }^{1042}$. Cuando esto suceda, el penado cumplirá de forma efectiva la pena de privación del derecho a conducir, mientras que la pena pecuniaria para el caso de carecer de medios económicos podrá ser abonada por un tercero, dejando sin sentido la finalidad de la misma. Acerca de la ausencia de contenido aflictivo y falta del fin de prevención especial la jurisprudencia ha señalado ${ }^{1043}$, que el hecho que se imponga la pena de multa en su cuantía mínima provoca que la misma carezca de capacidad disuasoria, reparadora y además estaría vacía de efectos preventivos, finalidades que son relevantes en los delitos en que además de la pena de multa se impone la pena de privación del derecho a conducir.

El tercer aspecto problemático entorno a la aplicación de la pena de multa en los delitos contra la seguridad vial es su escasa eficacia resocializadora ${ }^{1044}$. La idea que

\footnotetext{
1040 Art.53.1 CP: Si el condenado no satisficiere, voluntariamente o por vía de apremio, la multa impuesta, quedará sujeto a una responsabilidad personal subsidiaria de un día de privación de libertad por cada dos cuotas diarias no satisfechas, que, tratándose de delitos leves, podrá cumplirse mediante localización permanente.
}

1041 Vid. SAP de Tenerife, núm. 710/2008, Sección 2ª̣, de 10 de octubre de 2008, ponente IImo. Sr. Joaquín Luis Astor Landete (JUR 2009/52342).

1042 Vid. MANZANARES SAMANIEGO, José Luis, "La pena de multa", Diario La Ley, Sección Doctrina 1996. Ref. D-30, tomo 2, Ed. La Ley. La Ley 12162/2001 y TRAPERO BARREALES, María.A., Los delitos..., op.cit., p.546, nota al pie no 61 .

${ }^{1043}$ Con relación a la ineficacia de la pena de multa cuando se impone en su cuantía mínima, vid. SAP de Tenerife, núm. 710/2008, Sección 2ª , de 10 de octubre de 2008, ponente Ilmo. Sr. Joaquín Luis Astor Landete. (JUR 2009/52342).

1044 Acerca de la ausencia de la finalidad reformadora de la pena de multa, Vid. ROCA AGAPITO, Luis, La responsabilidad..., op.cit., p.80. 
puede transmitir la imposición de la pena de multa con la pena de privación del derecho a conducir, es que aquella se trate de un instrumento meramente recaudatorio por parte de la Administración, estando despojada de objetivos reeducativos para el penado.

\subsubsection{Concurrencia con la pena de trabajos en beneficio de la comunidad}

El objetivo del epígrafe es definir cuándo se aplica de forma conjunta la pena de TBC y la pena de privación del derecho a conducir, así como concretar los delitos en los que procede su imposición de forma acumulativa. En la concurrencia de ambas penas, la de TBC se puede acordar bien como pena principal bien como pena sustitutiva, siendo el tipo delictivo del art. $379 \mathrm{CP}$ el único en el que se impone como pena principal con la pena de privación derecho a conducir. En este sentido hemos de destacar el alto grado de aplicación que ha tenido la pena de TBC tras la LO 15/2007 de 30 de noviembre ${ }^{1045}$, que en numerosas ocasiones se ha impuesto de forma conjunta con la pena de privación del derecho a conducir por la vía del art.379 CP. También se hace hincapié en las finalidades que comparten ambas penas, especialmente cuando se imponen de forma acumulativa, así como se determinan los problemas que se derivan en su ejecución.

\section{a) Marco normativo y ámbito de aplicación}

Nos hallamos ante dos penas privativas de derechos, ya que la pena de TBC y la pena de privación del derecho a conducir, están reguladas en el art.39 CP ${ }^{1046}$. Una de las penas obligará al penado a hacer algo (una prestación) mientras que la otra le impedirá ejercer un derecho (conducir) y su concurrencia en una misma sentencia puede plantear algunos problemas a lo que haremos referencia a continuación.

Para determinar el marco normativo de la pena de TBC, que puede ser impuesta bien como pena principal o pena sustitutiva, hemos de invocar el art.49 CP que está

\footnotetext{
1045 Vid. BRANDARIZ GARCÍA, José Ángel, La sanción..., op.cit., p.449.

1046 En relación con la ubicación en el CP de la pena de TBC, así como de su naturaleza, vid. TORRES ROSELL, Núria, La pena de Trabajos en beneficio de la comunidad. Reformas legales y problemas de aplicación, Ed. Tirant lo Blanch, Valencia, 2006, p.279 y BOLDOVA PASAMAR, Miguel.A, "Penas Privativas de Derechos", en AA.VV. Lecciones..., op.cit., pp.74-75.
} 
dedicado específicamente a la misma, y en el que se establecen sus características, así como la forma en la que se ha de ejecutar ${ }^{1047}$.

El primer aspecto a destacar de la pena de TBC es que únicamente se impondrá si el penado consiente su realización, como establece el art.49 $\mathrm{CP}^{1048}$. A diferencia de las penas de prisión y multa, la pena de TBC únicamente será impuesta con el consentimiento expreso del penado. De lo contrario, el Juzgado o Tribunal se verá obligado a imponer la pena alternativa que exista para el delito en concreto, bien sea prisión o multa ${ }^{1049}$. Con la imposición de la pena de TBC, el penado decide voluntariamente que la forma de resarcir a la sociedad por el delito cometido es a través de realizar trabajos comunitarios ${ }^{1050}$.

La pena de TBC puede ser impuesta con la pena de privación del derecho a conducir a través de cuatro vías diferentes. En primer lugar, la pena de TBC se configura como pena principal únicamente en el delito del art.379 CP. En segundo lugar, existe la posibilidad que la pena de TBC sea pena sustitutiva de la pena de prisión cuando ésta es inferior a tres meses al amparo de lo establecido en el art.71.2 CP. En los delitos contra la vida e integridad corporal de las personas, así como en los delitos contra la seguridad vial en los que se imponga pena de prisión inferior a tres meses, esta puede ser sustituida por la pena de TBC, ex art. 71.2 CP. Ello puede producirse, entre otros, en los delitos contra la seguridad vial como el art. 382 bis apartado tercero, en el tipo del art 383 CP así como en el delito lesiones por imprudencia grave del art 152.1 apartado primero del CP. La tercera vía para imponer la pena de TBC es cuando se determina que esta es la forma de cumplir la responsabilidad penal subsidiaria por impago establecida en el art.53.1 CP tras no

\footnotetext{
1047 Vid. BRANDARIZ GARCÍA, José Ángel, "La pena de trabajos en beneficio de la comunidad", en AA.VV. Las penas privativas de derechos y otras alternativas a la privación de libertad, FARALDO CABANA, Patricia/ PUENTE ABA, Luz María (Directoras), Ed. Tirant lo Blanch, Valencia, 2013, p.345.

1048 Relativo al requisito del consentimiento del penado para llevar a cabo la pena de TBC, vid. TORRES ROSELL, Núria, La pena..., op.cit., p.278 y 286. Vid. también BRANDARIZ GARCÍA, José Ángel, La sanción penal de trabajos en beneficio de la comunidad, Ed. Tirant lo Blanch, 2009. Valencia, p.287 y VILLACAMPA ESTIARTE, Carolina/TORRES ROSELL, Núria, "El nuevo régimen de ejecución de las sanciones alternativas a la prisión", Revista de Derecho y Proceso Penal, núm.27/2012, Ed. Aranzadi, pp.227-278.

1049 Vid. BLAY GIL, ESTER, "Nueve tópicos acerca del trabajo en beneficio de la comunidad: la necesidad de una discusión basada en conocimientos empíricos", Indret, Revista para el análisis del Derecho, no 4, 2007, p. 10 y NUÑO DE LA ROSA AMORES, José Antonio, "Aplicación práctica...", op.cit., pp.118-119.

1050 La característica de la pena de TBC, como una forma de reparación del penado hacia la sociedad ha sido destacada por BOLDOVA PASAMAR, Miguel.A, "Penas Privativas de Derechos", en AA.VV. Lecciones..., op.cit., pp.74-75.
} 
haber satisfecho el penado la pena de multa ${ }^{1051}$. Finalmente, la cuarta vía para acordar los TBC es a través del art. $84 \mathrm{CP}$, no como pena, sino como prestación, y ello sucederá en los casos de suspensión de la pena de prisión ${ }^{1052}$. Tras la entrada en vigor de la LO 1/2015 de 30 de marzo se pueden imponer trabajos en beneficio de la comunidad en el trámite de suspensión de penas privativas de libertad ex art.84 y $80.3 \mathrm{CP}^{1053}$. Un sector doctrinal mantiene que los trabajos en beneficio de la comunidad en estos casos no pueden ser considerados una pena ${ }^{1054}$, por lo que no se producirá la aplicación acumulativa de la pena de privación del derecho a conducir con la pena de TBC, sino que los trabajos en beneficio de la comunidad han de ser considerados prestaciones o medidas.

Probablemente una de las cuestiones que mayor interés suscite en relación con la aplicación de la pena de TBC en el ámbito de la seguridad vial, y, por lo tanto, en supuestos en los que puede coincidir con la pena de privación del derecho a conducir, es la posibilidad que su ejecución consista en la participación del penado en cursos de formación en materia de seguridad vial. La ejecución de la pena de TBC se halla regulada en el RD 840/2011 de 17 de junio por el que se establecen las circunstancias de ejecución de las penas de trabajo en beneficio de la comunidad y de localización permanente en centro penitenciario, de determinadas medidas de seguridad, así como de la suspensión de la ejecución de las penas privativas de libertad y sustitución de penas ${ }^{1055}$. El RD 840/2011 de 17 de junio ${ }^{1056}$,

\footnotetext{
1051 En relación con el marco normativo de la pena de TBC, vid. TORRES ROSELL, Núria, "La pena de localización permanente y la pena de trabajos en beneficio de la comunidad", en AA.VV. La reforma Penal de 2010: Análisis y comentarios, en QUINTERO OLIVARES, Gonzalo (Dir.), Ed. Thomson Reuters- Aranzadi, Cizur Menor (Navarra), 2010, p.95, también VILLACAMPA ESTIARTE, Carolina/TORRES ROSELL, Núria, "EI nuevo régimen...", op.cit., p.4 y BRANDARIZ GARCÍA, José Ángel, "La pena..." op.cit., p.345.

1052 Acerca de las cuatro formas en las que se puede imponer la pena de TBC vid. DAUNIS RODRÍGUEZ, Alberto., Ejecución de penas..., op.cit., pp.311-312.

1053 Vid. TORRES ROSELL, Núria, "Trabajos en beneficio de la comunidad y localización permanente", en AA.VV. Comentario..., QUINTERO OLIVARES, Gonzalo (Dir.), op.cit, pp.106-108.

1054 Vid. GARCíA ALBERO, Ramón, "La suspensión de la ejecución de las penas", en AA.VV. Comentario a la reforma penal de 2015, QUINTERO OLIVARES, Gonzalo (Dir.), Ed.Thomson Reuters- Aranzadi, Cizur Menor (Navarra), 2015, p.154; TORRES ROSELL, Núria, "Trabajos en beneficio de la comunidad y localización permanente", en AA.VV. Comentario..., QUINTERO OLIVARES, Gonzalo (Dir.), op.cit, pp.106-108 y ROIG TORRES, Margarita, "Suspensión de la ejecución de las penas privativas de libertad (arts.80, 81 y 82 )", en AA.VV. Comentarios a la Reforma del Código Penal de 2015 GONZÁLEZ CUSSAC, José.L (Dir.), MATALLÍN EVANGELIO, Ángela/ GÓRRIZ ROYO, Elena (Coords.), Ed. Tirant Lo Blanch, Valencia, 2015, p. 331.
}

1055 Vid. en: https://www.boe.es/diario boe/txt.php?id=BOE-A-2011-10598 (último acceso: 13/11/2020).

1056 Con relación al RD 840/2011 de 17 de junio, vid. MAGRO SERVET, Vicente/SURIÁ MARTíNEZ, Raquel/HERNÁNDEZ RAMOS, Carmelo/CUÉLLAR OTÓN, J. Pablo, "La eficacia de la implantación 
especifica en su Capítulo II la forma de cumplimiento de la pena de TBC, y especifica la opción de cumplir la pena de TBC, a través de los talleres de actividades en materia de seguridad vial (en adelante TASEVAL) ${ }^{1057}$ siendo ésta una alternativa al cumplimiento a través de trabajos de carácter social ${ }^{1058}$. Esta regulación administrativa perfila la ejecución de la pena de TBC y servirá para acotar su alcance cuando se impone junto con la pena de privación del derecho a conducir ${ }^{1059}$.

La pena de TBC había tenido históricamente poca relevancia en los delitos contra la seguridad vial, a pesar de que era un terreno idóneo para su imposición ${ }^{1060}$. Esta circunstancia fue destacada por la doctrina, con carácter general para todo tipo de delitos $^{1061}$, y en particular en el art.379 CP ${ }^{1062}$. La escasa utilización histórica de la pena de TBC en nuestro sistema penal, se contrapone con su empleo en el derecho comparado, ya que en los delitos relacionados con el tráfico viario ha sido en los que más desarrollo ha tenido ${ }^{1063}$. El punto de inflexión que supuso un incremento del uso de la pena de TBC en los delitos contra la seguridad vial fue la reforma operada por la LO 15/2007 de 30 de noviembre, en concreto, en lo que atañe a los delitos contra la seguridad vial previstos en los arts.379 y $384 \mathrm{CP}^{1064}$.

del programa TASEVAL en la reeducación de condenados por delitos contra la seguridad vial", Tráfico y Seguridad Vial, № 182, 2014.

1057 El contenido de los TASEVAL se divide en nueve grandes bloques, entre otros: accidentes de tráfico, alcohol, drogas o conducción temeraria. En relación con las nueve áreas vid. DAUNIS RODRÍGUEZ, Alberto., Ejecución de penas..., op.cit., pp.176-177.

1058 En relación con la modificación introducida por el Real Decreto 1849/2009 de 4 de diciembre, vid. MAGRO SERVET, Vicente,"El Real Decreto 1849/2009...", op.cit., pp.5-14 y también MONTERO HERNANZ, Tomás, "La reforma penal...", op.cit., pp.15-26.

1059 Con anterioridad al RD 840/2011 de 17 de junio, la ejecución de los TBC estuvo regulada por el RD 515/2005 de 6 de mayo por el que se establecen las circunstancias de ejecución de las penas de trabajos en beneficio de la comunidad y de localización permanente, de determinadas medidas de seguridad, así como de la suspensión de la ejecución de las penas privativas de libertad y por el RD 1849/2009 de 4 de diciembre por el que se modifica el Real Decreto 515/2005, de 6 de mayo, que establece las circunstancias de ejecución de las penas de trabajos en beneficio de la comunidad y de localización permanente, de determinadas medidas de seguridad, así como de la suspensión de la ejecución de las penas privativas de libertad. Recurso electrónico disponible en: http://www.boe.es/boe/dias/2009/12/05/pdfs/BOE-A-2009-19564.pdf (último acceso: 13/11/2020).

1060 Vid. la Instrucción 3/2006 de la FGE, sobre criterios de actuación del Ministerio Fiscal para una efectiva persecución de los ilícitos penales relacionados con la circulación de vehículos a motor, p.18.

1061 Referente a la escasa aplicación de la pena de TBC con carácter general, vid. BRANDARIZ GARCíA, José Ángel, La sanción..., op.cit., p.447; Grupo de Estudios de Política Criminal, Una propuesta..., op.cit., p.40 y BLAY GIL, ESTER, "Nueve tópicos...", op.cit., pp.4-5.

1062 Vid. RODRÍGUEZ LEÓN, Luis Carlos, Seguridad..., op.cit., p.49.

1063 Vid. TORRES ROSELL, Núria, La pena..., op.cit., p.355.

1064 Respecto a la importancia que adquirido la pena de TBC tras la reforma operada por la LO 15/2007, véase la Circular 10/2011 de la FGE "Sobre criterios para la unidad de actuación 
La modificación del art.379 mediante la LO 5/2010 de 22 de junio introdujo un régimen de alternatividad entre las penas de prisión, multa o TBC a las que se añadirá en todo caso la pena de privación del derecho a conducir. Con el redactado del CP anterior a la LO 5/2010 de 22 de junio, en el delito del art.379 se imponía siempre la pena de TBC y la privación del derecho a conducir, a las que se añadía bien la pena de prisión o bien la pena de multa. Tal como ha señalado GÓMEZ PAVÓN, con la LO 5/2010 de 22 de junio se ha eliminado la alternatividad que existía entre la pena de prisión y multa, pasando ahora a una triple opción al incluir como pena la de $\mathrm{TBC}^{1065}$, lo que ha provocado una flexibilización a la hora de imponer esta pena. Debido al régimen de la alternatividad en el art.379 CP, la pena de TBC cuando se aplica de forma conjunta con la pena de privación del derecho a conducir, dependerá de la voluntad del penado en una sentencia de conformidad y del propio criterio judicial al entender que será la pena más apropiada para el acusado en relación con los hechos cometidos ${ }^{1066}$.

La aplicación conjunta de la pena de TBC y la pena de privación del derecho a conducir en el art.379 CP, puede ser la más idónea dentro del régimen de alternatividad existente y considero que debería ser de imposición preferente en detrimento a la pena de multa o la de prisión ${ }^{1067}$ ya que al imponerse de forma conjunta refuerzan los fines de prevención especial ${ }^{1068}$. Los datos de la FGE reflejan oscilaciones en la aplicación de la pena de TBC en el ámbito de la seguridad vial puesto que durante el año 2012 se produjo un incremento de la pena de TBC y un

especializada del Ministerio Fiscal en materia de seguridad vial", pp.80-81. Esta circunstancia ya había sido preconizada en la Instrucción 3/2006 de la FGE, sobre criterios de actuación del Ministerio Fiscal para una efectiva persecución de los ilícitos penales relacionados con la circulación de vehículos a motor, p.18. En el mismo sentido vid. BRANDARIZ GARCíA, José Ángel, La sanción..., op.cit., pp.450-451.

1065 Acerca de la reforma de la LO 5/2010 en el art.379 y su influencia en la pena de TBC, vid. GÓMEZ PAVÓN, Pilar, "La reforma de los delitos contra la seguridad del tráfico (arts.379, 381, 385 bis y 385 ter)", en AA.VV. Comentarios..., op.cit., p.431.

1066 Respecto al incremento del poder de decisión del Juez o Magistrado a la hora de imponer la pena de TBC conjuntamente con la pena de privación del derecho a conducir en el art.379, vid. MARTÍNEZ ZAPATER, Luis Fernando, "Los delitos contra la seguridad vial, arts.379, 381, 384, 385 bis y 385 ter", en AA.VV. La reforma..., op. cit., p.88.

1067 En este sentido también podemos destacar la finalidad de rehabilitación de los TBC, en los delitos como el del art.379 en el que se pueden imponer de forma conjunta con la pena de privación del derecho a conducir, vid. MARTÍN LORENZO, María, "Negativa a someterse a las pruebas de medición de alcohol y detección de drogas", en AA.VV. Protección Penal de la Seguridad Vial, GUTIÉRREZ RODRÍGUEZ, María (Coord.), Ed. Tirant lo Blanch, Valencia, 2009, pp.289-290.

1068 Referente a los fines de prevención especial de la pena de TBC, vid. GUTIÉRREZ CASTAÑEDA, Ana, Las penas..., op.cit., pp.173-174; TRAPERO BARREALES, María.A., Los delitos..., op.cit., p.547, nota al pie número 64; también VALEIJE ÁLVAREZ, Inmaculada, "El sistema de penas en los delitos contra la seguridad vial", en AA.VV. Prevención y control..., op.cit., p.472. 
descenso de la pena de multa ${ }^{1069}$. Sin embargo, durante los años 2013 a 2018, se produjo un descenso de las penas de TBC y aumento de la pena de multa en los delitos contra la seguridad vial, tendencia que se ha roto en el año 2019, ya que se ha producido un descenso tanto en el número de penas de TBC como de multa impuestas en los delitos contra la seguridad vial ${ }^{1070}$.

Al margen de las posibilidades de aplicación de la pena de TBC como sustitutivo o en la suspensión, en cuanto pena principal para delitos contra la seguridad vial está limitada al art.379 CP. No obstante, esta pena, aplicada conjuntamente con una pena de privación del derecho a conducir vehículos podría resultar una opción punitiva adecuada para otros tipos delictivos. Así, por ejemplo, en delitos contra la seguridad vial relacionados con la conducción temeraria, de los arts.380 y 381 $\mathrm{CP}^{1071}$ así como en el delito de abandono del lugar del accidente del art. 382 bis o el delito de negativa a someterse a las pruebas legalmente establecidas del art. 383 CP. En estos casos, además de la pena de privación del derecho a conducir, la imposición con la pena de TBC sería beneficiosa para la reeducación de estos conductores, debido a que la pena de TBC tiene un alto contenido aflictivo ${ }^{1072}$ y persigue fines de retribución y reparación del delito cometido ${ }^{1073}$. Asimismo, y también de lege ferenda, su aplicación podría ser interesante en delitos de los de homicidio por imprudencia y de lesiones por imprudencia cometidos con la utilización de vehículo a motor o ciclomotor $^{1074}$.

La pena de TBC es recomendable para el perfil delictivo de los delincuentes viales ya que éstos en numerosas ocasiones son personas con una vida social estable y normalizada y no es necesario un proceso de reinserción, pero sí estimo imprescindible que se realice una toma de conciencia de las consecuencias que

\footnotetext{
1069 Vid. Memoria de la FGE, año 2013, pp.404-405.

1070 Vid. Memoria de la FGE, año 2014, p.432, Memoria de la FGE, año 2015, p.483, Memoria de la FGE, año 2016, p.527, Memoria de la FGE año 2017, p.583, Memoria de la FGE año 2018, pp.664665, Memoria de la FGE año 2019, p.876 y Memoria de la FGE año 2020, pp.912-913.

1071 En estos tipos delictivos, VALLESPÍN PÉREZ considera que la pena de TBC se debería haber incluido dentro del catálogo de penas existentes. Vid. VALLESPÍN PÉREZ, David, Aspectos procesales..., op.cit., p.87.

1072 En relación con el valor que tiene la pena de TBC en cuanto desde el punto de vista pedagógico así como resocializador, vid. VALEIJE ÁLVAREZ, Inmaculada,"El sistema de penas en los delitos contra la seguridad vial", en AA.VV. Prevención y control..., op.cit., p.472.

1073 Con relación a los elementos que definen la pena de TBC, vid. TORRES ROSELL, Núria, La pena..., op.cit., pp.279-280.

${ }^{1074}$ En este sentido sectores doctrinales son partidarios de potenciar la pena de TBC, especialmente en el ámbito de los delitos contra la seguridad vial así como las imprudencias que causen lesiones
} 
derivan del delito cometido ${ }^{1075}$. Un aspecto destacado de los fines que persigue tanto la pena de TBC como la pena de privación del derecho a conducir es que aquella tiene un cumplimiento en libertad y en la mayoría de supuestos en el propio entorno familiar, social y laboral del penado, lo que puede coadyuvar a su correcto cumplimiento ${ }^{1076}$. Todo ello, sin reducir el contenido aflictivo que existe tanto en la pena de TBC $^{1077}$ como la pena de privación del derecho a conducir ya que en ambas se puede ver limitada en cierta forma la libertad deambulatoria del penado y puede limitarse el tiempo libre del condenado ${ }^{1078}$. La opción de incrementar la utilización de la pena de TBC en el ámbito de los delitos contra la seguridad vial ha sido defendida por VIDALES RODRÍGUEZ ${ }^{1079}$ y considero que sería positiva ya que además de ser una pena bien recibida por la sociedad ${ }^{1080}$, su imposición conjunta con la pena de privación del derecho a conducir puede tener importantes fines de prevención especial positiva, así como de reeducación y resocialización del penado, máxime si se ambas se cumplen de manera correcta y se evita que la pena de TBC prescriba.

\section{b) Cuestiones de ejecución}

Analizamos a continuación algunas cuestiones relevantes vinculadas a la aplicación acumulativa de la pena de TBC y la pena de privación del derecho a conducir en el marco de la ejecución de las mismas. Una primera cuestión importante es que ninguna de las dos penas se podrá suspender ni sustituir ${ }^{1081}$. Es por ello que en los

como pueden ser las originadas por la utilización de un vehículo a motor o ciclomotores. Vid. Grupo de Estudios de Política Criminal, Una propuesta..., op.cit., pp.40-41.

1075 Acerca de los fines de reeducación de la pena de TBC, vid. VALLESPÍN PÉREZ, David, Aspectos procesales..., op.cit., p.87.

1076 Vid. GUTIÉRREZ CASTAÑEDA, Ana, Las penas..., op.cit., p.174.

1077 Sobre el contenido aflictivo de la pena de TBC, vid. BRANDARIZ GARCÍA, José Ángel, "La pena...", op.cit., p.346.

1078 En relación con las limitaciones que se derivan para el penado de la pena de TBC, se han citado la libertad general de acción y el libre desarrollo de la personalidad, véase al respecto BOLDOVA PASAMAR, Miguel Ángel, "Penas Privativas de Derechos", en AA.VV. Lecciones..., op.cit., p.75.

1079 Vid. VIDALES RODRÍGUEZ, Caty," Trabajos en beneficio de la comunidad (art.49)", en AA.VV. Comentarios a la Reforma Penal de 2010, ÁLVAREZ GARCíA, Francisco.J/ GONZÁLEZ CUSSAC, José.L (Dirs.), Ed. Tirant lo Blanch, Valencia, 2010, p.109.

${ }^{1080}$ En torno a la finalidad de la pena y su papel en la sociedad, vid. Grupo de Estudios de Política Criminal, Una propuesta..., op.cit., p.40. También ha de destacarse la Circular 10/2011 de la FGE "Sobre criterios para la unidad de actuación especializada del Ministerio Fiscal en materia de seguridad vial", p.81.

${ }^{1081}$ En relación con la efectiva aplicación de la pena de TBC, vid. BRANDARIZ GARCíA, José Ángel, La sanción..., op.cit., p.450. 
delitos relacionados con la circulación de vehículos a motor y ciclomotores en los que se impone la pena de TBC de forma conjunta con la privación del derecho a conducir, para que ambas puedan cumplir sus fines es necesario que se ejecuten correctamente ${ }^{1082}$, y especialmente que no se quebranten ${ }^{1083}$.

Como hemos indicado anteriormente, tras la entrada en vigor del RD 1849/2009 de 4 de diciembre por el que se modifica el RD 515/2005, de 6 de mayo, que establece las circunstancias de ejecución de las penas de trabajos en beneficio de la comunidad y de localización permanente, de determinadas medidas de seguridad, así como de la suspensión de la ejecución de las penas privativas de libertad, ha cobrado importancia el cumplimiento de la pena de TBC a través del programa PROSEVAL y de los TASEVAL ${ }^{1084}$, que son talleres de sensibilización en seguridad vial. En cuanto a su aplicación hemos de señalar que los TASEVAL, están previstos para penados con hasta 60 jornadas de TBC, mientras que el programa PROSEVAL, se aplicará para aquellos penados con más de 60 jornadas de TBC, cumpliendo éstos en todo caso, primero el TASEVAL, para después llevar a cabo una fase terapéutica de 6 meses $^{1085}$. Esta forma de cumplimiento de la pena de TBC, en determinados territorios se ha convertido en la forma más usual, tal como señaló la Memoria del año 2013 de la Fiscalía de la Comunidad Foral de Navarra ${ }^{1086}$. En el ámbito nacional, el Fiscal de Sala Coordinador de Seguridad Vial ha destacado que en el año 2018 el $22 \%$ de las penas de TBC en el ámbito de la delincuencia vial se han cumplido a través de los programas PROSEVAL y TASEVAL ${ }^{1087}$. A pesar de la amplia aceptación que están teniendo los talleres

\footnotetext{
1082 Vid. VALEIJE ÁLVAREZ, Inmaculada, "El sistema de penas en los delitos contra la seguridad vial", en AA.VV. Prevención y control..., op.cit., pp.472-473.

1083 Los problemas de quebrantamiento en la pena de TBC han sido destacados por la Memoria de la FGE del año 2012, pp. 1249-1251.

1084 En relación con los TASEVAL y su forma de cumplimiento vid. la Instrucción 4/2014 de la Secretaria General de Instituciones Penitenciarias, sobre el cumplimiento de la pena de trabajos en beneficio de la comunidad en los casos de delitos contra la seguridad del tráfico. Ampliación del ámbito de aplicación de los talleres de sensibilización en seguridad vial TASEVAL. También es importante destacar la Instrucción 10/2015, de 18 de diciembre, de la Dirección General de Instituciones Penitenciarias, sobre los nuevos programas de intervención de penas y medidas alternativas. Procedimientos y metodología.

1085 Respecto del ámbito de aplicación del programa PROSEVAL y los talleres TASEVAL, vid. CERVERA SALVADOR, Sabina, "Ejecución de la pena de trabajos en beneficio de la comunidad", Revista de Jurisprudencia, Ed. Lefebvre-El Derecho, № 2, 15 de enero de 2019.

1086 Vid. la Memoria del año 2013 (ejercicio 2012) de la Fiscalía de la Comunidad Foral de Navarra, p.100.

1087 Vid. la nota de prensa del Fiscal de Sala Coordinador de Seguridad Vial de 30 de julio de 2019.

Recurso electrónico disponible en:

https://www.fiscal.es/documents/20142/0/NOTA+RUEDA+DE+PRENSA+30-7-

19+REDUCIDA.pdf/5384e9f1-d6fe-b50d-e607-b15c6ffc126d (último acceso: 05/11/2020).
} 
TASEVAL, sobre todo en el ámbito de la seguridad vial, BRANDARIZ GARCÍA se ha mostrado crítico con esta opción con el argumento que en ocasiones puede llegar a desnaturalizar la pena de TBC porque considera que los talleres TASEVAL no pueden ser considerados "un verdadero trabajo de utilidad pública" ${ }^{1088}$.

La cobertura normativa a la práctica de cumplir los TBC mediante la participación en un curso formativo vino determinada por la modificación del art.49 CP mediante LO $5 / 2010$ de 22 de junio, que supuso una novedad en la aplicación conjunta de la pena de TBC con la pena de privación del derecho a conducir al permitir que aquella se cumpla asistiendo a los talleres o programas formativos o de reeducación de educación vial ${ }^{1089}$. Esta reforma, que se llevó a cabo en consonancia con el RD 1849/2009 de 4 de diciembre, permite el cumplimiento de la pena de TBC a través de la realización de estos talleres ${ }^{1090}$ que tienen una clara vinculación con el delito que se ha cometido. Las modificaciones realizadas, contribuyeron a la mejora de la ejecución de la pena de TBC siendo calificado por la FGE en la Circular 10/2011 como una "flexibilización del cómputo del sistema del trabajo"1091.

Con la modificación realizada en el art.49 CP, para el cumplimiento de la pena de TBC se instalan en plano de igualdad tanto la realización de trabajo por parte del penado como la asistencia a los talleres TASEVAL. Esta circunstancia podría contribuir a una mayor eficacia en su ejecución, evitando posibles quebrantamientos, y a su vez también podría mejorar los fines de prevención especial ya que el penado cumplirá las dos penas impuestas: la pena de TBC y la pena de privación del derecho a conducir ${ }^{1092}$. Precisamente, debido al elevado

Hemos de señalar que, en el año 2019, en el ámbito de la Administración General del Estado, a través de los TASEVAL se cumplieron 4348 condenas a TBC y a través de los PROSEVAL, 806 condenas a TBC. Vid. la estadística en el informe "Seguridad Vial y su incidencia en el ámbito penitenciario", elaborado por el Ministerio del Interior, p.30.

1088 Vid. la opinión crítica con los TASEVAL de BRANDARIZ GARCÍA, José Ángel, "La pena..." op.cit., p.361.

1089 Referente a dicha modificación que afecta a la pena de TBC, vid. VIDALES RODRÍGUEZ, Caty,"Trabajos en beneficio de la comunidad (art.49)", en AA.VV. Comentarios... op.cit., p.107 y BLAY GIL ESTER, "El papel de los jueces en la ejecución de las penas comunitarias: una investigación empírica y algunas propuestas para la reflexión”, en AA.VV., Penas comunitarias en Europa, LARRAURI, ELENA/BLAY GIL ESTER, Ed. Trotta, Madrid, 2011, p. 76.

1090 Vid. VILLACAMPA ESTIARTE, Carolina/TORRES ROSELL, Núria, "El nuevo régimen...", op.cit., p.17.

1091 Vid. la Circular 10/2011 de la FGE "Sobre criterios para la unidad de actuación especializada del Ministerio Fiscal en materia de seguridad vial", pp.82.

1092 En relación con los efectos de prevención especial de la nueva regulación de la pena de TBC, vid. MARTÍNEZ ZAPATER, Luis Fernando, "Los delitos contra la seguridad vial, arts.379, 381, 384, 385 bis y 385 ter", en AA.VV. La reforma..., op.cit., pp. 320-321. También desde la FGE, en la 
número de sentencias condenatorias dictadas por el art.379 $\mathrm{CP}$, con anterioridad a la reforma de la LO 5/2010 de 22 de junio, en numerosas ocasiones la pena de TBC prescribía sin llegar a ser ejecutada ${ }^{1093}$.

El aparente éxito de los talleres y cursos TASEVAL motivó que el propio BCPP contemplara la posibilidad de que el investigado en la fase de instrucción pudiera participar en programas de educación vial, como medida alternativa a la prisión preventiva (art. 181). La previsión del BCPP es relevante por dos motivos: en primer lugar, posibilita la realización de unos cursos o talleres formativos como alternativa a la prisión provisional. En segundo lugar, en el caso que se dictara sentencia condenatoria con aplicación de la pena de trabajos, podrían reconocerse los cursos o programas seguidos en sede de medidas cautelares, de tal forma que podría suceder que el penado en fase de ejecución únicamente debería cumplir la pena de privación del derecho a conducir, ya que la pena de TBC la habría cumplido en sede de instrucción a través de los talleres TASEVAL. El correcto cumplimiento de los programas o cursos de formación en la fase de instrucción puede favorecer también el cumplimiento de la ulterior pena de privación del derecho a conducir que se imponga ya que el penado habrá cumplido sin quebrantar una obligación impuesta por el juez. Es importante destacar que también han existido problemas en el cumplimiento de la pena de TBC a través de los talleres TASEVAL, básicamente en lo relativo a cuestiones de incumplimiento ${ }^{1094}$, aunque en términos generales su implantación ha sido positiva.

Memoria del año 2011, p. 1062, nota al pie 154, se ha destacado la eficacia preventiva de los TASEVAL.

${ }^{1093}$ Acerca de los porcentajes de incumplimiento de la pena de TBC, que estaban alrededor de un 60 $\%$, antes de la entrada en vigor de la LO 5/2010, vid. la Circular 10/2011 de la FGE "Sobre criterios para la unidad de actuación especializada del Ministerio Fiscal en materia de seguridad vial", p.81. En relación con los problemas de prescripción, véase la Memoria de la FGE del año 2012, pp.12491250. Hemos de destacar los esfuerzos realizados por el legislador en la última década para favorecer una correcta aplicación de la pena de TBC con la entrada en vigor del Real Decreto 1849/2009 de 4 de diciembre; del RD 840/2011 de 17 de junio, así como la reforma operada en el CP por la LO 5/2010 y la Resolución de 10 de mayo de 2018, de la Secretaría General Técnica del Ministerio del Interior, por la que se publica el Convenio entre la Secretaría General de Instituciones Penitenciarias y la Fundación Diagrama, para el desarrollo de los programas Proseval, Probeco, Cuenta Contigo y el Taller Taseval en el ámbito de las penas y medidas alternativas, BOE de 18 de mayo de 2018.

1094 Podemos señalar que se han generado numerosos problemas de incumplimiento de la pena de TBC a través de los talleres TASEVAL como puede comprobarse en diversas resoluciones judiciales. Vid. SAP de Madrid, núm. 502/2013, Sección 15ª , de 17 de junio de 2013, ponente Ilma. Sra. María Isabel Valldecabres Ortiz. (TOL4.085.124), SAP de Castellón, núm. 152/2017, Sección 1ặ, de 22 de febrero de 2017, ponente IImo. Sr. Pedro Luis Garrido Sancho. (TOL6.154.279), SAP de Tenerife, núm. 338/2018, Sección 2a , de 9 de noviembre de 2018, ponente Ilmo. Sr. Fernando Paredes Sánchez. (TOL7.066.784) y SAP de Pontevedra, núm. 12/2019, Sección 2ª , de 23 de enero de 2019, ponente Ilma. Sra. Rosa del Carmen Collazo Lugo (TOL7.155.049). 
Todo parece indicar que la pena de privación del derecho a conducir TBC mantendrá en el futuro unos niveles elevados de aplicación conjunta con la pena de TBC en el ámbito del art.379 CP, aun cuando el actual régimen de alternatividad de este artículo, haya podido reducir su uso ${ }^{1095}$.

\subsubsection{Concurrencia de la pena de privación del derecho a conducir con la pena de inhabilitación para el ejercicio de profesión y oficio}

Siguiendo con el análisis de la aplicación conjunta de la pena de privación del derecho a conducir vehículos a motor y ciclomotores con otras penas, estudiamos la posibilidad que aquella se imponga junto con la pena de inhabilitación especial para profesión u oficio, industria y comercio. El tema tiene especial interés en aquellos casos en que las penas se imponen a un profesional que requiere del uso del vehículo a motor o ciclomotor para el desarrollo de su actividad laboral lo que puede dar lugar a algunos problemas a los que nos referiremos en este apartado.

La concurrencia de ambas penas sucederá cuando la acción delictiva se haya cometido en el marco de la actividad profesional del autor de los hechos, por lo que además de la pena de privación del derecho a conducir se puede imponer la pena de inhabilitación especial para el ejercicio de la actividad profesional. La aplicación de esta pena está guiada por un fin específico como es el de evitar el ejercicio de la profesión u oficio, ya que el desarrollo de esta actividad comporta que el penado tenga que utilizar el vehículo a motor o ciclomotor con el que ha perpetrado un delito ${ }^{1096}$. De esta forma se puede evitar que el penado tenga al alcance los medios a través de los cuales se causó el delito por el que fue condenado, ya que el derecho al trabajo debe ser limitado únicamente en aquellos supuestos estrictamente necesarios ${ }^{1097}$.

\footnotetext{
1095 Respecto del cambio de tendencia en la pena de TBC en los delitos contra la seguridad vial, vid. BRANDARIZ GARCÍA, José Ángel, "La pena...", op.cit., p.346.

1096 En este sentido ROCA AGAPITO ha señalado que la pena de inhabilitación profesional tiene unos fines de prevención de futuros delitos relacionados con la actividad profesional que desarrolla, en nuestro caso relacionados con la utilización de vehículos a motor o ciclomotores, y que bien pueden atentar contra la seguridad vial o contra la vida o integridad física o psíquica de las personas. Relativo a la finalidad preventiva de la inhabilitación profesional vid. ROCA AGAPITO, Luis, El sistema..., op.cit., p.209.

1097 En relación con la finalidad de la pena vid. RAMOS VÁZQUEZ, José Antonio, "La pena de inhabilitación especial para profesión, oficio, industria o comercio", en AA.VV. Las penas privativas de derechos y otras alternativas a la privación de libertad, FARALDO CABANA, Patricia/ PUENTE ABA, Luz María (Dirs.), Ed. Tirant lo Blanch, Valencia, 2013, p.121.
} 
La pena de inhabilitación profesional está regulada en el art.39.b CP que contempla como penas privativas de derechos: "Las de inhabilitación especial para empleo o cargo público, profesión, oficio, industria o comercio, u otras actividades determinadas en este Código"1098. Esta pena priva temporalmente para desarrollar la actividad profesional1099, pero no priva de la autorización o licencia para desarrollar su actividad, en el que caso que exista y fuera necesaria para ejercerla. Referente a este particular destacamos la similitud con la pena de privación del derecho a conducir, que es una suspensión temporal del derecho a conducir, igual que sucede con la pena de inhabilitación profesional, ya que una vez haya transcurrido el plazo de la pena impuesta se podrá volver a ejercer de nuevo ambos derechos.

Por otro lado, el art.45 CP determina que esta inhabilitación ha de concretarse de forma expresa y motivada en la sentencia y que, en relación con su contenido, priva al penado de la facultad de ejercer la profesión durante el tiempo de la condena. El umbral temporal que puede tener la pena de inhabilitación especial, se halla regulado en el art. $40 \mathrm{CP}$ que establece que tienen una duración de tres meses a veinte años ${ }^{1100}$.

Una característica de la pena de inhabilitación profesional es que tiene una doble naturaleza, al contemplarse como principal y como accesoria ${ }^{1101}$. El 56.1.3 CP establece que la pena de inhabilitación como pena accesoria se puede imponer en las penas de prisión inferiores a diez años ${ }^{1102}$. La pena de inhabilitación para profesión y oficio, tiene la consideración de pena accesoria cuando está regulada en el art.56 CP, y procederemos a su análisis para determinar su aplicación conjunta con la pena de privación del derecho a conducir. Tal como se indica en el CP, nos

\footnotetext{
1098 La concreción de las posibles inhabilitaciones no es uniforme en los diversos tipos penales en las que se aplica. En este sentido vid. RAMOS VÁZQUEZ, José Antonio, "La pena de inhabilitación especial para profesión, oficio, industria o comercio”, en AA.VV. Las penas..., op.cit., p.117.

1099 En referencia a este aspecto, vid. CORDERO LOZANO, Carlos, Condenas..., op.cit., p.45.

1100 Art. 40 CP: 1. La pena de inhabilitación absoluta tendrá una duración de seis a 20 años; las de inhabilitación especial, de tres meses a 20 años, y la de suspensión de empleo o cargo público, de tres meses a seis años.

1101 Vid. RAMOS VÁZQUEZ, José Antonio, "La pena de inhabilitación especial para profesión, oficio, industria o comercio", en AA.VV. Las penas..., op.cit., p.115.

1102 Art.56.1.3 CP: 1. En las penas de prisión inferiores a diez años, los jueces o tribunales impondrán, atendiendo a la gravedad del delito, como penas accesorias, alguna o algunas de las siguientes: 3. Inhabilitación especial para empleo o cargo público, profesión, oficio, industria, comercio, ejercicio de la patria potestad, tutela, curatela, guarda o acogimiento o cualquier otro derecho, la privación de la patria potestad, si estos derechos hubieran tenido relación directa con el delito cometido, debiendo determinarse expresamente en la sentencia esta vinculación, sin perjuicio de la aplicación de lo previsto en el artículo 579 de este Código.
} 
hallamos ante una inhabilitación de carácter especial y en la que se ha de determinar para su imposición la concreta relación que tiene con el delito por el que ha sido condenado.

Nos referiremos a continuación a los supuestos en los que la pena de privación del derecho a conducir puede aplicarse conjuntamente con una pena de inhabilitación. La inhabilitación profesional puede aplicarse tanto como pena principal como pena accesoria. En la primera modalidad, esto es, como pena principal, la inhabilitación puede imponerse junto a la pena de privación del derecho a conducir en los casos de homicidio imprudente del art.142.1 y lesiones imprudentes del art.152.1 CP, causadas con vehículo a motor o ciclomotor, y se estime que la imprudencia pueda llegar a ser calificada como profesional ${ }^{1103}$, existiendo una triple respuesta penológica por la aplicación conjunta de la pena de prisión y dos penas privativas de derechos. Los delitos tipificados en los arts.142.1 y $152.1 \mathrm{CP}$, son los únicos supuestos relacionados con la circulación de vehículos a motor y ciclomotores en los que la pena de inhabilitación profesional, se impondrá como pena principal de manera conjunta con la pena de privación del derecho a conducir, aunque han tenido una escasa relevancia práctica ${ }^{1104}$. Una de las hipótesis formuladas por la doctrina en torno a este uso reducido está relacionada con el hecho que los tipos de los arts.142.1 y 152.1 CP, al prever de forma imperativa la pena de privación del derecho a conducir, ya supone una inhabilitación especial de facto ${ }^{1105}$.

En los tipos delictivos de los arts.142.1 y 152.1 CP se prevé una duración de la pena de privación del derecho a conducir cuyo máximo límite temporal coincide con el máximo umbral temporal de la pena de inhabilitación para profesión, oficio o cargo por lo que no existirá discordancia en el cumplimiento temporal máximo de ambas penas. Que el legislador haya establecido un mismo límite superior tanto para la pena de privación del derecho a conducir como para la pena de

\footnotetext{
1103 Respecto a los delitos en los que se aplica la pena de inhabilitación profesional como pena principal vid. RAMOS VÁZQUEZ, José Antonio, "La pena de inhabilitación especial para profesión, oficio, industria o comercio", en AA.VV. Las penas..., op.cit., p.116. La pena de inhabilitación profesional, cuando se acuerda de forma conjunta con la privación del derecho a conducir en los delitos de homicidio por imprudencia, art.142.1 CP y lesiones por imprudencia del art.152.1 CP, se impone de forma específica para "profesión, oficio o cargo", sin hacer referencia a la industria o comercio. A pesar de ello, no existe problema en interpretar que la inhabilitación ha de afectar a la profesión, el oficio o el cargo en su más amplio sentido y en relación con la actividad que realizaba en el momento de cometer el delito.

1104 En relación con la escasa aplicación de la pena de inhabilitación profesional en los tipos penales de los arts.142.1 y 152.1, vid. CORCOY BIDASOLO, Mirentxu, "Homicidio y lesiones en el ámbito viario. Problemática concursal entre los delitos contra la seguridad en el tráfico y los resultados lesivos a ellos imputables", en AA.VV. Seguridad vial..., op.cit., p.92.
}

1105 Ibídem, p.93. 
inhabilitación en los casos de condena por imprudencia profesional ha sido criticado por CORCOY BIDASOLO ${ }^{1106}$, quien considera que la inhabilitación ha de tener una penalidad igual o mayor que la pena de privación del derecho a conducir, dado que la imprudencia es más grave al haberse cometido en el ámbito profesional. Además, la pena de inhabilitación profesional se impone a profesionales de la conducción por lo que su duración debería ser más elevada debido a la mayor exigencia en términos de experiencia y formación a la que se somete a estos conductores y que no requieren la generalidad de conductores.

Uno de los problemas que pueden aparecer en este ámbito es que cuando se imponen de forma conjunta ambas penas, puede suceder que la duración de la pena de privación del derecho a conducir y la pena de inhabilitación no sea igual y por lo tanto no finalicen a la vez. Según el redactado del actual art.142.1 CP la duración de la pena de inhabilitación puede ser diferente a la pena de privación del derecho a conducir por lo que de facto nos hallaremos ante una doble punición ${ }^{1107}$. Dicha circunstancia es factible que se produzca ya que el umbral inferior de ambas penas es diferente, al ser un año para la privación de conducir y tres para la inhabilitación profesional. Así, por ejemplo, puede darse el caso que la privación de conducir se imponga por periodo de dos años y la inhabilitación por periodo de cuatro años. Si ello se produjera, de facto, significará que el penado que se dedicara profesionalmente al transporte no podrá conducir en ese periodo de cuatro años y se extenderán las consecuencias de la pena de privación del derecho a conducir ${ }^{1108}$. Esta disparidad en los umbrales punitivos en los casos que se imponen

\footnotetext{
1106 Vid. CORCOY BIDASOLO, Mirentxu, "Homicidio y lesiones imprudentes cometidos con vehículos a motor o ciclomotor", en AA.VV. Derecho Penal y Seguridad Vial, DE VICENTE MARTíNEZ, Rosario (Dir.), Estudios de Derecho Judicial no 114, Ed. Centro de Documentación Consejo General del Poder Judicial, Madrid, 2007, p. 105, y también la misma autora, "Homicidio y lesiones en el ámbito viario. Problemática concursal entre los delitos contra la seguridad en el tráfico y los resultados lesivos a ellos imputables", en AA.VV. Seguridad Vial...op.cit., p.94.
}

1107 Sin embargo, no estimo que la doble imposición de la pena de inhabilitación profesional y la pena de privación del derecho a conducir suponga una infracción del principio non bis in ídem, ni del principio de proporcionalidad ya que formalmente ambas tienen un contenido diferente. Algún sector de la doctrina sí estima que, en determinados casos, por aplicación del principio de proporcionalidad de las penas, únicamente con la pena de privación del derecho a conducir sería suficiente para cumplir los fines de prevención especial y prevención general. Con relación al principio de proporcionalidad y los fines de la pena, vid. NAVARRO FRÍAS, Irene, "El principio de proporcionalidad en sentido estricto: ¿Principio de proporcionalidad entre el delito y la pena 0 balance global de costes y beneficios?", Indret, Revista para el análisis del Derecho, oㅡ 2, 2010, pp.16-17. También recurso electrónico disponible en: http://www.indret.com/pdf/724.pdf (último acceso: 05/11/2020).

1108 Un ejemplo de la discordancia temporal entre pena de privación del derecho a conducir y pena de inhabilitación profesional podemos ver la Sentencia del Juzgado de lo Penal no 27 de Barcelona, de 21/10/2011, ratificando en cuanto a la pena por la SAP de Barcelona, núm. 788/2012, Sección 6áa, de 7 de noviembre de 2012, ponente Ilma.Sra. María Dolores Balibrea Pérez (TOL2.714.210), en la que se impone una pena de privación del derecho a conducir de 3 años y 6 meses y la pena de 
de forma conjunta la pena de privación del derecho a conducir y la pena de inhabilitación profesional también concurre en el delito de lesiones por imprudencia grave del art.152.1 CP, siendo umbral inferior de un año para la privación de conducir y seis meses para la inhabilitación profesional. Sin embargo, esta regulación en lo que se refiere a su ejecución no es problemática ya que ambas penas de cumplirán de forma simultánea.

La segunda modalidad es la opción de imponer la pena de inhabilitación profesional como pena accesoria cuando se dicte sentencia condenatoria por una pena de prisión inferior a diez años. Además, el art.45 CP ${ }^{1109}$ establece que la imposición de la pena de inhabilitación profesional requiere de una necesaria concreción y motivación en la sentencia que se dicte ${ }^{1110}$, siendo además necesario que los hechos cometidos y la actividad profesional en la que se aplica la pena han de tener una relación directa ${ }^{1111}$. La sentencia que aplique esta pena ha de fundamentar que el autor de los hechos es merecedor de un reproche penal que motive la inhabilitación para la profesión en cuyo ejercicio ha cometido el delito, y a su vez poder ejercer otras profesiones no relacionadas con el delito perpetrado ${ }^{1112}$. Puesto que la pena de prisión inferior a diez años se contempla en varios delitos contra la seguridad vial y contra la vida y la salud en los que además también se puede aplicar la pena de privación del derecho a conducir, podemos afirmar que ambas penas pueden llegar a concurrir en los supuestos de los artículos 379, 380, 381, 382 bis y $383 \mathrm{CP}$, por lo que podrá sancionarse con la pena de inhabilitación regulada en el art.56 CP como pena accesoria. Esta posibilidad puede resultar factible en aquellos casos de conductores profesionales (taxistas, camioneros, repartidores, etc.), que en el ejercicio de su actividad profesional han podido cometer uno de los delitos citados.

inhabilitación para la profesión de conductor de 4 años y 6 meses. También se ha producido dicha discordancia temporal en la SAP de Madrid, Sección $7^{\mathfrak{a}}$, de 23 de enero de 2002, ponente llma. Sra.Ana Mercedes Del Molino Romera (TOL240.163), en la que se impone la pena de privación del derecho a conducir por cinco años e inhabilitación especial para el ejercicio de la profesión u oficio relacionada con el transporte público de viajeros por tiempo de seis años.

1109 Art.45 CP: La inhabilitación especial para profesión, oficio, industria o comercio o cualquier otro derecho, que ha de concretarse expresa y motivadamente en la sentencia, priva al penado de la facultad de ejercerlos durante el tiempo de la condena.

1110 Vid. MOLINA BLÁZQUEZ Mํㅡㄹ Concepción, La aplicación..., op.cit., p.36.

1111 Vid. ROCA AGAPITO, Luis, El sistema..., op.cit., p. 209; MOLINA BLÁZQUEZ Ma Concepción, La aplicación..., op.cit., p.36 y RAMOS VÁZQUEZ, José Antonio, "La pena de inhabilitación especial para profesión, oficio, industria o comercio", en AA.VV. Las penas..., op.cit., p.120 y ORTS BERENGUER, Enrique/ GONZÁLEZ CUSSAC, José.L. Compendio..., op.cit., p.473.

1112 En torno a la aplicación restrictiva de la pena de inhabilitación profesional, vid. POZUELO PÉREZ, Laura., Las penas..., op.cit., p.47. 
Podemos plantearnos si en los supuestos que se impone la pena de privación del derecho a conducir a aquellos penados para los que es necesario el ejercicio de dicho derecho en su actividad profesional ésta tiene un doble efecto e incluso no sería necesaria la imposición expresa de la inhabilitación según lo preceptuado en los arts. 45 y 56.1.3 $\mathrm{CP}^{1113}$, ya que al ser de carácter más amplio le impedirá conducir cualquier tipo de vehículo a motor y ciclomotor, y por ende desarrollar cualquier actividad profesional que requiera el uso de cualquiera de ellos. Para el caso que un conductor cometa un delito utilizando un vehículo a motor o ciclomotor por imprudencia profesional, podría considerarse que con la imposición única de la pena de privación del derecho a conducir quedaría sancionado el desvalor de la conducta realizada ${ }^{1114}$ y que el penado reciba dos penas derivadas de un mismo hecho, puede resultar desproporcionado. En estos supuestos, podría sostenerse que la aplicación conjunta de ambas penas no se adecua a los fines que puedan tener las penas si lo que originan es una "condena al hambre"1115, al obligar al penado a desarrollar una actividad laboral diferente a la que realizaba antes de la comisión del delito. Si bien estoy de acuerdo con el hecho que el fin de ambas penas no ha de ser excluir socialmente al penado, sino que han de procurar su reinserción y resocialización, no puede obviarse que cuando se impongan a conductores profesionales, comportará de forma casi obligatoria la pérdida de su puesto de trabajo. Esta circunstancia puede acontecer de manera más notoria en los casos que la pena de inhabilitación profesional sea superior a la pena de privación del derecho a conducir, por lo que nos hallaremos ante dos periodos acumulativos en los que el penado no podrá ejercer ni su derecho a conducir ni su actividad profesional ${ }^{1116}$. Un argumento contrario a la doble punición cuando se imponen ambas penas, es el que a pesar de que nos hallamos ante dos penas muy similares no tienen un contenido idéntico, por lo que la motivación para su aplicación también será diferente ${ }^{1117}$.

\footnotetext{
1113 Vid. TRAPERO BARREALES, María. A., Los delitos..., op.cit., p.567.

${ }^{1114}$ En relación con el principio de proporcionalidad y el desvalor de la acción delictiva cometida, vid. MUÑOZ CONDE, Francisco/GARCÍA ARÁN, Mercedes, Derecho..., op.cit., p.85 y AGUADO CORREA, Teresa, El principio de proporcionalidad en derecho penal, Ed. Edersa, Madrid, 1999, pp.147-148.

1115 Acerca de dicha expresión a POZUELO PÉREZ, Laura, Las penas..., op.cit., p.47; ROCA AGAPITO, Luis, El sistema..., op.cit., p.209 y, RAMOS VÁZQUEZ, José Antonio, "La pena de inhabilitación especial para profesión, oficio, industria o comercio", en AA.VV. Las penas..., op.cit., p.121, citando a BOLDOVA PASAMAR.

1116 Este supuesto ha sido destacado por TRAPERO BARREALES, María. A., Los delitos..., op.cit., p.568.

1117 Respecto a la similitud entre la pena de privación del derecho a conducir y la inhabilitación profesional, vid. CORCOY BIDASOLO, Mirentxu, "Homicidio y lesiones imprudentes cometidos con vehículos a motor o ciclomotor" en AA.VV. Derecho Penal..., op.cit., p.105.
} 
Una segunda cuestión a resolver es si el penado al que se le imponga conjuntamente la pena de privación del derecho a conducir y la pena accesoria de inhabilitación profesional, podrá ejercer el derecho a conducir en el supuesto que la inhabilitación profesional sea de una duración temporal superior a la pena estudiada. Para solventar la cuestión hemos de precisar si existe algún impedimento en el hecho que el penado que ya ha cumplido la pena de privación del derecho a conducir pueda seguir conduciendo aun cuando no haya cumplido la pena de inhabilitación especial para su profesión. En este sentido, considero que debe interpretarse la prohibición en el sentido de que dicho penado pueda ejercer su derecho a conducir cuando no lo lleve a cabo en su condición de conductor profesional y lo ejercite como particular, ya que la pena únicamente afecta a una profesión que en el supuesto planteado sería la relativa a la de conductor profesional o transportista ${ }^{1118}$. Asimismo, la pena de inhabilitación profesional tampoco puede afectar a esferas privadas ajenas a la actividad laboral relacionada con el delito cometido. Por ello es importante que la sentencia concrete en qué determinada actividad o ámbito laboral se ha de aplicar la pena de inhabilitación profesional ya que los penados pueden realizar diferentes actividades relacionadas con la conducción de vehículos a motor y ciclomotor (camionero, conductor de autobús taxista, repartidor, etc.). Entiendo que cuando proceda la imposición de esta pena, únicamente se podrá acordar en aquella concreta actividad profesional que el penado estaba realizando en el momento que cometió el delito, ya que de aplicarse de manera global podría vulnerarse el derecho al trabajo del penado tal como ha destacado ROCA AGAPITO ${ }^{1119}$.

La sentencia que acuerde la pena de inhabilitación profesional, no priva del título habilitante ${ }^{1120}$, en nuestro caso el permiso o licencia para conducir y ejercer su profesión, y lo que no podrá realizar el penado es ejercer la profesión de la que depende el título, es decir el permiso ${ }^{1121}$.

\footnotetext{
1118 En referencia a las actividades o profesiones a las que afecta la pena de inhabilitación profesional, vid. POZUELO PÉREZ, Laura., Las penas..., op.cit., p.47.

1119 Vid. ROCA AGAPITO, Luis, El sistema..., op.cit., p.209.

1120 Vid. la referencia a la doctrina mayoritaria citada por VILLACAMPA ESTIARTE, Carolina, "Las penas de inhabilitación en la Unión Europea: regulación comparada y proceso de armonización", en AA.VV. Las sanciones penales en Europa, Revista Aranzadi de Derecho y Proceso Penal, TAMARIT SUMALLA, Josep (Coord.), Ed. Aranzadi, Cizur Menor (Navarra), 2009, p. 256.

1121 Vid. POZUELO PÉREZ, Laura., Las penas..., op.cit., pp.47-48, así como CORDERO LOZANO, Carlos, Ejecución..., op.cit., p.141.
} 
Una vez determinado el ámbito y los requisitos de aplicación de la pena de inhabilitación profesional, analizamos los problemas que puedan surgir durante su ejecución cuando tal pena se ha impuesto de forma conjunta con la pena de privación del derecho a conducir. La sentencia dictada concretará la actividad profesional para la que se inhabilita al penado junto a la pena de privación del derecho a conducir, y cuando concurran ambas penas en una misma sentencia su cumplimiento se ejecutará de forma simultánea con independencia que tengan o no la misma duración. En la fase de ejecución de sentencia existen similitudes entre la forma de ejecutar la pena de inhabilitación profesional y la pena de privación del derecho a conducir, requiriéndose en ambos casos que se proceda a la liquidación de condena y una vez decretada su firmeza se proceda al requerimiento personal al penado con apercibimiento de cometer delito de quebrantamiento de condena ${ }^{1122}$. Además, si se trata de una profesión en la que es necesaria la colegiación, se remitirá testimonio de la sentencia al Colegio correspondiente; en otro caso, al órgano de control que se considere más oportuno, como puedan ser autoridades locales, registros municipales, corporaciones oficiales de comerciantes, o incluso el auxilio de la policía judicial para comprobar el efectivo cumplimiento. Debido a que la pena de inhabilitación profesional tiene un carácter más específico, ya que inhabilita para el ejercicio de la profesión u oficio con un vehículo a motor o ciclomotor, han de activarse estos mecanismos más concretos para asegurar su cumplimiento que los existentes cuando únicamente se impone la pena de privación del derecho a conducir.

Como conclusión en relación con la correcta ejecución en los casos que se impongan ambas penas en un mismo procedimiento, la solución más adecuada sería que se impusieran por idéntico lapso temporal ya que así el penado cumpliría las dos a la vez. Si se hiciera de esta forma, se evitarían posibles disfunciones en el penado y que éste pudiera incurrir en un posible quebrantamiento de condena de la pena pendiente de ejecutar.

El último aspecto que tratamos es la relevancia práctica que ha tenido la aplicación conjunta de la pena de privación del derecho a conducir y la pena de inhabilitación profesional, así como los criterios jurisprudenciales para su imposición ${ }^{1123}$.

\footnotetext{
1122 En relación con la ejecución de la pena de inhabilitación especial, vid. CORDERO LOZANO, Carlos, Ejecución..., op.cit., p.141.

${ }^{1123}$ Es destacable la escasa aplicación que históricamente ha tenido la apreciación de la imprudencia profesional en la jurisprudencia como ha señalado CORCOY BIDASOLO, Ibídem, pp.102-103.
} 
Podemos encontrar la imposición conjunta de la pena de privación del derecho a conducir con la pena de inhabilitación profesional bien sea como pena principal bien sea como pena accesoria, en condenas por acciones de conductores profesionales, entre los cuales podemos destacar taxistas, camioneros, transportistas en general, etc. En los casos relacionados con la actividad laboral de estos conductores profesionales y tras realizar una conducta constitutiva de delito, puede valorarse que además de la genérica pena de privación del derecho a conducir se imponga su inhabilitación profesional por el mayor reproche que ha de merecer su acción. Esta circunstancia se ha producido en conductas realizadas por conductores profesionales de autobús o camión que han causado un siniestro por imprudencia con el resultado de personas fallecidas y lesionadas de gravedad ${ }^{1124}$, así como en supuestos de taxistas que cometen un atropello sobre un peatón provocando el posterior fallecimiento ${ }^{1125}$ o realizan un giro prohibido a una velocidad inadecuada con una cliente en el interior del vehículo y colisiona con un motorista que fallece ${ }^{1126}$. La jurisprudencia también ha establecido que en aquellas acciones al volante en las que no quede determinada la relación directa entre la pena de inhabilitación profesional impuesta y los hechos acaecidos, no es procedente acordar la pena de inhabilitación especial para la profesión ${ }^{1127}$. En contraposición, determinadas acciones dolosas cometidas con la utilización de un vehículo a motor o ciclomotor por conductores profesionales, desde el punto de vista de las consecuencias jurídicas considero que no tienen una respuesta adecuada en la jurisprudencia. En estos casos, podemos hallarnos ante el hecho que ni se imponga la pena de privación del derecho a conducir ni tampoco la pena de inhabilitación

1124 Vid. SAP de Barcelona, núm. 788/2012, Sección 6ª , de 7 de noviembre de 2012, ponente Ilma.Sra. María Dolores Balibrea Pérez (TOL2.714.210), en la que se impone una pena de privación del derecho a conducir de 3 años y 6 meses y la pena de inhabilitación para la profesión de conductor de 4 años y 6 meses, además de la pena de prisión de dos años y seis meses y SAP de Tenerife, núm. 103/2014, Sección 2a a de 14 de marzo de 2014, ponente Ilma.Sra. Francisca Soriano Vela (TOL4.319.918), en la que se impone una pena de privación del derecho a conducir de 2 años y la pena de inhabilitación para la profesión de conductor de vehículos para el transporte de mercancías y viajeros por carretera de 2 años, además de la pena de prisión de dos años.

1125 Vid. SAP de Madrid, Sección 7á, de 23 de enero de 2002, ponente IIma. Sra.Ana Mercedes Del Molino Romera (TOL240.163), en la que se impone la pena de privación del derecho a conducir por cinco años e inhabilitación especial para el ejercicio de la profesión u oficio relacionada con el transporte público de viajeros por tiempo de seis años.

1126 Vid. SAP de Sevilla, núm.417/2015, Sección 7ạ , de 14 de septiembre de 2015, ponente llmo. Sr. Juan José Romeo Laguna (TOL5.544.544), en la que se impone la pena de privación del derecho a conducir por cuatro años e inhabilitación especial para el ejercicio de la profesión de taxista por tiempo de cuatro años.

1127 Vid. SAP de Salamanca, núm. 15/2009, Sección 1aㅡ, de 5 de febrero de 2009, ponente Ilmo. Sr. José Ramón González Clavijo (TOL1.546.387), en la que se revoca la pena de inhabilitación profesional como gruista durante un año que se había impuesto en la sentencia dictada, manteniéndose la pena de privación del derecho a conducir por plazo de dos años. 
profesional, a pesar de que desde el punto de vista del reproche penal de la acción cometida estaría claramente justificada ${ }^{1128}$.

La imposición conjunta de la pena de privación del derecho a conducir y la pena de inhabilitación profesional en la jurisprudencia ha sido escasa. Únicamente en aquellos supuestos de gravedad o de relevancia y alarma social, se ha optado por inhabilitar para la profesión al conductor además de imponerle la pena de privación del derecho a conducir. La opción de sancionar con mayor severidad a los conductores profesionales que cometan hechos delictivos en el ejercicio profesional, además de ser viable desde el punto de vista penal, es una posibilidad destacada por la Fiscalía para reducir la siniestralidad y prevenir futuras conductas delictivas ${ }^{1129}$. Precisamente son este tipo de conductores, los que debido a su actividad profesional están más horas circulando con el vehículo a motor o ciclomotor, y deben tener ese plus de exigencia en una proporción mayor que el resto de conductores.

\subsection{Concurrencia de la pena de privación del derecho a conducir y medidas de seguridad}

En este apartado se analiza la posibilidad de aplicación acumulativa de la pena de privación del derecho a conducir con las medidas de seguridad, tanto con las privativas de libertad como las no privativas de libertad, haciendo especial referencia a los eventuales problemas que esta coincidencia pueda generar. En la mayor parte de casos tal concurrencia quedará reducida a supuestos protagonizados por sujetos semiimputables, a quienes el juez reconozca una eximente incompleta por concurrir solamente algunos de los requisitos para la apreciación conjunta de la circunstancia eximente.

La aplicación conjunta de penas y medidas de seguridad en los delitos relacionados con la utilización de vehículos a motor y ciclomotores puede ser amplia, al poder

\footnotetext{
${ }^{1128}$ Es destacable la STS, núm. 224/2013, Sala Segunda, de 19 de marzo de 2013, ponente Excmo. Sr. Francisco Monterde Ferrer (TOL3.408.174), en la que a un taxista cuyos clientes no le pagan la carrera y es condenado por tentativa de homicidio al atropellar dolosamente a uno de ellos, no se le impone ni la pena de privación del derecho a conducir ni tampoco la pena de inhabilitación profesional.

1129 En este sentido destacar la opinión del Fiscal de Seguridad Vial en Galicia solicitando mayor severidad para los conductores profesionales.

Vid. en: http://www.laopinioncoruna.es/galicia/2013/04/02/fiscalia-pide-penas-duras-transportistasescolares-delincan/707664.html (último acceso: 05/11/2020).
} 
combinarse la pena de privación del derecho a conducir con diversas opciones que ofrecen las medidas de seguridad, tanto las privativas como no privativas de libertad. Además, la presencia de una medida de seguridad entre las no privativas de libertad cuya nomenclatura coincide con la pena objeto de estudio nos lleva a plantearnos en este espacio la posibilidad de imponer conjuntamente la pena y la medida de seguridad de privación del derecho a conducir ${ }^{1130}$.

Sin embargo, resulta también posible que la pena de privación del derecho a conducir se aplique conjuntamente con alguna de las medidas de seguridad privativas de libertad, omnicomprensivas de tres tipos diferentes de internamiento, así como con otras medidas de seguridad no privativas de libertad que incluyen tanto la inhabilitación profesional, la libertad vigilada y la privación del derecho a conducir, analizando la imposición conjunta con la pena de privación del derecho a conducir.

\subsubsection{Concurrencia con medidas de seguridad privativas de libertad}

Con carácter introductorio hemos de señalar que las medidas de seguridad privativas de libertad están reguladas en el art.96.2 $\mathrm{CP}$, siendo tres las que se pueden imponer: el internamiento en centro psiquiátrico; el internamiento en centro de educación especial y el internamiento en centro de deshabituación. La característica común a todas ellas es que se han de "adecuar a la personalidad del sujeto"1131, pudiendo además establecer una diferencia entre medidas curativas, como son el internamiento en centro psiquiátrico y deshabituación, y la medida educativa de internamiento en centro educativo especial ${ }^{1132}$. El requisito para que pueda concurrir la pena de privación del derecho a conducir junto una medida de seguridad privativa de libertad es que al autor de los hechos se le aprecie una eximente incompleta de los arts.20.1, 20.2 y 20.3 CP, pues en estos casos, a tenor de lo dispuesto en el art.21.1 CP el penado experimentará una atenuación de la

\footnotetext{
1130 Con relación a la privación del derecho a conducir como pena y medida de seguridad, vid. GÓMEZ PAVÓN, Pilar, El delito..., op.cit., p.222 y TRAPERO BARREALES, María.A., Los delitos..., op.cit., p.574-575.

1131 En torno a las medidas privativas de libertad, vid. GRACIA MARTíN, Luis, en "Las medidas de seguridad y reinserción social", en AA.VV. Lecciones de consecuencias jurídicas del delito: el sistema de penas, de medidas de seguridad, de consecuencias accesorias y de responsabilidad civil derivada del delito, GRACIA MARTíN, Luis (Coord.)/ BOLDOVA PASAMAR, MIGUEL ÁNGEL/ ALASTUEY DOBÓN, M. Carmen, Ed. Tirant lo Blanch, Valencia, 2012, 4ª edición, p.175.

1132 Respecto a la división entre medidas curativas y educativas, vid. AYO FERNÁNDEZ, Manuel, Las penas..., op.cit., pp.239-240.
} 
pena prevista para el delito y además, el juez, atendiendo al riesgo de reiteración delictiva, podrá aplicar una medida de seguridad.

La medida de seguridad privativa de libertad de internamiento en centro psiquiátrico, se puede acordar cuando al autor de los hechos delictivos se le haya apreciado la eximente incompleta del art.20.1을 $\mathrm{CP}^{1133}$, como determina el art.104.1 $\mathrm{CP}^{1134}$. Para que concurran la pena de privación del derecho a conducir con la medida de seguridad de internamiento en centro psiquiátrico, es necesario que la pena a imponer por el delito sea privativa de libertad, por lo que los tipos delictivos en que podrían interaccionar son los delitos de los arts.142.1, 152.1, 379, 380, 381, 382 bis y $383 \mathrm{CP}$, ya que en todos ellos pueden concurrir la pena de prisión y la pena de privación del derecho a conducir. Si convergen los requisitos expuestos, y además se detecta una peligrosidad en el penado, se podrá acordar su ingreso en centro psiquiátrico siendo una opción facultativa para el juzgador. La ejecución simultánea de ambas sanciones, internamiento y privación, comportará que el sujeto no pueda ejercer su derecho a conducir asegurándose de esta forma el efectivo cumplimiento de la pena de privación del derecho a conducir. Sin embargo, cuando la medida de internamiento en centro psiquiátrico y la pena de privación del derecho a conducir no tengan una misma duración ${ }^{1135}$, la observancia del cumplimiento de la pena de privación del derecho a conducir que se haya impuesto quedará sujeta a las mismas vicisitudes que en los supuestos anteriormente expuestos de concurrencia con otras penas.

La segunda medida de seguridad privativa de libertad es la de internamiento en centro de deshabituación, regulada en el art.96.2. $2^{\circ} \mathrm{CP}^{1136}$, y hemos de determinar

\footnotetext{
1133 En relación los requisitos para la adopción de esta medida de seguridad vid. GARCíA ALBERO, Ramón; "De las medidas de seguridad", en AA.VV. Comentarios..., QUINTERO OLIVARES, Gonzalo (Dir.), MORALES PRATS, Fermín (Coord.), op.cit, p.647.
}

1134 Art.104.1 CP: En los supuestos de eximente incompleta en relación con los números 1. ㅇ, 2. ํ y 3. - del artículo 20, el Juez o Tribunal podrá imponer, además de la pena correspondiente, las medidas previstas en los artículos 101, 102 y 103. No obstante, la medida de internamiento sólo será aplicable cuando la pena impuesta sea privativa de libertad y su duración no podrá exceder de la pena prevista por el Código para el delito. Para su aplicación se observará lo dispuesto en el artículo 99.

1135 Un ejemplo lo tenemos en la SAP de Murcia, núm. 87/2012, Sección $3^{3}$, de 28 de marzo de 2012, ponente IImo.Sr.Juan del Olmo Gálvez (JUR\2012\140582), en la que se confirma la sentencia establece un periodo de internamiento en centro psiquiátrico de 4 meses de duración y la pena de privación del derecho a conducir por dos años o la SAP de Málaga, núm. 308/2011, Sección 9a , de 31 de mayo de 2011, ponente IImo.Sr. Enrique Peralta Prieto (JUR\2012l66600), en la que se establece un periodo de internamiento en centro psiquiátrico de 7 meses y 15 días de duración y la pena de privación del derecho a conducir por nueve meses.

1136 Vid. GARCÍA ALBERO, Ramón, "De las medidas de seguridad", en AA.VV. Comentarios..., QUINTERO OLIVARES, Gonzalo (Dir.), MORALES PRATS, Fermín (Coord.), op.cit, p.649. 
si se puede aplicar de forma conjunta con la pena de privación del derecho a conducir. Es posible que se apliquen de forma acumulativa la pena de privación del derecho a conducir y la medida de seguridad de internamiento en centro de deshabituación en aquellos casos que se dicte sentencia condenatoria por un delito que conlleve la pena de privación del derecho a conducir y en su producción haya influido la posible adicción al alcohol, drogas tóxicas o estupefacientes ${ }^{1137}$. La combinación de esta medida de seguridad con la pena de privación del derecho a conducir, puede ser eficaz por cuanto, además de contribuir a que el penado pueda superar su adicción, durante un determinado tiempo no podrá conducir vehículos a motor o ciclomotores.

La tercera medida de seguridad privativa de libertad que puede concurrir con la pena de privación del derecho a conducir es la de internamiento en centro educativo especial, acordándose al amparo del art.104 CP. La finalidad de esta medida de seguridad tiene un carácter educativo ${ }^{1138}$ y terapéutico ${ }^{1139}$. Al igual que lo observado en las anteriores medidas, la ejecución y cumplimiento de la medida de internamiento en centro educativo especial y la pena de privación del derecho a conducir, puede realizarse de modo simultáneo, y es posible que no coincida la duración de ambas.

\subsubsection{Las medidas de seguridad no privativas de libertad}

Tras estudiar la concurrencia de las medidas de seguridad privativas de libertad y la pena de privación del derecho a conducir, a continuación, se analizarán las medidas de seguridad no privativas de libertad que pueden aplicarse de forma conjunta con la pena estudiada a los sujetos en los que concurre la eximente incompleta de los arts.20.1, 2 y $3 \mathrm{CP}$ en la comisión de algún delito que conlleva la pena de privación del derecho a conducir. En cuanto a la forma en la que se pueden acordar estas medidas no privativas de libertad, puede ser bien de forma directa bien como sustitutivas de otra medida ex art.97 CP. Nos centraremos en la aplicación acumulativa de la inhabilitación profesional, la medida de libertad vigilada y la medida de privación del derecho a conducir que son las que pueden tener relación

\footnotetext{
1137 Vid. STS, núm. 723/2000, Sala Segunda, de 27 de abril de 2000, ponente Excmo. Sr. Luis Román Puerta (EDJ 2000/9207).

1138 Vid. AYO FERNÁNDEZ, Manuel, Las penas..., op.cit., p.240.

1139 Vid. GARCÍA ALBERO, Ramón; "De las medidas de seguridad", en AA.VV. Comentarios..., QUINTERO OLIVARES, Gonzalo (Dir.), MORALES PRATS, Fermín (Coord.), op.cit, p.650.
} 
con la seguridad vial en aras a determinar cómo se aplican de forma conjunta con la pena de privación del derecho a conducir ${ }^{1140}$.

\section{a) La inhabilitación profesional}

Una de las medidas de seguridad no privativas de libertad que prevé el CP en el art.96.3.1 es la inhabilitación profesional y hemos de valorar si puede ser impuesta juntamente con la pena de privación del derecho a conducir. En principio dicha medida de seguridad no podrá ser impuesta a los semiimputables, ya que no es una medida de seguridad de las reguladas en el art.105 CP, esto es, ni libertad vigilada, ni custodia familiar, ni privación del derecho a la tenencia y porte de armas, ni privación del derecho a conducir. No obstante, algunos sectores doctrinales mantienen que sí podría acordarse la medida de seguridad de inhabilitación profesional para los declarados semiimputables ${ }^{1141}$, pero de forma indirecta como mecanismo que sustituya al internamiento. Ello podría suceder cuando al amparo de lo establecido en el art. $99 \mathrm{CP}$, se remite a las medidas no privativas de libertad del art. 96.3 CP entre las hallamos tipificada en el apartado $1^{\circ}$ ) la medida de inhabilitación profesional. Cuando esta situación se produzca, podríamos hallarnos ante el único caso que sí podría concurrir la medida de seguridad de inhabilitación profesional con la pena de privación del derecho a conducir. En tal caso, la medida de seguridad de inhabilitación profesional a semiimputables, podría ser aplicable a conductores profesionales (taxistas, camioneros, conductores de autobuses, repartidores, etc.), que hubiesen cometido un delito que conlleve la pena de privación del derecho a conducir. En estos casos, existiendo en el CP la pena de inhabilitación profesional, entiendo que carece de sentido la imposición de la medida de seguridad de inhabilitación profesional ya que ambas tienen un contenido similar1142. Por último, hemos de destacar que no hemos localizado ninguna resolución que aplique conjuntamente la medida de seguridad de inhabilitación profesional y la pena de privación del derecho a conducir.

\footnotetext{
1140 Sobre la aplicación conjunta de penas y medidas de seguridad, vid. TAPIA BALLESTEROS, Patricia "Las medidas de seguridad. Reforma más recientes y últimas propuestas", Revista Jurídica de Castilla y León, núm. 32, Enero de 2014, pp.15-16.

1141 Vid. LEAL MEDINA, Julio, Un Estudio..., op.cit., p.418, quien mantiene que "teóricamente" sí se puede imponer a semiimputables ex.art.99 y $96.3 \mathrm{CP}$.

1142 Vid. AYO FERNÁNDEZ, Manuel, Las penas..., op.cit., p.248 y RUBIO LARA, Pedro Ángel, Las medidas..., op.cit., p.74.
} 


\section{b) La libertad vigilada}

En el grupo de las medidas de seguridad no privativas de libertad, analizaremos si es posible la aplicación conjunta de la pena de privación del derecho a conducir con la medida de seguridad de libertad vigilada. En primer lugar, determinaremos en qué supuestos es posible que impongan de forma acumulativa ambas sanciones penales y posteriormente definir qué medidas de las que integran la libertad vigilada se pueden imponer de forma conjunta con la pena analizada en el presente trabajo.

Los supuestos de hecho en los que se pueden imponer ambas sanciones penales son dos. El primero es cuando se condena a un sujeto imputable por homicidio por imprudencia grave o menos grave, la conducta se ha realizado con un vehículo a motor o ciclomotor y se impone la pena de privación del derecho a conducir. Tras la entrada en vigor de la LO $1 / 2015$ de 30 de marzo, el art.140 bis ${ }^{1143}$ CP faculta al juez o Tribunal para imponer en estos dos casos además de las penas correspondientes, entre las que se encuentra la pena de privación del derecho a conducir, la medida de seguridad de libertad vigilada ${ }^{1144}$. El segundo supuesto en el que se puede aplicar de forma conjunta la pena de privación del derecho a conducir y la libertad vigilada, es el de los penados en los que concurre la eximente incompleta de los arts.20.1, 2 y 3 CP en la comisión de algún delito que conlleva la pena de privación del derecho a conducir. Si se acumulan ambos requisitos, como establece el art. $104 \mathrm{CP}$, en los supuestos de eximente incompleta el Juez o Tribunal además de la pena correspondiente, entre las que se incluye la pena de privación del derecho a conducir, puede imponer alguna de las medidas de seguridad reguladas en los arts.101, 102 y 103 CP. En los arts.101, 102 y 103, además se indica que: "...se le podrá aplicar...cualquier otra de las medidas previstas en el apartado 3 del artículo 96...". Es aquí donde podemos hacer referencia a la libertad vigilada, ya que esta medida de seguridad forma parte del grupo de medidas reguladas en el art.96.3 CP. Por ello estimo que en estos casos sí pueden aplicarse de forma acumulativa la pena de privación del derecho a conducir y la medida de seguridad de libertad vigilada ${ }^{1145}$.

\footnotetext{
1143 Art.140 bis CP: A los condenados por la comisión de uno o más delitos comprendidos en este Título se les podrá imponer además una medida de libertad vigilada.

1144 La posibilidad existente en el CP tras la reforma operada por la LO 1/2015 de 30 de marzo de concurrencia de la libertad vigilada junto a las penas en los delitos de homicidio imprudente ha sido considerada como: "torpeza", "grotesco" y "disparatado", por parte de la doctrina. Vid. SUÁREZMIRA RODRÍGUEZ, Carlos, "Del homicidio y sus formas", Comentarios..., GONZÁLEZ CUSSAC, José.L (Dir.), MATALLÍN EVANGELIO, Ángela/ GÓRRIZ ROYO, Elena (Coords.), op.cit., 481-482.

1145 Respecto del cumplimiento de las penas no privativas de libertad y la medida no privativa de libertad, vid. RUBIO LARA, Pedro Ángel, Teoría de la pena..., op.cit., pp. 202-203.
} 
Del grupo de medidas que conforman la libertad vigilada, detalladas en el art.106 $\mathrm{CP}$, destacamos las reguladas en las letras j) y k $)^{1146}$. El apartado j) se refiere a la obligación de participar en programas formativos, lo que podría llevar a incluir programas formativos en materia de seguridad vial que sean complementarios a los que han de realizar todos los penados a los que se les impone la pena de privación del derecho a conducir, de sensibilización y reeducación vial, que pueden coadyuvar a evitar la reincidencia como ha señalado RUBIO LARA ${ }^{1147}$. Respecto a las medidas del art.106. k), esto es, la obligación de seguir tratamiento médico externo o de someterse a un control médico periódico, pueden ser aplicables a los penados a quienes se haya apreciado la eximente incompleta del art.20.1 relacionada con anomalía o alteración psíquica, y se imponga la medida de seguridad de seguir tratamiento médico externo para la enfermedad psíquica que padezca $^{1148}$. Si se ha cometido algún delito en los que intervenga el consumo de alcohol, drogas tóxicas o sustancias estupefacientes como podrían ser los regulados en el art.379.2 $\mathrm{CP}$, sería adecuado que en los casos que se pueda imponer la medida de seguridad, el penado sea sometido a tratamiento médico externo o someterse a un control médico periódico, para controlar la ingesta de alcohol, drogas tóxicas o estupefacientes, como se ha considerado en diversas sentencias $^{1149}$. Esta medida, en el mismo sentido que la regulada en el apartado j) del art.106 CP, puede ser positiva para evitar la reiteración delictiva y para favorecer la reinserción del penado que ha podido cometer el delito debido a su adicción a determinadas sustancias ${ }^{1150}$.

\footnotetext{
1146 Art.106.1 CP: j) La obligación de participar en programas formativos, laborales, culturales, de educación sexual u otros similares. K) La obligación de seguir tratamiento médico externo, o de someterse a un control periódico. Vid. la referencia a las mismas en RUBIO LARA, Pedro Ángel, Teoría de la pena..., op.cit., p.191.

1147 En relación con su finalidad para evitar la reincidencia vid. RUBIO LARA, Pedro Ángel, Las medidas..., op.cit., p.85.

1148 En este sentido vid. SAP de Valencia, núm.189/2009 de 25 de marzo de 2009, ponente Ilma. Sra.Regina Marrades Gómez (JUR\2009\260253) y SAP de Valencia, núm.473/2013, Sección 3å de 3 de julio de 2013, ponente Ilmo.Sr. Lamberto Juan Rodríguez Martínez (JUR\2013\279983).

1149 Un ejemplo de la interacción entre la pena de privación del derecho a conducir, y la medida de seguridad de libertad vigilada con la obligación de seguir tratamiento médico de deshabituación al alcohol, lo tenemos en la SAP de Murcia núm.277/2011, Sección 5ạ, de 27 de octubre de 2011, ponente Ilmo.Sr. Fernando J. Fernández-Espinar López (JURl2011\401307) y también en la SAP de Pontevedra, núm. 156/2014, Sección 4ạa, de 18 de septiembre de 2014, ponente Ilma.Sra. María Cristina Navares Villar (TOL4.523.050).
}

1150 Vid. RUBIO LARA, Pedro Ángel, Las medidas..., op.cit., p.85. 


\section{c) La medida consistente en la privación del derecho a conducir vehículos a motor y ciclomotores}

Del grupo de medidas de seguridad no privativas de libertad, es destacable que junto a la pena de privación del derecho a conducir formalmente se puede imponer también la medida de seguridad que priva del mismo derecho ${ }^{1151}$. A los conductores que sean declarados inimputables, únicamente se les podrá imponer la medida de seguridad de privación del derecho a conducir y no podrán ser condenados a la pena que priva del mismo derecho, debido a que estarán exentos de responsabilidad criminal ${ }^{1152}$. Sin embargo, cuando se haya declarado semiimputable al autor de los hechos, al amparo de los arts.99 y 104 CP sería posible la aplicación conjunta de la pena de privación del derecho a conducir y la medida de seguridad que priva del mismo derecho, aunque no se ha localizado ninguna sentencia que imponga ambas sanciones penales a la vez.

Aun cuando formalmente se pueda imponer conjuntamente la pena y la medida de seguridad de privación del derecho a conducir, algunos autores sostienen ${ }^{1153}$ que carece de sentido el cumplimiento de ambas de forma conjunta e incluso dicha posibilidad ha sido calificada por sectores doctrinales como una "hipótesis absurda"1154. En el mismo sentido GARCíA ALBERO ${ }^{1155}$ mantiene que la posibilidad que los penados semiimputables, puedan ser condenados a la privación del derecho a conducir de forma conjunta a través de la pena y la medida de seguridad no es posible. Por ello estimo que no sería procedente la acumulación de las dos sanciones al tener un contenido material idéntico ya que la pena y de la medida de seguridad de privación del derecho a conducir persiguen el mismo fin: que el penado no origine nuevos riesgos para la circulación ${ }^{1156}$. Debido a la identidad del contenido de la pena de privación del derecho a conducir y la medida de seguridad

\footnotetext{
1151 En relación con esta posibilidad vid. TAMARIT SUMALLA, Josep/ LUQUE REINA, Ma Eulàlia, Automóviles, delitos y penas..., op.cit., p.137.

1152 El contenido de la pena y medida de seguridad de privación del derecho a conducir es similar, aunque el fundamento y régimen de aplicación de ambas es claramente diferente. Respecto a la similitud entre medidas de seguridad y penas privativas de derechos vid. MUÑOZ CONDE, Francisco/GARCÍA ARÁN, Mercedes, Derecho..., op.cit., p.587.

1153 Vid. TRAPERO BARREALES, María.A., Los delitos..., op.cit., p.580.

1154 Vid. TAMARIT SUMALLA, Josep/ LUQUE REINA, Mํㅡㄹ Eulàlia, Automóviles, delitos y penas..., op.cit., p.137.

1155 Vid. GARCÍA ALBERO, Ramón; "De las medidas de seguridad", en AA.VV. Comentarios..., QUINTERO OLIVARES, Gonzalo (Dir.), MORALES PRATS, Fermín (Coord.), op.cit., pp.678-679.

1156 La similitud entre la pena de privación del derecho a conducir y la medida de seguridad de prohibición de conducir ya fue destacada por TRAPERO BARREALES, María.A., Los delitos..., op.cit., p. 575.
} 
del mismo nombre, cuando ambas se aplican de forma conjunta incluso podríamos considerar que puede vulnerarse el principio de proporcionalidad ${ }^{1157}$. Si esta posibilidad teórica se materializase, podría suceder que los penados declarados semiimputables debido a problemas psíquicos o a su dependencia a determinadas sustancias, se vieran más perjudicados penalmente que los totalmente inimputables o bien aquellos que son imputables, al no apreciar en ellos ni tan siquiera una eximente incompleta. La prevención de futuros delitos, así como la protección de la seguridad vial y la vida e integridad física y psíquica de las personas considero que se puede alcanzar con la imposición en estos casos bien de la pena o bien de la medida de privación del derecho a conducir, pero no de ambas de forma conjunta.

\subsection{La pena de privación del derecho a conducir y el decomiso}

El último apartado del capítulo está dedicado a la consecuencia accesoria del decomiso cuando se aplica de forma conjunta con la pena de privación del derecho a conducir ${ }^{1158}$. He considerado necesario estudiar el decomiso, ya que, a pesar de tener repercusiones importantes para el penado dado la pérdida de la propiedad del vehículo a motor o ciclomotor, no se le ha prestado hasta el momento en el ámbito doctrinal la atención que probablemente merece ${ }^{1159}$. El decomiso que se analizará en este epígrafe está relacionado con los instrumentos con los que se comete el delito que genera la pena de privación del derecho a conducir: el vehículo a motor o el ciclomotor.

\subsubsection{Marco normativo y ámbito de aplicación}

La primera cuestión a determinar es el marco normativo que regula el decomiso del vehículo a motor y ciclomotor, para definir posteriormente los supuestos en los que procede su imposición. La regulación legal del decomiso la hallamos en los arts.127

\footnotetext{
1157 En relación con el principio de proporcionalidad, vid. AGUADO CORREA, Teresa, El principio..., op.cit., pp.147-148.

1158 Referente al concepto de consecuencia accesoria, como es el decomiso, vid. CORDERO LOZANO, Carlos, Ejecución..., op.cit., p.187.

1159 El escaso desarrollo doctrinal y jurisprudencial del decomiso de vehículos a motor o ciclomotores, se ha puesto de manifiesto en la SAP de Zaragoza, núm.185/2013. Sección 6ª , de 12 de junio de 2013, ponente IImo.Sr. Rubén Blasco Obede (JUR 2013/235088).
} 
y $128 \mathrm{CP}$, tipificados en el Título VI del CP, en el que se especifican las consecuencias accesorias ${ }^{1160}$.

Históricamente la aplicación del decomiso a los vehículos a motor y ciclomotores ha sido reducida ${ }^{1161}$ y el legislador dio un primer paso para aumentar su imposición en los delitos contra la seguridad vial con la aprobación de la LO 15/2007 de 30 de noviembre de reforma del CP, al introducir en su apartado 381.3 la posibilidad que el vehículo fuera considerado instrumento del delito a los efectos de lo preceptuado en los arts.127 y $128 \mathrm{CP}^{1162}$. A pesar de que la voluntas legislatoris fue incrementar el uso del decomiso en los delitos relacionados con la seguridad vial, ciertos sectores doctrinales consideraron que la reforma quedó huérfana al no poder acordar el decomiso en el resto de delitos ya que la previsión legal para su imposición únicamente alcanzaba al art. 381, que era el tipo penal que expresamente había previsto el legislador ${ }^{1163}$. El criterio de la Fiscalía en relación con esta consecuencia accesoria empezó a cambiar en el año 2008 al mostrarse favorable a acordar el decomiso en todos los delitos relacionados con la seguridad vial y, por ende, a una mayor aplicación con la pena de privación del derecho a conducir $^{1164}$, iniciándose un debate que fue la génesis de la reforma del CP del año 2010.

\footnotetext{
1160 Sobre el decomiso como consecuencia accesoria y su evolución en los últimos veinte años vid. PLANCHADELL GARGALLO, Andrea/ VIDALES RODRíGUEZ, Caty, "Decomiso: comentario crítico desde una perspectiva constitucional", Estudios penales y criminológicos, Vol. XXXVIII, 2018, Universidad Santiago de Compostela, pp.44-46.

1161 En relación con la escasa aplicación que históricamente ha tenido el decomiso de vehículos, vid. TAMARIT SUMALLA, Josep/ LUQUE REINA, Mํㅡㄹ Eulàlia, Automóviles, delitos y penas..., op.cit.144 y también MARTÍNEZ ZAPATER, Luis Fernando, "Los delitos contra la seguridad vial, arts.379, 381, 384, 385 bis y 385 ter", en AA.VV. La reforma..., op.cit., p.322.

1162 Art.381.3 CP según redacción dada por la LO 15/2007: El vehículo a motor o ciclomotor utilizado en los hechos previstos en el presente precepto se considerará instrumento del delito a los efectos del artículo 127 de este Código.

Puede verse el texto completo en: http://www.boe.es/boe/dias/2007/12/01/pdfs/A49505-49509.pdf (último acceso: 13/11/2020).

1163 Respecto a la posibilidad de aplicación del decomiso tras la reforma de la LO 5/2007, vid. GUTIÉRREZ RODRÍGUEZ, María "Excesos de velocidad e intoxicaciones punibles", en AA.VV. Protección Penal... op.cit., p. 129 y VIZUETA FERNÁNDEZ, Jorge, "Delitos contra la seguridad vial. El comiso del vehículo de motor o ciclomotor antes y después de la LO 5/2010 de Reforma del Código Penal", Revista Electrónica de Ciencia Penal y Criminología (RECPC), 13-02, (2011), pp.1213. Recurso electrónico disponible en: http://criminet.ugr.es/recpc/13/recpc13-02.pdf (último acceso: 05/11/2020).

1164 En relación con la postura de la Fiscalía, vid. DE VICENTE MARTíNEZ, Rosario, "El comiso del vehículo a motor y los delitos cometidos en el contexto de la circulación Vial", Actualidad Jurídica Aranzadi, 798. 2010.
} 
La consecuencia que el decomiso en el ámbito de la seguridad vial no tuviera un correcto desarrollo es que el legislador a través de la LO 5/2010 de 22 de junio tuvo la necesidad de regularlo, mediante un nuevo precepto específico: el art.385 bis $\mathrm{CP}^{1165}$. Este artículo, haciendo referencia los genéricos arts.127 y $128 \mathrm{CP}$, está en el Capítulo IV, del Título XVII, insertado específicamente en los delitos contra la seguridad vial, con la finalidad de clarificar y facilitar una mayor utilización del decomiso del vehículo a motor o ciclomotor. Con la regulación de los arts.127 y 128 CP, vigente antes de la reforma operada por la LO 5/2010 de 22 de junio que introdujo el art.385 bis CP, la jurisprudencia había determinado que era posible aplicar el decomiso del vehículo a motor o ciclomotor en todos los delitos dolosos cometidos contra la seguridad vial ${ }^{1166}$. En el mismo sentido, sectores doctrinales han considerado que existía base jurídica suficiente para proceder al decomiso del vehículo a motor o ciclomotor sin el art.385 bis $\mathrm{CP}$, calificándolo como un artículo "innecesario"1167. Una muestra de ello es que la Fiscalía de Seguridad Vial reconoce que el art.127.2 CP faculta el decomiso del vehículo en los delitos de homicidio y lesiones por imprudencia ex art.142.1 y 152.1. $2^{\circ}$ y $3^{\circ}$, que no son delitos del capítulo contra la seguridad vial y no se les aplica el art.385 bis ${ }^{1168}$. Nada obsta que al amparo del art.127.2 $\mathrm{CP}^{1169}$ se pueda acordar también el decomiso del vehículo en delitos que no son dolosos, sino que se cometen por imprudencia ${ }^{1170}$. En estos

\footnotetext{
1165 El vehículo a motor o ciclomotor utilizado en los hechos previstos en este Capítulo se considerará instrumento del delito a los efectos de los artículos 127 y 128.

1166 Vid. la SAP de Álava, núm. 43/2009, Sección 2a ${ }^{a}$, de 12 de febrero de 2009, ponente IImo. Sr. Jesús Alfonso Poncela García (TOL1.568.988), SAP de Pontevedra, núm. 153/2009, Sección 2ª , de 30 de junio de 2009, ponente Ilma. Sra. María del Rosario Cimadevila Cea. (TOL1.631.564).
}

1167 Acerca de la innecesariedad del art.385 bis vid. la opinión de MARTíNEZ ZAPATER, Luis Fernando, "Los delitos contra la seguridad vial, arts.379, 381, 384, 385 bis y 385 ter", en AA.VV. La reforma..., op.cit., p.323 y también VIZUETA FERNÁNDEZ, Jorge, "Delitos contra...", op.cit., pp.2223.

1168 Vid. la Circular 10/2011 de la FGE "Sobre criterios para la unidad de actuación especializada del Ministerio Fiscal en materia de seguridad vial", pp.77-78, y también RUIZ DE ERENCHUN ARTECHE, Eduardo/SÁNCHEZ-OSTIZ GUTIÉRREZ, Pablo, "El comiso", en AA.VV. El nuevo Código Penal: Comentarios a la Reforma, SILVA SÁNCHEZ, Jesús-María (Dir.), PASTOR MUÑOZ, Nuria (Coord.), Ed. La Ley, Las Rozas (Madrid), 2012, pp.215-216.

1169 Art.127.2 CP: En los casos en que la ley prevea la imposición de una pena privativa de libertad superior a un año por la comisión de un delito imprudente, el Juez o Tribunal podrá acordar la pérdida de los efectos que provengan del mismo y de los bienes, medios o instrumentos con que se haya preparado o ejecutado, así como las ganancias provenientes del delito, cualquiera que sean las transformaciones que hubieran podido experimentar.

1170 En relación con la posibilidad de aplicar el decomiso a los delitos imprudentes, vid. GRACIA MARTíN, Luis, "Consecuencias jurídicas no penales derivadas de la comisión del delito (I) las consecuencias accesorias generales y las específicas para personas jurídicas y entidades sin personalidad jurídica", en AA.VV. Lecciones de consecuencias jurídicas del delito: el sistema de penas, de medidas de seguridad, de consecuencias accesorias y de responsabilidad civil derivada del delito, GRACIA MARTÍN, Luis (Coord.)/ BOLDOVA PASAMAR, Miguel Ángel/ ALASTUEY 
supuestos se puede imponer la pena de privación del derecho a conducir, por lo que serán dos casos relacionados con la circulación de vehículos a motor o ciclomotores cometidos por imprudencia grave en los que la consecuencia accesoria y la pena pueden aplicarse de forma conjunta.

A pesar de las reformas realizadas en los años 2007 y 2010, el uso del decomiso fue escaso. Así, por ejemplo, la Fiscalía de la Comunidad Foral de Navarra en su Memoria del año $2013^{1171}$ destacó la escasa aplicación de esta consecuencia accesoria ya que en el año 2012 únicamente se dictó una sentencia acordando el decomiso del vehículo en la Comunidad Foral de Navarra. Sin embargo, VIZUETA FERNÁNDEZ ${ }^{1172}$, considera que, debido a las reformas legislativas operadas, los juzgados han sido más proclives a utilizarlo al poderse acordar en todos los delitos contra la seguridad vial. En la actualidad, el decomiso del vehículo a motor o ciclomotor puede adoptarse conjuntamente con la pena de privación del derecho a conducir en los hechos que sean constitutivos de delito del art.379, 380, 381, 382 bis y del art.383 CP, ya que todos acarrean la pena de privación del derecho a conducir $^{1173}$. Asimismo, en los delitos contra la vida e integridad física y psíquica de las personas podría acordarse el decomiso en los arts.142.1 y $152.1 \mathrm{CP}$, ya que puede tener un papel importante desde la perspectiva de la víctima del delito, al ser el instrumento con el que se ha producido un homicidio o unas lesiones graves ${ }^{1174}$. Sin embargo, en los delitos de los arts.142.2 y 152.2 de homicidio y lesiones por imprudencia menos grave causadas con vehículo a motor incorporados en el CP tras la LO 1/2015 de 30 de marzo de reforma del CP, estimo que formalmente no existe óbice para que también se pueda acordar el decomiso del vehículo a motor o ciclomotor en ambos casos, aunque después de cinco años de la entrada en vigor de dichos delitos no hemos localizado ninguna resolución en la que se haya acordado el decomiso del vehículo a motor o ciclomotor.

DOBÓN, M.Carmen, Ed. Tirant lo Blanch, Valencia 2012, 4ª edición, p.208, y MOLINA FERNÁNDEZ, Fernando, Delitos..., op.cit., p.28.

1171 Vid. Memoria del año 2013 (ejercicio 2012) de la Fiscalía de la Comunidad Foral de Navarra, p.100.

1172 Con relación a la mayor aplicación del decomiso en los últimos años, vid. VIZUETA FERNÁNDEZ, Jorge, "Delitos contra...", op.cit., p.9

1173 Respecto al ámbito de aplicación del decomiso en los delitos contra la seguridad vial, vid. SERRANO MAÍLLO, Alfonso, "El artículo 385 bis del Código Penal y el vehículo a motor como instrumento del delito", AA.VV. El delito de conducción de vehículos a motor o ciclomotores sin licencia administrativa cometido por menores de edad, MORILLAS FERNÁNDEZ, David Lorenzo (Coordinador), Ed. Dykinson, Madrid, 2018, pp.313-314. 
Tras fijar el marco normativo y el ámbito de aplicación, detallaremos los requisitos necesarios para acordar el decomiso cuando puede concurrir con la pena de privación del derecho a conducir. La Fiscalía ha determinado unos parámetros para ser aplicados por los cuerpos y fuerzas policiales en relación con la intervención policial del vehículo y que son similares a los que se aplicarán al decomiso en el ámbito judicial ${ }^{1175}$. Debido a las graves consecuencias que se derivan del decomiso del vehículo a motor o ciclomotor, debería reservarse para los supuestos de mayor gravedad y reiteración delictiva ${ }^{1176}$, atendiendo al principio de la proporcionalidad que ha de guiar el criterio judicial para la adopción del decomiso, ya que siempre ha de existir proporcionalidad entre el delito cometido y la consecuencia accesoria ${ }^{1177}$.

La aplicación de la consecuencia accesoria del decomiso es facultativa ${ }^{1178}$, a diferencia de la pena de privación del derecho a conducir que en la mayoría de los delitos en los que está prevista se impone de forma preceptiva. Esta característica de discrecionalidad en la adopción del decomiso del vehículo por parte del juzgador, evita el automatismo y permite valorar cuando es necesaria su adopción para evitar la reiteración delictiva, atendiendo también a la gravedad de los hechos acaecidos ${ }^{1179}$. Además, para que los Juzgados y Tribunales puedan adoptar la consecuencia accesoria del decomiso, éste ha de ser peticionado por la acusación.

1174 Vid. ESTRELLA RUIZ, Manuel,"La reforma de los delitos contra la seguridad vial y especial referencia al comiso del vehículo", Revista de Jurisprudencia, El Derecho, no 2, 1 de octubre de 2012.

1175 En este sentido podemos citar el Decreto del Fiscal Superior de la Comunidad Autónoma del País Vasco, sobre intervención Policial de vehículos en atestado por delitos contra la seguridad vial, de 19 de abril de 2011, al que se hace referencia en la en la Memoria de la Fiscalía del País Vasco del año 2011, p.84.

Recurso electrónico disponible en:

https://www.justizia.eus/servlet/Satellite?blobcol=urldata\&blobheader=application\%2Fpdf\&blobheader name $1=$ Content -

Disposition\&blobheadervalue1=filename\%3DMEMORIA FISCALIA PAIS VASCO 2011 PDF.pdf\& blobkey=id\&blobtable=MungoBlobs\&blobwhere $=1290510244008 \&$ ssbinary=true (último acceso: 05/11/2020).

1176 En referencia a los requisitos de aplicación del decomiso, vid. la Instrucción 1/2011 de la Fiscalía Provincial de Madrid, "Sobre algunas cuestiones en materia de seguridad vial", p.8, así como en el ámbito doctrinal vid. PAREDES PORRO, Miguel Ángel, Tratamiento..., op.cit., p.220.

1177 El principio de la proporcionalidad en la adopción del decomiso del vehículo, ha sido destacado por, VIZUETA FERNÁNDEZ, Jorge, "Delitos contra...", op.cit., pp.24-28.

1178 La discrecionalidad de la consecuencia accesoria del decomiso ha sido destacada por PAREDES PORRO, Miguel Ángel, Tratamiento..., op.cit., p.220 así como por HIDALGO DE MORILLO JIMÉNEZ, Agustín, "Aspectos comunes a los delitos contra la seguridad vial", La dogmática penal..., op.cit., p.48.

1179 En relación con la discrecionalidad judicial para la aplicación del decomiso del vehículo, vid. MAGRO SERVET, Vicente, "La pena de comiso del vehículo de motor y ciclomotores en los delitos contra la seguridad del tráfico tras la Ley Orgánica 5/2010", Tráfico y Seguridad Vial, no 146, 2011, pp.17-24. 
De no producirse expresamente dicha petición, los Juzgados no podrán acordarla de oficio ${ }^{1180}$, en contraposición a lo que sucede con la mayoría los delitos que conllevan la pena de privación del derecho a conducir que se caracteriza por su carácter imperativo o con los efectos del art.47.3 CP que se acuerdan ex lege.

Otro requisito para acordar el decomiso está relacionado con la peligrosidad que puede generar el vehículo a motor o ciclomotor ${ }^{1181}$, pero debido a su carácter genérico es de difícil valoración al no ser sencillo acreditar la peligrosidad del vehículo a motor o ciclomotor. Este criterio relaciona la peligrosidad del vehículo con su posible utilización por parte del penado como factores que puedan generar un riesgo para la seguridad vial y puedan coadyuvar a la adopción del decomiso. Por las dificultades planteadas, considero que no es un criterio ni objetivo ni útil que pueda servir para la adopción del decomiso del vehículo a motor o ciclomotor. En la misma línea debería excluirse como parámetro para acordar un ulterior decomiso el hecho que se haya acordado durante la instrucción del procedimiento la intervención judicial del vehículo. El motivo es que la normativa procesal penal no regula la posibilidad de un decomiso temporal del vehículo, por lo que la intervención judicial del vehículo es una medida judicial de distinta naturaleza y no puede servir como fundamento para la adopción del decomiso del vehículo a motor o ciclomotor ${ }^{1182}$. La diferencia radica, tal como ha señalado ROCA AGAPITO ${ }^{1183}$, en que el decomiso del vehículo a motor o ciclomotor únicamente puede ser adoptado en sentencia firme, mientras que las medidas cautelares al ser de carácter temporal y provisional pueden ser adoptadas en sede de instrucción y sin necesidad de sentencia condenatoria, por lo que la naturaleza y finalidad de ambas no es equiparable.

El decomiso del vehículo a motor o ciclomotor se podrá acordar respecto de los vehículos cuyo propietario carezca del permiso o licencia, ya que ambas situaciones no han de estar vinculadas, al derivar el decomiso del delito cometido y no de la

1180 En relación con los requisitos para que el decomiso sea acordado en cuanto a la petición de parte, vid. RíOS MARTíN, Julián Carlos/ SEGOVIA BERNABÉ, José Luis/ PASCUAL RODRÍGUEZ, Esther, Las penas..., op.cit., p.201; CORDERO LOZANO, Carlos, Ejecución. op.cit., p.196; HURTADO YELO, Juan José, "Los delitos contra la seguridad vial. Análisis de la reforma del Código Penal por LO 5/2010, de 22 de junio", Revista Aranzadi Doctrinal núm. 8/2010, Ed. Aranzadi, 2010 y también ESTRELLA RUIZ, Manuel, "La reforma de los delitos contra la seguridad vial y especial referencia al comiso del vehículo", Revista de Jurisprudencia. El Derecho, ํㅡ 2, 1 de octubre de 2012.

1181 Vid. VIZUETA FERNÁNDEZ, Jorge, "Delitos contra...", op.cit., pp.23-24.

1182 En este aspecto difiero del criterio que sostiene la Fiscalía Provincial de Madrid, en la Instrucción 1/2011, "Sobre algunas cuestiones en materia de seguridad vial", p.8.

1183 Vid. ROCA AGAPITO, LUIS, El sistema..., op.cit., p.582. 
habilitación del penado para poder conducir el vehículo a motor o ciclomotor. No existe problema alguno en imponer la pena de privación del derecho a conducir a los penados que carezcan del permiso o licencia, por lo que tampoco existe óbice alguno en acordar el comiso del vehículo a motor o ciclomotor propiedad de estos penados que carecen de la autorización para conducir.

Con el fin de orientar la decisión sobre la adopción del decomiso, un criterio a tomar en consideración por parte del tribunal podría ser la imposición de una pena de privación del derecho a conducir superior a los dos años. En estos supuestos podría establecerse como criterio general que la adopción del decomiso estaría justificada a los fines que el mismo persigue, ya que los dos años es el umbral establecido por el legislador en el art.47.3 CP como límite que implica la pérdida del permiso o licencia ${ }^{1184}$. Cuando se activen los efectos del art.47.3 CP significará que existe bien un hecho delictivo con una evidente gravedad o una posible reiteración delictiva, por lo que podría ser un criterio extrapolable para la adopción del decomiso. En estos casos que se acuerde el decomiso del vehículo a motor y ciclomotor, la pérdida definitiva del permiso o licencia por mor del art.47.3 CP y la pena de privación del derecho a conducir, existirá como mínimo una triple respuesta en forma de sanciones penales ante un hecho delictivo de gravedad. Es por ello que estimo que podría ser una solución adecuada a los hechos cometidos y podría coadyuvar al aumento de la eficacia en el cumplimiento de las penas impuestas, especialmente la pena de privación del derecho a conducir ya que el penado no podrá utilizar el vehículo a motor o ciclomotor de su propiedad que habrá sido decomisado.

Una vez se ha determinado el marco normativo y el ámbito de aplicación y los requisitos para la adopción del decomiso del vehículo a motor o ciclomotor cuando se aplica de forma acumulativa a la pena objeto de estudio, detallaremos los fines vinculados a la adopción de estas dos sanciones penales. En primer lugar, a través de la pena de privación del derecho a conducir y del decomiso del vehículo a motor o ciclomotor se reducen las posibilidades que el penado vuelva a conducir y evitar con ello el riesgo de reiteración delictiva ${ }^{1185}$. Ello contribuye a realizar una finalidad asegurativa del correcto cumplimiento de la pena de privación del derecho a

\footnotetext{
1184 Acerca de la excepcionalidad de la aplicación del decomiso, se ha manifestado ESTRELLA RUIZ, Manuel, "La reforma de los delitos contra la seguridad vial y especial referencia al comiso del vehículo", Revista de Jurisprudencia, El Derecho, № 2, 1 de octubre de 2012.

1185 En relación con la finalidad del decomiso, vid. MAGRO SERVET, Vicente, "La pena de comiso...", op.cit., pp.17-24 y también HIDALGO DE MORILLO JIMÉNEZ, Agustín, "Aspectos comunes a los delitos contra la seguridad vial", La dogmática penal..., op.cit., p.47. Asimismo, en relación a la finalidad "preventiva e incluso represiva" del comiso vid. AGUADO CORREA, Teresa, EI comiso, Ed. Edersa, Madrid, 2000, p.36.
} 
conducir, ya que tanto el decomiso como la pena de privación del derecho a conducir pretenden impedir que el penado conduzca y utilice el vehículo ${ }^{1186}$. En estos casos, el penado tendrá una mayor dificultad si quiere volver a conducir ${ }^{1187}$, ya que la adquisición de un nuevo vehículo puede suponer una traba económica, sin perjuicio que el mismo sujeto tenga la posibilidad de emplear otros vehículos propios o de terceros (de la empresa, de familiares, etc.). Esta última opción considero que al penado le resultará más compleja ya que los terceros titulares de vehículos probablemente conozcan sus antecedentes delictivos y puede obtener una negativa en la cesión del vehículo a motor o ciclomotor. La finalidad asegurativa del comiso en estos casos fue destacada en relación con el art.468 CP cuando éste sancionaba con anterioridad al año 2007 los quebrantamientos de condena relacionados con la pena de privación del derecho a conducir ${ }^{1188}$, y puede trasladarse al art.384 CP que tras la reforma operada por la LO 15/2007 de 30 de noviembre, sanciona los quebrantamientos específicos relacionados con la seguridad vial.

También detectamos en la aplicación acumulativa de la pena de privación del derecho a conducir con el decomiso del vehículo a motor o ciclomotor unos fines de prevención especial negativa ${ }^{1189}$, ya que además que el penado estará privado de conducir durante el tiempo de la condena, no podrá utilizar el vehículo con el que cometió el delito. Debido al carácter personalísimo de la pena de privación del derecho a conducir, para que el decomiso del vehículo a motor o ciclomotor surta efectos preventivos cuando interacciona con aquella debe recaer en un vehículo titularidad del penado, ya que éste será el que más fácilmente podrá utilizar. Sin embargo, es evidente que el penado siempre podrá utilizar vehículos de terceros durante el periodo de privación del derecho a conducir, aunque puede tener mayores dificultades para poder hacerlo que con el vehículo que era de su titularidad. Por este motivo y para preservar la finalidad de prevención especial de

\footnotetext{
1186 Esta finalidad conjunta de la pena de privación del derecho a conducir y el decomiso ha sido destacada en la SAP de Zaragoza, núm. 185/2013, Sección 6ª , de 12 de junio de 2013, ponente Ilmo.Sr. Rubén Blasco Obede. (JUR 2013/235088).

1187 Vid. MAGRO SERVET, Vicente, “La pena de comiso...”, op.cit., pp.17-24.

1188 Vid. la opinión de RODRíGUEZ LEÓN, Luis Carlos, Seguridad Vial..., op.cit., p.48.

1189 La finalidad de prevención especial del decomiso del vehículo ha sido destacada en la Instrucción 1/2011 de la Fiscalía Provincial de Madrid, "Sobre algunas cuestiones en materia de seguridad vial', p.8, así como por VALLESPÍN PÉREZ, David, Aspectos procesales..., op.cit., p.91. En relación con la finalidad de prevención especial de la pena de privación del derecho a conducir vid. FARALDO CABANA, Patricia/ PUENTE ABA, Luz María, "Concepto y funciones", en AA.VV. en Las penas..., op.cit., p.31.
} 
ambas sanciones ${ }^{1190}$, deben quedar excluidos del decomiso los vehículos a motor o ciclomotores que sean titularidad de terceros de buena fe, tal como mantienen destacadas posiciones doctrinales ${ }^{1191}$.

Asimismo, cabe señalar que se ha llegado a proponer que el decomiso actúe como un mecanismo alternativo a la pena de prisión, como determinó en su memoria del año 2013 la FGE ${ }^{1192}$. Esta opción como medida penal alternativa junto a la pena de privación del derecho a conducir, puede ser viable cuando atendiendo a las circunstancias del penado sea más coherente sustituir la pena de prisión por el decomiso del vehículo, cumpliendo en todo caso la pena de privación del derecho a conducir que se imponga. Con esta fórmula sustitutiva de aplicación conjunta con la pena de privación del derecho a conducir podría aumentarse la eficacia en el cumplimiento de esta pena, ya que el conductor penado evita la pena de prisión, se verá privado del instrumento delictivo con el que podría quebrantar la pena impuesta y además se puede prevenir la comisión de nuevos delitos relacionados con la seguridad vial ${ }^{1193}$.

\subsubsection{Análisis jurisprudencial}

Para finalizar el estudio de la adopción del decomiso del vehículo a motor o ciclomotor junto con la pena de privación del derecho a conducir, analizaremos diversas resoluciones jurisprudenciales en las que se han aplicado de manera conjunta, tanto con anterioridad a la entrada en vigor del art.385 bis CP, así como con posterioridad, destacando los requisitos para que no se aplique dicha consecuencia accesoria.

La jurisprudencia ha aplicado históricamente el decomiso del vehículo a motor y ciclomotor, tanto con anterioridad a la reforma de LO 15/2007 de 30 de noviembre

\footnotetext{
1190 En relación con la finalidad preventiva especial del comiso vid. AGUADO CORREA, Teresa, El comiso, op.cit., p.41.

1191 Vid. MOLINA BLÁZQUEZ Mํㅡㄹ Concepción, La aplicación..., op.cit., p.174; RÍOS MARTíN, Julián Carlos/ SEGOVIA BERNABÉ, José Luis/ PASCUAL RODRÍGUEZ, Esther, Las penas... op.cit., p.200; ROCA AGAPITO, LUIS, El sistema..., op.cit., pp.587-588 y también GÓMEZ PAVÓN, Pilar, El delito..., op.cit., p. 232.

1192 La opción de utilizar una consecuencia accesoria, como es el decomiso del vehículo a motor, como alternativa a la pena de prisión ha sido valorada positivamente por la FGE en la Memoria del año 2013, p.404.

1193 Estas finalidades preventivas y educativas del decomiso, fueron destacadas por DE VICENTE MARTÍNEZ, Rosario, "El comiso del vehículo a motor y los delitos cometidos en el contexto de la circulación Vial". Actualidad Jurídica Aranzadi, 798. 2010.
} 
como tras la entrada en vigor del art.385 bis CP mediante la LO 5/2010 de 22 de junio. El motivo era que, aun cuando se hiciera referencia al decomiso del vehículo a motor o ciclomotor únicamente en el art.381.3 CP, existían los arts.127 y $128 \mathrm{CP}$ que facultaban la imposición de dicha consecuencia accesoria ${ }^{1194}$. Uno de los criterios que ha seguido la jurisprudencia para no aplicar el decomiso, es que el vehículo con el que se ha cometido el delito sea el medio de transporte a través del que se desarrolla la actividad laboral del penado o de su familia ${ }^{1195}$. Otra regla utilizada por la jurisprudencia es que cuando por la acusación no se solicite el decomiso del vehículo, bien el amparo del art. 385 bis CP bien el amparo del art.127 $\mathrm{CP}$, no procederá su adopción de oficio por el Tribunal ${ }^{1196}$. También se ha considerado que no sería procedente la adopción del decomiso cuando el penado carezca de antecedentes delictivos por hechos similares en los que se haya utilizado el vehículo a motor, así como que la conducta al volante no se haya materializado en peligro concreto para la seguridad vial o para la vida o integridad física o psíquica de las personas ${ }^{1197}$. Por último, existen resoluciones jurisprudenciales que han establecido que únicamente es procedente adoptar el decomiso del vehículo a motor o ciclomotor en aquellos casos de gravedad y en los que existan evidencias que las penas impuestas en anteriores condenas han devenido ineficaces ${ }^{1198}$.

De entre los criterios utilizados por la jurisprudencia para acordar el decomiso del vehículo a motor o ciclomotor destacan los siguientes: la finalidad de evitar la comisión de nuevos delitos con el vehículo, la gravedad del hecho, la peligrosidad del sujeto y el juicio de proporcionalidad con el que se valorará todas las

\footnotetext{
1194 Siguiendo este criterio podemos citar la SAP de Álava, núm. 43/2009, Sección 2ª , de 12 de febrero de 2009, ponente Ilmo. Sr. Jesús Alfonso Poncela García (TOL1.568.988).

1195 Vid. SAP de Tenerife, núm. 113/2013, Sección 2ª , de 15 de marzo de 2013, ponente Ilmo. Sr. Fernando Paredes Sánchez (TOL3.723.701), en la que se deniega la aplicación del decomiso a la furgoneta con la que se transporta fruta y es el medio de vida del penado y la SAP de Barcelona, núm. 312/2016, Sección 7ª̣, de 6 de mayo de 2016, ponente llma. Sra. Ana Rodríguez Santamaría (TOL5.967.640), en la que se deniega la aplicación del comiso ya que la mujer del acusado utilizado el vehículo para desarrollar su actividad laboral, por lo que de aplicarse el comiso quebraría el juicio de proporcionalidad.

1196 Podemos citar la SAP de Tarragona, núm. 265/2012, Sección 2ª , de 31 de mayo de 2012, ponente Ilmo.Sr. Ángel Martínez Sáez (TOL2.603.186).

1197 Estos criterios han sido descritos en la SAP de Zaragoza, núm.185/2013. Sección 6ª , de 12 de junio de 2013, ponente IImo.Sr. Rubén Blasco Obede (JUR 2013/235088) y en la SAP de Navarra, núm. 39/2017, Sección 2ª a de 27 de febrero de 2017, ponente Ilma. Sra. Raquel Fernandino Nosti (TOL6.151.492).

1198 Vid. SAP de Castellón, núm. 144/2015, Sección 1ª , de 31 de marzo de 2015, ponente llma. Sra. Aurora de Diego González (TOL4.947.304).
} 
circunstancias que coadyuven en cada caso concreto ${ }^{1199}$. Además, la reiteración delictiva por sentencias relacionadas con la seguridad vial también ha sido utilizada por la jurisprudencia para acordar el decomiso del vehículo, atendiendo a la nula eficacia disuasoria que las sentencias dictadas han tenido en el penado ${ }^{1200}$.

Podemos concluir que la consecuencia accesoria del decomiso del vehículo a motor o ciclomotor es aplicable a todos los delitos en los que se pueda imponer la pena de privación del derecho a conducir, y no se acuerda exclusivamente en los delitos contra la seguridad vial como puede desprenderse del redactado del art.385 bis CP. Por todo lo expuesto en el capítulo, estimo que la pena de privación del derecho a conducir es un instrumento indispensable en la actualidad para la prevención de delitos relacionados con la utilización de vehículos a motor y ciclomotores, máxime cuando pueda aplicarse de forma acumulativa a otras penas, medidas de seguridad y consecuencias accesorias ${ }^{1201}$.

\footnotetext{
1199 Pueden comprobarse estos parámetros para la adopción del decomiso en la SAP de Badajoz, núm. 31/2012, Sección 1a a de 1 de marzo de 2012, ponente Ilmo. Sr. José Antonio Patrocinio Polo (TOL2.484.379) y en la SAP de Castellón, núm. 382/2015, Sección $1^{1}$ a de 20 de octubre de 2015, ponente IImo. Sr. Esteban Solaz Solaz (TOL5.742.306).

1200 Vid. SAP de Tarragona, núm. 46/2013, Sección 2ª , de 31 de enero de 2013, ponente llma. Sra. María Concepción Montardit Chica (TOL3.244.378), en la que se confirma el decomiso adoptado, en unos hechos en los que el acusado previamente había sido condenado en cinco ocasiones por delitos relacionados con la seguridad vial. También podemos destacar en la misma línea la SAP de Pontevedra, núm. 593/2015, Sección 5ạ, de 1 de diciembre de 2015, ponente Ilma. Sra. Victoria Eugenia Fariña Conde (TOL5.633.647) y la SAP de Barcelona, núm. 23/2016, Sección 9ạ, de 18 de enero de 2016, ponente IImo. Sr. Julio Hernández Pascual (TOL5.655.233).

1201 Respecto a la justificación de la pena estoy plenamente de acuerdo con VAELLO ESQUERDO con la calificación de instrumento "necesario" e "insustituible", vid. VAELLO ESQUERDO, Esperanza, Las consecuencias..., op.cit., p.18 y también ROCA AGAPITO, LUIS, El sistema..., op.cit., p.73, al señalar que: "la necesidad de la pena parece, hoy por hoy, un principio irrenunciable".
} 


\section{CAPÍTULO 6. PROPUESTAS DE LEGE FERENDA RELATIVAS A LA APLICACIÓN Y LA EJECUCIÓN DE LA PENA DE PRIVACIÓN DEL DERECHO A CONDUCIR}

En el último capítulo del trabajo se realizan diversas propuestas de lege ferenda que tienen como objetivo ampliar y mejorar el ámbito de aplicación de la pena de privación del derecho a conducir y facilitar el régimen de ejecución y el control de su cumplimiento. Nos referiremos en primer lugar a las propuestas de lege ferenda relacionadas con la regulación de la aplicación de la pena de privación del derecho a conducir y en segundo lugar se abordan las relativas a la ejecución. En el primer apartado del capítulo se propone la extensión de la pena analizada en este estudio a otros delitos relacionados con los vehículos a motor y ciclomotores que actualmente no la prevén. En el segundo apartado del capítulo se plantea la posibilidad de aplicar la pena de privación del derecho a conducir a nuevos tipos penales relacionados con la delincuencia vial. También en el ámbito de la regulación, como tercera propuesta de lege ferenda, definiremos la viabilidad de regular la pena que analizamos como pena accesoria, siendo la cuarta propuesta la de extender los efectos del art. 385 ter $\mathrm{CP}$, que sólo están previstos para la pena de prisión, a la pena de privación del derecho a conducir. En los últimos apartados del capítulo también examinamos dos propuestas relacionadas con la ejecución de la pena objeto de estudio. La primera de ellas está vinculada con la inmovilización del vehículo a motor o ciclomotor durante el tiempo de cumplimiento de la pena de privación del derecho a conducir. En segundo lugar, y para finalizar el capítulo, realizamos un examen de dos opciones que en el ámbito de la ejecución no están previstas para la pena que hemos estudiado: la sustitución y la suspensión.

\subsection{Extensión de la aplicación de la pena de privación del derecho a conducir a otros delitos}

En este apartado analizamos la posibilidad de extender la pena de privación del derecho a conducir a tipos delictivos diferentes a los que prevén su aplicación en la actualidad. Algunos autores se han mostrado partidarios de extender el ámbito de aplicación de esta pena, y ya en la década de los ochenta RODRíGUEZ DEVESA ${ }^{1202}$ se mostró favorable a prever la aplicación de la pena de privación del permiso de conducir a todos los delitos cometidos con vehículo a motor y no exclusivamente en los culposos o en los delitos contra la seguridad del tráfico. En la misma línea QUINTERO OLIVARES plantea que las penas privativas de derechos, 
cuando son impuestas como penas principales en delitos como los relacionados con el tráfico vial, "pueden ser las reacciones más adecuadas y menos traumáticas"1203. Se plantean diferentes modificaciones en tipos penales que pueden ser idóneos en los que se pueda imponer la pena de privación del derecho a conducir con el objetivo de reducir la reiteración delictiva y la comisión de delitos relacionados con la utilización de vehículos a motor o ciclomotores. Esta propuesta la realizamos asumiendo que un incremento punitivo en modo alguno ha de ser la fórmula más eficaz para evitar la comisión de delitos ${ }^{1204}$, pero la adopción de las penas adecuadas puede resultar más idónea para evitar la reiteración delictiva que el incremento de la pena de prisión. En este sentido hemos de valorar el gran número de vehículos a motor y ciclomotores que circulan por las carreteras españolas, lo que inexorablemente comporta que se cometan delitos relacionados con la seguridad vial. Por ello, considero en primer lugar, necesario que en nuestro CP se mantenga y potencie la pena que estudiamos y, en segundo lugar, incrementar su presencia en determinados delitos, ya que, a través de su imposición, se puede apartar de forma temporal a los conductores que no respetan las normas viarias.

La mayor utilización de la pena de privación del derecho a conducir está relacionada con la evolución legislativa y la política criminal de seguridad vial que se ha llevado a cabo desde hace más de una década, especialmente tras la LO 15/2007 de 30 de noviembre, que incrementó su aplicación en los delitos del art.379 y la introdujo en el delito del art.383 CP. Así, la modificación realizada en el art.383 CP en el año 2007 pone de relieve que la ampliación del ámbito de aplicación de la pena de privación del derecho a conducir a otros delitos puede ser un proceso lento. Con la aprobación del CP de 1995 el legislador estimó que no era necesario que se pudiera imponer la pena de privación del derecho a conducir en el antiguo art.380 $\mathrm{CP}$ que regulaba la negativa a someterse a las pruebas de alcoholemia establecida ${ }^{1205}$, a pesar de las críticas desde cierto sector de la doctrina que consideraba que sí debía llevar aparejada la pena que analizamos ${ }^{1206}$. Sin embargo,

\footnotetext{
1202 Vid. la referencia al mismo realizada por GÓMEZ PAVÓN, Pilar, El delito..., op.cit., pp. 220-221.

1203 Vid. QUINTERO OLIVARES, Gonzalo, “Las penas privativas de derechos”, Parte General del Derecho Penal, en QUINTERO OLIVARES, Gonzalo/ MORALES PRATS, Fermín (colaborador), Ed. Thomson Reuters-Aranzadi, Cizur Menor (Navarra), 2015, 5ª edición, p. 574.

1204 Referente a este aspecto vid. la referencia a la doctrina citada por VALLESPÍN PÉREZ, David, Aspectos procesales..., op.cit., p.15

1205 Vid. al respecto la referencia de TAMARIT SUMALLA, Josep/ LUQUE REINA, Mª Eulàlia, Automóviles, delitos y penas..., op.cit., p.130.

1206 En este sentido podemos señalar la opinión de DE VICENTE MARTÍNEZ, Rosario, "La reforma penal en curso en materia de siniestralidad vial", en AA.VV. Derecho Penal y Seguridad Vial, DE
} 
con la reforma operada en 2007, se incorporó la pena de privación del derecho a conducir a dicho delito. El art.383 CP sirve como muestra para la propuesta que se realiza de una mayor utilización de la pena de privación del derecho a conducir y su extensión a otros delitos en los que no aparece regulada en la actualidad ${ }^{1207 .}$

Si bien la LO 5/2010 de 22 de junio introdujo reformas relacionadas con la seguridad vial, no se estableció una extensión en el ámbito de aplicación de la pena de privación del derecho a conducir, lo que tampoco sucedió tras la aprobación de la LO $1 / 2015$ de 30 de marzo ${ }^{1208}$. Sin embargo, como hemos destacado con anterioridad, con la entrada en vigor de la LO 2/2019 de 1 de marzo, el legislador ha dotado de mayor importancia a la pena estudiada con la creación de nuevos tipos delictivos que sí prevén su imposición y ha cambiado la tendencia de la política criminal de los últimos años.

Las propuestas que se realizan, en la mayoría de los casos son acordes con el principio de intervención mínima que rige el Derecho Penal y, en algún caso puntual, lo que se propone es elevar a la categoría de delito determinadas infracciones administrativas que considero que pueden tener encaje en la esfera penal y para las que la penan de privación del derecho a conducir sería adecuada, entre otras como puedan ser la pena de multa o la pena de TBC. Por ello, el límite ha de situarse en no trasladar a la esfera penal comportamientos realizados con un vehículo a motor o ciclomotor que tengan una escasa afectación sobre los bienes jurídicos que se protegen en el Código Penal.

\subsubsection{Delitos relacionados con la vida e integridad física y psíquica}

El primer grupo de tipos delictivos en los que se propone introducir la pena de privación del derecho a conducir son los que atentan contra la vida y la integridad

VICENTE MARTínEZ, Rosario (Dir.), Estudios de Derecho Judicial oㅜ 114, Ed. Centro de Documentación Consejo General del Poder Judicial, Madrid, 2007, pp.354-355.

1207 La ampliación de la pena a nuevos delitos, como sucedió con el art.383 CP, puede suponer un acierto con fines de prevención general, al aumentar el conocimiento en la población de la pena de privación del derecho a conducir. En relación con la reforma que se realizó en el art.383 vid. Ibídem, p. 355.

${ }^{1208}$ A pesar de que se crearon los delitos de homicidio y lesiones causadas por imprudencia menos grave de los arts. 142.2 y $152.2 \mathrm{CP}$, que conllevan la pena de privación del derecho a conducir, también se suprimieron las faltas de homicidio y lesiones por imprudencia leve, por lo que no se produjo un aumento en la utilización de dicha pena. En relación con dichas reformas vid. SUÁREZMIRA RODRÍGUEZ, Carlos, "Del homicidio y sus formas", en AA.VV. Comentarios..., GONZÁLEZ CUSSAC, José.L (Dir.), MATALLÍN EVANGELIO, Ángela/ GÓRRIZ ROYO, Elena (Coords), op.cit., pp.481-486 y 493-498. 
física y psíquica de las personas y que han sido cometidos de forma dolosa con un vehículo a motor o ciclomotor. En la actualidad tales delitos no la prevén en su catálogo de penas, pero sería fácilmente justificable su adecuación en la punición de las acciones dolosas cometidas con vehículo a motor y ciclomotor que sean constitutivas de un delito de homicidio del art.138 CP o de lesiones del art.147 CP y ss. CP, en similares términos a lo que el CP prevé para las modalidades imprudentes ${ }^{1209}$. El delito de homicidio del art.138 CP no prevé la pena de privación del derecho a conducir ni como pena principal ni como accesoria en los casos que dicha conducta se ha realizado utilizando un vehículo a motor o ciclomotor ${ }^{1210}$. Tampoco es posible imponer esta pena en los delitos de lesiones de los arts.147 y ss. CP, cuando se haya utilizado para su causación un vehículo a motor o ciclomotor $^{1211}$. La regulación de estos delitos dolosos hemos de compararla con los delitos de homicidio y lesiones que a título de imprudencia grave cometida con vehículo a motor o ciclomotor conllevan de forma imperativa la pena de privación del derecho a conducir. Desde esta perspectiva considero que sería procedente la revisión de los tipos penales dolosos cometidos con vehículo a motor o ciclomotor, para sancionar el desvalor de las acciones cometidas dolosamente con la pena principal de privación del derecho a conducir ${ }^{1212}$.

1209 La no inclusión de la pena de privación del derecho a conducir en los delitos de homicidio doloso utilizando un vehículo a motor o ciclomotor fue destacada por VELASCO NÚÑEZ, Eloy. Vid., "Privación del derecho...", op.cit., p.2.

1210 En este sentido vid. STS, núm. 224/2013 Sala Segunda, de 19 de marzo de 2013, ponente Excmo. Sr. Francisco Monterde Ferrer (TOL3.408.174), en la que se condena a un taxista por tentativa de homicidio, pero no se le impone la pena de privación del derecho a conducir, a pesar de que los hechos se produjeron con el vehículo con el que desarrollaba su actividad laboral. También podemos destacar la STS, núm. 4/2019, Sala Segunda, de 14 de enero de 2019, ponente Excmo. Sr. Miguel Colmenero Menéndez de Luarca (TOL6.999.041), en la que se condena a un transportista profesional por conducción temeraria en concurso con delito de homicidio por dolo eventual cometido con un vehículo a motor y por mor del art. $382 \mathrm{CP}$, al penarse la infracción más grave no se impone la pena de privación del derecho a conducir. En el mismo sentido la STS, núm. 22/2019, Sala Segunda, de 23 de enero de 2019, ponente Excma. Sra. Carmen Lamela Díaz (TOL7.011.653), en la que confirma la sentencia condenatoria por delito doloso de tentativa de homicidio y lesiones dolosas ambos cometidos con vehículo a motor, imponiéndose en ambos pena de prisión para cada uno de ellos, pero no la pena de privación del derecho a conducir. También en un caso de asesinato, podemos citar la STSJ de Castilla La Mancha, núm. 34/2019, Sala de lo Civil y Penal, Sección 1ª , de 18 de octubre de 2019, IImo. Sr. Vicente Manuel Rouco Rodríguez (TOL7.606.822), relativa a un caso de asesinato cometido con vehículo a motor y que no se impone la pena de privación del derecho a conducir por este delito.

1211 Vid. STS, núm. 423/2012 Sala Segunda, de 22 de mayo de 2012, ponente Excmo. Sr. Alberto Gumersindo Jorge Barreiro (TOL2.557.838), STS, núm. 520/2013 Sala Segunda de 19 de junio de 2013, ponente Excmo. Sr. Cándido Conde-Pumpido Tourón (TOL3.791.145), y también la STS núm. 124/2018 Sala Segunda de 15 de marzo de 2018, ponente Excmo. Sr. Andrés Palomo del Arco (TOL6.562.271), en las que se condena por delito de lesiones con instrumento peligroso al ser causadas con vehículo a motor, pero no se impone pena de privación del derecho a conducir.

1212 En este sentido RODRíGUEZ MORO también es partidario de la inclusión de la pena de privación del derecho a conducir en estos tipos delictivos. Vid. RODRÍGUEZ MORO, Luis, "La pena 
El legislador, con la reforma operada por la LO 2/2019 de 1 de marzo de modificación del Código Penal ha intentado paliar este déficit por la vía del art. 382 $\mathrm{CP}$, apartado segundo ${ }^{1213}$, en el sentido de determinar que cuando concurra un resultado lesivo junto con el delito de conducción temeraria del art. $381 \mathrm{CP}$, se impondrá en todo caso la pena de privación del derecho a conducir en la mitad superior. Sin embargo, como crítica hemos de señalar que no en todos los supuestos se podrá acusar de un delito de conducción temeraria, por lo que seguirán existiendo supuestos en los que se causen resultados lesivos con carácter doloso a personas, bien a título de dolo directo o de dolo eventual, en los que no se podrá imponer la pena de privación del derecho a conducir, y ello aun cuando las lesiones hayan sido causadas con vehículo a motor o ciclomotor.

Por otro lado, entre los delitos dolosos a los que se propone extender la pena de privación del derecho a conducir podemos señalar el delito de atentado del art.550.1 en relación con el art.551.3 $\mathrm{CP}^{1214}$, que sancionan las acciones constitutivas de atentado contra agente de la autoridad o funcionario público cuando se cometen con un vehículo a motor o ciclomotor. Estimo que en estas acciones se debería imponer, en todo caso, como pena principal la pena de privación del derecho a conducir cuando se lleven a cabo utilizando un vehículo a motor o ciclomotor. En este tipo delictivo, no se ha valorado en las últimas reformas penales relacionadas con la seguridad vial la posibilidad que se incluyera la pena de privación del derecho a conducir junto a la prisión y la multa. Las reformas del CP operadas a través de la LO 1/2015 de 30 de marzo y LO 2/2019 de 1 de marzo tampoco han determinado de forma explícita en el tipo del art. 551.3 CP que el atentado se pueda realizar con ciclomotores, pero nada obstaría a que éstos fueran incluidos en el apartado $1^{\circ}$ del art.551 CP, ya que la jurisprudencia pacíficamente ha determinado que ambos vehículos han de ser considerados instrumentos peligrosos ${ }^{1215}$. La justificación de incluir la pena de privación del derecho a conducir en estos delitos es por la relación

de privación del derecho a conducir vehículos a motor y ciclomotores" en AA.VV. Las penas..., op.cit., pp.103-104.

1213 Art.382 apartado segundo: Cuando el resultado lesivo concurra con un delito del artículo 381, se impondrá en todo caso la pena de privación del derecho a conducir vehículos a motor y ciclomotores prevista en este precepto en su mitad superior.

1214 Art.551 CP: Se impondrán las penas superiores en grado a las respectivamente previstas en el artículo anterior siempre que el atentado se cometa: $3^{\circ}$ Acometiendo a la autoridad, a su agente $o$ al funcionario público haciendo uso de un vehículo de motor.

1215 Vid. la STS, núm. 841/2010, Sala Segunda de 6 de octubre de 2010, ponente Excmo. Sr. Miguel Colmenero Menéndez de Luarca (TOL1.974.762); STS núm. 79/2010, Sala Segunda, de 3 de febrero de 2010, ponente Excmo. Sr. Manuel Marchena Gómez (TOL1.792.960) o STS, núm. 226/2009 Sala Segunda, de 26 de febrero de 2009, ponente Excmo. Sr. Joaquín Giménez García (TOL1.486.875). 
directa que existe entre el delito y el medio con el que se comete, ya que el autor de los hechos siempre lo realizará empleando como instrumento un vehículo a motor o ciclomotor $^{1216}$. En estos supuestos, será indiferente que el penado posea o no el permiso o licencia pues al privarse del derecho a conducir no podrá obtener tampoco dicho permiso durante el tiempo de la condena.

\subsubsection{Delitos relacionados con la propiedad}

Otro ámbito criminal en el que podría aplicarse la pena de privación del derecho a conducir es el de hurto y robo de uso de vehículos a motor y ciclomotores, cuya regulación en el $\mathrm{CP}$ no prevé que se pueda imponer esta pena privativa de derechos $^{1217}$. Los tipos penales que se detallan en el art.244 CP siempre están relacionados con un vehículo a motor y ciclomotor, motivo por el que estimo que la pena de privación del derecho a conducir sería idónea debido a la relación entre el delito y el instrumento con el que se comete. De hecho, en el CP de 1973 en los tipos penales regulados en el antiguo art.516 bis $\mathrm{CP}^{1218}$ ya se imponía la pena de privación del derecho a conducir de tres meses y un día a cinco años, así como también se imponía la prohibición de obtener el permiso en dicho plazo. Sin embargo, el legislador de 1995 suprimió estas penas y no han sido reintroducidas en las reformas posteriores, a pesar de que ambos puedan ser considerados idóneos para llevar aparejada la pena que analizamos ${ }^{1219}$. Hay que destacar que existían, y existen argumentos contrarios a la imposición de la pena de privación del derecho a conducir en estos tipos delictivos, al mantener que no había una relación directa de la pena con el bien jurídico que protegían ambos tipos penales que era la propiedad ajena del vehículo a motor o ciclomotor ${ }^{1220}$. Sin embargo, en sentido

\footnotetext{
1216 Un ejemplo de atentado contra agente de la autoridad cometido con vehículo a motor y en el que no se impuso la pena de privación del derecho a conducir lo hallamos en la STS núm. 468/2015, Sala Segunda, de 16 de julio de 2015, ponente Excmo. Sr. Andrés Palomo del Arco. (TOL5.390.963).

1217 Vid. FERNÁNDEZ PANTOJA, Pilar, "Delitos contra la seguridad del tráfico: la pena de privación del derecho a conducir", en AA.VV. Delincuencia..., op.cit., p.66.

1218 En relación con la aplicación en dichos tipos penales de la pena de privación del derecho a conducir, vid. STS Sala Segunda, de 13 de julio de 1987, ponente Excmo. Sr. Enrique Ruiz Vadillo, (TOL2.333.797) citada por LUZÓN PEÑA, Diego-Manuel, Derecho Penal de la circulación. Estudio de la jurisprudencia del Tribunal Supremo, Ed. PPU, Barcelona, 1990, 2ª edición, pp.261-263.

1219 Vid. el comentario de TAMARIT SUMALLA, Josep, "De las penas privativas de derechos", en AA.VV. Comentarios al nuevo..., QUINTERO OLIVARES, Gonzalo (Dir.), MORALES PRATS, Fermín (Coord.), op.cit., p.380.

1220 Acerca de la supresión de la pena de privación del derecho a conducir en estos delitos, vid. GANZENMÜLLER ROIG, Carlos/ DE LAMO RUBIO, Jaime/ ROBLEDO VILLAR, Antonio, ESCUDERO MORATALLA, José Francisco y FRIGOLA VALLINA, Joaquín; Delitos..., op.cit., p.398 y
} 
contrario, puede sostenerse que hechos que sean constitutivos de los delitos de hurto y robo de uso de vehículo a motor siempre tendrán relación con vehículos a motor y ciclomotores ya que éstos son los objetos sobre los que se comete el delito $^{1221}$.

Por lo tanto, sería partidario que la pena de privación del derecho a conducir se pudiera introducir en dichos tipos penales puesto que en ambos casos existe una cierta relación entre la acción cometida y la seguridad vial, ya que generalmente, tras la sustracción del vehículo, éste se incorpora al tráfico viario. Ello puede provocar en ocasiones conducciones peligrosas debido a que los autores del delito son sabedores que conducen un vehículo procedente de un delito. En estos casos, así como en aquellos en los que no se haya creado un riesgo concreto para la seguridad vial, considero que la pena debería imponerse en todo caso, ya que se estará accediendo al tráfico viario de una forma ilegal, a través de un vehículo a motor o ciclomotor que ha sido sustraído a su legítimo propietario.

En los delitos contra la propiedad que pueden ser idóneos para la extensión de la pena de privación del derecho a conducir, también se propone el delito de daños tipificado en el art.263 CP cuando se hayan causado con la utilización de un vehículo a motor o ciclomotor ${ }^{1222}$. En los supuestos que se produzca el delito de daños, empleando de forma dolosa un vehículo a motor o ciclomotor para su causación debido a que se habrá utilizado el derecho a conducir de forma contraria a la normativa de seguridad vial propongo de lege ferenda que se contemple como pena principal la privación del derecho a conducir, junto a la pena de multa.

\subsubsection{Delitos formales relacionados con la seguridad vial}

En la propuesta de ampliación a delitos a los que anexar la pena de privación del derecho a conducir se ha optado por agrupar en un tercer bloque una serie de delitos meramente formales relacionados con la seguridad vial que estimo adecuados para que se pueda incluir en ellos la pena analizada.

TAMARIT SUMALLA, Josep/ LUQUE REINA, Maㅡ Eulàlia, Automóviles, delitos y penas... op.cit., pp. 140-141.

1221 Un sector de la doctrina penal española no estuvo de acuerdo con la eliminación de la pena de privación del derecho a conducir en ambos delitos. Vid. SUÁREZ LÓPEZ, José María, El tratamiento penal del hurto y robo de uso de vehículos a motor, Ed. Dykinson, Madrid, 2013, pp.166-167.

$1222 \mathrm{Al}$ respecto también es partidaria de dicha reforma FERNÁNDEZ PANTOJA, Pilar, "Delitos contra la seguridad del tráfico: la pena de privación del derecho a conducir", en AA.VV. Delincuencia..., op.cit., p.66. 
El primer tipo delictivo relacionado con la seguridad vial en el que se propone incluir la pena de privación del derecho a conducir es el art.384 CP, que sanciona todas las conductas relacionadas con los posibles quebrantamientos, conducciones sin puntos y conducción sin haber obtenido nunca el permiso de conducir. El art.384 CP tiene una penalidad basada en la alternatividad de la pena de prisión, multa o TBC, no incluyéndose en ninguna de sus conductas la imposición de la pena de privación del derecho a conducir. Esta circunstancia puede reducir la eficacia preventiva de la norma ${ }^{1223}$, ya que en numerosas ocasiones dicha infracción se castiga con una multa o con TBC, puesto que la pena de prisión se establece de forma alternativa. La modificación de lege ferenda que se propone en el art.384 CP debería seguir la misma estructura que el art.379 CP, debido a que la penalidad alternativa es idéntica en ambos y únicamente debería introducirse también como pena principal la pena de privación del derecho a conducir. Veamos a continuación cuales son las conductas contenidas en el art. $384 \mathrm{CP}$ y los motivos por los que consideramos que la pena de privación del derecho a conducir puede resultar una sanción adecuada a cada una de ellas.

Las dos primeras conductas descritas en el art.384 CP en las que se podría prever la aplicación de la pena de privación del derecho a conducir son, la de conducir sin haber tenido nunca permiso o licencia y la de conducir habiendo perdido la vigencia del permiso o licencia por la pérdida total de puntos. En estos supuestos además de la pena alternativa prevista se propone que se pueda privar al penado del derecho a conducir, ya que ello, unido a la obligatoriedad de realizar el curso para la recuperación de puntos puede servir a los fines de prevención especial. En relación con dichas modalidades delictivas existía una posición jurisprudencial reciente de la Audiencia Provincial de Toledo, que, aunque minoritaria, se mostraba partidaria de la no punición por la vía penal de estas conductas relativas a la conducción sin carnet y conducción con pérdida de vigencia por puntos ${ }^{1224}$. Esta línea jurisprudencial mantenía que la conducción de los que nunca han tenido permiso o licencia o de los que conducen tras haber perdido todos los puntos del permiso o licencia, al estar también prevista en la normativa administrativa, debía ser

\footnotetext{
1223 Vid. SOLA RECHE, Esteban, "Los viejos..." op.cit, p.6. Como dato estadístico podemos destacar que se han incoado más procedimientos judiciales por el art. $384 \mathrm{CP}$ en el año 2018 que, en el año 2013, lo que puede ser un indicador de una escasa eficacia preventiva. Vid. la estadística en la Memoria de la FGE del año 2019, p. 869.

1224 Vid. SAP de Toledo, núm. 16/2013, Sección 1aㅡ, de 14 de febrero de 2013, ponente Ilmo.Sr. Manuel Gutiérrez Sánchez Caro (TOL3.525.284). En esta sentencia se recoge la doctrina jurisprudencial de esta Audiencia Provincial en relación con el tipo del art.384 CP y se hace referencia al Acuerdo de Pleno de fecha 15 de enero de 2013 de la referida Audiencia Provincial.
} 
sancionada en dicho ámbito y únicamente cuando se acredite con los hechos que esa conducción ha generado un riesgo superior al que protege el Derecho Administrativo sancionador será constitutiva de delito. De hecho, dicha línea jurisprudencial era única en todo el Estado ya que el resto de las Audiencias Provinciales mantenían una posición favorable a la punición penal de estas conductas. En aras a zanjar la controversia existente, en el año 2017 el Tribunal Supremo ha dictado diversas resoluciones en las que se determina que la conducta del tipo del art. 384 CP de conducir sin haber obtenido nunca el correspondiente permiso o licencia o bien conducir habiendo quedado sin efecto el permiso 0 licencia por la pérdida total de puntos es constitutiva de delito y no una mera infracción administrativa, por lo que se reafirma la intervención penal en este ámbito de la seguridad vial' ${ }^{1225}$.

En mi opinión, dichos tipos delictivos deben seguir tipificados en el CP ya que a través de los mismos las penas que se imponen pueden cumplir funciones preventivas, así como también se pueden proteger de forma más eficaz bienes jurídicos como la seguridad vial o la vida. En las dos conductas descritas estimo que sería adecuado que el art. 384 CP estableciera la pena de privación del derecho a conducir, ya que en ambos supuestos nos encontramos ante conductores que o bien nunca han tenido permiso o licencia o bien han perdido el mismo por haber cometido numerosas infracciones que les ha generado que no tengan puntos en su carnet. Por estos motivos, en aras a una adecuada protección de la seguridad vial sería interesante que se pudiera imponer además la privación del derecho a conducir, ya que nos hallamos ante conductores que o bien carecen de las habilidades necesarias para conducir un vehículo a motor o ciclomotor o bien las han perdido debido a la reiterada comisión de infracciones contra las normas de seguridad vial. A ello hemos de añadir que una de las consecuencias que implica la condena a la pena de privación del derecho a conducir para las personas que carecen de permiso o licencia, es que no podrán obtener una autorización para conducir durante el periodo de condena.

La segunda conducta regulada en el art. $384 \mathrm{CP}$, es la relacionada con el delito de quebrantamiento de condena o medida cautelar de la privación del derecho a conducir, en la que también sería positiva la imposición de esta pena, ya que podría 
tener un efecto disuasorio tanto en los que ya han sido penados, los que todavía tienen la condición de investigados, así como en otros conductores. En la actualidad, a numerosos conductores condenados por el delito del art.384 CP, apartado segundo, que regula el quebrantamiento de condena o de medida cautelar, se les impone una pena de multa que se puede satisfacer de forma fraccionada, en cómodos plazos y no afecta a la pena o medida cautelar de privación del derecho a conducir que se impuso en la inicial resolución judicial quebrantada. En este sentido, considero que, para reforzar la eficacia del tipo penal, sí debería incluirse en el tipo del art.384 CP, además de la alternatividad en la pena de prisión, multa o TBC, una nueva pena de privación del derecho a conducir. Es más, escaso sentido tiene que el quebrantamiento de una prohibición de conducir se salde con una pena de prisión, multa o TBC sin garantizar que se mantiene vigente la pena de privación del derecho a conducir. Si en estos supuestos delictivos se impusiera esta pena, estimo que podrían potenciarse los fines de prevención especial y general asociados a la misma, y podrían evitarse quebrantamientos de condena de privación del derecho a conducir. Se debería añadir en la penalidad de todas las conductas descritas en el art.384 CP la pena de privación del derecho a conducir, ya que sería muy relevante para evitar que los conductores perciban que la comisión de estos delitos carece de importancia.

Cabe señalar que durante la tramitación parlamentaria del art.384 CP en la reforma del CP del año 2007 se previó que todas las conductas que se detallaban en el tipo penal acarrearan la pena de privación del derecho a conducir durante un plazo de 1 a 6 años, además de la pena de prisión, multa y TBC ${ }^{1226}$. Sin embargo, en la versión finalmente aprobada el Pleno del Congreso eliminó la posibilidad que el art.384 CP conllevara la pena de privación del derecho a conducir, estableciéndose la triple opción punitiva de pena de prisión, multa o pena de $\mathrm{TBC}^{1227}$. La justificación de la no inclusión de la pena de privación del derecho a conducir en el elenco de penas del art.384 está relacionada con que la reforma operada por la LO 15/2007 de 30 de noviembre pretendía reducir el número de conductores que conducían sin tener la

Excmo. Sr. Julián Artemio Sánchez Melgar (TOL6.346.233), en la que se establece que es delito la conducción tras haber perdido la vigencia el permiso por pérdida de todos los puntos.

1226 Vid. GARCÍA DEL BLANCO, Victoria, "EI nuevo artículo 384 del Código Penal: Quebrantamientos, desobediencias y conductas afines", en AA.VV. Protección Penal..., op.cit., p.471.

1227 Vid. DE VICENTE MARTÍNEZ, Rosario, "La conducción con pérdida...", Revista Aranzadi Doctrinal, núm. 8/2012, BIB $2012 \backslash 3384$.

Puede comprobarse la tramitación parlamentaria del art.384 del Código Penal en la reforma del año 2007 en: http://www.congreso.es/public oficiales/L8/CONG/DS/PL/PL 290.PDF (último acceso: 15/04/2020). 
correspondiente autorización administrativa ${ }^{1228}$. Si el legislador hubiera acordado que se pudiera imponer en el art.384 la pena objeto de análisis ello podría ser contrario a los objetivos del tipo penal, especialmente en los casos de conductores penados que nunca han poseído permiso o licencia ya que supondría que tampoco podrían examinarse para la obtención de los mismos durante el periodo de duración de la pena de privación del derecho a conducir y por ende existiría el riesgo que pudieran conducir de nuevo sin poseer la autorización administrativa correspondiente. No obstante, la Fiscalía afirma en sus Memorias anuales tener conocimiento de la existencia de conductores que a pesar de haber sido penados por el art.384 CP han seguido conduciendo y no han obtenido su permiso de conducir $^{1229}$, por lo que la finalidad buscada con la no inclusión de la pena de privación del derecho a conducir en el tipo del art.384 ha podido quedar vacía de contenido, debido a que estos conductores pueden seguir conduciendo sin cumplir los requisitos administrativos exigidos para el ejercicio del derecho.

Ni durante la tramitación parlamentaria de la reforma operada en la LO 5/2010 de 22 de junio ni la LO 1/2015 de 30 de marzo, ni la LO 2/2019 de 1 de marzo se han valorado tan siquiera la posibilidad que se pudiera imponer la pena de privación del derecho a conducir en las conductas reguladas en el art.384 CP, y parece ser que el legislador ha dejado definitivamente apartada la opción que al menos se debatió en la reforma del CP de 2007. Si analizamos las estadísticas de los procedimientos penales incoados por el tipo delictivo tras la reforma operada en el año 2007 podemos comprobar que, en el ámbito de los delitos contra la seguridad vial, tras los delitos sancionados por la vía del art.379.2 CP, el art. 384 CP es el más numeroso. A pesar de haber pasado más de una década desde la entrada en vigor de la LO 15/2007 de 30 de noviembre, podemos observar que en el año 2017 se incoaron más procedimientos penales que en el año 2008 por este tipo delictivo, lo que puede indicar que el tipo penal no resulta del todo eficaz ${ }^{1230}$. La propuesta que se plantea considero que puede ser positiva, al hallarnos ante conductas relacionadas con la seguridad vial y en las que la pena de privación del derecho a conducir se podría imponer en el mismo sentido que otros tipos penales como el actual art.379 CP.

1228 Esta finalidad es defendida por DE VICENTE MARTÍNEZ, Rosario, "La conducción con pérdida...", Revista Aranzadi Doctrinal, núm. 8/2012, BIB 201213384 y también se cita por GARCíA DEL BLANCO, Victoria, "El nuevo artículo 384 del Código Penal: Quebrantamientos, desobediencias y conductas afines", en AA.VV. Protección Penal..., op.cit., p.471.

1229 No pueden aportarse estadísticas concretas, ya que como se reconoce en la Memoria de la FGE del año 2013, los datos existentes únicamente hacen referencia al art.384 CP, y no se diferencia los tres tipos delictivos que componen dicho artículo. Vid. Memoria de la FGE año 2013, pp.428-429.

1230 En relación con la estadística de la última década vid. Memoria de la FGE año 2018, p. 658. 


\subsubsection{Otros delitos relacionados con la seguridad vial}

Junto a los delitos anteriormente expuestos, existen otras conductas relacionadas con la seguridad vial y la circulación de vehículos en las que el recurso a la pena que analizamos puede ser adecuado. Una de las acciones relacionadas con la seguridad vial es la manipulación de tacógrafos, conducta que en la actualidad viene calificándose como un delito de falsedad y que por lo tanto no prevé la pena de privación del derecho a conducir ${ }^{1231}$. Estas acciones se realizan primordialmente por profesionales del transporte, que pasan largas horas circulando con su vehículo con el ánimo de reducir los tiempos de descanso entre trayectos, y así evitar una lectura real de las velocidades, las horas a las que se transita e incluso la identidad del conductor ${ }^{1232}$. Las conductas descritas, pueden incrementar los riesgos en la circulación viaria y atentan entonces contra el bien jurídico seguridad vial, por lo que podrían tener encaje en los "delitos de peligro o mero riesgo" 1233 . A pesar de que estas acciones pueden penarse como delitos de falsedad documental, la tendencia reciente en la jurisprudencia y en la doctrina es favorable a su atipicidad y a su sanción por el Derecho Administrativo ${ }^{1234}$. A título ilustrativo, son escasas las resoluciones judiciales que han impuesto la condena por estas conductas delictivas $^{1235}$, siendo mayoritarias las que entienden que estas acciones han de ser remitidas a la vía administrativa ${ }^{1236}$. Sin embargo, la situación ha cambiado

\footnotetext{
1231 No son conductas puntuales, sino que según algunos medios de comunicación estas acciones se han incrementado y se están convirtiendo en una práctica que realizan los profesionales del transporte cada vez con más frecuencia, incrementando el riesgo para la seguridad vial. Vid. https://www.navarra.es/home_es/Actualidad/Sala+de+prensa/Noticias+de+seguridad+publica/2014/0 2/13/policia+foral+imputa+camioneros+delito+falsedad+documental+manipulacion+tacografo.htm y también, otros hechos del año 2018, lo que acredita que el problema persiste durante todos estos años. Vid. https://www.diaridetarragona.com/costa/Detenidos-dos-camioneros-por-manipular-eltacografo-en-la-AP-7-20180522-0049.html (último acceso: 05/11/2020).
}

1232 La relación entre la manipulación de tacógrafos y la seguridad vial ha sido destacada por HIDALGO DE MORILLO JIMÉNEZ, Agustín, "Otros temas de interés", La dogmática penal sobre el asfalto: un enfoque práctico de los delitos contra la seguridad vial, AGÜERO RAMÓN-LLIN, Elena/HIDALGO DE MORILLO JIMÉNEZ, Agustín/ LANZAROTE MARTíNEZ, Pablo/ PRIETO GONZÁLEZ, HELENA M Ed. Comares, Granada, 2012, pp.278-279.

${ }^{1233} \mathrm{Al}$ estimar esta actividad como un delito de peligro o de mero riesgo, sí podría prever en estas conductas la aplicación de la pena de privación del derecho a conducir. En este sentido y en relación con las penas privativas de derechos estos tipos delictivos se han considerado idóneos para su aplicación como señala SANZ MULAS, Nieves, Alternativas..., op.cit., p.361.

1234 Vid. REQUEJO CONDE, Carmen, Delitos relativos..., op.cit., pp.234-235.

1235 Vid. SAP de Barcelona, núm. 283/2013, Sección 7ª̣, de 8 de marzo de 2013, ponente IImo.Sr. Luis Fernando Martínez Zapater (TOL3.729.115) y SAP de Asturias, núm. 546/2015, Sección 3a 30 de diciembre de 2015, ponente IImo. Sr. Francisco Javier Rodríguez Santocildes (TOL5.736.375).

1236 Vid. AAP de Tarragona, núm. 27/2010, Sección 2a José Manuel Sánchez Siscart (TOL2.604.652), AAP de Tarragona, núm. 27/2010, Sección 2ª̣ de 29 
recientemente ya que el Tribunal Supremo ha dictado una sentencia en el año 2020 resolviendo un recurso de casación y en la que determina que estos comportamientos han de ser constitutivos de delito de falsedad documental ${ }^{1237}$.

Extender la pena de privación del derecho a conducir a estas acciones calificadas como falsedad documental puede percibirse como excesivo, ya que nunca en nuestra historia penal estas acciones han comportado la aplicación de esta pena privativa de derechos. Además, incluso de preverse esta pena en el CP existiría todavía un obstáculo que debería salvarse como es el de acreditar quién ha modificado el tacógrafo, ya que ello sería imprescindible para lograr que se impusiera la pena de privación del derecho a conducir. En los casos que han llegado a juicio por este delito ha sido difícil acreditar la autoría en la modificación del tacógrafo ${ }^{1238}$.

Para una mayor protección de la seguridad vial, las conductas de modificación de tacógrafos deberían suponer una mayor punición, imponiéndose la pena de privación del derecho a conducir, ya que se ha convertido en un problema real para la seguridad vial ${ }^{1239}$. De llevarse a cabo la propuesta que se realiza, la pena de privación del derecho a conducir cumpliría fines de prevención general con relación al colectivo de profesionales del transporte, así como de prevención especial para aquellos que hubiesen sido condenados por estos hechos ${ }^{1240}$, además de los fines. Si bien es cierto que en la actualidad estas conductas pueden ser sancionadas también en el ámbito administrativo, la sanción de las mismas con la pena de privación del derecho a conducir supondría que los penados no pudieran ejercer su derecho a conducir durante un determinado periodo de tiempo. Esto no se puede conseguir desde el ámbito administrativo, ya que sus acciones supondrían sólo una

de septiembre de 2011, ponente Ilma.Sra. María Concepción Montardit Chica (TOL3.602.346); SAP de Tarragona, núm. 286/2014, Sección 2a , de 19 de julio de 2014, ponente Ilma.Sra. Samantha Romero Adán (TOL4.481.612); SAP de Tarragona, núm. 292/2017, Sección 2ª ${ }^{\mathrm{a}}$, de 26 de mayo de 2017, ponente Ilma.Sra. María Espiau Benedicto (TOL6.420.005) y SAP de Barcelona, núm. 251/2018, Sección 2ª ${ }^{\mathrm{a}}$, de 3 de abril de 2018, ponente IIma.Sra. María José Magaldi Paternostro (TOL6.647.185).

1237 STS, núm. 672/2019, Sala Segunda, de 15 de enero de 2020, ponente IImo. Sr. Eduardo de Porres Ortiz de Urbina (TOL7.701.429).

1238 Al respecto podemos citar la SAP de Tarragona, núm. 443/2014, Sección 4 $4^{\text {a }}$, de 3 de noviembre de 2014, ponente IImo.Sr. Jorge Mora Amante (TOL4.719.844), que absuelve a un conductor por manipular el tacógrafo al no poderse acreditar la autoría.

1239 Vid. Memoria FGE del año 2013 pp.377-379 y Memoria FGE del año 2017, p.567.

1240 La preocupación de la Fiscalía y Guardia Civil en Galicia en relación con estas conductas por los siniestros que han generado puede comprobarse en:

http://www.farodevigo.es/sucesos/2013/07/04/juzgado-vigues-dicta-primera-condena/839809.html (último acceso: 05/11/2020). 
sanción pecuniaria o en el peor de los casos, una pérdida de puntos en el permiso de conducir, por lo que los infractores podrían seguir conduciendo sin problema alguno. Por este motivo entiendo que estaría justificada la inclusión de la pena de privación del derecho a conducir en el tipo penal específico que regulara la manipulación de tacógrafos, ya que cuando se realiza esta conducta se incrementa el riesgo para el resto de usuarios de la vía. De hecho, el Fiscal de Sala de Seguridad Vial, en fecha 2 de marzo de 2020 remitió un oficio a las policías competentes para la persecución penal por delito de falsedad documental en los supuestos de manipulaciones de tacógrafos.

Otro delito en el que podríamos plantearnos incluir la pena de privación del derecho a conducir es el del art.385 CP, en el que se diferencian dos conductas relacionadas con la creación de riesgos para la circulación: la primera está relacionada con la colocación en la vía de obstáculos, derramar sustancias o alterar la señalización existente. La segunda conducta que sanciona el art.385 CP es la de no restablecer la seguridad de la vía cuando exista la obligación de hacerlo. Una dificultad para implementar la pena estudiada en este tipo delictivo es que las dos conductas reguladas en el art.385 CP no necesariamente han de ser cometidas utilizando un vehículo a motor o ciclomotor, ya que los sujetos activos son variados: peatones, conductores, vecinos de la vía, etc. ${ }^{1241}$. Por este motivo TRAPERO BARREALES rechaza la posibilidad que se imponga la pena de privación del derecho a conducir en las conductas del art.385 CP, ya que en la mayoría de las ocasiones no se realizan conduciendo un vehículo a motor o ciclomotor ${ }^{1242}$. A ello podríamos unir como argumento en contra de alterar la penalidad en este tipo delictivo la escasa utilización del art.385 CP, ya que su aplicación es muy escasa y en los últimos años estaba en retroceso ${ }^{1243}$, por lo que la aplicación de la pena de privación del derecho a conducir puede ser del todo innecesaria. Esta tendencia hemos de destacar que se ha roto en el año 2019 ya que los procedimientos

1241 En relación con los sujetos activos vid. REQUEJO CONDE, Carmen, Delitos relativos..., op.cit., p.142.

1242 Vid. TRAPERO BARREALES, María.A., Los delitos..., op.cit., p.558.

1243 Relativo a la escasa aplicación del art.385 CP, vid. PRIETO GONZÁLEZ, Helena María, "La creación de graves riesgos para la circulación: un tipo penal olvidado", La dogmática penal sobre el asfalto: un enfoque práctico de los delitos contra la seguridad vial, AGÜERO RAMÓN-LLIN, Elena/HIDALGO DE MORILLO JIMÉNEZ, Agustín/ LANZAROTE MARTíNEZ, Pablo/ PRIETO GONZÁLEZ, Helena María, Ed. Comares, Granada, 2012, pp.219-220. También podemos indicar que la Memoria de la FGE del año 2012, p.396 lo calificaba como: "...cuantitativamente intrascendente en el conjunto de la delincuencia vial". Podemos destacar que en el año 2008 se incoaron 985 procedimientos penales por este tipo penal y en el año 2018, el número se redujo a 389, es decir, más de la mitad. Vid. Memoria de la FGE del año 2019, p.869. 
incoados en relación a este tipo delictivo han sufrido un incremento que han llevado las cifras a las existentes en el año $2015^{1244}$.

No obstante, en las conductas tipificadas en el art.385 CP que se realizaran con un vehículo a motor o ciclomotor se podría introducir una penalidad específica. La forma que podríamos utilizar para acordar la pena de privación del derecho a conducir en el delito del art.385 $\mathrm{CP}$, es que únicamente se podría imponer en cuando las conductas descritas se realizaran con la utilización de un vehículo a motor o ciclomotor. En estos casos, además de la penalidad genérica de prisión o multa y en todo caso la pena de TBC debería añadirse con carácter de pena principal la privación del derecho a conducir. Sería partidario de la punición con la pena de privación del derecho a conducir en los supuestos del art.385 CP que se hayan cometido utilizando un vehículo a motor o ciclomotor, ya que se habrá atentado contra el bien jurídico seguridad vial de una forma más grave, al realizar la conducta con un instrumento que no estaba destinado para dicho fin. Por este motivo, aquellos penados que atentan contra dicho bien jurídico, no deberían tener la posibilidad de conducir un vehículo a motor o ciclomotor durante un periodo determinado de tiempo para salvaguardar el buen funcionamiento de la seguridad vial.

A pesar de lo que se propone en este apartado, debe existir un límite en la extensión de la pena de privación del derecho a conducir a conductas que ni tan siquiera son sancionables administrativamente. Acciones como fumar o usar dispositivos de navegación cuando se conduce un vehículo a motor o ciclomotor no deberían ser elevadas a categoría de delito ni tampoco prever que en ellas se pudiera imponer la pena de privación del derecho a conducir ${ }^{1245}$. Sin embargo, debido a la tendencia expansiva del Derecho Penal en el ámbito de la seguridad vial $^{1246}$, no sería extraño que en sucesivas reformas del CP se tipificaran como delitos conductas muy comunes como el uso de inhibidores de radar o la alteración de placas de matrícula tal como ha señalado HORTAL IBARRA ${ }^{1247}$ o una de las infracciones administrativas más comunes en la actualidad como es la de hablar por

\footnotetext{
1244 Vid. Memoria de la FGE del año 2020, p.908.

1245 La hipótesis que dichas conductas sean elevadas a la categoría de delito ha sido expuesta por HORTAL IBARRA, Juan Carlos, “La mutación...”, op.cit., p.5.

1246 La expansión del Derecho Penal al ámbito de la seguridad vial ha sido criticada por FERNÁNDEZ BERMEJO. Vid. FERNÁNDEZ BERMEJO, Daniel, "El delito de conducción de vehículos de motor bajo la influencia de los efectos del alcohol", La Ley Penal, № 119, 2016, pp.4-7.

1247 En torno a la posible consideración como delito de dichas conductas, vid. HORTAL IBARRA, Juan Carlos, “La mutación...", op.cit., p.5
} 
teléfono móvil cuando se está conduciendo ${ }^{1248}$, lo que genera numerosos accidentes por distracción.

Tras lo expuesto, considero que el sistema español de penas no ha efectuado un correcto desarrollo de las penas privativas de derechos en general y de la privación del derecho a conducir en particular. Estoy de acuerdo con lo que expresaba DíEZ RIPOLLÉS ${ }^{1249}$, en cuanto a que se debería ampliar la utilización de las penas privativas de derechos, y en nuestro caso, extender los efectos de la pena de privación del derecho a conducir a tipos delictivos que tengan relación con la utilización de vehículos a motor y ciclomotores y que en la actualidad no la prevén. La extensión de la pena de privación del derecho a conducir a otros delitos relacionados con el tráfico viario puede ser uno de los mecanismos más importantes del "moderno" Derecho Penal del tráfico ${ }^{1250}$ para combatir la delincuencia vial, ya que como hemos venido destacando en el trabajo, la pena analizada tiene un gran contenido aflictivo, así como efectos preventivo generales y especiales, por lo que podría tener más eficacia que la pena de multa o penas cortas de prisión. Si bien las reformas del CP operadas en los años 2010 y 2015 no fueron en la línea de ampliar el ámbito de aplicación de la pena de privación del derecho a conducir, lo que estaba en consonancia con ciertos sectores doctrinales que mantenían que es una pena que tiene una eficacia político-criminal reducida ${ }^{1251}$, el legislador, como hemos señalado anteriormente, parece ser que ha cambiado esta tendencia con la entrada en vigor de la LO 2/2019 de 1 de marzo, incrementando el uso de la pena de privación del derecho a conducir vehículos a motor y ciclomotores.

\subsection{Aplicación de la pena de privación del derecho a conducir a posibles nuevos tipos penales en el ámbito de la seguridad vial}

En otro orden de cosas, se propone elevar a la categoría de delito las acciones consistentes en conducir un vehículo a motor o ciclomotor sin tener contratado el seguro obligatorio de responsabilidad civil, que comportaría que entre las penas a

\footnotetext{
${ }_{1248} \mathrm{Vid} . \quad$ http://www.dgt.es/es/prensa/notas-de-prensa/2017/20171128-zoido-presenta-campana-usomovil.shtml (último acceso: 05/11/2020).

1249 Referente al sistema de penas y en concreto las penas privativas de derechos, vid. DíEZ RIPOLLES, JOSÉ LUIS "La evolución...."op.cit., p.25.

1250 Sobre el concepto "moderno" Derecho Penal del tráfico y las herramientas que el mismo utiliza, vid. MIRÓ LLINARES, Fernando, "EI moderno...". op.cit., pp.5-7.

1251 Vid. VALEIJE ÁLVAREZ, Inmaculada, "El sistema de penas en los delitos contra la seguridad vial", en AA.VV. Prevención y control..., op.cit., p.477.
} 
imponer estuviera prevista la privación del derecho a conducir. Dicha conducta actualmente es una infracción administrativa y está regulada en el art.78 de la LTSV $^{1252}$ y en el art.3 del RD Legislativo 8/2004 de 29 de octubre por el que se aprueba el texto refundido de la Ley sobre responsabilidad civil y seguro en la circulación de vehículos a motor ${ }^{1253}$.

La DGT ha estimado en casi dos millones los vehículos que transitan por las carreteras españolas sin el seguro obligatorio, siendo aproximadamente el $10 \%$ del parque de vehículos que circulan, imponiéndose 50.000 multas en el año 2015 por este motivo, lo que acredita la importancia del problema ${ }^{1254}$. La tendencia en la comisión de este tipo de infracciones es ascendente, ya que en el año 2017 se contabilizaron 132.288 vehículos circulando sin seguro obligatorio y fueron sancionados por las patrullas de la Guardia Civil de Tráfico ${ }^{1255}$, a lo que habría que añadir las sanciones impuestas por la Ertzaintza y Mossos d'Esquadra, siendo el récord de los últimos años y con un incremento de 9.000 denuncias respecto del año 2016 y 10.000 más en relación con el año 2015. Si bien es cierto que dicho incremento también puede ser debido al aumento de los controles policiales sobre los vehículos a motor y ciclomotores, lo cierto es que el número de ellos que circulan sin seguro obligatorio por nuestras carreteras es muy elevado. La magnitud de dichos datos, puede evidenciar que las sanciones administrativas no han resultado eficaces para acabar con el hecho de conducir un vehículo a motor o ciclomotor sin el correspondiente seguro obligatorio, a lo que hemos de añadir que probablemente en muchas ocasiones los propietarios de los vehículos son insolventes, por lo que las multas administrativas pueden tener una eficacia disuasoria nula. Incluso también podemos destacar en este sentido como en un Informe elaborado por la aseguradora Línea Directa en el mes de abril de 2017, en una encuesta realizada el $43 \%$ de los entrevistados son partidarios que dicha

\footnotetext{
1252 Art. 78 LTSV: 1. Las infracciones derivadas del incumplimiento de la obligación de asegurar los vehículos a motor se regularán y sancionarán con arreglo a su legislación específica. 2. Las estaciones de inspección técnica de vehículos requerirán la acreditación del seguro obligatorio en cada inspección ordinaria o extraordinaria del vehículo. El resultado de la inspección no podrá ser favorable en tanto no se verifique este requisito.
}

1253 Art.3 RD 8/2004, apartado c): Una sanción pecuniaria de 601 a 3.005 euros de multa, graduada según que el vehículo circulase o no, su categoría, el servicio que preste, la gravedad del perjuicio causado, en su caso, la duración de la falta de aseguramiento y la reiteración de la misma infracción.

1254 Puede verse la nota de prensa de la DGT con dichos datos en: http://www.dgt.es/es/prensa/notas-de-prensa/2016/20160102-dgt-utiliza-medios-automatizadosdetectar-vehiculos-circulan-sin-seguro-obligatorio.shtml

(último acceso: 05/11/2020). 
acción constituya delito ${ }^{1256}$, lo que pone de relieve que existe una percepción en un número importante de personas que nos hallamos ante un problema.

Además de la preocupación en el ámbito nacional, podemos destacar que a nivel comunitario también se ha abordado la cuestión de los vehículos que circulan sin el seguro obligatorio. Ello ha culminado con la aprobación en el pasado 30 de mayo de 2018 de una propuesta de directiva del Parlamento Europeo y del Consejo en la que se destacaba que la conducción de vehículos sin seguro era "un problema tanto a nivel nacional como europeo"1257, proponiendo una serie de actuaciones, aunque no se recomendaba una intervención penal en esta materia.

Ciertamente las propuestas de elevar a la categoría de delito lo que hasta ahora son meras infracciones administrativas han sido criticadas por considerarse una "administrativización del Derecho Penal"1258, que se ha observado ya en la línea de la política criminal de seguridad vial instaurada tras la reforma operada por la LO 15/2007 de 30 de noviembre del mismo modo que se realizó con alguna de las conductas del art.384 CP que, con anterioridad a dicha reforma, eran una mera sanción administrativa y se elevaron a categoría de delito ${ }^{1259}$. Esta propuesta tiene un precedente en el ordenamiento penal español, ya que esta conducta fue sancionada como falta desde la entrada en vigor del CP de 1995 hasta la reforma

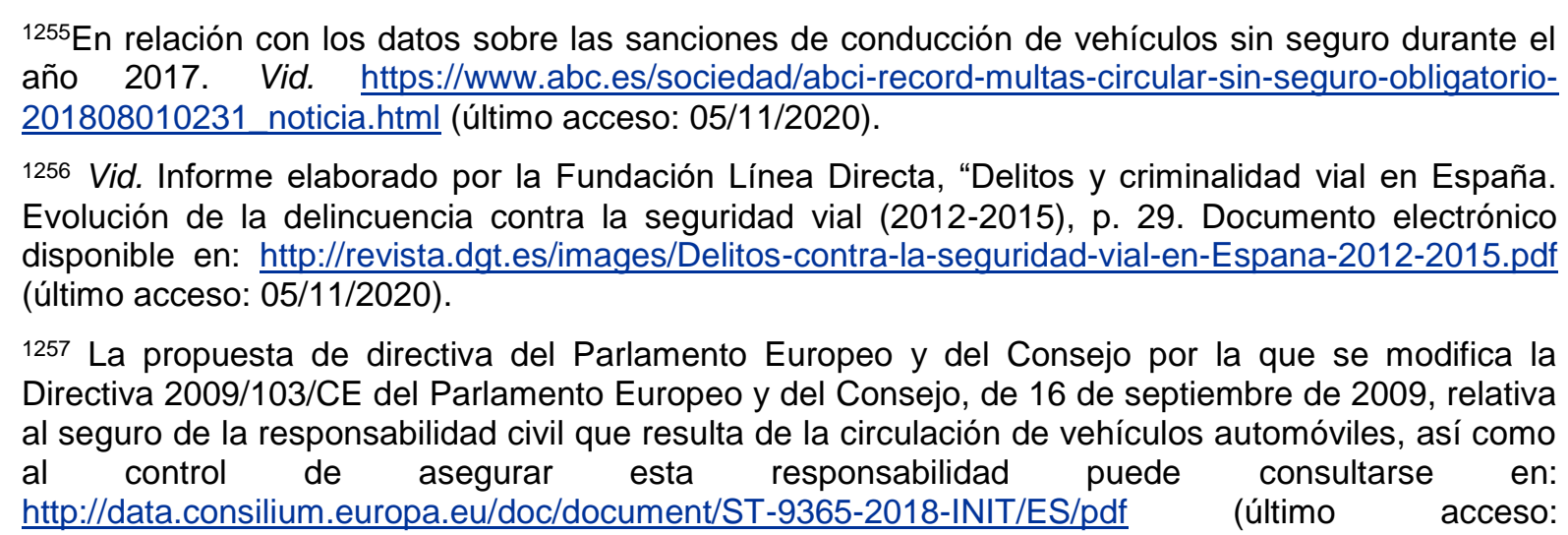
05/11/2020).

1258 En torno a dicho fenómeno vid. QUINTERO OLIVARES, Gonzalo, Adonde va el derecho penal, Ed. Civitas, Madrid, 2004, p.171, POLAINO-ORTS, Miguel, "Delitos contra la seguridad vial: visión crítica de la nueva regulación española", en AA.VV. Entre libertad..., op.cit., p.701 y también QUERALT JIMÉNEZ, Joan J.," El nuevo derecho penal vial: generalidades críticas", en AA.VV. Seguridad Vial...op.cit., p. 66 y ALASTUEY DOBÓN, Carmen/ ESCUCHURI AISA, Estrella, "llícito penal e ilícito administrativo en materia de tráfico y seguridad vial", Estudios penales $y$ criminológicos, Vol. XXXI, 2011, Universidad Santiago de Compostela, pp.10-11.

Recurso electrónico disponible en: http://www.usc.es/revistas/index.php/epc/article/view/137 (último acceso: 05/11/2020).

1259 Vid. respecto la comparativa e influencia de la antigua falta del art.636 CP y el CP 384 introducido por la LO 15/2007, citada por MIRÓ LLINARES, Fernando, “El moderno...", op.cit., pp.1819. 
operada por la LO 15/2003 de 25 de noviembre, pero únicamente suponía la imposición de la pena de multa ${ }^{1260}$. Somos conscientes que la propuesta de tipificar la conducta de conducción sin el seguro obligatorio puede considerarse como un doble salto: en primer lugar significa criminalizar lo que hoy día es una sanción administrativa $^{1261}$, y en segundo lugar elevarlo a la categoría de delito leve ante la inexistencia de las faltas en el CP tras la entrada en vigor de la LO 1/2015 de 30 de marzo de reforma del $\mathrm{CP}$, pero considero que puede ser necesario a los efectos de garantizar que todos los vehículos a motor y ciclomotores que circulan por nuestras carreteras lo hacen cumpliendo la normativa relacionada con la seguridad vial. Si realizamos una comparativa con otra conducta que está tipificada como delito, como es la conducción sin permiso o licencia del art. $384 \mathrm{CP}$, nos hallaríamos ante dos conductas que sancionarían penalmente la conducción de un vehículo a motor o ciclomotor sin cumplir la normativa administrativa.

Las críticas que podrían efectuarse a esta propuesta serían las que realizó parte de la doctrina en relación con la antigua falta que sancionaba esta conducta ${ }^{1262}$, siendo una de las más destacadas que la conducción sin seguro no generaba ningún riesgo para la seguridad vial, ya que era una mera infracción de una obligación de carácter administrativo. También podría invocarse que a través de la vía penal se está utilizando un mecanismo para sancionar una conducta que puede tener una respuesta adecuada en el Derecho Administrativo sancionador, por lo que en aplicación de los principios de intervención mínima y ultima ratio que rigen el Derecho Penal, carecería de sentido criminalizar de nuevo la conducción sin seguro de vehículos a motor y ciclomotores ${ }^{1263}$. En relación con el principio de intervención mínima, como apunta QUINTERO OLIVARES, se ha de "procurar que haya el menor número posible de delitos y que las penas sean limitadas a lo imprescindible para afirmar el Derecho"1264.

\footnotetext{
1260 Con relación a la despenalización de la falta por circular con un vehículo a motor o ciclomotor sin el preceptivo seguro obligatorio, vid. GANZENMÜLLER ROIG, Carlos/ DE LAMO RUBIO, Jaime/ ROBLEDO VILLAR, Antonio, ESCUDERO MORATALLA, José Francisco y FRIGOLA VALLINA, Joaquín; Delitos..., op.cit., pp.400-401.

1261 Sobre la despenalización de dicha conducta vid. REQUEJO CONDE, Carmen, Delitos relativos..., op.cit., p.148.

1262 Vid. DE VICENTE MARTÍNEZ, Rosario, Derecho..., op.cit., pp.830-831.

1263 En este sentido vid. MAGRO SERVET, Vicente, "La despenalización de la conducción de vehículos de motor y ciclomotores sin seguro en la reforma del código penal", Diario La Ley ํㅜ 5843, La Ley 1470/2003.

1264 Vid. QUINTERO OLIVARES, GONZALO, "Aspectos generales", op.cit., p. 32 y también en relación con los principios de intervención mínima y ultima ratio, vid. "Mitos y modas del derecho penal tras algunos años de experiencia", Anuario de derecho penal y ciencias penales, Ed. Ministerio de Justicia y Boletín Oficial del Estado, Madrid, Tomo 73, 2020, pp.36-38.
} 
Sin embargo, tras haberse acreditado la existencia de esta problemática en el tráfico viario, es posible que la intervención del Derecho Administrativo sancionador a través de la imposición de multas económicas sea insuficiente en aras a reducir los vehículos a motor y ciclomotores que circulan sin seguro obligatorio ${ }^{1265}$. Una actuación en el ámbito penal con la imposición de sanciones como la pena de TBC junto con la pena de privación del derecho a conducir, considero que podrían comportar efectos positivos para los penados y dejar la sensación que estas conductas salen "gratis" al ser sancionadas administrativamente para personas que, en muchos casos, incluso puedan ser insolventes. La pena objeto de estudio, puede ser una herramienta adecuada para la protección de bienes jurídicos colectivos como la seguridad vial y otros individuales como pueden ser la vida e integridad física y psíquica de las personas, ayudando además a reducir tanto la siniestralidad vial como de fallecidos y lesionados derivados de accidentes de tráfico. Un factor que puede coadyuvar a conseguir tales objetivos es que el vehículo a motor o ciclomotor con que se conduce circule con todas las garantías, y uno de los requisitos exigibles para la circulación viaria es que posea en vigor el seguro obligatorio de responsabilidad civil. La actuación en este ámbito desde el Derecho Penal sería interesante desde la perspectiva de la prevención especial para los propios infractores, así como también desde los fines de prevención general, al ser conocedores los potenciales infractores que la conducción sin seguro obligatorio no se sancionará únicamente con una sanción pecuniaria, sino que tendrán que cumplir unas penas con un contenido aflictivo importante.

Uno de los mayores hándicaps que se vislumbran en la propuesta que se realiza es que la obligación de aseguramiento del vehículo a motor o ciclomotor es del titular del mismo y no del conductor, y en ocasiones sucede que el conductor del vehículo no es el titular por lo que podría invocar el error o desconocimiento en el hecho que el vehículo careciera del correspondiente seguro. En todo caso, creo que la propuesta que se realiza es viable que sea implementada en el ámbito del CP ya que en numerosas ocasiones los conductores de los vehículos a motor y ciclomotores son sus propietarios. En estos casos sí estimo factible poder sancionar penalmente a los mismos, siempre que se aplicara en supuestos en los que coincidan conductor y propietario del vehículo a motor o ciclomotor. Para ello, la aplicación de la pena de privación del derecho a conducir debería preverse de forma facultativa y no obligatoria, de tal modo que el juez valorara previamente su 
adecuación al caso. En todo caso quedaría todavía por determinar el responsable penal al que se le debería imputar la infracción, siendo este un tema controvertido como ya fue en su momento cuando se imputaban dichas acciones a título de falta, ya que se generaron resoluciones jurisprudenciales en todos los sentidos posibles $^{1266}$. Existían posiciones jurisprudenciales que mantenían que únicamente podía ser condenado como autor de la falta de conducción sin seguro el propietario del vehículo a motor o ciclomotor mientras que otra línea jurisprudencial abogaba por condenar únicamente a la persona que conducía el vehículo sin asegurar. Incluso se dictaron resoluciones que mantenían que podía existir la condena indistinta tanto del propietario no conductor del vehículo como del conductor que a sabiendas de la inexistencia de aseguramiento lo conducía.

A pesar de las objeciones que pueden formularse a la propuesta que se realiza, debe apuntarse que ya se mencionó en el año 2006 dicha posibilidad por parte de la Comisión no Permanente sobre Seguridad Vial y Prevención de Accidentes de Tráfico $^{1267}$. Por ello, estimo que en caso de lege ferenda se procediera a criminalizar la conducción sin seguro de vehículos a motor y ciclomotores, bien como delito o delito leve, se debería implementar la pena de privación del derecho a conducir, como pena principal, de aplicación facultativa, y junto a otras alternativas que bien pudieran ser la localización permanente, la pena de TBC o la pena de multa. En relación con la pena de multa, hemos de indicar que, en aras a una mayor eficacia de la sanción penal, y que tenga verdaderos efectos preventivos para el penado sería interesante que las multas penales no tengan un menor importe que las sanciones administrativas ${ }^{1268}$.

\footnotetext{
1265 Podría mantenerse como crítica a la propuesta, que utilizar el Derecho Penal para erradicar dicha problemática es contrario tanto a los principios de ofensividad como de ultima ratio. En este sentido vid. QUINTERO OLIVARES, GONZALO, "Aspectos generales", op.cit., pp. 36-37.

1266 Vid. la controversia en NAGORE ARCHILLA, Carlos.S, en: "La falta del artículo 636 del Código Penal en relación con el seguro en la circulación de vehículos de motor", Ed. Thomson Aranzadi, BIB 2001/307, DE VICENTE MARTÍNEZ, Rosario, Derecho... op.cit., pp.829-830 y también REQUEJO CONDE, Carmen, Delitos relativos..., op.cit., p.149.

1267 Vid. la alusión a dicha posibilidad en DE VICENTE MARTÍNEZ, Rosario, Derecho..., op.cit., p.834, nota al pie núm. 851.

1268 Este aspecto fue destacado por el Tribunal Supremo en la STS, núm. 1729/2001, Sala Segunda, de 15 de octubre de 2001, ponente IImo. Sr. Cándido Conde-Pumpido Tourón (TOL4.964.107).
} 


\subsection{Regulación de la pena de privación del derecho a conducir como pena accesoria}

En aras a una mejor aplicación de la pena de privación del derecho a conducir en el $\mathrm{CP}$, las opciones que hemos podido determinar son dos: bien una extensión a determinados delitos con los que pueda tener relación y que ha sido explicada anteriormente, bien regular la pena de privación del derecho a conducir como una pena accesoria. Esta segunda alternativa es la que trataremos de argumentar en el presente apartado, es decir, que se mantenga la actual regulación de la pena de privación del derecho a conducir como pena privativa de derechos con carácter principal en los delitos que está prevista, pero que además se introduzca en el catálogo de penas accesorias. Esta propuesta se podría articular siguiendo lo establecido en la legislación penal de Menores, ya que en la LORPM el art. 7.1.n) ${ }^{1269}$ prevé que la medida de privación del derecho a conducir se puede acordar como accesoria en aquellos delitos que se hayan cometido utilizando un vehículo a motor o ciclomotor. Esta opción existente en el Derecho Penal Juvenil, podría trasladarse por el legislador al CP para extender la pena de privación del derecho a conducir a todos aquellos delitos dolosos o imprudentes que se hubieran cometido con un vehículo a motor o ciclomotor. Con la regulación del CP ello es imposible ya que ningún Juzgado ni Tribunal podrán imponer la pena de privación del derecho a conducir como pena accesoria en los delitos que no la prevén como pena principal y ello porque el art.56 CP, no contempla como pena accesoria la privación del derecho a conducir vehículos a motor o ciclomotores ${ }^{1270}$. Tampoco se podría imponer en los casos de delitos de homicidio o lesiones cometidos con vehículo a motor, y que a través de lo preceptuado en el art. $57 \mathrm{CP}$ podría entenderse que son tributarios de la imposición de una pena accesoria, al no diferenciar que hayan sido causados por dolo o imprudencia, y además no estar regulada la privación del derecho a conducir como pena accesoria en el art. $48 \mathrm{CP}$.

\footnotetext{
1269 Art.7.1.n) LORPM: "Las medidas que pueden imponer los Jueces de Menores, ordenadas según la restricción de derechos que suponen, son las siguientes: $n$. Privación del permiso de conducir ciclomotores y vehículos a motor, o del derecho a obtenerlo, o de las licencias administrativas para caza o para uso de cualquier tipo de armas. Esta medida podrá imponerse como accesoria cuando el delito o falta se hubiere cometido utilizando un ciclomotor o un vehículo a motor, o un arma, respectivamente".

1270 En este sentido también se ha expresado TAMARIT SUMALLA, Josep/ LUQUE REINA, Ma Eulàlia, Automóviles, delitos y penas..., op.cit., p.130 y TAMARIT SUMALLA, Josep, "La pérdida definitiva del derecho de conducir o del derecho a la tenencia y porte de armas", en AA.VV. La adecuación... op.cit., p.125. En el mismo sentido vid. GUTIÉRREZ CASTAÑEDA, Ana, "Penas privativas y restrictivas de derechos", en AA.VV., Las consecuencias..., op.cit., pp.56-57.
} 
Ante dicha situación, se propone una modificación de lege ferenda para que la pena de privación del derecho a conducir, además de ser pena principal tuviera la categoría de pena accesoria. La viabilidad de esta propuesta se acredita con el hecho que todas las penas privativas de derechos tienen la consideración de accesorias con la salvedad de la pena de privación del derecho a conducir y la privación del derecho a la tenencia y porte de armas ${ }^{1271}$. Además, la propuesta que se realiza no tendría una especial dificultad técnica, ya que se podría incorporar un cuarto apartado al artículo $57 \mathrm{CP}$ que hiciera referencia a la pena de privación del derecho a conducir como pena accesoria y cuya imposición sería de carácter facultativo por el Juzgado o Tribunal.

La doctrina mayoritaria ha determinado claramente que la pena de privación del derecho a conducir en la actualidad no tiene la consideración de pena accesoria ${ }^{1272}$. Sin embargo, hemos de señalar que existen posiciones doctrinales, como la de CARDENAL MONTRAVETA ${ }^{1273}$, que consideran que la pena de privación del derecho a conducir puede ser impuesta como pena accesoria al amparo del art. 56 $\mathrm{CP}$ ya que este precepto hace referencia a la inhabilitación de "cualquier otro derecho". En el mismo sentido se posiciona TRAPERO BARREALES, aunque no sea de forma explícita, al hacer también referencia al art. 56.1.3 CP como mecanismo para acordar la pena de privación del derecho a conducir como pena accesoria $^{1274}$. También existe doctrina, que, aunque minoritaria, considera que la pena que hemos analizado está configurada como principal o accesoria ${ }^{1275}$. En relación con estas posiciones doctrinales hemos de realizar dos puntualizaciones. La primera de ellas es que, de considerarse también su naturaleza como pena accesoria, únicamente sería aplicable a aquellas sentencias condenatorias en las que se acordara la pena de prisión, limitación que viene ex art. $56 \mathrm{CP}$ ya que dispone en su apartado 1: "En las penas de prisión inferiores a diez años...". La segunda apreciación es que, tras el estudio de la jurisprudencia no hemos hallado ninguna resolución en la que se imponga la pena de privación del derecho a conducir como pena accesoria, sino que en todos los casos se ha impuesto como

\footnotetext{
1271 Vid. RODRÍGUEZ MORO, Luis, La pena de privación..., op.cit., p. 100.

1272 Vid. TAMARIT SUMALLA, Josep, "La prohibición de conducir y otras sanciones penales relacionadas con los vehículos", en AA.VV. Las sanciones..., op.cit., p.326 y RODRíGUEZ MORO, con referencia a diversas posiciones doctrinales, Vid. RODRÍGUEZ MORO, Luis, La pena de privación..., op.cit., p.100.

1273 Vid. CARDENAL MONTRAVETA, Sergi,"Título III. De las penas", en AA.VV. Comentarios..., op.cit., p.228.

1274 Vid. TRAPERO BARREALES, María.A., Los delitos..., op.cit., p.560.

1275 Vid.TOLEDO CASTILLO, Francisco/ CAMPÓN DOMÍNGUEZ, José Andrés/ MARTíN UCLÉS, Francisco, Manual..., op.cit., pp.295-296.
} 
pena principal y acompañada de la pena de prisión, de la pena de multa o de la pena de TBC.

La propuesta que se realiza en este apartado tendría una similitud en el ámbito del derecho comparado, en concreto en el código penal alemán, que regula la privación del derecho a conducir como pena accesoria ${ }^{1276}$ en el artículo 44 del StGB. Asimismo, POZUELO PÉREZ1277 ha destacado que las penas privativas de derechos, en general, en países de nuestro entorno tales como Portugal, Italia o Alemania, están previstas como penas accesorias y no como penas principales, por lo que la propuesta que realizamos, en cierto modo, tiene claro encaje en el derecho comparado.

En cuanto al ámbito de aplicación de la pena de privación del derecho a conducir como pena accesoria, considero que se podría aplicar en todos los delitos en los que en su comisión se hubiera utilizado un vehículo a motor o ciclomotor, ya que son esos los casos en los que tendría sentido en los que se impusiera. Acordar la pena de privación del derecho a conducir como pena accesoria podría desarrollar fines de prevención general y especial, con carácter disuasorio, y de esta forma evitar la comisión de nuevos delitos tanto por parte del penado como también de del resto de conductores, por lo que a priori, sería partidario de explorar su aplicación en todos los delitos que tuvieran relación con la utilización del vehículo a motor o ciclomotor.

Uno de los óbices que estimo podría alegarse en relación con la posibilidad que la pena de privación del derecho a conducir tenga en el CP la consideración de pena accesoria, es la posible relación de proporcionalidad con alguna de las penas con la que debería ser impuesta de forma conjunta, como podrían ser la pena de multa o la pena de TBC, ya que siempre deberá estar vinculada a otras principales ${ }^{1278}$. Aquí podríamos preguntarnos si sería posible aplicar una pena de privación del derecho a conducir cuando la pena principal es la de multa o TBC, circunstancia ésta que podría suponer una disfunción. El motivo sería el siguiente: el delito por el que el penado habría sido condenado comportaría una pena principal, bien la pena de multa o la de TBC, que no afectarían a su esfera personal o laboral o si lo hacen será de forma limitada, y sin embargo, a través de una pena accesoria, como sería

\footnotetext{
1276 En este sentido vid. CHOCLÁN MONTALVO, José Antonio, "Las penas privativas...,", 'op.cit., p.158.

1277 Vid. POZUELO PÉREZ, Laura., Las penas..., op.cit., pp.18-19.
} 
la privación del derecho a conducir, podría verse afectado gravemente su entorno familiar, económico o laboral, ya que podría implicar que se quedara sin su puesto de trabajo, que en muchos casos puede ser el único ingreso de la familia. En este sentido, el juez debería valorar con carácter previo a su aplicación los efectos preventivos especiales y generales que pudieran derivarse de su ejecución. Ello supone tomar en consideración tanto los perjuicios personales que como el hecho que los potenciales infractores, al conocer que si cometen un delito por el que se les puede imponer esta pena ello les puede originar graves problemas económicos a su entorno familiar, quizás respeten el ordenamiento jurídico y la normativa de tráfico,

Respecto a la forma de ejecutar la pena de privación del derecho a conducir en los casos que se acordara como pena accesoria de la pena de prisión como pena principal, podemos señalar que el penado podría instar la suspensión de la ejecución de dicha pena principal. Posiciones doctrinales que son minoritarias como la de CHOCLÁN MONTALVO mantienen que la suspensión de la pena principal privativa de libertad determina la suspensión de la pena accesoria, que en nuestro caso sería la privación del derecho a conducir ${ }^{1279}$. En sentido contrario, la doctrina mayoritaria mantiene que no puede suspenderse la ejecución de las penas accesorias, como han señalado MAGRO SERVET y SOLAZ SOLAZ ${ }^{1280}$. En esta misma línea se expresó la FGE a través de la Circular 1/2005 sobre aplicación de la reforma del Código Penal operada por Ley Orgánica 15/2003 de 25 de noviembre (segunda parte), que mantenía la imposibilidad de suspensión de las penas que no sean privativas de libertad. Personalmente, considero que la pena de privación del derecho a conducir, en el caso que se pudiera acordar como accesoria, en todo caso debería cumplirse, ya que por mor del art. $80 \mathrm{CP}$ únicamente pueden dejarse en suspenso las penas privativas de libertad y no las privativas de derechos ${ }^{1281}$.

Hemos visto en el capítulo tercero que los delitos en los que está prevista la aplicación de la pena de privación del derecho a conducir son escasos, aunque

\footnotetext{
1278 Acerca de la vinculación entre pena accesoria y penal principal vid. AGUDO FERNÁNDEZ, Enrique/ JAÉN VALLEJO, Manuel/ PERRINO PÉREZ, Ángel Luis, Penas..., op.cit., p.162.

1279 Vid. CHOCLÁN MONTALVO, José Antonio, "Las penas privativas...,"'op.cit., p.167.

1280 Respecto a las dos posturas que mantienen la posibilidad de suspender las penas privativas de derechos impuestas como accesorias vid. MAGRO SERVET, Vicente/ SOLAZ SOLAZ, Esteban, Manual práctico..., op.cit., pp.38-42.

1281 Podemos destacar la STC, núm. 166/1993, Sala Primera, de 20 de mayo de 1993, ponente Excmo. Sr. Rafael de Mendizábal Allende (TOL82.189) y la STS, núm. 950/1999, Sala Segunda, de 19 de julio de 1999, ponente Excmo. Sr. Cándido Conde-Pumpido Tourón (TOL5.134.336), en las que se determinaba que no era ajustado a Derecho la suspensión de las penas privativas de derechos.
} 
desde el punto de vista de las sentencias dictadas sí suponen un número importante. Con la propuesta que realizamos, podría ampliarse la utilización de la pena analizada a delitos en los que en la actualidad no está prevista a través de su consideración como pena accesoria, lo que valoro que sí que podría tener importancia desde el punto de vista de política criminal. Si los Juzgados o Tribunales, además de imponer la pena objeto de estudio como pena principal en determinados delitos, tuvieran la opción de acordarla como pena accesoria en aquellos que no la prevean como pena principal, podrían incrementarse las herramientas existentes en el ámbito penal. De esta forma, una pena como privación del derecho a conducir, que juzgo necesario que esté presente en el $\mathrm{CP}$, podría adquirir una mayor relevancia para combatir una criminalidad moderna como es la relacionada con la utilización de vehículos a motor y ciclomotores, ya que a través de la misma se puede proteger la seguridad vial "apartando" de las carreteras a los conductores que han evidenciado una conducción peligrosa para el resto de usuarios de la vía. Por todo lo expuesto, y atendiendo a que existen posiciones doctrinales favorables, a que existen precedentes en el ámbito del derecho comparado y existen otras penas privativas de derechos en nuestro sistema penal que son también penas accesorias, estimo que sería positivo el hecho que se regulara también la pena de privación del derecho a conducir como pena accesoria, de imposición facultativa por el Juzgado o Tribunal, con independencia que ya aparezca regulada como pena principal en determinados delitos.

\subsection{Extensión de la atenuación prevista en el art.385 ter CP a la pena de privación del derecho a conducir}

Se plantea la posibilidad de extender la previsión del art. 385 ter relativa a la pena de prisión a la pena de privación del derecho a conducir. En este sentido, el redactado del art.385 ter $\mathrm{CP}^{1282}$ faculta al juez a rebajar en un grado la pena de prisión prevista en los delitos de los arts.379, 383, 384 y 385 CP en atención a la menor entidad del riesgo causado y a las demás circunstancias del hecho.

El tenor literal del precepto, que hace referencia exclusiva a la pena de prisión, excluye la posibilidad de aplicar los efectos del art.385 ter CP a la pena de privación

\footnotetext{
1282 Art.385 ter. En los delitos previstos en los artículos 379, 383, 384 y 385, el Juez o Tribunal, razonándolo en sentencia, podrá rebajar en un grado la pena de prisión en atención a la menor entidad del riesgo causado y a las demás circunstancias del hecho.
} 
del derecho a conducir, así como a otras penas no privativas de libertad ${ }^{1283}$. La exposición de motivos de la LO 5/2010 de 22 de junio por la que se aprobó la entrada en vigor del art.385 ter $\mathrm{CP}$, indica claramente que sus efectos únicamente se circunscriben a la pena de prisión y en aras a una mayor proporcionalidad entre los hechos cometidos y la pena de prisión a imponer ${ }^{1284}$. El CP es taxativo respecto a que sus efectos únicamente podrán ser aplicables a la pena de prisión como establece el texto del art.385 ter. La jurisprudencia mayoritaria se ha posicionado en esta línea acotando los efectos del art.385 ter a la pena prisión y no al resto de penas, como la multa, TBC o la privación del derecho a conducir ${ }^{1285}$. Sin embargo, existe una línea jurisprudencial minoritaria que sí ha aplicado los efectos del art. 385 ter CP a la pena de multa, aunque ha sido en supuestos de delitos de conducción sin licencia o permiso del art. 384 y en los que no se prevé la aplicación de la pena de privación del derecho a conducir, y la juzgadora de instancia ha optado por la pena de multa en lugar de la pena de prisión ${ }^{1286}$.

Puede entenderse que el legislador haya previsto esta posibilidad con relación a la pena más grave de las existentes en el CP, con la finalidad de evitar cuando sea posible el impacto negativo derivado de ingreso en un centro penitenciario. Sin embargo, tal como hemos puesto de relieve en este trabajo, en determinados supuestos para los penados puede llegar a ser más gravosa la pena de privación

\footnotetext{
1283 Vid. GÓMEZ PAVÓN, Pilar, "La reforma de los delitos contra la seguridad del tráfico (arts.379, 381, 385 bis y 385 ter)", en AA.VV. Comentarios..., op.cit., p.436 y también MARTíNEZ ZAPATER, Luis Fernando, "Los delitos contra la seguridad vial, arts.379, 381, 384, 385 bis y 385 ter", en AA.VV. La reforma..., op.cit., p.321 y MOLINA FERNÁNDEZ, Fernando, Delitos..., op.cit., p.26.

1284 Vid. LO 5/2010, de 22 de junio, por la que se modifica la LO 10/1995 de 23 de noviembre del Código Penal, Exposición de Motivos, apartado XXV. Recurso electrónico disponible en: http://www.boe.es/boe/dias/2010/06/23/pdfs/BOE-A-2010-9953.pdf (último acceso: 13/11/2020).

1285 Vid. SAP de Barcelona, núm.350/2012, Sección 10ª , de 20 de marzo de 2012, ponente llmo.Sr. José María Planchat Teruel. (TOL2.518.655) y la SAP de Madrid, núm. 80/2013, Sección 30a”, de 15 de febrero de 2013, ponente Ilmo. Sr. Carlos Martín Meizoso (TOL3.414.266), en la que se procede a la rebaja de la pena de prisión en aplicación del art.385 ter y se determina la imposibilidad de rebajar la pena de privación del derecho a conducir en aplicación de este artículo. También podemos destacar la SAP de Madrid, núm. 266/2012 Sección 17a , de 21 de febrero de 2012, ponente IIma. Sra. Carmen Lamela Díaz (TOL2.485.050), y la SAP de Lleida, núm. 195/2017, Sección 1ª de 18 de mayo de 2017, ponente IImo. Sr. Victor Manuel García Navascués (TOL6.416.595), que establecen la imposibilidad de extender los efectos del art.385 ter a la pena de multa y las SAP de Alicante, núm. 298/2015, Sección 10ä, de 9 de julio de 2015, ponente Ilmo. Sr. Jesús Gómez-Angulo Rodríguez (TOL5.745.943) y SAP Ciudad Real, núm.19/2016, Sección 2aㄹ, de 1 de febrero de 2016, ponente IImo. Sr. Ignacio Escribano Cobo (TOL5.665.904), que determinan que el art. 385 ter únicamente es aplicable a la pena de prisión. Podemos citar también la STS, núm. 38/2020, Sala Segunda, de 6 de febrero de 2020, ponente Excma. Sra. Carmen Lamela Díaz. (TOL7.763.421).

1286 En este sentido vid. SAP de Pontevedra, núm.9/2015, Sección 4a , de 20 de enero de 2015, ponente Ilmo. Sr. José Ramón Sánchez Herrero (TOL4.734.716) y la SAP de Pontevedra, núm. 565/2015, Sección 5á , de 17 de noviembre de 2015, ponente llmo. Sr. José Ramón Sánchez Herrero (TOL5.593.586).
} 
del derecho a conducir que una pena corta de prisión ${ }^{1287}$. Por este motivo, creo que podría ampliarse los efectos del art.385 ter CP a la pena de privación del derecho a conducir, facultando a los juzgadores a una mayor flexibilidad punitiva igual que sucede con la pena de prisión en el art.385 ter CP en determinados delitos contra la seguridad vial ${ }^{1288}$. Esta previsión podría hacerse también extensiva a la pena de TBC o de multa como propuso HURTADO YELO ${ }^{1289}$. De esta forma la pena de privación del derecho a conducir podría verse reducida por debajo del umbral del año que es la duración mínima en los delitos contra la seguridad vial en los que está prevista, estableciéndose un mecanismo para su graduación en supuestos de escasa gravedad ${ }^{1290}$.

Con la extensión de los efectos del art.385 ter a la pena de privación del derecho a conducir se intenta dotar de mayores mecanismos para modular esta pena por parte de los Juzgados y Tribunales, al ser una problemática que se ha venido planteando desde hace más de veinte años ${ }^{1291}$. Por parte de diferentes defensas en los procedimientos que se puede imponer la pena de privación del derecho a conducir se ha intentado que de forma analógica se aplicaran los efectos del art.385 ter también a esta pena y no quedara reducida únicamente a la pena de prisión. De forma unánime la jurisprudencia ha denegado dichas peticiones ${ }^{1292}$ pero ello no ha de ser óbice para que se pueda explorar la posibilidad de aprobar una propuesta de lege ferenda como la que se plantea y obtener una mejor respuesta de los Tribunales ante determinadas conductas relacionadas con la circulación de vehículos a motor y ciclomotores.

1287 En relación con las consecuencias que generan determinadas penas privativas como la privación del derecho a conducir, y que puede ser más gravosa que la pena de prisión, vid. SANZ MULAS, Nieves, Alternativas..., op.cit., p.360.

1288 En relación con la flexibilidad punitiva, vid. MARTíNEZ ZAPATER, Luis Fernando, "Los delitos contra la seguridad vial, arts.379, 381, 384, 385 bis y 385 ter", en AA.VV. La reforma..., op.cit., p.321.

1289 Vid. HURTADO YELO, Juan José, "Los delitos...", Revista Aranzadi Doctrinal no 8/2010, Ed. Aranzadi, 2010.

1290 En relación con los criterios de graduación de la pena de privación del derecho a conducir, vid. FERNÁNDEZ PANTOJA, Pilar, "Delitos contra la seguridad del tráfico: la pena de privación del derecho a conducir", en AA.VV. Delincuencia..., op.cit., pp.79-81.

1291 En este sentido destacar que la STS, núm. de recurso 1275/1994, Sala Segunda, de 14 de diciembre de 1994, ponente Excmo. Sr. Justo Carrero Ramos, (TOL403.798) ya planteó la problemática relacionada con la rebaja de la pena de privación del derecho a conducir a la mínima extensión.

1292 Vid. SAP de Barcelona, núm. 350/2012, Sección 10ª de 20 de marzo de 2012, ponente llmo.Sr. José María Planchat Teruel, (TOL2.518.655); SAP de Alicante, núm. 464/2012, Sección 3ª̣a de 19 de septiembre de 2012, ponente Ilmo. Sr. José Daniel Mira-Perceval Verdú. (TOL3.410.839) y la SAP de Madrid, núm. 184/2013, Sección 16a , de 19 de marzo de 2013, ponente Ilmo. Sr. Francisco David Cubero Flores (TOL3.708.667). 
En lo relativo al catálogo de tipos delictivos que podrían verse afectados por esta previsión considero que debería ser distinto al establecido en el vigente art.385 ter $\mathrm{CP}$, ya que podría aplicarse a los arts.379, 383 y 382 bis CP, pero no a los arts.384 ni $385 \mathrm{CP}$ que no prevén en su penalidad la pena de privación del derecho a conducir. Tampoco deberían aplicarse los efectos del art.385 ter CP a los arts.380 y 381 CP que regulan la conducción temeraria, debido a la gravedad de la acción que se comete en ambos. En relación con los otros dos delitos en que se puede imponer la pena de privación del derecho a conducir, los del art.142 y 152 CP de homicidio y lesiones por imprudencia grave y menos grave cometidos con vehículo a motor, de acuerdo al criterio establecido en el art.385 ter CP, estarían excluidos de su aplicación ya que tal como se prevé la regla específica del art.66.2 CP, existe una mayor discrecionalidad por parte del órgano jurisdiccional para poder determinar la pena ${ }^{1293}$. Los tipos delictivos que tendrían un mayor encaje en la propuesta son los de los arts.379, 382 bis y $383 \mathrm{CP}$, ya que en ambos la pena de privación del derecho a conducir se impone en todo caso, siendo pena principal y no existiendo una posibilidad de alternativa. Por ello estimo procedente la propuesta que se realiza atendiendo a que en numerosas ocasiones son delitos de escasa ofensividad y en el caso del art.379 CP de peligro abstracto ${ }^{1294}$.

El criterio para su aplicación debería seguir el esquema del actual art.385 ter, de modo que la reducción de la pena de privación del derecho a conducir fuera facultativa para el Juzgado o Tribunal. Dos de los parámetros que fundamentan el uso del art.385 ter CP para reducir la pena de prisión ${ }^{1295}$, como son la menor entidad del riesgo causado y las circunstancias periféricas del hecho acaecido pueden también trasladarse a la posibilidad planteada. La propia exposición de motivos de la LO 5/2010, hace referencia al principio de proporcionalidad en relación con los delitos de peligro abstracto ${ }^{1296}$, y este principio también puede ser aplicable a la propuesta realizada para reducir la pena de privación del derecho a conducir que se pueda imponer. Por ello, en determinados casos, debería permitirse al juez a quo poder rebajar la pena de privación del derecho a conducir al amparo

\footnotetext{
1293 Art.66.2 CP: En los delitos leves y en los delitos imprudentes, los jueces o tribunales aplicarán las penas a su prudente arbitrio, sin sujetarse a las reglas prescritas en el apartado anterior.

1294 Referente a la "menor peligrosidad" de los delitos tipificados en los arts.379.1 y 379.2, vid. MOLINA FERNÁNDEZ, Fernando, Delitos..., op.cit., p.26-27.

1295 En relación con los criterios para la aplicación del art.385 ter, vid. GÓMEZ PAVÓN, Pilar, "La reforma de los delitos contra la seguridad del tráfico (arts.379, 381, 385 bis y 385 ter)", en AA.VV. Comentarios..., op.cit., p.437 y también VALEIJE ÁLVAREZ, Inmaculada, "El sistema de penas en los delitos contra la seguridad vial", en AA.VV. Prevención y control..., op.cit., p.463.
}

1296 Vid. al respecto la Exposición de Motivos de la LO 5/2010 de 22 de junio, apartado XXV. 
de una propuesta como la que se realiza, ya que a pesar de que el propio CP en el art.66.1.6 CP permite individualizar la pena ${ }^{1297}$, existen unos límites mínimos que no se podrán rebasar. Un supuesto en el que se podría acordar la extensión del art.385 ter CP a la pena de privación del derecho a conducir es cuando el penado arroja un resultado positivo en un control de alcoholemia, sin que existan lesionados ni daños materiales. También podría aplicarse en supuestos de conducción con exceso de velocidad del art.379 CP, así como en los casos del art.383 CP por negativa a realizar las pruebas de alcoholemia, y no existieran síntomas que acreditaran una posible embriaguez ${ }^{1298}$.

La posibilidad de aplicar unos efectos similares a los previstos en el art.385 ter CP a la pena de privación del derecho a conducir no sería una rebaja de la respuesta punitiva del Estado en relación con esta pena privativa de derechos, sino todo lo contrario. La propuesta dotaría de una mayor flexibilidad en la imposición de la pena a Juzgados y Tribunales, mitigando el automatismo que caracteriza su aplicación, y éstos podrían aplicar el principio de proporcionalidad con mayor coherencia de lo que sucede en la actualidad. Además, uno de los fines de la pena de privación del derecho a conducir es el de prevención especial, y la propuesta que se realiza puede coadyuvar a mejorar este fin en el penado al que se le imponga esta pena.

En el ámbito de las propuestas de lege ferenda, en segundo lugar, analizaremos las dos propuestas realizadas con la pena de privación del derecho a conducir en la fase de ejecución.

\subsection{Inmovilización temporal del vehículo a motor o ciclomotor por tiempo igual a la pena de privación del derecho a conducir}

Una de las dificultades que se han detectado en este trabajo en relación con la aplicación de la pena de privación del derecho a conducir es la relativa al control de su cumplimiento, dados los problemas para garantizar de una forma más eficaz que el penado cumplirá la pena y no conducirá durante el periodo de ejecución de la misma. Por este motivo, considero que pudiera resultar adecuada la introducción en

\footnotetext{
1297 Art.66.1.6 CP: Cuando no concurran atenuantes ni agravantes aplicarán la pena establecida por la ley para el delito cometido, en la extensión que estimen adecuada, en atención a las circunstancias personales del delincuente y a la mayor o menor gravedad del hecho.

1298 Este último supuesto también fue citado con relación a la pena de prisión y el art.385 ter en la Instrucción $n^{\circ}$ 1/2011, "Sobre algunas cuestiones en material de seguridad vial" de la Audiencia Provincial de Madrid, p.7. Vid. la citada Instrucción en: http://www.apifiscales.es/seccionesterritoriales/madrid. último acceso: (05/11/2020).
} 
el ordenamiento penal español de una medida consistente en la inmovilización temporal del vehículo a motor o ciclomotor que se aplicaría durante el periodo de cumplimiento de la pena de privación del derecho a conducir.

En las siguientes páginas nos plantearemos cual debería ser, en su caso, la naturaleza jurídica de esta medida y también el ámbito de aplicación objetivo, subjetivo y temporal, así como determinaremos como llevar a cabo su ejecución. La delimitación del ámbito de aplicación debería poder contribuir a que esta medida de inmovilización temporal del vehículo a motor o ciclomotor sirva, en determinados supuestos, para garantizar una mejora en el cumplimiento de la pena, pero sin que su imposición deba suponer un exceso punitivo sobre el penado ${ }^{1299}$. La medida de inmovilización temporal del vehículo a motor o ciclomotor que se propone está relacionada directamente con la pena de privación del derecho a conducir, ya que sería aplicable de forma acumulativa a esta pena y tendría un cumplimiento simultáneo y sería, en todo caso, de imposición facultativa por el juzgado o tribunal.

La utilización de esta medida podría tener sentido en los delitos cometidos con vehículo a motor o ciclomotor, y tendría un alcance práctico ya que el penado estaría privado de utilizar un vehículo mientras dure su condena de privación del derecho a conducir, lo que reduciría las opciones para conducir. Aun cuando la medida que se propone no pueda garantizar de forma absoluta que el penado conduzca un vehículo distinto al inmovilizado, puede suponer en la mayor parte de casos, a menos que el penado disponga de diversos vehículos, una importante restricción, reduciendo además el riesgo de posibles quebrantamientos de condena.

En lo relativo a su naturaleza jurídica, y a la cuestión sobre si debería articularse como una medida de naturaleza penal o administrativa, considero que debería ser una medida penal ya que la misma se acordaría tras la comisión de un delito y estaría asociada a la pena de privación del derecho a conducir. La naturaleza penal sería la más adecuada para la medida propuesta, ya que de esta forma se la dotaría de idéntica relevancia que las penas a las sanciones penales a las que iría asociada, tanto la pena de privación del derecho a conducir, la prisión, multa o TBC, y además su control estaría en el mismo ámbito penal, por lo que de esta forma se evitaría duplicidades en la ejecución. En lo que a la concreta naturaleza penal de la medida atañe, cabe plantear si resulta más oportuno configurarla como una consecuencia accesoria o como una pena accesoria. Así, en primer lugar, una de 
las opciones en cuanto a la regulación y naturaleza jurídica es que la medida propuesta pudiera configurarse como una consecuencia accesoria, dada su similitud con la figura del decomiso. En efecto, el decomiso constituye la incautación de los instrumentos que se hayan utilizado para la comisión del delito y el CP determina en el art.127 que tiene carácter preceptivo, aunque en los delitos contra la seguridad vial el art.385 bis, lo regula con carácter facultativo. Si partimos de la regulación del decomiso en los arts.127, 128 y 385 bis CP, nada obstaría a que se pudiera aplicar esta propuesta similar al decomiso e interpretar que el vehículo a motor o ciclomotor es un instrumento con el que se ha cometido el delito. Debido al carácter temporal de la medida que se propone, sus consecuencias jurídicas serían distintas al decomiso, ya que éste según los arts.127 y 128 CP es una consecuencia accesoria definitiva e impuesta en sentencia firme, como se establece en el Libro Primero, Título $\mathrm{VI}^{1300}$, mientras que la medida propuesta estaría limitada a un periodo de tiempo determinado. La propuesta es relativamente novedosa, pues fue ya planteada por parte de los Fiscales Delegados de Seguridad Vial en las jornadas celebradas en León los días 25 y 26 de enero de 2009 como ha señalado VIZUETA FERNÁNDEZ ${ }^{1301}$. Se planteó por los Fiscales Delegados de Seguridad Vial que el decomiso parcial del art. $128 \mathrm{CP}$ estuviera relacionado, no tanto con la privación de la propiedad del vehículo, sino con limitar temporalmente su uso, siendo similar a la propuesta que aquí se realiza. En este sentido entiendo que dicha expresión sería difícil de poderla aplicar a la medida que se propone, ya que el texto del art.128 CP excluiría una "inmovilización temporal" en los términos que se plantea en el presente apartado.

Respecto la posibilidad de identificar la medida propuesta con el decomiso, cabe señalar que en ambos casos el instrumento con el que el penado ha cometido el delito queda en poder de la administración de Justicia. No obstante, a pesar de dicha coincidencia, no parece que ambas figuras puedan ser asimiladas puesto que el decomiso es una medida definitiva, mientras que la inmovilización temporal sería únicamente por un periodo coincidente con la pena de privación del derecho a conducir. En efecto, la temporalidad sería la principal característica de esta medida, a diferencia de la consecuencia accesoria del decomiso, ya que la propuesta contempla retornar la posesión del vehículo a motor o el ciclomotor al penado una vez se haya cumplido la pena de privación del derecho a conducir. Ello es relevante

\footnotetext{
1299 Sobre la necesidad de imponer medidas penales en el vehículo del condenado por delitos contra la seguridad vial, vid. TAMARIT SUMALLA, Josep/ LUQUE REINA, Maㅡ Eulàlia, Automóviles, delitos y penas..., op.cit., p.149.

1300 Respecto al decomiso vid. LANDROVE DÍAZ, Gerardo, Las consecuencias..., op.cit., p. 125.
} 
puesto que el penado no perdería nunca la propiedad del vehículo a motor o ciclomotor lo que motiva que la medida propuesta no pueda ser considerada un decomiso ${ }^{1302}$.

Podemos plantearnos si la inmovilización temporal compartiría ciertos matices con la medida cautelar de intervención del vehículo ${ }^{1303}$, ya que sería acordada por el juez penal de forma motivada y también susceptible de quebrantamiento. La respuesta ha de ser negativa dado que la propuesta que se realiza no tendría un encaje absoluto en el marco de la medida cautelar de intervención judicial del vehículo del art. 764.4 de la LECrim, ya que aquella no tendrá finalidades relacionadas con la investigación del delito ni tampoco servirá para asegurar las futuras responsabilidades civiles dimanantes del mismo ${ }^{1304}$. Si bien la intervención judicial del vehículo también tiene como finalidad la de evitar la comisión de nuevos delitos al amparo del art. 13 de la LECrim durante la instrucción del procedimiento, la diferencia con la propuesta que se realiza es que ésta no se acuerda como una medida cautelar, sino que se adoptaría en una sentencia firme y siempre iría aparejada a una pena de privación del derecho a conducir. Ciertamente, considero que no sería idóneo denominar a la medida que se propone como "intervención", ya que dicha expresión puede ir asociada a la provisionalidad de una medida cautelar, y la propuesta que se realiza siempre se acordará en una sentencia condenatoria firme.

Una segunda opción, desde el punto de vista de su naturaleza y su regulación en el $\mathrm{CP}$, sería su incorporación al catálogo de penas accesorias previstas en el art. 56 o 57 CP. Ello posibilitaría su aplicación como pena accesoria cuando se imponga como pena principal la pena de privación del derecho a conducir. Se trataría, en definitiva, de añadir un tercer apartado en el art. 56 CP o un cuarto apartado en el art. $57 \mathrm{CP}$, que reflejara que en aquellos casos en los que se imponga la pena estudiada, además, el Juzgado o Tribunal, con carácter facultativo, podría imponer la inmovilización temporal del vehículo a motor o ciclomotor por tiempo de duración

\footnotetext{
1301 Vid. la referencia en VIZUETA FERNÁNDEZ, Jorge, "Delitos contra...", op.cit., p.6.

1302 En el ámbito de la doctrina, DE VICENTE MARTíNEZ realizó una propuesta similar, aunque ubicada en el ámbito del Derecho Administrativo, que también proponía la "paralización inmediata y bloqueo del vehículo durante un cierto periodo de tiempo". Vid. la propuesta realizada por DE VICENTE MARTÍNEZ, Rosario, Derecho..., op.cit., p.66.

1303 La similitud con la medida cautelar ha sido destacada por DE VICENTE MARTíNEZ, Rosario, Derecho..., op.cit., p.68.

${ }^{1304}$ En relación con la medida de intervención cautelar del vehículo y su diferencia con la medida propuesta de inmovilización temporal, vid. HIDALGO DE MORILLO JIMÉNEZ, Agustín, "Aspectos comunes a los delitos contra la seguridad vial”, La dogmática penal..., op.cit., p.47.
} 
igual que la pena principal de privación del derecho a conducir vehículos a motor o ciclomotores $^{1305}$. Un problema que podría generarse es que sí se aprobara esta propuesta de lege ferenda y también en un futuro estuviera prevista la pena de privación del derecho a conducir como pena accesoria, existirían dificultades para poder acordar la inmovilización temporal del vehículo en los casos en los que la pena objeto de estudio se acordara como accesoria y no como principal, aunque estos casos serían residuales. A la vista de lo expuesto, estimo que la propuesta tendría un encaje tanto como consecuencia accesoria como pena accesoria, descartando su calificación como medida cautelar, al hallarnos ante una sentencia condenatoria firme.

La propuesta no resulta ajena en el contexto del Derecho comparado. En este sentido, cabe apuntar la medida existente en el CP francés en el art. 221.8. 9, para los casos de homicidio involuntario art.221.6.1 cometidos por el conductor de un vehículo terrestre a motor ${ }^{1306}$. La medida regulada en el art. 221.8. 9 CP francés como pena accesoria establece la inmovilización del vehículo con el que se haya cometido el homicidio involuntario durante el plazo máximo de un año, siempre que el condenado sea el propietario del vehículo ${ }^{1307}$. De igual modo en el CP francés existe una medida similar a la que se propone en los delitos de riesgo tipificados en el art.223.1, para los cuales está prevista la inmovilización temporal del vehículo si el penado es el propietario durante el plazo de un año ${ }^{1308}$ al amparo del art.223.18. $7^{\circ}$ del texto penal1309. Asimismo, el art.131.6. $5^{\circ}$ prevé que en los delitos que se castiguen con pena de prisión, se podrá acordar la inmovilización por una duración

\footnotetext{
1305 Un posible redactado del apartado 3, del artículo 56 o un cuarto en el art. 57 sería: En aquellos casos en los que se imponga la pena de privación del derecho a conducir vehículos a motor y ciclomotor, los jueces o tribunales, podrán imponer atendiendo a la gravedad del delito y/o antecedentes del penado, la inmovilización temporal de un vehículo a motor o ciclomotor del penado por tiempo igual a la duración de la pena de privación del derecho a conducir.

1306 Vid. el comentario al respecto, CARDENAL MONTRAVETA, Sergi, "Los delitos relacionados con la seguridad del tráfico en el derecho comparado", Indret, Revista para el análisis del Derecho, ํㅡ 3, 2007, p.12.

1307 Art.221.8.9 CP francés: En los casos previstos por el artículo 221-6-1, la inmovilización, hasta por un año, del vehículo del que se haya servido el condenado para cometer la infracción, si es su propietario.

1308 Art.223.18.7ํ CP francés: Si la infracción se cometió con ocasión de la conducción de un vehículo terrestre de motor, la inmovilización, por un período de hasta un año, del vehículo del que se haya servido el condenado para cometer la infracción, si es su propietario.

1309 Vid. DE VICENTE MARTÍNEZ, Rosario, "El delito de conducción bajo la influencia de drogas tóxicas, estupefaciente, sustancias psicotrópicas o bebidas alcohólicas y su propuesta de reforma. La cuestionable necesidad de modificar el art. 370 del C. Penal", La Ley, núm. 6653, 16 de febrero de 2007.
} 
máxima de un año de uno o varios vehículos propiedad del condenado ${ }^{1310}$. A pesar de la similitud que la medida propuesta comparte con las medidas existentes en el CP francés, existe una diferencia sustancial y es que la inmovilización temporal no estaría limitada a un periodo de un año, sino que siempre tendría una duración idéntica a la pena de privación del derecho a conducir ya que su imposición será conjunta con esta pena, por lo que puede superar el plazo de un año que fija como límite el derecho penal francés. En este sentido, sería interesante que la medida tuviera una duración idéntica a la pena de privación del derecho a conducir que se imponga en la sentencia firme que siempre será pena principal, y acumular la privación de conducir a la imposibilidad de utilizar un vehículo titularidad del penado.

En cuanto a las finalidades perseguidas mediante la aplicación de esta medida de intervención temporal pueden señalarse las siguientes. La primera sería la de evitar y prevenir que se cometan nuevos hechos delictivos por el penado durante el periodo de cumplimiento de la pena de privación del derecho a conducir ${ }^{1311}$. La segunda finalidad sería la de disuadir al resto de conductores, ya que éstos podrían percibir que, en determinados supuestos, además que se les imponga la pena de privación del derecho a conducir, se podría acordar la inmovilización temporal del vehículo a motor o ciclomotor. Es por ello por lo que podríamos inferir una finalidad de prevención general negativa con relación a los otros conductores ${ }^{1312}$. La tercera finalidad que podríamos asociar a la propuesta que se plantea sería la de evitar quebrantamientos de condena de la pena de privación del derecho a conducir por parte del penado ${ }^{1313}$. El cumplimiento de la pena objeto de este trabajo sería doblemente eficaz, ya que en primer lugar al penado se le privaría del derecho a conducir y, en segundo lugar, al proceder a la inmovilización temporal del vehículo a motor o ciclomotor con el que se haya cometido el delito se puede evitar que lo conduzca durante el tiempo de la condena, y minimizar el riesgo que el penado puede suponer para la seguridad vial ${ }^{1314}$. La pena de privación del derecho a conducir puede ser fácilmente quebrantada, pero es difícil de detectar ya que depende del mero azar o la suerte que puedan tener las Fuerzas y Cuerpos de

\footnotetext{
1310 Con relación a la normativa francesa vid. TAMARIT SUMALLA, Josep/ LUQUE REINA, Mª Eulàlia, Automóviles, delitos y penas..., op.cit., p.124.

1311 Vid. el comentario de GONZÁLEZ CUSSAC, José Luis, "La reforma penal de los delitos contra la seguridad vial (Proyecto CP 2006)", en AA.VV., Derecho Penal..., op.cit., p.316.

1312 Respecto de la prevención general negativa vid. ROCA AGAPITO, LUIS, El sistema..., op.cit., p.85.

${ }^{1313}$ La finalidad de evitar incumplimientos en la pena ha sido también destacada por DE VICENTE MARTÍNEZ, Rosario, Derecho..., op.cit., p. 68.

1314 Vid. TAMARIT SUMALLA, Josep," La pérdida definitiva del derecho de conducir o del derecho a la tenencia y porte de armas", en AA.VV. La adecuación..., op.cit., p.126.
} 
Seguridad en los controles preventivos que realizan. De implementarse la intervención temporal, se reducirían los factores suerte o azar ya que la Administración de Justicia tendría en su poder el instrumento con el que se ha cometido el delito que ha acarreado la pena de privación del derecho a conducir. Por lo tanto, lo relativo a los fines de esta medida predominaría la finalidad de prevención especial negativa ${ }^{1315}$, ya que el penado además de no poder utilizar el vehículo a motor o ciclomotor durante el tiempo de la condena, estará privado del derecho a conducir y ligado a esta prohibición se aplica la obligación de realizar el curso de sensibilización y reeducación vial. La combinación de estas tres medidas sería positiva para el penado en aras a tomar conciencia de la infracción cometida y evitar a la vez el quebrantamiento de la pena de privación del derecho a conducir impuesta.

Atendiendo al ámbito de aplicación de la inmovilización temporal, considero que podría tener encaje en todos los delitos contra la seguridad vial en los que se prevé la aplicación de la pena de privación del derecho a conducir, es decir los arts.379, $380,381,382$ bis y 383 CP. Otro ámbito en el que se podría aplicar la propuesta serían las infracciones en las que el vehículo a motor o ciclomotor es instrumento del delito, como serían el homicidio o lesiones por imprudencia grave y menos grave cometidas con vehículo a motor o ciclomotor de los arts.142 y $152 \mathrm{CP}$, en los que también se puede imponer la pena de privación del derecho a conducir. La inmovilización temporal no supondría la pérdida de titularidad del vehículo a motor o ciclomotor, y sería aplicable en supuestos en los que el juzgador estime que no es necesario acordar el decomiso del vehículo ${ }^{1316}$, pero sí debe imponerse otra sanción penal, para evitar la reiteración delictiva durante el tiempo que dure la pena de privación del derecho a conducir, al no ser suficiente únicamente esta pena.

A la vista de las consideraciones realizadas, una cuestión a plantearse es si la inmovilización temporal únicamente debería aplicarse a los delitos dolosos que implican la pena de privación del derecho a conducir o también podría imponerse en los delitos imprudentes. Para resolver esta cuestión puede resultar útil acudir a la regulación prevista para el decomiso. En este sentido, el CP de 1995 determinó que el decomiso únicamente se debía aplicar a los delitos dolosos, excluyendo los

\footnotetext{
1315 En relación con los fines de prevención especial del decomiso, vid. TAMARIT SUMALLA, Josep/ LUQUE REINA, Mª Eulàlia, Automóviles, delitos y penas..., op.cit., p.104.

1316 En cuanto a la estadística relativa a la aplicación del decomiso de vehículos a motor y ciclomotores, hemos de señalar que no existen datos ni a nivel de CGPJ ni de la FGE.
} 
delitos imprudentes ${ }^{1317}$. Sin embargo, tras la entrada en vigor de la LO 5/2010, de 22 de junio, el art.127.2 permite la adopción del decomiso en los delitos imprudentes que conlleven una pena de prisión superior a un año, lo que podría servirnos como pauta para acordar la inmovilización temporal en los delitos de los arts.142.1 y 152.1 .2 y 3 CP cometidos por imprudencia grave ${ }^{1318}$. La propuesta no es un decomiso estricto sensu, por lo que sí podría aplicarse a los delitos imprudentes tanto los que conllevan una pena privativa de libertad superior a un año como los cometidos por imprudencia menos grave, e incluir a los que no afecta la cláusula del art.385 bis CP. Si bien el decomiso ha de ser reservado para los comportamientos de mayor gravedad, desde el punto de vista de la culpabilidad como son los hechos dolosos ${ }^{1319}$, la inmovilización temporal, que tendría diferencias con dicha consecuencia accesoria, podría incluir los delitos de homicidio y lesiones por imprudencia grave y menos grave cometidos con vehículo a motor o ciclomotor, atendiendo al resultado que se produce en los mismos. En todo caso, para que se aplique la propuesta, ésta ha de estar guiada por uno de los principios que también rigen el decomiso como es el principio de proporcionalidad entre los hechos cometidos y la adopción de la medida ${ }^{1320}$.

Asimismo, de optar el legislador por introducir esta medida, cabe señalar que la misma podría resultar adecuada para tipos delictivos para los que hoy día no prevén la pena de privación del derecho a conducir pero que sí podría contemplarla de acuerdo con la propuesta que formulamos. Así, podemos señalar el delito de quebrantamiento de condena de la pena de privación del derecho a conducir del art.384 CP, los delitos de los arts.138 CP y 148 de homicidio y lesiones causadas con instrumento peligroso y el tipo penal del art.550.1 en relación con el art.551.3 $\mathrm{CP}$, que tipifica el delito de atentado cometido con vehículo a motor.

En lo que atañe a ámbito subjetivo de aplicación, podemos señalar las siguientes observaciones. En primer lugar, la inmovilización temporal sólo se podría aplicar si

\footnotetext{
1317 Vid. la opinión de RODRÍGUEZ LEÓN, Luis Carlos, Seguridad Vial..., op.cit., p.47.

1318 Art.127.2 CP: En los casos en que la ley prevea la imposición de una pena privativa de libertad superior a un año por la comisión de un delito imprudente, el Juez o Tribunal podrá acordar la pérdida de los efectos que provengan del mismo y de los bienes, medios o instrumentos con que se haya preparado o ejecutado, así como las ganancias provenientes del delito, cualquiera que sean las transformaciones que hubieran podido experimentar.

1319 En este sentido, también puede destacarse la crítica a la aplicación del decomiso a los hechos imprudentes, LANDROVE DÍAZ, Gerardo, Las consecuencias..., op.cit., p.125.

1320 El principio de proporcionalidad también está presente en el comiso regulado en el Código Penal Alemán. Vid. AGUADO CORREA, Teresa, El comiso, op.cit., p.59, in fine, y la referencia al ordenamiento penal suizo, p.62, in fine.
} 
además de imponer la pena de privación del derecho a conducir el penado fuera titular de vehículos a motor o ciclomotores. El objeto sobre el que implementaría la propuesta sería el vehículo a motor o ciclomotor con el que el penado haya cometido el delito en el supuesto de que el vehículo sea de su propiedad. En los casos que el penado hubiese cometido el delito con un vehículo titularidad de un tercero se debería acordar que la inmovilización temporal recayera sobre el vehículo a motor o ciclomotor del que fuera titular el autor de los hechos, aun cuando no fuera el empleado en la perpetración del delito. Ello supone que cuando el autor de los hechos no fuere titular de ningún vehículo a motor o ciclomotor, no procedería acordar la inmovilización temporal ni siquiera en el supuesto en que el penado fuera usuario habitual de un vehículo del que, sin embargo, no fuera titular. Y ello con el fin de no perjudicar a un tercero - familiar, empresario, etc.- que no hubiese tenido ningún tipo de relación con el hecho delictivo. En este sentido, dado que, como se ha señalado, la inmovilización debe vincularse a la aplicación de una pena de privación del derecho a conducir, la medida dejaría de tener sentido de recaer en el vehículo de un tercero no penado.

En segundo lugar, podría suceder que el penado fuera efectivamente el titular del vehículo en el registro de la DGT ya que ex art. 59.3 de la LTSV ${ }^{1321}$ sólo se admite un único titular en las autorizaciones administrativas para circular. Sin embargo, podría suceder que dicho vehículo fuera cotitularidad de varias personas en virtud de documento privado. En estos supuestos, entiendo que no debería procederse a la inmovilización dado que ello podría suponer un perjuicio para el resto de cotitulares que no han tenido relación alguna con el delito. En tercer lugar, en el supuesto que el conductor penado fuere propietario de diversos vehículos a motor o ciclomotores, cuya constancia se acreditaría previa consulta en el Registro de Vehículos de la DGT, lo procedente sería aplicarla sobre el vehículo a motor o ciclomotor con el que se haya cometido el hecho delictivo. Finalmente, en el supuesto en que el penado fuera titular de diversos vehículos a motor, considero que el Juzgado o Tribunal podría determinar cuál de los vehículos procedería inmovilizar de entre aquellos que sean titularidad del penado. En este último supuesto sí que debemos admitir que la contribución de la medida que se propone a garantizar la ejecución de pena de privación del derecho a conducir puede ser relativa, ya que el conductor penado podrá tener a su disposición otro de sus vehículos y poder quebrantar la pena impuesta.

1321 Art.59.3 LTSV: En las autorizaciones administrativas de circulación únicamente constará un titular. 
En cuanto a la duración temporal de la propuesta considero que para que la ejecución de la pena de privación del derecho a conducir sea eficaz al aplicarse de forma conjunta con la inmovilización del vehículo a motor o ciclomotor, ésta debería tener idéntica duración que aquella. Es decir, la duración de ambas sería la misma, aunque debería preverse que el juzgado o Tribunal de forma facultativa, pudiera establecer un periodo inferior de inmovilización temporal al de la pena de privación del derecho a conducir si la duración de aquella fuera tan prolongada en el tiempo que pudiera provocar daños irreparables en el mismo por su falta de utilización. Por ello, como criterio general valoro que debería coincidir temporalmente la pena privativa de derechos con la inmovilización, aunque con la facultad del Juzgado o Tribunal de modular esta última.

Una de las claves para que la propuesta que se realiza sea viable es que se pueda ejecutar correctamente. Debido a que la inmovilización temporal del vehículo a motor o ciclomotor se aplicaría de forma conjunta con la pena de privación del derecho a conducir se puede ejecutar a través de dos vías. La primera, daría inicio en el mismo Juzgado de Guardia en los casos de sentencias condenatorias de conformidad en los procedimientos tramitados como Diligencias Urgentes-Juicio Rápido. Para ello deberían coordinarse los Juzgados de Guardia, las Jefaturas Provinciales de Tráfico y los Cuerpos y Fuerzas de Seguridad, a los efectos de asegurar el efectivo cumplimiento desde el mismo momento que se dictara sentencia condenatoria de conformidad en el Juzgado de Guardia. La segunda vía sería a través del procedimiento ordinario y se llevaría a cabo a través de los Juzgados de Instrucción, Juzgados de lo Penal, Audiencias Provinciales o Juzgados de Ejecutorias Penales. Tanto en los supuestos que se adopte la medida propuesta en los casos de Diligencias Urgentes-Juicio Rápido ante el Juzgado de Guardia como en los del procedimiento ordinario, debería instaurarse el mecanismo de inmovilización temporal al mismo tiempo que se entregara el permiso o licencia en los supuestos de los penados que lo poseyeran. En los casos de los penados que carezcan de permiso o licencia, el inicio de la inmovilización temporal del vehículo a motor o ciclomotor se podría llevar a cabo cuando se realiza el trámite de advertencia de abstenerse de conducir. De esta forma, en los dos casos, se realizarían ambos trámites a la vez, máxime si recordamos que la medida propuesta tiene que ir aparejada al plazo de duración de la pena de privación del derecho a conducir.

En cuanto a la forma de dar inicio a la ejecución de la inmovilización temporal, se propone que el penado informe al Juzgado o Tribunal encargado de la ejecución de la medida del lugar en el que se encuentre estacionado el vehículo a motor o 
ciclomotor de su propiedad para que la comisión judicial se encargue del traslado del mismo, siempre que no conste ya inmovilizado por la autoridad policial. Una vez se haya comprobado que el vehículo a motor o ciclomotor se encontrase a disposición del Juzgado o Tribunal, se procedería a su precinto y sería llevado por una grúa a las instalaciones destinadas a albergarlo durante el periodo que durase la inmovilización temporal, evitando de esta forma que pueda circular durante el tiempo que dure la pena de privación del derecho a conducir.

No puede finalizarse este apartado sin señalar también los obstáculos y limitaciones que se perciben para la implementación de la propuesta. El primero sería de índole logístico, ya que implicaría que durante un periodo de tiempo determinado el vehículo a motor o ciclomotor deba estar inmovilizado, depositado en naves o aparcamientos vigilados destinados a tal efecto para evitar que puedan ser utilizados. Estos lugares deberían estar dotados de las medidas de vigilancia y condiciones idóneas para evitar que los vehículos a motor o ciclomotores fueran dañados, robados, etc., ya que a pesar de estar en posesión de la Administración de Justicia, la titularidad seguiría siendo de los penados La segunda dificultad tendría que ver con el elevado número de condenas que incluyen la pena de privación del derecho a conducir, y serían procedimientos en los que potencialmente podría ser aplicada la inmovilización temporal. Para articular un correcto sistema de ejecución sería necesario disponer de una infraestructura de grandes dimensiones que pudiera tener la capacidad para asimilar la inmovilización de numerosos vehículos durante largos periodos de tiempo, ya que la duración mínima en abstracto de la pena de privación del derecho a conducir es de un año. Otro problema serían los gastos económicos que generarían estas infraestructuras por lo que habría que determinar si han de ser asumidos por la Administración de Justicia o por el contrario deberían ser asumidos por los penados a los que se les impone la inmovilización temporal del vehículo a motor o ciclomotor, siendo una posibilidad a través de la condena en costas.

A pesar de estas dificultades enunciadas lo cierto es que desde la entrada en vigor de la LO 5/2010 de 22 de junio, y en concreto el art.385 bis el legislador ha optado en los delitos contra la seguridad vial por incidir en el instrumento del delito que es el vehículo a motor o ciclomotor. Desde hace diez años, no son residuales los casos que se acuerda el decomiso del vehículo a motor o ciclomotor con la pena analizada en el presente trabajo, y la inmovilización temporal del vehículo a motor o ciclomotor continúa esta línea al incidir en el instrumento del delito. En los delitos contra la seguridad vial, la propuesta que se realiza podría seguir el recorrido de la consecuencia accesoria del decomiso. Con anterioridad a la reforma de la LO 
5/2010 de 22 de junio, por parte de la Fiscalía de Seguridad Vial incluso se propuso el decomiso como medida ejemplarizante en los conductores que eran reincidentes en delitos contra la seguridad vial cometidos con tasas positivas de alcohol ${ }^{1322}$. Por ello, la posibilidad de implementar una propuesta de inmovilización temporal del vehículo a motor o ciclomotor podría tener una acogida más positiva que hace diez años cuando el decomiso del vehículo se aplicaba de forma restrictiva.

La propuesta que se plantea estimo que no sería difícil de llevar a cabo, aunque no estaría exenta de dificultades tal como hemos destacado. Sin embargo, históricamente la justicia penal española no ha sido proclive a acordar medidas similares como puede ser el decomiso del vehículo ${ }^{1323}$, por lo que su aplicación tendría una inicial reticencia en la praxis judicial. A pesar de ello, considero que en nuestro sistema penal existen cimientos para que el legislador pueda implementar la medida que se propone u otra de similares características y se acuerde la inmovilización temporal del vehículo a motor o ciclomotor por tiempo igual a la condena de privación del derecho a conducir. En este sentido soy partidario de aplicar esta medida con carácter temporal y reducir en el penado el uso del vehículo durante un determinado periodo de tiempo a pesar de que ciertos sectores doctrinales se muestren reticentes a medidas como la aquí planteada ${ }^{1324}$.

\subsection{Sustitución y suspensión en la ejecución de la pena de privación del derecho a conducir}

Debido a la elevada aplicación la pena de privación del derecho a conducir y la generalidad de personas a las que puede afectar hemos de plantear el debate acerca de si la pena objeto de estudio debe ser en todo caso ejecutada o si cabe plantear, de lege ferenda, la posibilidad de dejar en suspenso su ejecución atendiendo a determinadas circunstancias. Existe una disfunción en nuestro sistema de ejecución penal, que es la ausencia de un mecanismo que faculte discrecionalmente al juez, previa petición del penado, para dejar en suspenso o sustituir la pena de privación del derecho a conducir. Sin embargo, sí existen mecanismos para dejar en suspenso una pena privativa de libertad como la pena de

\footnotetext{
1322 Vid. GARCÍA RUIZ, Marian, "Los reincidentes del alcohol”, Tráfico y Seguridad Vial, Dirección General de Tráfico, № 196/2009, p.27.

1323 Vid. TAMARIT SUMALLA, Josep/ LUQUE REINA, Maㅡ Eulàlia, Automóviles, delitos y penas..., op.cit., p.144.

1324 Se ha mostrado contrario a medidas como la que se propone VIZUETA FERNÁNDEZ, Jorge, "Delitos contra...", op.cit., pp.27-28.
} 
prisión. Ante la falta de mecanismos legales para suspender, sustituir o fraccionar el cumplimiento de la pena de privación del derecho a conducir la última opción que les resta a los penados es la de la presentación de la petición de indulto o recurso de amparo con petición de suspensión de ejecución de la pena. Por este motivo, se expondrán dos propuestas de mejora en la ejecución penal, como son la posibilidad de sustituir y la de suspender la pena de privación del derecho a conducir tras dictarse sentencia condenatoria firme.

\subsubsection{Sustitución de la pena de privación del derecho a conducir}

La primera propuesta es la posibilidad de sustituir la pena de privación del derecho a conducir por otra sanción penal. La opción que se plantea está vedada en el CP, al no existir ningún precepto que posibilite la sustitución de la pena de privación del derecho a conducir ${ }^{1325}$, lo que impide cualquier opción jurisprudencial que tenga por objeto acordar la sustitución de la pena de privación del derecho a conducir. Que el legislador no haya previsto dicha posibilidad no es óbice para que de lege ferenda no se pueda explorar dicha opción máxime cuando desde sectores doctrinales y de la Fiscalía han existido propuestas al respecto tal como señalaremos a continuación. La opción que se plantea pasa por una reforma del $\mathrm{CP}$, en el sentido de introducir un artículo similar al antiguo art.88 CP, pero aplicable a la pena de privación del derecho a conducir. Si hasta la entrada en vigor de la LO 1/2015 de 30 de marzo el CP permitía con el art.88 CP la sustitución de la pena de prisión, también debe explorarse la viabilidad de una reforma para establecer mecanismos de sustitución de penas privativas de derechos, como la del derecho a conducir.

Si analizamos las penas que se pueden imponer en los delitos relacionados con el tráfico viario, la pena de privación del derecho a conducir únicamente podría ser sustituida bien por multa bien por TBC. A colación de esta circunstancia, una de las críticas que podrían realizarse a la propuesta que se plantea es que de sustituirse por multa nos podríamos encontrar que aquellos que más medios económicos dispusieran podrían hacer uso de este mecanismo con mayor facilidad. La posibilidad de sustituir la pena de privación del derecho a conducir por pena de

\footnotetext{
1325 HOLGADO MERINO, indica que únicamente es sustituible la pena de prisión, y no existe la opción de sustituir penas privativas de derechos, vid. HOLGADO MERINO, José Manuel, "La pena de multa", en AA.VV. Las penas y medidas de seguridad, ECHAVARRI GARCÍA, María Auxiliadora (Dir.), Consejo General del Poder Judicial, Centro de Documentación Judicial, Madrid, 2007, pp.255256. También relativo a la imposibilidad actual de sustituir la pena de privación del derecho a conducir, vid. VALEIJE ÁLVAREZ, Inmaculada, "EI sistema de penas en los delitos contra la seguridad vial", en AA.VV. Prevención y control..., op.cit., p.480.
} 
multa se ha peticionado en la praxis judicial pero dicha opción ha sido rechazada por el TS ${ }^{1326}$. Los argumentos vertidos para negar la sustitución se basan en que la finalidad de la pena de privación del derecho a conducir es "tan específica que nunca puede ser idónea la multa para sustituirla", pues la pena de multa no podría equiparse en sus fines a la pena analizada. En el mismo sentido que el TS, negando la posibilidad de sustituir la pena de privación de conducir, se ha posicionado jurisprudencia menor con el argumento que el CP no prevé un sistema de sustitución de dicha pena ${ }^{1327}$. Probablemente el mecanismo más igualitario para todos los penados es que la sustitución se realizara siempre por TBC. Sin embargo, existiría el inconveniente que para la imposición de la pena de TBC es obligatoria la conformidad del penado. La jurisprudencia también ha resuelto peticiones que han planteado la posibilidad de sustituir la pena de privación del derecho a conducir por la pena de $\mathrm{TBC}^{1328}$, denegando dicha opción. En este caso, el argumento utilizado no es tanto que la finalidad de ambas penas sea distinta sino la inexistencia de cobertura legal que habilite la posibilidad de una sustitución, así como la obligatoriedad de su ejecución inmediata tal como preceptúa el art.794 de la LECrim.

La alternativa que se plantea en este trabajo podría tener como base doctrinal la idea de sustitución limitada enunciada por $\mathrm{VON} \mathrm{HIRSCH}{ }^{1329}$, que parte de la idea que hay sanciones que son más idóneas que otras que tengan un grado de severidad similar. De esta forma, al poder realizar la sustitución de una pena por otra que sea más idónea, pero de una naturaleza similar, pueden alcanzarse en el caso concreto objetivos como puede ser el de evitar la reincidencia. Las razones que podrían justificar la sustitución de la pena de privación del derecho a conducir por otra pena, han de estar relacionadas con los fines preventivos de aquella pena, en concreto con la prevención especial en supuestos de conductores profesionales o personas que precisan el carnet para ir a trabajar ${ }^{1330}$. De la sustitución de la pena de privación del derecho a conducir por otra pena, atendiendo a las graves

\footnotetext{
1326 Vid. STS, núm. de recurso 1275/1994, Sala Segunda, 14 de diciembre de 1994, ponente Excmo. Sr. Justo Carrero Ramos. (TOL403.798).

1327 En este sentido, vid. el AAP de Barcelona, núm.553/2007, Sección 7ạ, de 12 de septiembre de 2007, ponente Ilma.Sra. Ana Rodríguez Santamaría (JUR 2007/330401); AAP de Barcelona, núm. 391/2007, Sección 5ạ, 16 de julio de 2007, ponente Ilma.Sra. Beatriz Grande Pesquero. (JUR 2007/284593) y el AAP de Barcelona, núm.1276/2012, Sección 21aa de 30 de septiembre de 2012, ponente IImo. Sr. Carles Almeida Espallargas (TOL5.354.127).
}

1328 Vid. AAP de Madrid, núm. 615/2012, Sección 3a , de 14 de agosto de 2012, ponente Ilmo.Sr. Francisco Buenaventura Ferrer Pujol (TOL3.574.444).

1329 Vid. VON HIRSCH, Andrew, Censurar..., op. cit., pp.106-107. 
consecuencias que en determinados supuestos comporta su ejecución, se ha hecho eco cierto sector doctrinal ${ }^{1331}$. La opción de poder sustituir la pena de privación del derecho a conducir, bien por pena de multa bien por la pena de TBC, fue planteada en el año 2005 por el Grupo de Estudios de Política Criminal ${ }^{1332}$, en aras a reformar la pena de privación del derecho a conducir. Las propuestas realizadas por el Grupo de profesores tomaban especialmente en cuenta las repercusiones de la pena en conductores profesionales.

Si bien por la Fiscalía se realizó una propuesta en el sentido de aplicar la suspensión en la ejecución de la pena de privación del derecho a conducir, respecto a la sustitución no se han realizado propuestas por lo que es necesario valorar dicha posibilidad. Actualmente ante la imposibilidad de sustituir la pena de privación del derecho a conducir, se recurre a mecanismos como el indulto total o parcial para evitar el efectivo cumplimiento de la misma, como se ha analizado en el capítulo IV de este trabajo. Es por ello que para facilitar una correcta ejecución y evitar recurrir de manera "encubierta" al indulto como alternativa a la sustitución, de lege ferenda debería plantearse la plasmación en el CP de la propuesta que se realiza. Por todo lo expuesto estimo que deberían explorarse opciones de reforma legislativa del CP para introducir el mecanismo de la sustitución en la pena de privación del derecho a conducir vehículos a motor y ciclomotores.

\subsubsection{Suspensión de la pena de privación del derecho a conducir}

La propuesta de suspensión de la pena de privación del derecho a conducir gravita en el mismo sentido que la sustitución y podría resultar adecuada en supuestos de escasa gravedad, tales como tasas de alcoholemia positivas en controles preventivos, así como cuando no existan daños materiales ni personales ${ }^{1333}$. La propuesta puede articularse en torno a la base de posiciones doctrinales y jurisprudenciales, así como de la Fiscalía favorables a esta opción y que puedan

\footnotetext{
1330 En este sentido ya se expresó el AAP de Barcelona, núm. 346/2007, Sección 6º, de 17 de julio de 2007, ponente Ilma. Sra. Bibiana Segura Cros. (JUR 2007/284515).

1331 En relación con la posibilidad de suspender la pena, vid. GARCíA DEL BLANCO, Victoria "EI nuevo artículo 384 del Código Penal: Quebrantamientos, desobediencias y conductas afines", en AA.VV. Protección Penal..., op.cit., p.444.

1332 Vid. Grupo de Estudios de Política Criminal, Una propuesta..., op.cit., pp.37-38.

1333 La posibilidad de suspender de la pena de privación del derecho a conducir no existe en el CP, e igual que el resto de penas privativas de derechos no tiene previsión legal que lo permita. Vid. DE URBANO CASTRILLO, Eduardo, "La privación...", op.cit., p.9 y VELASCO NÚÑEZ, Eloy, "Privación del derecho...", op.cit., p.4.
} 
servir para que de lege ferenda se prevea en el CP la opción de suspender la ejecución de la pena de privación del derecho a conducir.

En primer lugar, considero una disfunción que en el sistema de penas no exista la opción de suspender la pena de privación del derecho a conducir. Salvo que prospere una petición de indulto ${ }^{1334}$ el cumplimiento de la pena de privación del derecho a conducir es obligatorio, lo que evidencia la excesiva rigidez de nuestro sistema penal que limita la posibilidad que el juez pueda tener opciones alternativas a la hora de imponer o ejecutar una pena privativa de derechos ${ }^{1335}$. Esta anomalía está relacionada con el hecho que en el CP existen mecanismos para poder suspender la pena de prisión de hasta dos años y en determinados casos hasta cinco años, y sin embargo no existan mecanismos para suspender la pena de privación del derecho a conducir, que es privativa de derechos y no de libertad ${ }^{1336}$. Esto es, si el legislador considera pertinente dejar en suspenso en determinadas circunstancias la pena más severa, también debería poder valorarse dicha opción frente a penas menos severas, pero con un impacto importante, y en ocasiones incluso desproporcionado, en la vida del penado. Con la actual regulación del CP nos podemos encontrar con la paradoja que el penado solicite y se le conceda la suspensión de la pena de prisión por ser inferior a dos años, ex art.80 CP y sin embargo la pena de privación del derecho a conducir que se impone como principal y de forma conjunta no se suspenda y se deba ejecutar ${ }^{1337}$.

La posibilidad de suspender la pena de privación del derecho a conducir implica la renuncia a la ejecución de la pena. Para ello el legislador debería valorar incluir la posibilidad de suspender las penas privativas de derechos ${ }^{1338}$, y posteriormente plasmarlo en una reforma legal. Por este motivo, la propuesta que se realiza ha de ser de lege ferenda para modificar el CP que en relación con la pena analizada ha

\footnotetext{
${ }^{1334}$ Vid. GARCÍA DEL BLANCO, Victoria, "El nuevo artículo 384 del Código Penal: Quebrantamientos, desobediencias y conductas afines", en AA.VV. Protección Penal..., op.cit., p.445.

1335 En torno a la excesiva rigidez del sistema penal español, vid. TAMARIT SUMALLA, Josep, "Sistema de sanciones...", op.cit., pp.12-13.

1336 Sobre esta comparativa vid. HERNÁNDEZ-CARRILLO FUENTES José.Ma, "La suspensión y/o fraccionamiento del cumplimiento de la pena de privación del derecho a conducir un vehículo a motor o ciclomotor", Tráfico y Seguridad Vial, № 100, 2007, pp.19-24.

1337 Vid. RíOS MARTíN, Julián Carlos/ SEGOVIA BERNABÉ, José Luis/ PASCUAL RODRíGUEZ, Esther, Las penas... op.cit., p.111 y en relación con la no posibilidad de suspensión de la pena de privación del derecho a conducir, vid. HERNÁNDEZ-CARRILLO FUENTES, José $M^{\mathrm{a}}$ "La suspensión...", op.cit., pp.19-24.

1338 Con relación a esta cuestión vid STC, núm. 209/1993, Sala Primera, de 28 de junio de 1993, ponente Excmo. Sr. Rafael de Mendizábal Allende (TOL82.231).
} 
de ser más flexible y facilitar más opciones de las actualmente vigentes ${ }^{1339}$. Estimo acertada la posición de TRAPERO BARREALES ${ }^{1340}$ quien es favorable a la posibilidad de suspender la pena de privación del derecho a conducir, sometiendo al penado a determinadas obligaciones, ya que así estaríamos ante una suspensión condicionada a obligaciones que tenga relación con el delito cometido, y la acción cometida no quedaría impune. En la misma línea se posiciona ABEL SOUTO, quien se considera que sería acertado poder aplicar la suspensión de la ejecución tanto a la pena de multa como a las penas privativas de derechos ${ }^{1341}$.

La facultad de suspender la pena privativa del derecho a conducir no anularía los fines de prevención general que tiene esta pena, sino todo lo contrario ya que serviría para reforzar la eficacia y sentido de la misma ya que el penado debería de cumplir las condiciones de suspensión, también con contenido aflictivo, y no considero que la confianza de la población en el CP se viera reducida. Esta propuesta tiene como fundamento el art. 25 de la CE que se aplica a las penas de prisión y medidas de seguridad, ya que con la suspensión de la ejecución de la pena de privación del derecho a conducir se fomentaría la reinserción y reeducación social de los penados, que podrían seguir insertados en su entorno social y laboral sin ser excluidos de la sociedad. De hecho, en la legislación de menores, el art. 40 de la LORPM no prohíbe que la suspensión de la ejecución de las medidas se pueda extender a las medidas privativas de derechos, como sería la privación del permiso para conducir ${ }^{1342}$.

Si bien estimo que la situación actual es de disfunción en lo relativo a la suspensión de las penas privativas de derechos, la jurisprudencia del Tribunal Constitucional ha determinado que no existe tal discriminación al no prever el CP dicha suspensión ${ }^{1343}$. En el mismo sentido, la posibilidad de suspensión de la pena de

1339 En relación con la imposibilidad de suspender la pena de privación del derecho a conducir, vid. VALEIJE ÁLVAREZ, Inmaculada, "El sistema de penas en los delitos contra la seguridad vial", en AA.VV. Prevención y control..., op.cit., p.480 y también en GRACIA MARTíN, Luis/ ALASTUEY DOBÓN, M. Carmen, "Suspensión de la ejecución y sustitución de las penas privativas de libertad", en AA.VV. Lecciones de consecuencias jurídicas del delito: el sistema de penas, de medidas de seguridad, de consecuencias accesorias y de responsabilidad civil derivada del delito, pp.132-133.

1340 Vid. TRAPERO BARREALES, María.A., Los delitos..., op.cit., pp.568-569.

1341 Vid. ABEL SOUTO, Miguel, La suspensión de la ejecución de la pena tras la Ley Orgánica 1/2015, Ed. Tirant lo Blanch, Valencia, 2017, p.40.

1342 Vid. ABEL SOUTO, Miguel, La suspensión..., op.cit., p.41.

1343 Vid. STC, núm. 209/1993, Sala Primera, de 28 de junio de 1993, ponente Excmo. Sr. Rafael de Mendizábal Allende (TOL82.231). 
privación del derecho a conducir ha sido denegada por la jurisprudencia ${ }^{1344}$, que ha determinado que no es posible la suspensión de penas privativas de derechos, sino que únicamente cabe en las penas privativas de libertad. Tampoco se puede optar por una interpretación analógica del art.80.1 CP, y en una de las escasas resoluciones que han resuelto respecto de dicha posibilidad se ha llegado a calificar como una "aberración jurídica"1345. Otro supuesto en que se ha denegado la opción de suspensión de la pena de privación del derecho a conducir es cuando sí se acuerda la suspensión de la pena de prisión, pues la ejecución ha de proseguir respecto la pena privativa de derechos ${ }^{1346}$.

Con este mecanismo, así como con la opción del cumplimiento fraccionado que se ha analizado anteriormente podrían evitarse la comisión de nuevos hechos delictivos relacionados con el quebrantamiento de condena, y además la pena saldría reforzada en sus fines de prevención especial positiva. En esta línea considero un acierto lo planteado por la FGE en el año 2005 sobre la posibilidad de reformar el art.80.1 CP para que en casos excepcionales se pudiera dejar en suspenso la pena de privación del derecho a conducir ${ }^{1347}$. Esta propuesta nunca vio la luz, tal vez porque para que se concediera dicha suspensión entraba en juego un concepto jurídico indeterminado como el de: "...perjuicios de muy difícil o imposible reparación", daría lugar a diversas situaciones y podríamos hallarnos ante resoluciones contradictorias. Por el contrario, en la propuesta realizada por la FGE existían criterios fácilmente aplicables como las ausencias de daños materiales o personales siendo en ambos casos elementos objetivos que no ofrecen discusión. La propuesta que se planteó en el año 2005 por la FGE creo que no tenía una gran complejidad ya que consistía en añadir un segundo párrafo al art.80.1 CP${ }^{1348}$. Sin

\footnotetext{
1344 En este sentido vid. AAP de Madrid, núm. 877/2011, Sección 17ª̣, de 14 de septiembre de 2011, ponente IImo.Sr. Carlos Águeda Holgueras (TOL3.639.336); AAP de Granada núm. 45/2012, Sección 2 $2^{\mathrm{a}}$, de 27 de enero de 2012, ponente Ilmo.Sr. Juan Carlos Cuenca Sánchez (JUR/2012/393625), AAP de Madrid, núm. 577/2012, Sección 30ạ, de 31 de julio de 2012, ponente Ilmo.Sr. Carlos Martín Meizoso (JUR/2012/336173) y AAP de Madrid, núm. 921/2012, Sección 3å , de 17 de diciembre de 2012, ponente Ilma. Sra. Rosa Esperanza Rebollo Hidalgo (TOL3.739.475).

1345 Así fue calificada dicha posibilidad por el AAP de Zamora, núm. 118/2000, de 20 de noviembre de 2000, ponente Ilmo.Sr. Pedro Jesús García Garzón (EDJ 2000/47313).

1346 En este sentido destacar el AAP de Burgos, núm. 538/2010, Sección 1 ${ }^{a}$, de 7 de julio de 2010, ponente Ilmo.Sr. Francisco Manuel Marín Ibáñez (TOL2.084.731) y AAP de Barcelona, núm. 231/2006, Sección 7ª , de 16 de marzo de 2006, ponente IImo.Sr. Enrique Rovira del Canto. (JUR 2006/ 221159).

1347 Vid. Memoria FGE, año 2005, p.603.

1348 Propuesta de reforma: También se podrá aplicar este beneficio a la ejecución de la pena de privación del permiso de conducir vehículos a motor y ciclomotores cuando el condenado acredite de forma fehaciente que la ejecución de la pena le supondrá perjuicios de muy difícil o imposible reparación y el delito no haya causado daños materiales o personales.
} 
embargo, el espíritu de la reforma se imbuía de un carácter de excepcionalidad, así como de aplicación residual para los casos más graves, y ese aspecto es lo que no casaba con el texto propuesto para su reforma. Con el redactado propuesto por la FGE en el año 2005 la suspensión de la pena de privación del derecho a conducir podría llegar a generalizarse precisamente por lo genérico de los términos “...muy difícil o imposible reparación", que provocarían un aluvión de peticiones ya que la inmensa mayoría de los penados considerarían que se les estaba generando una situación de dificultades y perjuicios irreparables. La modificación legislativa propuesta por la Fiscalía diseñó una línea de política criminal positiva ya que es una realidad que muchos de los penados con la pena de privación del derecho a conducir ven directamente afectada su esfera personal, económica y laboral ${ }^{1349}$. Dicha propuesta me parece acertadísima máxime en los supuestos de conductores profesionales que hayan sido condenados por delitos donde no existan daños materiales ni personales, y a pesar de ello la ejecución de la pena de privación del derecho a conducir, aunque de una escasa duración, les supondrá unos perjuicios de difícil reparación. Podemos realizar una comparativa con la pena de prisión que puede suspenderse en determinadas circunstancias, por lo que también deberían articularse mecanismos en el CP para suspender la pena de privación del derecho a conducir, ya que nos encontramos ante una pena privativa de derechos cuyas consecuencias pueden ser más perjudiciales que una pena corta de prisión, básicamente en los casos de conductores profesionales ${ }^{1350}$.

La opción de suspender la ejecución de la pena de privación del derecho a conducir no significaría otorgar carta blanca al penado y transmitir una sensación de impunidad sino todo lo contrario, ya que deberá cumplir las condiciones de suspensión de ejecución que se le impongan, entre las cuales podrían contemplarse las siguientes: no volver a delinquir en el periodo de suspensión, la asistencia a cursos o programas formativos sobre seguridad vial o la participación en programas de deshabituación al consumo de alcohol, drogas tóxicas o sustancias estupefacientes. Con ello se podría alcanzar la finalidad que busca la pena de privación del derecho a conducir: se evitaría la comisión de nuevos hechos delictivos y se incrementarían los fines de prevención especial positiva en el conductor al que se le suspende la pena. Si el penado cumple con las condiciones

\footnotetext{
1349 Estos aspectos han sido destacados por DE VICENTE MARTíNEZ, Rosario, Derecho..., op.cit., pp.453-455.

1350 En este sentido VON HIRSCH manifiesta que "...cortos periodos de prisión pueden ser de severidad equivalente a otras sanciones no privativas de libertad". En nuestro caso, sería la pena privativa del derecho a conducir que en determinados casos puede ser más gravosa que una pena de prisión de corta duración. Vid. VON HIRSCH, Andrew: Censurar y castigar, op.cit., p.104.
} 
de suspensión, la pena de privación del derecho a conducir que se le ha impuesto será remitida como sucede con la pena de prisión ${ }^{1351}$. Por el contrario, si el penado volviera a delinquir durante el periodo de suspensión establecido de la pena de privación del derecho a conducir, debería cumplir la pena en suspenso, así como la nueva pena que se le imponga. En este sentido, la propuesta que aquí se propone también es viable y en modo alguno se generaría problemas en los supuestos de revocación de la suspensión en casos de nuevos hechos delictivos ${ }^{1352}$.

Por lo expuesto es por lo que considero que de lege ferenda, con carácter excepcional y debido a la relevancia que tiene la pena de privación del derecho a conducir en nuestra sociedad, debería abrirse el debate para conceder la suspensión de la ejecución de la pena en determinados supuestos, según los parámetros que hemos detallado en este apartado tales como: no volver a delinquir en el periodo de suspensión; la asistencia a cursos o programas formativos sobre seguridad vial o la participación en programas de deshabituación al consumo de alcohol, drogas tóxicas o sustancias estupefacientes.

${ }^{1351}$ Acerca de la remisión condicional de la pena de prisión, vid. STC, núm. 251/2005, Sala Segunda, de 10 de octubre de 2005, ponente Excmo. Sr. Eugeni Gay Montalvo (TOL736.270).

1352 En este sentido no estoy de acuerdo con lo argumentado en el AAP de Zamora, núm.118/2000, de 20 de noviembre de 2000, ponente IImo. Sr. Pedro Jesús García Garzón (EDJ 2000/47313), con relación a que se crearía un "serio problema" si hubiera que revocar la condena suspendida. 


\section{CONCLUSIONES}

Una vez analizados y expuestos en los capítulos precedentes los diversos elementos relativos a la regulación, aplicación y especialmente la ejecución de la pena de privación del derecho a conducir vehículos se expondrán a continuación las principales conclusiones alcanzadas. Para ello se parte de la base que el objetivo de este trabajo ha sido el realizar un análisis integral de la pena de privación del derecho a conducir que permita un mejor conocimiento del rol que pueda atribuírsele y la función a desarrollar en el marco del sistema sancionador penal. Con este fin se ha analizado de forma minuciosa su regulación legal, acudiendo cuando ha sido necesario también al ámbito del Derecho Administrativo, y todo ello con el fin de definir su actual configuración en el Código Penal, proponer interpretaciones al texto legal vigente que permitan una aplicación adecuada y proporcional de la pena y, formular propuestas de modificación legal destinadas a mejorar la aplicación de esta sanción.

I. Se trata de una pena con una relevancia práctica muy notable, por cuanto su aplicación se dirige mayoritariamente a los delitos contra la seguridad vial, un sector de la criminalidad especialmente relevante, en particular tras las reformas penales que llevaron a una mayor intervención del Derecho penal en el ámbito de la seguridad vial. Destaca, en este sentido, que hasta un $30 \%$ del total de las sentencias condenatorias impuestas en España en estos últimos años corresponden a delitos contra la seguridad vial. Además, la sanción penal que he analizado también representa un porcentaje importante en el total de penas que se imponen en nuestro Estado y en el año 2019 representó el 8\%.

En el ámbito de los delitos viales, la pena de privación del derecho a conducir es la consecuencia jurídica por antonomasia, ya que es la pena más directamente vinculada con esta tipología delictiva puesto que la conducta siempre se habrá realizado con un vehículo a motor o ciclomotor, lo que unido a sus características como pena privativa de derechos que no puede ser suspendida ni sustituida, significa que siempre se deba cumplir. Se ha constatado la existencia de una relación directa entre el bien jurídico que se trata de proteger, que es la seguridad vial en general, y la privación que impone la sanción, que es el derecho a conducir de los penados. A ello ha de añadirse que la conducta típica que determina su imposición deriva en la mayor parte de ocasiones de una conducción que pone en riesgo la seguridad vial. La pena de privación del derecho a conducir es una de las herramientas jurídicas más útiles para poder combatir la delincuencia vial, ya que si se cumple de forma adecuada comportará que los penados no conduzcan un 
vehículo a motor o ciclomotor durante un determinado periodo de tiempo, evitando la reiteración delictiva. Con todo, el cumplimiento de la pena de privación del derecho a conducir supone una afectación real a la libertad individual y deambulatoria, con efectos económicos y laborales, y que redunda en numerosas ocasiones en el derecho al desarrollo personal y social de los penados.

La pena de privación del derecho a conducir puede considerarse una de las herramientas jurídicas más útiles para poder combatir la delincuencia vial, ya que si la misma se cumple de forma adecuada comportará que los penados no conduzcan un vehículo a motor o ciclomotor durante un determinado periodo de tiempo, lo que, unido a las funciones de prevención que esta pena posee, hace que la misma sea necesaria en nuestro sistema de penas, y en especial en todos aquellos delitos relacionados con el tráfico vial.

II. La realización de esta investigación ha permitido constatar la limitada relevancia histórica de la pena de privación del derecho a conducir vehículos a motor y ciclomotores en el sistema penal español. No obstante, la situación cambió a raíz de la reforma del CP operada por la LO 15/2007 de 30 de noviembre, que modificó sustancialmente los delitos contra la seguridad vial. Esta reforma provocó que se incrementara notablemente la aplicación de la pena objeto de investigación, lo que de forma paralela supuso que también se incrementara la casuística, siendo una prueba de ello las numerosas resoluciones judiciales que analizan aspectos problemáticos y que han conseguido perfilar cuestiones que el legislador todavía no ha fijado normativamente.

Ni con la reforma del CP del año 2010 ni con la aprobación de la LO 1/2015 de 30 de marzo se operaron modificaciones en los delitos relacionados con la seguridad vial, y el legislador parecía mantener intacto el ámbito de aplicación de la pena de privación del derecho a conducir. Además, la LO 1/2015 de 30 de marzo introdujo una novedad en cuanto a la supresión del libro tercero del Código penal, y con él las faltas de homicidio y lesiones por imprudencia causadas con vehículo a motor y ciclomotor. Estas conductas se reubicaron en los arts. 142.2 y 152.2 en relación con el homicidio y las lesiones por imprudencia menos grave y se mantuvo la previsión como pena facultativa en los mismos términos que se establecía en la anterior regulación de las extintas faltas. Sin embargo, la política criminal de seguridad vial ha cambiado en relación con la pena de privación del derecho a conducir tras la entrada en vigor de la LO 2/2019 de 1 de marzo de reforma del Código Penal, ya que se han incorporado al CP nuevos delitos que conllevan dicha pena como el del art. 382 bis CP relativo al abandono del lugar del accidente. También se ha 
procedido a incorporar esta pena en los delitos de lesiones por imprudencia menos grave relacionados con las lesiones del art. 147.1 CP cometidas mediante vehículo a motor, por lo que, en cierta forma, se ha vuelto a la situación existente con las antiguas faltas. Dado lo reciente de la reforma, deberemos estar atentos a los criterios jurisprudenciales que se aplicarán en los nuevos tipos penales ya que pueden aumentar el número de sentencias condenatorias en las que se imponga la pena de privación del derecho a conducir.

En cuanto al ámbito de aplicación de la pena de privación de conducir vehículos, los tipos delictivos que actualmente se conminan con esta pena se limitan fundamentalmente a dos ámbitos delictivos, los delitos contra la vida e integridad física y psíquica de las personas y los delitos contra la seguridad vial.

III. Interesa poner de relieve el papel de la Fiscalía de Seguridad Vial en la interpretación de la regulación y la aplicación de la pena de privación del derecho a conducir. Ya desde su creación en el año 2006, la Fiscalía ha hecho referencia en cada una de sus memorias anuales a las diversas cuestiones conflictivas que presenta esta sanción. En consecuencia, la visión de la Fiscalía de Seguridad Vial ha resultado fundamental para dirimir algunas de las cuestiones más controvertidas que afectan a la pena de privación del derecho a conducir y ha sido una fuente de ideas importante para la elaboración de este trabajo. En lo que a la jurisprudencia respecta, cabe señalar que la jurisprudencia que se ha ocupado de la pena de privación del derecho a conducir vehículos ha sido mayoritariamente la de las diferentes Audiencias Provinciales, ya que debido a la tipología delictiva en la que se impone raramente ha sido analizada ni por los Tribunales Superiores de Justicia ni por el Tribunal Supremo. Sin embargo, dicha situación ha cambiado tras la reforma operada en la LECrim en el año 2015, habiéndose dictado ya diversas sentencias por el Tribunal Supremo en las que se analiza indirectamente la pena estudiada en el trabajo. Finalmente, cabe señalar que desde el ámbito doctrinal no se ha otorgado una gran atención a la pena de privación del derecho a conducir, ya que son escasos los estudios que se han dedicado en exclusiva a la misma y casi siempre ha sido analizada en el marco general de las penas privativas de derechos.

IV. En lo relativo a la naturaleza jurídica de la privación del derecho a conducir se considera que a pesar que la misma se ha ubicado tradicionalmente a caballo entre el Derecho Penal y el Derecho Administrativo sancionador, después de analizar los dos ámbitos se ha podido acreditar que dicha privación de derechos, como sanción temporal, tiene en la actualidad su hábitat natural en el Derecho Penal, al no existir en el ámbito administrativo una sanción similar que pueda equipararse a la pena de 
privación del derecho a conducir. La naturaleza penal de la privación del derecho a conducir se extrae de su regulación en el Código penal y en la Ley procesal penal: en el CP existe como pena y como medida de seguridad; está regulada como medida cautelar en la LECrim y también como medida en el ámbito de la jurisdicción de menores, mientras que en el ámbito administrativo su utilización como sanción es puramente residual, ya que está prevista como medida cautelar pero únicamente en determinados supuestos de nulidad o lesividad y pérdida de vigencia del permiso de conducir.

Ello no obsta para poner de relieve la influencia que en la actual regulación de la pena objeto de estudio ha tenido la ordenación administrativa, inicialmente a través de la Ley 17/2005 de 19 de julio, que instauró el sistema del "carnet por puntos" y, desde el mes de enero de 2016, a través de la propia LTSV. En este sentido, se ha evidenciado, tras el examen de la pena, la constante conexión entre el Derecho Administrativo y el Derecho Penal, en particular en cuanto a la ejecución de la pena, y ello hasta el punto que incluso la LTSV regula determinadas consecuencias inherentes a la condena que impone la pena de privación del derecho a conducir, como por ejemplo, cuando se prohíbe obtener el permiso de conducir a los conductores que hayan sido condenados a la pena de privación del derecho a conducir. Ello determina que sea necesario mantener, el actual sistema de coordinación entre el ámbito penal y el administrativo para el correcto control de la ejecución de esta pena, siendo relevantes los avances realizados en los últimos años para logar reducir las posibles disfunciones que existían en el pasado por la falta de coordinación en el envío y la recepción de la información relativa a la pena entre la Administración de Justicia y la DGT. Hasta hace un lustro, ello suponía que entre el momento en el que se dictaba una sentencia condenatoria y la anotación de la pena en los archivos de la DGT existía un lapso temporal en el que no podía controlarse el correcto cumplimiento de la ejecución.

Sin perjuicio que en el ámbito del Derecho Administrativo sancionador existan otro tipo de sanciones como las multas pecuniarias o la pérdida de puntos para los supuestos de infracciones contra la seguridad vial, soy partidario que la privación del derecho a conducir permanezca en el ámbito penal, ya que puede ser aplicada para la protección de bienes jurídicos de carácter individual que han de ser especialmente protegidos como la vida o la integridad física y psíquica de las personas, así como otros de carácter colectivo como la seguridad vial, que nos afecta directa o indirectamente a todos los ciudadanos, siendo ello compatible con el principio de ofensividad. Si bien es cierto que algunos delitos en los que está prevista la pena son de peligro abstracto, y algún sector doctrinal critica esta 
cuestión, en todos ellos existe cierto peligro lo que justifica la imposición de la pena de privación del derecho a conducir. Los delitos que prevén esta pena no son simples desobediencias a la ley, sino que son conductas activas que se realizan conduciendo un vehículo a motor o ciclomotor y que o bien han causado un resultado concreto o bien tienen una potencialidad abstracta para atentar contra bienes jurídicos.

V. Desde la esfera penal la privación del derecho a conducir despliega su funcionalidad en un amplio ámbito de aplicación. En este sentido, no solamente se configura como pena sino también como medida de seguridad, como medida cautelar en la LECrim y también como medida en el ámbito de la jurisdicción de menores. Centrándonos en la privación del derecho a conducir a título de pena, considero adecuado su configuración como pena principal ya que además de no depender de otras penas para ser impuesta, de esta forma se le confiere mayor visibilidad y adquiere idéntica importancia a la que tiene una pena privativa de libertad como la pena de prisión. Con independencia de ello, sería interesante que además de su carácter de pena principal se explorara la posibilidad que pudiera ser también impuesta como pena accesoria en determinados tipos delictivos que actualmente no prevén esta sanción, como la conducción sin permiso o el quebrantamiento de condena del art. $384 \mathrm{CP}$, siempre condicionado a que el juez valorara su adecuación, atendiendo a las circunstancias del caso, del mismo modo que sucede en el ámbito de la justicia penal de menores.

En cuanto a la configuración como medida cautelar, la privación del derecho a conducir vehículos regulada en los arts. 529 bis y 764.4 de la LECrim, se considera una medida adecuada para evitar que el investigado conduzca un vehículo a motor o un ciclomotor durante un determinado periodo de tiempo, preservando así el bien jurídico seguridad vial, así como la vida e integridad física y psíquica de las personas. Se trata de asegurar temporalmente de forma efectiva que un conductor no pueda conducir durante la instrucción del proceso judicial. De concurrir los fines previstos legalmente para la aplicación como medida cautelar y, en particular, cuando pueda existir riesgo de reiteración delictiva o nos hallemos ante hechos delictivos de cierta gravedad, el juez puede aplicar la privación del derecho a conducir. En caso de condena, el tiempo transcurrido será abonado en la ulterior liquidación de la pena en virtud del art. 58.4 CP.

Merece una valoración positiva la previsión de la privación del derecho a conducir como medida de seguridad no privativa de libertad en respuesta a los supuestos en los que el autor es declarado inimputable o semiimputable. En este sentido, la 
sanción se impone como medida de seguridad en aras a la prevención de futuros delitos debido al pronóstico de peligrosidad del autor de los hechos. Por ello, ha de valorarse positivamente la actual regulación que prevé su naturaleza como pena y como medida de seguridad, ya que de esta forma puede protegerse tanto la seguridad vial como la vida e integridad de las personas para el caso que el autor de los hechos sea declarado inimputable o semiimputable. Sin embargo, resulta criticable que no pueda aplicarse la previsión del art. 47.3 CP en la medida de seguridad de privación del derecho a conducir, por lo que en los casos en los que ésta sea superior a los dos años, el declarado inimputable o semiimputable no perderá su permiso o licencia de conducir. Además, tampoco existiría para éste la obligación de superar un curso de sensibilización y reeducación vial para poder volver a conducir, como sí se prevé para los sujetos imputables. Ambas consecuencias, previstas para la pena, serían de interesante previsión en la medida de seguridad ya que su aplicación puede ayudar a proteger bienes jurídicos relacionados con la seguridad vial.

VI. El trabajo asume que cualquier valoración o propuesta sobre la aplicación y la ejecución de la pena de privación del derecho de conducir debe partir de una previa definición de los fines que pueden atribuirse a esta sanción. Por esta razón, uno de los objetivos ha sido precisamente el análisis de los fines de esta pena.

En este sentido, en la tesis se sostiene que la pena de privación del derecho a conducir tiene un contenido aflictivo relevante que admite la realización de fines retributivos, ya que la misma supone un mal que en mayor o medida genera inconvenientes a los penados y es la consecuencia proporcional por haber cometido un delito. Este contenido aflictivo se concreta en que los penados no podrán ejercer su derecho a conducir durante el tiempo de la condena, lo que supone una afectación real a la libertad individual y ambulatoria del individuo, con efectos económicos y laborales para el penado, y que redunda en numerosas ocasiones en una afectación al derecho al desarrollo personal y social lo que en una sociedad como la del S. XXI, supone una limitación de las actividades diarias tanto laborales, sociales o familiares. Sin embargo, la presencia en el CP debe explicarse desde una perspectiva fundamentalmente de carácter preventivo, tanto en términos de prevención especial -por cuanto la pena puede ser idónea para evitar la reiteración delictiva del penado-, como en términos de prevención general -dado el efecto disuasorio que origina la propia aplicación de la pena y la percepción de las consecuencias adversas que genera. Esta orientación en cuanto a los fines de la pena es importante a efectos de definir los términos en que se regula su aplicación y ejecución, y en particular con cuestiones como la posibilidad de ser o no sustituida 
o suspendida, así como la necesidad de combinarla con una mayor educación vial y con planes formativos eficaces e individualizados para los penados, con el fin de evitar la reincidencia.

La orientación que se defiende en el trabajo coincide, en términos generales, con las posiciones dominantes entre la doctrina científica y la jurisprudencia. Así, en primer lugar, la doctrina mayoritaria considera que la pena analizada tiene unos fines eminentemente preventivos, predominando los preventivo-especiales, siendo minoritarias las posiciones doctrinales que otorgan preeminencia a los fines retributivos de la pena de privación del derecho a conducir. En cuanto a la orientación preventivo-especial, la misma es primordialmente de carácter negativo, ya que la pena se configura como instrumento orientado a evitar la reincidencia del penado por la vía de evitar que conduzca durante el periodo de duración de aquella. No obstante, algunas particularidades en la ejecución de la pena acreditan la voluntad de dotarla de un cierto contenido preventivo-especial positivo, en cuanto se prevé la participación del penado en cursos de sensibilización y de reeducación vial.

La jurisprudencia reconoce la pretensión de realizar fines retributivos con la aplicación de esta pena, si bien los tribunales, y en particular, las resoluciones de las Audiencias, dado que la pena ha sido escasamente analizada por el TS, coinciden con la doctrina mayoritaria en su mayor alusión a los fines preventivoespeciales.

VII. En relación con el contenido de la pena, este consiste en la privación del derecho a conducir vehículos a motor y ciclomotores durante el tiempo que se determine en la sentencia, siendo de aplicación tanto a quienes poseen el permiso o licencia como a quienes carecen del mismo. Tanto la doctrina como la jurisprudencia definen sin especiales dificultades lo que debe entenderse por vehículo a motor y ciclomotor y no existen en este ámbito discrepancias sustanciales. Sin embargo, se trata de una cuestión que puede generar controversia en un futuro no lejano pues, gracias a los avances técnicos, han surgido y, sin duda alguna, surgirán nuevos vehículos que habrá que determinar si se ven afectados por la pena de privación del derecho a conducir o si, por el contrario, al no tener la consideración de vehículo a motor no alcanza a sus usuarios dicha prohibición. En este sentido podemos destacar los vehículos de movilidad personal (VMP) respecto de los que en un futuro próximo podría exigirse algún tipo de permiso o licencia para su conducción y que alguno de sus múltiples modelos pueda ser considerado vehículo a motor. La ausencia de un concepto penal de lo que ha de considerarse vehículo a motor, puede generar en el futuro dificultades en la aplicación de la pena 
analizada, al existir dudas sobre si ha de aplicarse o no en comportamientos que supongan un riesgo para la seguridad vial mediante el empleo de determinados vehículos.

Otras cuestiones relativas al contenido de la pena están, a día de hoy, menos resueltas, por lo menos, formalmente. Así, en primer lugar, se plantea si la imposición de la pena implica adicionalmente la prohibición de obtener el permiso o licencia, dado que el CP no establece dicha prohibición, sino que la misma se halla prevista en la normativa administrativa, lo que ha originado discrepancias doctrinales. Dada la existencia de este vacío en el CP, sería recomendable que el legislador clarificara esta cuestión incluyendo en el texto penal la prohibición expresa de obtener el permiso o licencia correspondiente durante el periodo de vigencia de la pena.

Asimismo, se ha planteado, en relación con el contenido de la pena objeto de análisis, los efectos administrativos que la misma comporta y, en concreto, la obligatoriedad de realizar el curso de sensibilización y reeducación vial. La doctrina se ha planteado si el curso de formación que se impone al penado durante la ejecución de la pena forma parte del contenido de la misma. Considero que este curso no forma parte del contenido penal por cuanto que no aparece regulado en el Código Penal ni tampoco se contempla en el fallo de las sentencias dictadas en el orden jurisdiccional penal. Esto supone que nos hallamos ante una consecuencia administrativa derivada de la condena penal, y que ha de ser ejecutada y controlada por la DGT y no por el juez penal. Por consiguiente, la no realización del referido curso no supondrá un delito de quebrantamiento de condena, siempre que la pena de privación del derecho a conducir haya sido correctamente ejecutada. En todo caso, estimo adecuado que se imponga por vía administrativa la obligatoriedad de realizar el curso de sensibilización y educación vial, ya que de esta forma además de las penas recibirá una formación que puede ser de utilidad para evitar la reincidencia delictiva.

VIII. La previsión contenida en el art. 47.3 CP que determina la pérdida de vigencia del permiso o licencia cuando la sentencia impone la pena por un periodo superior a los dos años, tiene como consecuencia que no recupere su derecho a conducir por el transcurso del tiempo de la condena y tenga que examinarse de nuevo para obtener la autorización que le habilite para conducir vehículos a motor y ciclomotores. Aun cuando en términos generales puede ser un buen mecanismo asociado a los fines de la pena, debería ser revisado en lo relativo al automatismo con el que se acuerda. En este sentido, sería necesario revisar su aplicación 
imperativa y permitir que el juez recurra a criterios de proporcionalidad en aras a valorar en cada caso si las circunstancias del hecho o de su autor requieren la aplicación de las consecuencias que comporta el art. 47.3 CP. Asimismo considero que debería revisarse el umbral de dos años de privación del derecho a conducir a partir del cual debe aplicarse el art. 47.3 CP, de tal modo que podría aumentarse el marco temporal a partir del cual ha de aplicarse este precepto y todo ello con el fin de evitar que, en determinados supuestos se pueda vulnerar el principio de proporcionalidad y que los penados pierdan la vigencia de su permiso o licencia de conducir por aplicación de dicho precepto cuando la afectación a nivel profesional o personal sea muy elevada.

El debate acerca del contenido del art. 47.3 CP no se limita únicamente a su alcance, sino que resulta igualmente interesante determinar si la pérdida de vigencia del permiso o licencia forma o no parte del contenido de la pena de privación del derecho a conducir. En relación con esta cuestión se sostiene en este estudio que no forma parte del contenido de la pena, ya que su aplicación práctica se lleva a cabo a través de la normativa extrapenal y por parte de las autoridades de la Dirección General de Tráfico, siendo una consecuencia administrativa de la pena. Sin lugar a dudas, el art. 47.3 CP es uno de los aspectos relacionados con el contenido de la pena de privación del derecho a conducir en torno a los que pueden existir mayores posibilidades de reforma en los próximos años, destinadas a flexibilizar su aplicación.

IX. El ámbito de la ejecución de la pena de privación del derecho a conducir vehículos es uno de los aspectos de mayor desarrollo doctrinal y jurisprudencial, y ello debido a las peticiones formuladas por los propios penados que han dado lugar a numerosas resoluciones jurisprudenciales. La realización del trabajo ha permitido constatar que no existen dificultades relevantes en la ejecución ordinaria de la pena ya que legal, doctrinal y jurisprudencialmente están definidas las diferentes fases y trámites que han de cumplimentarse. En este sentido considero que fue positiva la implantación de los Juicios Rápidos en el año 2003, ya que desde su entrada en vigor puede suceder que entre el hecho delictivo y el inicio de la ejecución de la sentencia condenatoria firme pasen escasamente 72 horas, lo que favorece los efectos preventivos y retributivos de dicha pena. Esta característica es muy importante ya que la hace merecedora del calificativo de ser una pena de ejecución cuasi inmediata, lo que la diferencia positivamente de otras penas existentes en nuestro CP como la multa o los TBC, en las que el inicio de su cumplimiento puede demorarse en el tiempo. 
$X$. Se puede subrayar como singularidad en la pena de privación del derecho a conducir el hecho que no puede ser sustituida ni suspendida, por cuanto ha de cumplirse de forma efectiva. Este es uno de los principales óbices identificados en la ejecución de la referida pena, ya que no existen en el CP mecanismos de suspensión o de sustitución para las penas privativas de derechos como los previstos para la pena de prisión, por lo que en numerosas ocasiones se ha realizado peticiones de cumplimiento alternativo, en especial cuando su cumplimiento afecta a la esfera laboral. Ello me ha motivado a plantear como propuestas de lege ferenda, la posibilidad que en determinados supuestos pueda suspenderse o sustituirse, aun siendo conscientes que dicha opción no halla partidarios entre la doctrina mayoritaria dadas las dificultades por la inexistencia de una previsión legal que lo regule. Sin embargo, considero que tales dificultades podrían salvarse con una modificación legislativa que regulara dichas opciones, puesto que ello permitiría una flexibilización en la ejecución en los casos en los que se produzca una afectación al ámbito laboral.

Por el contrario, la suspensión de la ejecución sí se contempla mientras se resuelve el recurso de amparo, así como también la petición de indulto. Esta posibilidad no es muy problemática, ya que ambas opciones están reguladas normativamente y se ciñen a parámetros jurisprudenciales para su denegación o concesión. A pesar de la existencia de dichos criterios, siempre se deberá valorar el caso particular y las circunstancias personales tanto del autor del delito, así como a los datos periféricos que rodean el hecho delictivo para que se pueda acordar la suspensión de la ejecución.

XI. Uno de los aspectos más problemáticos en la ejecución de la pena es el relativo al cumplimiento fraccionado de la pena de privación del derecho a conducir. En la actualidad sigue sin existir un adecuado desarrollo de esta opción de cumplimiento, y se deberá estar a posibles proyectos de reforma legislativa que lo prevean expresamente. Si bien la posición mayoritaria tanto en la doctrina como en la jurisprudencia es contraria al cumplimiento fraccionado, no existe prohibición legal para que se lleve a cabo. Por ello he defendido en este trabajo la posibilidad de aplicar esta opción de cumplimiento en aquellos supuestos en que el fraccionamiento de la ejecución permita una mejor conciliación de los fines de la pena con las circunstancias personales y/o laborales del penado. Ello puede plantearse, en aquellos casos en los que los penados sean conductores profesionales y la imposición y ejecución de la pena de privación del derecho a conducir conlleve la pérdida automática de su puesto de trabajo, y con ello, la principal fuente de ingresos de la familia. No se trata, en ningún caso de pretender 
evitar los fines preventivo-especiales y generales de la pena ni tampoco su contenido aflictivo o retributivo, sino de compaginar tales fines con las concretas circunstancias del penado. Para ello, se debería tomar en consideración por un lado los factores laborales, personales, económicos, familiares y sociales del penado en aras a valorar si éstos le pueden hacer tributario de la concesión del cumplimiento fraccionado de la pena. Además, por otro lado, también debería valorarse la escasa gravedad del hecho, así como la inexistencia de antecedentes penales por hechos similares. Si bien en modo alguno puede generalizarse el cumplimiento fraccionado, sería interesante contemplar formas de cumplimiento que permitieran tomar en consideración las circunstancias personales, laborales o penológicas referidas. Se defiende, en definitiva, la regulación de una modalidad de cumplimiento fraccionado de la pena de privación del derecho a conducir vehículos, que siempre tendrá que aplicarse de forma excepcional y cuando concurran algunas de las circunstancias referidas.

Asimismo, existen otras opciones de cumplimiento alternativo de la pena como el aplazamiento del inicio de la ejecución. Esta cuestión ya se ha planteado jurisprudencialmente y ha sido aceptada en casos en los que por circunstancias laborales se estima procedente demorar la fecha de inicio de la ejecución, pero no existe todavía un desarrollo normativo que lo regule. Por ello, siendo que la ejecución de la pena analizamos puede ser versátil, sería necesaria una regulación de su ejecución que incluyera diversas modalidades de cumplimiento que deberían redundar en un cumplimiento de la pena evitando un excesivo efecto retributivo.

XII. El cumplimiento transnacional de la pena de privación del derecho a conducir constituye uno de los problemas más relevantes en la ejecución de esta sanción penal. Se trata de un auténtico punto débil de esta pena, dadas las dificultades para controlar el cumplimiento de la prohibición fuera de las fronteras del Estado que la impone. Así, en España existe una gran dificultad para controlar la ejecución de penas de esta naturaleza impuestas en otros Estados y viceversa. Sin duda, en el ámbito comunitario debería incidirse en este aspecto y dotar de mecanismos procesales para que pueda controlarse la ejecución transnacional de la pena de privación del derecho a conducir. Este es uno de los ámbitos en los que siguen existiendo reductos de impunidad para estos penados, por lo que sería necesaria una armonización a nivel europeo para la correcta ejecución de esta pena a nivel supranacional, ya que de lo contrario puede quedar vacía de contenido en aquellos supuestos en los que los penados no sean nacionales residentes del país en el que se comete el delito vial. 
En este sentido destacar el Convenio de 17 de junio de 1998, establecido en el Acto 98/C, 216/01 del Consejo sobre las decisiones de privación del derecho a conducir, que en mi opinión puede considerarse que ha sido el mecanismo más adecuado que en el ámbito comunitario para intentar garantizar el cumplimiento transnacional de la pena de privación del derecho a conducir, aunque no pudo ser aplicado ya que nunca entró en vigor, por lo que no ha podido ser utilizado por las autoridades judiciales españolas.

XIII. En último término, se valoran positivamente los esfuerzos realizados para dotar de una mayor eficacia el cumplimiento de la pena, a pesar de la dificultad para controlar de forma efectiva tal cumplimiento y para detectar supuestos de quebrantamiento, siendo un ejemplo el protocolo de 10 de febrero de 2015 para la remisión telemática de penas, medidas de seguridad y medidas cautelares en materia de seguridad vial de la Administración de Justicia a la DGT. El sistema de control de la ejecución de la pena de privación del derecho a conducir es, por lo general, adecuado, atendiendo a los medios que se disponen, y las acciones emprendidas desde el año 2007 han redundado en ello, pero teniendo siempre presente que el control absoluto de todos los penados es imposible. En el trabajo se formulan también algunas propuestas para contribuir a la mejor ejecución de la pena y, en definitiva, a disuadir a los penados de posibles quebrantamientos. En esta dirección, se apuesta por sancionar también con pena de privación del derecho a conducir el quebrantamiento de la propia pena y no solamente con una pena de prisión, multa o TBC como actualmente se contempla en el art. $384 \mathrm{CP}$. Por ello, en las consecuencias del incumplimiento de la pena debería preverse también la imposición de una nueva pena de privación del derecho a conducir, circunstancia ésta que sería interesante como factor disuasorio de los potenciales quebrantadores.

XIV. Atendiendo a la previsión aplicativa de esta pena en el Código Penal se ha constatado que la misma se puede acordar de forma acumulativa con penas privativas de libertad, penas privativas de derechos y penas pecuniarias, además que se pueda imponer conjuntamente con una consecuencia accesoria como el decomiso del vehículo a motor y ciclomotor. En ocasiones la pena de privación del derecho a conducir, en combinación con otro tipo de sanciones y medidas penales no privativas de libertad puede ser una herramienta óptima para evitar el recurso a la pena de prisión, desplegando igualmente el contenido punitivo y preventivo. Por ello soy partidario que en términos similares a lo actualmente previsto en la LORPM una futura reforma legislativa reduzca, en la medida de lo posible, la previsión de cumplimiento conjunto de la pena de privación del derecho a conducir y la pena de 
prisión, potenciando la aplicación de aquella con otras penas como la pena de TBC o la pena de multa, lo que contribuiría al desarrollo de un sistema sancionador menos dependiente de la pena de prisión, pero tal vez más efectivo en términos preventivos. La combinación con la pena de TBC permite infligir al penado un componente aflictivo, pero al estar ambas guiadas por fines preventivos especiales pueden resultar eficaces para evitar la comisión de nuevos delitos relacionados con la utilización de vehículos a motor y ciclomotores. Con ello no se aboga por suprimir totalmente la aplicación de la pena de privación del derecho a conducir con la pena de prisión, puesto que esta opción puede ser conveniente en determinados supuestos de mayor gravedad, en los homicidios y lesiones por imprudencia grave, así como en las conducciones temerarias.

Finalmente considero necesario reconsiderar la imposición conjunta de la pena de privación del derecho a conducir con la pena de inhabilitación profesional cuando el delito se hubiere cometido utilizando un vehículo a motor o ciclomotor ya que puede conculcar el principio de proporcionalidad en la aplicación de las penas cuando se aplica a conductores profesionales. Si bien es cierto que ambas concurren de forma residual, puede ser suficiente con la aplicación de una de ellas para asegurar los fines preventivos y retributivos. En este caso, sería recomendable la imposición únicamente de la pena de privación del derecho a conducir.

XV. A pesar de que, tradicionalmente, las medidas adoptadas en materia de seguridad vial han incidido especialmente en el conductor, resulta interesante poder actuar también sobre el instrumento del delito, es decir, en el vehículo a motor o ciclomotor. Valoro positivamente la tendencia a una mayor aplicación conjunta de la pena de privación del derecho a conducir vehículos y el decomiso de los mismos.

Ha de señalarse que, en los últimos años, desde la jurisprudencia se ha incrementado la imposición conjunta de la pena analizada y el decomiso del vehículo a motor o ciclomotor, debido a la tendencia de la FGE a peticionar ambas medidas, así como también se ha visto favorecida por las reformas legislativas operadas. Si bien dicha aplicación acumulativa no debe generalizarse, y aun cuando, como se ha puesto de manifiesto en el correspondiente capítulo, la aplicación del decomiso del vehículo no siempre impide que el penado pueda emplear otro vehículo a su alcance, considero que en los casos de mayor gravedad o en los de reincidencia delictiva puede ser positiva esta medida en aras a evitar que pueda cometer nuevos delitos contra la seguridad vial conduciendo un vehículo a motor o ciclomotor, contribuyendo, de esta forma, a los fines de prevención especial negativa de la pena. 
Otra medida destinada a la intervención penal sobre el instrumento del delito, para el supuesto de los delitos contra la seguridad vial es la regla de conducta del art. 83.1.8 CP, conocida como alcolock. Cuando al penado se le aplica una pena de prisión y una pena de privación del derecho a conducir, puede plantearse la suspensión de la pena de la primera con la aplicación de la regla de conducta del art. 83.1.8. En este caso se combina una pena privativa de derechos que afecta directamente al autor del delito con una medida que actúa sobre el vehículo a motor, mediante la implementación de mecanismos tecnológicos que impiden el arranque del vehículo cuando el penado presenta una determinada tasa de alcohol. A pesar de su escasa aplicación inicial y de las dificultades técnica que presenta, tras su entrada en vigor en el año 2015 su implementación ha aumentado año tras año, lo que evidencia que los avances tecnológicos pueden combinarse con las sanciones penales tradicionales para aumentar de esta forma su efectividad.

$\mathrm{XVI}$. En el trabajo se han desarrollado diversas propuestas de lege ferenda destinadas a incrementar los potenciales de la pena de privación del derecho a conducir en un ámbito tan dinámico como es la circulación de vehículos a motor y ciclomotores. Se propone en este sentido, en primer lugar, incluir esta sanción para la conminación de tipos delictivos en los que actualmente no aparece regulada y que están directamente relacionados con la utilización de vehículos a motor y ciclomotores como son: el homicidio o lesiones dolosas causadas con vehículo a motor, el hurto y uso de vehículos a motor y ciclomotores, los daños causados dolosamente con un vehículo a motor o ciclomotor y las conductas delictivas tipificadas en el art. $384 \mathrm{CP}$.

En segundo lugar, y como he apuntado anteriormente, considero que en los delitos contra la seguridad vial la respuesta penal no debe limitarse únicamente al conductor, sino que es interesante promover medidas asociadas al instrumento con el que se comete el delito. Por ello se realiza la propuesta de inmovilización temporal del vehículo a motor o ciclomotor por tiempo igual a la pena de privación del derecho a conducir, con la que se persigue que el penado no pueda utilizar el instrumento con el que ha cometido el delito mientras cumple la sanción que le ha sido impuesta. De esta forma, se pueden reducir, aunque nunca eliminar, las posibilidades que conduzca un vehículo durante el periodo de cumplimiento de la pena.

En tercer lugar, resultaría interesante explorar mecanismos para adaptar la duración o el cumplimiento de la pena de privación del derecho a conducir a las 
circunstancias del penado. Con ello me refiero a la facultad del juzgador de rebajar la pena según el hecho cometido siguiendo la estela del art. 385 ter $\mathrm{CP}$, que prevé tal facultad, rebajándola en un grado, pero únicamente en relación con la pena de prisión. También a la posibilidad de suspender o sustituir dicha pena cuando concurran determinados requisitos. $O$ bien que en determinados supuestos excepcionales la pena se pueda incluso acomodar a las circunstancias del penado elaborando un plan individualizado de ejecución. Estas propuestas están dirigidas a lograr una mayor flexibilización tanto en el momento de dictar la sentencia penal como en la ejecución de la pena, ya que son dos déficits importantes que se han detectado a lo largo de los diversos capítulos del trabajo, especialmente cuando la pena se impone a profesionales de la conducción o a personas que necesitan conducir para realizar su actividad laboral. Las propuestas planteadas, no deben impedir que la pena se mantenga como un mecanismo adecuado para proteger la seguridad vial y la vida e integridad de los usuarios de las vías, sino todo lo contrario, ya que puede incluso cumplir mejor sus fines, reduciendo el riesgo de quebrantamiento.

Las propuestas de lege ferenda formuladas tendrán mayores o menores opciones para ver la luz, según la política criminal en materia de seguridad vial que se siga en cada momento. En todo caso, todas ellas se han valorado como viables una vez identificados los aspectos que en la actualidad plantean disfunciones en la pena de privación del derecho a conducir y en aras a su mejora.

A pesar de la necesidad de adaptar y mejorar algunos aspectos de la regulación de esta pena, de lo que no cabe duda es que merece permanecer en el catálogo de sanciones penales, si bien adaptándola a una realidad social que, está evolucionando con nuevas formas de movilidad que conllevan nuevos riesgos. Por ello, considero que el legislador debería explorar cambios normativos que conlleven una aplicación adecuada y una mejora en la ejecución de la misma en el sentido apuntado en este trabajo. 


\section{BIBLIOGRAFÍA}

AA.VV. Recomendaciones y resoluciones del Comité de Ministros del Consejo de Europa en Materia de Justicia. Ministerio de Justicia. Secretaria General Técnica. Centro de Publicaciones, Madrid, 1992.

AA.VV. Libro verde sobre la seguridad vial. La sociedad civil ante el reto de la seguridad vial. Edita: Asociación Española de la Carretera, Madrid, 2006.

AA.VV. Infotrànsit, no 12, Ed. Servei Català de Trànsit, Diciembre, 2007.

AA.VV. Documents sobre execució penal. Centre d’Estudis Jurídics i Formació Especialitzada. Generalitat de Catalunya. Estudis i Formació de I’Administració de Justícia. Barcelona, 2011, 1ํㅡㄹ edición.

AA.VV. Memoria de la FGE de los años 2005, 2007, 2008, 2009, 2010, 2011, 2012 , 2013, 2014, 2015, 2016, 2017, 2018 y 2019.

ABEL SOUTO, Miguel, La suspensión de la ejecución de la pena tras la Ley Orgánica 1/2015, Ed. Tirant lo Blanch, Valencia, 2017.

AGUADO CORREA, Teresa, El principio de proporcionalidad en derecho penal, Ed. Edersa, Madrid, 1999.

- El comiso, Ed.Edersa, Madrid, 2000.

AGUDO FERNÁNDEZ, Enrique/ JAÉN VALLEJO, Manuel/ PERRINO PÉREZ, Ángel Luis, Penas, medidas y otras consecuencias jurídicas del delito, Ed. Dykinson, Madrid, 2017.

AGÜERO RAMÓN-LLÍN, Elena, "Aspectos comunes a los delitos contra la seguridad vial", La dogmática penal sobre el asfalto: un enfoque práctico de los delitos contra la seguridad vial, AGÜERO RAMÓN-LLIN, Elena/HIDALGO DE MORILLO JIMÉNEZ, Agustín/ LANZAROTE MARTÍNEZ, Pablo/ PRIETO GONZÁLEZ, Helena María, Ed.Comares, Granada, 2012.

- "Los delitos de conducción etílica y de conducción bajo la influencia de bebidas alcohólicas", La dogmática penal sobre el asfalto: un enfoque práctico de los delitos contra la seguridad vial, AGÜERO RAMÓN-LLIN, Elena/HIDALGO DE MORILLO JIMÉNEZ, Agustín/ LANZAROTE MARTÍNEZ, Pablo/ PRIETO GONZÁLEZ, Helena María, Ed.Comares, Granada, 2012.

ALASTUEY DOBÓN, Carmen/ ESCUCHURI AISA, Estrella, "Ilícito penal e ilícito administrativo en materia de tráfico y seguridad vial". Estudios penales y criminológicos. Vol. XXXI, 2011, Universidad Santiago de Compostela.

ALONSO, Francisco/ PASTOR, Juan Carlos/ MONTORO, Luis/ ESTEBAN, Cristina, "Driving under the influence of alcohol: frequency, reasons, perceived risk and punishment", Substance Abuse Treatment, Prevention, and Policy, 2015, 10:11.

ÁLVAREZ GARCÍA, Francisco Javier, Consideraciones sobre los fines de la pena en el ordenamiento constitucional español, Ed. Tomares, Granada, 2001. 
ÁlVARO LÓPEZ, Mari Cruz/ PERDICES LÓPEZ, Araceli, Delitos de Tráfico. Criterios y respuestas de los Tribunales Penales en Seguridad Vial, Ed. Lex Nova, Valladolid, 2010.

ANDRÉS DOMÍNGUEZ, Ana Cristina, "Cuestión controvertida: Los vehículos de movilidad personal, ¿Instrumento típico de un delito contra la seguridad vial?'. Estudios penales y criminológicos. Vol. XL, 2020, Universidad Santiago de Compostela.

ARMENTA DEU, Teresa, Lecciones de derecho procesal penal, Ed. Marcial Pons, Madrid, 2018.

ARMENTEROS LEÓN, Miguel, Las faltas: derecho sustantivo y procesal, Ed. Tirant lo Blanch, Valencia, 2007.

AYO FERNÁNDEZ, Manuel, Las penas, medidas de seguridad y consecuencias accesorias. Manual de determinación de las penas y de las demás consecuencias jurídico-penales del delito, Ed. Aranzadi, Pamplona, 1997.

BARONA VILAR, Silvia, "Especialidades procedimentales", en AA.VV. Derecho Jurisdiccional III. Proceso penal, MONTERO AROCA, Juan/GÓMEZ COLOMER, Juan Luis/BARONA VILAR, Silvia/ESPARZA LEIBAR, Iñaki/EXTEBERRÍA GURDI, José F., Ed.Tirant lo Blanch, Valencia, 2018, 26 ${ }^{\underline{a}}$ edición.

BAUTISTA ORTUÑO, Rebeca/ MIRÓ LLINARES, Fernando, “¿Por qué algunos siempre incumplen? Infractores y multi-infractores en seguridad vial", Indret, Revista para el análisis del Derecho, № 4, 2015.

BECCARIA, Cesare, De los delitos y de las penas, Alianza Editorial, Madrid, 1968, Sexta reimpresión, 1993, traducción de Juan Antonio de las Casas.

BENÍTEZ ORTÚZAR, Ignacio Francisco, "El bien jurídico en el delito de conducción sin permiso o licencia”, en AA.VV. El delito de conducción de vehículos a motor o ciclomotores sin licencia administrativa cometido por menores de edad, MORILLAS FERNÁNDEZ, David Lorenzo (Coordinador), Ed. Dykinson, Madrid, 2018.

BOLDÓ PRATS, Gabriela, "La Disposición Adicional decimotercera y el delito contra la seguridad vial, en concreto: el tipo penal del art.384". Revista de Derecho vLex, no 123, Julio 2014.

BOLDOVA PASAMAR, Miguel Ángel, "Penas Privativas de Derechos", en AA.VV. Lecciones de consecuencias jurídicas del delito: el sistema de penas, de medidas de seguridad, de consecuencias accesorias y de responsabilidad civil derivada del delito, GRACIA MARTÍN, Luis (Coord.)/ BOLDOVA PASAMAR, Miguel Ángel/ ALASTUEY DOBÓN, M.Carmen, Ed. Tirant lo Blanch, Valencia, 2012, 4aㅡ edición.

BLAY GIL, ESTER, "Nueve tópicos acerca del trabajo en beneficio de la comunidad: la necesidad de una discusión basada en conocimientos empíricos", Indret, Revista para el análisis del Derecho, n 4, 2007.

- BLAY GIL ESTER, "El papel de los jueces en la ejecución de las penas comunitarias: una investigación empírica y algunas propuestas para la reflexión", en AA.VV., Penas comunitarias en Europa, LARRAURI, ELENA/BLAY GIL, ESTER, Ed. Trotta, Madrid, 2011. 
BRAGE CENDÁN, Santiago B, "Algunas consideraciones en torno a las reglas para la aplicación de las medidas previstas en la ley reguladora de la responsabilidad penal de los menores", Revista Xuridica Galega, Rexurga, 2003, no 39 .

BRANDARIZ GARCÍA, José Ángel, La sanción penal de trabajos en beneficio de la comunidad, Ed. Tirant lo Blanch, 2009, Valencia.

- "La pena de trabajos en beneficio de la comunidad", en AA.VV. Las penas privativas de derechos y otras alternativas a la privación de libertad, FARALDO CABANA, Patricia/ PUENTE ABA, Luz María (Dirs.), Tirant lo Blanch, Valencia, 2013.

- "Las penas de trabajos en beneficio de la comunidad y localización permanente (arts.40, 48 y 35)"; en AA.VV. Comentarios a la Reforma del Código Penal de 2015, GONZÁLEZ CUSSAC José. L (Dir.), MATALLíN EVANGELIO, Ángela/ GÓRRIZ ROYO, Elena (Coords.), Ed. Tirant Lo Blanch, Valencia, 2015.

BUJOSA VADELL, Lorenzo, "Reconocimiento y ejecución de sentencias penales extranjeras", Diario La Ley, Sección Doctrina, 2001. Ref. D-167, Tomo 5, Ed. La Ley, La Ley 1390/2002.

CABALLERO GEA, José-Alfredo, Delitos contra la Seguridad Vial. Código Penal y Derecho Procesal Penal, Ed.Dykinson, Madrid, 2008.

CANCIO MELIÁ, Manuel, "De nuevo: ¿<< Derecho penal $>>$ del enemigo?, Derecho Penal del enemigo, JAKOBS, Günter/ CANCIO MELIÀ, Manuel, Ed.Thomson Civitas, 2 ${ }^{\text {a }}$ Ed, Cizur Menor (Navarra), 2006.

CARBONELL MATEU, Juan Carlos, "La reforma del tratamiento penal de la seguridad vial"; en AA.VV. Delincuencia en materia de tráfico y seguridad vial. Aspectos penales, civiles y procesales, MORILLAS CUEVA, Lorenzo (Coord.), Ed.Dykinson, Madrid, 2007.

- $\quad$ "La Ley Orgánica de Reforma del Código Penal en materia de seguridad vial: un comentario de urgencia", en AA.VV. Reforma del Código Penal: Respuestas para una sociedad del siglo XXI, BENÍTEZ ORTÚZAR, Ignacio Francisco (Coord.), Ed.Dykinson, Madrid, 2008.

CARDENAL MONTRAVETA, Sergi, "Los delitos relacionados con la seguridad del tráfico en el derecho comparado", InDret, Revista para el análisis del Derecho, n 3, 2007.

- $\quad$ "La protección penal de la seguridad vial", AA.VV, Seguridad Vial y Derecho Penal.Análisis de la LO 15/2007, que modifica el Código Penal en materia de Seguridad Vial, MIR PUIG Santiago y CORCOY BIDASOLO, Mirentxu (Dirs.) / CARDENAL MONTRAVETA, Sergi (Coord.), Ed.Tirant lo Blanch, Valencia, 2008.

- "Título III. De las penas"; en AA.VV. Comentarios al Código Penal. Reforma LO 1/2015 y LO 2/2015, CORCOY BIDASOLO, Mirentxu/MIR PUIG, Santiago (Dirs.), VERA SÁNCHEZ, Juan Sebastián (Coord.), Ed.Tirant lo Blanch, Valencia, 2015. 
CARRERAS ESPALLARDO, Juan Antonio, "Visión criminológica de los delitos contra la seguridad vial en España", Archivos de Criminología, Criminalística y Seguridad Privada, Vol.VII, enero-julio, 2012.

CASTRO CORREDOIRA, María/ GUINARTE CABADA, Gumersindo, "La reforma de los delitos de lesiones (arts.147, 152 y 156 CP)"; en AA.VV. Comentarios a la Reforma del Código Penal de 2015, GONZÁLEZ CUSSAC, José. L (Dir.), MATALLÍN EVANGELIO, Ángela/ GÓRRIZ ROYO, Elena (Coords.), Ed. Tirant Lo Blanch, Valencia, 2015.

CASTRO MORENO, Abraham, "Comentario crítico a la LO 2/2019, de 1 de marzo, de reforma del Código Penal, en materia de imprudencia en la conducción de vehículos a motor y ciclomotores: nuevo delito de abandono del lugar del accidente", La Ley Penal, no 138, 2019.

CERES MONTES, José Francisco, "La Reforma del Código Penal en materia de seguridad vial por la Ley Orgánica 15/2007, desde la perspectiva de su ejecución", La Ley Penal, no 48, 2008.

CERVELLÓ DONDERIS, Vicenta, "Consecuencias jurídicas de las infracciones penales: las penas", en AA.VV. Esquemas de Teoría Jurídica del delito y de la pena, en QUINTERO OLIVARES, Gonzalo et al. (Dir.) Tirant lo Blanch, Valencia, 2010.

- Derecho Penitenciario, Ed. Tirant lo Blanch, Valencia, 2012, 3a edición.

CERVERA SALVADOR, Sabina, "Ejecución de la pena de trabajos en beneficio de la comunidad", Revista de Jurisprudencia, Ed. Lefebvre-El Derecho, nํ2, 15 de enero de 2019,

CHOCLÁN MONTALVO, José Antonio, "Las penas privativas de derechos en la reforma penal”, Actualidad Penal, no 8, 1997.

COLÁS TURÉGANO, Ascensión, Derecho Penal de Menores, Ed. Tirant lo Blanch, Valencia, 2011.

CORCOY BIDASOLO, Mirentxu, "Homicidio y lesiones imprudentes cometidos con vehículos a motor o ciclomotor", en AA.VV. Derecho Penal y Seguridad Vial, en DE VICENTE MARTÍNEZ, Rosario (Dir.), Estudios de Derecho Judicial no 114, Ed. Centro de Documentación Consejo General del Poder Judicial, Madrid, 2007.

- $\quad$ "Homicidio y lesiones en el ámbito viario. Problemática concursal entre los delitos contra la seguridad en el tráfico y los resultados lesivos a ellos imputables", en AA.VV. Seguridad Vial y Derecho Penal. Análisis de la LO 15/2007, que modifica el Código Penal en materia de Seguridad Vial, MIR PUIG, Santiago y CORCOY BIDASOLO, Mirentxu (Dirs.) / CARDENAL MONTRAVETA, Sergi (Coord.), Ed.Tirant lo Blanch, Valencia, 2008.

CORDERO LOZANO, Carlos, Condenas penales privativas de libertad y de derechos. Actualizado a la reforma del C.P 2010 (LO 5/2010), Biblioteca Básica de Práctica Procesal. Ed. Bosch, Barcelona, 2010.

- $\quad$ Ejecución penal, Ed. Bosch, Barcelona, 2011. 
CRUZ BLANCA, María José, "Tratamiento penal y medidas aplicables a los menores de edad que condujeran sin la correspondiente licencia administrativa. Los resultados de un análisis empírico", en AA.VV. El delito de conducción de vehículos a motor o ciclomotores sin licencia administrativa cometido por menores de edad, MORILLAS FERNÁNDEZ, David Lorenzo (Coordinador), Ed. Dykinson, Madrid, 2018.

CUELLO CALÓN, Eugenio, Ley penal del automóvil, Ed. Bosch, Barcelona, 1950.

CUELLO CONTRERAS, Joaquín/ MAPELLI CAFFARENA, Borja, Curso de derecho penal: Parte general, Ed. Tecnos, Madrid, 2015.

CUESTA PASTOR, Pablo.J., El delito de conducción bajo la influencia de bebidas alcohólicas y el sistema de sanción por puntos de la Ley 17/2005, de 19 de julio, Dykinson, Madrid, 2012.

CUTIÑNO RAYA, Salvador, Fines de la pena, sistema penitenciario y política criminal, Ed.Tirant lo Blanch, Valencia, 2017.

DAUNIS RODRÍGUEZ, Alberto, Ejecución de penas en España. La reinserción social en retirada, Ed. Comares, Granada, 2016.

DE URBANO CASTRILLO, Eduardo, "La privación del derecho a conducir", Boletín de Derecho de la Circulación, El Derecho Editores, nำ4, Enero de 2007.

- "La fuga del lugar del accidente", Revista de Derecho de la Circulación, El Derecho Editores, no 4, Febrero de 2013.

DE VICENTE MARTÍNEZ, Rosario, "La reforma penal en curso en materia de siniestralidad vial", en AA.VV. Derecho Penal y Seguridad Vial, en DE VICENTE MARTÍNEZ, Rosario (Dir.), Estudios de Derecho Judicial no 114, Ed. Centro de Documentación Consejo General del Poder Judicial, Madrid, 2007.

- "El delito de conducción bajo la influencia de drogas tóxicas, estupefacientes, sustancias psicotrópicas o bebidas alcohólicas y su propuesta de reforma. La cuestionable necesidad de modificar el art.379 del C.Penal", La Ley, núm. 6653, 16 de febrero de 2007

- Derecho Penal de la circulación. Delitos relacionados con el tráfico vial, Ed. Bosch, Barcelona, 2008. 2ª edición revisada.

- "Seguridad Vial y Derecho Penal. En especial el homicidio imprudente cometido con vehículo a motor", Abogacía, nำ 1, 2009.

- "El comiso del vehículo a motor y los delitos cometidos en el contexto de la circulación vial”, Actualidad Jurídica Aranzadi, núm. 798, 2010.

- "La conducción con pérdida de la totalidad de los puntos transcurrido el plazo de la sanción pero sin la realización del curso de sensibilización y reeducación vial ¿es típica a los efectos del art.384.1 del CP?", Revista Aranzadi Doctrinal, núm. 8/2012, Ed. Aranzadi, 2012.

- Alcohol, drogas y delitos contra la seguridad vial, Ed. Reus, Madrid, 2018.

- Siniestralidad vial, delitos imprudentes y fuga, Ed. Reus, Madrid, 2019.

DE LAMO RUBIO, Jaime, Penas y medidas de seguridad en el nuevo código, Ed. Bosch, Barcelona, 1997. 
DÍAZ y GARCÍA CONLLEDO, Miguel, " Omisión de socorro a la propia víctima", en AA.VV. Derecho Penal y Seguridad Vial, en DE VICENTE MARTíNEZ, Rosario (Dir.), Estudios de Derecho Judicial no 114, Ed. Centro de Documentación Consejo General del Poder Judicial, Madrid, 2007.

DÍEZ RIPOLLÉS, José Luis, "El Derecho penal simbólico y los efectos de la pena", en AA.VV. Crítica y justificación del Derecho penal en el cambio de siglo, ARROYO ZAPATERO, Luis /NEUMANN, Ulfrid /NIETO MARTíN, Adán (Coords.), Ediciones de la Universidad de Castilla-La Mancha, Cuenca, 2003.

- "De la sociedad del riesgo a la seguridad ciudadana: un debate desenfocado", Revista Electrónica de Ciencia Penal y Criminología (RECPC), 07-01, (2005).

- "La evolución del sistema de penas en España: 1975-2003", Revista Electrónica de Ciencia Penal y Criminología (RECPC), 08-07, (2006).

DOLZ LAGO, Manuel Jesús, Comentarios a la legislación penal de menores, Ed.Tirant lo Blanch, Valencia, 2007.

DOVAL PAIS, Antonio, "El nuevo régimen penal de las imprudencias menos graves y leves", en AA.VV. Comentario a la reforma penal de 2015, QUINTERO OLIVARES, Gonzalo (Dir.), Ed.Thomson Reuters- Aranzadi, Cizur Menor (Navarra), 2015.

ESTRELLA RUIZ, Manuel, "La reforma de los delitos contra la seguridad vial y especial referencia al comiso del vehículo", Revista de Jurisprudencia, El Derecho, no 2, 1 de octubre de 2012.

FARALDO CABANA, Patricia/ PUENTE ABA, Luz María, "Concepto y funciones", en FARALDO CABANA, Patricia/ PUENTE ABA, Luz María (Dirs.), Las penas privativas de derechos y otras alternativas a la privación de libertad, Ed. Tirant lo Blanch, Valencia, 2013.

FERNÁNDEZ BERMEJO, Daniel, "El delito de conducción de vehículos de motor bajo la influencia de los efectos del alcohol", La Ley Penal, nำ 119, 2016.

FERNÁNDEZ HERNÁNDEZ, Antonio, "Supresión de las faltas y creación de delitos leves”, en GONZÁLEZ CUSSAC, José. L (Dir.), MATALLíN EVANGELIO, Ángela/ GÓRRIZ ROYO, Elena (Coords.), Comentarios a la Reforma del Código Penal de 2015, Ed. Tirant Lo Blanch, Valencia, 2015.

FERNÁNDEZ PANTOJA, Pilar, "Delitos contra la seguridad del tráfico: la pena de privación del derecho a conducir", en AA.VV. Delincuencia en materia de tráfico y seguridad vial. Aspectos penales, civiles y procesales, MORILLAS CUEVA, Lorenzo (Coord.), Ed.Dykinson, Madrid, 2007.

- "La concurrencia delictiva en delitos contra la seguridad vial: especial referencia a las conductas relacionadas con los menores de edad", en AA.VV. El delito de conducción de vehículos a motor o ciclomotores sin licencia administrativa cometido por menores de edad, MORILLAS FERNÁNDEZ, David Lorenzo (Coordinador), Ed. Dykinson, Madrid, 2018.

FERRAJOLI, Luigi, Derecho y razón, Ed. Trotta, Madrid, 2011.

FERRER GUTIÉRREZ, Antonio, Manual práctico sobre ejecución penal y derecho penitenciario, Ed. Tirant Lo Blanch, Valencia, 2011. 
GANZENMÜLLER, Carlos/ DE LAMO RUBIO, Jaime/ ROBLEDO VILLAR, Antonio/ ESCUDERO MORATALLA, José Francisco/ FRIGOLA VALLINA, Joaquín, Delitos contra la Seguridad del Tráfico. Los delitos cometidos con ocasión de la conducción de vehículos a motor y ciclomotores, Ed.Bosch, Sabadell, (Barcelona), 2005.

GARCÍA ALBERO, Ramón, "La nueva política criminal de la seguridad vial”, Revista Electrónica de Ciencia Penal y Criminología (RECPC), 09-11, (2007).

- "De las medidas de seguridad", AA.VV, en Comentarios al Código Penal Español, Tomo I, (Artículos 1 a 233), en: QUINTERO OLIVARES, Gonzalo (Dir.), MORALES PRATS, Fermín (Coord.), Aranzadi-Thomson Reuters, Cizur-Menor (Navarra), 2011, 6ª edición.

- "La suspensión de la ejecución de las penas", AA.VV, Comentario a la reforma penal de 2015, en: QUINTERO OLIVARES, Gonzalo (Dir.), Ed.Thomson Reuters- Aranzadi, Cizur Menor (Navarra), 2015.

GARCÍA DEL BLANCO, Victoria, "Delitos contra la seguridad vial: cuestiones comunes", en AA.VV. Protección Penal de la Seguridad Vial, GUTIÉRREZ RODRÍGUEZ, María (Coord.), GARCÍA DEL BLANCO, Victoria / MARTÍN LORENZO, María y SANZ-DÍEZ DE ULZURRUN LLUCH, Marina, Ed.Tirant lo Blanch, Valencia, 2009, 1ª edición.

- "El nuevo artículo 384 del Código Penal: Quebrantamientos, desobediencias y conductas afines", en AA.VV. Protección Penal de la Seguridad Vial, GUTIÉRREZ RODRÍGUEZ, María (Coord.), Ed. Tirant lo Blanch, Valencia, 2009.

- "Delitos contra la seguridad vial: cuestiones comunes", en AA.VV. Protección Penal de la Seguridad Vial, GUTIÉRREZ RODRÍGUEZ, María (Coord.), GARCÍA DEL BLANCO, Victoria / MARTÍN LORENZO, María y SANZ-DÍEZ DE ULZURRUN LLUCH, Marina, Ed.Tirant lo Blanch, Valencia, 2013, $2^{a}$ edición.

GARCÍA PÉREZ, Octavio, Las medidas y su ejecución en el sistema de justicia penal juvenil, Ed. Tirant Lo Blanch, Valencia, 2019.

GARCÍA RUIZ, Marian, "Los reincidentes del alcohol", Tráfico y Seguridad Vial, Dirección General de Tráfico, núm. 196, 2009.

GIL GIL, Alicia/ LACRUZ LÓPEZ, Juan Manuel/ MELENDO PARDOS, Mariano/ NÚÑEZ FERNÁNDEZ, José, Consecuencias jurídicas del delito. Regulación y datos de la respuesta a la infracción penal en España, Ed. Dykinson, Madrid, 2018.

GIMENO SENDRA, Vicente, Manual de Derecho Procesal Penal, Ediciones Jurídicas Castillo de Luna, Valencia, 2018.

GIRALT PADILLA, Cristina, "La acumulación de condenas tras la LO 1/2015 de reforma del Código Penal. Comentario a la STS 367/2015, de 11 de junio", Diario La Ley, no 8616, 1 de octubre de 2015. 
GÓMEZ PAVÓN, Pilar, "La reforma de los delitos contra la seguridad del tráfico (arts.379, 381, 385 bis y 385 ter)", en AA.VV., Comentarios a la Reforma Penal de 2010, ÁlVAREZ GARCÍA, Francisco.J/ GONZÁlEZ CUSSAC, José.L (Dirs.), Ed. Tirant lo Blanch, Valencia, 2010.

- El delito de conducción bajo la influencia del alcohol, drogas tóxicas o estupefacientes. $Y$ análisis del art.383 del C.Penal, Ed.Bosch, Barcelona, 2010, 4ㄹa edición.

- "La reforma de los delitos contra la seguridad vial", Revista Jurídica de la Comunidad Autónoma de Madrid, nº 25, 2012.

GONZÁLEZ COLLANTES, Tàlia, "Seguridad vial, reformas penales y reeducación", en AA.VV. Prevención y control de la siniestralidad vial. Un análisis jurídico y criminológico, en: ORTS BERENGUER, Enrique (Coord.), Ed. Tirant lo Blanch, Valencia, 2011.

GONZÁLEZ CUSSAC, José Luis, "La reforma penal de los delitos contra la seguridad vial (Proyecto CP 2006)", en AA.VV. Derecho Penal y Seguridad Vial, en DE VICENTE MARTÍNEZ, Rosario (Dir.), Estudios de Derecho Judicial no 114, Ed. Centro de Documentación Consejo General del Poder Judicial, Madrid, 2007.

- “¿Es adecuada la intervención penal en materia de seguridad vial? Líneas básicas del anteproyecto de ley orgánica de reforma del código penal de 2006”, en A.AV.V., Seguridad del Tráfico: riesgos y respuestas, Academia Galega de Seguridad Pública, Xornadas nº 8, Xunta de Galicia, Santiago de Compostela, 2007.

GONZÁLEZ CUSSAC, José Luis/VIDALES RODRÍGUEZ, Caty, "La reforma del Código Penal en materia de seguridad vial", Revista Xuridica Galega, Rexurga, 2007, no 55.

GONZÁLEZ CUSSAC, José Luis/VIDALES RODRÍGUEZ, Caty, "Los nuevos delitos contra la seguridad vial”, en AA.VV. Seguridad Vial (Especial referencia a la reforma operada en el Código Penal mediante la Ley Orgánica 15/2007, de 30 de noviembre), en VIDALES RODRÍGUEZ, Caty y MERA REDONDO, Antonio (Coords.), Tirant lo Blanch, Valencia, 2008.

GRACIA MARTÍN, Luis, "El sistema de penas", en AA.VV., Lecciones de consecuencias jurídicas del delito: el sistema de penas, de medidas de seguridad, de consecuencias accesorias y de responsabilidad civil derivada del delito, GRACIA MARTÍN, Luis (Coord.)/ BOLDOVA PASAMAR, Miguel Ángel/ ALASTUEY DOBÓN, M.Carmen, Ed. Tirant lo Blanch, Valencia, 2012, $4^{\text {a }}$ edición.

- "La pena de multa", en AA.VV. Lecciones de consecuencias jurídicas del delito: el sistema de penas, de medidas de seguridad, de consecuencias accesorias y de responsabilidad civil derivada del delito, GRACIA MARTÍN, Luis (Coord.)/ BOLDOVA PASAMAR, Miguel Ángel/ ALASTUEY DOBÓN, M.Carmen, Ed. Tirant lo Blanch, Valencia, 2012, 4aㅡ edición.

- "Las medidas de seguridad y reinserción social", en AA.VV. Lecciones de consecuencias jurídicas del delito: el sistema de penas, de medidas de seguridad, de consecuencias accesorias y de responsabilidad civil derivada 
del delito, GRACIA MARTÍN, Luis (Coord.)/ BOLDOVA PASAMAR, Miguel Ángel/ ALASTUEY DOBÓN, M.Carmen, Ed. Tirant lo Blanch, Valencia, 2012, 4를 edición.

- "La responsabilidad penal de los menores", en AA.VV. Lecciones de consecuencias jurídicas del delito: el sistema de penas, de medidas de seguridad, de consecuencias accesorias y de responsabilidad civil derivada del delito, GRACIA MARTíN, Luis (Coord.)/ BOLDOVA PASAMAR, Miguel Ángel/ ALASTUEY DOBÓN, M.Carmen, Ed. Tirant lo Blanch, Valencia, 2012, $4^{\text {a }}$ edición.

- "Consecuencias jurídicas no penales derivadas de la comisión del delito (I) las consecuencias accesorias generales y las específicas para personas jurídicas y entidades sin personalidad jurídica", en AA.VV. Lecciones de consecuencias jurídicas del delito: el sistema de penas, de medidas de seguridad, de consecuencias accesorias y de responsabilidad civil derivada del delito, GRACIA MARTíN, Luis (Coord.)/ BOLDOVA PASAMAR, Miguel Ángel/ ALASTUEY DOBÓN, M.Carmen, Ed. Tirant lo Blanch, Valencia, 2012, 4aㅡ edición.

- "Suspensión de la ejecución y sustitución de las penas privativas de libertad", en AA.VV. Lecciones de consecuencias jurídicas del delito: el sistema de penas, de medidas de seguridad, de consecuencias accesorias $y$ de responsabilidad civil derivada del delito, GRACIA MARTÍN, Luis (Coord.)/ BOLDOVA PASAMAR, Miguel Ángel/ ALASTUEY DOBÓN, M.Carmen, Ed. Tirant lo Blanch, Valencia, 2012, 4를 edición.

GRIMA LIZANDRA, Vicente, "Los delitos contra la seguridad vial: lectura desde los principios penales", en AA.VV. Prevención y control de la siniestralidad vial. Un análisis jurídico y criminológico, ORTS BERENGUER, Enrique (Coord.), Ed. Tirant lo Blanch, Valencia, 2011.

Grupo de Estudios de Política Criminal, Una propuesta alternativa al sistema de penas y su ejecución, y a las medidas cautelares personales, Ed. Grupo de Estudios de Política Criminal, Valencia, 2005.

GUTIÉRREZ CASTAÑEDA, Ana, Las penas privativas de derechos políticos $y$ profesionales. Bases para un nuevo modelo regulativo, Ed. Tirant lo Blanch, Valencia, 2012.

- "Penas privativas y restrictivas de derechos", en AA.VV., Las consecuencias jurídicas del delito, ROCA DE AGAPITO, Luis (Dir.), Ed. Tirant lo Blanch, Valencia, 2017.

GUTIÉRREZ RODRÍGUEZ, María, "Delitos contra la seguridad vial: cuestiones comunes", en AA.VV. Protección Penal de la Seguridad Vial, GUTIÉRREZ RODRÍGUEZ, María (Coord.), GARCÍA DEL BLANCO, Victoria / MARTÍN LORENZO, María y SANZ-DIEZ DE ULZURRUN LLUCH, Marina, Ed.Tirant lo Blanch, Valencia, 2009, 1a edición.

- "Excesos de velocidad e intoxicaciones punibles", en AA.VV., Protección Penal de la Seguridad Vial, en GUTIÉRREZ RODRÍGUEZ, María (Coord.), Ed. Tirant lo Blanch, Valencia, 2009. 1aㅡ edición. 
- "Dos años tras la reforma penal: cuestiones comunes sobre los delitos contra la seguridad vial y aplicación del artículo 379 del Código Penal", Tráfico y Seguridad Vial, no 136, 2010.

- "Incidencia de la reforma del Código Penal de 2010 en los delitos contra la seguridad vial", Tráfico y Seguridad Vial, № 145, 2011.

- "Delitos contra la seguridad vial: cuestiones comunes", en AA.VV. Protección Penal de la Seguridad Vial, GUTIÉRREZ RODRÍGUEZ, María (Coord.), GARCÍA DEL BLANCO, Victoria / MARTÍN LORENZO, María y SANZ-DÍEZ DE ULZURRUN LLUCH, Marina, Ed.Tirant lo Blanch, Valencia, 2013, 2 ${ }^{\mathrm{a}}$ edición.

HENRÍQUEZ RODRÍGUEZ, Francisco Javier, "Los accidentes de circulación y su relación con los delitos contra la seguridad del tráfico", en AA.VV. La reforma de la justicia penal (Estudios en homenaje al Prof. Klaus Tiedemann), GÓMEZ COLOMER, Juan Luis/ GONZÁLEZ CUSSAC, José Luis (Coords.) Publicacions de la Universitat Jaume I, Castelló de la Plana, 1997.

HERNÁNDEZ-CARRILLO FUENTES, José Mํㅡㄹ, "La suspensión y/o fraccionamiento del cumplimiento de la pena de privación del derecho a conducir un vehículo a motor o ciclomotor", Tráfico y Seguridad Vial, № 100, 2007.

HERRERO ÁLVAREZ, Sergio, "Doce novedades en el procedimiento abreviado (reforma de octubre de 2002 de la ley de enjuiciamiento criminal)", Sala de Togas, Revista del Ilustre Colegio de Abogados de Gijón, número 45, abril 2003.

HIDALGO DE MORILLO JIMÉNEZ, Agustín, "Aspectos comunes a los delitos contra la seguridad vial", La dogmática penal sobre el asfalto: un enfoque práctico de los delitos contra la seguridad vial, AGÜERO RAMÓN-LLIN, Elena/HIDALGO DE MORILLO JIMÉNEZ, Agustín/ LANZAROTE MARTíNEZ, Pablo/ PRIETO GONZÁLEZ, Helena María, Ed.Comares, Granada, 2012.

- "El delito de conducción temeraria", La dogmática penal sobre el asfalto: un enfoque práctico de los delitos contra la seguridad vial, AGÜERO RAMÓNLLIN, Elena/HIDALGO DE MORILLO JIMÉNEZ, Agustín/ LANZAROTE MARTínEZ, Pablo/ PRIETO GONZÁLEZ, Helena María, Ed.Comares, Granada, 2012.

HILTERMAN, Ed/ TRASOVARES NAVARRETE, Mavi, ¿Cómo conducimos después de un programa formativo de seguridad vial?, Generalitat de Catalunya, Departament de Justícia, Centre d’Estudis Jurídics i Formació Especialitzada, Barcelona, 2010.

HILTERMAN, Ed/ MANCHO FORA, Roger, Evaluación de Programas Formativos de Seguridad Vial y la reincidencia posterior. Generalitat de Catalunya, Departament de Justícia Centre d’Estudis Jurídics i Formació Especialitzada, Barcelona, 2012.

HOLGADO MERINO, José Manuel, "La pena de multa", en AA.VV. Las penas y las medidas de seguridad, ECHAVARRI GARCIAA, María Auxiliadora (Dir.), Consejo General del Poder Judicial, Centro de Documentación Judicial, Madrid, 2007. 
HORTAL IBARRA, Juan Carlos, "La mutación del derecho penal vial: la criminalización de los excesos de velocidad como paradigma", La ley Penal, nำ 100, 2013.

HURTADO YELO, Juan José, "Los delitos contra la seguridad vial. Análisis de la reforma del Código Penal por LO 5/2010, de 22 de junio", Revista Aranzadi Doctrinal, núm.8/2010, Ed. Aranzadi, 2010.

IGLESIAS GARCÍA, María Concepción, "Derecho penal de menores", en AA.VV. Las consecuencias jurídicas del delito, ROCA DE AGAPITO, Luis (Dir.), Ed. Tirant lo Blanch, Valencia, 2017.

JAKOBS, Günter, Sobre la teoría de la pena, Cuadernos de conferencias y artículos no 16, Universidad Externado de Colombia, Centro de Investigaciones de Derecho Penal y Filosofía del Derecho, 1998, Bogotá (Colombia), traducción de Manuel Cancio Meliá.

JARAMILLO GARCÍA, Antonio, Novísimo Código Penal comentado y cotejado con el de 1870, Volumen II, Imprenta Silvestre Ferreira, Salamanca, 1928.

KAISER, Günther, Delincuencia de tráfico y prevención general. Investigaciones sobre la Criminología y el Derecho Penal del tráfico. (trad. J.M. Rodríguez Devesa), Ed.Espasa Calpe, Madrid, 1979.

LANDROVE DÍAZ, Gerardo, Las consecuencias jurídicas del delito, Ed.Tecnos, Madrid, 2002.

- El nuevo derecho penal, Ed. Tirant lo Blanch, Valencia, 2009.

LANZAROTE MARTÍNEZ, Pablo, "El quebrantamiento de la privación del derecho a conducir vehículos a motor o ciclomotores después de la reforma del CP por la LO 15/2007". Sepin, Tráfico, Circulación y Seguridad Vial, Marzo-Abril2009, no 23.

- "Aspectos Comunes a los delitos contra la Seguridad Vial", La dogmática penal sobre el asfalto: un enfoque práctico de los delitos contra la seguridad vial, AGÜERO RAMÓN-LLIN, Elena/HIDALGO DE MORILLO JIMÉNEZ, Agustín/ LANZAROTE MARTíNEZ, Pablo/ PRIETO GONZÁLEZ, Helena María, Ed.Comares, Granada, 2012.

- "Algunas cuestiones discutidas en el delito de conducción punible del art.384 del Código Penal", La dogmática penal sobre el asfalto: un enfoque práctico de los delitos contra la seguridad vial, AGÜERO RAMÓN-LLIN, Elena/HIDALGO DE MORILLO JIMÉNEZ, Agustín/ LANZAROTE MARTÍNEZ, Pablo/ PRIETO GONZÁLEZ, Helena María, Ed.Comares, Granada, 2012.

- "El nuevo delito de abandono del lugar del accidente y otras importantes novedades de la inminente reforma del Código Penal en materia de imprudencia", Diario La Ley, no 2650/2019.

LAURELL, H, "Hacia unas carreteras sin alcohol en Europa", Revista de Trastornos adictivos, 2004; Volumen 6, núm. 4. 
LEAL MEDINA, Julio, Un Estudio de las Actuales Medidas de seguridad y los interrogantes que plantean en la moderna dogmática del Derecho Penal, Revista Aranzadi de Derecho y Proceso Penal, Número 20. AranzadiThomson Reuters, Cizur Menor (Navarra), 2008, 1를 edición.

LEDESMA MUÑIZ, Ramón, "El nuevo procedimiento sancionador de tráfico", $D A$, Revista de Derecho Administrativo, no 284-285, mayo-diciembre, 2009, Ed.INAP, Madrid.

LESCH, Heiko H., La función de la pena, Cuadernos Luis Jiménez de Asúa, núm. 4, Ed.Dykinson, Madrid, 1999, traducción de Javier Sánchez-Vera Gómez Trelles.

LÓPEZ BARJA DE QUIROGA, Jacobo, "Las penas privativas de derechos", Revista del Poder Judicial no 53, Primer Trimestre 1999, Ed. Consejo General del Poder Judicial.

LUZÓN PEÑA, Diego-Manuel, Derecho penal de la circulación. Estudios de la jurisprudencia del Tribunal Supremo, PPU (Promociones y Publicaciones Universitarias S.A), Barcelona, 1990, $2^{\underline{a}}$ edición.

MAGRO SERVET, Vicente, "La despenalización de la conducción de vehículos de motor y ciclomotores sin seguro en la reforma del código penal", Diario La Ley, no 5843, La Ley, 1470/2003.

- "La vulneración del Derecho a la intimidad en la seguridad vial. Análisis de la sentencia del TC de 24 de septiembre de 2007", Tráfico y Seguridad vial, №111, 2008.

- "La criminalización de la conducción sin permiso de conducir o retirado", Tráfico y Seguridad vial, ㄲo 113, 2008.

- "¿Es posible fraccionar la ejecución de la pena de privación del permiso de conducir?", Tráfico y Seguridad Vial, nº115-116, 2008.

- "El Real Decreto 1849/2009, de 4 de diciembre y la introducción de la reeducación en la seguridad vial para cumplir la pena de trabajos en beneficio de la comunidad", Tráfico y Seguridad Vial, № 134, 2010.

- Análisis de las novedades legislativas en seguridad vial, Ed. El Derecho Grupo Editorial, Madrid, 2010.

- "La pena de comiso del vehículo de motor y ciclomotores en los delitos contra la seguridad del tráfico tras la Ley Orgánica 5/2010". Tráfico y Seguridad Vial, no 146, 2011.

- "Medidas que afectan a la seguridad vial incluidas en el nuevo Código Procesal Penal”, Tráfico y Seguridad Vial no 177, 2013.

- "Ciclistas: víctimas de delitos contra la seguridad vial sobre todo en vacaciones", Tráfico y Seguridad vial, № 219, 2017.

- "El nuevo delito de fuga del art. $382 \mathrm{CP}$ en la siniestralidad vial", Diario La Ley, no 9346, Sección Doctrina, 28 de enero de 2019.

- "¿Cómo se van a tramitar ahora las reclamaciones por accidente de tráfico en vía penal?", Diario La Ley, ํo 9370, Sección Doctrina, 5 de marzo de 2019. 
MAGRO SERVET, Vicente/ SOLAZ SOLAZ, Esteban, Manual práctico sobre la ejecución penal. Las medidas alternativas a la prisión: suspensión, sustitución y expulsión, Ed. La Ley, Madrid, 2008, 1a edición.

MAGRO SERVET, Vicente/ SURIÁ MARTÍNEZ, Raquel/ HERNÁNDEZ RAMOS, Carmelo/CUÉLLAR OTÓN, J. Pablo, "La eficacia de la implantación del programa TASEVAL en la reeducación de condenados por delitos contra la seguridad vial”, Tráfico y Seguridad Vial, nำ 182, 2014.

MANZANARES SAMANIEGO, José Luis, "La pena de multa", Diario La Ley, Sección Doctrina 1996, Ref D-30, tomo 2, Ed. La Ley, La Ley 12162/2001.

- Código Penal (Adaptado a la Ley Orgánica 5/2010 de 22 de junio) (Comentarios y jurisprudencia), I, Parte general (artículos 1 a 137), Ed. Comares, Granada, 2010.

- "El abono de las medidas cautelares en la duración de las penas", Diario la Ley, no 8293, 2014.

MAPELLI CAFFARENA Borja/TERRADILLOS BASOCO, Juan, Las consecuencias jurídicas del delito, Ed.Civitas, Madrid, 1993, 2ª edición.

MARTÍN LORENZO, María, "Delitos contra la seguridad vial: cuestiones comunes", en AA.VV. Protección Penal de la Seguridad Vial, GUTIÉRREZ RODRÍGUEZ, María (Coord.), GARCÍA DEL BLANCO, Victoria / MARTÍN LORENZO, María y SANZ-DIEZ DE ULZURRUN LLUCH, Marina, Ed.Tirant lo Blanch, Valencia, 2009, 1a edición.

- "Negativa a someterse a las pruebas de medición de alcohol y detección de drogas", en AA.VV. Protección Penal de la Seguridad Vial, en GUTIÉRREZ RODRÍGUEZ, María (Coord.), Ed. Tirant lo Blanch, Valencia, 2009.

- "Delitos contra la seguridad vial: cuestiones comunes", en AA.VV. Protección Penal de la Seguridad Vial, GUTIÉRREZ RODRÍGUEZ, María (Coord.), GARCÍA DEL BLANCO, Victoria / MARTÍN LORENZO, María y SANZ-DÍEZ DE ULZURRUN LLUCH, Marina, Ed.Tirant lo Blanch, Valencia, 2013, $2^{a}$ edición.

MARTÍN UCLÉS, Francisco, Aspectos Jurídicos y Policiales de la Alcoholemia, Ed.Tirant Lo Blanch, Valencia, 2003.

MARTÍNEZ DÍAZ, Manuel/ LUACES GUTIÉRREZ Ana-Isabel, "El proceso penal de Menores ", en AA.VV. Derecho Penal Juvenil, VÁZQUEZ GONZÁLEZ, Carlos/ SERRANO TÁRRAGA, María Dolores (Editores), Ed. Dykinson, 2007, Madrid, $2^{a}$ edición.

MARTÍNEZ PARDO, Vicente José, La ejecución de las medidas en el proceso de menores, Ed.Tirant Lo Blanch, Valencia, 2012.

MARTÍNEZ ZAPATER, Luis Fernando, "Los delitos contra la seguridad vial, arts.379, 381, 384, 385 bis y 385 ter", en AA.VV. La reforma Penal de 2010: Análisis y comentarios, QUINTERO OLIVARES, Gonzalo (Dir.), Thomson Reuters- Aranzadi, 2010, Cizur Menor (Navarra). 
MARZAL RAGA, Consuelo de dos Reyes, "La nueva justicia administrativa de tráfico", en AA.VV. Prevención y control de la siniestralidad vial. Un análisis jurídico y criminológico, ORTS BERENGUER, Enrique (Coord.), Ed. Tirant lo Blanch, Valencia, 2011.

MATUS ACUÑA, Jean Pierre, "Penas privativas de derechos", en AA.VV. Penas alternativas a la prisión, CID MOLINÉ, José/LARRAURI PIJOAN, Elena (Coord.), Ed. Bosch, Barcelona, 1997.

MAZA MARTÍN, José Manuel, "Penas privativas de derechos y accesorias en el nuevo Código Penal"; en AA.VV. Penas y medidas de seguridad en el nuevo Código Penal, POZA CISNEROS, María (Dir.), Cuadernos de Derecho Judicial, Ed. Consejo General del Poder Judicial, Madrid, 1996.

MINGORANCE SÁNCHEZ, José Antonio, "La seguridad vial en el ordenamiento penal: justificación y crítica", Revista de Derecho UNED, no 20-2017.

MIR PUIG, Santiago, "El principio de proporcionalidad como fundamento constitucional de límites materiales del Derecho Penal", en AA.VV. Constitución y principios del Derecho Penal: algunas bases constitucionales, MIR PUIG, Santiago/ QUERALT JIMÉNEZ, Joan. (Dirs.), FERNÁNDEZ BAUTISTA, Silvia (Coord.), Ed. Tirant lo Blanch, Valencia, 2010.

MIRÓ LLINARES, Fernando, "El moderno derecho penal vial y la penalización de la conducción sin permiso", InDret, Revista para el análisis del Derecho, no 3, 2009.

- "El "moderno" Derecho Penal Vial y la penalización de la conducción sin permiso", en AA.VV. Protección Penal de la Seguridad Vial, OLMEDO CARDENETE, Miguel/ARÁNGUEZ SÁNCHEZ, Carlos (Eds.), Ed. Alea Blanca 2010, Granada.

MIRÓ LLINARES, Fernando/ BAUTISTA ORTUÑO, Rebeca, “¿Por qué cumplimos las normas penales? Sobre la disuasión en materia de seguridad vial”, InDret, Revista para el análisis del Derecho, nำ 4, 2013.

MOLINA BLÁZQUEZ, Ma ${ }^{a}$ Concepción, La aplicación de la pena, Ed.Bosch, Barcelona, 2002, 3ª edición.

MOLINA FERNÁNDEZ, Fernando, Delitos contra la seguridad vial: su aplicación jurisprudencial, Ediciones Francis Lefebvre, Madrid, 2014.

MOLINA GIMENO, Francisco Javier, "Delitos contra la Seguridad Vial. Comentarios a la reforma del Código Penal operada por la LO 15/2007 de 30 de noviembre", Revista El Ligall, II.lustre Col.legi d'Advocats de Granollers, no 41, año 2008.

MONER MUÑOZ, Eduardo, Aspectos y problemas de la pena de privación del permiso de conducir, Ed. Universidad de Valencia, Facultad de Derecho, Valencia, 1976.

MONTANER FERNÁNDEZ, Raquel, "Los nuevos delitos contra la seguridad vial: una muestra de la Administración del Derecho Penal", Revista de Documentación Administrativa, nº 284-285, mayo-diciembre 2009. 
- "Delitos contra la seguridad vial", en AA.VV. El nuevo Código Penal: Comentarios a la Reforma, SILVA SÁNCHEZ, Jesús-María (Dir.), PASTOR MUÑOZ, Nuria (Coord.), Ed. La Ley, Las Rozas (Madrid), 2012.

MONTERO HERNANZ, Tomás, "Reflexiones sobre la política criminal en España (A propósito de la completa entrada en vigor de la LO 15/2007)", Diario la Ley, no 7065, 26 de noviembre de 2008, año XXIX, Ref.D-340

- "La reforma penal en materia de seguridad vial desde una óptica penitenciaria", Tráfico y Seguridad Vial, no 143, 2010.

MORALES PRATS, Fermín, "La vuelta a la prevención general", Parte General del Derecho Penal, en QUINTERO OLIVARES, Gonzalo (Dir.), Ed.ThomsonAranzadi, Cizur Menor (Navarra), 2007, 2ª edición.

- "Del homicidio y sus formas", en AA.VV. Comentarios a la Parte Especial del Derecho Penal, en QUINTERO OLIVARES, Gonzalo (Dir.), MORALES PRATS, Fermín (Coord.), Ed.Thomson-Aranzadi, Cizur Menor ( Navarra ), 2011, 9a edición.

MORELL ALDANA, Laura Cristina, Delitos contra la seguridad vial y siniestralidad de los nuevos tipos de vehículo, Ed. Bosch, Wolters Kluwer, Las Rozas (Madrid), 2019.

MORENO CATENA, Víctor/CORTÉS DOMíNGUEZ, Valentín, Derecho Procesal Penal, Tirant lo Blanch, Valencia, 2017, 8ª edición.

MORILLAS CUEVA, Lorenzo, "Delitos contra la seguridad del tráfico: una preocupada reflexión global", en AA.VV, Delincuencia en materia de tráfico y seguridad vial. Aspectos penales, civiles y procesales, MORILLAS CUEVA, Lorenzo (Coord.), Ed.Dykinson, Madrid, 2007.

- "La función de la pena en el Estado Social y Democrático de Derecho", Revista Internacional de Doctrina y Jurisprudencia, Vol.4, Diciembre de 2013.

MUÑOZ CONDE, Francisco/ GARCÍA ARÁN, Mercedes, Derecho Penal. Parte General, Tirant lo Blanch, Valencia, 2010, 8를 edición.

MUÑOZ CUESTA, Francisco Javier, "Estudios de algunos aspectos sustantivos y procesales relevantes de las medidas de seguridad", Repertorio de jurisprudencia (Estudios doctrinales) ㄲo 6/2009, Ed. Aranzadi.

MUÑOZ GARRIDO, Rubén, "La privación del derecho a conducir y la pérdida de vigencia del permiso de conducción en el ámbito de la Unión Europea", Tráfico y Seguridad Vial, № 173, 2013.

MUÑOZ RUIZ, Josefa, "Modalidades típicas del delito de conducción sin permiso y menores", en AA.VV. El delito de conducción de vehículos a motor o ciclomotores sin licencia administrativa cometido por menores de edad, MORILLAS FERNÁNDEZ, David Lorenzo (Coordinador), Ed. Dykinson, Madrid, 2018.

NAGORE ARCHILLA, Carlos.S., "La falta del artículo 636 del Código Penal en relación con el seguro en la circulación de vehículos de motor", Ed. Thomson Aranzadi, BIB 2001/307

NAVARRO CARDOSO, Fernando, Infracción administrativa y delito: Límites a la intervención del derecho penal, Ed.Colex, Madrid, 2001. 
NAVARRO FRÍAS, Irene, "El principio de proporcionalidad en sentido estricto: ¿Principio de proporcionalidad entre el delito y la pena o balance global de costes y beneficios?", InDret, Revista para el análisis del Derecho, no 2, 2010.

NUÑO DE LA ROSA AMORES, José Antonio, "Aplicación práctica de la normativa sobre seguridad vial, con especial consideración de las reformas legales más recientes" en AA.VV. Prevención y control de la siniestralidad vial. Un análisis jurídico y criminológico, ORTS BERENGUER, Enrique (Coord.), Ed. Tirant lo Blanch, Valencia, 2011.

OLMEDO CARDENETE, Miguel, "Aspectos prácticos de los delitos contra la seguridad del tráfico tipificados en los arts.379 y 380 del C.Penal", Revista Electrónica de Ciencia Penal y Criminología (RECPC), 04-02, (2002).

- "Omisión del deber de socorro", en AA.VV, Delincuencia en materia de tráfico y seguridad vial. Aspectos penales, civiles y procesales, MORILLAS CUEVA, Lorenzo (Coord.), Ed.Dykinson, Madrid, 2007,

ORTS BERENGUER Enrique/ FERRANDIS CIPRIÁN, Daniel: "Elementos comunes de todos o de algunos de los delitos contra la seguridad vial", en AA.VV. Prevención y control de la siniestralidad vial. Un análisis jurídico y criminológico, ORTS BERENGUER, Enrique (Coord.), Ed. Tirant lo Blanch, Valencia, 2011.

ORTS BERENGUER, Enrique/ GONZÁLEZ CUSSAC, José.L., Compendio de Derecho Penal. Parte General, Ed. Tirant Lo Blanch, Valencia, 2017.

PALOMO DEL ARCO, Andrés, "Reconocimiento y ejecución de sentencias penales dictadas en otro estado europeo", Revista jurídica de Castilla y León, núm.21, Mayo 2010.

PALLÍN IBÁÑEZ, Gabriela, El impacto de las últimas reformas legales en la delincuencia vial en España. Especial referencia a la LO 1/2015 y su nueva clasificación de la imprudencia, Ed. Thomson-Aranzadi, Cizur Menor (Navarra), 2017.

PAREDES PORRO, Miguel Ángel, Tratamiento Policial de los Delitos contra la seguridad vial, Ed.Tecnos. 2010, Madrid.

PIPAÓN PULIDO Jorge Guillermo/ PEDREÑO NAVARRO Lucía/ BAL FRANCÉS, Edmundo, Los delitos contra la seguridad vial. Análisis práctico y formularios de aplicación, Ed.Lex Nova, Valladolid, 2009,1a edición.

PLANCHADELL GARGALLO, Andrea/ VIDALES RODRÍGUEZ, Caty, "Decomiso: comentario crítico desde una perspectiva constitucional", Estudios penales y criminológicos, Vol. XXXVIII, 2018, Universidad Santiago de Compostela.

POLAINO-ORTS, Miguel, "Delitos contra la seguridad vial: visión crítica de la nueva regulación española", en AA.VV. Entre libertad y castigo: dilemas del estado contemporáneo. Estudios en homenaje a la maestra Emma Mendoza Bremauntz. CAMPOS DOMÍNGUEZ, Fernando Gerardo/ CIENFUEGOS SALGADO, David/ RODRÍGUEZ LOZANO, Luis Gerardo/ ZARAGOZA HUERTA, José (Coords.), Facultad de Derecho de la Universidad Nacional Autónoma de México, Centro de Investigación de Tecnología Jurídica y Criminológica de la Universidad Autónoma de Nuevo León, México, 2011. 
POZUELO PÉREZ, Laura, Las penas privativas de derechos en el Código Penal, Ed. Colex, Madrid, 1998.

PRIETO GONZÁLEZ, Helena María, "El delito de conducción sin permiso en la reforma de los delitos contra "la seguridad vial", en AA.VV. Seguridad Vial y Derecho Penal. Análisis de la LO 15/2007, que modifica el Código Penal en materia de Seguridad Vial, MIR PUIG, Santiago y CORCOY BIDASOLO, Mirentxu (Dirs.) / CARDENAL MONTRAVETA, Sergi (Coord.), Ed. Tirant lo Blanch, Valencia, 2008.

- "Los controles preventivos de drogas: estado de la cuestión", La dogmática penal sobre el asfalto: un enfoque práctico de los delitos contra la seguridad vial, AGÜERO RAMÓN-LLIN, Elena/HIDALGO DE MORILLO JIMÉNEZ, Agustín/ LANZAROTE MARTíNEZ, Pablo/ PRIETO GONZÁlEZ, Helena María, Ed.Comares, Granada, 2012.

- "La creación de graves riesgos para la circulación: un tipo penal olvidado", La dogmática penal sobre el asfalto: un enfoque práctico de los delitos contra la seguridad vial, AGÜERO RAMÓN-LLIN, Elena/HIDALGO DE MORILLO JIMÉNEZ, Agustín/ LANZAROTE MARTíNEZ, Pablo/ PRIETO GONZÁLEZ, Helena María, Ed.Comares, Granada, 2012.

- "Otros temas de interés", La dogmática penal sobre el asfalto: un enfoque práctico de los delitos contra la seguridad vial, AGÜERO RAMÓN-LLIN, Elena/HIDALGO DE MORILLO JIMÉNEZ, Agustín/ LANZAROTE MARTíNEZ, Pablo/ PRIETO GONZÁLEZ, Helena María, Ed.Comares, Granada, 2012.

QUERALT JIMÉNEZ, Joan J., "El nuevo derecho penal vial: generalidades críticas", en AA.VV. Seguridad Vial y Derecho Penal. Análisis de la LO 15/2007, que modifica el Código Penal en materia de Seguridad Vial, MIR PUIG, Santiago y CORCOY BIDASOLO, Mirentxu (Dirs.) / CARDENAL MONTRAVETA, Sergi (Coord.), Ed. Tirant lo Blanch, Valencia, 2008.

QUINTERO OlIVARES, Gonzalo, Adonde va el Derecho Penal, Ed.Civitas, Madrid, 2004.

- "El derecho penal: concepto, principios informadores y evolución", Parte General del Derecho Penal, QUINTERO OLIVARES, Gonzalo (Dir.) Ed.Thomson-Aranzadi, Cizur Menor (Navarra), 2007, 2ª edición.

- "La progresiva renuncia a la prisión y la respuesta ante el delincuente violento y peligroso", en AA.VV. Las sanciones penales en Europa, Revista Aranzadi de Derecho y Proceso Penal, TAMARIT SUMALLA, Josep (Coord.), Ed. Aranzadi, Cizur Menor (Navarra), 2009.

- "Aspectos generales", en AA.VV, Derecho Penal Constitucional, QUINTERO OLIVARES, GONZALO (Dir.)/ JARIA I MANZANO, Jordi (Coord.), Ed. Tirant lo Blanch, Valencia, 2015.

- "Las penas privativas de derechos", Parte General del Derecho Penal, en QUINTERO OLIVARES, Gonzalo/ MORALES PRATS, Fermín (colaborador), Ed. Thomson Reuters-Aranzadi, Cizur Menor (Navarra), 2015, 5ae edición. 
- "Mitos y modas del derecho penal tras algunos años de experiencia", Anuario de derecho penal y ciencias penales, Ed. Ministerio de Justicia y Boletín Oficial del Estado, Madrid, Tomo 73, 2020.

RAMOS VÁZQUEZ, José Antonio, "La pena de inhabilitación especial para profesión, oficio, industria o comercio", Las penas privativas de derechos $y$ otras alternativas a la privación de libertad, en FARALDO CABANA, Patricia/ PUENTE ABA, Luz María (Dirs.), Tirant lo Blanch, Valencia, 2013.

RANDO CASERMEIRO, Pablo, "El modelo penal de la seguridad ciudadana en el derecho administrativo sancionador", InDret, Revista para el análisis del Derecho, $\mathrm{n}^{0}$ 1, 2010.

REQUEJO CONDE, Carmen, Delitos relativos al tráfico viario, Valencia, 2011.

- El delito de conducir sin permiso. Análisis jurisprudencial, J Bosch Editor, 2013.

REVILLA REVILLA, Eusebio, "La pena de multa", Diario la Ley, Sección Doctrina, 1997, Ref. D-220, tomo 4, Ed. La Ley.

RÍOS MARTÍN, Julián Carlos/ SEGOVIA BERNABÉ José Luis/ PASCUAL RODRÍGUEZ Esther, Las penas y su aplicación. Contenido legal, doctrinal y jurisprudencial, Ed.Colex, Madrid, 2007, 3a edición.

ROBLEDO VILLAR, Antonio, La protección penal de la seguridad vial (configuración de los tipos delictivos tras la LO 15/2007, de 30 de noviembre, sobre modificación del C.Penal), Ed. Ilustre Col-legi d'Advocats de Lleida, 2008.

ROCA AGAPITO, Luis, La responsabilidad personal subsidiaria por impago de la pena de multa, Ed. Lex Nova, Valladolid, 2003, 1a edición.

- El sistema de sanciones en el Derecho Penal Español, Ed.Bosch, Barcelona 2007.

ROCA DE AGAPITO, Luis, "Sistema de consecuencias jurídicas del delito", en AA.VV. Las consecuencias jurídicas del delito, ROCA DE AGAPITO, Luis (Dir.), Ed. Tirant lo Blanch, Valencia, 2017.

RODRÍGUEZ FERNÁNDEZ, Ignacio, "Consideraciones metodológicas sobre el alcance de la privación del derecho a conducir vehículos a motor y ciclomotores en la legislación penal”, Actualidad Penal, no 32, 2003.

RODRÍGUEZ LAINZ, José Luis, “Juzgado de Guardia y ejecución de sentencias de conformidad”, Diario La Ley, no 7465, Sección Doctrina 10-09-2010, Año XXI, La Ley 5617/2010.

- "Los nuevos delitos leves de imprudencia menos grave en materia de tráfico: aspectos sustantivos y procesales", Diario La Ley, no 9392, 2019.

RODRÍGUEZ LEÓN, Luis Carlos, Seguridad Vial. Crónica de una reforma penal, Ed.Instituto Andaluz de Administración Pública, Sevilla, 2008.

RODRÍGUEZ-MEDEL NIETO, Carmen/ SEBASTIÁN MONTESINOS, Ángeles, Manual práctico de reconocimiento mutuo penal en la Unión Europea, Ed. Tirant lo Blanch, Valencia, 2015. 
RODRÍGUEZ MESA, Mำ José, "Las razones del derecho penal. Modelos de fundamentación y legitimación", Revista electrónica de ciencia penal y criminología, (RECPC), 9-10 (2007).

RODRÍGUEZ MORO, Luis, "La pena de privación del derecho a conducir vehículos a motor y ciclomotores"; en AA.VV. Las penas privativas de derechos y otras alternativas a la privación de libertad, FARALDO CABANA, Patricia/ PUENTE ABA, Luz María (Dirs.). Ed. Tirant lo Blanch, Valencia, 2013.

- La pena de privación del derecho a conducir vehículos a motor y ciclomotores, Ed. Tirant lo Blanch, Valencia, 2016.

ROIG TORRES, Margarita, "Suspensión de la ejecución de las penas privativas de libertad (arts.80, 81 y 82)", en AA.VV. GONZÁLEZ CUSSAC José. L (Dir.), MATALLÍN EVANGELIO, Ángela/ GÓRRIZ ROYO, Elena (Coords.), Comentarios a la Reforma del Código Penal de 2015, Ed. Tirant Lo Blanch, Valencia, 2015.

ROMEO CASABONA, Carlos María, Conducta peligrosa e imprudencia en la sociedad del riesgo, Ed. Comares, Granada, 2005.

ROSÓN FERNÁNDEZ, Antonio, "La reforma de los delitos contra la seguridad vial. La L.O. 15/2007", Noticias Jurídicas (www.noticias.juridicas.com), Julio 2009.

ROXIN, Claus, Problemas básicos del derecho penal, Ed. Reus, Madrid, 1976, traducción Diego-Manuel Luzón Peña.

RUBIO LARA, Pedro Ángel, Las medidas de seguridad tras la Reforma de la Lo 5/2010 de 22 de junio, del Código Penal: Perspectivas Doctrinales y Jurisprudenciales. Problemas y soluciones, Revista Aranzadi de Derecho y Proceso Penal, Número 25. Aranzadi- Thomson Reuters, Cizur Menor (Navarra), 2011.

- Teoría de la pena y consecuencias jurídicas del delito. Análisis doctrinal y jurisprudencial, Ed. Tirant lo Blanch, Valencia 2017.

RUIZ DE ERENCHUN ARTECHE, Eduardo, Sistema de Penas, Reglas de Determinación de la Pena y Suspensión de la Ejecución de la Pena, Ed. Aranzadi, Pamplona, 2017.

RUIZ DE ERENCHUN ARTECHE, Eduardo/SÁNCHEZ-OSTIZ GUTIÉRREZ, Pablo, "El comiso", en AA.VV. El nuevo Código Penal: Comentarios a la Reforma, SILVA SÁNCHEZ, Jesús-María (Dir.), PASTOR MUÑOZ, Nuria (Coord.), Ed. La Ley, Las Rozas (Madrid), 2012.

RUSCA NADAL, Oriol, "Reforma del Código Penal: Seguridad Vial. Aspectos básicos de la LO 15/2007", Economist \& Jurist, Febrero 2008, Vol.16, núm. 117.

SÁNCHEZ MORENO, José, Conducción bajo la influencia de bebidas alcohólicas. Biblioteca básica de práctica procesal penal, Ed. Bosch. Barcelona, 2010.

SANZ-DÍEZ DE ULZURRUN LLUCH, Marina, "Los nuevos delitos contra la seguridad vial contenidos en la LO 15/2007 de 30 de noviembre", Revista Cuatrimestral de las Facultades de Derecho y Ciencias Económicas y Empresariales, Icade. № 74, Mayo-agosto de 2008. 
- "Delitos contra la seguridad vial: cuestiones comunes", en AA.VV. Protección Penal de la Seguridad Vial, GUTIÉRREZ RODRÍGUEZ, María (Coord.), GARCÍA DEL BLANCO, Victoria / MARTÍN LORENZO, María y SANZ-DÍEZ DE ULZURRUN LLUCH, Marina, Ed.Tirant lo Blanch, Valencia, 2009, 1a edición.

- "Delitos contra la seguridad vial: cuestiones comunes", en AA.VV. Protección Penal de la Seguridad Vial, GUTIÉRREZ RODRÍGUEZ, María (Coord.), GARCÍA DEL BLANCO, Victoria / MARTÍN LORENZO, María y SANZ-DÍEZ DE ULZURRUN LLUCH, Marina, Ed.Tirant lo Blanch, Valencia, 2013, 2 ${ }^{\text {a }}$ edición.

SANZ FERNÁNDEZ-VEGA, Mario, Tráfico y Seguridad Vial, Dirección General de Tráfico, núm. 225, marzo/abril 2014.

SANZ MULAS, Nieves, Alternativas a la pena privativa de libertad. Análisis crítico y perspectivas de futuro en las realidades española y centroamericana, Ed.Colex, Madrid, 2000.

SERRANO MAÍLLO, Alfonso, "El artículo 385 bis del Código Penal y el vehículo a motor como instrumento del delito", AA.VV. El delito de conducción de vehículos a motor o ciclomotores sin licencia administrativa cometido por menores de edad, MORILLAS FERNÁNDEZ, David Lorenzo (Coordinador), Ed. Dykinson, Madrid, 2018.

SERRANO MAÍlLO, Alfonso/REALPE QUINTERO, María Fernanda, Criminología del delincuente vial. La generalidad de la desviación en la conducción de vehículos a motor, Ed. Edisofer, Madrid, 2015.

SERRANO TÁRRAGA, María Dolores, "Medidas susceptibles de imposición a los menores", en AA.VV., Derecho Penal Juvenil, VÁZQUEZ GONZÁLEZ, Carlos/ SERRANO TÁRRAGA, María Dolores (Editores), Ed. Dykinson, Madrid, 2007, 2ª edición.

SOLA RECHE, Esteban, "Los viejos problemas de los nuevos delitos contra la seguridad vial”, Revista General de Derecho Penal, 10 (2008).

SUÁREZ LÓPEZ, José María, El tratamiento penal del hurto y robo de uso de vehículos a motor, Ed. Dykinson, Madrid, 2013.

SUÁREZ-MIRA RODRÍGUEZ, Carlos, "Del homicidio y sus formas", en GONZÁLEZ CUSSAC José. L (Dir.), MATALLÍN EVANGELIO, Ángela/ GÓRRIZ ROYO, Elena (Coords.), Comentarios a la Reforma del Código Penal de 2015, Ed. Tirant Lo Blanch, Valencia, 2015.

TAMARIT SUMALLA, Josep, "De las penas privativas de derechos", en AA.VV. Comentarios al nuevo Código Penal, QUINTERO OLIVARES, Gonzalo (Dir.), MORALES PRATS, Fermín (Coord.), Aranzadi-Thomson Reuters, CizurMenor (Navarra), 2005, 4ª edición.

- "Sistema de sanciones y política criminal. Un estudio de derecho comparado europeo", Revista Electrónica de Ciencia Penal y Criminología (RECPC), 0906 (2007).

- "La prohibición de conducir y otras sanciones penales relacionadas con los vehículos", Las sanciones penales en Europa, Revista Aranzadi de Derecho 
y Proceso Penal. TAMARIT SUMALLA, Josep (Coord.), № 21, Ed. Aranzadi, Cizur Menor (Navarra), 2009.

- "La pérdida definitiva del derecho de conducir o del derecho a la tenencia y porte de armas", en AA.VV. La adecuación del Derecho penal español al Ordenamiento de la Unión Europea. La política criminal europea, ÁLVAREZ GARCÍA, F.J. (Dir.), Tirant lo Blanch, Valencia, 2009.

- "De las penas privativas de derechos", en AA.VV. Comentarios al Código Penal Español, Tomo I, (Artículos 1 a 233), QUINTERO OLIVARES, Gonzalo (Dir.), MORALES PRATS, Fermín (Coord.), Aranzadi-Thomson Reuters, Cizur-Menor (Navarra), 2011, 6ª edición.

- "De las lesiones", AA.VV. Comentarios a la Parte Especial del Derecho Penal, QUINTERO OLIVARES, Gonzalo (Dir.), MORALES PRATS, Fermín (Coord.), Ed.Thomson-Aranzadi, Cizur Menor (Navarra), 2011, 9ª edición.

- "De los delitos contra la seguridad Vial", AA.VV. Comentarios a la Parte Especial del Derecho Penal, QUINTERO OLIVARES, Gonzalo (Dir.), MORALES PRATS, Fermín (Coord.), Ed. Aranzadi-Thomson Reuters, Cizur Menor (Navarra), 2011, 9ae edición.

- "El nuevo tratamiento legal de la imprudencia y el delito de abandono del lugar del accidente", Las reformas penales de 2019, QUINTERO OLIVARES, Gonzalo/ MORALES PRATS, Fermín/ TAMARIT SUMALLA, Josep Maria/ GARCÍA ALBERO, Ramón, Ed. Aranzadi, Cizur Menor (Navarra), 2019.

TAMARIT SUMALLA, Josep Maㄴ LUQUE REINA, Maㅡ Eulàlia, Automóviles, Delitos y Penas. Estudio de la criminalidad y de las sanciones penales relacionadas con los vehículos a motor, Ed. Tirant lo Blanch, Valencia, 2006.

TAPIA BALLESTEROS, Patricia, "Las medidas de seguridad. Reforma más recientes y últimas propuestas", Revista Jurídica de Castilla y León, núm. 32, Enero de 2014.

TENA SÁNCHEZ, Jordi, "Cambios en la política criminal de seguridad vial en España entre 2004 y 2010: Un análisis centrado en el diseño institucional”, Estudios de Deusto, julio-diciembre 2010, volumen 58, no 2, 2010.

TOLEDO CASTILLO, Francisco/ CAMPÓN DOMÍNGUEZ, José Andrés/ MARTÍN UCLÉS, Francisco, Manual de Seguridad Vial: El factor alcohol. Adaptado a la LO 15/2007 de 30 de noviembre por la que se modifica el Código Penal en materia de seguridad vial, Ed. Thomson Reuters-Aranzadi, Cizur Menor (Navarra), 2009, $1^{\text {a }}$ edición.

TORRES FERNÁNDEZ, Ma Elena, "Reflexiones sobre algunos efectos administrativos del llamado "carnet por puntos" en las consecuencias penales de los delitos contra la seguridad en el tráfico", en AA.VV, Delincuencia en materia de tráfico y seguridad vial. Aspectos penales, civiles y procesales, MORILLAS CUEVA, Lorenzo (Coord.), Ed.Dykinson, Madrid, 2007.

TORRES ROSELL, Núria, La pena de Trabajos en beneficio de la comunidad. Reformas legales y problemas de aplicación, Ed. Tirant lo Blanch, Valencia, 2006. 
- "La pena de localización permanente y la pena de trabajos en beneficio de la comunidad", en AA.VV. La reforma Penal de 2010: Análisis y comentarios, QUINTERO OLIVARES, Gonzalo (Dir.). Thomson Reuters- Aranzadi. 2010, Cizur Menor (Navarra).

- "Trabajos en beneficio de la comunidad y localización permanente", en AA.VV. Comentario a la reforma penal de 2015, QUINTERO OLIVARES, Gonzalo (Dir.), Ed.Thomson Reuters- Aranzadi, Cizur Menor (Navarra), 2015.

TRABADO ÁLVAREZ, Concepción, "Non bis in idem por la condena contra la seguridad del tráfico, alcoholemia y de negativa a someterse a las pruebas de alcoholemia". Diario la Ley, no 7681, 26 de julio de 2011, año XXXII, Ref.D-315.

TRAPERO BARREALES, María. A, Los delitos contra la seguridad vial ¿Una reforma de ida y vuelta?, Tirant Lo Blanch, Valencia, 2011.

- El nuevo modelo de suspensión de la ejecución de las penas privativas de libertad, Ed. Dykinson, Madrid, 2017.

- "Comentario urgente sobre la reforma penal vial y otros aspectos controvertidos", Revista Electrónica de Ciencia Penal y Criminología (RECPC), 21-11 (2019).

VAELLO ESQUERDO, Esperanza, Las consecuencias jurídicas del delito, Publicaciones Universidad de Alicante, 2004.

VALEIJE ÁLVAREZ, Inmaculada, "El sistema de penas en los delitos contra la seguridad vial", en AA.VV. Prevención y control de la siniestralidad vial. Un análisis jurídico y criminológico, ORTS BERENGUER, Enrique (Coord.), Ed. Tirant lo Blanch, Valencia, 2011.

VARONA GÓMEZ, Daniel, "La suspensión de la pena de prisión: razones de una historia de éxito", Revista Española de Investigación Criminológica, número 17, 2019.

- VARONA GÓMEZ, Daniel, "Fundamentación y aplicación práctica de la suspensión de la pena de prisión"; en AA.VV. La ejecución de las penas, Cuadernos penales José María Lidón, número 15, Ed. Universidad de Deusto, Bilbao, 2019.

VALLESPÍN PÉREZ, David, Aspectos Procesales de los Delitos contra la seguridad vial, Ed. Bosch, Barcelona, 2011.

VÁZQUEZ IRUZUBIETA, Carlos, Comentario al Código Penal: actualizado por LO 5/2010, de 22 de junio, Ed. La Ley, Madrid, 2010.

VELASCO NÚÑEZ, Eloy, "Privación del derecho a conducir vehículos a motor y ciclomotores", Boletín de Derecho de la Circulación, Ed. El Derecho Editores, no 8, Junio de 2007.

VELÁZQUEZ VIOQUE, David, El juicio de faltas por imprudencia en la seguridad vial, Ed.Bosch, Sabadell (Barcelona), 2008.

VIDALES RODRÍGUEZ, Caty, "Trabajos en beneficio de la comunidad (art.49)", en AA.VV. Comentarios a la Reforma Penal de 2010, ÁlVAREZ GARCÍA, Francisco.J/ GONZÁLEZ CUSSAC, José.L (Dirs.), Ed. Tirant lo Blanch, Valencia, 2010. 
VILLACAMPA ESTIARTE, Carolina, "Las penas de inhabilitación en la Unión Europea: regulación comparada y proceso de armonización"; en AA.VV. Las sanciones penales en Europa, Revista Aranzadi de Derecho y Proceso Penal, TAMARIT SUMALLA, Josep (Coord.), Ed. Aranzadi, Cizur Menor (Navarra), 2009.

VILLACAMPA ESTIARTE, Carolina/TORRES ROSELL, Núria, "EI nuevo régimen de ejecución de las sanciones alternativas a la prisión", Revista de Derecho y Proceso Penal, núm.27/2012, Ed. Aranzadi.

VIZUETA FERNÁNDEZ, Jorge, "Delitos contra la seguridad vial. El comiso del vehículo de motor o ciclomotor antes y después de la LO 5/2010 de Reforma del Código Penal", Revista Electrónica de Ciencia Penal y Criminología, (RECPC) 13-02 (2011).

- "Novedades del Proyecto de reforma del Código Penal de 2013 en algunos delitos contra bienes jurídicos fundamentales", Diario La Ley no 8311, 2014.

VON HIRSCH, Andrew, Censurar y castigar, Ed. Trotta, 1998, Madrid, traducción de Elena Larrauri.

- "Retribución y prevención como elementos de justificación de la pena", en AA.VV. Crítica y justificación del Derecho penal en el cambio de siglo, ARROYO ZAPATERO, Luis/NEUMANN, Ulfrid/NIETO MARTÍN, Adán (Coords.), Ediciones de la Universidad de Castilla-La Mancha, Cuenca, 2003. 


\section{ANEXO DE JURISPRUDENCIA}

Del Tribunal de Justicia de la Unión Europea

Sentencias

Gran Sala, de 6 de mayo de 2014, núm. de recurso C-43/12 (TOL4.219.330)

Sala 5aㅗ de 14 de mayo de 2020, núm. de recurso C-615/18 (TOL7.917.465)

Del Tribunal Constitucional

Autos

ATC, núm. 172/1985, Sala Segunda, Sección 3ª , de 6 de marzo de 1985 (RTC 1985/172 AUTO)

ATC, núm. 136/1996, Sala Segunda, de 27 de mayo de 1996, (RTC 1996/136 AUTO)

ATC, núm. 361/2003, Sala Primera, de 10 de noviembre de 2003 (RTC 2003/361 AUTO)

ATC, núm. 258/2004, Sala Primera, de 12 de julio de 2004 (JUR 2004/242773)

ATC, núm. 291/2004, Sala Segunda, de 19 de julio de 2004 (JUR 2004/242785)

ATC, núm. 241/2005, Sala Primera, de 06 de junio de 2005 (RTC 2005/241 AUTO)

ATC, núm. 128/2006, Sala Primera, de 3 de abril de 2006 (RTC 2006/128 AUTO)

ATC, núm. 196/2006, Sala Segunda, de 19 de junio de 2006 (RTC 2006/196 AUTO)

ATC, núm. 324/2006, Sala Primera, de 25 de septiembre de 2006 (JUR 2006/256533)

ATC, núm. 282/2008, Sala Segunda, de 22 de septiembre de 2008 (JUR 2008/350169)

ATC, núm. 185/2014, Sala Segunda, de 8 de julio de 2014 (TOL4.519.858)

Sentencias

STC, núm.18/1981, Sala Primera, de 8 de junio de 1981, ponente Excmo. Sr. Rafael Gómez-Ferrer Morant (TOL110.823)

STC, núm. 62/1982, Sala Primera, de 15 de octubre de 1982, ponente Excmo.Sr.Rafael Gómez-Ferrer Morant (TOL79.035) 
STC, núm. 77/1983, Sala Segunda, de 3 de octubre de 1983, ponente Excmo. Sr. Luis Díez-Picazo (TOL79.242)

STC, núm. 67/1984, Sala Primera, de 7 de junio de 1984, ponente Excmo. Sr. Rafael Gómez-Ferrer Morant (TOL79.357)

STC, núm. 2/1987, Sala Primera, de 21 de enero de 1987, ponente Excmo. Sr. Miguel Rodríguez-Piñero y Bravo-Ferrer (TOL340.205)

STC, núm. 148/1989, Sala Primera, de 21 de septiembre de 1989, ponente Excmo. Sr.Carlos de la Vega Benayas (TOL81.596)

STC, núm. 152/1990, Sala Primera, de 4 de octubre de 1990, ponente Excmo.Sr. Fernando García-Mon y González-Regueral (TOL81.831)

STC, núm. 166/1993, Sala Primera, de 20 de mayo de 1993, ponente Excmo. Sr. Rafael de Mendizábal Allende (TOL82.189)

STC, núm. 209/1993, Sala Primera, de 28 de junio de 1993, ponente Excmo. Sr. Rafael de Mendizábal Allende (TOL82.231)

STC, núm. 177/1999, Sala Segunda, de 11 de octubre de 1999, ponente Excmo. Sr. Pablo García Manzano (TOL81.219)

STC, núm. 2/2003, dictada por el Pleno del Tribunal Constitucional, de 16 de enero de 2003, ponente Excma. Sra. María Emilia Casas Bahamonde (TOL228.958)

STC, núm. 110/2003, Sala Primera, de 16 de junio de 2003, ponente Excmo. Sr. Jorge Rodríguez-Zapata Pérez (TOL285.440)

STC, núm. 251/2005, Sala Segunda, de 10 de octubre de 2005, ponente Excmo. Sr. Eugeni Gay Montalvo (TOL736.270)

STC, núm. 155/2009, dictada por el Pleno del Tribunal Constitucional, de 25 de junio de 2009, ponente Excmo. Sr. Vicente Conde Martín de Hijas (TOL1.568.033)

Del Tribunal Supremo

Sentencias

STS, Sección 1aㅡ, de 5 de junio de 1972, ponente Excmo. Sr. Fernando Díaz Palos (TOL4.263.271)

STS, Sección 1aㅡ, de 5 de abril de 1974, ponente Excmo. Sr. Jesús Sáez Jiménez (TOL4.254.191)

STS, Sala Segunda, de 3 de julio de 1985, ponente Excmo. Sr. José Augusto De Vega Ruiz (TOL2.313.893)

STS, Sala Segunda, de 27 de marzo de 1987, ponente Excmo. Sr. José Hermenegildo Moyna Menguez (TOL2.333.203) 
STS, Sala Segunda, de 13 de julio de 1987, ponente Excmo. Sr. Enrique Ruiz Vadillo (TOL2.333.797)

STS, Sala Segunda, de 13 de diciembre de 1993, Excmo. Sr. Cándido CondePumpido Ferreiro (TOL401.968)

STS, núm. de recurso 1275/1994, Sala Segunda, de 14 de diciembre de 1994, ponente Excmo. Sr. Justo Carrero Ramos (TOL403.798)

STS, núm. 1468/1997, Sala Segunda, de 1 de diciembre de 1997, ponente Excmo. Sr. José Manuel Martínez-Pereda Rodríguez (TOL407.780)

STS, núm. 950/1999, Sala Segunda, de 19 de julio de 1999, ponente Excmo. Sr. Cándido Conde-Pumpido Tourón (TOL5.134.336)

STS, núm. 723/2000, Sala Segunda, de 27 de abril de 2000, ponente Excmo. Sr. Luis Román Puerta (EDJ 2000/9207)

STS, núm. 1729/2001, Sala Segunda, de 15 de octubre de 2001, ponente Ilmo. Sr. Cándido Conde-Pumpido Tourón (TOL4.964.107)

STS, núm. 427/2007, Sala Segunda, de 8 de mayo de 2007, ponente Excmo. Sr. Luis Román Puerta (TOL1.079.766)

STS, núm. 226/2009, Sala Segunda, de 26 de febrero de 2009, ponente Excmo. Sr. Joaquín Giménez García (TOL1.486.875)

STS núm. 79/2010, Sala Segunda, de 3 de febrero de 2010, ponente Excmo. Sr. Manuel Marchena Gómez (TOL1.792.960)

STS, núm. 841/2010, Sala Segunda de 6 de octubre de 2010, ponente Excmo. Sr. Miguel Colmenero Menéndez de Luarca (TOL1.974.762)

STS, núm.1019/2010, Sala Segunda, de 2 de noviembre de 2010, ponente Excmo. Sr. Julián Artemio Sánchez Melgar (TOL2.018.420)

STS, núm. 423/2012 Sala Segunda, de 22 de mayo de 2012, ponente Excmo. Sr. Alberto Gumersindo Jorge Barreiro (TOL2.557.838)

STS, núm. 706/2012, Sala Segunda, de 24 de septiembre de 2012, ponente Excmo. Sr. Antonio del Moral García (TOL2.651.939)

STS, núm. 224/2013, Sala Segunda, de 1 de marzo de 2013, ponente Excmo. Sr. Francisco Monterde Ferrer (TOL3.408.174)

STS, núm. 520/2013 Sala Segunda de 19 de junio de 2013, ponente Excmo. Sr. Cándido Conde-Pumpido Tourón (TOL3.791.145)

STS, núm.1/2014, Sala Segunda, de 21 de enero de 2014, ponente Excmo. Sr. Joaquín Giménez García (TOL4.082.880)

STS, núm. 717/2014, Sala Segunda, de 29 de enero de 2015, ponente Excmo. Sr. Andrés Martínez Arrieta (TOL4.776.636)

STS núm.468/2015, Sala Segunda, de 16 de julio de 2015, ponente Excmo. Sr. Andrés Palomo del Arco (TOL5.390.963) 
STS, núm.138/2017, Sala Segunda, de 28 de marzo de 2017, ponente Excmo. Sr. Julián Artemio Sánchez Melgar (TOL5.967.909)

STS, núm.369/2017, Pleno de la Sala Segunda, de 22 de mayo de 2017, ponente Excmo. Sr. Julián Artemio Sánchez Melgar (TOL6.356.029)

STS, núm.419/2017, Sala Segunda, de 8 de junio de 2017, ponente Excmo. Sr. Alberto Gumersindo Jorge Barreiro (TOL6.172.049)

STS, núm.436/2017, Sala Segunda, de 15 de junio de 2017, ponente Excmo. Sr. Antonio del Moral García (TOL6.185.691)

STS, núm. 612/2017, Sala Segunda, de 13 de septiembre de 2017, ponente Excmo. Sr. Julián Artemio Sánchez Melgar (TOL6.346.233)

STS, núm. 64/2018, Sala Segunda, de 6 de febrero de 2018, ponente Excmo. Sr. Andrés Martínez Arrieta (TOL6.508.915)

STS núm. 124/2018, Sala Segunda, de 15 de marzo de 2018, ponente Excmo. Sr. Andrés Palomo del Arco (TOL6.562.271)

STS, núm. 4/2019, Sala Segunda, de 14 de enero de 2019, ponente Excmo. Sr. Miguel Colmenero Menéndez de Luarca (TOL6.999.041)

STS, núm. 22/2019, Sala Segunda, de 23 de enero de 2019, ponente Excma. Sra. Carmen Lamela Díaz (TOL7.011.653)

STS, núm. 672/2019, Sala Segunda, de 15 de enero de 2020, ponente Ilmo. Sr. Eduardo de Porres Ortiz de Urbina (TOL7.701.429)

STS, núm. 38/2020, Sala Segunda, de 6 de febrero de 2020, ponente Excma. Sra. Carmen Lamela Díaz (TOL7.763.421)

STS, núm. 350/2020, Sala Segunda, de 25 de junio de 2020, ponente Excmo. Sr. Julián Artemio Sánchez Melgar. (TOL8.001.069)

STS, núm. 41/2020, Sala Segunda, de 22 de julio de 2020, ponente Excmo. Sr. Antonio Del Moral García (TOL8.036.243)

De los Tribunales Superiores de Justicia

Sentencias

STSJ de la Comunidad Valenciana, núm. 20/2017, Sala de lo Civil y Penal, Sección $1^{a}$, de 28 de junio de 2017, IImo. Sr. José Francisco Ceres Montes (TOL6.563.841) STSJ de Castilla La Mancha, núm. 34/2019, Sala de lo Civil y Penal, Sección 1a, de 18 de octubre de 2019, IImo. Sr. Vicente Manuel Rouco Rodríguez (TOL7.606.822) 
De Audiencias Provinciales

Autos

AAP de Zamora, núm.118/2000, de 20 de noviembre de 2000, ponente Ilmo.Sr. Pedro Jesús García Garzón (EDJ 2000/47313)

AAP de Castellón, núm. 344/2001, Sección 3ạ, de 12 de diciembre de 2001, ponente Ilma.Sra. María Filomena Ibáñez Solaz (TOL2.670.005)

AAP de Vizcaya, núm.158/2003, Sección 6ª , de 11 de marzo de 2003, ponente Ilma.Sra. Ma José Martínez Sáinz (JUR 2003/238381)

AAP de Madrid, núm. 331/2003, Sección 23ạ , de 30 de abril de 2003, ponente Ilmo.Sr. Rafael Mozo Muelas (JUR 2005/248150)

AAP de Madrid, núm. 56/2004, Sección 2ª , de 6 de febrero de 2004, ponente Ilma.Sra. Susana García Polo (TOL2.553.218)

AAP de Lleida, Sección 1aㅡ, de 10 de marzo de 2004, ponente IImo. Sr. Francisco Segura Sancho (EDJ 2004/13930)

AAP de Guipúzcoa, Sección 2ª , de 10 de diciembre de 2004, ponente Ilma.Sra. Ana Maite Loyola Iriondo (JUR 2005/56916)

AAP de Madrid, núm. 486/2004, Sección 2ª , de 10 de diciembre de 2004, ponente Ilmo.Sr. José Luis Sánchez Trujillano (TOL744.516)

AAP de Vizcaya, núm. 658/2005, Sección 1a, de 29 de septiembre de 2005, ponente Ilma.Sra. Miren Nekane Sanmiguel Bergaretxe (JUR 2006/7228)

AAP de Córdoba, núm. 200/2005, Sección 3aa de 30 de noviembre de 2005, ponente Ilmo. Sr. Felipe Luis Moreno Gómez (EDJ 2005/298496)

AAP de Cáceres, núm. 261/2005, Sección 2ª , de 13 de diciembre de 2005, ponente Ilmo. Sr. Pedro V. Cano Maíllo Rey (JUR 2006/32471)

AAP de Madrid, Sección 17aa , de 25 de enero de 2006, ponente Ilmo. Sr. Fernando F. Orteu Cebrián (JUR 2006/100336)

AAP de Barcelona, núm.231/2006, Sección 7ª̣, de 16 de marzo de 2006, ponente Ilmo.Sr. Enrique Rovira del Canto (JUR 2006/221159)

AAP de Madrid, núm. 363/07, Sección 17ª̣ , de 29 de marzo de 2007, ponente Ilma.Sra. Rosa Ma Brobia Varona (TOL2.435.925)

AAP de Toledo, núm. 63/2007, Sección 1a, 4 de junio de 2007, ponente Ilma.Sra.Gema Adoración Ocáriz Azaustre (JUR 2007/302493)

AAP de Barcelona, núm. 391/2007 Sección 5a, 16 de julio de 2007, ponente Ilma.Sra Beatriz Grande Pesquero (JUR 2007/284593)

AAP de Barcelona, núm. 346/2007, Sección 6ª , de 17 de julio de 2007, ponente Ilma. Sra. Bibiana Segura Cros (JUR 2007/284515) 
AAP de Barcelona, núm. 553/2007, Sección 7ª̣ , de 12 de septiembre de 2007, ponente Ilma.Sra.Ana Rodríguez Santamaría (JUR 2007/330401)

AAP de Madrid, núm. 595/2007, Sección 16ª , de 27 de septiembre de 2007, ponente Ilmo.Sr. Miguel Hidalgo Abia (JUR 2007/325219)

AAP de Guipúzcoa, núm. 59/2008, Sección 1ạ, de 18 de marzo de 2008, Recurso 1038/2008, ponente IImo. Sr. Augusto Maeso Ventureira (JUR 2008/ 172556)

AAP de Zaragoza, núm. 380/2008, Sección 1aㅡ, de 21 de abril de 2008, ponente Ilmo.Sr. Antonio Eloy López Millán (JUR 2008/215624)

AAP de Madrid, núm.887/2008, Sección 23a, de 15 de octubre de 2008, ponente Ilmo.Sr. Rafael Mozo Muelas (JUR 2009/79682)

AAP de Las Palmas, núm. 667/2008, Sección 1aㅡ, de 24 de octubre de 2008, ponente Ilmo. Sr. Secundino Alemán Almeida (EDJ 2008/279696)

AAP de Madrid, núm.11/2009, Sección 2ª ${ }^{\text {, }}$ de 13 de enero de 2009, Rec: 346/2008, ponente Ilmo.Sr. Mario Pestana Pérez (JUR 2009/113209)

AAP de Madrid, núm. 272/2009 Sección 16á , de 2 de abril de 2009, ponente Ilma.Sra.Rosa Esperanza Rebollo Hidalgo (TOL2.253.101)

AAP de Castellón, núm.142/2009, Sección 2ª , de 4 de mayo de 2009, ponente Ilma. Sra. María Luisa Cuerda Arnau (TOL1.579.489)

AAP de Zaragoza, núm. 499/2009, Sección 3a ${ }^{\text {, }}$, de 3 de julio de 2009, ponente Ilmo.Sr. Mauricio Manuel Murillo García-Atance (JUR 2009/329385)

AAP de Madrid, núm. 921/2012, Sección 3aㅗ de 17 de diciembre de 2012, ponente IIma. Sra. Rosa Esperanza Rebollo Hidalgo (TOL3.739.475)

AAP de Tarragona, núm. 27/2010, Sección 2ạ , de 21 de enero de 2010, ponente Ilmo.Sr. José Manuel Sánchez Siscart (TOL2.604.652)

AAP de Madrid, núm. 355/ 2010, Sección 17ª̣, de 29 de marzo de 2010, ponente IImo.Sr. Ramiro José Ventura Faci (TOL2.084.748)

AAP de Vizcaya, núm. 267/10, Sección 1aㅡ, de 8 de abril de 2010, ponente, Ilma. Sra. Reyes Goenaga Olaizaola (TOL3.653.824)

AAP de Madrid, núm. 393/2010, Sección 3ª , de 25 de mayo de 2010, ponente IImo. Sr. Juan Pelayo María García Llamas (TOL3.572.214)

AAP de Burgos, núm. 538/2010, Sección 1a, de 7 de julio de 2010, ponente Ilmo.Sr. Francisco Manuel Marín Ibáñez (TOL2.084.731)

AAP de Tarragona, núm. 540/2010 Sección 2ª ponente Ilma. Sra. Samantha Romero Adán (TOL3.716.473)

AAP de Barcelona, núm. recurso: 202/2010, Sección 6aㅡ, de 22 de noviembre de 2010, ponente Ilmo.Sr. Miguel Ángel Gimeno Jubero (TOL3.551.959)

AAP de Castellón, núm. 465/2010, Sección 2ª , de 30 de diciembre de 2010, ponente Ilma. Sra. Eloísa Gómez Santana (TOL3.608.679) 
AAP de Vizcaya núm. 7/2011, Sección 2ª̣ ${ }^{\underline{a}}$ de 11 de enero de 2011, ponente llmo.Sr. Manuel Ayo Fernández (JUR 2011/305945)

AAP de Girona núm. 61/2011, Sección 3aㅗ , de 9 de febrero de 2011, ponente IImo. Sr. Ildefonso Carol Grau (TOL3.575.148)

AAP de Barcelona núm. 116/2011, Sección 5aa de 16 de febrero de 2011, ponente Ilmo.Sr. Sergi Cardenal Montraveta (TOL3.717.244)

AAP de Vizcaya, núm. 411/2011, Sección 2ª , de 31 de mayo de 2011, ponente Ilmo.Sr. Manuel Ayo Fernández (TOL3.632.636)

AAP de Madrid, núm. 877/2011, Sección 17ạa, de 14 de septiembre de 2011, ponente IImo.Sr. Carlos Águeda Holgueras (TOL3.639.336)

AAP de Tarragona, núm. 27/2010, Sección 2ª , de 29 de septiembre de 2011, ponente Ilma.Sra. María Concepción Montardit Chica (TOL3.602.346)

AAP de Vizcaya, núm. 775/11, Sección 2ª ${ }^{-}$, de 26 de octubre de 2011, ponente IIma. Sra. María José Martínez Sáinz (TOL3.582.599)

AAP de Cádiz, núm. 484/2011, Sección 8ª de 27 de diciembre de 2011, ponente Ilmo. Sr. Ignacio Rodríguez Bermúdez de Castro (TOL3.641.742)

AAP de Sevilla, núm. 784/2011, Sección 3를 de 30 de diciembre de 2011, ponente IImo.Sr. Ángel Márquez Romero (TOL3.578.869)

AAP de Barcelona, núm. recurso 682/2011 Sección 10ª, de 12 de enero de 2012, ponente Ilmo. Sr. Santiago Vidal Marsal (TOL3.632.830)

AAP de Granada, núm. 45/2012, Sección 2ª , de 27 de enero de 2012, ponente Ilmo.Sr. Juan Carlos Cuenca Sánchez (JUR/2012/393625)

AAP de Madrid, núm.1045/2012, Sección 5aㅡ, de 12 de marzo de 2012, ponente IImo.Sr. Arturo Beltrán Núñez (TOL3.565.093)

AAP de Barcelona, núm. recurso 215/2012, Sección 5ª , de 20 de abril de 2012, ponente Ilma.Sra. María del Pilar Pérez de Rueda (TOL3.605.142)

AAP de Barcelona, núm. recurso 425/2012, Sección 6ª , de 26 de abril de 2012, ponente IImo.Sr. Eduardo Navarro Blasco (TOL3.553.670)

AAP de Granada, núm. 348/2012, Sección 2ª , de 30 de abril de 2012, ponente Ilmo.Sr. Pedro Ramos Almenara (TOL3.592.149)

AAP de Sevilla, núm. 316/2012, Sección 1aㅡ, de 02 de mayo de 2012, ponente Ilma. Sra. Ma Auxiliadora Echavarri García (TOL3.583.131)

AAP de Lleida, núm. 236/2012, Sección 1a, de 17 de mayo de 2012, ponente IIma.

Sra. Mํㅡ Lucía Jiménez Márquez (TOL5.346.410)

AAP de Madrid, núm. 685/2012, Sección 17ª̣ , de 17 de mayo de 2012, ponente Ilmo. Sr. Ramiro José Ventura Faci (TOL3.563.687)

AAP de Asturias, núm. 476/2012, Sección 3ª , de 15 de junio de 2012, ponente IImo. Sr. Javier Gustavo Fernández Teruelo (TOL3.642.952) 
AAP de Tarragona, núm. 318/2012, Sección 2ª ${ }^{\text {, }}$ de 5 de julio de 2012, ponente Ilma. Sra. Mª Concepción Montardit Chica (TOL3.591.641)

AAP de Sevilla, núm. 464/2012, Sección 3a ${ }^{\underline{a}}$, de 17 de julio de 2012, ponente Ilmo.Sr. Luis Gonzaga de Oro-Pulido Sanz (TOL3.640.627)

AAP de Tarragona, núm. 498/2012, Sección 2ª̣ , de 26 de julio de 2012, ponente Ilmo.Sr. José Manuel Sánchez Siscart (TOL3.654.421)

AAP de Madrid, núm. 577/2012, Sección 30ª , de 31 de julio de 2012, ponente Ilmo.Sr. Carlos Martín Meizoso (JUR/2012/336173)

AAP de Madrid, núm.615/2012, Sección 3ạ, de 14 de agosto de 2012, ponente IImo.Sr. Francisco Buenaventura Ferrer Pujol (TOL3.574.444)

AAP de Madrid, núm. 603/2012, Sección 6ª , de 13 de septiembre de 2012, ponente María Luz Almeida Castro (TOL3.546.629)

AAP de Barcelona, núm.1276/2012, Sección 21aㅡ, de 30 de septiembre de 2012, ponente IImo. Sr. Carles Almeida Espallargas (TOL5.354.127)

AAP de Madrid, núm.735/12, Sección 1ạa de 18 de octubre de 2012, ponente Eduardo de Porres Ortiz de Urbina (TOL3.631.316)

AAP de La Coruña, Sección $2^{\underline{a}}$, de 22 de octubre de 2012, ponente Ilmo.Sr. Salvador Pedro Sanz Crego (JUR 2012/399709)

AAP de Madrid, núm.796/2012, Sección 15aㅡ, de 21 de noviembre de 2012, ponente IIma. Sra. Ana Victoria Revuelta Iglesias (TOL3.560.874)

AAP de Madrid, Sección 1aㅡ, de 3 de diciembre de 2012, ponente Ilmo.Sr. Eduardo de Porres Ortiz de Urbina (JUR 2013/5365)

AAP de Madrid, núm. 931/2012, Sección 16ª , de 5 de diciembre de 2012, ponente Ilma. Sra. Rosa Brobia Varona (TOL3.556.125)

AAP de Madrid, núm. 921/2012, Sección 1aㅡ de 21 de diciembre de 2012, ponente IIma. Sra. María Cruz Álvaro López (TOL3.626.934)

AAP de Madrid, núm. 889/2012, Sección 30ª̄, de 28 de diciembre de 2012, ponente Ilmo. Sr. Carlos Martín Meizoso (TOL5.363.507)

AAP de Madrid, núm.11/2013, Sección 6ª ${ }^{a}$, de 11 de enero de 2013, ponente Ilmo.Sr. Pedro Javier Rodríguez González-Palacios (TOL3.881.432)

AAP de Madrid, núm. 39/2013, Sección 2ª , de 23 de enero de 2013, ponente Ilma.Sra. Lucía María Torroja Ribera (TOL3.880.078)

AAP de Tarragona, núm. 54/2013, Sección 2ª , de 24 de enero de 2013, ponente Ilmo. Sr. José Manuel Sánchez Siscart (TOL3.881.747)

AAP de Madrid, Sección 23aㅡ, de 6 de febrero de 2013, ponente Ilmo. Sr. Jesús Eduardo Gutiérrez Gómez (JUR 2013/92474)

AAP de Madrid, núm. 533/2013, Sección 15aㅡ, de 6 de junio de 2013, ponente Ilma. Sra. María del Pilar de Prada Bengoa (TOL4.581.225) 
AAP de Cantabria, núm. 357/2015, Sección 3ạ , de 26 de agosto de 2015, ponente Ilma. Sra. Paz Mercedes Aldecoa Álvarez-Santullano (TOL5.562.610)

AAP de Madrid, núm. 938/2015, Sección 16aㅗ , de 30 de octubre de 2015, ponente Ilmo. Sr. Miguel Hidalgo Abia (TOL5.598.500)

AAP de Cantabria, núm. 524/2015, Sección 3a, de 21 de diciembre de 2015, ponente Ilmo. Sr. Agustín Alonso Roca (TOL5.658.875)

AAP de Barcelona, núm. 83/2016, Sección 7ª̣, de 29 de enero de 2016, ponente Ilmo. Sr. Luis Fernando Martínez Zapater (TOL5.967.679)

AAP de Barcelona, núm. 743/2016, Sección 2ª , de 7 de noviembre de 2016, ponente Ilma. Sra. María José Magaldi Paternostro (TOL5.969.031)

AAP de Soria, núm. 146/2016, Sección 1ạ, de 28 de noviembre de 2016, ponente Ilmo. Sr. José Luis Rodríguez Greciano (TOL6.067.897)

AAP de Cáceres, núm. 832/2016, Sección 2ª , de 16 de diciembre de 2016, ponente Ilmo. Sr. Valentín Pérez Aparicio (TOL5.987.506)

AAP de Ciudad Real, núm. 476/2016, Sección 1aㅡ, de 16 de diciembre de 2016, ponente Ilma. Sra. María Pilar Astray Chacón (TOL5.987.575)

AAP de Burgos, núm. 60/2017 Sección 1aㅡ, de 31 de enero de 2017, ponente IIma. Sra. María Dolores Fresco Rodríguez (TOL6.002.556)

AAP de Valladolid, núm.143/2017, Sección 2aa de 9 de marzo de 2017, ponente Ilmo. Sr. Feliciano Trebolle Fernández (TOL6.068.035)

AAP de Salamanca, núm. 95/2017, Sección 1를 de 13 de marzo de 2017, ponente Ilmo. Sr, José Antonio Vega Bravo (TOL6.084.204)

AAP de Navarra, núm. 90/2017, Sección 2ª , de 20 de marzo de 2017, ponente Ilmo. Sr. José Francisco Cobo Sáenz (TOL6.156.838)

AAP de Pontevedra, núm. 241/2017, Sección 4aa de 28 de marzo de 2017, ponente IIma.Sra. María Cristina Navares Villar (TOL.6.084.192)

AAP de Huelva, núm. 142/2017, Sección 1ạ, de 6 de abril de 2017, ponente llmo. Sr. Antonio Germán Pontón Práxedes (TOL6.223.227)

AAP de Barcelona, núm. 377/2017, Sección 2ª , de 17 de mayo de 2017, ponente Ilma. Sra. María Carmen Hita Martiz (TOL6.238.950)

AAP de Valladolid, núm. 268/2017, Sección 4⿳a , de 1 de junio de 2017, ponente Ilma. Sra. María Teresa González Cuartero (TOL6.218.402)

AAP de Pontevedra, núm. 448/2017, Sección 5aㅗ de 21 de junio de 2017, ponente Ilma. Sra. María Mercedes Pérez Martín-Esperanza (TOL6.264.435)

AAP de Sevilla, núm. 614/2017, Sección 1ª , de 30 de junio de 2017, ponente Ilmo. Sr. Juan Antonio Calle Peña (TOL6.364.525)

AAP de Barcelona, núm. 470/2017, Sección 9ª , de 3 de julio de 2017, ponente Ilmo. Sr. Ignacio de Ramón Forns (TOL6.400.984) 
AAP de Barcelona, núm. 530/2017, Sección 9ª̣, de 27 de julio de 2017, ponente Ilmo. Sr. Ignacio de Ramón Fors (TOL6.400.952)

AAP de A Coruña, núm. 725/2017, Sección 1aa de 8 de septiembre de 2017, ponente Ilma. Sra. María Teresa Cortizas González-Criado (TOL6.370.999)

AAP de Burgos, núm. 580/2017, Sección 1a, de 22 de septiembre de 2017, ponente Ilmo. Sr. Francisco Manuel Marín Ibáñez (TOL6.381.299)

AAP de Murcia, núm. 853/2017, Sección 3aㅗ de 9 de octubre de 2017, ponente IImo. Sr. Álvaro Castaño Penalva (TOL6.418.507)

AAP de León, núm. 1238/2017, Sección 3ª , de 16 de noviembre de 2017, ponente Ilmo. Sr. Miguel Ángel Amez Martínez (TOL6.472.891)

AAP de Murcia, núm. 1048/2017, Sección 3ª , de 24 de noviembre de 2017, ponente Ilmo.Sr. José Luis García Fernández (TOL6.486.552)

AAP de Girona, núm. 698/2017, Sección 4aa , de 20 de diciembre de 2017, ponente IImo. Sr. Daniel Varona Gómez (TOL6.652.766)

AAP de Barcelona, núm. recurso 280/2018, Sección $8^{\underline{a}}$, de 2 de mayo de 2018, ponente Ilmo. Sr. Jesús Navarro Morales (TOL6.776.648)

AAP de Vizcaya, núm. 90189/2018, Sección 2ª , de 3 de mayo de 2018, ponente Ilmo. Sr. Manuel Ayo Fernández (TOL6.683.230)

AAP de Madrid, núm. 375/2018, Sección 29ạ , de 4 de junio de 2018, ponente IIma. Sra. María Luz García Monteys (TOL6.756.742)

AAP de Madrid, núm. 400/2018, Sección 29a, de 8 de junio de 2018, ponente Ilma. Sra. María del Pilar Rasillo López (TOL6.756.758)

AAP de Valencia, núm. 601/2018, Sección 2ª ${ }^{\underline{a}}$, de 14 de junio de 2018, ponente Ilmo. Sr. José Manuel Ortega Lorente (TOL6.669.817)

AAP Barcelona, núm. 685/2018, Sección 3를 de 3 de septiembre de 2018, ponente IImo.Sr. Fernando Jerónimo Valle Esque (TOL6.925.737)

AAP de Guipúzcoa, núm. 722/2018, Sección 1aㅡ, de 16 de noviembre de 2018, ponente Ilma.Sra. María Josefa Barbarín Urquiaga (TOL7.072.577)

AAP de Guipúzcoa, núm. 745/2018, Sección 1a, de 23 de noviembre de 2018, ponente IImo. Sr. Augusto Maeso Ventureira (TOL.7.072.593)

AAP de Madrid, núm. 868/2018, Sección 4⿳a , de 26 de noviembre de 2018, ponente IImo. Sr. José Joaquín Hervás Ortiz (TOL7.000.719)

AAP de Vizcaya, núm. 90643/2018, Sección 6ª ${ }^{-}$, de 3 de diciembre de 2018, ponente Ilmo. Sr. José Ignacio Arévalo Lassa (TOL7.076.651)

AAP de Asturias, núm. 837/2018, Sección 3a , de 20 de diciembre de 2018, ponente IImo.Sr. Francisco Javier Rodríguez Santolcides (TOL7.122.775)

AAP de Guipúzcoa, núm. 834/2018 Sección 1aㅡ, de 26 de diciembre de 2018, ponente Ilma.Sra. María Josefa Barbarín Urquiaga (TOL7.068.118) 
AAP de Asturias, núm. 34/2019, Sección 2ạa de 22 de enero de 2019, ponente Ilma.Sra.María Covadonga Vázquez Llorens (TOL7.131.920)

AAP de Zaragoza, núm. 3106/2019, Sección 1a, de 19 de febrero de 2019, ponente Ilmo. Sr. Alfredo José Lajusticia Pérez (TOL7.121.270)

AAP de Burgos, núm. 157/2019, Sección 1aㅡ, de 26 de febrero de 2019, ponente Ilma. Sra. María Teresa Muñoz Quintana (TOL7.123.531)

AAP de Zaragoza, núm. 167/2019, Sección 1a, de 13 de marzo de 2019, ponente Ilmo. Sr. Juan Alberto Belloch Julbe (TOL7.195.357)

AAP de León, núm. 318/2019, Sección 3ạa, de 21 de marzo de 2019, ponente Ilmo. Sr. Carlos Miguélez del Río (TOL7.191.363)

AAP de Zaragoza, núm. 207/2019 Sección 1a, de 28 de marzo de 2019, ponente Ilmo. Sr. Alfonso Ballestín Miguel (TOL7.195.393)

AAP de Burgos, núm. 268/2019 Sección 1aㅡ, de 2 de abril de 2019, ponente IIma. Sra. María Dolores Fresco Rodríguez (TOL7.210.739)

AAP de Zaragoza, núm. 215/2019, Sección 6 $6^{\mathfrak{a}}$, de 7 de mayo de 2019, ponente Ilma. Sra. María Victoria López Asín (TOL7.238.719)

AAP de Lleida, núm. 408/2019, Sección 1aㅡ, de 16 de julio de 2019, ponente Ilma.Sra. Mercé Juan Agustín (TOL7.464.889)

AAP de Zaragoza, núm. 485/2019 Sección 6ª , de 30 de octubre de 2019, ponente Ilmo.Sr.Francisco José Picazo Blasco (TOL7.558.560)

AAP de Zaragoza, núm. 170/2020, Sección 6ª , de 12 de mayo de 2020, ponente Ilma.Sra. María del Milagro Rubio Gil (TOL7.992.220)

AAP de Córdoba, núm. 274/2020, Sección 3르, de 15 de mayo de 2020, ponente Ilmo. Sr. Félix Degayón Rojo (TOL8.004.802)

AAP de Barcelona, núm. 180/2020, Sección 8ª , de 3 de junio de 2020, ponente IIma. Sra. Montserrat Arroyo Romagosa (TOL8.036.894)

AAP de Girona, núm. 424/2020, Sección 4aa de 14 de septiembre de 2020, ponente Ilmo. Sr. Daniel Varona Gómez, (TOL8.194.418)

Sentencias

SAP de Huesca, de 16 de abril de 1997, ponente IImo.Sr. Antonio Angos Ullate (TOL389.167)

SAP de Huesca, de 28 de abril de 1997, ponente IImo.Sr. Gonzalo Gutiérrez Celma (TOL389.179)

SAP de Cantabria, núm. 61/1997, Sección 2ª , de 13 de mayo de 1997, ponente Ilmo.Sr. Javier de la Hoz de la Escalera (ARP 1997/707) 
SAP de Badajoz, núm. 27/1998, Sección 1aㅡ, de 26 de marzo de 1998 (ARP 1998/1148)

SAP de Alicante, Sección 2aㅡ, de 16 de noviembre de 1998, ponente Ilmo.Sr. Faustino de Urquía Gómez (ARP 1998/4831)

SAP de Guipúzcoa, núm. 436/1998, Sección 3ª , de 16 de diciembre de 1998, ponente IImo.Sr. Juan Piqueras Valls (EDJ 1998/37932)

SAP de Tarragona, núm. 410/2001, de 12 de noviembre de 2001, Sección 2ª ponente Ilmo.Sr. Eduardo López Causapé (JUR 2002/20313)

SAP de Madrid, Sección 7ª̣, de 23 de enero de 2002, ponente Ilma.Sra. Ana Mercedes Del Molino Romera (TOL240.163)

SAP de Madrid, Sección 23ạ , de 25 de enero de 2002, ponente IImo.Sr. Ángel Luis Hurtado Adrián (TOL161.181)

SAP de Madrid, Sección 7ª̣, de 23 de enero de 2002, ponente Ilma.Sra. Ana Mercedes Del Molino Romera (TOL240.163)

SAP de Asturias, Sección $8^{\mathfrak{a}}$, de 3 de abril de 2002, ponente IIma Sra. Alicia Martínez Serrano (TOL212.728)

SAP de Valladolid, núm. 792/2002, Sección 2ª ${ }^{\text {, }}$ de 31 de octubre de 2002, ponente Ilmo. Sr. Nicolás Cabezudo Rodríguez (TOL1.539.102)

SAP de Huelva, Sección 1aㅡ, de 17 de diciembre de 2002, ponente IImo.Sr. Santiago García García (EDJ 2002/70847)

SAP de Cuenca, núm. 55/2005, Sección 1a, de 25 de mayo de 2005, ponentellmo.Sr. Ernesto Casado Delgado (TOL666.276)

SAP de Valencia, núm. 355/2006, Sección 2a , de 17 de mayo de 2006, ponente Ilmo. Sr. Carlos Turiel Sandín (TOL1.029.305)

SAP de Sevilla, núm. 553/2006, Sección 1aa de 5 de octubre de 2006, ponente IIma.

Sra. Inmaculada Adelaida Jurado Hortelano (TOL6.103.132)

SAP de Vizcaya, núm. 557/2006, Sección 1aㅡ, de 13 de octubre de 2006, ponente IImo. Sr. Rafael Yangüela Criado (TOL1.061.486)

SAP de Madrid, núm. 893/2007, Sección 17ª̣ , de 3 de septiembre de 2007, ponente Ilma. Sra. Manuela Carmena Castrillo (TOL1.179.522)

SAP de Tarragona, núm. 324/2008, Sección $2^{\underline{a}}$, de 7 de julio de 2008, ponente IIma.Sra. Samantha Romero Adán (TOL1.372.790)

SAP de Girona, núm. 507/2008, Sección 3ª , de 8 de agosto de 2008, ponente IImo. Sr. José Antonio Soria Casao (TOL1.384.137)

SAP de Tenerife, núm. 710/2008, Sección 2ª , de 10 de octubre de 2008, ponente Ilmo.Sr. Joaquín Luis Astor Landete (JUR 2009/52342)

SAP de Barcelona, núm. 25/2009, Sección 2a , de 21 de enero de 2009, ponente Ilmo. Sr. Pedro Martín García (TOL1.487.893) 
SAP de Cuenca, núm. 9/2009, Sección 1aㅡ, de 29 de enero de 2009, ponente Ilmo. Antonio Díaz Delgado (TOL1.561.043)

SAP de Salamanca, núm. 15/2009, Sección 1ª , de 5 de febrero de 2009, ponente Ilmo. Sr. José Ramón González Clavijo (TOL1.546.387)

SAP de Álava, núm. 43/2009, Sección 2ª̣, de 12 de febrero de 2009, ponente Ilmo. Sr. Jesús Alfonso Poncela García (TOL1.568.988)

SAP de Barcelona, núm. 99/2009, Sección 2ª , de 16 de febrero de 2009, ponente Ilma.Sra.Ma José Magaldi Paternostro (TOL1.582.845)

SAP de Murcia, núm. 21/2009, Sección 5ª̣ , de 12 de marzo de 2009, ponente Ilmo. Sr. José Manuel Nicolás Manzanares (TOL6.758.464)

SAP de Valencia, núm.189/2009, de 25 de marzo de 2009, ponente Ilma.Sra. Regina Marrades Gómez (JUR\2009\260253)

SAP de Alicante, núm. 289/2009 Sección 3aㅗ de 27 de mayo de 2009, ponente Ilmo. Sr. José Daniel Mira-Perceval Verdú (TOL1.239.273)

SAP de Valencia, núm. 389/2009, Sección 2ª , de 10 de junio de 2009, ponente Ilmo. Sr. José María Tomás y Tio (TOL1.859.602)

SAP de Pontevedra, núm. 153/2009, Sección 2ª , de 30 de junio de 2009, ponente IIma. Sra. María del Rosario Cimadevila Cea (TOL1.631.564)

SAP de Madrid, núm.709/2009, Sección 16aㅡ, de 11 de noviembre de 2009, ponente Ilmo.Sr. Miguel Hidalgo Abia (TOL1.771.189)

SAP de la Coruña, núm.115/2009, Sección 6ª , de 18 de diciembre de 2009, ponente IImo.Sr. José Gómez Rey (TOL1.964.241)

SAP de Alicante, núm. 71/2010, Sección 1aa de 2 de febrero de 2010, ponente Ilmo. Sr. José Antonio Durá Carrillo (TOL5.281.685)

SAP de Guipúzcoa, núm. 100/2010, Sección 1ª̣, de 22 de febrero de 2010, ponente IImo.Sr. Ignacio José Subijana Zunzunegui (EDJ 2010/259973)

SAP de Córdoba, núm. 559/2010, Sección 1aㅡ, de 6 de julio de 2010, ponente IImo. Sr. José María Magaña Calle (TOL2.110.509)

SAP de Barcelona, núm. 802/2010, Sección 7ª̣, de 19 de octubre de 2010, ponente IIma. Sra. Ana Ingelmo Fernández (TOL2.058.920)

SAP de Tarragona, núm. 528/2010, Sección 2ª , de 18 de noviembre de 2010, ponente Ilma.Sra. María De Los Ángeles Barcenilla Visus (TOL2.060.382)

SAP de Tarragona, núm.538/2010, Sección 2ª ${ }^{a}$, de 2 de diciembre de 2010, ponente Ilmo. Sr. Ángel Martínez Sáez (TOL2.061.030)

SAP de Vizcaya, núm. 103/2011, Sección 2ª , de 18 de febrero de 2011, ponente Ilma. Sra. María José Martínez Sáinz (TOL2.214.536)

SAP de Barcelona, núm. 247/2011, Sección 22ª , de 13 de abril de 2011, ponente Ilmo.Sr. Francisco Abellanet Guillot (TOL2.129.283) 
SAP de Madrid, núm.158/2011, Sección 32ª , de 26 de abril de 2011, ponente Ilma. Sra. Josefina Molina Marín (TOL2.152.409)

SAP de Málaga, núm. 308/2011, Sección 9ạ, de 31 de mayo de 2011, ponente Ilmo.Sr. Enrique Peralta Prieto (JUR\2012166600)

SAP de Pontevedra, núm. 231/2011, Sección 2ª , de 28 de julio de 2011, ponente Ilmo. Sr. Celso Joaquín Montenegro Viéitez (TOL2.226.077)

SAP de Murcia, núm. 277/2011, Sección 5aa de 27 de octubre de 2011, ponente IImo.Sr. Fernando J. Fernández-Espinar López (JUR\2011\401307)

SAP de Murcia, núm. 409/2011, Sección 2a ${ }^{a}$, de 29 de octubre de 2011, ponente IIma.Sra. Beatriz Lourdes Carrillo Carrillo (TOL2.278.059)

SAP de Tenerife, núm. 617/2011, Sección $2^{2}$, de 25 de noviembre de 2011, ponente IIma. Sra. Francisca Soriano Vela (TOL2.473.712)

SAP de La Coruña, núm. 484/2011, Sección 2ª , de 30 de diciembre de 2011, ponente Ilmo.Sr. Agustín Jesús Pérez-Cruz Martín (TOL2.406.204)

SAP de Valencia, núm. 67/2012, Sección 3ª ${ }^{-}$, de 31 de enero de 2012, ponente IImo. Sr Lamberto Juan Rodríguez Martínez (TOL2.532.773)

SAP de Madrid, núm. 266/2012 Sección $17^{\text {a }}$, de 21 de febrero de 2012, ponente IIma. Sra. Carmen Lamela Díaz (TOL2.485.050)

SAP de Badajoz, núm. 31/2012, Sección 1aㅡ, de 1 de marzo de 2012, ponente IImo. Sr. José Antonio Patrocinio Polo (TOL2.484.379)

SAP de Barcelona, núm. 350/2012, Sección 10ª , de 20 de marzo de 2012, ponente Ilmo.Sr. José María Planchat Teruel (TOL2.518.655)

SAP de Murcia, núm. 87/2012, Sección 3ạ, de 28 de marzo de 2012, ponente IImo.Sr. Juan del Olmo Gálvez (JUR\2012\140582)

SAP de Burgos, núm.157/2012, Sección 1aㅡ, de 9 de abril de 2012, ponente llmo.Sr. Roger Redondo Argüelles (TOL2.509.401)

SAP de Almería, núm. 126/2012, Sección 3aㅡ, de 13 de abril de 2012, ponente Ilmo.Sr. Jesús Martínez Abad (TOL3.665.790)

SAP de La Coruña, núm. 259/2012, Sección 1aa de 16 de mayo de 2012, ponente Ilmo.Sr. José María Sánchez Jiménez (TOL2.576.616)

SAP de Tarragona, núm. 265/2012, Sección 2ª , de 31 de mayo de 2012, ponente Ilmo.Sr. Ángel Martínez Sáez (TOL2.603.186)

SAP de Tarragona, núm. 422/2012 Sección 2ª , de 20 de septiembre de 2012, ponente Ilma. Sra. M ${ }^{a}$ Concepción Montardit Chica (TOL2.671.082)

SAP de Badajoz, núm. 232/2012, Sección 3ạ, de 10 de octubre de 2012, ponente Ilma. Sra. María Isabel Bueno Trenado (TOL2.689.286)

SAP de Barcelona, núm. 788/2012, Sección 6ª , de 7 de noviembre de 2012, ponente Ilma.Sra. María Dolores Balibrea Pérez (TOL2.714.210) 


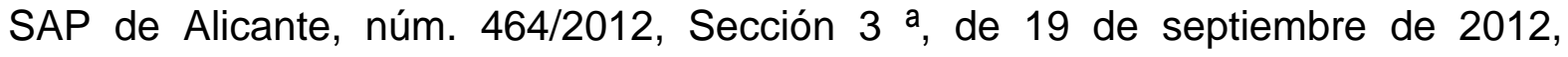
ponente Ilmo. Sr. José Daniel Mira-Perceval Verdú (TOL3.410.839)

SAP de Navarra, núm. 259/2012, Sección 2ª ${ }^{a}$, de 21 de diciembre de 2012, ponente Ilmo. Sr. Francisco José Goyena Salgado (TOL3.916.016)

SAP de Tarragona, núm. 46/2013, Sección 2aㅡ, de 31 de enero de 2013, ponente Ilma. Sra. María Concepción Montardit Chica (TOL3.244.378)

SAP de Toledo, núm. 16/2013, Sección 1ª , de 14 de febrero de 2013, ponente Ilmo.Sr. Manuel Gutiérrez Sánchez Caro (TOL3.525.284)

SAP de Madrid, núm. 80/2013, Sección 30aㅡ, de 15 de febrero de 2013, ponente IImo. Sr. Carlos Martín Meizoso (TOL3.414.266)

SAP de Teruel, núm. 4/2013, Sección 1ạ , de 19 de febrero de 2013, ponente IIma. Sra. María Teresa Rivera Blasco (TOL3.667.572)

SAP de Barcelona, núm. 283/2013, Sección 7ª̣a de 8 de marzo de 2013, ponente IImo.Sr. Luis Fernando Martínez Zapater (TOL3.729.115)

SAP de Tenerife, núm. 113/2013, Sección $2^{2}$, de 15 de marzo de 2013, ponente Ilmo. Sr. Fernando Paredes Sánchez (TOL3.723.701)

SAP de Madrid, núm. 184/2013, Sección $16^{\text {a }}$, de 19 de marzo de 2013, ponente Ilmo. Sr. Francisco David Cubero Flores (TOL3.708.667)

SAP de Zaragoza, núm.185/2013. Sección 6aa de 12 de junio de 2013, ponente Ilmo.Sr. Rubén Blasco Obede (JUR 2013/235088)

SAP de León, núm. 474/13, Sección 3aㅗ de 17 de junio de 2013, ponente Ilmo. Sr. Teodoro González Sandoval (TOL3.849.234)

SAP de Barcelona, núm. 336/2013, Sección $6 \stackrel{\text { a }}{\text {, de }} 12$ de abril de 2013, ponente IIma. Sra. María Carmen Domínguez Naranjo (TOL3.757.514)

SAP de La Coruña, núm. 351/2013 Sección 2ª , de 28 de mayo de 2013, ponente IIma.Sra. Mํㅡㄹ Dolores Fernández Galiño (TOL3.874.055)

SAP de Zaragoza, núm.185/2013. Sección 6aa de 12 de junio de 2013, ponente Ilmo.Sr. Rubén Blasco Obede (JUR 2013/235088)

SAP de Madrid, núm. 502/2013, Sección 15ª , de 17 de junio de 2013, ponente IIma.

Sra. María Isabel Valldecabres Ortiz (TOL4.085.124)

SAP de Valencia, núm. 473/2013, Sección $3^{\text {a }}$, de 3 de julio de 2013, ponente IImo.Sr. Lamberto Juan Rodríguez Martínez (JUR\2013\279983)

SAP de Barcelona, núm. 778/2013, Sección 5aㅡ, de 30 de septiembre de 2013, ponente Ilma.Sra. Elena Guindulain Oliveras (TOL4.016.566)

SAP de Sevilla, núm. 624/2013, Sección 1aㅡ, de 11 de diciembre de 2013, ponente Ilma.Sra. María Dolores Sánchez García (TOL4.037.201)

SAP de Badajoz, núm. 144/2013, Sección 1aㅡ, de 20 de diciembre de 2013, ponente Ilmo. Sr. Emilio Francisco José Serrano Molera (TOL4.095.015) 
SAP de Barcelona, núm. recurso 241/2014, Sección 10ª , de 30 de diciembre de 2013, ponente IIma. Sra. Montserrat Comas de Argemir Cendra (TOL5.002.062)

SAP de Tenerife, núm.103/2014, Sección 2a Ilma.Sra. Francisca Soriano Vela (TOL4.319.918)

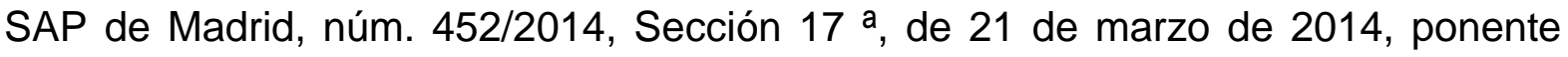
Ilma. Sra. Carmen Lamela Díaz (TOL4.360.790)

SAP de Ourense, núm.167/2014, Sección 2ª ${ }^{a}$, de 21 de abril de 2014, ponente IIma. Sra. Ana María del Carmen Blanco Arce (TOL4.477.356)

SAP de Asturias, núm. 223/2014, Sección 2ª̣ , de 28 de abril de 2014, ponente Ilmo. Sr. Agustín Pedro Lobejón Martínez (TOL4.406.332)

SAP de Tarragona, núm. 286/2014, Sección 2ª , de 19 de julio de 2014, ponente Ilma.Sra. Samantha Romero Adán (TOL4.481.612)

SAP de Pontevedra, núm. 156/2014, Sección 4aㅡ, de 18 de septiembre de 2014, ponente Ilma.Sra. María Cristina Navares Villar (TOL4.523.050)

SAP de Cantabria, núm. 408/2014, Sección 3ạ, de 21 de octubre de 2014, ponente Ilma. Sra. María Almudena Congil Díez (TOL5.574.369)

SAP de Tarragona, núm. 443/2014, Sección 4ª , de 3 de noviembre de 2014, ponente Ilmo.Sr. Jorge Mora Amante (TOL4.719.844)

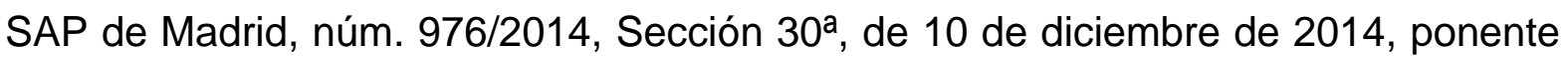
Ilmo. Sr. Carlos Martín Meizoso (TOL4.713.426)

SAP de Pontevedra, núm.9/2015, Sección 4⿳a , de 20 de enero de 2015, ponente IImo. Sr. José Ramón Sánchez Herrero (TOL4.734.716)

SAP de Guipúzcoa, núm. 16/2015, Sección 1aㅡ, de 26 de enero de 2015, ponente Ilma. Sra. María Josefa Barbarín Urquiaga (TOL4.806.366)

SAP de Málaga, núm.137/2015, Sección 9ạ , de 16 de marzo de 2015, ponente Ilma.

Sra. Lourdes García Ortiz (TOL5.005.184)

SAP de Castellón, núm. 144/2015, Sección 1ạ, de 31 de marzo de 2015, ponente Ilma. Sra. Aurora de Diego González (TOL4.947.304)

SAP de Zaragoza, núm. 141/2015, Sección 3ạ, de 17 de junio de 2015, ponente Ilmo. Sr. Miguel Ángel López López del Hierro (TOL5.202.957)

SAP de Alicante, núm. 298/2015, Sección 10ª, de 9 de julio de 2015, ponente IImo. Sr. Jesús Gómez-Angulo Rodríguez (TOL5.745.943)

SAP de Santander, núm. 345/2015, Sección 3ạ , de 24 de julio de 2015, ponente Ilmo. Sr. Agustín Alonso Roca (TOL5.559.800)

SAP de Madrid, núm. 683/2015, Sección 2ª ${ }^{\text {a }}$ de 24 de julio de 2015, ponente Ilmo. Sr. Eduardo de Urbano Castrillo (TOL5.396.459)

SAP de Barcelona, núm. 697/2015 Sección 6ª ${ }^{\text {, de }} 27$ de julio de 2015, ponente Ilmo. Sr. Pablo Llarena Conde. (TOL5.579.261) 
SAP de Sevilla, núm. 417/2015, Sección 7ạa de 14 de septiembre de 2015, ponente Ilmo. Sr. Juan José Romeo Laguna (TOL5.544.544)

SAP de Castellón, núm. 382/2015, Sección 1aㅡ, de 20 de octubre de 2015, ponente Ilmo. Sr. Esteban Solaz Solaz (TOL5.742.306)

SAP de Pontevedra, núm. 565/2015, Sección 5ª , de 17 de noviembre de 2015, ponente IImo. Sr. José Ramón Sánchez Herrero (TOL5.593.586)

SAP de Pontevedra, núm. 593/2015, Sección 5ª , de 1 de diciembre de 2015, ponente IIma. Sra. Victoria Eugenia Fariña Conde (TOL5.633.647)

SAP de Guipúzcoa, núm. 252/2015, Sección 1a, de 18 de diciembre de 2015, ponente Ilma. Sra. María Josefa Barbarin Urquiaga (TOL5.674.471)

SAP de Asturias, núm. 546/2015, Sección 3a, de 30 de diciembre de 2015, ponente IImo. Sr. Francisco Javier Rodríguez Santocildes (TOL5.736.375)

SAP de Barcelona, núm. 23/2016, Sección 9ạ , de 18 de enero de 2016, ponente IImo. Sr. Julio Hernández Pascual (TOL5.655.233)

SAP de Girona, núm. 59/2016, Sección 3ª ${ }^{\text {, de }} 29$ de enero de 2016, ponente IIma. Sra. Fátima Ramírez Souto (TOL5.676.401)

SAP Ciudad Real, núm.19/2016, Sección 2ª ${ }^{\text {, }}$, de 1 de febrero de 2016, ponente Ilmo. Sr. Ignacio Escribano Cobo (TOL5.665.904)

SAP de Málaga, núm. 67/2016, Sección 8aㅗ de 4 de febrero de 2016, ponente IImo. Sr. Pedro Molero Gómez (TOL5.777.575)

SAP de Ciudad Real, núm. 32/2016, Sección 1aㅡ, de 28 de marzo de 2016, ponente Ilma. Sra. María Pilar Astray Chacón (TOL5.715.376)

SAP de Barcelona, núm. 312/2016, Sección 7ª̣, de 6 de mayo de 2016, ponente Ilma. Sra. Ana Rodríguez Santamaría (TOL5.967.640)

SAP de Barcelona, núm. 417/2016, Sección 9ạ, de 17 de mayo de 2016, ponente IIma. Sra. María Inmaculada Vacas Márquez (TOL5.815.474)

SAP de Valencia, núm. 514/2016, Sección 3aㅗ de 29 de julio de 2016, ponente IImo. Sr. Lamberto Juan Rodríguez Martínez (TOL5.829.577)

SAP de Castellón, núm. 231/2016, Sección $2^{2}$, de 11 de octubre de 2016, ponente Ilmo. Sr. Horacio Badenes Puentes (TOL5.934.981)

SAP de Ávila, núm. 108/2016, Sección 1aㅡ, de 27 de octubre de 2016, ponente IImo.Sr. Jesús García García (TOL5.899.856)

SAP de Sevilla, núm. 451/2016, Sección $7^{a}$, de 8 de noviembre de 2016, ponente Ilma. Sra. Mercedes Alaya Rodríguez (TOL6.145.679)

SAP de Guipúzcoa, núm. 32/2017, Sección 1aㅡ, de 10 de febrero de 2017, ponente Ilmo. Sr. Jorge Juan Hoyos Moreno (TOL6.493.403)

SAP de Castellón, núm. 152/2017, Sección 1ª , de 22 de febrero de 2017, ponente Ilmo. Sr. Pedro Luis Garrido Sancho. (TOL6.154.279) 
SAP de Navarra, núm. 39/2017, Sección 2ª , de 27 de febrero de 2017, ponente IIma. Sra. Raquel Fernandino Nosti (TOL6.151.492)

SAP de La Coruña, núm.132/2017 Sección 2ª̣ , de 17 de marzo de 2017, ponente Ilma. Sra. M ${ }^{\underline{a}}$ del Carmen Taboada Caseiro (TOL6.100.564)

SAP de Cádiz, núm. 100/2017, Sección 8ª , de 23 de marzo de 2017, ponente Ilmo. Sr. Blas Rafael Lope Vega (TOL6.115.378)

SAP de Cantabria, núm. 123/2018, Sección 1aㅡ, de 23 de marzo de 2017, ponente IIma. Sra. María Gallardo Monje (TOL6.625.867)

SAP de Lleida, núm. 195/2017, Sección 1a, de 18 de mayo de 2017, ponente Ilmo. Sr. Victor Manuel García Navascués (TOL6.416.595)

SAP de Tarragona, núm. 292/2017, Sección 2ª , de 26 de mayo de 2017, ponente Ilma.Sra. María Espiau Benedicto (TOL6.420.005)

SAP de Barcelona, núm. 478/2017, Sección 7ª̣, de 11 de julio de 2017, ponente IIma. Sra. Ana Rodríguez Santamaría (TOL6.443.716)

SAP de Guadalajara, núm. 19/2017, Sección 1aㅡ, de 22 de septiembre de 2017, ponente IIma. Sra. María Elena Mayor Rodrigo (TOL6.378.913)

SAP de Murcia, núm. 387/2017, Sección 3ạ, de 22 de septiembre de 2017, ponente IImo. Sr. Álvaro Castaño Penalva (TOL6.397.049)

SAP de Albacete, núm. 384/2017, Sección 2ª , de 28 de septiembre de 2017, ponente Ilmo. Sr. Manuel Mateos Rodríguez (TOL6.420.927)

SAP de llles Balears, núm.1/2018, Sección 1a, de 8 de enero de 2018, ponente IIma. Sra. Eleonor Moya Rossello (TOL6.528.276)

SAP de Barcelona, núm. 251/2018, Sección 2ª , de 3 de abril de 2018, ponente Ilma.Sra. María José Magaldi Paternostro (TOL6.647.185)

SAP de La Coruña, núm. 458/2018, Sección 1ª , de 27 de septiembre de 2018, ponente IImo. Sr. Alejandro Moran Llorden (TOL6.918.812)

SAP de Madrid, núm. 685/2018, Sección 16a , de 8 de octubre de 2018, ponente IImo.Sr. Francisco Javier Teijeiro Dacal (TOL6.927.475)

SAP de Tenerife, núm. 338/2018, Sección 2ª̣ , de 9 de noviembre de 2018, ponente IImo. Sr. Fernando Paredes Sánchez. (TOL7.066.784)

SAP de Tarragona, núm. 543/2018, Sección 2ª ${ }^{\text {e }}$, de 27 de noviembre de 2018, ponente Ilmo.Sr. Antonio Fernández Mata (TOL7.014.255)

SAP de Guipúzcoa, núm. 292/2018, Sección 3ạ, de 12 de diciembre de 2018, ponente Ilma. Sra. Juana María Unanue Arratibel (TOL7.068.411)

SAP de Pontevedra, núm. 12/2019, Sección 2a ${ }^{\text {e }}$, de 23 de enero de 2019, ponente IIma. Sra. Rosa del Carmen Collazo Lugo (TOL7.155.049)

SAP de Alicante, núm. 127/2019, Sección 2ª , de 29 de marzo de 2019, ponente Ilma.Sra. María Cristina Costa Hernández (TOL7.487.774) 
SAP de Las Palmas, núm. 238/2019, Sección 6ª ${ }^{-}$de 29 de julio de 2019, ponente IIma. Sra. Oscarina Inmaculada Naranjo García (TOL7.543.377)

SAP de Navarra, núm. 205/2019, Sección 1a, de 13 de septiembre de 2019, ponente Ilma. Sra. María Esther Erice Martínez (TOL7.568.572)

SAP de Cáceres, núm. 329/2019, Sección 2ª ${ }^{\text {, de }} 28$ de noviembre de 2019, ponente Ilma. Sra. Julia Domínguez Domínguez (TOL7.742.072)

SAP de Barcelona, núm. 982/2019, Sección 22ª , de 12 de diciembre de 2019, ponente IImo. Sr. Mariano David García Esteban (TOL7.811.798)

SAP de Badajoz, núm. 422/2019, Sección 3ª ${ }^{\text {, de }} 12$ de diciembre de 2019, ponente IImo. Sr. Joaquín González Casso (TOL7.744.956)

SAP de Pontevedra, núm. 228/2019, Sección 4ạ , de 30 de diciembre de 2019, ponente IIma. Sra. María Cristina Navares Villar (TOL7.814.554)

SAP de Cáceres, núm. 44/2020, Sección $2^{2}$, de 7 de febrero de 2020, ponente IImo. Sr. Valentín Pérez Aparicio (TOL7.791.823)

SAP de Murcia, núm. 81/2020, Sección 2ª̣, de 24 de marzo de 2020, ponente IImo. Sr. Enrique Domínguez López (TOL7.945.600)

De Juzgados de lo Penal

Sentencia del Juzgado de lo Penal no 1 de Córdoba, núm.76/2011, Sección 2ª , de 24/2/2011, Magistrada IIma. Sra. Ascensión Miranda Castañón (TOL2.057.442)

Sentencia del Juzgado de lo Penal no 7 de Alicante, núm. 44/2016 de 1 de marzo de 2016, Magistrado IImo. Sr. Leopoldo David Macia Llobregat (TOL5.666.675) 
La Pena de privación del derecho a conducir vehículos a motor y ciclomotores en el sistema penal español
David Lanaspa Mainz

La Pena de privación del derecho a conducir vehículos a motor y ciclomotores en el sistema penal español
David Lanaspa Mainz

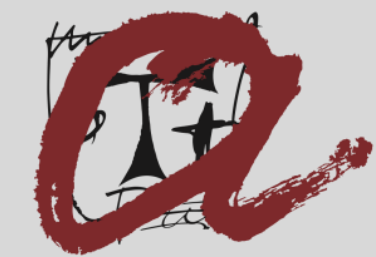

UNIVERS I TAT ROVIRA i VIRGILI (1)

\section{ROVIRA IVIRGILI}

